\title{
\#USAS
}

\section{Status and Trends of Land Change in the Great Plains of the United States -1973 to 2000}

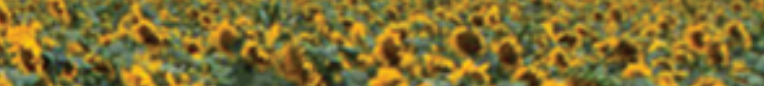

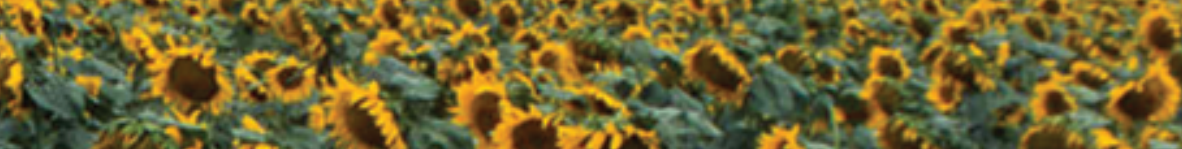

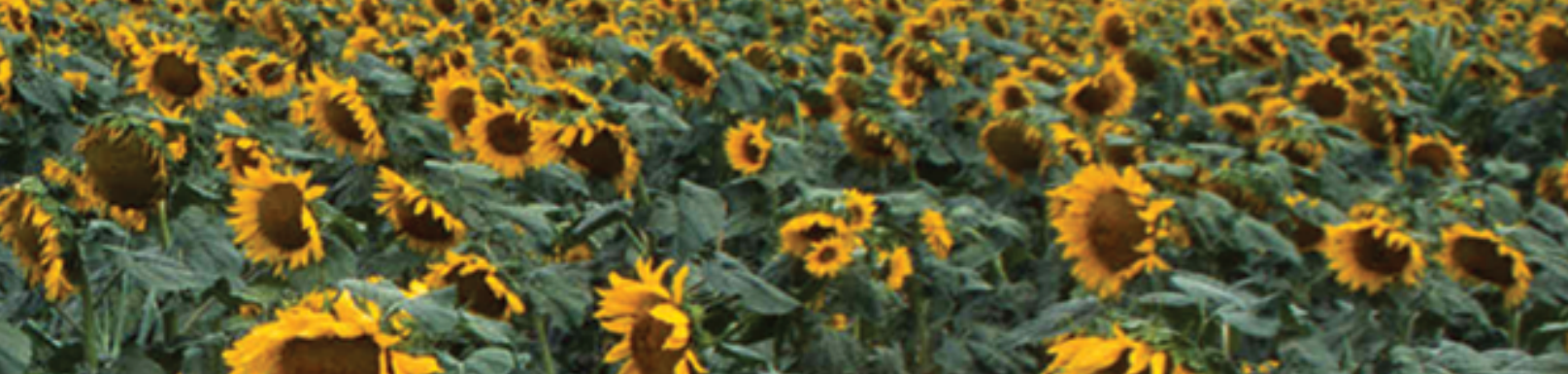

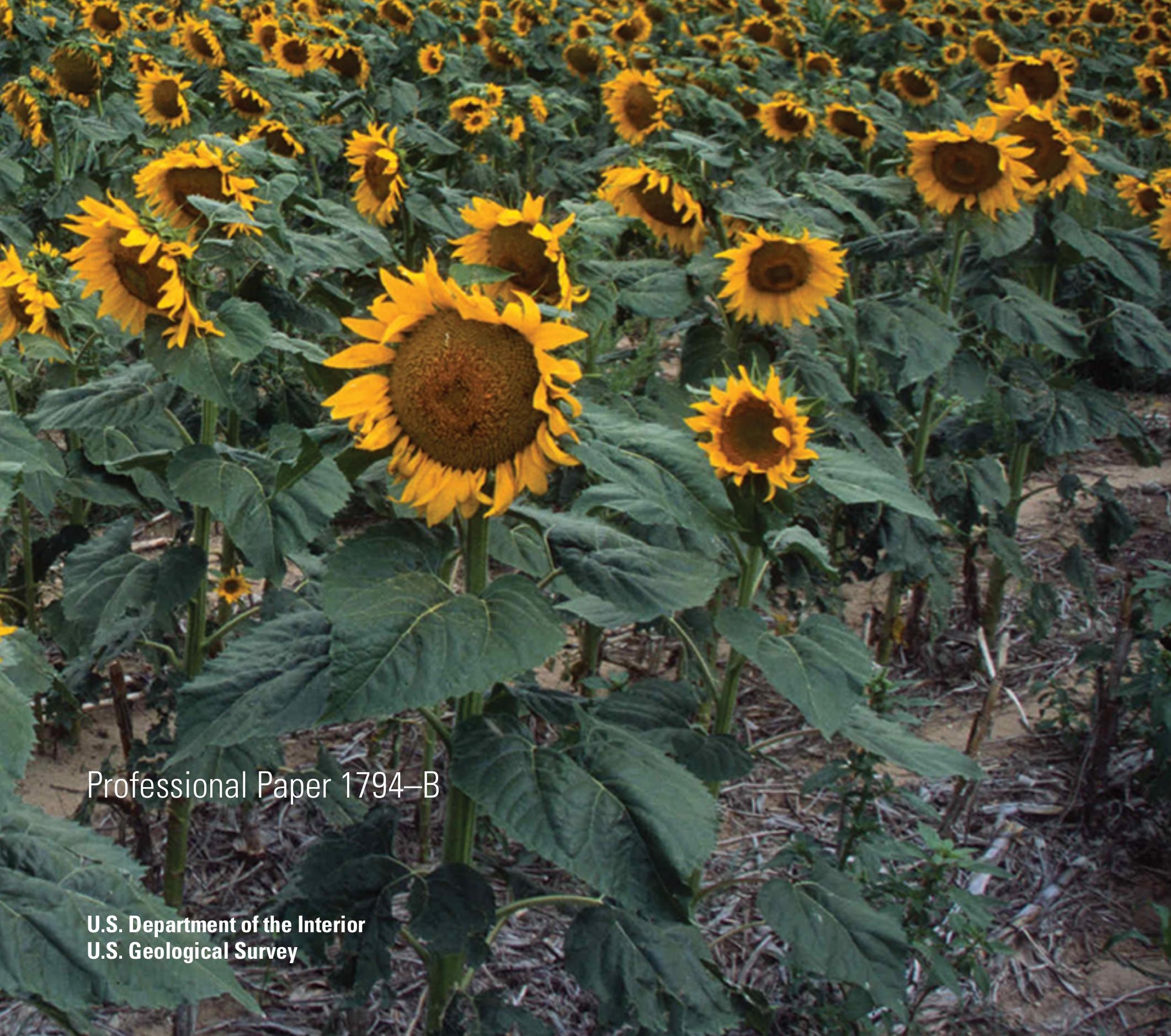



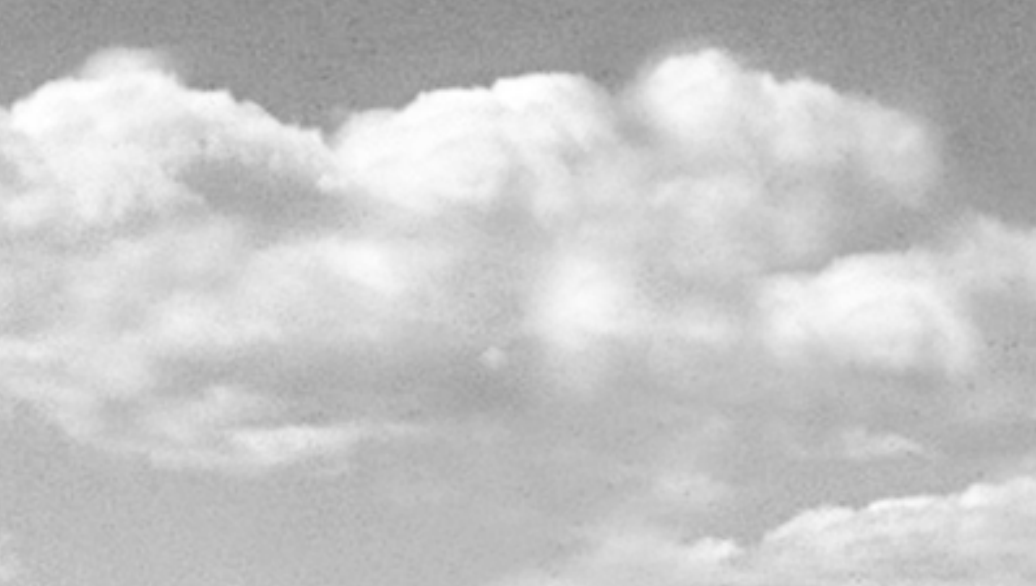

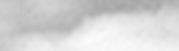

tra

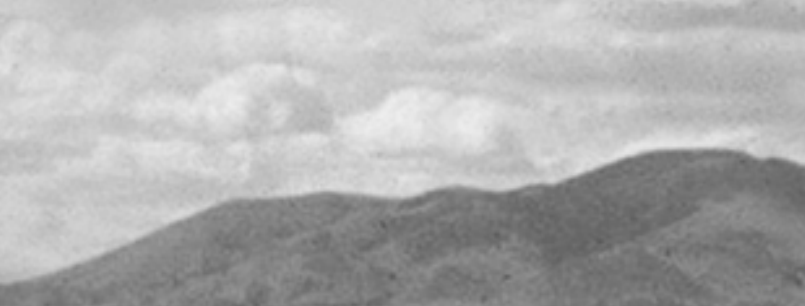

s.

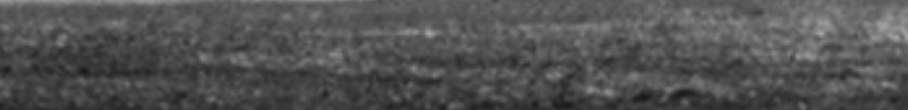

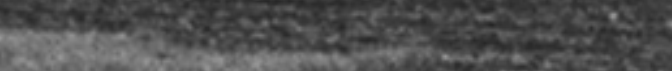

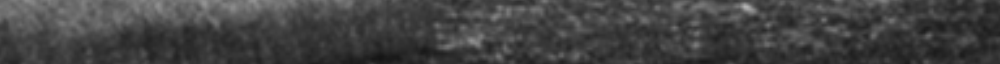

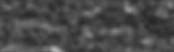

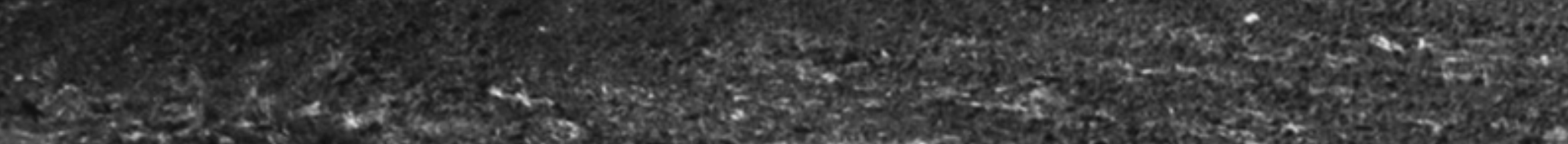

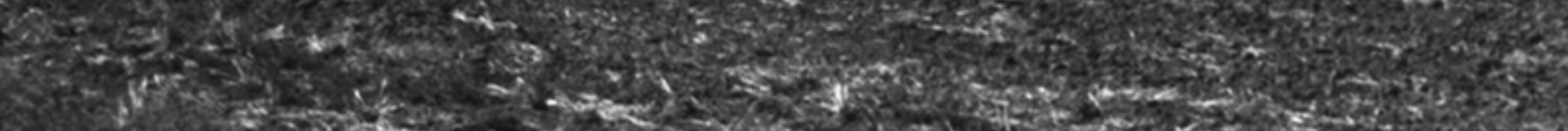
(3)

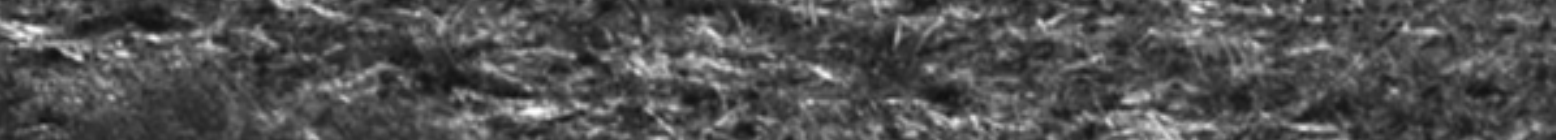

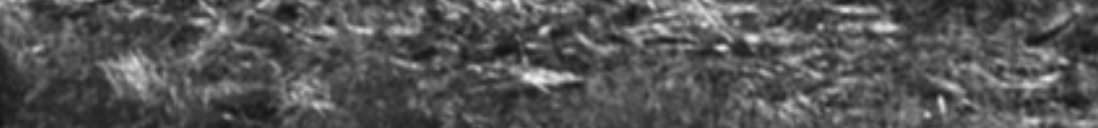
1.1. (2)

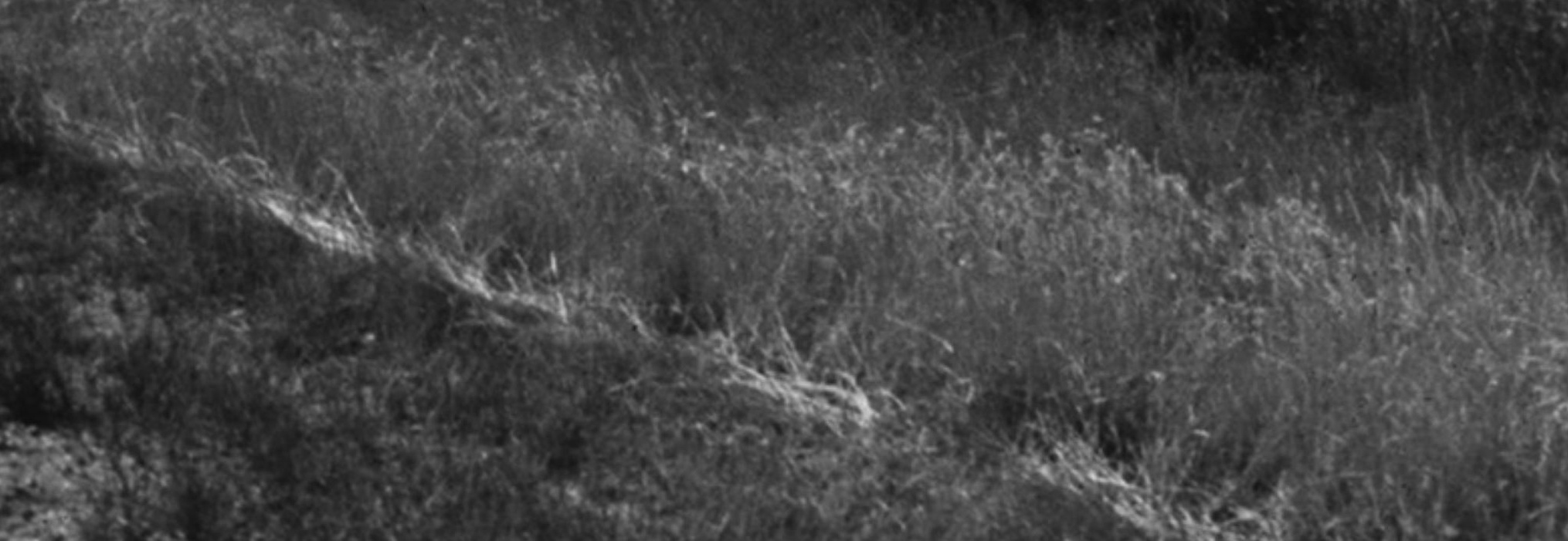




\section{Status and Trends of Land Change in the Great Plains of the United States- 1973 to 2000}

Edited by Janis L. Taylor, William Acevedo, Roger F. Auch, and Mark A. Drummond

Professional Paper 1794-B 


\title{
U.S. Department of the Interior SALLY JEWELL, Secretary
}

\section{U.S. Geological Survey \\ Suzette M. Kimball, Acting Director}

\author{
U.S. Geological Survey, Reston, Virginia: 2015
}

For more information on the USGS - the Federal source for science about the Earth, its natural and living resources, natural hazards, and the environment—visit http://www.usgs.gov/ or call 1-888-ASK-USGS (1-888-275-8747).

For an overview of USGS information products, including maps, imagery, and publications, visit http://www.usgs.gov/pubprod/.

To order this and other USGS information products, visit http://store.usgs.gov/.

Any use of trade, product, or firm names is for descriptive purposes only and does not imply endorsement by the U.S. Government.

Although this information product, for the most part, is in the public domain, it also may contain copyrighted materials as noted in the text. Permission to reproduce copyrighted items must be secured from the copyright owner.

Suggested citation:

Taylor, J.L., Acevedo, W., Auch, R.F., and Drummond, M.A., eds., 2015, Status and trends of land change in the Great Plains of the United States - 1973 to 2000: U.S. Geological Survey Professional Paper 1794-B, 180 p., http://dx.doi.org/10.3133/pp1794B.

ISSN 1044-9612 (print)

ISSN 2330-7102 (online)

http://dx.doi.org/10.3133/pp1794B

Cover:

Field of sunflowers in Elbert County, Colorado, about $80 \mathrm{~km}$ east of Colorado Springs, Colorado. Photograph taken in 2006.

Inside cover:

Wheat fields, with Sweet Grass Hills in background, in Liberty County, Montana, about 25 km north of Chester, Montana, and about $25 \mathrm{~km}$ south of Canadian border. Photograph taken in 2005. 


\section{Foreword}

This Professional Paper is the first multitemporal assessment of late-20th-century land change in the conterminous United States across all regions and all land-use and land-cover sectors. The work is the culmination of nearly 10 years of research and development by the U.S. Geological Survey, with support from the U.S. Environmental Protection Agency and the National Aeronautics and Space Administration, as well as university collaborators. It represents the most complete and comprehensive analysis of the rates, types, distribution, and drivers of recent changes in land use and land cover. The study bridges the gap between coarse-scale continental and global assessments and fine-scale local and regional case studies.

Land-change studies attempt to explain the "what, where, when, how, and why" of changes to the vegetation and to the use of the land. Land-change research is aimed specifically at measuring where change is occurring (and where it is not occurring); which land-use and land-cover classes are changing (and what they are changing to); how much land is changing (and how fast); and what drivers are responsible for the measured changes. The goal is not only to understand the scope of change but also to provide the information base necessary to evaluate, predict, and manage the consequences of change.

Like many key issues in climate change and ecosystem functioning, land use and land cover are both drivers and indicators of environmental quality. The National Research Council has identified the understanding of land-use dynamics as one of the grand challenges for environmental research — no other global-change parameter is so tightly intertwined with issues of past, present, and future land-use practices, weather patterns, soil and carbon dynamics, ecosystem health and diversity, economic development and policy, technology issues, human population size and distribution, and overall human health. People and their use of the land are interrelated in complex ways, and the effects of land-use and land-cover change can have a huge impact on their quality of life, on the goods and services that they can expect from the land, and on the hazards that they may face. Despite these profound consequences, the Intergovernmental Panel on Climate Change's Third Assessment Report has cited the lack of scientific understanding about the timing, magnitude, and direction of response of ecological, social, and economic systems to the combined effects of climate change and land-use and land-cover change as a key uncertainty in determining societal vulnerabilities and predicting both regional and global impacts of climate change.

Prior to this study, only sectorally specific or spatially limited assessments and inventories had been conducted to categorize land change in the United States. These efforts often included only certain land-use and land-cover classes or ownership categories, or they were conducted over short time intervals only, and integrating these various assessments into a comprehensive and consistent national synthesis of land change was not possible. The research presented in this Professional Paper has been specifically designed to provide the first comprehensive measurement of land-cover change in the conterminous United States.

Relying on Landsat satellite imagery — the longest continuous and consistent dataset of synoptic Earth observations - the authors characterize changes across 11 primary land-use and land-cover classes spanning four time periods between 1973 and 2000. For each of these time periods and classes, estimates of change are developed for each of 84 distinct ecological regions - or ecoregions - across the conterminous United States.

The results provide useful, if not essential, information for understanding climate change, biodiversity, resource management and planning, resource security, and disaster planning. A significant conclusion is that no single profile of land-use and land-cover change exists. Numerous different, and often complex, interactions between an ecoregion's socioeconomic drivers and its biological and physical characteristics have produced widespread regional and temporal variability in the rates, types, and total extent of land change. Among the scientific findings presented are estimates of overall forest decline in response to increased rates of disturbance, urbanization, and agricultural intensification.

This research provides a critical ecoregional to national perspective of U.S. land change in the conterminous United States. With the completion of the 1973-2000 assessment, this study lays a foundation for understanding the Nation's land-change dynamics and makes possible a new era for analyzing the consequences of land change, as well as for modeling future land changes.

\section{Suzattr h tumbare}

Acting Director, USGS 


\section{Preface}

U.S. Geological Survey (USGS) Professional Paper 1794-B is the second in a four-volume series on the status and trends of the Nation's land use and land cover, providing an assessment of the rates and causes of land-use and land-cover change in the Great Plains of the United States between 1973 and 2000. Volumes A, C, and D provide similar analyses for the Western United States, the Midwest-South Central United States, and the Eastern United States, respectively. The assessments of land-use and land-cover trends are conducted on an ecoregion-by-ecoregion basis, and each ecoregion assessment is guided by a nationally consistent study design that includes mapping, statistical methods, field studies, and analysis. Individual assessments provide a picture of the characteristics of land change occurring in a given ecoregion; in combination, they provide a framework for understanding the complex national mosaic of change and also the causes and consequences of change. Thus, each volume in this series provides a regional assessment of how (and how fast) land use and land cover are changing, and why. The four volumes together form the first comprehensive picture of land change across the Nation.

Geographic understanding of land-use and land-cover change is directly relevant to a wide variety of stakeholders, including land and resource managers, policymakers, and scientists. The chapters that follow present brief summaries of the patterns and rates of land change observed in each ecoregion in the Great Plains of the United States, together with field photographs, statistics, and comparisons with other assessments. In addition, a synthesis chapter summarizes the scope of land change observed across the entire Great Plains of the United States. The studies provide a way of integrating information across the landscape, and they form a critical component in the efforts to understand how land use and land cover affect important issues such as the provision of ecological goods and services and also the determination of risks to, and vulnerabilities of, human communities. Results from this project also are published in peer-reviewed journals, and they are further used to produce maps of change and other tools for land management, as well as to provide inputs for carbon-cycle modeling and other climate change research.

This report is only one of the products produced by USGS on land-use and land-cover change in the United States. Other reports and land-cover statistics are available online at http://landcovertrends.usgs.gov.

\section{Acknowledgments}

The U.S. Environmental Protection Agency's Office of Research and Development and the National Aeronautics and Space Administration provided initial funding to support this project.

The U.S. Geological Survey's (USGS) Geographic Analysis and Monitoring Program and Climate and Land Use Change Research and Development Program provided long-term support for this research.

Adam Davis (USGS) provided extensive support in the production of figures and tables.

All photographs contained within this Professional Paper were taken by various members of the Land Cover Trends research project while conducting field investigations between 1999 and 2010.

\section{Author Affiliations}

\author{
William Acevedo \\ Roger F. Auch \\ Mark S. Brooks \\ Mark A. Drummond \\ Beverly A. Friesen \\ Steven Kambly \\ Krista A. Karstensen \\ Carl L. Rich \\ Kristi L. Sayler \\ Michael P. Stier \\ Janis L. Taylor
}

U.S. Geological Survey

U.S. Geological Survey

U.S. Geological Survey

U.S. Geological Survey

U.S. Geological Survey

U.S. Geological Survey

U.S. Geological Survey

U.S. Geological Survey

U.S. Geological Survey

U.S. Geological Survey

Stinger Ghaffarian Technologies 


\section{Contents}

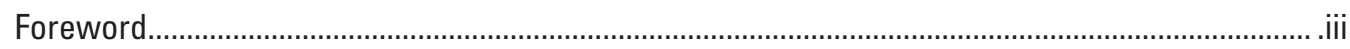

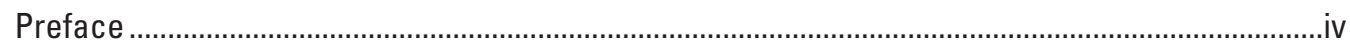

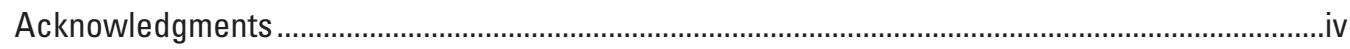

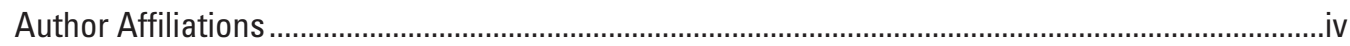

Regional Synthesis

Land-Cover Trends in the Great Plains of the United States - 1973 to 2000 ........................... 3

By Mark A. Drummond and Roger F. Auch

\section{Western Plains Ecoregions}

1. Central Great Plains Ecoregion ..............................................................................................

By Mark A. Drummond

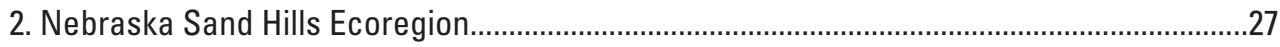

By Janis L. Taylor

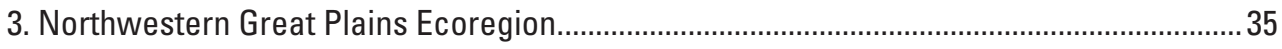

By Kristi L. Sayler

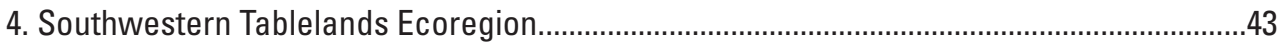

By Carl L. Rich and Mark A. Drummond

5. Western High Plains Ecoregion

By Mark A. Drummond

\section{Glaciated Plains Ecoregions}

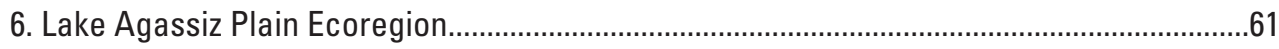

By Mark S. Brooks

7. Northern Glaciated Plains Ecoregion.................................................................................69

By Roger F. Auch

8. Northwestern Glaciated Plains Ecoregion........................................................................

By Janis L. Taylor

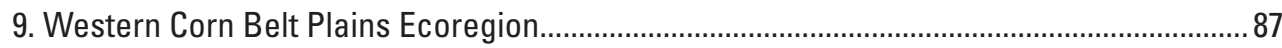

By Roger F. Auch

\section{East-Central Plains Ecoregions}

10. Central Irregular Plains Ecoregion.................................................................................... 99

By Krista A. Karstensen

11. Flint Hills Ecoregion......

By Steven Kambly

\section{Southern Plains Ecoregions}

12. Central Oklahoma/Texas Plains Ecoregion.

By Michael P. Stier

13. East Central Texas Plains Ecoregion.

By Krista A. Karstensen

14. Edwards Plateau Ecoregion.

By Michael P. Stier and Beverly A. Friesen 
15. Southern Texas Plains Ecoregion

141

By Michael P. Stier

16. Texas Blackland Prairies Ecoregion.

By Roger F. Auch

17. Western Gulf Coastal Plain Ecoregion

By Mark A. Drummond

Appendix 1. Map of Ecoregions in Conterminous United States. 169

Appendix 2. Abbreviations for Ecoregions in the Great Plains of the United States.

Appendix 3. Land-Cover Classification System Used in "Status and Trends of Land Change" Study. 173

Appendix 4. Methodology Used in "Status and Trends of Land Change" Study.

\section{Conversion Factors}

\begin{tabular}{lcl}
\hline Inch/Pound to SI & Multiply by & To obtain \\
\hline inch (in.) & Length & \\
inch (in.) & 2.54 & centimeter (cm) \\
foot (ft) & 25.4 & millimeter (mm) \\
mile (mi) & 0.3048 & meter (m) \\
\hline & 1.609 & kilometer $(\mathrm{km})$ \\
\hline acre & Area & \\
square mile (mi') & 0.004047 & square kilometer $\left(\mathrm{km}^{2}\right)$ \\
\hline
\end{tabular}

Temperature in degrees Celsius $\left({ }^{\circ} \mathrm{C}\right)$ may be converted to degrees Fahrenheit $\left({ }^{\circ} \mathrm{F}\right)$ as follows: ${ }^{\circ} \mathrm{F}=\left(1.8 \times{ }^{\circ} \mathrm{C}\right)+32$

Temperature in degrees Fahrenheit $\left({ }^{\circ} \mathrm{F}\right)$ may be converted to degrees Celsius $\left({ }^{\circ} \mathrm{C}\right)$ as follows: ${ }^{\circ} \mathrm{C}=\left({ }^{\circ} \mathrm{F}-32\right) / 1.8$ 


\section{Regional Synthesis}
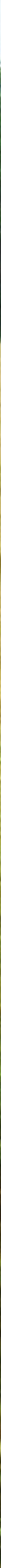


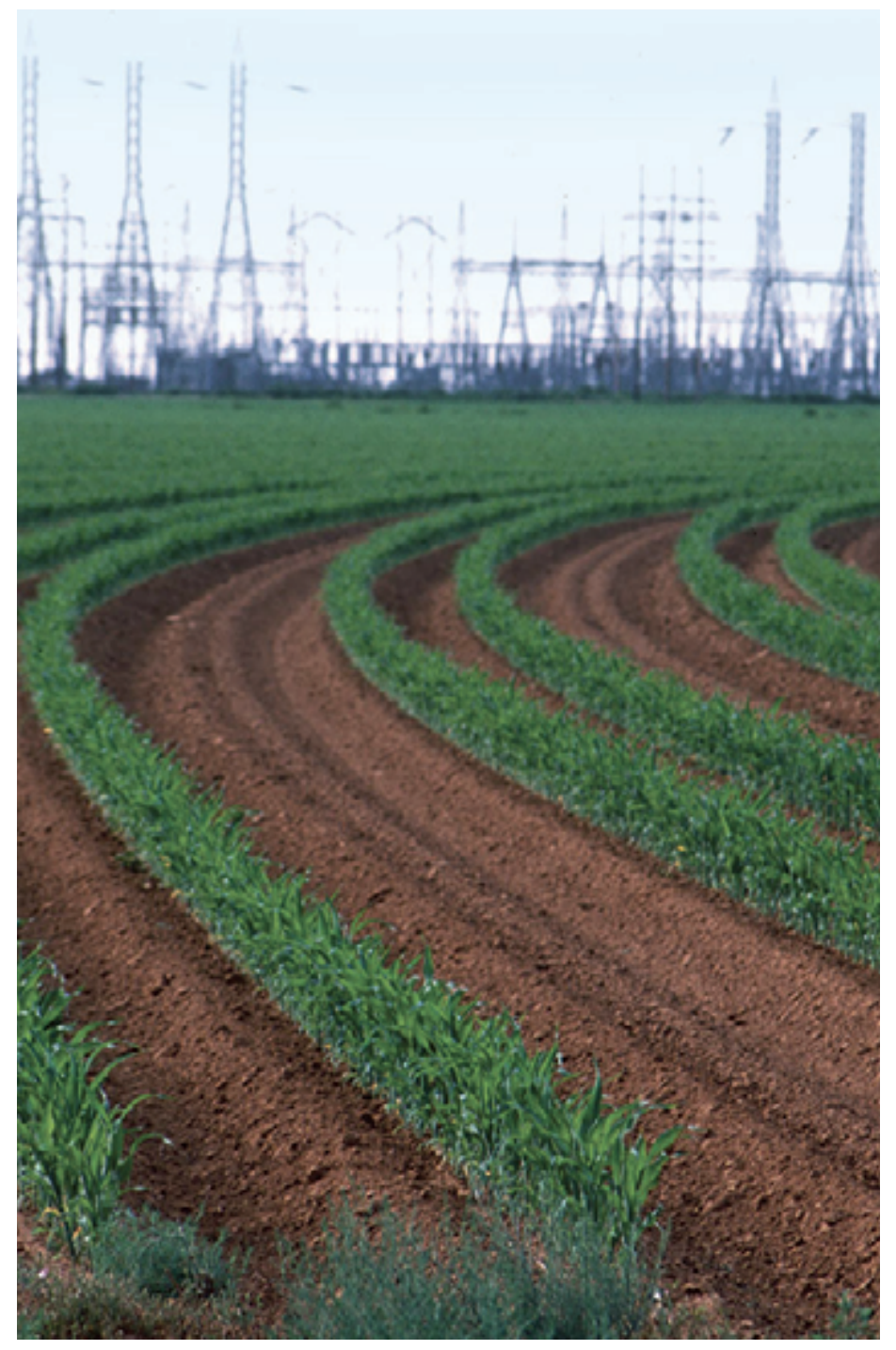




\title{
Land-Cover Trends in the Great Plains of the United States-1973 to 2000
}

\author{
By Mark A. Drummond and Roger F. Auch
}

\section{Introduction}

One of the important stories of the Great Plains of the United States is the geographic and temporal variability of recent land-use and land-cover change, including the underlying causes of land conversion. Because it is an agricultural region, land use in the Great Plains depends in large part on the available natural resources, as well as the inherent suitability of the region for crop production and rangeland grazing. Areas that have favorable soils and climate have had a long history of cultivation, whereas areas that are unsuitable for crops often are used for livestock grazing. Given a range of conditions and land-use regimes across such a large expanse, analysis shows distinct regional characteristics of land change that also vary across relatively short time scales, as human activities intersect with the environmental setting. The prevailing climate and other biological and physical factors (for example, precipitation variability, soil quality, water availability, and topography) affect in complex ways the actions of people and society (for example, public policies, regional and global economic opportunities, population and demographic change, technological advances, and local cultural histories) and, thus, can control the rates and characteristics of land-use and land-cover change.

The Great Plains as a geographic region has been variously defined (Rossum and Lavin, 2000). The region generally lies between the dense forests of the East and the mountains and deserts of the West. The vast, flat-to-rolling plains are used primarily for cropland, rangeland, and settlements. Weather can be extreme, and drought periodically affects the region. Precipitation amounts, which are limited in the western plains that sit in the rain shadow of the Rocky Mountains, increase toward the east, and temperature has a strong north-south gradient. The northeastern and extreme northern parts of the Great Plains are glaciated areas that have numerous "prairie pothole" wetlands, and they have more cropland than the western plains. The western plains primarily are a semiarid shortgrass steppe in which both streamside and groundwater irrigation from the High Plains (Ogallala) aquifer are important in places. Shrubland and forest are more prevalent in the southeastern part of the Great Plains where land-use practices and fire suppression have encouraged woody encroachment (Engle and others, 2008). Few large cities are situated in the interior plains, and population loss is a concern in numerous communities. Most large population centers in the Great Plains are on the fringes of the plains, especially in the southeastern part.

Beyond these broad generalizations, many areas within this expansive region have contrasting socioeconomic and environmental characteristics that potentially can have different effects on their land-use/land-cover trends. Ecoregions - that is, areas that are similar in their biotic-, abiotic-, terrestrial-, and aquatic-ecosystem components, with humans considered as part of the biota (McMahon and others, 2001) - serve as useful entities for studying regional land-use/land-cover change, as they can encapsulate both the similarities and differences in the range of potential land-use/land-cover changes that are likely to occur regionally (Gallant and others, 2004).

To understand the rates, types, and causes of land change, as well as to aid in assessing the consequences of change, the U.S. Geological Survey interpreted and analyzed trends of land-use/land-cover change, using the U.S. Environmental Protection Agency's Level III Ecoregions (Omernik, 1987; U.S. Environmental Protection Agency, 1999) as the spatial stratification. A statistical sampling approach was used, in part, to account for the large amount of error that can occur in assessing wall-to-wall change for multiple time-steps across large regions (Stehman and others, 2005). For the 17 ecoregions in the Great Plains of the United States, a set of $10 \times 10 \mathrm{~km}$ sample blocks was randomly selected for each ecoregion from a uniform grid. Within each sample block, land use/land cover was mapped, and its changes were interpreted, at a 60-m resolution using Landsat Multispectral Scanner, Thematic Mapper, and Enhanced Thematic Mapper Plus satellite data for five study dates:1973, 1980, 1986, 1992, and 2000. A detailed explanation of project methodology can be found in appendix 4 (see also, Loveland and others [2002] and Stehman and others [2003]). The approach provides a systematic basis for understanding land-use/landcover change and can aid in managing and planning for future human-environmental interaction.

\section{Regional Synthesis}

The U.S. Geological Survey analyzed land-use/land-cover change for 17 ecoregions in the Great Plains of the United States as part of a national assessment of land change (fig. 1A). For purposes of discussion, the 17 Great Plains ecoregions, which cover about 2,231,159 $\mathrm{km}^{2}\left(861,455 \mathrm{mi}^{2}\right)$, have been 


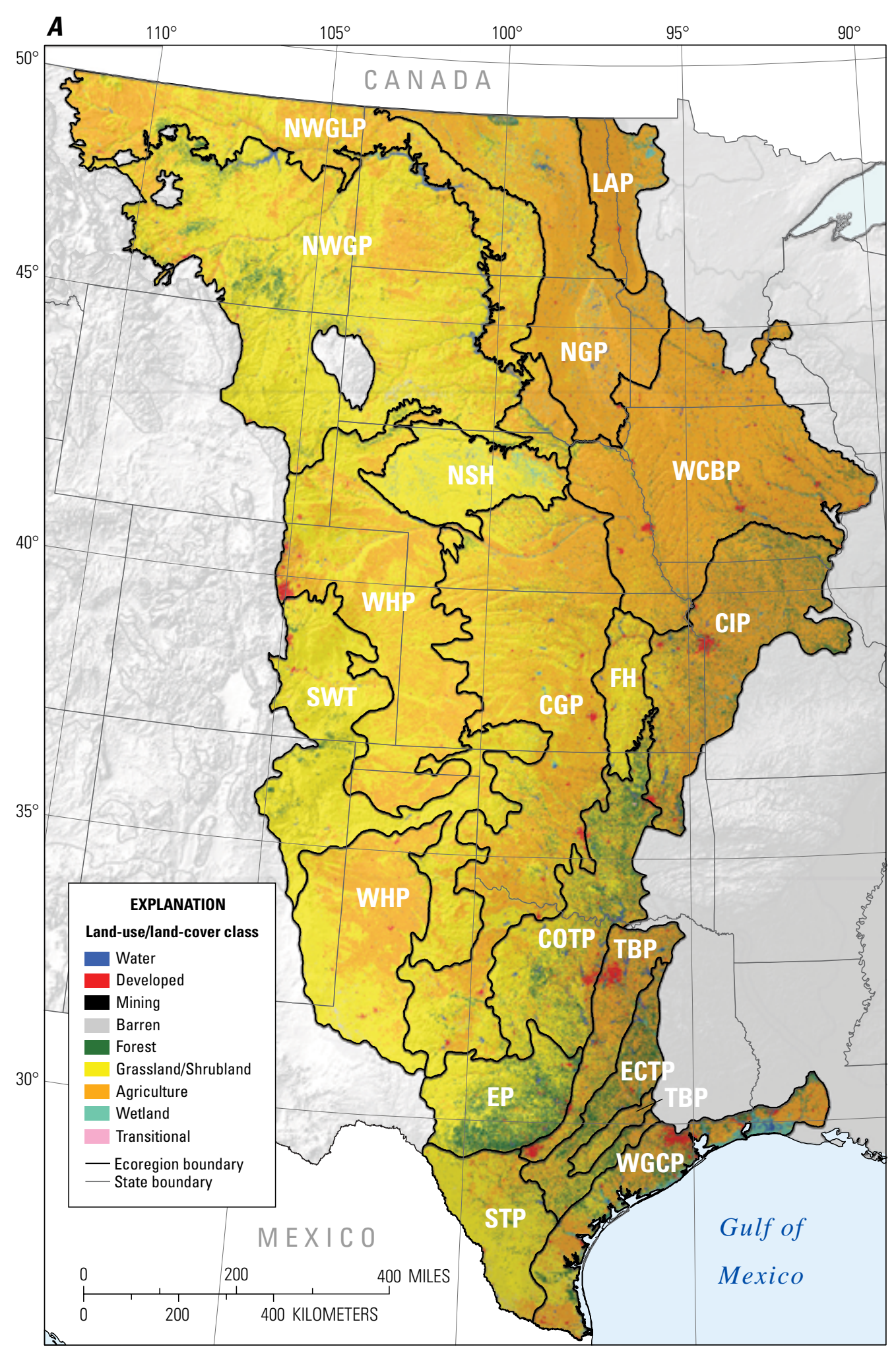

Figure 1. A, Map of all 17 ecoregions in Great Plains of United States, showing land-use/land-cover classes from 1992 National Land-Cover Database (Vogelmann and others, 2001); note that, for this "Status and Trends of Land Change" study, transitional land-cover class was subdivided into mechanically disturbed and nonmechanically disturbed classes. $B$, Map showing four main Great Plains ecoregion groups, modified from U.S. Environmental Protection Agency's (1997) Level II Ecoregions for Great Plains of United States. Within each ecoregion group, individual ecoregions share many similar physical and biological characteristics. $C$, List of four main Great Plains ecoregion groups depicted in figure $1 B$; also listed are individual ecoregions included in each ecoregion group, as well as ecoregion abbreviations used in figure $1 A$. 
divided into four main groups, within which the ecoregions share many similar physical and biological characteristics: the Western Plains Ecoregions, the Glaciated Plains Ecoregions, the East-Central Plains Ecoregions, and the Southern Plains Ecoregions (fig. 1B).

Agriculture and grassland/shrubland are the dominant land-cover classes in the Great Plains ecoregions (fig. 2). A substantial shift between the amount of both agriculture land cover, which includes all cropland and related agricultural uses except rangeland, and grassland/shrubland land cover occurred over the 27-year study period (table 1). Agriculture was the dominant land-cover class mapped in the 1973, 1980, and 1986 study dates. The total percentage of agriculture in the ecoregions increased from 46.0 percent in 1973 to 46.4 percent in both 1980 and 1986. Grassland/ shrubland became the dominant land-cover class by 2000 when it reached its greatest extent of 44.4 percent of the ecoregions. Taken together, grassland/shrubland and agriculture make up more than 88 percent of all land cover in the Great Plains ecoregions (fig. 3).

The total extent of forest land cover in the ecoregions was 5.8 percent in 2000, a slight decline from 1973 (5.9 percent). The total extent of water land cover in the ecoregions remained at 1.8 percent between 1973 and 1992, increasing to 2.1 percent in 2000. Developed land cover increased steadily in the ecoregions, increasing from 1.1 percent in 1973 to 1.5 percent in 2000. Wetland land cover was relatively consistent (1.8 percent, decreasing to 1.6 percent in 2000) through the study period (fig. 4), as was barren land cover, which remained at 0.6 percent. All other land-cover classes remained at or below 0.1 percent of the ecoregions (table 1). Because the biological and physical underpinnings, as well as the socioeconomic factors, vary across all the ecoregions, land-use/land-cover change in the Great Plains can be further understood by examining individual ecoregions.

Overall, an estimated 8.4 percent $\left(186,616 \mathrm{~km}^{2}\right)$ of land cover in the Great Plains ecoregions changed at least once between 1973 and 2000 (table 2). However, the overall amount of change varied substantially across the 17 Great Plains ecoregions (fig. 5). The ecoregion that experienced the highest amount of change was the Northwestern Glaciated Plains Ecoregion, at 14.1 percent, and the ecoregion that experienced the lowest amount of change was the Lake Agassiz Plain Ecoregion, at 1.5 percent. Both of these ecoregions are part of the Glaciated Plains Ecoregions group, which includes areas of Wisconsin-age glaciation and former glacial lakes in the northern and northeastern parts of the Great Plains.

Across the Great Plains, the characteristics of land-cover change varied from ecoregion to ecoregion, depending on both biological and physical factors. For example, the four ecoregions that had overall spatial change amounts of less than 5 percent have contrasting characteristics that constrain land-cover change and enable stability. For example, the Western Corn Belt Plains Ecoregion (3.2 percent overall spatial change) and the Lake Agassiz Plain Ecoregion (1.5 percent overall spatial change) have level topography and glacial-till soils that are well suited for intensive cultivation. Conversely, the Nebraska Sand Hills Ecoregion (4.0 percent overall spatial change) and the Flint Hills Ecoregion (2.2 percent overall spatial change) have hilly topography and poor soils, a combination that constrains cultivation in favor of rangeland use and grassland maintenance. However, both types of characteristics (prime cropland versus historical rangeland) resulted in relatively stable land-use patterns and low rates of change.

Ecoregions that have high rates of spatial change tend to have lands that are marginal for agriculture. Under adverse climatic or economic conditions, these marginal lands either cease to be viable cropland or are subject to other land-change processes. For example, fluctuations between grassland/shrubland and agriculture in the Northwestern Glaciated Plains Ecoregion (14.1 percent overall spatial change) and the Western High Plains Ecoregion (12.5 percent overall spatial change) contributed to the high rates of overall spatial change as marginal lands were brought into and out of production, depending on changing commodity prices, farm practices, and farm-program incentives. Cyclical clearance of mesquite (Prosopis spp.), juniper (Juniperus spp.), and scrub oak (Quercus spp.) for rangeland improvement and to enhance water availability contributed to the high rates of change in four of the ecoregions in the Southern Plains Ecoregions group, particularly in the Southern Texas Plains

Figure 1.-Continued

\author{
COTP - Central Oklahoma/Texas Plains Ecoregion \\ ECTP - East Central Texas Plains Ecoregion \\ EP-Edwards Plateau Ecoregion \\ STP - Southern Texas Plains Ecoregion \\ TBP - Texas Blackland Prairies Ecoregion \\ WGCP - Western Gulf Coastal Plain Ecoregion
}


Table 1. Areal percentages of land-use/land-cover classes in all $17 \mathrm{Great}$ Plains ecoregions for each of five study years $(1973,1980,1986,1992,2000)$ and corresponding margin-of-error values for 85-percent confidence interval (in brackets).

[Percentages are of total area in all Great Plains ecoregions. See appendix 3 for definitions of land-use/land-cover classifications]

\begin{tabular}{lccccc}
\hline \multicolumn{1}{c}{ Land-use/land-cover class } & $\begin{array}{c}\mathbf{1 9 7 3} \\
\text { [margin of error] } \\
(\% \text { of area) }\end{array}$ & $\begin{array}{c}\mathbf{1 9 8 0} \\
\text { [margin of error] } \\
(\% \text { of area) }\end{array}$ & $\begin{array}{c}\mathbf{1 9 8 6} \\
\text { [margin of error] } \\
(\% \text { of area) }\end{array}$ & $\begin{array}{c}\mathbf{1 9 9 2} \\
\text { [margin of error] } \\
(\% \text { of area) }\end{array}$ & $\begin{array}{c}\mathbf{2 0 0 0} \\
\text { [margin of error] } \\
(\% \text { of area) }\end{array}$ \\
\hline Water & $1.8[0.5]$ & $1.8[0.5]$ & $1.8[0.5]$ & $1.8[0.4]$ & $2.1[0.5]$ \\
Developed & $1.1[0.2]$ & $1.2[0.2]$ & $1.3[0.3]$ & $1.4[0.2]$ & $1.5[0.2]$ \\
Mechanically disturbed & $0.0[<0.1]$ & $0.0[<0.1]$ & $0.0[<0.1]$ & $0.1[<0.1]$ & $0.1[<0.1]$ \\
Mining & $0.1[<0.1]$ & $0.1[<0.1]$ & $0.1[<0.1]$ & $0.1[<0.1]$ & $0.1[<0.1]$ \\
Barren & $0.6[0.3]$ & $0.6[0.3]$ & $0.6[0.3]$ & $0.6[0.3]$ & $0.6[0.3]$ \\
Forest & $5.9[0.4]$ & $5.9[0.4]$ & $5.8[0.4]$ & $5.8[0.4]$ & $5.8[0.4]$ \\
Grassland/Shrubland & $42.7[1.6]$ & $42.2[1.6]$ & $42.1[1.2]$ & $44.2[1.6]$ & $44.4[1.6]$ \\
Agriculture & $46.0[1.6]$ & $46.4[1.6]$ & $46.4[1.6]$ & $44.2[1.6]$ & $43.8[1.6]$ \\
Wetland & $1.8[0.2]$ & $1.8[0.2]$ & $1.8[0.2]$ & $1.8[0.2]$ & $1.6[0.2]$ \\
Nonmechanically disturbed & $0.1[>0.1]$ & $0.0[0.0]$ & $0.0[0.0]$ & $0.0[<0.1]$ & $0.0[<0.1]$ \\
\hline
\end{tabular}

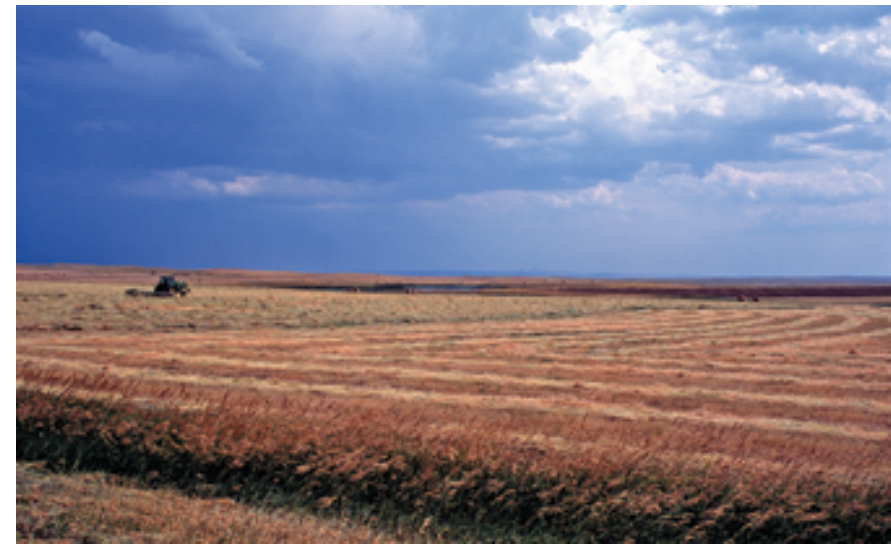

Figure 2. Dryland agriculture in Northwestern Great Plains Ecoregion.

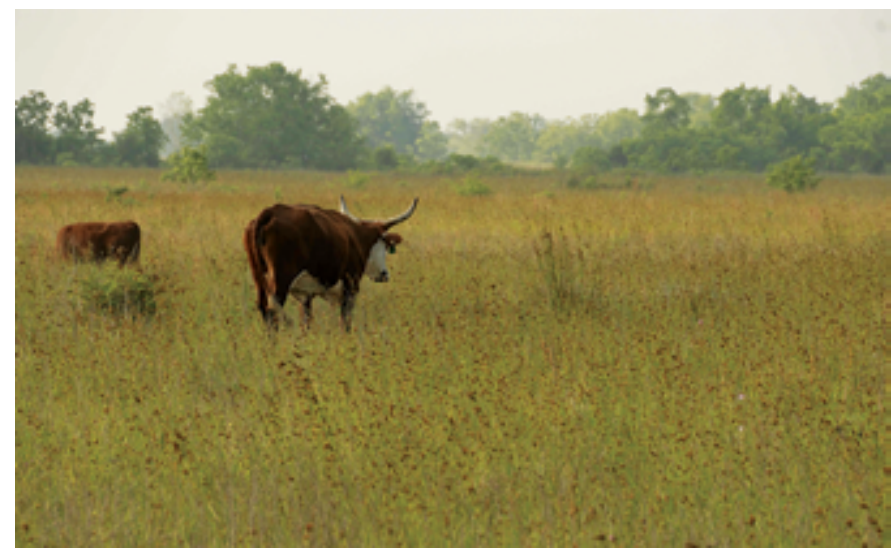

Figure 3. Livestock grazing in Western Gulf Coastal Plain Ecoregion.

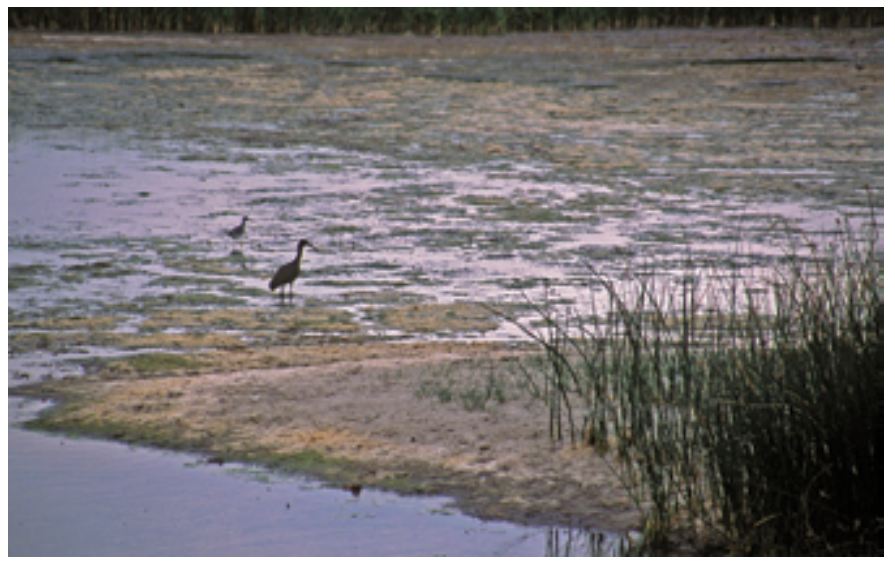

Figure 4. Wetland area in Nebraska Sand Hills Ecoregion. Wetlands dot many Great Plains ecoregions, providing vital habitat for birds and other wildlife.

Ecoregion (12.0 percent overall spatial change) where woody vegetation is removed periodically, often through state-funded brush-control programs.

Population changes in smaller cities across the Great Plains, and in the Southern Plains Ecoregions group in particular, affected the conversion of agriculture and grassland/shrubland. For example, in the Texas Blackland Prairies Ecoregion (11.1 percent overall spatial change), urbanization of former agriculture land made up a large component of change. The Western High Plains Ecoregion (12.5 percent overall spatial change) has had the most land enrolled in the Conservation Reserve Program (CRP) since it was enacted by Congress in 1985 to provide economic incentive to convert environmentally sensitive cropland from agriculture to perennial grassland/shrubland cover. 


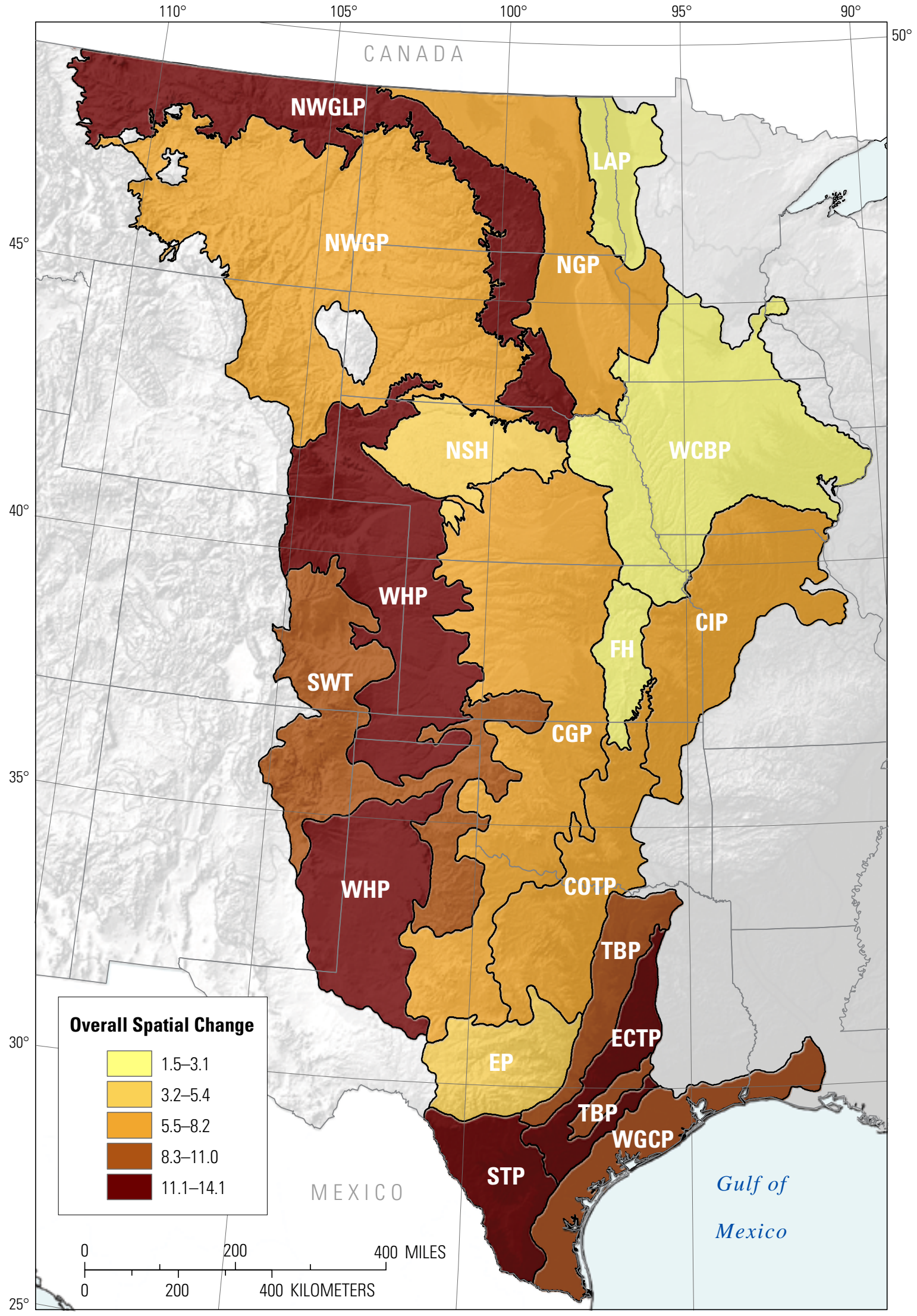

Figure 5. Map showing overall spatial change, as percent of ecoregion area, for each of 17 Great Plains ecoregions over entire study period (1973-2000). 
Table 2. Overall spatial change in each Great Plains ecoregion (in square kilometers and as percent of ecoregion) for entire study period (1973 to 2000) and corresponding margin-of-error values for 85-percent confidence interval (in brackets).

\begin{tabular}{|c|c|c|c|c|}
\hline \multirow{2}{*}{ Ecoregion } & & \multirow{2}{*}{$\begin{array}{l}\text { Ecoregion } \\
\text { area }\left(\mathbf{k m}^{2}\right)\end{array}$} & \multicolumn{2}{|c|}{ Overall spatial change [margin of error] } \\
\hline & & & $\left(\mathbf{k m}^{2}\right)$ & (\% of ecoregion) \\
\hline \multicolumn{5}{|c|}{ Western Plains Ecoregions } \\
\hline Western High Plains Ecoregion & & 288,752 & $36,094[6,641]$ & $12.5[2.3]$ \\
\hline Southwestern Tablelands Ecoregion & & 159,938 & $14,075[3,679]$ & $8.8[2.3]$ \\
\hline Central Great Plains Ecoregion & & 273,189 & $22,675[3,825]$ & $8.3[1.4]$ \\
\hline Northwestern Great Plains Ecoregion & & 346,883 & $25,669[6,938]$ & $7.4[2.0]$ \\
\hline \multirow[t]{2}{*}{ Nebraska Sand Hills Ecoregion } & & 60,541 & 2,422 [908] & $4.0[1.5]$ \\
\hline & Totals & $1,129,304$ & $100,934[11,293]$ & $8.9[1.0]$ \\
\hline \multicolumn{5}{|c|}{ Glaciated Plains Ecoregions } \\
\hline Northwestern Glaciated Plains Ecoregion & & 160,684 & $22,656[3,535]$ & $14.1[2.2]$ \\
\hline Northern Glaciated Plains Ecoregion & & 141,341 & $10,459[1,979]$ & $7.4[1.4]$ \\
\hline Western Corn Belt Plains Ecoregion & & 216,363 & $6,924[1,731]$ & $3.2[0.8]$ \\
\hline \multirow[t]{2}{*}{ Lake Agassiz Plain Ecoregion } & & 40,636 & $610[163]$ & $1.5[0.4]$ \\
\hline & Totals & 559,024 & $40,649[4,472]$ & $7.3[0.8]$ \\
\hline \multicolumn{5}{|c|}{ East-Central Plains Ecoregions } \\
\hline Central Irregular Plains Ecoregion & & 122,589 & $8,949[2,452]$ & $7.3[2.0]$ \\
\hline \multirow[t]{2}{*}{ Flint Hills Ecoregion } & & 27,911 & $614[140]$ & $2.2[0.5]$ \\
\hline & Totals & 150,500 & $9,563[2,408]$ & $6.4[1.6]$ \\
\hline \multicolumn{5}{|c|}{ Southern Plains Ecoregions } \\
\hline Central Oklahoma/Texas Plains Ecoregion & & 103,412 & $6,722[1,241]$ & $6.5[1.2]$ \\
\hline East Central Texas Plains Ecoregion & & 44,076 & $5,333[793]$ & $12.1[1.8]$ \\
\hline Southern Texas Plains Ecoregion & & 54,744 & $6,569[1,369]$ & $12.0[2.5]$ \\
\hline Texas Blackland Prairies Ecoregion & & 50,501 & $5,606[1,313]$ & $11.1[2.6]$ \\
\hline Western Gulf Coastal Plain Ecoregion & & 80,965 & $8,016[1,781]$ & $9.9[2.2]$ \\
\hline \multirow[t]{2}{*}{ Edwards Plateau Ecoregion } & & 58,634 & $3,225[704]$ & $5.5[1.2]$ \\
\hline & Totals & 392,333 & $35,470[2,311]$ & $9.0[0.8]$ \\
\hline All Great Plains ecoregions & & $2,231,161$ & $186,616[10,639]$ & $8.4[0.5]$ \\
\hline
\end{tabular}

Water availability in the Great Plains from streams and aquifers, which include the immense High Plains (Ogallala) aquifer and also the Missouri and Platte Rivers, enabled the expansion of intensive irrigation (fig. 6) and contributed to the conversion of grassland/shrubland to agriculture (Dennehy and others, 2002). However, water scarcity in the Western High Plains Ecoregion, caused in some areas by historically high rates of water use, also constrained expansion (fig. 7). Climate variability played a role as well, and changes in precipitation patterns resulted in both wetland conversion and lake expansion in the Northern Glaciated Plains Ecoregion (7.4 percent overall spatial change).
Changes throughout the entire 27-year study period resulted in net increases in grassland/shrubland, developed, water, mining, and mechanically disturbed land-cover classes (table 3; fig. 8). Grassland/shrubland also experienced the greatest amount of gross change, followed closely by agriculture (table 4). Net change in land cover is a measure of the end result of conversions associated with each land-cover class, whereas gross changes indicate the total area of change (table 4), which can be much larger than the net change (for example, timber-harvest cycles and also the cyclic transitions between agriculture and grassland/ shrubland). In addition, expansions in some locations often are counteracted by declines in others; the unidirectional, relatively permanent conversion to developed land is a notable exception. 
Table 3. Net areal changes in land-use/land-cover classes in all 17 Great Plains ecoregions during each of four time periods and corresponding margin-of-error values for 85-percent confidence interval (in brackets).

[See appendix 3 for definitions of land-use/land-cover classifications]

\begin{tabular}{lcccc}
\hline \multirow{2}{*}{ Land-use/land-cover class } & \multicolumn{4}{c}{ Net change [margin of error] (km²) } \\
\cline { 2 - 5 } & $\mathbf{1 9 7 3 - 1 9 8 0}$ & $\mathbf{1 9 8 0 - 1 9 8 6}$ & $\mathbf{1 9 8 6 - 1 9 9 2}$ & $\mathbf{1 9 9 2 - 2 0 0 0}$ \\
\hline Water & $-200[589]$ & $1,278[749]$ & $-743[1,486]$ & $5,573[1,585]$ \\
Developed & $2,686[791]$ & $1,628[370]$ & $2,003[473]$ & $3,234[667]$ \\
Mechanically disturbed & $172[292]$ & $101[316]$ & $656[977]$ & $-48[1,057]$ \\
Mining & $286[112]$ & $386[183]$ & $323[142]$ & $412[127]$ \\
Barren & $-75[169]$ & $-367[233]$ & $499[540]$ & $-89[393]$ \\
Forest & $-1,253[311]$ & $-567[376]$ & $-804[404]$ & $-1,083[349]$ \\
Grassland/Shrubland & $-9,780[3,417]$ & $-2,952[3,277]$ & $46,853[7,084]$ & $4,730[5,262]$ \\
Agriculture & $9,249[2,780]$ & $967[3,268]$ & $-49,506[7,094]$ & $-9,438[5,166]$ \\
Wetland & $305[529]$ & $-473[486]$ & $682[740]$ & $-3,596[1,332]$ \\
Nonmechanically disturbed & $-1,390[1,992]$ & $0[0]$ & $36[37]$ & $305[452]$ \\
\hline
\end{tabular}

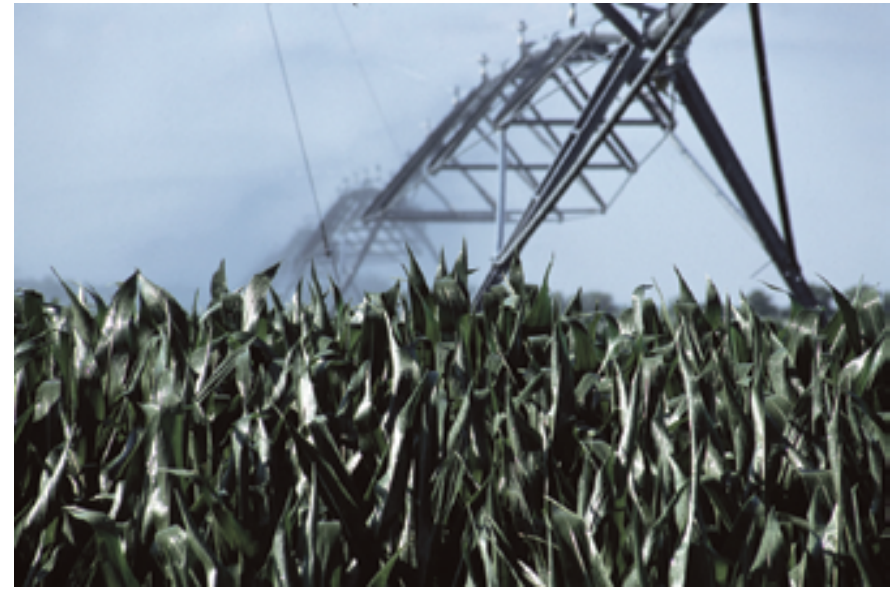

Figure 6. Irrigation of cropland in Central Great Plains Ecoregion.

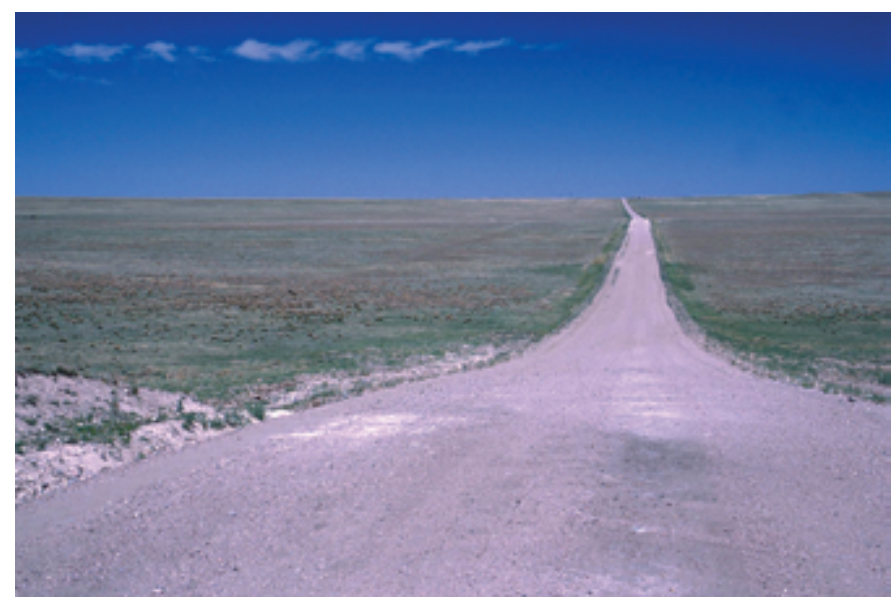

Figure 7. Open rangeland in Western High Plains Ecoregion.

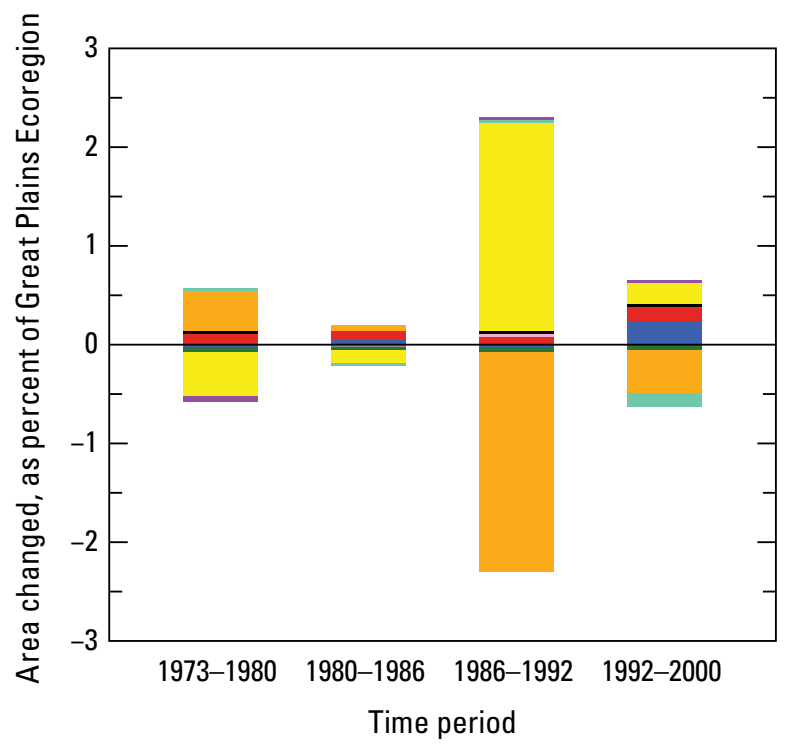

\section{EXPLANATION LAND-USE/LAND-COVER CLASS}

\begin{tabular}{|c|c|}
\hline Water & Forest \\
\hline Developed & Grassland/Shrubland \\
\hline Mechanically disturbed & Agriculture \\
\hline Mining & Wetland \\
\hline Barren & Nonmechanically disturbed \\
\hline & Ice/Snow \\
\hline
\end{tabular}

Figure 8. Estimated net change in all 17 Great Plains ecoregions by time period for each land-cover class. Bars above zero axis represent net gain, whereas bars below zero represent net loss. Note that not all land-cover classes shown in explanation may be represented in figure. See appendix 3 for definitions of land-use/ land-cover classifications. 
Table 4. Gross spatial changes and net areal changes in land-use/land-cover classes in all 17 Great Plains ecoregions for entire study period (1973 to 2000) and corresponding margin-of-error values for 85-percent confidence interval (in brackets).

[Percentages are of total area in all Great Plains ecoregions. See appendix 3 for definitions of land-use/land-cover classifications]

\begin{tabular}{lcccc}
\hline \multirow{2}{*}{\begin{tabular}{l} 
Land-use/land-cover class \\
\cline { 2 - 4 }
\end{tabular}} & \multicolumn{2}{c}{$\begin{array}{c}\text { Gross spatial change (1973-2000) } \\
\text { [margin of error] }\end{array}$} & $\begin{array}{c}\text { Net areal change (1973-2000) } \\
\text { [margin of error] }\end{array}$ \\
\cline { 2 - 5 } Water & $\mathbf{( k \mathbf { k m } ^ { 2 } )}$ & $\mathbf{( \% \text { of area) }}$ & $\mathbf{( \mathbf { k m } ^ { 2 } )}$ & $\mathbf{( \% \text { change) }}$ \\
Developed & $14,833[2,360]$ & $0.7[0.1]$ & $5,908[1,802]$ & 14.7 \\
Mechanically disturbed & $9,602[1,789]$ & $0.4[0.1]$ & $9,551[2,012]$ & 38.3 \\
Mining & $4,524[1,384]$ & $0.2[0.1]$ & $880[436]$ & 136.5 \\
Barren & $2,372[452]$ & $0.1[<0.1]$ & $1,407[389]$ & 116.6 \\
Forest & $2,636[917]$ & $0.1[<0.1]$ & $-33[611]$ & -0.2 \\
Grassland/Shrubland & $11,999[1,369]$ & $0.5[0.1]$ & $-3,706[911]$ & -2.8 \\
Agriculture & $159,861[10,634]$ & $7.2[0.5]$ & $38,851[9,938]$ & 4.1 \\
Wetland & $156,841[10,648]$ & $7.0[0.5]$ & $-48,728[9,812]$ & -4.8 \\
Nonmechanically disturbed & $12,917[2,125]$ & $0.6[0.1]$ & $-3,081[1,356]$ & -7.7 \\
\hline
\end{tabular}

\section{Agriculture Land-Cover Class}

The agriculture land-cover class, one of two primary landcover classes in the Great Plains ecoregions, declined 2.2 percent $\left(49,086 \mathrm{~km}^{2}\right)$ between 1973 and 2000, which was the greatest amount of net change, and it had a gross change of 7.0 percent $\left(156,841 \mathrm{~km}^{2}\right)$, the second highest amount (table 4). Only three ecoregions had a net gain in agriculture throughout the entire study period: the Nebraska Sand Hills Ecoregion (1.5 percent), the Southern Texas Plains Ecoregion (1.0 percent), and the Edwards Plateau Ecoregion ( 0.6 percent). In most ecoregions, agriculture expanded between 1973 and 1980, a period in which overseas grain exports provided new economic opportunities and public policies encouraged farmers to expand their land in cultivation. Some expansion continued between 1980 and 1986 in several ecoregions, although at a slower rate. The earlier gains in agriculture were more than offset between 1986 and 2000 by conversions from agriculture to grassland/shrubland. In the Edwards Plateau Ecoregion, forest clearance and agricultural expansion were the leading changes between 1973 and 2000.

Between 1973 and 1986, much of the increase in agriculture occurred in the Western Plains Ecoregions group, which had substantial amounts of land that was marginal for cultivation. Conversely, ecoregions that had an advantageous climate, as well as level topography and suitable soils (for example, the Western Corn Belt Plains and Lake Agassiz Plain Ecoregions), tended to be relatively stable or have small declines in agriculture. The largest decline in agriculture between 1973 and 1986 occurred in the Texas Blackland Prairies Ecoregion, which also had a substantial increase in development that continued throughout the entire study period.
Between 1986 and 1992, when the Conservation Reserve Program (CRP) took effect, all ecoregions lost agriculture land cover, and most continued to decline between 1992 and 2000. The total amount of CRP land in the United States reached a plateau in the early 1990s. The extent of CRP lands varied across the Great Plains: the Western High Plains Ecoregion had the most land enrolled in the program (9.5 percent), and the Edwards Plateau Ecoregion had the least (0.0 percent) (U.S. Department of Agriculture, 1920-2002 [various years]). Although the most common conversion during the 27-year study period was from agriculture to grassland/shrubland (106,603 km²), agriculture declines also were caused by urbanization, land abandonment, reservoir construction, wetland expansion, and mining. The trends of change during all four time periods indicate that land cover in the Great Plains ecoregions is capable of significant fluctuation, which is enabled by both their underlying biological and physical factors and the pressures of land-use and socioeconomic change (fig. 9).

\section{Grassland/Shrubland Land-Cover Class}

The grassland/shrubland land-cover class had the highest amount of gross change in the Great Plains ecoregions between 1973 and 2000, at 7.2 percent (159,861 $\left.\mathrm{km}^{2}\right)$; in addition, it had the second highest amount of net change, at 1.7 percent $\left(37,930 \mathrm{~km}^{2}\right)$ (table 4). In many regards, the characteristics of land-cover change in grassland/shrubland are inverse to those in agriculture (fig. 10). The total area of grassland/shrubland declined between 
1973 and 1986 as agriculture expanded, but, after 1986, grassland/shrubland expanded greatly owing to a decline in agriculture land cover. For example, in the semiarid Western High Plains Ecoregion, agriculture gained nearly 1.6 percent from grassland/shrubland as irrigation expanded between 1973 and 1980; however, this was followed by expansion of grassland/shrubland between 1986 and 2000, affecting about 7.5 percent of the ecoregion. Overall, the extent of grassland/ shrubland change was highest in the Great Plains ecoregions between 1986 and 1992, supporting the premise that the

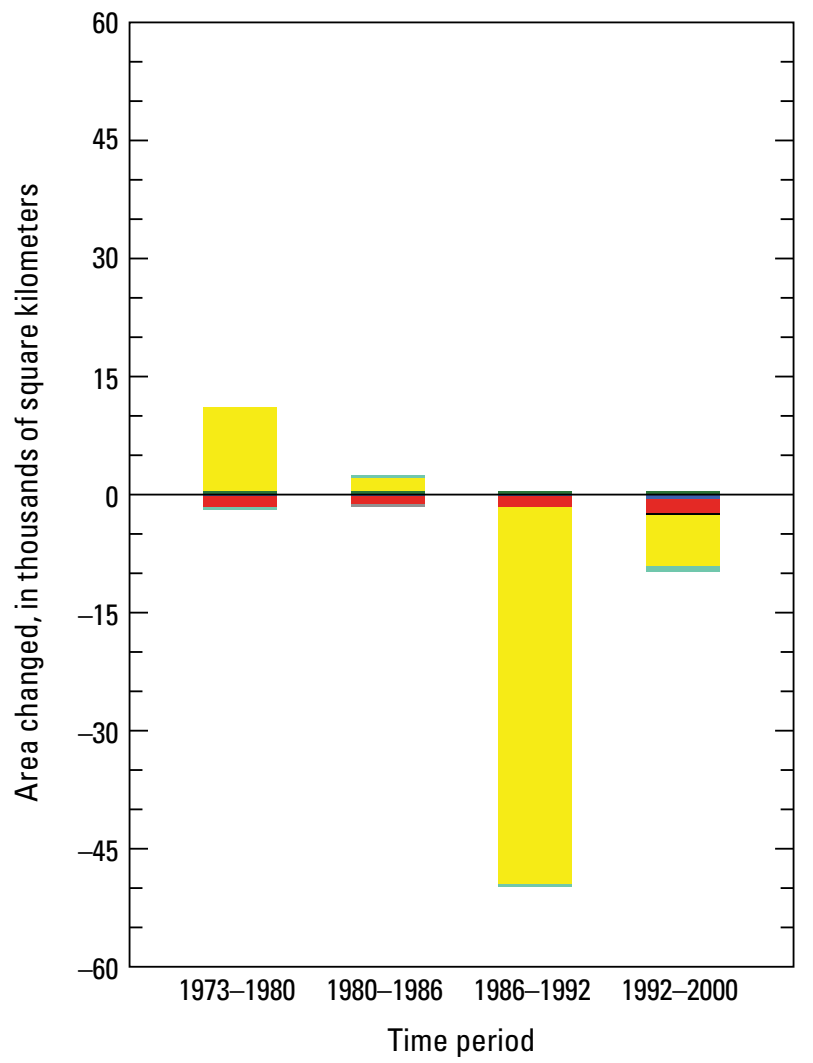

EXPLANATION LAND-USE/LAND-COVER CLASS

\begin{tabular}{|c|}
\hline Water \\
\hline Developed \\
\hline Mechanically disturbed \\
\hline Mining \\
\hline Barren \\
\hline
\end{tabular}

\begin{tabular}{l}
\hline Forest \\
\hline Grassland/Shrubland \\
\hline Agriculture \\
\hline$\square$ Wetland \\
Nonmechanically disturbed \\
Ice/Snow
\end{tabular}

Figure 9. Gross change (area gained from, and lost to, other land-cover classes) in agriculture land-cover class in all $17 \mathrm{Great}$ Plains ecoregions over entire study period (1973-2000). Colored bars above zero axis indicate land-cover classes that lost area to agriculture and amounts of area lost, whereas colored bars below zero axis indicate land-cover classes that gained area from agriculture and amounts of area gained.
CRP and other drivers of agricultural abandonment were important forces of grassland/shrubland change, including those changes that stem from the ongoing intensification, industrialization, and consolidation of agriculture.

Across the Great Plains ecoregions, grassland/shrubland converted to developed (3,152 $\left.\mathrm{km}^{2}\right)$ and to forest $\left(2,958 \mathrm{~km}^{2}\right)$, although the net result was often an increase in grassland/ shrubland because of its gains from agriculture. For example, the Texas Blackland Prairies Ecoregion had a net gain in grassland/shrubland during each time period as agriculture

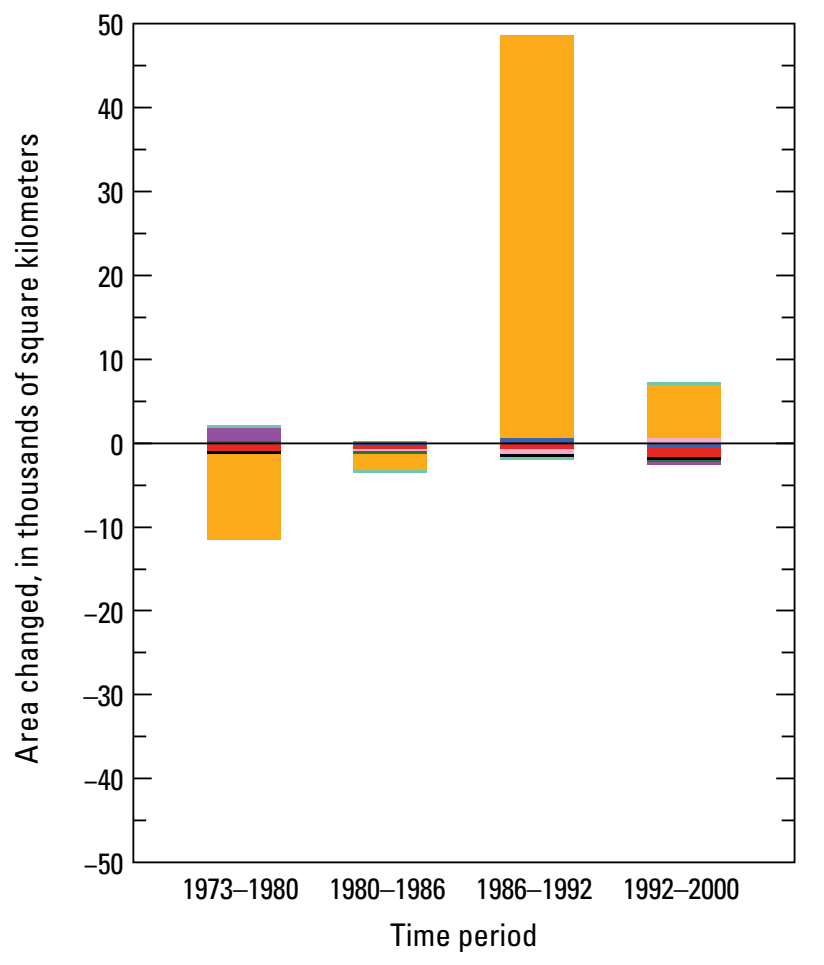

\section{EXPLANATION LAND-USE/LAND-COVER CLASS}

\begin{tabular}{|c|c|}
\hline Water & Forest \\
\hline Developed & Grassland/Shrubland \\
\hline Mechanically disturbed & Agriculture \\
\hline Mining & Wetland \\
\hline Barren & Nonmechanically disturbed \\
\hline & Ice/Snow \\
\hline
\end{tabular}

Figure 10. Gross change (area gained from, and lost to, other land-cover classes) in grassland/shrubland land-cover class in all 17 Great Plains ecoregions over entire study period (1973-2000). Colored bars above zero axis indicate land-cover classes that lost area to grassland/shrubland and amounts of area lost, whereas colored bars below zero axis indicate land-cover classes that gained area from grassland/shrubland and amounts of area gained. 
was abandoned or deintensified, despite a relatively large amount of urban expansion. Additional gross land-cover changes involving grassland/shrubland were found primarily in the Southern Plains Ecoregions group as a result of brush removal, a cyclical change that involves the conversion of grassland/shrubland to mechanically disturbed and then back to grassland/shrubland $\left(4,524 \mathrm{~km}^{2}\right)$ (fig. 11).

Grassland/shrubland either increased or was relatively constant in most ecoregions, the exception being small declines in the Central Great Plains Ecoregion (-0.1 percent), the Southern Texas Plains Ecoregion ( -0.9 percent), and the Nebraska Sand Hills Ecoregion (-1.4 percent). Decreases in the Southern Texas Plains Ecoregion were caused by brush removal for livestock grazing and invasive-species control, as well as for agricultural expansion and increases in developed land and mining. Grassland/shrubland in the sparsely populated Nebraska Sand Hills Ecoregion declined primarily as cropland expanded along the margins of the ecoregion.

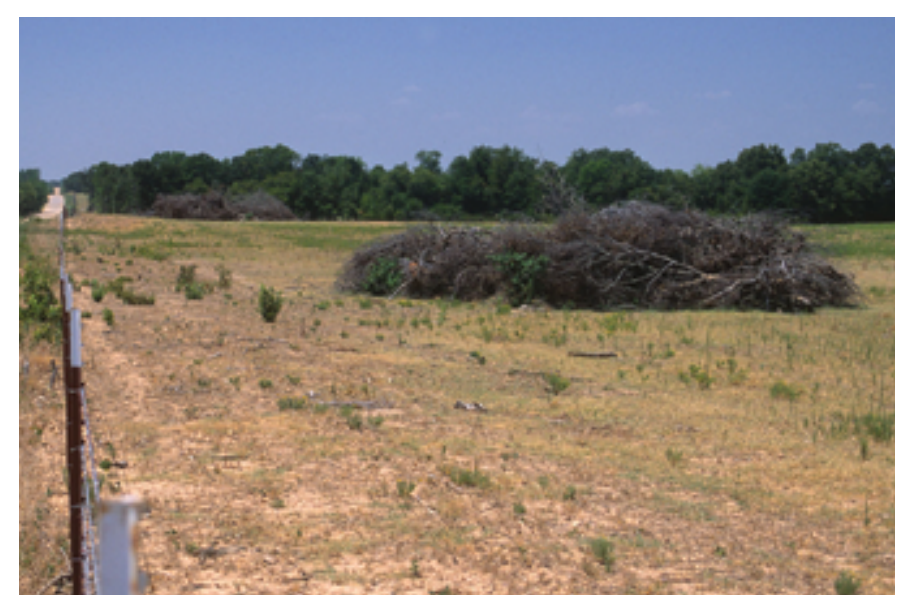

Figure 11. Brush clearance in Southern Texas Plains Ecoregion.

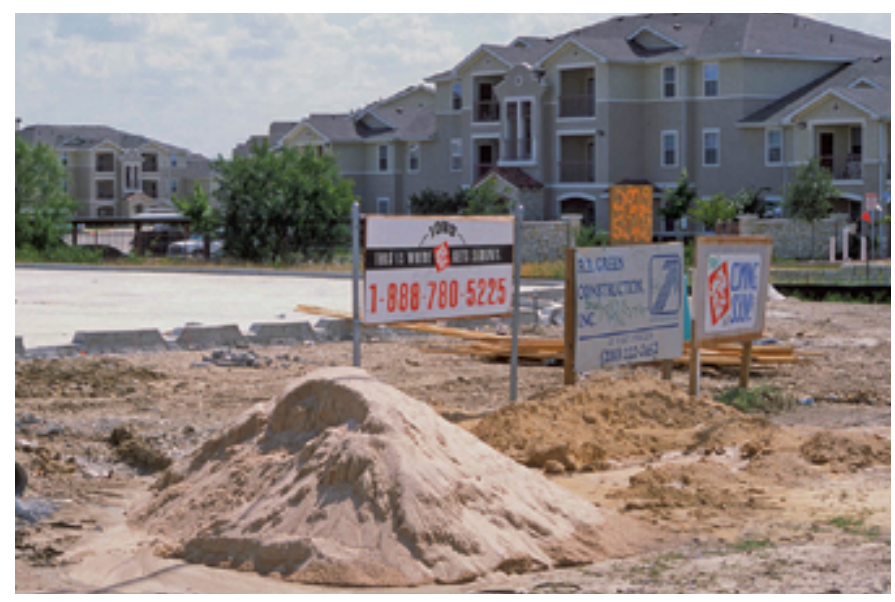

Figure 12. Urban expansion in Texas Blackland Prairies Ecoregion.

\section{Developed Land-Cover Class}

Across the Great Plains ecoregions, new developed land for commercial, industrial, residential, transportation, water treatment, and other similar land uses increased by 0.4 percent $\left(9,551 \mathrm{~km}^{2}\right)$ of the total area between 1973 and 2000 (fig. 12). As a percentage of change, the area of developed land-cover class increased by 38.3 percent from its estimated 1973 extent. New developed land was found primarily around regional and subregional centers of service, retail, and manufacturing that are located in micropolitan (that is, populations of at least 10,000 but less than 50,000) and metropolitan (that is, populations of 50,000 or more) areas. At least 106 micropolitan areas and 46 metropolitan areas are within, or partly within, the Great Plains ecoregions (U.S. Census Bureau, 2003).

Other developed land included recreational areas and, in some cases, additional industrial infrastructure. Some increases in amenity-based development occurred in localized areas, usually around existing or newly built reservoirs. In

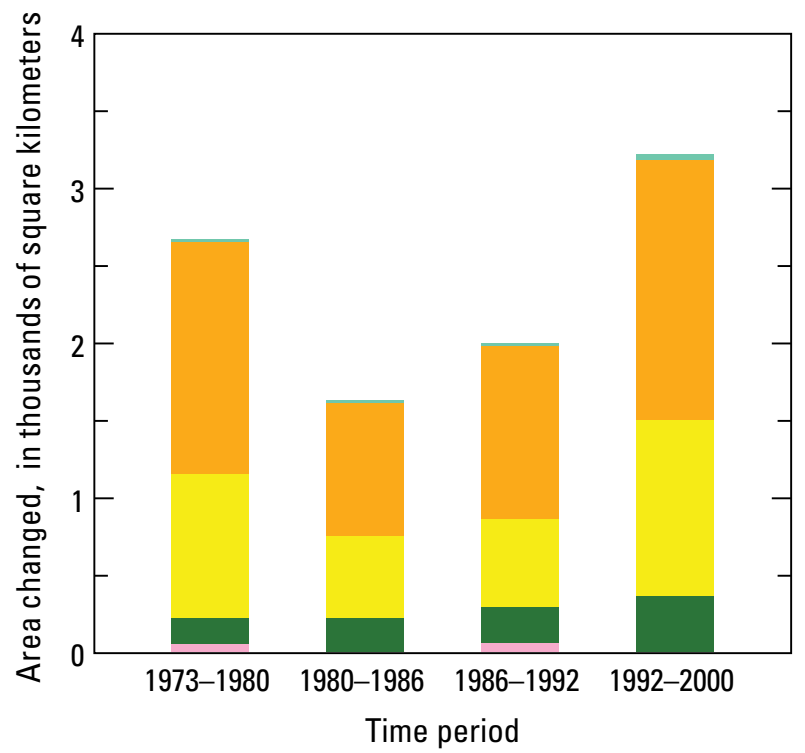

\section{EXPLANATION}

LAND-USE/LAND-COVER CLASS

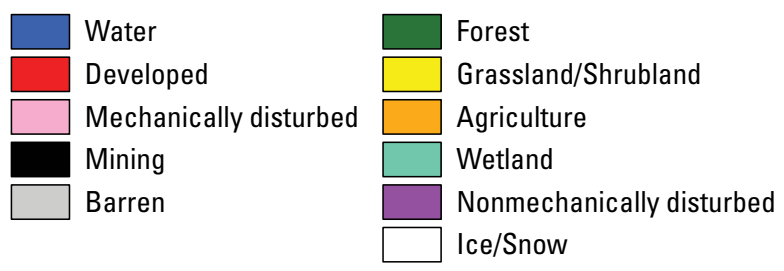

Figure 13. Average annual gains in developed land-cover class from other land-cover classes in all 17 Great Plains ecoregions over entire study period (1973 to 2000). Colored bars indicate land-cover classes that lost area to developed land and amounts of area lost. 
addition, several isolated industrial complexes (for example, power plants) were built between 1973 and 2000. Some sections of the original interstate highway system were completed during the first two time periods (1973-1980, 1980-1986), and subsequent additions of major multilane roads to federal and state highway systems occurred throughout the entire study period.

Between 1973 and 2000, 97 percent of the new developed land cover came from three sources (fig. 13): developed gained an estimated $5,176 \mathrm{~km}^{2}$ from agriculture, an estimated $3,152 \mathrm{~km}^{2}$ from grassland/shrubland, and an estimated 983 $\mathrm{km}^{2}$ from forest. The ratios of conversion to new developed land remained relatively stable across the entire study period, although the conversion of forest to developed increased from 6.6 percent during the first time period (1973-1980) to 12.0 percent thereafter.

The Texas Blackland Prairies Ecoregion had the greatest increase in developed land cover, gaining $1,919 \mathrm{~km}^{2}$ (3.8 percent), which is about 20 percent of the net increase in developed land in the Great Plains ecoregions. The Texas Blackland Prairies Ecoregion includes an axis of large urban areas in Texas, from Dallas in the north, through Austin, to San Antonio in the south. In terms of increased developed land, other leading ecoregions include the East Central Texas Plains Ecoregion (1.3 percent) and the Western Gulf Coastal Plain Ecoregion (1.2 percent). Growth in the Western Gulf Coastal Plain Ecoregion included coastal industrial and amenitybased development. However, sparsely populated ecoregions such as the Northwestern Great Plains, the Northwestern Glaciated Plains, and the Southwestern Tablelands Ecoregions experienced only small increases (less than 0.5 percent of ecoregion area) in developed land, especially those ecoregions that contain extensive rangeland.

\section{Water Land-Cover Class}

Climate in the Great Plains ecoregions, which ranges from semiarid to humid, can be highly variable both spatially and temporally, having long periods of drought in some ecoregions and cycles of above-average precipitation in others. Because of climate variability, many ecoregions rely on water storage in reservoirs to irrigate crops, as well as for livestock, for confined-feeding operations, and for household consumption. All of these water uses are related to land change.

Overall, the changes affecting the water land-cover class accounted for an estimated 14,833 $\mathrm{km}^{2}$ of the total gross land-cover change detected in the 17 Great Plains ecoregions between 1973 and 2000. Total net change, an increase of 0.3 percent, was much less, at an estimated 5,908 $\mathrm{km}^{2}$.

The top two changes affecting water land cover were both associated with wetland land cover. The wetland-towater conversion was the leading change $\left(8,494 \mathrm{~km}^{2}\right)$, and the water-to-wetland conversion was the second-leading change $\left(4,541 \mathrm{~km}^{2}\right)$, both of which occurred primarily in the Glaciated Plains Ecoregions group. Much of this change was driven by climatic conditions that varied between dry years, which caused lakes and ponds to become seasonal wetlands, and wet years, which caused open water to persist in wetland areas. The wetter-than-normal conditions during the 1990s in the Northern Glaciated Plains Ecoregion and the Northwestern Glaciated Plains Ecoregion (located in the "prairie pothole" region of the northern Great Plains) accounted for most of the wetland-towater expansion (Garbrecht and Rossel, 2002).

The Northwestern Great Plains Ecoregion, which contains four of the six main-stem reservoirs along the Missouri River, experienced similar water and wetland changes, but for slightly different reasons. Decreases in upstream water availability caused by regional droughts and exacerbated by the resulting decreases in mountain snowpack, as well as changes in reservoir management in response to these conditions, likely contributed to decreased reservoir storage. As water levels dropped, wetland vegetation grew in embayments formed by tributary streams. These changes took place in the late 1980s and early 1990s; however, the reservoirs had mostly recovered by the year 2000 (U.S. Army Corps of Engineers, 2004).

Conversions of grassland/shrubland to water, agriculture to water, and water to grassland/shrubland were the third-, fourth-, and fifth-leading changes, respectively, that affected the water land-cover class in the Great Plains ecoregions. Changes from grassland/shrubland to water across the ecoregions were caused primarily by the construction of new reservoirs and also by flooding from expanding lakebeds. A large number of small reservoirs, commonly called "stock dams" or "stock tanks," were built for livestock water supply, especially in more arid ecoregions such as the Northwestern Great Plains, Central Great Plains, Southern Texas Plains, and Southwestern Tablelands Ecoregions. Larger, multiuse reservoirs also were built. In addition, natural flooding of grassland/shrubland occurred primarily in the Glaciated Plains Ecoregions group, where wetter-than-normal years caused some lakebeds of glacial origin to increase in size. These water bodies may persist as larger surface areas for years before cyclical climatic conditions (for example, periods of drought or below-normal precipitation) reduce their size (Todhunter and Rundquist, 2004; Shapley and others, 2005). Conversions of water to grassland/shrubland resulted when reservoirs, especially small "stock dams," dried up during periods of below-normal precipitation. Overall, water land cover experienced a small net gain of an estimated $440 \mathrm{~km}^{2}$ from grassland/shrubland land cover between 1973 and 2000.

\section{Wetland Land-Cover Class}

Changes in the wetland land-cover class, the fifth-leading gross change in the Great Plains ecoregions, are closely associated with changes in the water land-cover class. As a percentage of land area in the 17 Great Plains ecoregions, wetland land cover decreased by 0.1 percent. As a percentage of the wetland areas in 1973, wetland land cover had decreased by an estimated 7.7 percent $\left(3,081 \mathrm{~km}^{2}\right)$ by the year 2000. The net decline was caused primarily by wetter climatic conditions, which caused wetland areas to be replaced with persistent open water. 
Much of the expansion of wetlands occurred in the Northern Glaciated Plains Ecoregion (part of the "prairie pothole" region) in the mid-1980s and mid- to late 1990s, when wetter-than-normal climatic conditions caused many temporary and seasonal wetlands that were previously farmed to stay persistently wet, keeping them out of crop production. The Western Corn Belt Plains Ecoregion, traditionally included in the "prairie pothole" region before its wetlands were mostly drained or modified to enable cultivation in the late 19th and early 20th centuries, also experienced wetland expansion, but it was only a small fraction when compared to the neighboring Northern Glaciated Plains Ecoregion (an estimated $74 \mathrm{~km}^{2}$ versus $\left.1,356 \mathrm{~km}^{2}\right)$.

In the Western Gulf Coastal Plain Ecoregion, conversions of agriculture to wetland had different factors that influenced this type of change. Substantial amounts of ground subsidence in coastal areas may have created wetland conditions on former agricultural land (Davidson and Mace,

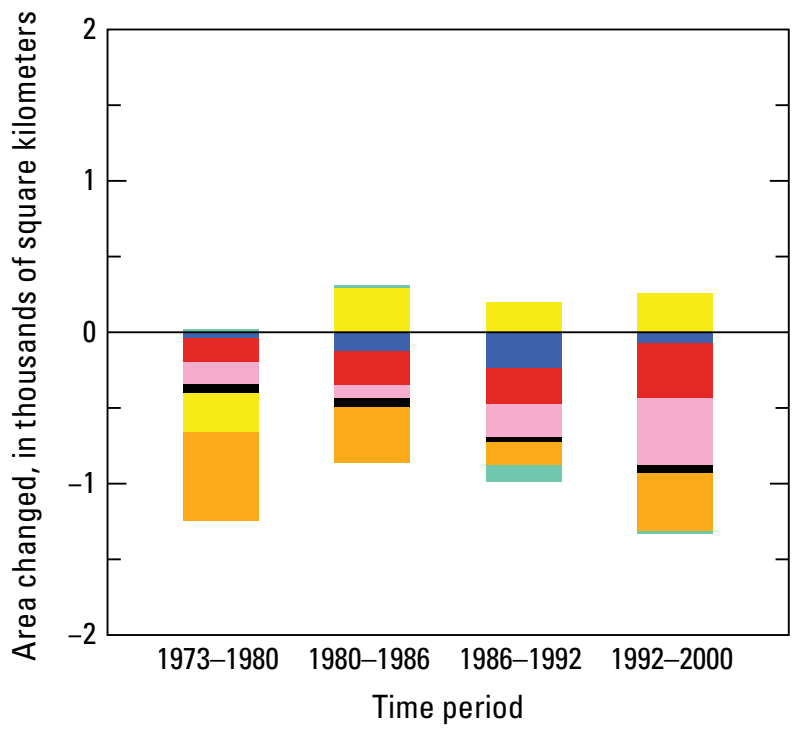

\section{EXPLANATION} LAND-USE/LAND-COVER CLASS

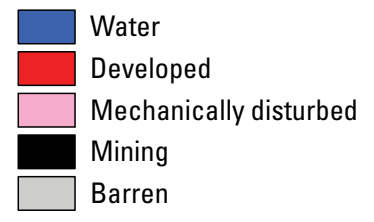

Forest Grassland/Shrubland Agriculture Wetland Nonmechanically disturbed Ice/Snow

Figure 14. Gross change (area gained from, and lost to, other land-cover classes) in forest land-cover class over entire study period (1973-2000). Colored bars above zero axis indicate landcover classes that lost area to forest and amounts of area lost, whereas colored bars below zero axis indicate land-cover classes that gained area from forest and amounts of area gained.
2006). Several National Wildlife Refuges also were created in the ecoregion, including the Cameron Prairie National Wildlife Refuge in southwestern Louisiana, where former agricultural land was converted back to wetlands (U.S. Fish and Wildlife Service, 2009).

Other changes affecting the wetland land-cover class were conversions from grassland/shrubland to wetland (an estimated gross change of $450 \mathrm{~km}^{2}$ ) and wetland to grassland/shrubland (an estimated gross change of $447 \mathrm{~km}^{2}$ ). These conversions took place primarily in the Glaciated Plains Ecoregions group, as well as in several ecoregions in the Southern Plains Ecoregions group, as changes in precipitation patterns contributed to fluctuations in wetland extent. Conversions from forest to wetland also occurred in the Southern Plains Ecoregions group, where reservoirs for metropolitan drinking water were constructed. As these reservoirs filled, upland forest areas were drowned and, thus, were replaced by wetland areas.

The Western Gulf Coastal Plain Ecoregion has a wide variety of wetlands within it, some of which include the western range of bald cypress (Taxodium distichum), a commercially valuable wetland tree. This ecoregion experienced the highest amount of conversion from wetland to mechanically disturbed land, a result of forest harvest. The Western Gulf Coastal Plain Ecoregion was also the leading ecoregion for conversion from wetland to developed land, primarily caused by increased urbanization and industrial growth.

\section{Forest Land-Cover Class}

A net decline in the forest land-cover class of 0.1 percent (about 3,706 $\mathrm{km}^{2}$ ) of the total area of the Great Plains ecoregions occurred during the 27-year study period. However, most forest change was in the Southern Plains Ecoregions group. The largest net decline occurred as agriculture expanded between 1973 and 2000 (about 2,678 km²). Loss of forest to developed land, clearcutting (mechanically disturbed land), and reservoir construction also made significant contributions to the rates of forest land-cover change (fig. 14).

\section{Mining Land-Cover Class}

A net gain in the mining land-cover class of less than 0.1 percent (about $1,407 \mathrm{~km}^{2}$ ) of the total area of the Great Plains ecoregions occurred between 1973 and 2000. Although this was a small amount of change, it more than doubled the area of the mining land-cover class. Most of the increase came from the conversion to mining from agriculture and grassland/shrubland. The expansion of quarrying, mineral excavation, and oil and gas extraction provided most of the increase in mining land cover, whereas declines resulted from mine abandonment and the revegetation of reclaimed mine sites. A small amount of mining land cover was abandoned or purposely converted to ponds for recreation or wildlife. 


\section{Mechanically Disturbed and Nonmechanically Disturbed Land-Cover Classes}

Three main processes resulted in a net expansion in the mechanically disturbed land-cover class and a net decline in the nonmechanically disturbed land-cover class. Expanded forest cutting in the Southern Plains Ecoregions group $\left(1,121 \mathrm{~km}^{2}\right)$ increased mechanically disturbed land. Large amounts of gross change associated with the cycles of woody-brush clearance and subsequent regrowth resulted in a small net gain of mechanically disturbed land. Changes in nonmechanically disturbed land (about $1,766 \mathrm{~km}^{2}$ of gross change, and a net-change decline of $1,049 \mathrm{~km}^{2}$ ) occurred as grassland/shrubland burned and then reestablished itself following fire disturbance.

\section{Barren Land-Cover Class}

A gross change of 2,636 $\mathrm{km}^{2}$ in the barren land-cover class was associated mostly with fluctuations in the extent of natural water bodies and grassland/shrubland. Transitions to and from barren land caused by changes in precipitation amounts resulted in a small net decline of $33 \mathrm{~km}^{2}$ of the barren land-cover class.

\section{Summary}

The highest amount of land-cover change that took place in the Great Plains ecoregions was due to fluctuations in agriculture, much of it on marginal land, as economic opportunities, sociocultural dynamics, agricultural technologies, and government farm policies changed. Most of the Great Plains ecoregions experienced an overall decline in agricultural land, which was facilitated by the policies and incentives of the Conservation Reserve PrHyperogram. The decline followed an earlier period of agricultural expansion between 1973 and 1980 at the expense of grassland/shrubland.

The drier Western Plains Ecoregions group and the brushy Southern Plains Ecoregions group had relatively high rates of change that reflect substantial fluctuations between agriculture and grassland/shrubland. Ecoregions having biological and physical conditions that were favorable to agriculture tended to have lower rates of change. Variability in precipitation patterns and temperature levels had effects on land-cover change that could be characterized as veiled to obvious. The expansion of surface water area in the Glaciated Plains Ecoregions group was an important story that is tied to both climate and human activity, as reservoirs were constructed throughout the region for flood control, crop irrigation, livestock and residential water supply, and industrial use.

All 17 Great Plains ecoregions saw small but steady increases in the developed land-cover class. Most increases in developed land occurred in the Southern Plains Ecoregions group as urbanization spread onto agricultural land and grassland/shrubland. Cycles of grassland/shrubland clearance in the Southern Plains Ecoregions group also contributed to high rates of gross land-cover change. The trajectories and causes of land-use/land-cover change varied substantially within each ecoregion, giving some indication of the complexity of land-cover-change processes at work across the Great Plains. To aid in the understanding of land-use/ land-cover change in greater detail, the remaining chapters in this report contain summaries of change for each of the 17 Great Plains ecoregions; these summaries document the rates, types, and drivers of late 20th century land-use/landcover change in the Great Plains of the United States.

\section{References Cited}

Davidson, S.C., and Mace, R.E., 2006, Aquifers of the Gulf Coast of Texas-An overview, in Mace, R.E., Davidson, S.C., Angle, E.S., and Mullican, W.F., III, eds., Aquifers of the Gulf Coast of Texas: Texas Water Development Board, Report 365, p. 1-21, available at https://www.twdb.texas. gov/publications/reports/numbered_reports/doc/R365/ R365_Composite.pdf.

Dennehy, K.F., Litke, D.W., and McMahon, P.B., 2002, The High Plains Aquifer, USA-Groundwater development and sustainability, in Hiscock, K.M., Rivett, M.O., and Davison, R.M., eds., Sustainable groundwater development: London, Geological Society, Special Publications, v. 193, p. 99-119, available at http:// sp.lyellcollection.org/content/193/1/99.abstract.

Engle, D.M., Coppedge, B.R., and Fuhlendorf, S.D., 2008, From the Dust Bowl to the Green Glacier-Human activity and environmental change in Great Plains grasslands, in van Auken, O.W., Western North American Juniperus communities-A dynamic vegetation type: New York, Springer, Ecological Studies 196, p. 253-271, available at http://link.springer.com/chapter/10.1007\%2F978-0-38734003-6_14\#page-1.

Gallant, A.L., Loveland, T.R., Sohl, T.L., and Napton, D.E., 2004, Using an ecoregion framework to analyze land-cover and land-use dynamics: Environmental Management, v. 34, p. S89-S110.

Garbrecht, J.D., and Rossel, F.E., 2002, Decade-scale precipitation increase in the Great Plains at the end of the 20th century: Journal of Hydrologic Engineering, v. 7, no. 1, p. 64-75.

Loveland, T.R., Sohl, T.L., Stehman, S.V., Gallant, A.L., Sayler, K.L., and Napton, D.E., 2002, A strategy for estimating the rates of recent United States land-cover changes: Photogrammetric Engineering \& Remote Sensing, v. 68 , no. 10 , p. 1,091-1,099. 
McMahon, G., Gredonis, S.M., Waltman, S.W., Omernik, J.M., Thorson, T.D., Freeouf, J.A., Rorick, A.H., and Keys, J.E., 2001, Developing a spatial framework of common ecological regions for the conterminous United States: Environmental Management, v. 28, no. 3, p. 293-316.

Omernik, J.M., 1987, Ecoregions of the conterminous United States: Annals of the Association of American Geographers, v. 77, no. 1, p. 118-125.

Rossum, S., and Lavin, S., 2000, Where are the Great Plains? A cartographic analysis: Professional Geographer, v. 52, no. 3, p. 543-552.

Shapley, M.D., Johnson, W.C., Engstrom, D.R., and Osterkamp, W.R., 2005, Late-Holocene flooding and drought in the northern great plains, USA, reconstructed from tree rings, lake sediments, and ancient shorelines: The Holocene, v. 15, no. 1, p. 29-41.

Stehman, S.V., Sohl, T.L., and Loveland, T.R., 2003, Statistical sampling to characterize recent United States land-cover change: Remote Sensing of Environment, v. 86, no. 4, p. 517-529.

Stehman, S.V., Sohl, T.L., and Loveland, T.R., 2005, An evaluation of sampling strategies to improve precision of estimates of gross change in land use and land-cover: International Journal of Remote Sensing, v. 26, no. 22, p. 4,941-4,957.

Todhunter, P.E., and Rundquist, B.C., 2004, Terminal lake flooding and wetland expansion in Nelson County, North Dakota: Physical Geography, v. 25, p. 68-85.

U.S. Army Corps of Engineers, 2004, Summary-Missouri River final environmental impact statement, master water control manual review and update: U.S. Army Corps of Engineers Northwestern Division, accessed February 19, 2009, at http://www.nwd-mr.usace.army.mil/mmanual/Summary.pdf.
U.S. Census Bureau, 2003, State-based metropolitan and micropolitan statistical areas maps: U.S. Census Bureau database, accessed February 10, 2009, at http://www.census. gov/geo/maps-data/maps/statecbsa.html.

U.S. Department of Agriculture, 1920-2002 [various years], Census of agriculture, geographic area series: U.S. Government Printing Office, U.S. Department of Agriculture National Agricultural Statistics Service, available at http://www.agcensus.usda.gov/Publications/ Historical_Publications/index.php.

U.S. Environmental Protection Agency, 1997, Descriptions of level III ecological regions for the CEC report on ecological regions of North America: U.S. Environmental Protection Agency database, accessed April 12, 2006, at http://www.epa.gov/wed/pages/ecoregions/na_eco. htm\#Downloads.

U.S. Environmental Protection Agency, 1999, Level III ecoregions of the continental United States: U.S. Environmental Protection Agency National Health and Environmental Effects Research Laboratory, scale 1:7,500,000, available at ftp:/ftp.epa.gov/wed/ecoregions/ us/Eco_Level_III_US.pdf.

U.S. Fish and Wildlife Service, 2009, Cameron Prairie National Wildlife Refuge: U.S. Fish and Wildlife Service, accessed February 26, 2009, at http://www.fws.gov/ southeast/pubs/facts/camcon.pdf.

Vogelmann, J.E., Howard, S.M., Yang, L., Larson, C.R., Wylie, B.K., and van Driel, N., 2001, Completion of the 1990s National Land Cover Data Set for the conterminous United States from Landsat Thematic Mapper data and ancillary data sources: Photogrammetric Engineering \& Remote Sensing, v. 67, p. 650-662. 


\section{Western Plains Ecoregions}

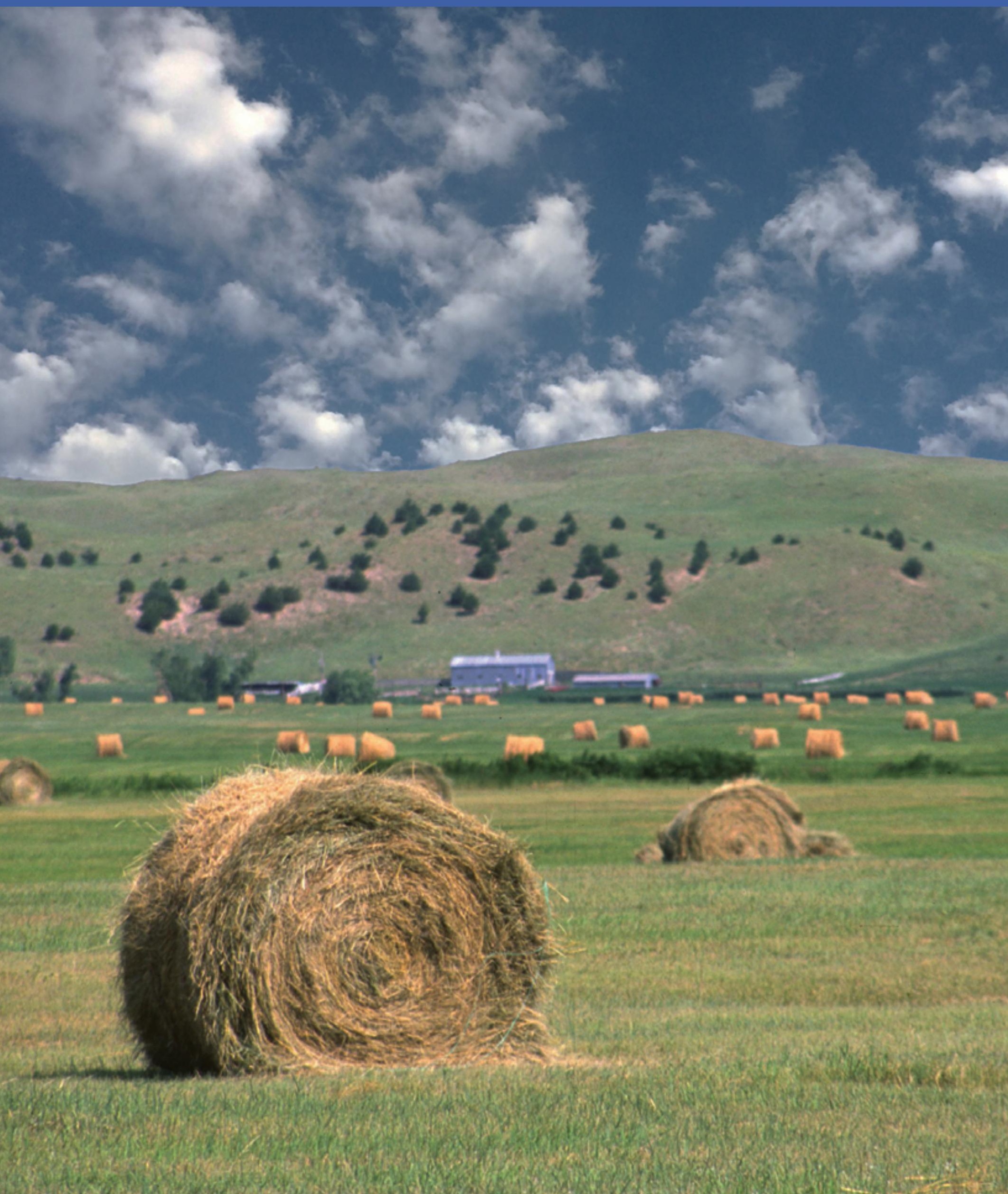




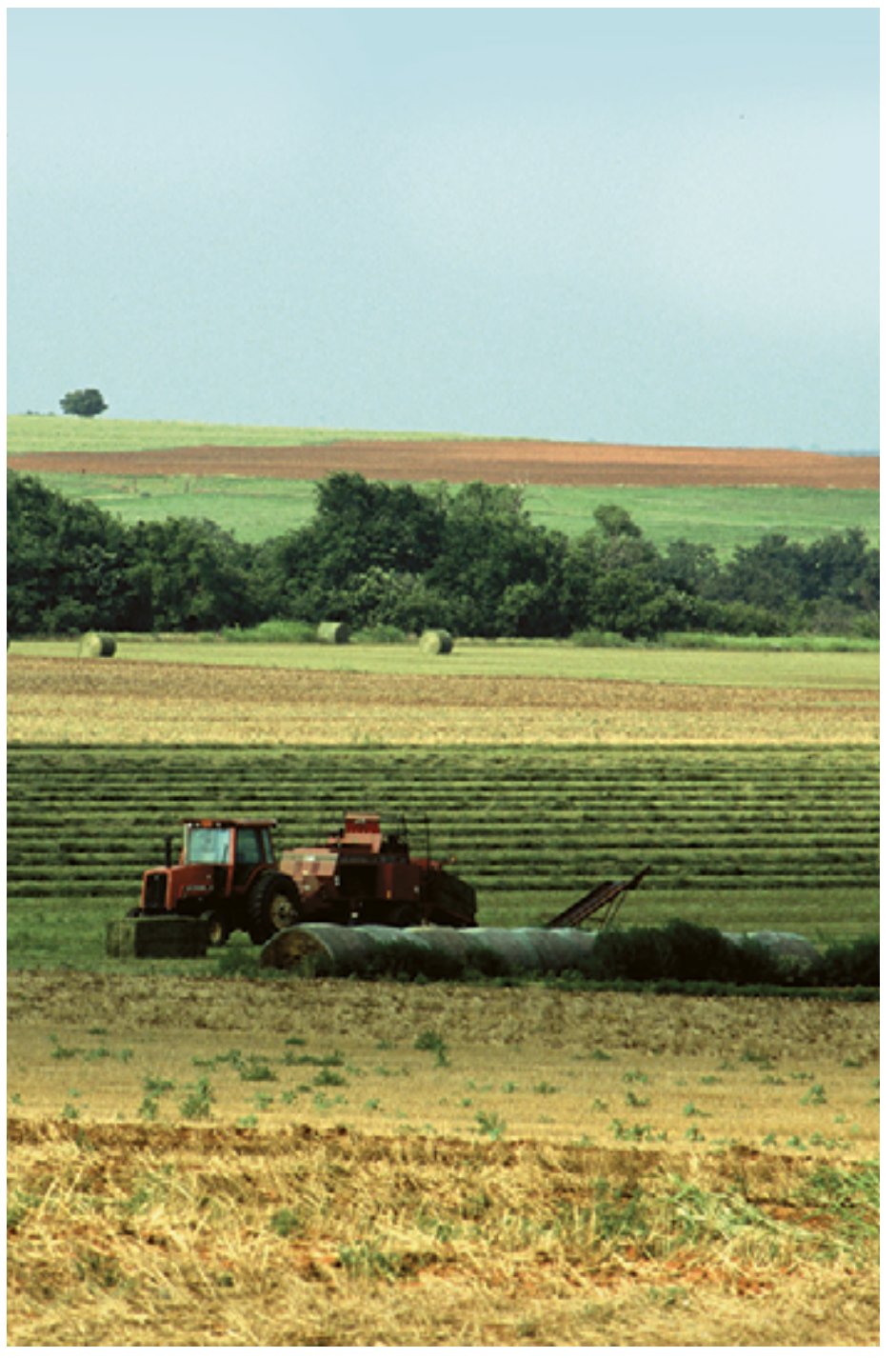




\section{Central Great Plains Ecoregion}

\author{
By Mark A. Drummond
}

\section{Ecoregion Description}

The Central Great Plains Ecoregion is a large, elongated area that covers about $273,189 \mathrm{~km}^{2}\left(105,479 \mathrm{mi}^{2}\right)$ from central Nebraska through Kansas and Oklahoma into north-central Texas (Omernik, 1987; U.S. Environmental Protection Agency, 1997) (fig. 1). The ecoregion is bounded on the west by the Western High Plains and the Southwestern Tablelands Ecoregions; on the north by the Nebraska Sand Hills Ecoregion; on the east by the Western Corn Belt Plains, Flint Hills, and Central Oklahoma/Texas Plains Ecoregions; and on the south by the Edwards Plateau Ecoregion and a small part of the Chihuahuan Deserts Ecoregion (Omernik, 1987).

Agriculture is the primary land use in the Central Great Plains Ecoregion where level topography, water availability, fertile soils, and a long growing season contribute to high productivity among several crops. Overall, about one-half of the ecoregion is in cropland, and much of the other one-half includes confined animal-feeding operations and livestock grazing. Agriculture is aided by warm summer temperatures. With a strong northsouth temperature gradient for much of the year, average July temperatures are at or above $27^{\circ} \mathrm{C}$ for most of the ecoregion. Annual precipitation levels range from about $500 \mathrm{~mm}$ (20 in.) per year in the western part of the ecoregion to $800 \mathrm{~mm}$ (32 in.) per year in the eastern part (National Atlas of the United States, 2008).

Native grasslands in the ecoregion consist primarily of a mixed-grass prairie that includes little bluestem (Schizachyrium scoparium) and grama (Bouteloua spp.) grasses, interspersed with mesquite (Prosopis spp.) shrublands in the south. Some grasslands and wetlands are managed as protected areas: in particular, the migratorybird habitat along the Platte River and in the Rainwater Basin Wetland Management District in south-central Nebraska. Millions of water birds migrating along the Central Flyway funnel

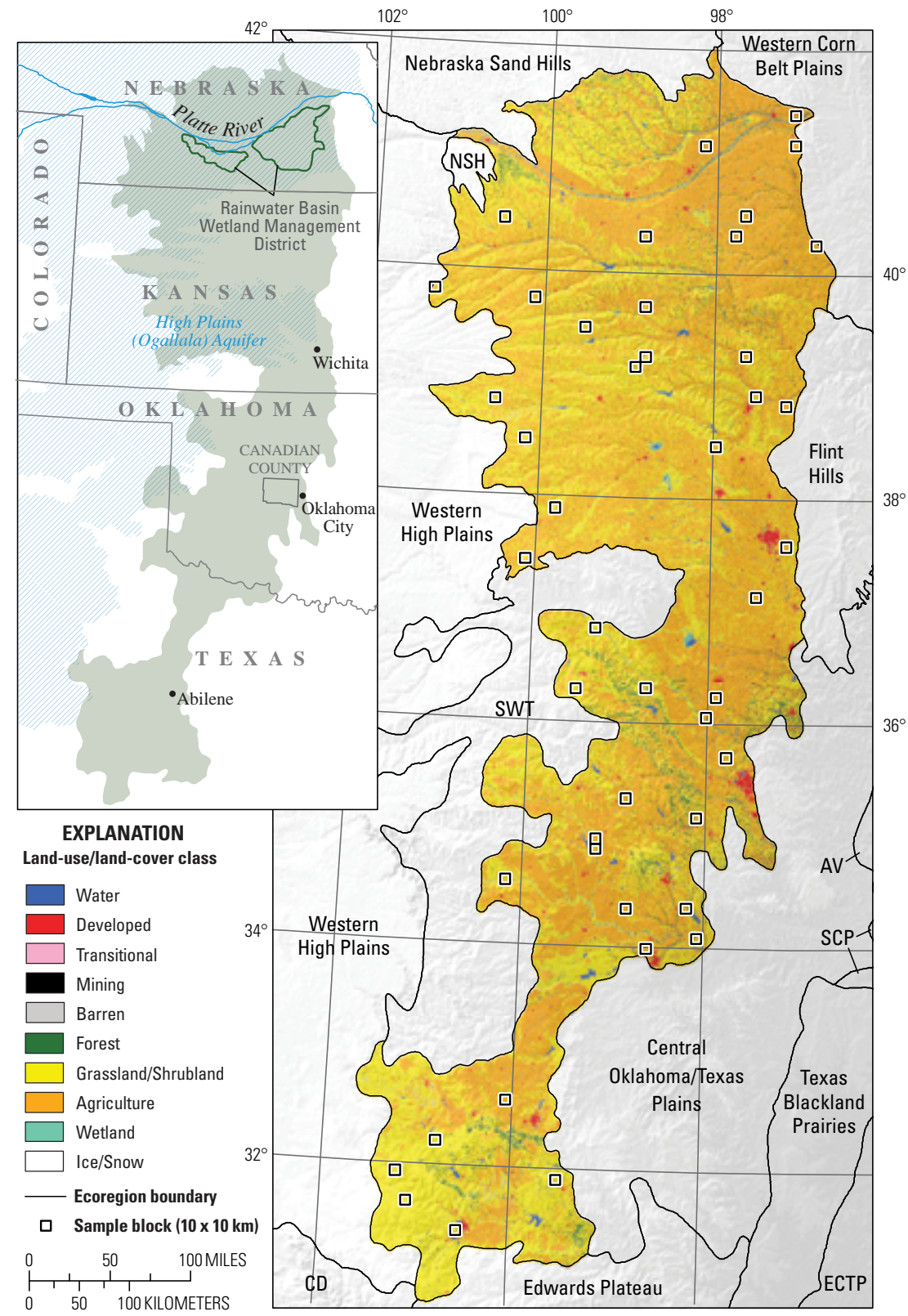

Figure 1. Map of Central Great Plains Ecoregion and surrounding ecoregions, showing land-use/land-cover classes from 1992 National Land Cover Dataset (Vogelmann and others, 2001); note that not all land-use/land-cover classes shown in explanation may be depicted on map; note also that, for this "Status and Trends of Land Change" study, transitional land-cover class was subdivided into mechanically disturbed and nonmechanically disturbed classes. Squares indicate locations of $10 \times 10 \mathrm{~km}$ sample blocks analyzed in study. Index map shows locations of geographic features mentioned in text. Abbreviations for Great Plains ecoregions are listed in appendix 2. Also shown are parts of one Western United States ecoregion (Chihuahuan Deserts [CD]) and two Midwest-South Central United States ecoregions (Arkansas Valley [AV] and South Central Plains [SCP]). See appendix 3 for definitions of land-use/land-cover classifications. 
into this narrow area each spring. Small, shallow playa lakes, which are common throughout the western and central parts of the Great Plains, also provide an ephemeral water source and seasonal-wildlife habitat. Natural and seminatural disturbance regimes that affect vegetation include periodic drought, wildfires that maintain grasslands and prevent encroachment of woody species, and grazing by wildlife and livestock.

The Central Great Plains Ecoregion covers much of the hard winter-wheat area of Kansas and Oklahoma, which is a mainstay of Great Plains agriculture (fig. 2). Wheat crops covered an average of 17.5 percent of the ecoregion during the study period (U.S. Department of Agriculture, 1970-2000 [various years]). In drier areas, wheat fields traditionally have lain fallow every other year, whereas areas of the ecoregion that have adequate moisture grow wheat continuously. Kansas is the top wheat-producing state, and several large grain elevators and flour mills operate in the ecoregion (fig. 3).

Agriculture in the northern part of the ecoregion is heavily irrigated along the Platte River in Nebraska, as well as in areas overlying the eastern extent of the High Plains (Ogallala) aquifer, the largest groundwater complex in the nation, where

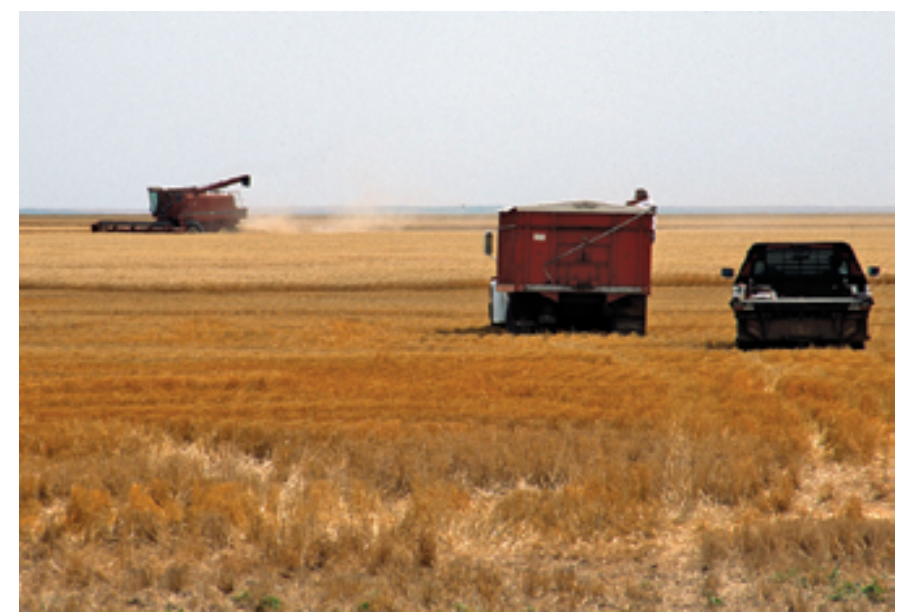

Figure 2. Harvesting of winter wheat in Central Great Plains Ecoregion.

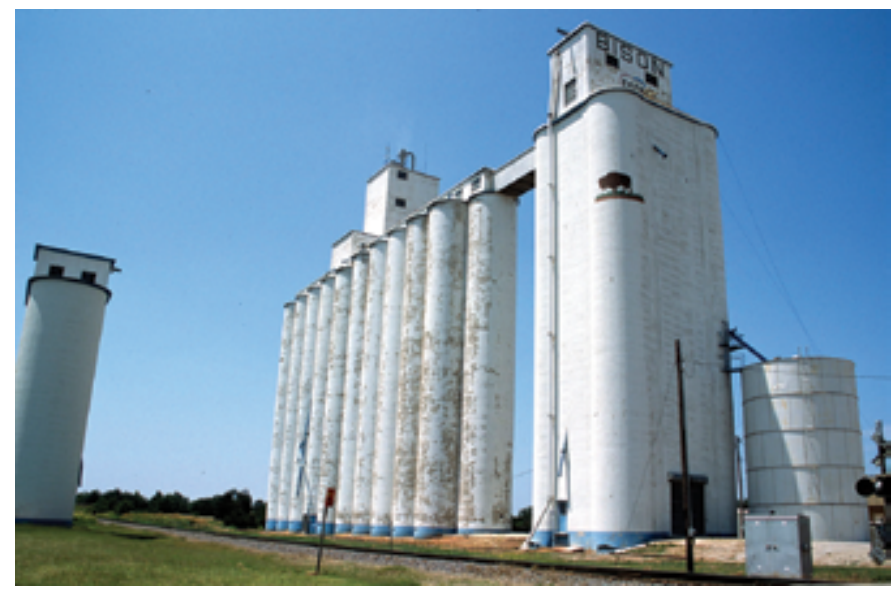

Figure 3. Large grain elevator, used to weigh, store, and convey grain, in Central Great Plains Ecoregion. feed corn is the principal crop (fig. 4). About 30 percent of groundwater used for crop irrigation in the United States is pumped from the High Plains aquifer (Dennehy, 2000), which also underlies the adjacent Western High Plains Ecoregion and the rangelands of the Nebraska Sand Hills Ecoregion.

As with other areas of the Great Plains, watermanagement issues are central to the Central Great Plains Ecoregion. For example, large-scale confined-feeding operations have expanded in the ecoregion, and they require a readily available source of water, bringing them into competition with other agricultural uses (fig. 5). The area of cropland irrigation also has increased more than 10 times in south-central Kansas, causing declining streamflows and groundwater levels and, thus, affecting water quality (Sophocleous and others, 1999). High evapotranspiration rates and variable amounts of rainfall also increase the need for irrigation. Cotton is an important crop in the southern part of the ecoregion, along with wheat, sorghum, and hay. The Conservation Reserve Program (CRP), which was initiated in 1985 to provide income to farmers for keeping fragile soils and wetlands out of crop production, accounted

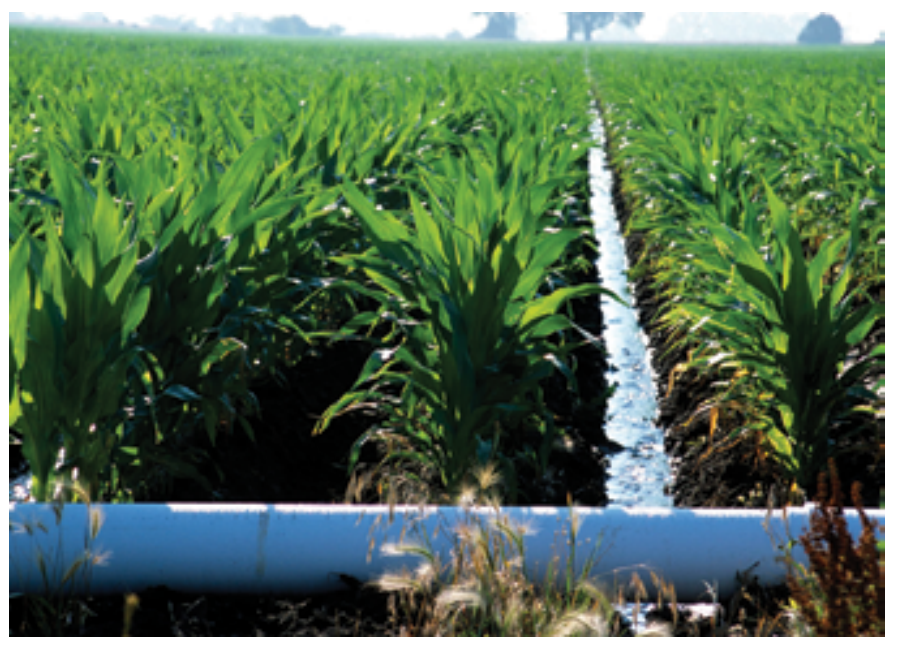

Figure 4. Furrow irrigation in Central Great Plains Ecoregion.

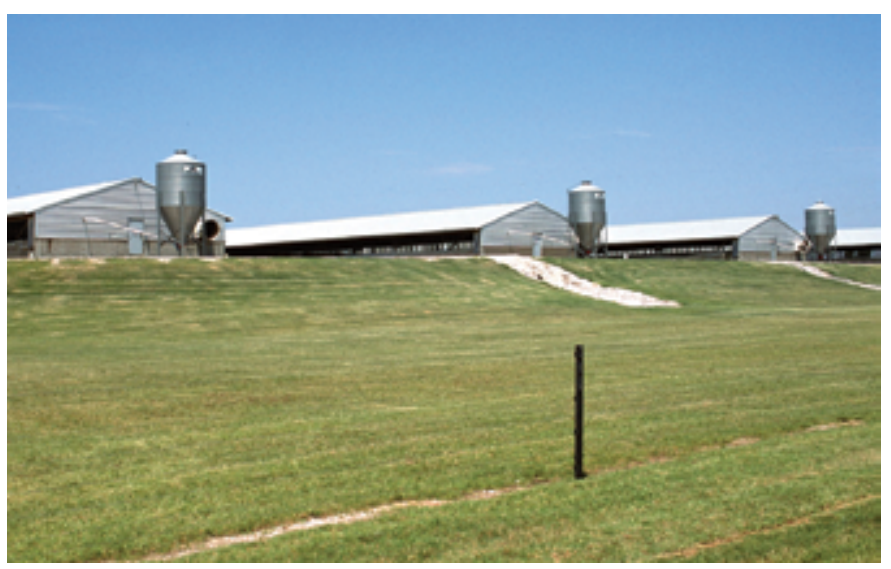

Figure 5. Confined animal-feeding operation in Central Great Plains Ecoregion. 
for 3 percent of the total ecoregion area in 2000 (U.S.

Department of Agriculture, 1970-2000 [various years]).

The population of the Central Great Plains Ecoregion was 2.5 million in 2000, a 12 percent increase since 1970; however, 65 percent of the counties lost population (U.S. Census Bureau, 1970-2000 [various years]). Most rural counties that had less than 10,000 people in 1970 lost population by 2000. Although the ecoregion is largely agricultural, modern farming methods often require only a small, seasonal workforce, and many farmers do not live on farms year-round (fig. 6). The consolidation of small family farms into large corporate operations also may account for some of the population shift. The seven largest counties in 1970, having at least 50,000 people, all gained in population by 2000. Canadian County, Oklahoma, gained the most population between 1970 and 2000, from 32,245 to 87,697 people. This 172 percent increase may relate to the proximity of Canadian County to Oklahoma City, Oklahoma, the largest metropolitan area in the ecoregion. Wichita, Kansas, and Abilene, Texas, are other large population centers.

\section{Contemporary Land-Cover Change (1973 to 2000)}

The overall spatial change (the percentage of land area that changed at least one time) in the Central Great Plains Ecoregion between 1973 and 2000 is estimated at 8.3 percent (table 1). Compared to other Great Plains ecoregions, change in the Central Great Plains Ecoregion was moderate (fig. 7): most of the area that changed (7.2 percent) did so in only one time period, 0.9 percent changed during two time periods, and 0.1 percent changed during three time periods. Multiple changes were caused mainly by successive conversions between agriculture and grassland/shrubland during two or more time periods but also by natural fluctuations in the surface extent of water and wetland areas. Overall, the estimated annual rates of change during each of the four time periods were relatively consistent (about $0.2-0.3$ percent), except between 1986 and 1992 when the annual rate was 0.6 percent of the ecoregion (fig. 8).

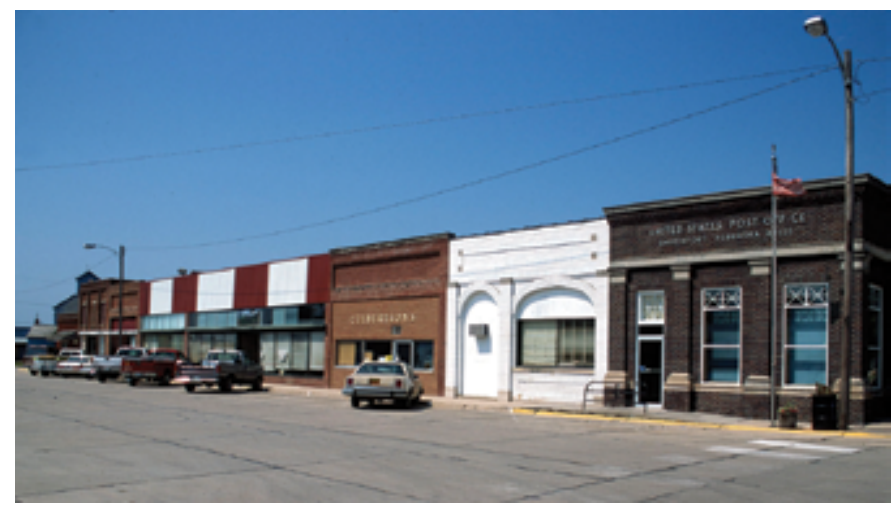

Figure 6. Small town in Central Great Plains Ecoregion, many of which are facing dwindling rural populations.

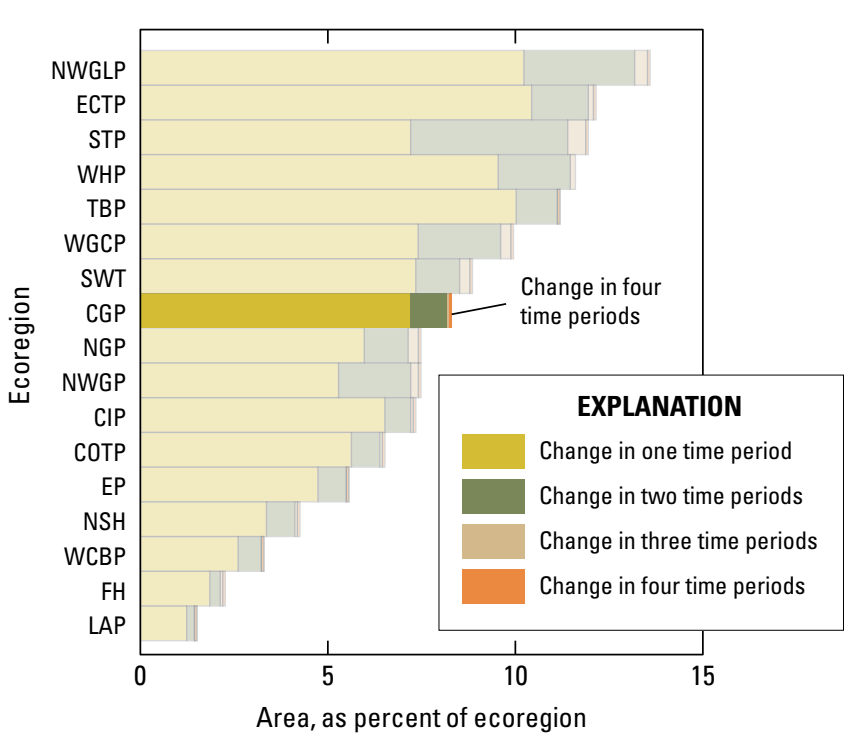

Figure 7. Overall spatial change in Central Great Plains Ecoregion (CGP; darker bars) compared with that of all 17 Great Plains ecoregions (lighter bars). Each horizontal set of bars shows proportions of ecoregion that experienced change during one, two, three, or four time periods; highest level of spatial change in Central Great Plains Ecoregion (four time periods) labeled for clarity. See table 4 for years covered by each time period. See appendix 2 for key to ecoregion abbreviations.

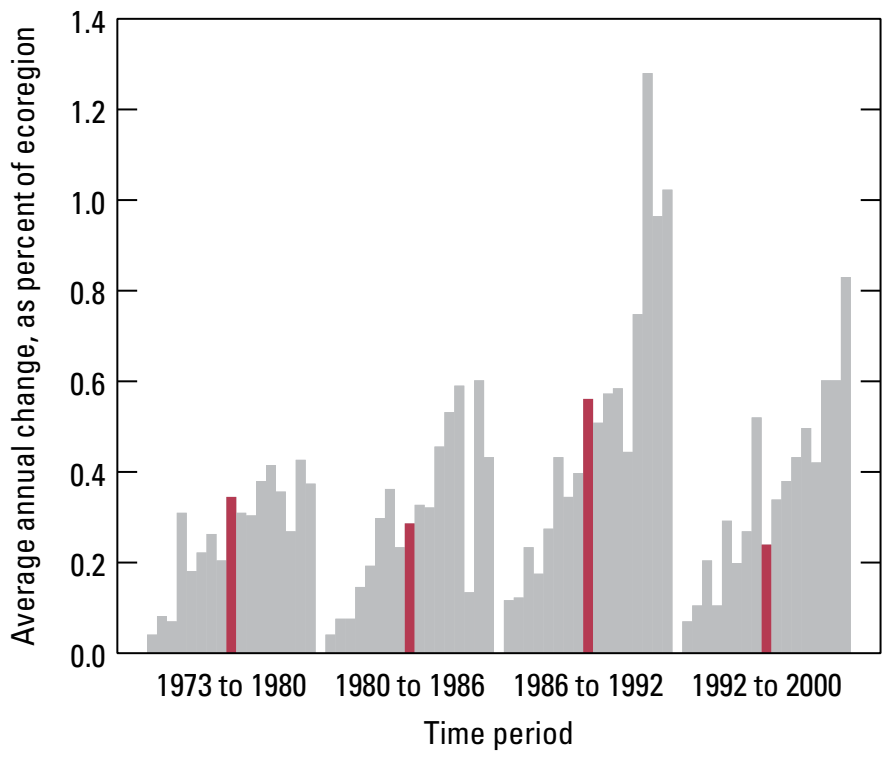

Figure 8. Estimates of land-cover change per time period, normalized to annual rates of change for all 17 Great Plains ecoregions (gray bars). Estimates of change for Central Great Plains Ecoregion are represented by red bars in each time period. 
Although most of the land-cover changes were conversions between agriculture and grassland/shrubland, the resulting net changes were relatively small over the entire 27-year study period. The most common land-cover conversion between 1973 and 1980 was grassland/shrubland to agriculture $\left(3,933 \mathrm{~km}^{2}\right)$ (table 2), a time when export prices for wheat, corn, and soybeans increased substantially. The expansion of economic opportunity contributed to an estimated 1.0 percent decline in grassland/shrubland between 1973 and 1980, from 41.3 percent to 40.3 percent of ecoregion area (table 3 ). Access to surface water and to High Plains aquifer groundwater, particularly in the northern part of the ecoregion, facilitated an increase in agriculture. Agricultural expansion continued, although at a substantially slower pace (0.1 percent), between 1980 and 1986, a time of financial distress and declining farmland prices. Although the real estate price of farmland during the 1970s had the largest decadal rate of increase on record, farmland values decreased between 1980 and 1986 at the steepest rates on record (nearly 10 percent annually) (Lindert, 1988).

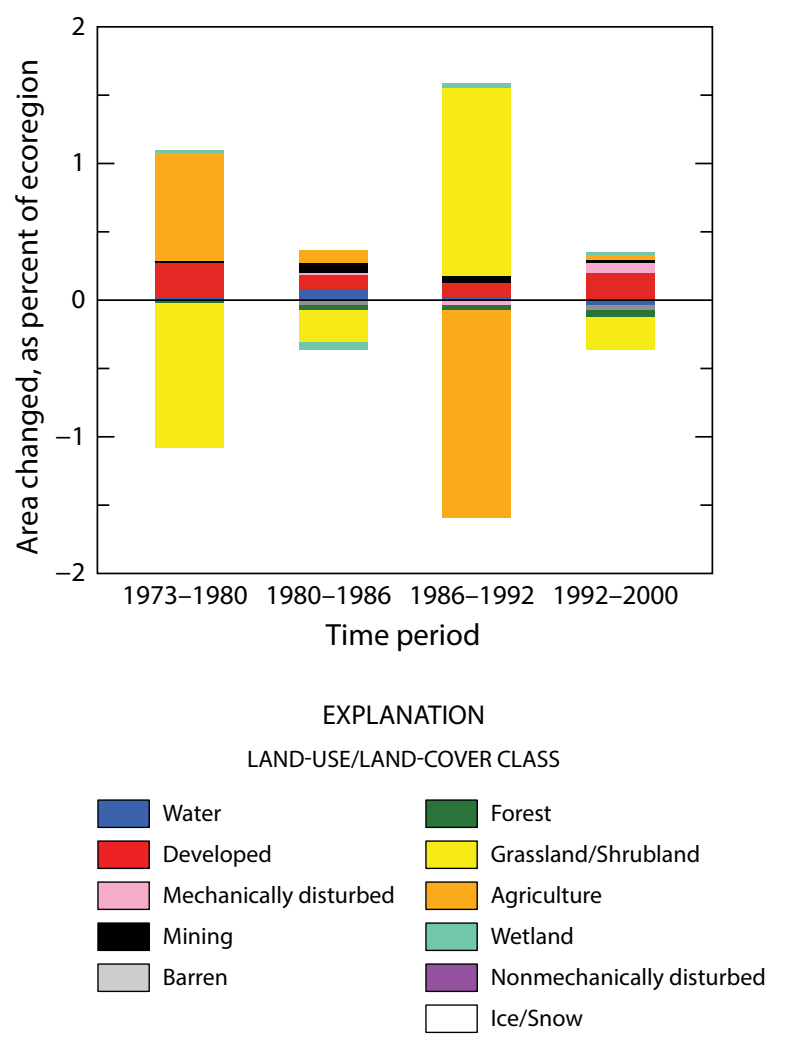

Figure 9. Normalized average net change in Central Great Plains Ecoregion by time period for each land-cover class. Bars above zero axis represent net gain, whereas bars below zero represent net loss. Note that not all land-cover classes shown in explanation may be represented in figure. See appendix 3 for definitions of land-use/land-cover classifications.
The trend changed significantly between 1986 and 1992, when the CRP was enacted and much agricultural land was converted to grassland/shrubland $\left(6,045 \mathrm{~km}^{2}\right)$ (table 2). Grassland/shrubland increased by 1.4 percent during this time period (fig. 9); this also was the period that had the highest percentage of total gross change, when 3.4 percent of the ecoregion changed (table 4), caused largely by agricultural land converting to grassland/shrubland through the CRP. Between 1992 and 2000, agriculture had little net change, as some CRP contracts expired and land was returned to crop production while other cropland was newly enrolled in the program.

Over the entire 27-year study period, the dynamics of land-use expansion and decline resulted in a similar amount of conversion from agriculture to grassland/shrubland $\left(10,868 \mathrm{~km}^{2}\right)$ and from grassland/shrubland to agriculture $\left(10,261 \mathrm{~km}^{2}\right)$ (table 2). Although the net result was only a small decrease in agriculture, the results suggest that agricultural land-cover class can be quite dynamic, as a substantial amount of marginal land is either in cultivation or abandoned, depending on economic conditions and farm policies.

A loss of 0.6 percent in agricultural land between 1973 and 2000 (fig. 10) was caused by conversion to developed land and by smaller net conversions to grassland/shrubland

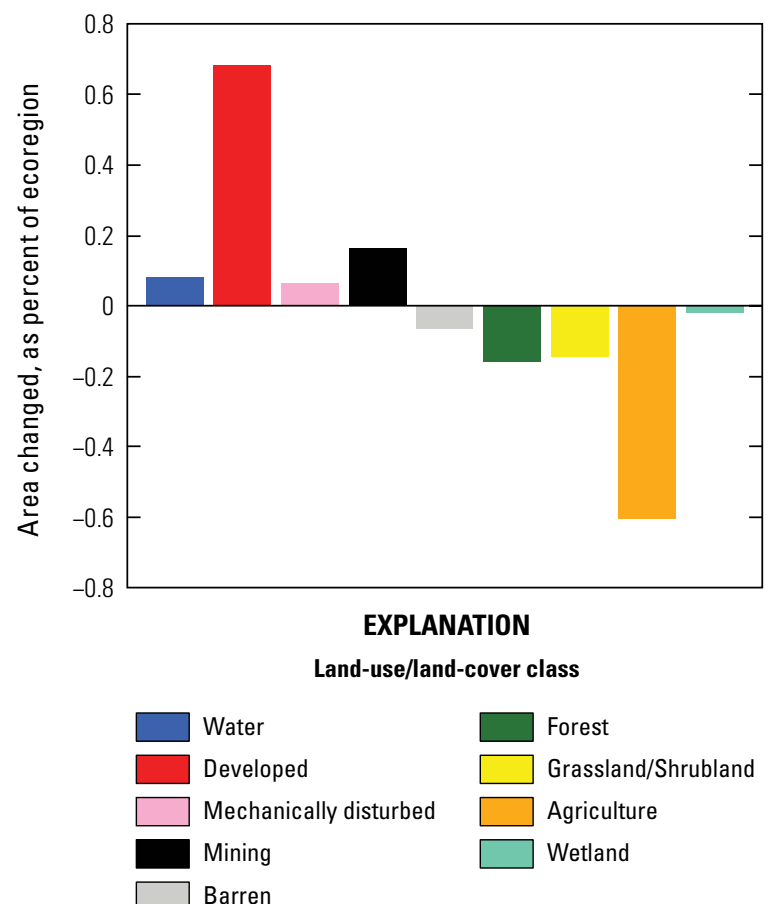

Figure 10. Estimates of net land-cover change in Central Great Plains Ecoregion for each land-cover class between 1973 and 2000. Bars above zero axis represent net gain, whereas bars below zero represent net loss. See appendix 3 for definitions of land-use/land-cover classifications. 
and water. The conversion to water primarily was caused by an increase in impounded water. However, agricultural land remained the dominant land-cover class throughout the entire study period (table 3). Grassland/shrubland decreased by 0.1 percent between 1973 and 2000, mostly attributable to the increase in development, mining, and water uses.

Developed land had the highest percentage of net change, with an increase of 0.7 percent $\left(1,869 \mathrm{~km}^{2}\right)$. Much of the increase in developed land likely is related to urban growth around metropolitan areas, as well as the 12 percent overall increase in the population of the ecoregion. The expansion of developed land generally is a permanent change, whereas spatial changes between agriculture and grassland/shrubland over the long term resulted in much gross change and little net change.
Table 1. Percentage of Central Great Plains Ecoregion land cover that changed at least one time during study period (1973-2000) and associated statistical error.

[Most sample pixels remained unchanged ( 91.7 percent), whereas 8.3 percent changed at least once throughout study period]

\begin{tabular}{ccccccc}
\hline $\begin{array}{c}\text { Number } \\
\text { of } \\
\text { changes }\end{array}$ & $\begin{array}{c}\text { Percent } \\
\text { of } \\
\text { ecoregion }\end{array}$ & $\begin{array}{c}\text { Margin } \\
\text { of error } \\
(+/-\%)\end{array}$ & $\begin{array}{c}\text { Lower } \\
\text { bound } \\
(\%)\end{array}$ & $\begin{array}{c}\text { Upper } \\
\text { bound } \\
(\%)\end{array}$ & $\begin{array}{c}\text { Standard } \\
\text { error } \\
(\%)\end{array}$ & $\begin{array}{c}\text { Relative } \\
\text { error } \\
(\%)\end{array}$ \\
\hline 1 & 7.2 & 1.1 & 6.1 & 8.3 & 0.8 & 10.5 \\
2 & 0.9 & 0.4 & 0.6 & 1.3 & 0.3 & 28.2 \\
3 & 0.1 & 0.0 & 0.0 & 0.1 & 0.0 & 35.9 \\
4 & 0.0 & 0.0 & 0.0 & 0.0 & 0.0 & 84.2 \\
\hline Overall & & & & & & \\
spatial & 8.3 & 1.4 & 6.8 & 9.7 & 1.0 & 11.8 \\
change & & & & & & \\
\hline
\end{tabular}


Table 2. Principal land-cover conversions in Central Great Plains Ecoregion, showing amount of area changed (and margin of error, calculated at 85-percent confidence level) for each conversion during each of four time periods and also during overall study period. See appendix 3 for definitions of land-cover classifications.

[Values given for "other" classes are combined totals of values for other land-cover classes not listed in that time period. Abbreviations: n/a, not applicable]

\begin{tabular}{|c|c|c|c|c|c|c|c|c|}
\hline Period & From class & To class & & $\begin{array}{c}\begin{array}{c}\text { Area } \\
\text { changed }\end{array} \\
\left(\mathrm{km}^{2}\right)\end{array}$ & $\begin{array}{c}\text { Margin of } \\
\text { error } \\
\left(+/-\mathrm{km}^{2}\right)\end{array}$ & $\begin{array}{c}\text { Standard } \\
\text { error } \\
\left(\mathbf{k m}^{2}\right)\end{array}$ & $\begin{array}{l}\text { Percent of } \\
\text { ecoregion }\end{array}$ & $\begin{array}{c}\text { Percent of all } \\
\text { changes }\end{array}$ \\
\hline \multirow[t]{7}{*}{ 1973-1980 } & Grassland/Shrubland & Agriculture & & 3,933 & 957 & 654 & 1.4 & 59.6 \\
\hline & Agriculture & Grassland/Shrubland & & 1,514 & 576 & 393 & 0.6 & 22.9 \\
\hline & Grassland/Shrubland & Developed & & 396 & 505 & 345 & 0.1 & 6.0 \\
\hline & Agriculture & Developed & & 305 & 378 & 258 & 0.1 & 4.6 \\
\hline & Grassland/Shrubland & Water & & 50 & 39 & 27 & 0.0 & 0.8 \\
\hline & Other & Other & & 401 & $\mathrm{n} / \mathrm{a}$ & $\mathrm{n} / \mathrm{a}$ & 0.1 & 6.1 \\
\hline & & & Totals & 6,599 & & & 2.4 & 100.0 \\
\hline \multirow[t]{7}{*}{ 1980-1986 } & Grassland/Shrubland & Agriculture & & 2,026 & 758 & 517 & 0.7 & 43.1 \\
\hline & Agriculture & Grassland/Shrubland & & 1,549 & 381 & 260 & 0.6 & 33.0 \\
\hline & Agriculture & Developed & & 171 & 193 & 132 & 0.1 & 3.6 \\
\hline & Wetland & Water & & 143 & 202 & 138 & 0.1 & 3.0 \\
\hline & Grassland/Shrubland & Developed & & 125 & 166 & 113 & 0.0 & 2.7 \\
\hline & Other & Other & & 681 & $\mathrm{n} / \mathrm{a}$ & $\mathrm{n} / \mathrm{a}$ & 0.2 & 14.5 \\
\hline & & & Totals & 4,695 & & & 1.7 & 100.0 \\
\hline \multirow[t]{7}{*}{ 1986-1992 } & Agriculture & Grassland/Shrubland & & 6,045 & 2,828 & 1,930 & 2.2 & 65.8 \\
\hline & Grassland/Shrubland & Agriculture & & 2,125 & 479 & 327 & 0.8 & 23.1 \\
\hline & Agriculture & Developed & & 231 & 276 & 188 & 0.1 & 2.5 \\
\hline & Grassland/Shrubland & Mining & & 139 & 100 & 68 & 0.1 & 1.5 \\
\hline & Forest & Agriculture & & 96 & 115 & 79 & 0.0 & 1.0 \\
\hline & Other & Other & & 549 & $\mathrm{n} / \mathrm{a}$ & $\mathrm{n} / \mathrm{a}$ & 0.2 & 6.0 \\
\hline & & & Totals & 9,185 & & & 3.4 & 100.0 \\
\hline \multirow[t]{7}{*}{ 1992-2000 } & Grassland/Shrubland & Agriculture & & 2,178 & 884 & 604 & 0.8 & 41.5 \\
\hline & Agriculture & Grassland/Shrubland & & 1,761 & 586 & 400 & 0.6 & 33.5 \\
\hline & Agriculture & Developed & & 353 & 269 & 184 & 0.1 & 6.7 \\
\hline & Grassland/Shrubland & Developed & & 222 & 245 & 167 & 0.1 & 4.2 \\
\hline & Water & Mechanically disturbed & & 160 & 220 & 150 & 0.1 & 3.0 \\
\hline & Other & Other & & 578 & $\mathrm{n} / \mathrm{a}$ & $\mathrm{n} / \mathrm{a}$ & 0.2 & 11.0 \\
\hline & & & Totals & 5,251 & & & 1.9 & 100.0 \\
\hline \multirow{7}{*}{$\begin{array}{c}\text { 1973-2000 } \\
\text { (overall) }\end{array}$} & Agriculture & Grassland/Shrubland & & 10,868 & 3,662 & 2,499 & 4.0 & 42.2 \\
\hline & Grassland/Shrubland & Agriculture & & 10,261 & 1,925 & 1,314 & 3.8 & 39.9 \\
\hline & Agriculture & Developed & & 1,061 & 1,049 & 716 & 0.4 & 4.1 \\
\hline & Grassland/Shrubland & Developed & & 790 & 949 & 648 & 0.3 & 3.1 \\
\hline & Forest & Agriculture & & 338 & 365 & 249 & 0.1 & 1.3 \\
\hline & Other & Other & & 2,411 & $\mathrm{n} / \mathrm{a}$ & $\mathrm{n} / \mathrm{a}$ & 0.9 & 9.4 \\
\hline & & & Totals & 25,730 & & & 9.4 & 100.0 \\
\hline
\end{tabular}


Table 3. Estimated area (and margin of error) of each land-cover class in Central Great Plains Ecoregion, calculated five times between 1973 and 2000. See appendix 3 for definitions of land-cover classifications.

\begin{tabular}{|c|c|c|c|c|c|c|c|c|c|c|c|c|c|c|c|c|c|c|c|c|}
\hline & \multicolumn{2}{|c|}{ Water } & \multicolumn{2}{|c|}{ Developed } & \multicolumn{2}{|c|}{$\begin{array}{l}\text { Mechan- } \\
\text { ically } \\
\text { disturbed }\end{array}$} & \multicolumn{2}{|c|}{ Mining } & \multicolumn{2}{|c|}{ Barren } & \multicolumn{2}{|c|}{ Forest } & \multicolumn{2}{|c|}{$\begin{array}{l}\text { Grassland/ } \\
\text { Shrubland }\end{array}$} & \multicolumn{2}{|c|}{ Agriculture } & \multicolumn{2}{|c|}{ Wetland } & \multicolumn{2}{|c|}{$\begin{array}{c}\text { Non- } \\
\text { mechanically } \\
\text { disturbed }\end{array}$} \\
\hline & $\%$ & $+/-$ & $\%$ & $+/-$ & $\%$ & $+/-$ & $\%$ & $+1-$ & $\%$ & $+/-$ & $\%$ & +- & $\%$ & $+/-$ & $\%$ & +- & $\%$ & +- & $\%$ & $+/-$ \\
\hline \multicolumn{21}{|c|}{ Area, in percent stratum } \\
\hline 1973 & 0.7 & 0.3 & 1.0 & 0.5 & 0.0 & 0.0 & 0.1 & 0.0 & 0.7 & 0.4 & 2.3 & 0.5 & 41.3 & 5.9 & 53.4 & 5.7 & 0.5 & 0.5 & 0.0 & 0.0 \\
\hline 1980 & 0.7 & 0.3 & 1.3 & 0.7 & 0.0 & 0.0 & 0.1 & 0.0 & 0.7 & 0.4 & 2.3 & 0.5 & 40.3 & 5.8 & 54.2 & 5.7 & 0.5 & 0.5 & 0.0 & 0.0 \\
\hline 1986 & 0.8 & 0.3 & 1.4 & 0.8 & 0.0 & 0.0 & 0.1 & 0.1 & 0.6 & 0.4 & 2.2 & 0.5 & 40.0 & 5.8 & 54.3 & 5.7 & 0.4 & 0.4 & 0.0 & 0.0 \\
\hline 1992 & 0.8 & 0.3 & 1.5 & 0.8 & 0.0 & 0.0 & 0.2 & 0.1 & 0.6 & 0.4 & 2.2 & 0.5 & 41.4 & 5.8 & 52.8 & 5.7 & 0.5 & 0.4 & 0.0 & 0.0 \\
\hline 2000 & 0.8 & 0.3 & 1.7 & 1.0 & 0.1 & 0.1 & 0.2 & 0.1 & 0.6 & 0.4 & 2.1 & 0.5 & 41.2 & 5.8 & 52.8 & 5.7 & 0.5 & 0.5 & 0.0 & 0.0 \\
\hline $\begin{array}{l}\text { Net } \\
\text { change }\end{array}$ & 0.1 & 0.2 & 0.7 & 0.5 & 0.1 & 0.1 & 0.2 & 0.1 & -0.1 & 0.1 & -0.2 & 0.2 & -0.1 & 1.3 & -0.6 & 1.3 & 0.0 & 0.0 & 0.0 & 0.0 \\
\hline $\begin{array}{l}\text { Gross } \\
\text { change }\end{array}$ & 0.3 & 0.2 & 0.7 & 0.5 & 0.1 & 0.1 & 0.2 & 0.1 & 0.1 & 0.1 & 0.2 & 0.2 & 5.7 & 1.4 & 5.8 & 1.4 & 0.1 & 0.1 & 0.0 & 0.0 \\
\hline \multicolumn{21}{|c|}{ Area, in square kilometers } \\
\hline 1973 & 1,878 & 711 & 2,788 & 1,376 & 0 & 0 & 158 & 73 & 1,810 & 1,224 & 6,245 & 1,398 & 112,936 & 15,984 & 146,004 & 15,612 & 1,371 & 1,252 & 0 & 0 \\
\hline 1980 & 1,940 & 725 & 3,492 & 1,835 & 10 & 14 & 199 & 95 & 1,829 & 1,205 & 6,185 & 1,391 & 110,040 & 15,808 & 148,119 & 15,470 & 1,377 & 1,257 & 0 & 0 \\
\hline 1986 & 2,151 & 772 & 3,790 & 2,061 & 74 & 94 & 361 & 193 & 1,717 & 1,097 & 6,094 & 1,374 & 109,402 & 15,853 & 148,389 & 15,571 & 1,212 & 1,166 & 0 & 0 \\
\hline 1992 & 2,205 & 816 & 4,079 & 2,307 & 1 & 2 & 531 & 311 & 1,698 & 1,024 & 5,978 & 1,346 & 113,177 & 15,913 & 144,252 & 15,534 & 1,269 & 1,221 & 0 & 0 \\
\hline 2000 & 2,099 & 717 & 4,657 & 2,612 & 179 & 221 & 606 & 346 & 1,635 & 980 & 5,812 & 1,302 & 112,540 & 15,773 & 144,348 & 15,447 & 1,313 & 1,242 & 0 & 0 \\
\hline $\begin{array}{l}\text { Net } \\
\text { change }\end{array}$ & 221 & 445 & 1,869 & 1,402 & 179 & 221 & 449 & 311 & -175 & 310 & -433 & 415 & -396 & 3,513 & $-1,656$ & 3,450 & -59 & 59 & 0 & 0 \\
\hline $\begin{array}{l}\text { Gross } \\
\text { change }\end{array}$ & 855 & 542 & 1,869 & 1,402 & 327 & 408 & 449 & 311 & 389 & 339 & 468 & 413 & 15,491 & 3,892 & 15,829 & 3,854 & 350 & 374 & 0 & 0 \\
\hline
\end{tabular}

Table 4. Raw estimates of change in Central Great Plains Ecoregion land cover, computed for each of four time periods between 1973 and 2000, and associated error at 85-percent confidence level.

[Estimates of change per period normalized to annual rate of change for each time period]

\begin{tabular}{|c|c|c|c|c|c|c|c|}
\hline Period & $\begin{array}{c}\text { Total } \\
\text { change } \\
\text { ( } \% \text { of } \\
\text { ecoregion) }\end{array}$ & $\begin{array}{c}\text { Margin of } \\
\text { error } \\
(+/-\%)\end{array}$ & $\begin{array}{c}\text { Lower } \\
\text { bound } \\
(\%)\end{array}$ & $\begin{array}{c}\text { Upper } \\
\text { bound } \\
(\%)\end{array}$ & $\begin{array}{c}\text { Standard } \\
\text { error } \\
(\%)\end{array}$ & $\begin{array}{c}\text { Relative } \\
\text { error } \\
(\%)\end{array}$ & $\begin{array}{c}\text { Average } \\
\text { rate } \\
\text { (\% per } \\
\text { year) }\end{array}$ \\
\hline \multicolumn{8}{|c|}{ Estimate of change, in percent stratum } \\
\hline $1973-1980$ & 2.4 & 0.4 & 2.0 & 2.8 & 0.3 & 12.1 & 0.3 \\
\hline 1980-1986 & 1.7 & 0.4 & 1.4 & 2.1 & 0.2 & 14.4 & 0.3 \\
\hline 1986-1992 & 3.4 & 1.0 & 2.3 & 4.4 & 0.7 & 21.2 & 0.6 \\
\hline $1992-2000$ & 1.9 & 0.5 & 1.5 & 2.4 & 0.3 & 16.2 & 0.2 \\
\hline \multicolumn{8}{|c|}{ Estimate of change, in square kilometers } \\
\hline $1973-1980$ & 6,599 & 1,171 & 5,429 & 7,770 & 799 & 12.1 & 943 \\
\hline 1980-1986 & 4,695 & 989 & 3,706 & 5,684 & 675 & 14.4 & 782 \\
\hline 1986-1992 & 9,185 & 2,858 & 6,326 & 12,043 & 1,951 & 21.2 & 1,531 \\
\hline 1992-2000 & 5,251 & 1,246 & 4,005 & 6,497 & 850 & 16.2 & 656 \\
\hline
\end{tabular}




\section{References Cited}

Dennehy, K.F., 2000, High Plains regional ground-water study: U.S. Geological Survey Fact Sheet 091-00, 6 p., available at http://pubs.usgs.gov/fs/2000/0091/report.pdf.

Lindert, P.H., 1988, Long-run trends in American farmland values: Agricultural History, v. 62, p. 45-85.

National Atlas of the United States, 2008, Average annual precipitation: National Atlas of the United States database, accessed May 21, 2013, at http://www.nationalatlas.gov.

Omernik, J.M., 1987, Ecoregions of the conterminous United States: Annals of the Association of American Geographers, v. 77, no. 1, p. 118-125.

Sophocleous, M.A., Koelliker, J.K., Govindaraju, R.S., Birdie, T., Ramireddygari, S.R., and Perkins, S.P., 1999, Integrated numerical modeling for basin-wide water managementThe case of the Rattlesnake Creek basin in south-central Kansas: Journal of Hydrology, v. 214, p. 179-196.

U.S. Census Bureau, 1970-2000 [various years], Census of population and housing: U.S. Census Bureau database, accessed September 1, 2008, at http://www.census.gov/ prod/www/decennial.html.

U.S. Department of Agriculture, 1970-2000 [various years], Census of Agriculture: U.S. Department of Agriculture database, accessed September 1, 2008, at http://www.agcensus. usda.gov/.

U.S. Environmental Protection Agency, 1997, Descriptions of level III ecological regions for the CEC report on ecological regions of North America: U.S. Environmental Protection Agency database, accessed April 12, 2006, at http://www. epa.gov/wed/pages/ecoregions/na_eco.htm\#Downloads.

Vogelmann, J.E., Howard, S.M., Yang, L., Larson, C.R., Wylie, B.K., and van Driel, N., 2001, Completion of the 1990s National Land Cover Data Set for the conterminous United States from Landsat Thematic Mapper data and ancillary data sources: Photogrammetric Engineering \& Remote Sensing, v. 67, p. 650-662. 


\title{
Chapter 2
}

\section{Nebraska Sand Hills Ecoregion}

\author{
By Janis L. Taylor
}

\section{Ecoregion Description}

The Nebraska Sand Hills Ecoregion covers about 60,541 $\mathrm{km}^{2}\left(23,375 \mathrm{mi}^{2}\right)$, almost entirely within the state of Nebraska (fig. 1). The ecoregion is surrounded by (clockwise, from the north) the Northwestern Great Plains, Northwestern Glaciated Plains, Western Corn Belt Plains, Central Great Plains, and Western High Plains Ecoregions (fig. 1). Nebraska's Sand Hills is an area of grass-stabilized sand dunes considered to be one of the most distinct and homogeneous ecoregions in North America (Omernik, 1987; U.S. Environmental Protection Agency, 1997). According to the Grassland Foundation (2005), Nebraska's Sand Hills is one of the largest and best examples of grasslands left in North America (fig. 2). Topographic relief varies by as much as $60 \mathrm{~m}$, and the sand layers range in thickness from a few meters to more than 122 m (Huntzinger and Ellis, 1993).
Figure 1. Map of Nebraska Sand Hills Ecoregion and surrounding ecoregions, showing land-use/land-cover classes from 1992 National Land Cover Dataset (Vogelmann and others, 2001); note that not all land-use/land-cover classes shown in explanation may be depicted on map; note also that, for this "Status and Trends of Land Change" study, transitional land-cover class was subdivided into mechanically disturbed and nonmechanically disturbed classes. Squares indicate locations of $10 \times 10 \mathrm{~km}$ sample blocks analyzed in study. Index map shows locations of geographic features mentioned in text. Abbreviations for Great Plains ecoregions are listed in appendix 2. Also shown is part of one Western United States ecoregion, Middle Rockies (MRK). See appendix 3 for definitions of land-use/land-cover classifications.

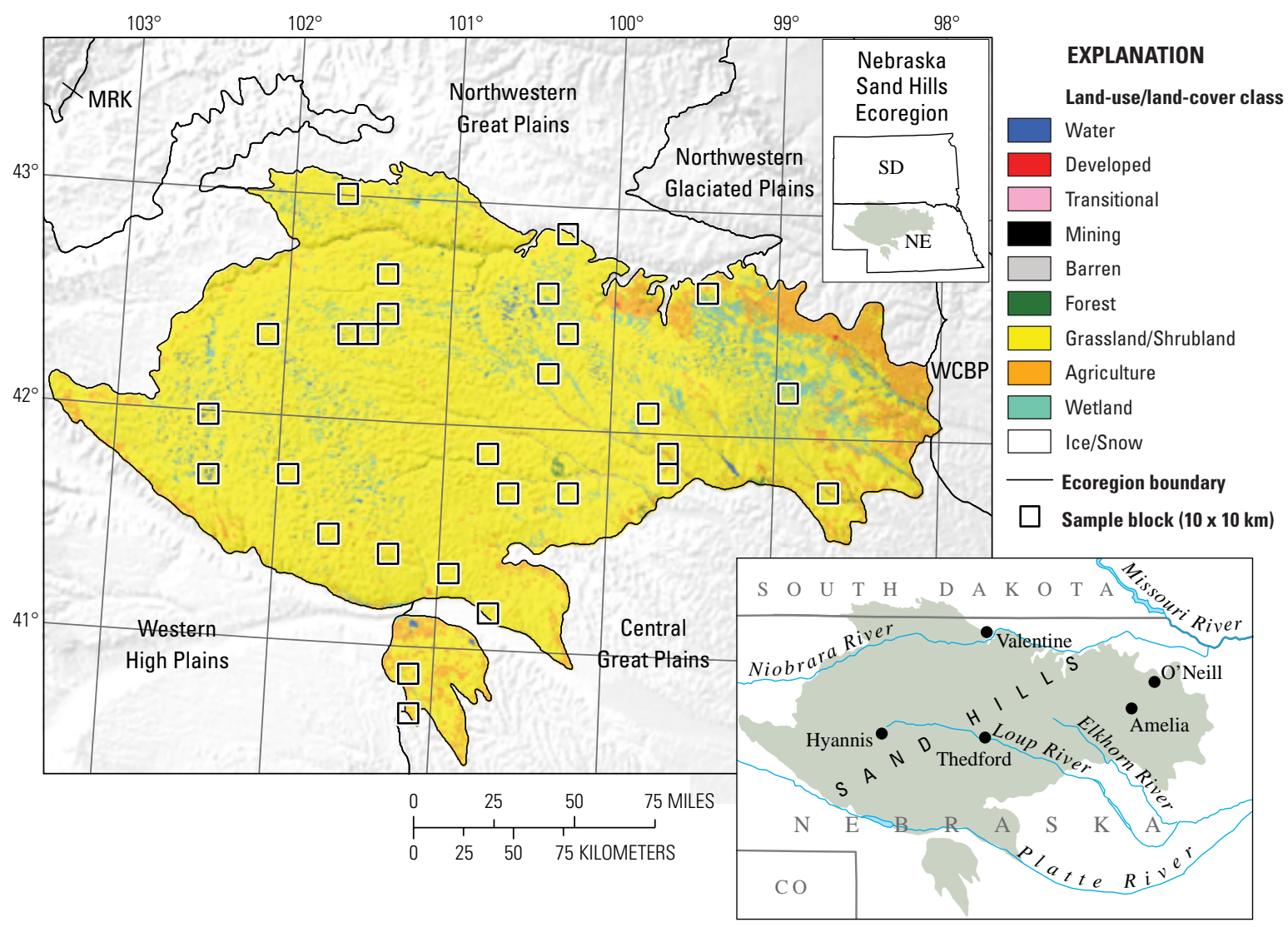



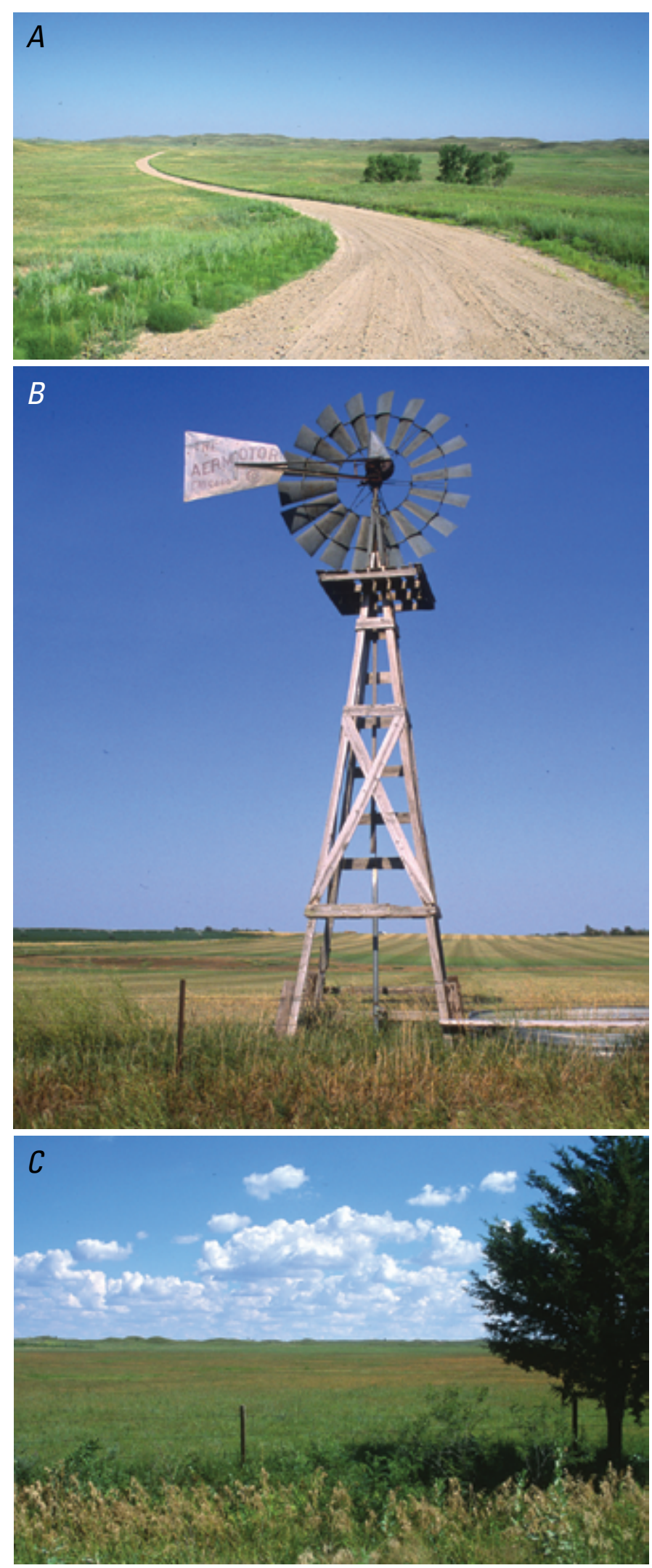

Figure 2. Grasslands extending as far as the eye can see in all directions, in Nebraska Sand Hills Ecoregion. $A$, Long gravel road. $B$, Functional windmill. $C$, Large field of grass.
The climate is considered semiarid, as the Nebraska Sand Hills Ecoregion is in the rain shadow of the Rocky Mountains to the west. The Gulf of Mexico is the principal source of moisture, with most precipitation falling during May and June. Soils in the Nebraska Sand Hills Ecoregion are classified as Aridisolssandy soils that have a coarse texture and low water-holding capacity — which have high infiltration rates and little runoff after precipitation falls. The water-holding capacity of the soil root zone is less than $100 \mathrm{~mm}$ (4 in.). Thus, ranchers and farmers involved in hay and range-livestock production are at high risk during periods of drought (Wilhelm and Wichita, 2002).

Wetlands are scattered throughout the Nebraska Sand Hills Ecoregion, in shallow, wet meadows, in the margins of lakes, and in backwaters associated with spring-fed streams. Wetlands are somewhat common in the valleys between dunes where the water table is at or near the surface (fig. 3). The Loup and Elkhorn Rivers originate in the Nebraska Sand Hills Ecoregion, and the Niobrara River flows across the northern part of the ecoregion. These rivers and their tributaries are sustained by shallow groundwater, and they have a consistent base flow (Bleed and Flowerday, 1998).

Most land within the Nebraska Sand Hills Ecoregion is privately owned, and the primary land uses include rangeland cattle grazing and hay production (fig. 4). Valentine, Hyannis, and Thedford are examples of small ranching communities found within the ecoregion. These rural towns and the counties
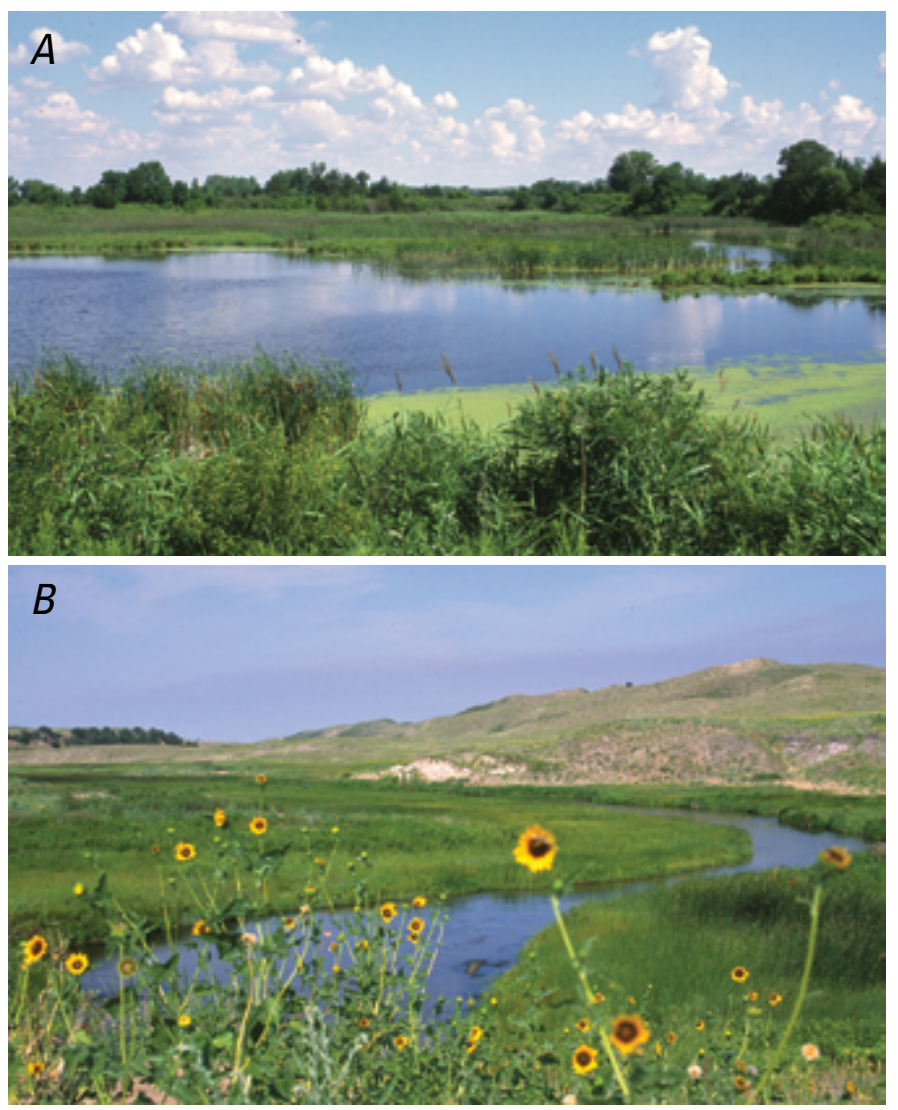

Figure 3. Wetlands in Nebraska Sand Hills Ecoregion. $A$, Pond and surrounding wetlands. $B$, Meandering river. 


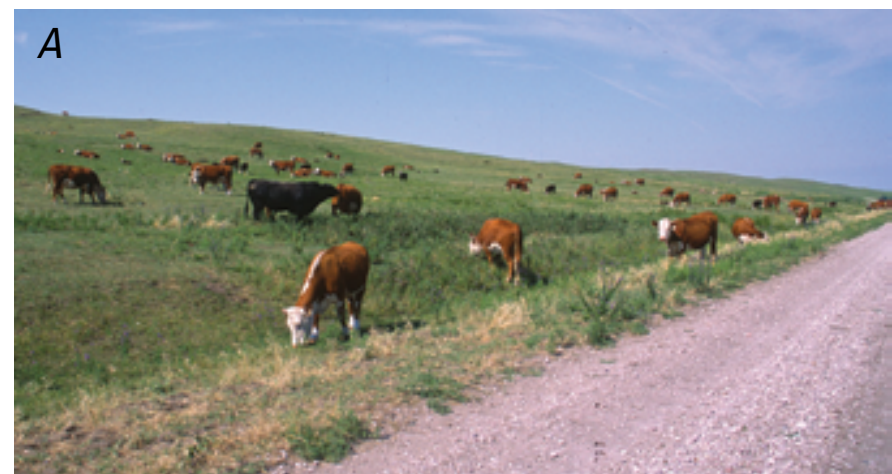

$B$
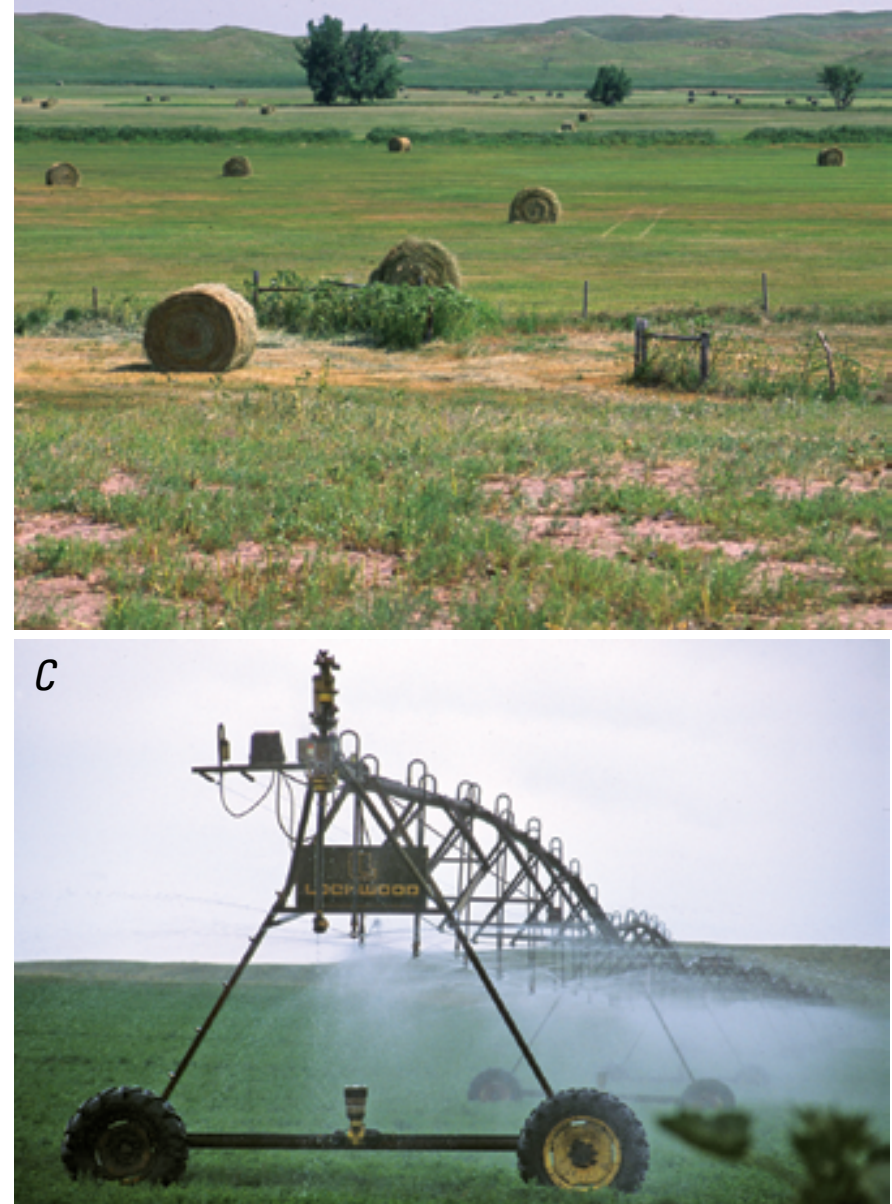

Figure 4. Livestock production and agriculture in Nebraska Sand Hills Ecoregion. $A$, Cattle grazing. $B$, Freshly baled hay. $C$, Centerpivot irrigation.

in which they lie are heavily dependent on agriculture (fig. 5). Between 1970 and 2000, Lincoln County was the only one of the 17 counties in the Nebraska Sand Hills Ecoregion that increased in population (table 1) (U.S. Census Bureau, 1995; Nebraska Department of Economic Development, 2013). In addition to decreasing populations, all 17 counties in the ecoregion have had increases in the median age of their residents (U.S. Census Bureau, 1995; Nebraska Department of Economic Development, 2013).
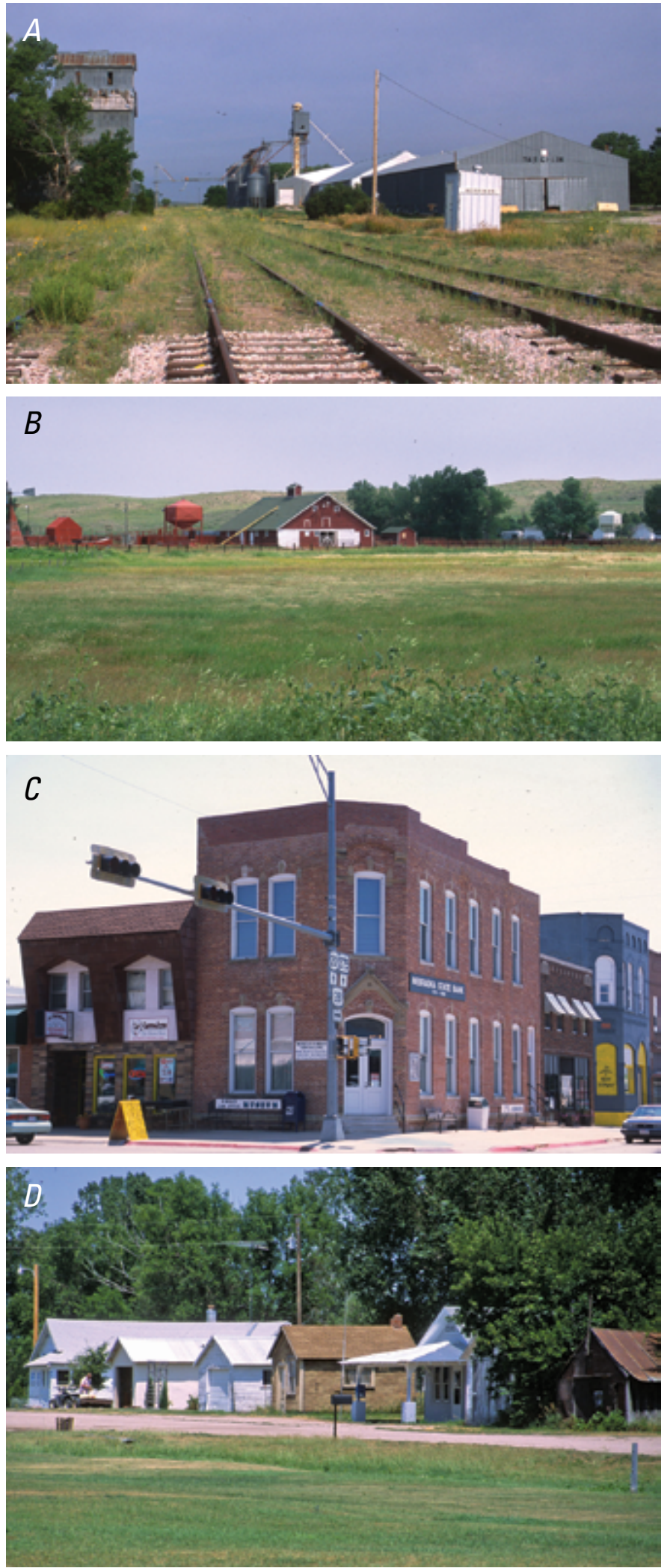

Figure 5. Rural character of Nebraska Sand Hills Ecoregion. $A$, Grain elevator along railroad tracks. $B$, Cattle ranch. $C$, Downtown 0 'Neill, Nebraska. D, Amelia, Nebraska. 


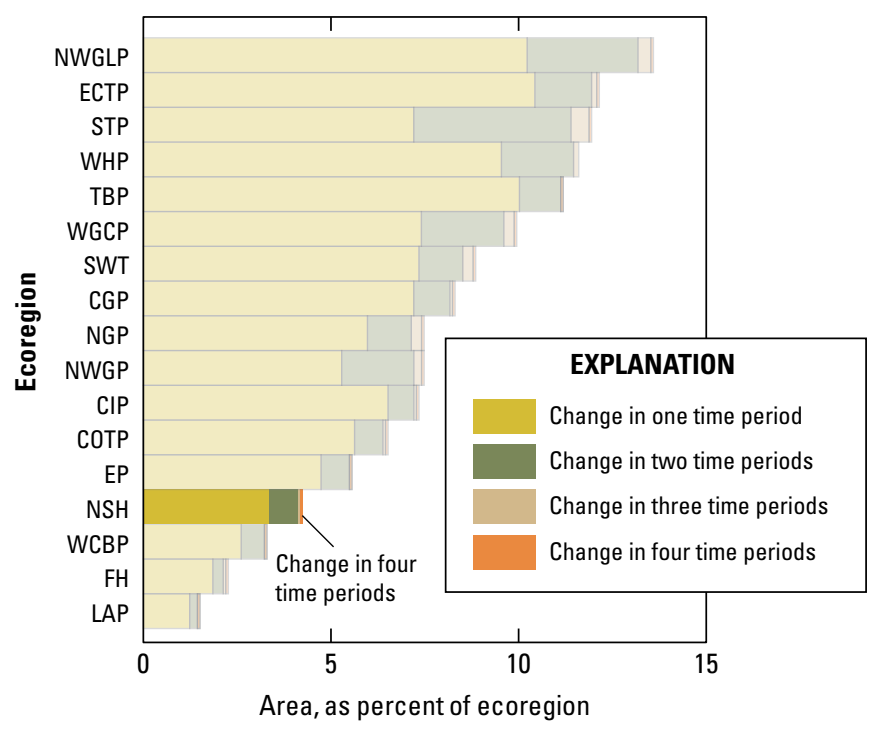

Figure 6. Overall spatial change in Nebraska Sand Hills Ecoregion (NSH; darker bars) compared with that of all 17 Great Plains ecoregions (lighter bars). Each horizontal set of bars shows proportions of ecoregion that changed during one, two, three, or four time periods; highest level of spatial change in Nebraska Sand Hills Ecoregion (four time periods) labeled for clarity. See table 3 for years covered by each time period. See appendix 2 for key to ecoregion abbreviations.

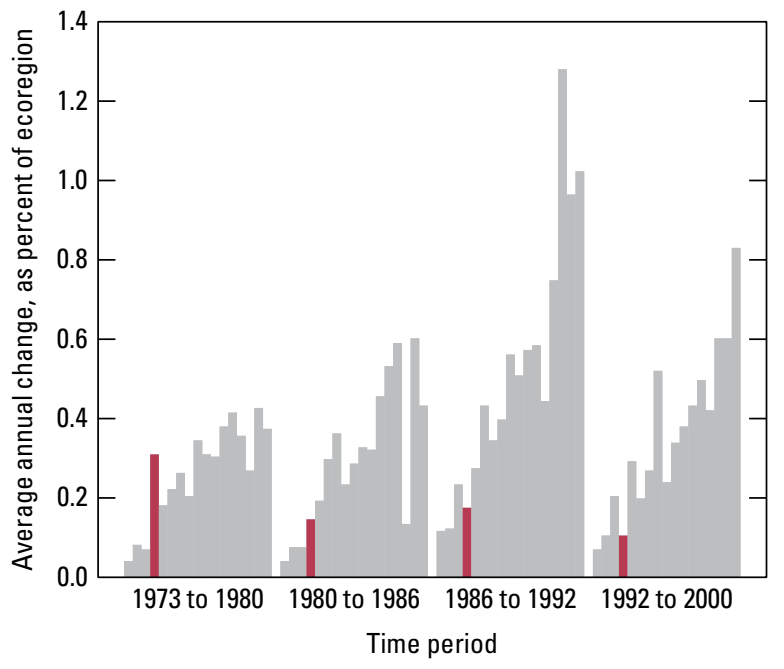

Figure 7. Estimates of land-cover change per time period, normalized to annual rates of change for all 17 Great Plains ecoregions (gray bars). Estimates of change for Nebraska Sand Hills Ecoregion are represented by red bars in each time period.

\section{Contemporary Land-Cover Change (1973 to 2000)}

The overall spatial change (the percentage of land area that changed at least one time) in the Nebraska Sand Hills Ecoregion between 1973 and 2000 is 4.0 percent $\left(2,422 \mathrm{~km}^{2}\right)$ (table 2). Compared to other Great Plains ecoregions, change in the ecoregion was low (fig. 6). Of the 4.0 percent land cover that changed, 3.1 percent changed one time, and 0.9 percent changed more than one time (table 2). Multiple changes during the study period primarily were related to conversions back and forth between grassland/shrubland and agriculture. Total change in each of the four time periods of the study ranged from a low of 0.8 percent between 1992 and 2000 to a high of 2.1 percent between 1973 and 1980 (table 3). After normalizing to an annual rate of change to account for the varying lengths in study periods, the rates ranged from a low of 0.1 percent per year between 1980 and 1986 and between 1992 and 2000 to a high of 0.3 percent per year between 1973 and 1980 (table 4; fig. 7).

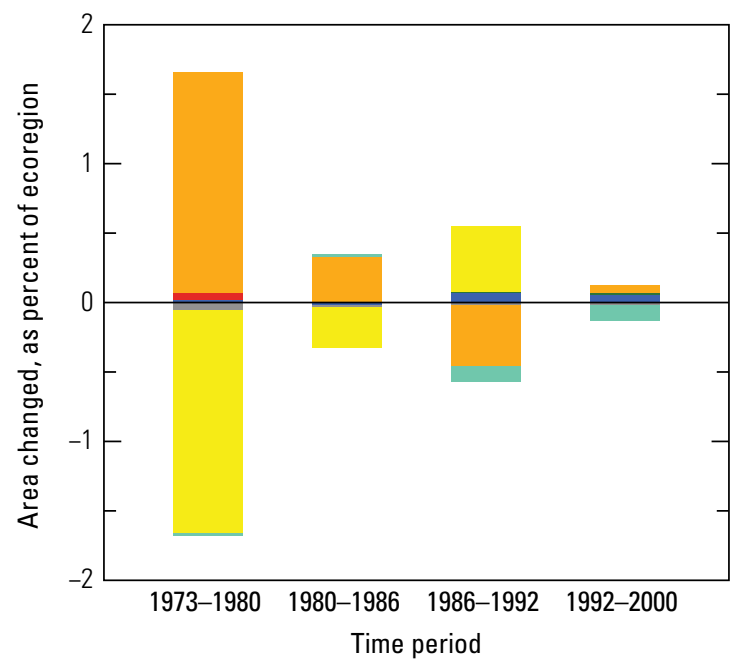

EXPLANATION

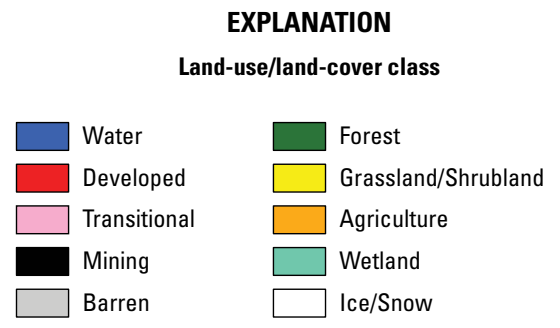

Figure 8. Normalized average net change in Nebraska Sand Hills Ecoregion by time period for each land-cover class. Bars above zero axis represent net gain, whereas bars below zero represent net loss. Note that not all land-cover classes shown in explanation may be represented in figure. See appendix 3 for definitions of land-use/land-cover classifications. 
Grassland/shrubland, agriculture, and wetland constituted about 97 percent of the land cover in the ecoregion during the entire study period. Grassland/shrubland decreased by 1.4 percent $\left(874 \mathrm{~km}^{2}\right)$, from 87.1 percent of the ecoregion in 1973 to 85.7 percent in 2000 (table 4; fig. 8). Agricultural land increased by 1.5 percent $\left(926 \mathrm{~km}^{2}\right)$, from 5.5 percent of the ecoregion in 1973 to 7.0 percent in 2000 (table 4; fig. 8). Wetlands decreased by only 0.2 percent $\left(139 \mathrm{~km}^{2}\right)$ between 1973 and 2000, from 4.6 percent of the ecoregion to 4.4 percent in 2000 (table 4; fig. 8).

Between 1973 and 2000, the two most common landcover conversions were from grassland/shrubland to agriculture $\left(1,691 \mathrm{~km}^{2}\right)$ and from agriculture to grassland/shrubland (791 $\left.\mathrm{km}^{2}\right)$. Overall, these two conversions constituted nearly 84 percent of all changes in the ecoregion during the study period (table 5; fig. 8). Grassland/shrubland to agriculture was the leading conversion in all time periods except between 1986 and 1992. During this time period, the leading conversion was from agriculture to grassland/shrubland, as land was enrolled in the Conservation Reserve Program (CRP) of the U.S. Department of Agriculture's Farm Service Agency. The CRP paid farmers to retire highly erodible cropland or other environmentally sensitive acreage from cultivation.

The third most common land-cover conversion during the study period was from wetland to water (table 5). During the entire study period, $121 \mathrm{~km}^{2}$ of wetlands became open water, likely because of climatic fluctuations such as increases in rainfall. The fourth most common conversion was from wetland to agriculture (table 5). This conversion was most common during the last three time periods (1980-1986, 1986-1992, 1992-2000) when wetlands were used for hay production in years when they were dry enough to accommodate machinery.

Overall, the Nebraska Sand Hills Ecoregion had little land-cover change during the study period, in contrast to adjacent ecoregions. The Western High Plains and Central Great Plains Ecoregions to the west and south and the Northwestern Great Plains Ecoregion to the north all changed much more than the Nebraska Sand Hills Ecoregion (12.5, 8.3, and 7.4 percent, respectively) (fig. 6). The deep sandy soils in the Nebraska Sand Hills Ecoregion limit its suitability to land uses other than grazing and hay production, which have been the main land uses for decades.

The changes that occurred (primarily the conversions between grassland/shrubland and agriculture) are due to water availability and fluctuations in agricultural economics. For example, agriculture increased in the ecoregion during the 1970s as center-pivot irrigation became economically and technically viable. However, the topography and deep sandy soils of the Nebraska Sand Hills Ecoregion were not suited to most centerpivot practices, and many newly farmed areas were subsequently abandoned. After 1986, many marginal lands still being farmed were placed in the CRP. However, along the south and west edges of the ecoregion, where sand sheets were thinner, agriculture persisted and continued to expand over the study period. Recent efforts to protect wetlands in order to improve the recharge of the High Plains (Ogalalla) aquifer and to enhance natural areas for wildlife have altered the direction of human-lead change. As agricultural communities struggle economically, more emphasis is placed on enhancing grassland and wetlands for wildlife, thereby expanding opportunities for hunters, anglers, and wildlife enthusiasts in general (Grassland Foundation, 2005).

Table 1. Population levels between 1970 and 2000, as well as median age in year 2000, in counties that intersect Nebraska Sand Hills Ecoregion.

[Data from U.S. Census Bureau (1995) and Nebraska Department of Economic Development (2013). All counties listed are in Nebraska]

\begin{tabular}{|c|c|c|c|c|c|}
\hline \multirow{2}{*}{ County } & \multicolumn{4}{|c|}{ Population } & \multirow{2}{*}{$\begin{array}{c}\text { Median age } \\
2000\end{array}$} \\
\hline & 1970 & 1980 & 1990 & 2000 & \\
\hline Arthur & 606 & 513 & 462 & 444 & 40.3 \\
\hline Blaine & 847 & 867 & 675 & 583 & 39.8 \\
\hline Brown & 4,021 & 4,377 & 3,657 & 3,525 & 43.1 \\
\hline Cherry & 6,846 & 6,758 & 6,307 & 6,148 & 39.4 \\
\hline Garden & 2,929 & 2,802 & 2,460 & 2,292 & 45.6 \\
\hline Garfield & 2,411 & 2,363 & 2,141 & 1,902 & 45.8 \\
\hline Grant & 1,019 & 877 & 769 & 747 & 39.9 \\
\hline Holt & 12,933 & 13,552 & 12,599 & 11,551 & 40.5 \\
\hline Hooker & 939 & 990 & 793 & 783 & 45 \\
\hline Lincoln & 29,538 & 36,455 & 32,508 & 34,632 & 37.8 \\
\hline Logan & 991 & 983 & 878 & 774 & 41.8 \\
\hline Loup & 854 & 859 & 683 & 712 & 42.9 \\
\hline McPherson & 623 & 593 & 546 & 544 & 40.6 \\
\hline Rock & 2,231 & 2,383 & 2,019 & 1,756 & 44 \\
\hline Sheridan & 7,285 & 7,544 & 6,750 & 6,198 & 42 \\
\hline Thomas & 954 & 973 & 851 & 729 & 44.2 \\
\hline \multirow[t]{2}{*}{ Wheeler } & 1,054 & 1,060 & 948 & 886 & 40.4 \\
\hline & \multicolumn{4}{|c|}{ Median age, all counties } & 41.9 \\
\hline
\end{tabular}

Table 2. Percentage of Nebraska Sand Hills Ecoregion land cover that changed at least one time during study period (19732000) and associated statistical error.

[Most sample pixels remained unchanged (96.0 percent), whereas 4.0 percent changed at least once throughout study period]

\begin{tabular}{ccccccc}
\hline $\begin{array}{c}\text { Number } \\
\text { of } \\
\text { changes }\end{array}$ & $\begin{array}{c}\text { Percent } \\
\text { of } \\
\text { ecoregion }\end{array}$ & $\begin{array}{c}\text { Margin } \\
\text { of error } \\
(+/-\%)\end{array}$ & $\begin{array}{c}\text { Lower } \\
\text { bound } \\
(\%)\end{array}$ & $\begin{array}{c}\text { Upper } \\
\text { bound } \\
(\%)\end{array}$ & $\begin{array}{c}\text { Standard } \\
\text { error } \\
(\%)\end{array}$ & $\begin{array}{c}\text { Relative } \\
\text { error } \\
(\%)\end{array}$ \\
\hline 1 & 3.1 & 1.2 & 1.9 & 4.4 & 0.8 & 26.5 \\
2 & 0.8 & 0.5 & 0.3 & 1.2 & 0.3 & 39.9 \\
3 & 0.1 & 0.0 & 0.0 & 0.1 & 0.0 & 51.0 \\
4 & 0.0 & 0.0 & 0.0 & 0.0 & 0.0 & 64.3 \\
\hline $\begin{array}{c}\text { Overall } \\
\text { spatial }\end{array}$ & & & & & & \\
change & 4.0 & 1.5 & 2.5 & 5.5 & 1.0 & 24.5 \\
\hline
\end{tabular}


Table 3. Raw estimates of change in Nebraska Sand Hills Ecoregion land cover, computed for each of four time periods between 1973 and 2000, and associated error at 85-percent confidence level.

[Estimates of change per period normalized to annual rate of change for each period]

\begin{tabular}{lccccccc}
\hline Period & $\begin{array}{c}\text { Total change } \\
(\% \text { of ecoregion) }\end{array}$ & $\begin{array}{c}\text { Margin of } \\
\text { error } \\
(+/-\%)\end{array}$ & $\begin{array}{c}\text { Lower } \\
\text { bound } \\
(\%)\end{array}$ & $\begin{array}{c}\text { Upper bound } \\
(\%)\end{array}$ & $\begin{array}{c}\text { Standard } \\
\text { error } \\
(\%)\end{array}$ & $\begin{array}{c}\text { Relative } \\
\text { error } \\
(\%)\end{array}$ & $\begin{array}{c}\text { Average rate } \\
(\% \text { per year) }\end{array}$ \\
\hline \multicolumn{7}{c}{ Estimate of change, in percent stratum } \\
\hline $1973-1980$ & 2.1 & 1.1 & 1.0 & 3.3 & 0.8 & 35.4 & 0.3 \\
$1980-1986$ & 0.9 & 0.3 & 0.6 & 1.2 & 0.2 & 23.0 & 0.1 \\
$1986-1992$ & 1.1 & 0.4 & 0.6 & 1.5 & 0.3 & 26.6 & 0.2 \\
$1992-2000$ & 0.8 & 0.4 & 0.5 & 1.2 & 0.3 & 30.2 & 0.1 \\
\hline \multicolumn{7}{c}{ Estimate of change, in square kilometers } \\
\hline $1973-1980$ & 1,294 & 679 & 615 & 1,973 & 458 & 35.4 & 185 \\
$1980-1986$ & 533 & 181 & 351 & 714 & 122 & 23.0 & 89 \\
$1986-1992$ & 638 & 252 & 387 & 890 & 170 & 26.6 & 106 \\
$1992-2000$ & 502 & 225 & 278 & 727 & 152 & 30.2 & 63 \\
\hline
\end{tabular}

Table 4. Estimated area (and margin of error) of each land-cover class in Nebraska Sand Hills Ecoregion, calculated five times between 1973 and 2000. See appendix 3 for definitions of land-cover classifications.

\begin{tabular}{|c|c|c|c|c|c|c|c|c|c|c|c|c|c|c|c|c|c|c|c|c|}
\hline & \multicolumn{2}{|c|}{ Water } & \multicolumn{2}{|c|}{ Developed } & \multicolumn{2}{|c|}{$\begin{array}{l}\text { Mechani- } \\
\text { cally dis- } \\
\text { turbed }\end{array}$} & \multicolumn{2}{|c|}{ Mining } & \multicolumn{2}{|c|}{ Barren } & \multicolumn{2}{|c|}{ Forest } & \multicolumn{2}{|c|}{$\begin{array}{l}\text { Grassland/Shru- } \\
\text { bland }\end{array}$} & \multicolumn{2}{|c|}{ Agriculture } & \multicolumn{2}{|c|}{ Wetland } & \multicolumn{2}{|c|}{$\begin{array}{c}\text { Non- } \\
\text { mechanically } \\
\text { disturbed }\end{array}$} \\
\hline & $\%$ & $+/-$ & $\%$ & $+/-$ & $\%$ & $+/-$ & $\%$ & $+/-$ & $\%$ & $+/-$ & $\%$ & $+/-$ & $\%$ & $+/-$ & $\%$ & $+/-$ & $\%$ & $+/-$ & $\%$ & $+/-$ \\
\hline \multicolumn{21}{|c|}{ Area, in percent stratum } \\
\hline 1973 & 1.2 & 0.7 & 0.2 & 0.2 & 0.0 & 0.0 & 0.0 & 0.0 & 0.3 & 0.1 & 1.0 & 1.0 & 87.1 & 2.3 & 5.5 & 2.1 & 4.6 & 1.6 & 0.0 & 0.0 \\
\hline 1980 & 1.2 & 0.7 & 0.2 & 0.3 & 0.0 & 0.0 & 0.0 & 0.0 & 0.3 & 0.1 & 1.0 & 1.0 & 85.5 & 2.8 & 7.1 & 2.9 & 4.6 & 1.6 & 0.0 & 0.0 \\
\hline 1986 & 1.2 & 0.7 & 0.3 & 0.3 & 0.0 & 0.0 & 0.0 & 0.0 & 0.3 & 0.1 & 1.0 & 1.0 & 85.2 & 2.8 & 7.4 & 2.9 & 4.6 & 1.6 & 0.0 & 0.0 \\
\hline 1992 & 1.3 & 0.8 & 0.3 & 0.3 & 0.0 & 0.0 & 0.0 & 0.0 & 0.2 & 0.1 & 1.0 & 1.0 & 85.7 & 2.8 & 7.0 & 2.8 & 4.5 & 1.5 & 0.0 & 0.0 \\
\hline 2000 & 1.4 & 0.8 & 0.3 & 0.3 & 0.0 & 0.0 & 0.0 & 0.0 & 0.2 & 0.1 & 1.0 & 1.0 & 85.7 & 2.9 & 7.0 & 2.9 & 4.4 & 1.5 & 0.0 & 0.0 \\
\hline $\begin{array}{l}\text { Net } \\
\text { change }\end{array}$ & 0.1 & 0.2 & 0.1 & 0.1 & 0.0 & 0.0 & 0.0 & 0.0 & -0.1 & 0.0 & 0.0 & 0.0 & -1.4 & 0.9 & 1.5 & 0.9 & -0.2 & 0.2 & 0.0 & 0.0 \\
\hline $\begin{array}{l}\text { Gross } \\
\text { change }\end{array}$ & 0.3 & 0.2 & 0.1 & 0.1 & 0.0 & 0.0 & 0.0 & 0.0 & 0.1 & 0.0 & 0.0 & 0.0 & 3.1 & 1.5 & 3.2 & 1.5 & 0.5 & 0.2 & 0.0 & 0.0 \\
\hline \multicolumn{21}{|c|}{ Area, in square kilometers } \\
\hline 1973 & 745 & 436 & 121 & 116 & 0 & 0 & 3 & 3 & 187 & 90 & 593 & 590 & 52,756 & 1,406 & 3,329 & 1,287 & 2,809 & 952 & 0 & 0 \\
\hline 1980 & 757 & 451 & 151 & 158 & 0 & 0 & 4 & 4 & 157 & 79 & 592 & 588 & 51,779 & 1,714 & 4,293 & 1,764 & 2,808 & 952 & 0 & 0 \\
\hline 1986 & 746 & 437 & 158 & 166 & 0 & 0 & 5 & 4 & 153 & 77 & 590 & 587 & 51,597 & 1,721 & 4,482 & 1,784 & 2,811 & 949 & 0 & 0 \\
\hline 1992 & 793 & 488 & 161 & 169 & 0 & 0 & 5 & 4 & 147 & 76 & 591 & 587 & 51,884 & 1,670 & 4,219 & 1,684 & 2,742 & 936 & 0 & 0 \\
\hline 2000 & 829 & 514 & 166 & 176 & 0 & 0 & 5 & 4 & 143 & 77 & 593 & 588 & 51,881 & 1,732 & 4,255 & 1,728 & 2,670 & 918 & 0 & 0 \\
\hline $\begin{array}{l}\text { Net } \\
\text { change }\end{array}$ & 84 & 94 & 45 & 63 & 0 & 0 & 2 & 2 & -44 & 27 & 0 & 5 & -874 & 554 & 926 & 551 & -139 & 93 & 0 & 0 \\
\hline $\begin{array}{l}\text { Gross } \\
\text { change }\end{array}$ & 165 & 118 & 45 & 63 & 0 & 0 & 2 & 2 & 51 & 29 & 8 & 6 & 1,877 & 927 & 1,929 & 920 & 281 & 119 & 0 & 0 \\
\hline
\end{tabular}


Table 5. Principal land-cover conversions in Nebraska Sand Hills Ecoregion, showing amount of area changed (and margin of error, calculated at 85-percent confidence level) for each conversion during each of four time periods and also during overall study period. See appendix 3 for definitions of land-cover classifications.

[Values given for "other” classes are combined totals of values for other land-cover classes not listed in that time period. Abbreviations: n/a, not applicable]

\begin{tabular}{|c|c|c|c|c|c|c|c|c|}
\hline Period & From class & To class & & $\begin{array}{c}\text { Area } \\
\text { changed } \\
\left(\mathbf{k m}^{2}\right)\end{array}$ & $\begin{array}{c}\text { Margin of } \\
\text { error } \\
\left(+/-\mathrm{km}^{2}\right)\end{array}$ & $\begin{array}{c}\text { Standard } \\
\text { error } \\
\left(\mathbf{k m}^{2}\right)\end{array}$ & $\begin{array}{l}\text { Percent of } \\
\text { ecoregion }\end{array}$ & $\begin{array}{c}\text { Percent } \\
\text { of all } \\
\text { changes }\end{array}$ \\
\hline \multirow[t]{7}{*}{ 1973-1980 } & Grassland/Shrubland & Agriculture & & 1,066 & 645 & 435 & 1.8 & 82.4 \\
\hline & Agriculture & Grassland/Shrubland & & 91 & 61 & 41 & 0.2 & 7.0 \\
\hline & Grassland/Shrubland & Developed & & 24 & 35 & 23 & 0.0 & 1.8 \\
\hline & Agriculture & Wetland & & 18 & 20 & 14 & 0.0 & 1.4 \\
\hline & Barren & Grassland/Shrubland & & 17 & 14 & 9 & 0.0 & 1.3 \\
\hline & Other & Other & & 78 & $\mathrm{n} / \mathrm{a}$ & $\mathrm{n} / \mathrm{a}$ & 0.1 & 6.0 \\
\hline & & & Totals & 1,294 & & & 2.1 & 100.0 \\
\hline \multirow[t]{7}{*}{ 1980-1986 } & Grassland/Shrubland & Agriculture & & 312 & 129 & 87 & 0.5 & 58.5 \\
\hline & Agriculture & Grassland/Shrubland & & 128 & 67 & 45 & 0.2 & 24.0 \\
\hline & Wetland & Agriculture & & 22 & 19 & 13 & 0.0 & 4.1 \\
\hline & Water & Wetland & & 21 & 16 & 11 & 0.0 & 4.0 \\
\hline & Agriculture & Wetland & & 14 & 11 & 7 & 0.0 & 2.6 \\
\hline & Other & Other & & 36 & $\mathrm{n} / \mathrm{a}$ & $\mathrm{n} / \mathrm{a}$ & 0.1 & 6.8 \\
\hline & & & Totals & 533 & & & 0.9 & 100.0 \\
\hline \multirow[t]{7}{*}{ 1986-1992 } & Agriculture & Grassland/Shrubland & & 388 & 233 & 157 & 0.6 & 60.7 \\
\hline & Grassland/Shrubland & Agriculture & & 120 & 75 & 51 & 0.2 & 18.9 \\
\hline & Wetland & Water & & 55 & 60 & 40 & 0.1 & 8.6 \\
\hline & Wetland & Agriculture & & 21 & 26 & 18 & 0.0 & 3.3 \\
\hline & Agriculture & Wetland & & 14 & 12 & 8 & 0.0 & 2.1 \\
\hline & Other & Other & & 41 & $\mathrm{n} / \mathrm{a}$ & $\mathrm{n} / \mathrm{a}$ & 0.1 & 6.4 \\
\hline & & & Totals & 638 & & & 1.1 & 100.0 \\
\hline \multirow[t]{7}{*}{ 1992-2000 } & Grassland/Shrubland & Agriculture & & 192 & 105 & 71 & 0.3 & 38.3 \\
\hline & Agriculture & Grassland/Shrubland & & 184 & 159 & 107 & 0.3 & 36.6 \\
\hline & Wetland & Water & & 41 & 33 & 22 & 0.1 & 8.2 \\
\hline & Wetland & Agriculture & & 33 & 24 & 16 & 0.1 & 6.5 \\
\hline & Wetland & Grassland/Shrubland & & 12 & 17 & 12 & 0.0 & 2.4 \\
\hline & Other & Other & & 40 & $\mathrm{n} / \mathrm{a}$ & $\mathrm{n} / \mathrm{a}$ & 0.1 & 7.9 \\
\hline & & & Totals & 502 & & & 0.8 & 100.0 \\
\hline \multirow{7}{*}{$\begin{array}{c}1973-2000 \\
\text { (overall) }\end{array}$} & Grassland/Shrubland & Agriculture & & 1,691 & 809 & 546 & 2.8 & 57.0 \\
\hline & Agriculture & Grassland/Shrubland & & 791 & 398 & 269 & 1.3 & 26.7 \\
\hline & Wetland & Water & & 121 & 100 & 67 & 0.2 & 4.1 \\
\hline & Wetland & Agriculture & & 83 & 49 & 33 & 0.1 & 2.8 \\
\hline & Water & Wetland & & 53 & 31 & 21 & 0.1 & 1.8 \\
\hline & Other & Other & & 228 & $\mathrm{n} / \mathrm{a}$ & $\mathrm{n} / \mathrm{a}$ & 0.4 & 7.7 \\
\hline & & & Totals & 2,967 & & & 4.9 & 100.0 \\
\hline
\end{tabular}




\section{References Cited}

Bleed, A.S., and Flowerday, C.A., eds., 1998, An atlas of the Sand Hills (RA-5b): Lincoln, University of Nebraska, Conservation and Survey Division, 260 p., available at http://nebraskamaps.unl.edu/productcart/pc/home.asp.

Grassland Foundation, 2005, Economic benefits of grassland protected areas: Lincoln, Neb., 64 p., available at http:// grasslandfoundation.org/publications/.

Huntzinger, T.L., and Ellis, M.J., 1993, Central Nebraska river basins, Nebraska: Water Resources Bulletin, v. 29, no. 4, p. 533-574.

Nebraska Department of Economic Development, 2013, Population-Population by age, sex, and ethnicity: Nebraska Department of Economic Development database, accessed on September 25, 2008, at http://www.neded.org/ business/data-a-research/population.

Omernik, J.M., 1987, Ecoregions of the conterminous United States: Annals of the Association of American Geographers, v. 77 , no. 1 , p. $118-125$.
U.S. Census Bureau, 1995, Nebraska-Population of counties by decennial census, 1900 to 1990: U.S. Census Bureau database, accessed September 25, 2008, at http://www. census.gov/population/cencounts/ne190090.txt.

U.S. Environmental Protection Agency, 1997, Descriptions of level III ecological regions for the CEC report on ecological regions of North America: U.S. Environmental Protection Agency database, accessed April 12, 2006, at http://www. epa.gov/wed/pages/ecoregions/na_eco.htm\#Downloads.

Vogelmann, J.E., Howard, S.M., Yang, L., Larson, C.R., Wylie, B.K., and van Driel, N., 2001, Completion of the 1990s National Land Cover Data Set for the conterminous United States from Landsat Thematic Mapper data and ancillary data sources: Photogrammetric Engineering \& Remote Sensing, v. 67, p. 650-662.

Wilhelmi, O.V., and Wilhite, D.A., 2002, Assessing vulnerability to agricultural drought-A Nebraska case study: Natural Hazards, v. 25, p. 37-58. 


\title{
Northwestern Great Plains Ecoregion
}

\author{
By Kristi L. Sayler
}

\section{Ecoregion Description}

The Northwestern Great Plains Ecoregion is a large ecoregion that covers about 346,883 $\mathrm{km}^{2}\left(133,932 \mathrm{mi}^{2}\right)$ of eastern Montana, northeastern Wyoming, western North Dakota, western South Dakota, and northern Nebraska (fig. 1) (Omernik, 1987; U.S. Environmental Protection Agency, 1997). The Missouri River and its system of dams and reservoirs (for example, Lake Sakakawea in North Dakota and Fort Peck Lake in Montana) make up the northern border of the ecoregion. The ecoregion is bounded by (clockwise, from the north) the Northwestern Glaciated Plains, Nebraska Sand Hills, Western High Plains, Southern Rockies, Wyoming Basin, Middle Rockies, Northern
Figure 1. Map of Northwestern Great Plains and surrounding ecoregions, showing land-use/land-cover classes from 1992 National Land Cover Dataset (Vogelmann and others, 2001); note that not all land-use/land-cover classes shown in explanation may be depicted on map; note also that, for this "Status and Trends of Land Change" study, transitional land-cover class was subdivided into mechanically disturbed and nonmechanically disturbed classes. Squares indicate locations of $10 \times 10 \mathrm{~km}$ sample blocks analyzed in study. Index map shows locations of geographic features mentioned in text. Abbreviations for Great Plains ecoregions are listed in appendix 2. Also shown are parts of five Western United States ecoregions: Middle Rockies (MRK), Montana Valley and Foothill Prairies (MVFP), Northern Rockies (NRK), Southern Rockies (SRK), and Wyoming Basin (WB). See appendix 3 for definitions of land-use/land-cover classifications.

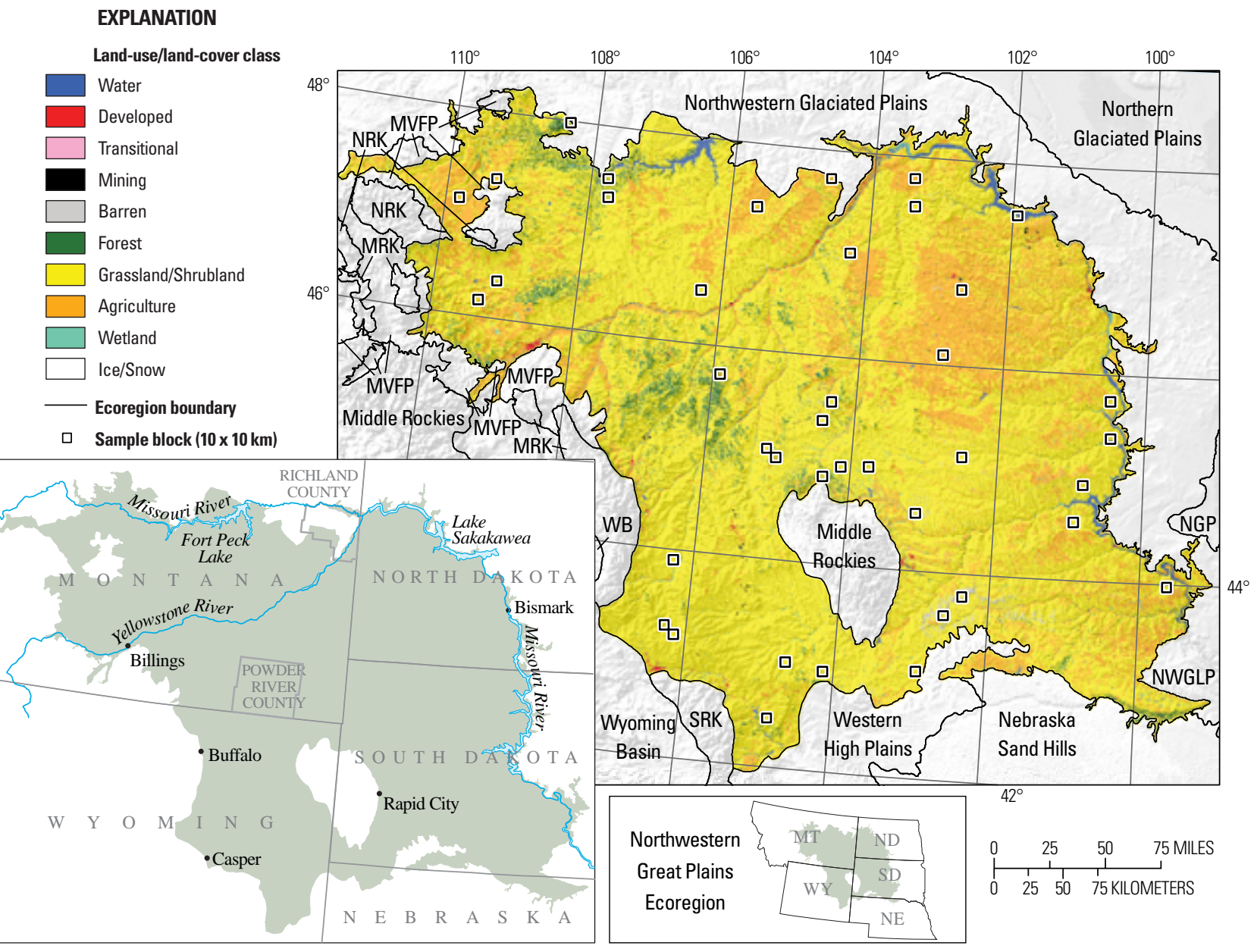


Rockies, and Montana Valley and Foothill Prairies Ecoregions (fig. 1). The Northwestern Great Plains Ecoregion contains much tribal, Federal, and State lands, including Indian reservations, national grasslands, Bureau of Land Management lands, national parks, and Montana State Trust Lands.

The Northwestern Great Plains Ecoregion is a semiarid rolling plain of shale- and sandstone-derived soils, punctuated by buttes and badlands (fig. 2). The badlands of North Dakota and South Dakota are unique features of the ecoregion and have been incorporated into national parks. The elevation of the ecoregion ranges from 450 to 1,200 $\mathrm{m}$ (McNab and Avers, 1994). This mostly unglaciated plain consists of shallow soils that have clayey textures not conducive to growing crops but are suitable for grazing. The climatic conditions include erratic annual precipitation amounts of 250 to $510 \mathrm{~mm}$ (10-20 in.), falling mostly during the summer growing season. Native semiarid grasslands cover most of the ecoregion, including western wheatgrass (Pascopyrum smithii), needlegrass (Achnatherum spp.), blue grama (Bouteloua gracilis), and buffalograss (Buchloe dactyloides) (Woods and others, 2002).

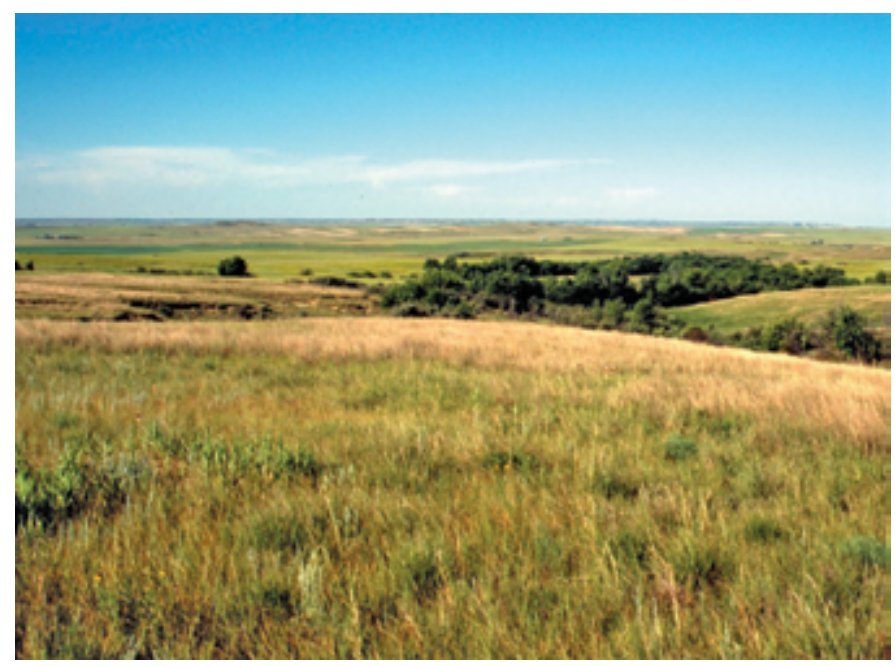

Figure 2. Grassland and cropland in Richland County, Montana, in Northwestern Great Plains Ecoregion.

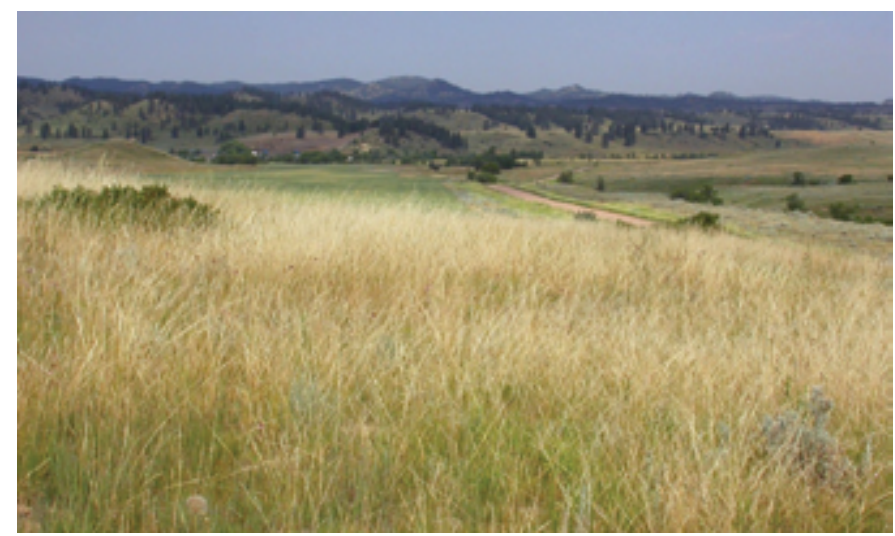

Figure 3. Mosaic of forested hills and grassland in Powder River County, Montana, in Northwestern Great Plains Ecoregion.
The most common land use in the Northwestern Great Plains Ecoregion is livestock grazing of cattle and sheep. Crop agriculture is limited by soil quality, precipitation levels, and the limited access to water for irrigation. The main agricultural areas, which are located in the Missouri Plateau physiographic province in North Dakota, South Dakota, and Montana, are composed mostly of dryland farming (Bryce and others, 1998). Spring wheat is the predominant crop, but smaller areas are planted with barley, oats, sunflowers, and alfalfa and other hay crops. However, drought-resistant, genetically modified crops such as soybeans are becoming increasingly common in the eastern part of the ecoregion (Higgins and others, 2002).

In 2000 , the land cover of the ecoregion was an estimated 77.1 percent grassland/shrubland, 15.4 percent agriculture, and 2 to 3 percent each of forest (2.7 percent), barren (2.3 percent), and water (2.1 percent) (table 1). Most forest land is limited to areas of ponderosa pine (Pinus ponderosa) in southeastern Montana, as well as small forests along major river valleys of the ecoregion (fig. 3). Mining (including petroleum extraction) also is a minor land use in the ecoregion, as oil, gas, and coal deposits are scattered throughout the Powder River Basin of southeastern Montana and northeastern Wyoming.

\section{Contemporary Land-Cover Change (1973 to 2000)}

The overall spatial change (the percentage of land area that changed at least one time) in the Northwestern Great Plains between 1973 and 2000 is 7.4 percent (table 2). Compared to other Great Plains ecoregions, change was moderate (fig. 4). An estimated 5.2 percent of the ecoregion changed only once during the 27-year study period, but other areas changed multiple times during the study period (table 1). Areas that experienced multiple changes included marginal agricultural land that was taken out of production early in the study period, which at first reverted to grassland/shrubland but later was converted back to agricultural land.

The total change per time period varied slightly between 1973 and 2000. The last two time periods (1986-1992,

1992-2000) had greater change than the first two time periods (1973-1980, 1980-1986) (table 3). When normalized to account for the varying lengths in study periods, the period between 1986 and 1992 had the greatest rate of change per year, at 0.5 percent, compared to 0.3 percent per year for the other three time periods (table 3; fig. 5).

Agriculture and grassland/shrubland had the most change during the study period (table 1). Agriculture decreased 1.8 percent, with most of the decrease coming from conversion of agricultural land to grassland/shrubland (table 1; fig. 5). Grassland/shrubland increased 2.2 percent (table 1; fig. 6). In terms of the amount of area changed, the largest conversions during the study period were from agriculture to grassland/ shrubland $\left(17,239 \mathrm{~km}^{2}\right)$ and from grassland/shrubland to agriculture $\left(11,013 \mathrm{~km}^{2}\right)$ (table 4$)$. These two conversions 
together constituted at least 82 percent of change in all time periods except between 1973 and 1980.

The first two time periods (1973-1980, 1980-1986) saw large conversions of grassland/shrubland to agriculture, which were driven mainly by changes in the agricultural economy, as well as by farm policies such as the Conservation Reserve Program (CRP). The CRP, which the U.S. Congress implemented in 1985 (U.S. Department of Agriculture, 2004), is a voluntary, long-term cropland retirement program that pays participants to retire highly erodible and environmentally sensitive cropland and pastureland from production for a period of 10 to 15 years. Because much of the land in the Northwestern Great Plains Ecoregion is marginal for crop production, it was

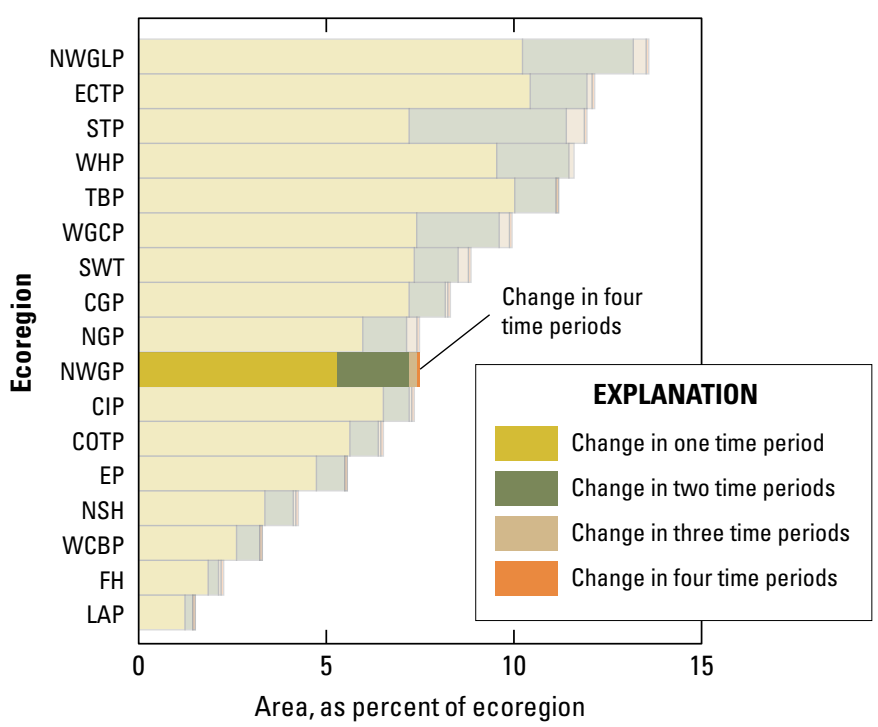

Figure 4. Overall spatial change in Northwestern Great Plains Ecoregion (NWGP; darker bars) compared with that of all 17 Great Plains ecoregions (lighter bars). Each horizontal set of bars shows proportions of ecoregion that changed during one, two, three, or four time periods; highest level of spatial change in Northwestern Great Plains Ecoregion (four time periods) labeled for clarity. See table 3 for years covered by each time period. See appendix 2 for key to ecoregion abbreviations. more economical for landowners to enroll their properties in the CRP rather than to continue using them for agricultural purposes. After 1986, the conversions reversed, as marginal croplands in the ecoregion could be more profitable as grassland/shrubland in the CRP. Nevertheless, about 2,400 km² of land in the ecoregion was enrolled in the CRP by the end of 1990 (U.S. Department of Agriculture, 2009).

Another significant change occurred during the first time period (1973-1980), in which a large area $\left(1,390 \mathrm{~km}^{2}\right)$ of nonmechanically disturbed land converted to grassland/ shrubland. This was largely because of a burned area that was mapped as nonmechanically disturbed in one of the sample blocks in 1973 but that had reverted to grassland/shrubland by 1980. Less significant conversions during the study period were noted between the water class and the grassland/shrubland, wetland, and barren classes, which fluctuated because of variations in precipitation over time in the ecoregion.

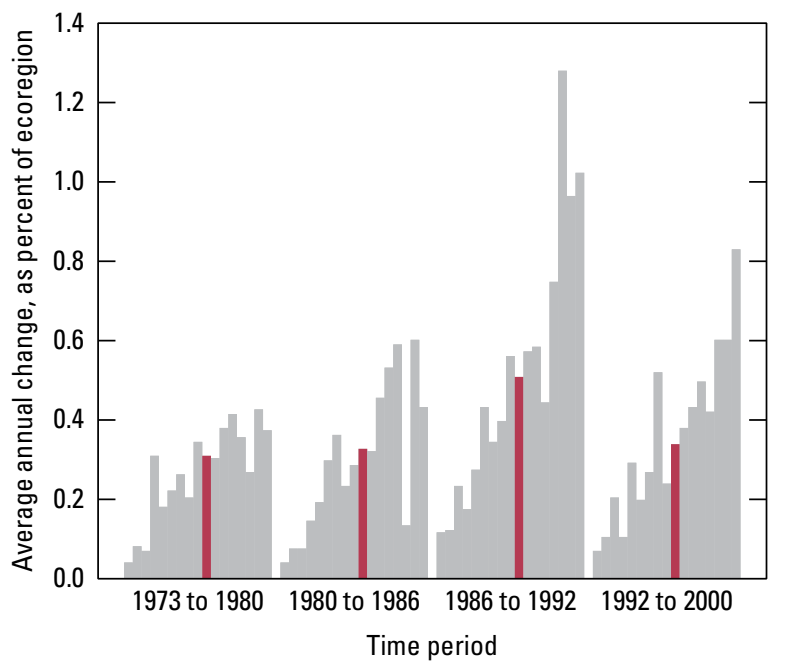

Figure 5. Estimates of land-cover change per time period, normalized to annual rates of change for all 17 Great Plains ecoregions (gray bars). Estimates of change for Northwestern Great Plains Ecoregion are represented by red bars in each time period. 


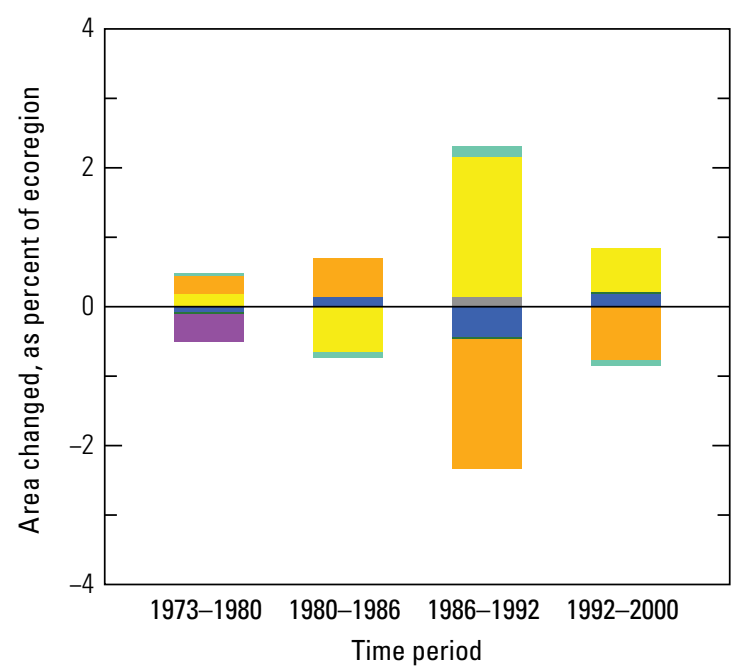

EXPLANATION

LAND-USE/LAND-COVER CLASS
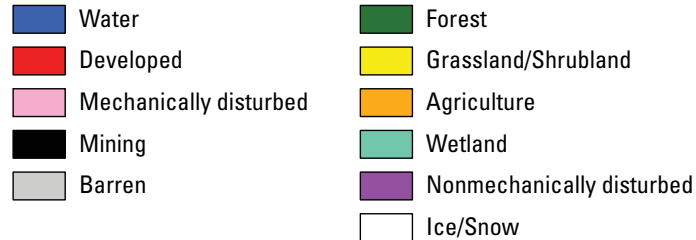

Figure 6. Normalized average net change in Northwestern Great Plains Ecoregion by time period for each landcover class. Bars above zero axis represent net gain, whereas bars below zero represent net loss. Note that not all land-cover classes shown in explanation may be represented in figure. See appendix 3 for definitions of land-use/land-cover classifications.

Table 1. Estimated area (and margin of error) of each land-cover class in Northwestern Great Plains Ecoregion, calculated five times between 1973 and 2000. See appendix 3 for definitions of land-cover classifications.

\begin{tabular}{|c|c|c|c|c|c|c|c|c|c|c|c|c|c|c|c|c|c|c|c|c|}
\hline & \multicolumn{2}{|c|}{ Water } & \multicolumn{2}{|c|}{$\begin{array}{c}\text { Devel- } \\
\text { oped }\end{array}$} & \multicolumn{2}{|c|}{$\begin{array}{l}\text { Mechani- } \\
\text { cally } \\
\text { disturbed }\end{array}$} & \multicolumn{2}{|c|}{ Mining } & \multicolumn{2}{|c|}{ Barren } & \multicolumn{2}{|c|}{ Forest } & \multicolumn{2}{|c|}{$\begin{array}{l}\text { Grassland/Shru- } \\
\text { bland }\end{array}$} & \multicolumn{2}{|c|}{ Agriculture } & \multicolumn{2}{|c|}{ Wetland } & \multicolumn{2}{|c|}{$\begin{array}{c}\text { Non- } \\
\text { mechanically } \\
\text { disturbed }\end{array}$} \\
\hline & $\%$ & $+/-$ & $\%$ & $+/-$ & $\%$ & $+/-$ & $\%$ & $+/-$ & $\%$ & $+1-$ & $\%$ & $+1-$ & $\%$ & $+/-$ & $\%$ & $+/-$ & $\%$ & $+/-$ & $\%$ & $+/-$ \\
\hline 1973 & 2.3 & 2.3 & 0.2 & 0.1 & 0.0 & 0.0 & 0.0 & 0.0 & 2.2 & 1.5 & 2.7 & 1.1 & 74.9 & 5.3 & 17.2 & 5.3 & 0.2 & 0.1 & 0.4 & 0.6 \\
\hline 1980 & 2.2 & 2.3 & 0.2 & 0.1 & 0.0 & 0.0 & 0.0 & 0.0 & 2.2 & 1.5 & 2.7 & 1.1 & 75.0 & 5.3 & 17.4 & 5.3 & 0.3 & 0.2 & 0.0 & 0.0 \\
\hline 1992 & 1.9 & 2.0 & 0.2 & 0.1 & 0.0 & 0.0 & 0.0 & 0.0 & 2.3 & 1.5 & 2.7 & 1.1 & 76.5 & 4.9 & 16.1 & 4.9 & 0.3 & 0.2 & 0.0 & 0.0 \\
\hline 2000 & 2.1 & 2.1 & 0.2 & 0.1 & 0.0 & 0.0 & 0.0 & 0.0 & 2.3 & 1.5 & 2.7 & 1.1 & 77.1 & 4.9 & 15.4 & 4.8 & 0.2 & 0.2 & 0.0 & 0.0 \\
\hline $\begin{array}{l}\text { Net } \\
\text { change }\end{array}$ & -0.2 & 0.2 & 0.0 & 0.0 & 0.0 & 0.0 & 0.0 & 0.0 & 0.1 & 0.1 & 0.0 & 0.0 & 2.2 & 1.4 & -1.8 & 1.3 & 0.1 & 0.1 & -0.4 & 0.6 \\
\hline $\begin{array}{l}\text { Gross } \\
\text { change }\end{array}$ & 1.0 & 0.7 & 0.0 & 0.0 & 0.0 & 0.0 & 0.0 & 0.0 & 0.3 & 0.3 & 0.0 & 0.0 & 6.4 & 1.9 & 5.9 & 1.9 & 0.4 & 0.4 & 0.4 & 0.6 \\
\hline 1980 & 7,673 & 7,886 & 580 & 421 & 7 & 10 & 22 & 26 & 7,643 & 5,359 & 9,256 & 3,806 & 260,330 & 18,394 & 60,498 & 18,364 & 875 & 659 & 0 & 0 \\
\hline 1986 & 8,182 & 7,981 & 580 & 421 & 0 & 0 & 23 & 26 & 7,623 & 5,355 & 9,256 & 3,806 & 258,123 & 17,990 & 62,468 & 18,133 & 629 & 418 & 0 & 0 \\
\hline 1992 & 6,625 & 6,769 & 591 & 426 & 2 & 2 & 25 & 26 & 8,088 & 5,353 & 9,241 & 3,796 & 265,213 & 17,129 & 55,966 & 17,045 & 1,131 & 758 & 0 & 0 \\
\hline 2000 & 7,308 & 7,296 & 596 & 427 & 20 & 26 & 23 & 26 & 8,097 & 5,347 & 9,264 & 3,810 & 267,376 & 17,075 & 53,345 & 16,792 & 854 & 619 & 0 & 0 \\
\hline $\begin{array}{l}\text { Net } \\
\text { change }\end{array}$ & -548 & 711 & 17 & 13 & 20 & 26 & 1 & 1 & 355 & 483 & -50 & 75 & 7,650 & 4,863 & $-6,274$ & 4,447 & 218 & $291-$ & $-1,390$ & 2,029 \\
\hline $\begin{array}{l}\text { Gross } \\
\text { change }\end{array}$ & 3,301 & 2,321 & 17 & 13 & 35 & 32 & 6 & 7 & 1,046 & 874 & 166 & 116 & 22,344 & 6,700 & 20,564 & 6,653 & 1,318 & 1,294 & 1,390 & 2,029 \\
\hline
\end{tabular}


Table 2. Percentage of Northwestern Great Plains Ecoregion land cover that changed at least one time during study period (1973-2000) and associated statistical error.

[Most sample pixels remained unchanged (92.6 percent), whereas 7.4 percent changed at least once throughout study period]

\begin{tabular}{ccccccc}
\hline $\begin{array}{c}\text { Number } \\
\text { of } \\
\text { changes }\end{array}$ & $\begin{array}{c}\text { Percent } \\
\text { of } \\
\text { ecoregion }\end{array}$ & $\begin{array}{c}\text { Margin } \\
\text { of error } \\
(+/-\%)\end{array}$ & $\begin{array}{c}\text { Lower } \\
\text { bound } \\
(\%)\end{array}$ & $\begin{array}{c}\text { Upper } \\
\text { bound } \\
(\%)\end{array}$ & $\begin{array}{c}\text { Standard } \\
\text { error } \\
(\%)\end{array}$ & $\begin{array}{c}\text { Relative } \\
\text { error } \\
(\%)\end{array}$ \\
\hline 1 & 5.2 & 1.6 & 3.7 & 6.8 & 1.1 & 20.4 \\
2 & 1.9 & 0.8 & 1.2 & 2.7 & 0.5 & 26.8 \\
3 & 0.2 & 0.1 & 0.1 & 0.3 & 0.1 & 39.7 \\
4 & 0.0 & 0.0 & 0.0 & 0.1 & 0.0 & 59.0 \\
\hline $\begin{array}{c}\text { Overall } \\
\text { spatial } \\
\text { change }\end{array}$ & 7.4 & 2.0 & 5.4 & 9.4 & 1.4 & 18.4 \\
\hline
\end{tabular}

Table 3. Raw estimates of change in Northwestern Great Plains Ecoregion land cover, computed for each of four time periods between 1973 and 2000, and associated error at an 85-percent confidence level.

[Estimates of change per period normalized to annual rate of change for each period]

\begin{tabular}{|c|c|c|c|c|c|c|c|}
\hline Period & $\begin{array}{l}\text { Total change } \\
\text { (\% of ecoregion) }\end{array}$ & $\begin{array}{c}\text { Margin of } \\
\text { error } \\
(+/-\%)\end{array}$ & $\begin{array}{c}\text { Lower } \\
\text { bound } \\
(\%)\end{array}$ & $\begin{array}{c}\text { Upper bound } \\
(\%)\end{array}$ & $\begin{array}{c}\text { Standard } \\
\text { error } \\
(\%)\end{array}$ & $\begin{array}{c}\text { Relative } \\
\text { error } \\
(\%)\end{array}$ & $\begin{array}{l}\text { Average rate } \\
\text { (\% per year) }\end{array}$ \\
\hline \multicolumn{8}{|c|}{ Estimate of change, in percent stratum } \\
\hline 1973-1980 & 2.1 & 0.7 & 1.4 & 2.9 & 0.5 & 22.7 & 0.3 \\
\hline 1980-1986 & 2.0 & 0.7 & 1.2 & 2.7 & 0.5 & 25.9 & 0.3 \\
\hline 1986-1992 & 3.0 & 1.2 & 1.9 & 4.2 & 0.8 & 26.1 & 0.5 \\
\hline $1992-2000$ & 2.7 & 0.9 & 1.8 & 3.7 & 0.6 & 23.9 & 0.3 \\
\hline \multicolumn{8}{|c|}{ Estimate of change, in square kilometers } \\
\hline $1973-1980$ & 7,458 & 2,487 & 4,970 & 9,945 & 1,694 & 22.7 & 1,065 \\
\hline 1980-1986 & 6,820 & 2,588 & 4,232 & 9,409 & 1,763 & 25.9 & 1,137 \\
\hline 1986-1992 & 10,535 & 4,034 & 6,501 & 14,569 & 2,748 & 26.1 & 1,756 \\
\hline 1992-2000 & 9,381 & 3,291 & 6,090 & 12,673 & 2,242 & 23.9 & 1,173 \\
\hline
\end{tabular}


Table 4. Principal land-cover conversions in Northwestern Great Plains Ecoregion, showing amount of area changed (and margin of error, calculated at 85-percent confidence level) for each conversion during each of four time periods and also during overall study period. See appendix 3 for definitions of land-cover classifications.

[Values given for "other" classes are combined totals of values for other land-cover classes not listed in that time period. Abbreviations: n/a, not applicable]

\begin{tabular}{|c|c|c|c|c|c|c|c|c|}
\hline Period & From class & To class & & $\begin{array}{c}\begin{array}{c}\text { Area } \\
\text { changed }\end{array} \\
\left(\mathrm{km}^{2}\right)\end{array}$ & $\begin{array}{c}\text { Margin of } \\
\text { error } \\
\left(+/-\mathrm{km}^{2}\right)\end{array}$ & $\begin{array}{c}\text { Standard } \\
\text { error } \\
\left(\mathrm{km}^{2}\right)\end{array}$ & $\begin{array}{l}\text { Percent of } \\
\text { ecoregion }\end{array}$ & $\begin{array}{c}\text { Percent } \\
\text { of all } \\
\text { changes }\end{array}$ \\
\hline \multirow[t]{7}{*}{ 1973-1980 } & Grassland/Shrubland & Agriculture & & 3,158 & 840 & 572 & 0.9 & 42.3 \\
\hline & Agriculture & Grassland/Shrubland & & 2,264 & 1,044 & 711 & 0.7 & 30.4 \\
\hline & Nonmechanically disturbed & Grassland/Shrubland & & 1,390 & 2,029 & 1,382 & 0.4 & 18.6 \\
\hline & Water & Wetland & & 241 & 346 & 236 & 0.1 & 3.2 \\
\hline & Barren & Grassland/Shrubland & & 105 & 135 & 92 & 0.0 & 1.4 \\
\hline & Other & Other & & 299 & $\mathrm{n} / \mathrm{a}$ & $\mathrm{n} / \mathrm{a}$ & 0.1 & 4.0 \\
\hline & & & Totals & 7,458 & & & 2.1 & 100.0 \\
\hline \multirow[t]{7}{*}{ 1980-1986 } & Grassland/Shrubland & Agriculture & & 4,058 & 2,413 & 1,644 & 1.2 & 59.5 \\
\hline & Agriculture & Grassland/Shrubland & & 2,082 & 755 & 514 & 0.6 & 30.5 \\
\hline & Grassland/Shrubland & Water & & 275 & 282 & 192 & 0.1 & 4.0 \\
\hline & Wetland & Water & & 244 & 322 & 220 & 0.1 & 3.6 \\
\hline & Barren & Grassland/Shrubland & & 54 & 70 & 47 & 0.0 & 0.8 \\
\hline & Other & Other & & 107 & $\mathrm{n} / \mathrm{a}$ & $\mathrm{n} / \mathrm{a}$ & 0.0 & 1.6 \\
\hline & & & Totals & 6,820 & & & 2.0 & 100.0 \\
\hline \multirow[t]{7}{*}{ 1986-1992 } & Agriculture & Grassland/Shrubland & & 7,609 & 3,448 & 2,349 & 2.2 & 72.2 \\
\hline & Grassland/Shrubland & Agriculture & & 1,125 & 620 & 422 & 0.3 & 10.7 \\
\hline & Water & Grassland/Shrubland & & 677 & 609 & 415 & 0.2 & 6.4 \\
\hline & Water & Wetland & & 474 & 465 & 317 & 0.1 & 4.5 \\
\hline & Water & Barren & & 431 & 517 & 352 & 0.1 & 4.1 \\
\hline & Other & Other & & 219 & $\mathrm{n} / \mathrm{a}$ & $\mathrm{n} / \mathrm{a}$ & 0.1 & 2.1 \\
\hline & & & Totals & 10,535 & & & 3.0 & 100.0 \\
\hline \multirow[t]{7}{*}{ 1992-2000 } & Agriculture & Grassland/Shrubland & & 5,284 & 2,797 & 1,905 & 1.5 & 56.3 \\
\hline & Grassland/Shrubland & Agriculture & & 2,671 & 911 & 620 & 0.8 & 28.5 \\
\hline & Grassland/Shrubland & Water & & 308 & 198 & 135 & 0.1 & 3.3 \\
\hline & Wetland & Water & & 241 & 312 & 212 & 0.1 & 2.6 \\
\hline & Barren & Water & & 231 & 261 & 178 & 0.1 & 2.5 \\
\hline & Other & Other & & 646 & $\mathrm{n} / \mathrm{a}$ & $\mathrm{n} / \mathrm{a}$ & 0.2 & 6.9 \\
\hline & & & Totals & 9,381 & & & 2.7 & 100.0 \\
\hline \multirow{7}{*}{$\begin{array}{c}\text { 1973-2000 } \\
\text { (overall) }\end{array}$} & Agriculture & Grassland/Shrubland & & 17,239 & 6,193 & 4,218 & 5.0 & 50.4 \\
\hline & Grassland/Shrubland & Agriculture & & 11,013 & 3,342 & 2,277 & 3.2 & 32.2 \\
\hline & Nonmechanically disturbed & Grassland/Shrubland & & 1,390 & 2,029 & 1,382 & 0.4 & 4.1 \\
\hline & Water & Grassland/Shrubland & & 846 & 610 & 416 & 0.2 & 2.5 \\
\hline & Water & Wetland & & 722 & 744 & 507 & 0.2 & 2.1 \\
\hline & Other & Other & & 2,984 & $\mathrm{n} / \mathrm{a}$ & $\mathrm{n} / \mathrm{a}$ & 0.9 & 8.7 \\
\hline & & & Totals & 34,195 & & & 9.9 & 100.0 \\
\hline
\end{tabular}




\section{References Cited}

Bryce, S.A., Omernik, J.M., Pater, D.E., Ulmer, Michael, Schaar, Jerome, Freeouf, Jerry, Johnson, Rex, Kuck, Pat, and Azevedo, S.H., 1998, Ecoregions of North and South Dakota: U.S. Geological Survey Ecoregion Map Series, scale 1:500,000, available at http://www.epa.gov/wed/pages/ecoregions/ndsd_eco.htm.

Higgins, K.F., Naugle, D.E., and Forman, K.J., 2002, A case study of changing land use practices in the northern Great Plains, U.S.A.-An uncertain future for waterbird conservation, in Parsons, K.C., Brown, S.C., Erwin, R.M., Czech, H.A., and Coulson, J.C., eds., Managing wetlands for waterbirdsIntegrated approaches: Waterbirds - The International Journal of Waterbird Biology, v. 25, Special Publication 2, p. 42-50.

McNab, W.H., and Avers, P.E., 1994, Great Plains-Palouse Dry Steppe, in Ecological subregions of the United States: U.S. Department of Agriculture, Forest Service, WO-WSA-5, chap. 41, available at http://www.fs.fed.us/land/pubs/ecoregions/ch41. html\#toc".

Omernik, J.M., 1987, Ecoregions of the conterminous United States: Annals of the Association of American Geographers, v. 77, no. 1, p. 118-125.

U.S. Department of Agriculture, 2004, The Conservation Reserve Program_Economic implications for rural America: U.S. Department of Agriculture, Economic Research Service, Agricultural Economic Report No. 834, 112 p., available at http://www.ers.usda.gov/publications/aer-agricultural-economicreport/aer834.aspx.
U.S. Department of Agriculture, 2009, Conservation Reserve Program-Cumulative enrollment by year (by county, FY 1986-FY 2007): U.S. Department of Agriculture, Farm Services Agency database, accessed June 12, 2009, at http://www.fsa.usda.gov/Internet/FSA_File/public.xls.

U.S. Environmental Protection Agency, 1997, Descriptions of level III ecological regions for the CEC report on ecological regions of North America: U.S. Environmental Protection Agency database, accessed June 12, 2006, at http://www.epa.gov/wed/pages/ecoregions/na_eco. htm\#Downloads.

Vogelmann, J.E., Howard, S.M., Yang, L., Larson, C.R., Wylie, B.K., and van Driel, N., 2001, Completion of the 1990s National Land Cover Data Set for the conterminous United States from Landsat Thematic Mapper data and ancillary data sources: Photogrammetric Engineering \& Remote Sensing, v. 67, p. 650-662.

Woods, A.J., Omernik, J.M., Nesser, J.A., Shelden, J., Comstock, J.A., Azevedo, S.H., 2002, Ecoregions of Montana (2d ed.): U.S. Geological Survey Ecoregion Map Series, scale 1:1,500,000, available at http://www.epa.gov/ wed/pages/ecoregions/mt_eco.htm. 



\title{
Southwestern Tablelands Ecoregion
}

\author{
By Carl L. Rich and Mark A. Drummond
}

\section{Ecoregion Description}

The Southwestern Tablelands Ecoregion encompasses about 159,938 km² (61,752 $\left.\mathrm{mi}^{2}\right)$ in Colorado, New Mexico, Texas, Oklahoma, and Kansas (fig. 1) (Omernik, 1987; U.S. Environmental Protection Agency, 1997). The ecoregion is bounded on the west by the Southern Rockies and the Arizona/ New Mexico Plateau Ecoregions, as well as a small part of the Chihuahuan Deserts Ecoregion; on the north and south by the Western High Plains Ecoregion; and on the east by the Central Great Plains Ecoregion (Omernik, 1987).
The Southwestern Tablelands Ecoregion generally is more rugged than the surrounding ecoregions of the Great Plains, with moderate to considerable local relief. Topographic features include areas of moderately rolling terrain and canyons that dissect the tablelands (fig. 2). Elevation varies from about $400 \mathrm{~m}$ in Kansas in the northeastern corner of the ecoregion to about 2,700 $\mathrm{m}$ in northeastern New Mexico (National Atlas of the United States, 2008). The highest elevations are at the tops of several old volcanic cones in this part of the Southwestern Tablelands Ecoregion.
Figure 1. Map of Southwestern Tablelands Ecoregion and surrounding ecoregions, showing land-use/land-cover classes from 1992 National Land Cover Dataset (Vogelmann and others, 2001); note that not all land-use/land-cover classes shown in explanation may be depicted on map; note also that, for this "Status and Trends of Land Change" study, transitional land-cover class was subdivided into mechanically disturbed and nonmechanically disturbed classes. Squares indicate locations of $10 \times 10 \mathrm{~km}$ sample blocks analyzed in study. Index map shows locations of geographic features mentioned in text. Abbreviations for Great Plains ecoregions are listed in appendix 2. Also shown are parts of four Western United States ecoregions: Arizona/New Mexico Mountains (ANMM), Arizona/ New Mexico Plateau (ANMP), Chihuahuan Deserts (CD), and Southern Rockies (SRK). See appendix 3 for definitions of landuse/land-cover classifications.

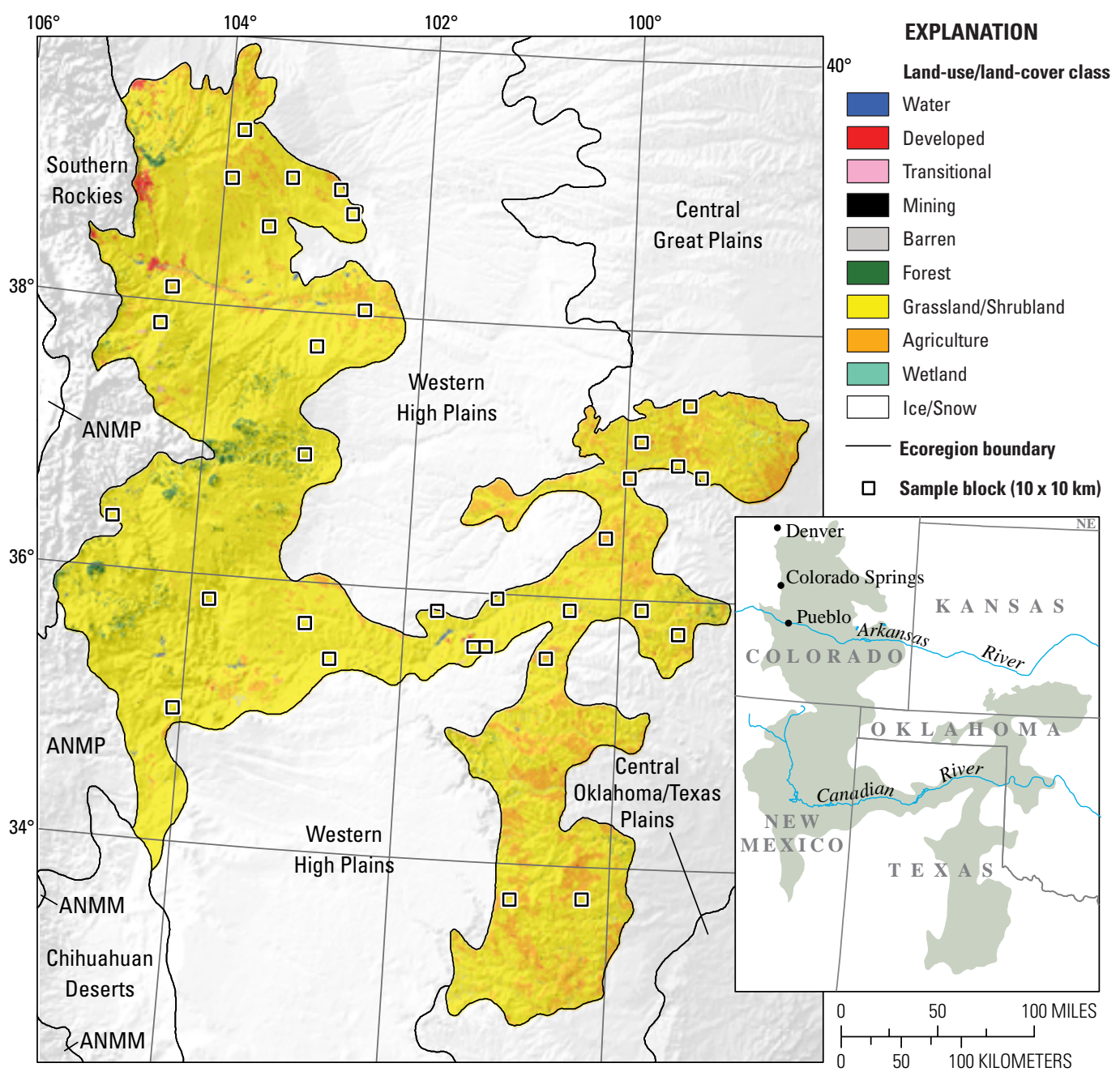


Precipitation in the Southwestern Tablelands Ecoregion ranges from about $250 \mathrm{~mm}$ (10 in.) per year in parts of Colorado and New Mexico to about 630 to $760 \mathrm{~mm}$ (25-30 in.) per year in Kansas (National Atlas of the United States, 2008). Grassland/shrubland dominates the land cover on most of the elevated tablelands and vast mesas in the ecoregion; much of it is used for grazing.

The natural vegetation in most of the area is blue grama (Bouteloua gracilis) and buffalo grass (Buchloe dactyloides); in the southeastern part of the ecoregion, it is mesquite (Prosopis spp.) and buffalo grass. Along the Canadian River in the Southwestern Tablelands Ecoregion is a vegetation community known as shinnery (U.S. Environmental Protection Agency, 2002), a midgrass prairie with open-to-dense broadleaf deciduous shrubs such as Gambel's oak (Quercus gambelii) and scrub oak (Quercus turbinella), with a few needleleaf evergreen low trees or shrubs (Kuchler, 1964). Although grassland/shrubland dominates the ecoregion, some forest lands also are present on the escarpments of the tablelands.

Land use in the Southwestern Tablelands Ecoregion differs from that of most of the surrounding ecoregions of the Great Plains by its relatively sparse cropland, except along the Arkansas River and in the wetter eastern parts of the ecoregion (figs. 3,4). The most common crop is wheat (Triticum

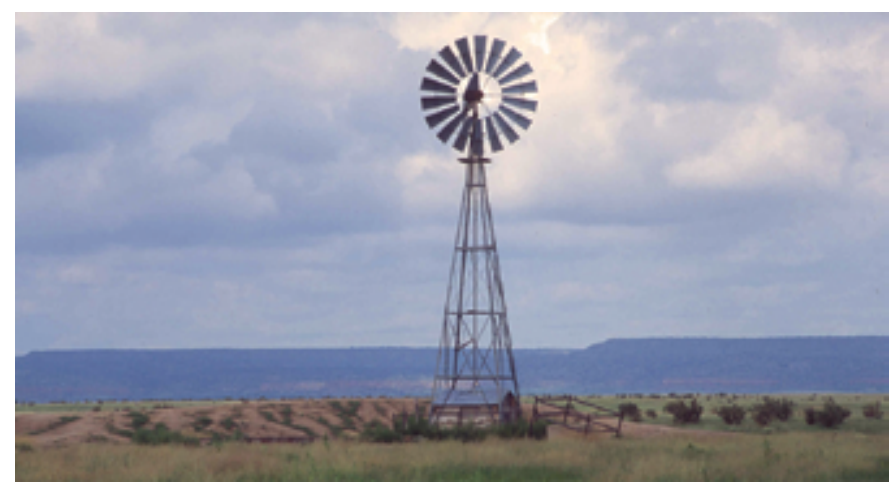

Figure 2. Rangeland, with tablelands in distance, in Southwestern Tablelands Ecoregion.

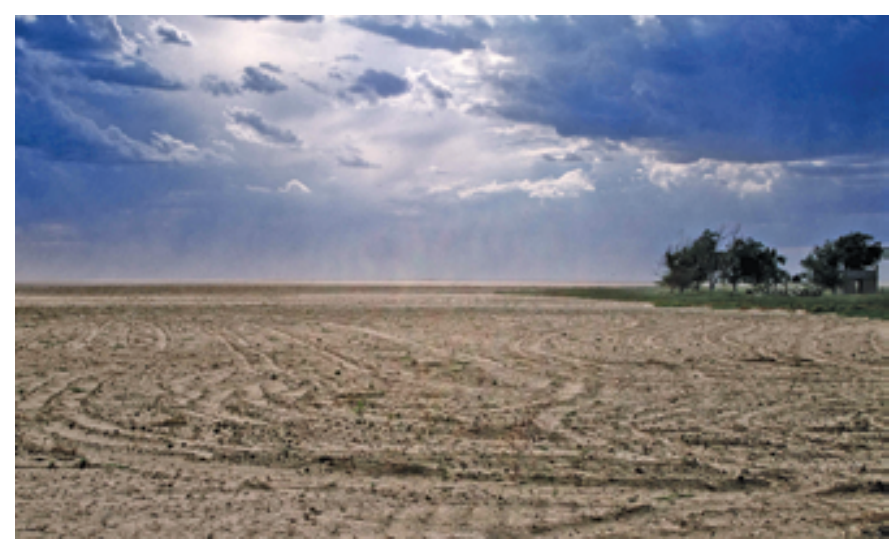

Figure 3. Sandy soil recently tilled in Southwestern Tablelands Ecoregion. aestivum) (U.S. Department of Agriculture, 1970-2000 [various years]). Livestock grazing on grassland/shrubland is the most extensive type of land use (fig. 5).

Minor but important land cover classes include developed and mining. Most of the Southwestern Tablelands Ecoregion is rural, with small towns scattered across the landscape. However, Colorado Springs and Pueblo, Colorado (populations in 2000 of 360,890 and 102,121, respectively), are two of the largest cities within the ecoregion (U.S. Census Bureau, 2000). The Southwestern Tablelands Ecoregion also includes the southern suburbs of Denver. Much of the population growth since 1970 has been in these urban areas of Colorado (U.S. Census Bureau, 1970-2000 [various years]). Petroleum and natural gas production is important in the ecoregion, especially in Texas. Although oil and gas extraction are included in the mining land-cover class in this study, many of the wells and pads are smaller than the minimum mapping unit of $60 \mathrm{~m}$, and so this land-cover class is likely undermapped.

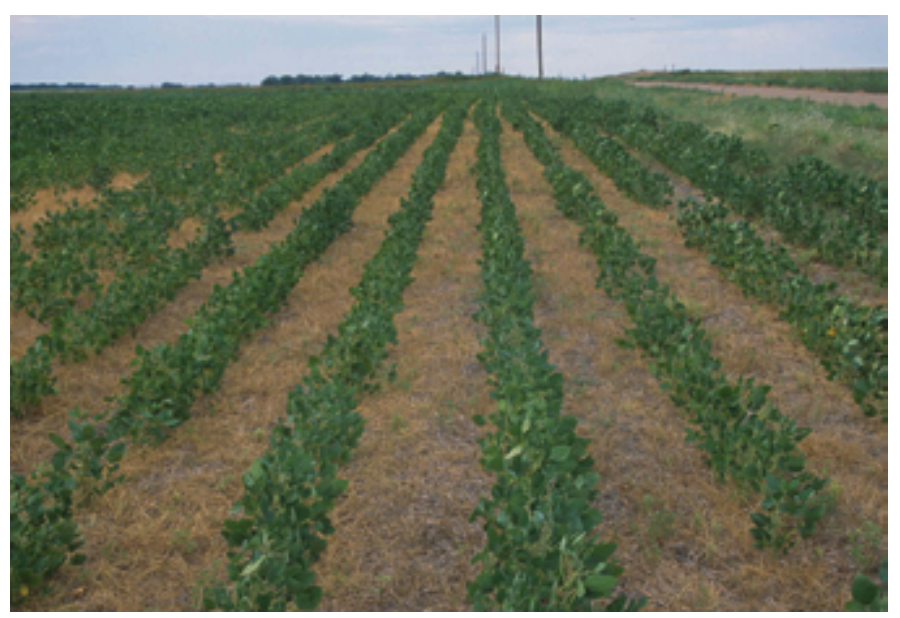

Figure 4. Field of soybeans in Southwestern Tablelands Ecoregion. No-till farming methods often are used to leave soils and crop residue intact.

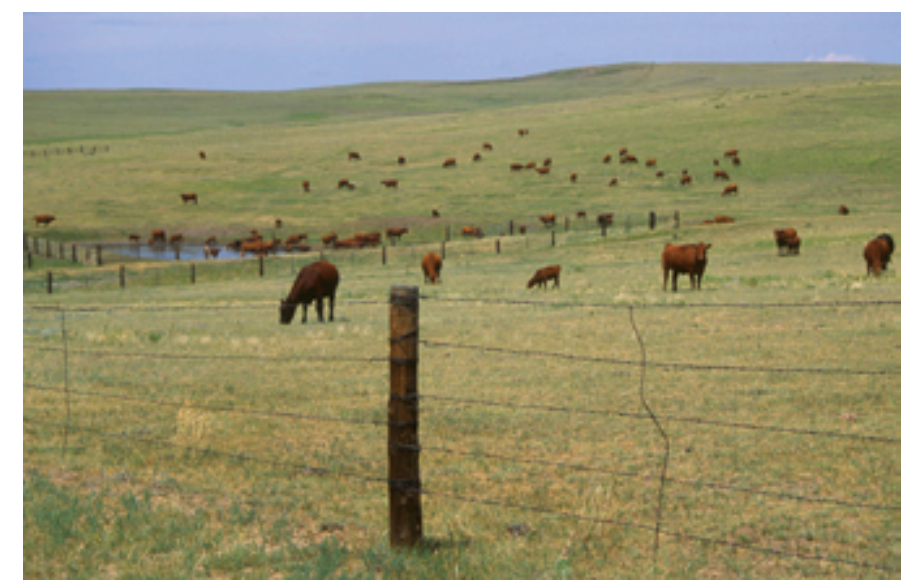

Figure 5. Livestock grazing, a common land use in Southwestern Tablelands Ecoregion. 


\section{Contemporary Land-Cover Change (1973 to 2000)}

The most common types of land-cover change in the Southwestern Tablelands Ecoregion between 1973 and 2000 were from agriculture to grassland/shrubland, and vice versa (table 1 ). Over the entire study period, these conversions constituted more than 90 percent of all landcover change. Other leading conversions included a onetime change from grassland/shrubland to nonmechanically disturbed between 1992 and 2000 caused by a fire in the Texas panhandle, and conversions from grassland/shrubland to water caused by water impoundment. However, fluctuations in water levels often caused additional types of land-cover change between the barren and grassland/ shrubland classes.

The fact that the dominant changes in the Southwestern Tablelands Ecoregion land cover involved grassland/shrubland and agriculture is not surprising given the overall composition of the land cover within the ecoregion. During all time periods, the ecoregion was composed of 80.0 to 81.9 percent grassland/shrubland and 16.1 to 18.1 percent agricultural land (table 2). Forest constituted an estimated 0.8 percent of the ecoregion, and developed land constituted an estimated 0.4 percent.

The overall spatial change (the percentage of land area that changed at least one time) in the Southwestern Tablelands Ecoregion between 1973 and 2000 is estimated at 8.8 percent (table 3 ). Most of the changes ( 7.3 percent of ecoregion area) occurred because of a one-time conversion; multiple changes were caused by switches between grassland/shrubland and agricultural land, as well as fluctuations in water levels of streams and impoundments that may be related to climate variability.

During the first time period (1973-1980), a small net increase occurred in the amount of agriculture land cover, 0.2 percent (table 2). The expansion took place during a period of increased grain exports; thus, it may have resulted, in part, from farm policies that encouraged expansion of cropland. However, unlike several other ecoregions in the Great Plains that experienced substantial agricultural expansion, expansion of cropland in the Southwestern Tablelands Ecoregion was relatively small. After 1980, agriculture land cover decreased.

During the last three time periods (1980-1986, 19861992, 1992-2000), a net increase occurred in grassland/ shrubland, although the trend was nearly flat between 1980 and 1986 (table 2). The greatest change from one class to another during a single time period was the change from agriculture to grassland/shrubland between 1986 and 1992 $\left(3,870 \mathrm{~km}^{2}\right)$ (table 1) when grassland/shrubland increased by an estimated 1.6 percent (table 2; fig. 6 ). This change was caused, in part, by the introduction of the Conservation Reserve Program (CRP). The CRP paid farmers to convert easily erodible or otherwise environmentally sensitive, low-productivity agricultural lands to grasslands (U.S. Department of Agriculture, 2008).

Compared to other Great Plains ecoregions, landcover change in the Southwestern Tablelands Ecoregion was moderate (fig. 7). Despite a consistently large area of grassland/shrubland, which made up more than 80 percent of the ecoregion's area in all four time periods, fluctuations involving agricultural land use and water were particularly high during the last two time periods (1986-2000). The per-period change estimates ranged from a low of 1.9 percent between 1980 and 1986 to a high of 3.4 percent between 1986 and 1992 when agricultural land began to be enrolled in the CRP (table 4). When the per-period change data are normalized to produce average annual rates of land-cover change, the results range from 0.3 percent between 1973 and 1980 to 0.6 percent between 1986 and 1992 (table 4; fig. 8).

Much of the cropland in the Southwestern Tablelands Ecoregion is considered marginal because of climate and soil conditions. These conditions contributed to fluctuations between grassland/shrubland and agriculture as
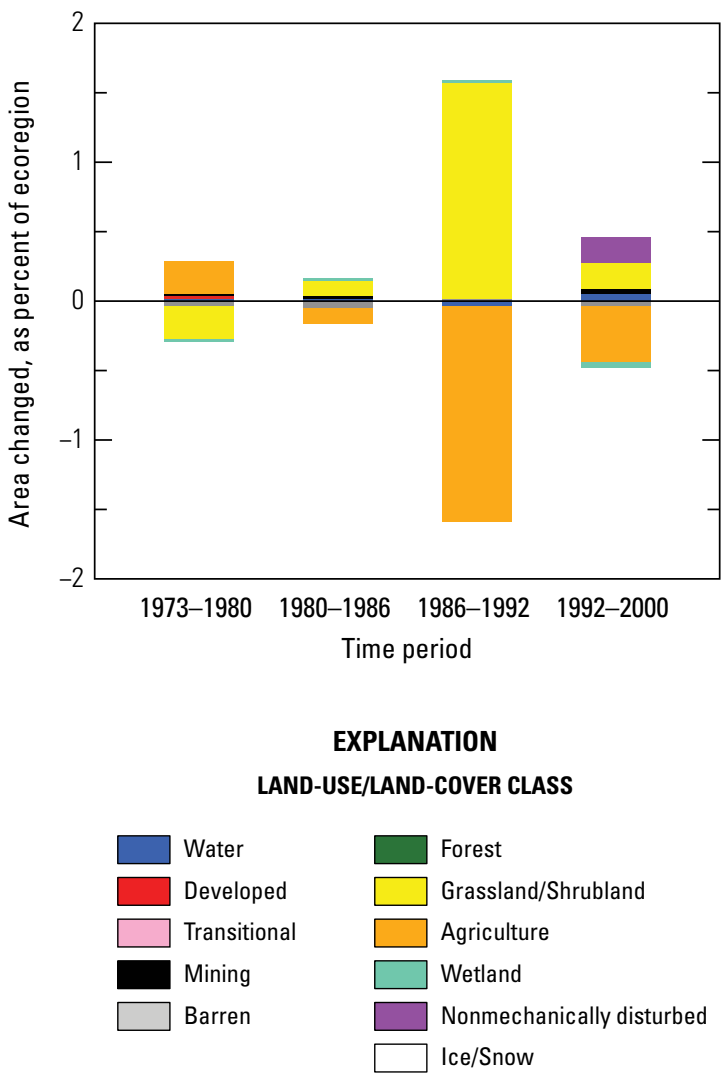

Figure 6. Normalized average net change in Southwestern Tablelands Ecoregion by time period for each land-cover class. Bars above zero axis represent net gain, whereas bars below zero represent net loss. Note that not all land-cover classes shown in explanation may be represented in figure. See appendix 3 for definitions of land-use/land-cover classifications. 
precipitation levels and socioeconomic conditions varied. Because the natural vegetation for most of the ecoregion is grassland/shrubland, it is not surprising that agriculture is continuously reverting back to grassland/shrubland. The rural rangeland character of the ecoregion also contributes to the overall pattern of land-cover change, with developed land concentrated only along its western edge.

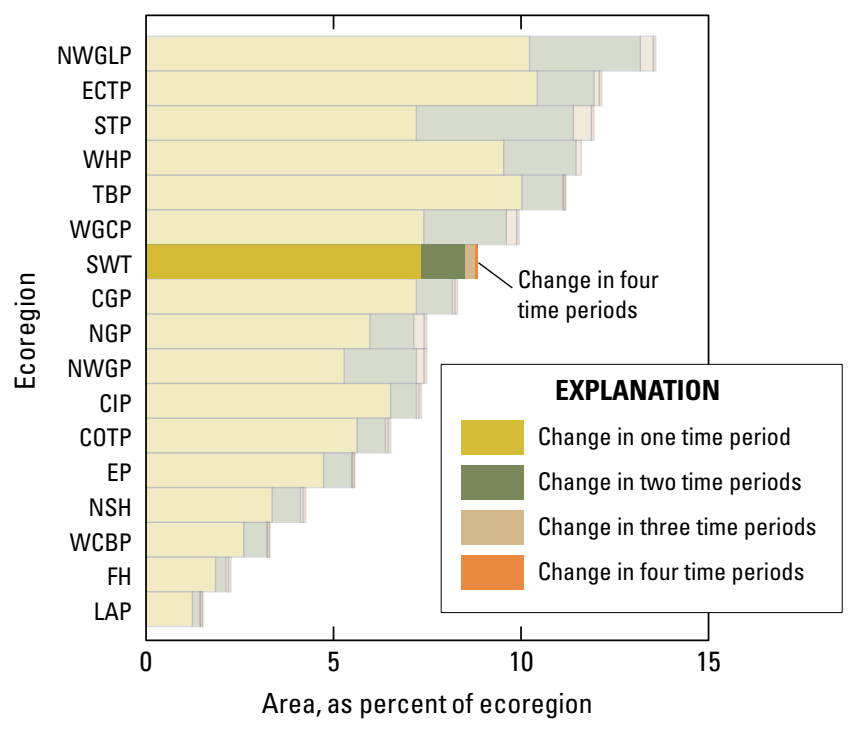

Figure 7. Overall spatial change in Southwestern Tablelands Ecoregion (SWT; darker bars) compared with that of all 17 Great Plains ecoregions (lighter bars). Each horizontal set of bars shows proportions of ecoregion that experienced change during one, two, three, or four time periods; highest level of spatial change in Southwestern Tablelands Ecoregion (four time periods) labeled for clarity. See table 4 for years covered by each time period. See appendix 2 for key to ecoregion abbreviations.

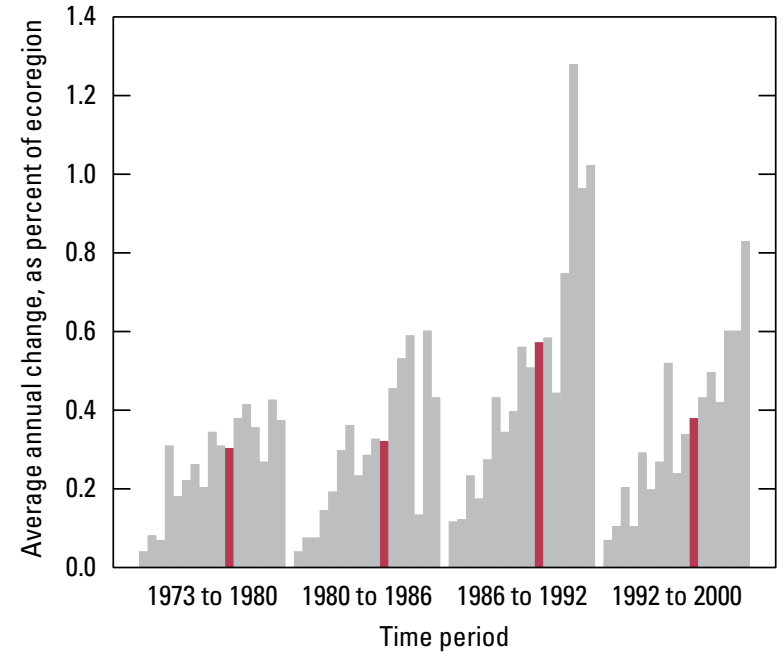

Figure 8. Estimates of land-cover change per time period, normalized to annual rates of change for all 17 Great Plains ecoregions (gray bars). Estimates of change for Southwestern Tablelands Ecoregion are represented by red bars in each time period. 
Table 1. Principal land-cover conversions in Southwestern Tablelands Ecoregion, showing amount of area changed (and margin of error, calculated at 85-percent confidence level) for each conversion during each of four time periods and also during overall study period. See appendix 3 for definitions of land-cover classifications.

[Values given for "other" classes are combined totals of values for other land-cover classes not listed in that time period. Abbreviations: n/a, not applicable]

\begin{tabular}{|c|c|c|c|c|c|c|c|}
\hline Period & From class & \multirow[t]{2}{*}{ To class } & $\begin{array}{c}\text { Area } \\
\text { changed } \\
\left(\mathrm{km}^{2}\right)\end{array}$ & $\begin{array}{c}\text { Margin of } \\
\text { error }\end{array}$ & $\begin{array}{c}\begin{array}{c}\text { Standard } \\
\text { error }\end{array} \\
\left(\mathrm{km}^{2}\right) \\
\end{array}$ & $\begin{array}{l}\text { Percent of } \\
\text { ecoregion }\end{array}$ & $\begin{array}{l}\text { Percent of } \\
\text { all changes }\end{array}$ \\
\hline \multirow{8}{*}{ 1973-1980 } & & & & & & & \\
\hline & Grassland/Shrubland & Agriculture & 1,753 & 823 & 558 & 1.1 & 51.9 \\
\hline & Agriculture & Grassland/Shrubland & 1,369 & 519 & 352 & 0.9 & 40.6 \\
\hline & Barren & Grassland/Shrubland & 54 & 75 & 50 & 0.0 & 1.6 \\
\hline & Grassland/Shrubland & Water & 32 & 25 & 17 & 0.0 & 1.0 \\
\hline & Grassland/Shrubland & Developed & 28 & 33 & 23 & 0.0 & 0.8 \\
\hline & Other & Other & 140 & $\mathrm{n} / \mathrm{a}$ & $\mathrm{n} / \mathrm{a}$ & 0.1 & 4.2 \\
\hline & & Totals & 3,377 & & & 2.1 & 100.0 \\
\hline \multirow[t]{7}{*}{ 1980-1986 } & Agriculture & Grassland/Shrubland & 1,475 & 782 & 530 & 0.9 & 48.3 \\
\hline & Grassland/Shrubland & Agriculture & 1,301 & 942 & 638 & 0.8 & 42.6 \\
\hline & Barren & Water & 52 & 75 & 51 & 0.0 & 1.7 \\
\hline & Barren & Grassland/Shrubland & 42 & 46 & 31 & 0.0 & 1.4 \\
\hline & Grassland/Shrubland & Water & 41 & 34 & 23 & 0.0 & 1.4 \\
\hline & Other & Other & 139 & $\mathrm{n} / \mathrm{a}$ & $\mathrm{n} / \mathrm{a}$ & 0.1 & 4.6 \\
\hline & & Totals & 3,051 & & & 1.9 & 100.0 \\
\hline \multirow[t]{7}{*}{ 1986-1992 } & Agriculture & Grassland/Shrubland & 3,870 & 1,533 & 1,039 & 2.4 & 70.4 \\
\hline & Grassland/Shrubland & Agriculture & 1,405 & 731 & 495 & 0.9 & 25.5 \\
\hline & Water & Grassland/Shrubland & 65 & 63 & 43 & 0.0 & 1.2 \\
\hline & Grassland/Shrubland & Water & 35 & 34 & 23 & 0.0 & 0.6 \\
\hline & Water & Barren & 23 & 34 & 23 & 0.0 & 0.4 \\
\hline & Other & Other & 103 & $\mathrm{n} / \mathrm{a}$ & $\mathrm{n} / \mathrm{a}$ & 0.1 & 1.9 \\
\hline & & Totals & 5,500 & & & 3.4 & 100.0 \\
\hline \multirow[t]{7}{*}{ 1992-2000 } & Agriculture & Grassland/Shrubland & 2,454 & 997 & 676 & 1.5 & 50.9 \\
\hline & Grassland/Shrubland & Agriculture & 1,811 & 976 & 661 & 1.1 & 37.5 \\
\hline & Grassland/Shrubland & Nonmechanically disturbed & 316 & 461 & 312 & 0.2 & 6.5 \\
\hline & Wetland & Water & 63 & 62 & 42 & 0.0 & 1.3 \\
\hline & Grassland/Shrubland & Mining & 44 & 31 & 21 & 0.0 & 0.9 \\
\hline & Other & Other & 137 & $\mathrm{n} / \mathrm{a}$ & $\mathrm{n} / \mathrm{a}$ & 0.1 & 2.8 \\
\hline & & Totals & 4,825 & & & 3.0 & 100.0 \\
\hline \multirow{7}{*}{$\begin{array}{c}\text { 1973-2000 } \\
\text { (overall) }\end{array}$} & Agriculture & Grassland/Shrubland & 9,169 & 3,259 & 2,208 & 5.7 & 54.7 \\
\hline & Grassland/Shrubland & Agriculture & 6,270 & 2,303 & 1,560 & 3.9 & 37.4 \\
\hline & Grassland/Shrubland & Nonmechanically disturbed & 316 & 461 & 312 & 0.2 & 1.9 \\
\hline & Grassland/Shrubland & Water & 144 & 92 & 63 & 0.1 & 0.9 \\
\hline & Barren & Grassland/Shrubland & 139 & 136 & 92 & 0.1 & 0.8 \\
\hline & Other & Other & 716 & $\mathrm{n} / \mathrm{a}$ & $\mathrm{n} / \mathrm{a}$ & 0.4 & 4.3 \\
\hline & & Totals & 16,754 & & & 10.5 & 100.0 \\
\hline
\end{tabular}


Table 2. Estimated area (and margin of error) of each land-cover class in Southwestern Tablelands Ecoregion, calculated five times between 1973 and 2000. See appendix 3 for definitions of land-cover classifications.

\begin{tabular}{|c|c|c|c|c|c|c|c|c|c|c|c|c|c|c|c|c|c|c|c|c|}
\hline & \multicolumn{2}{|c|}{ Water } & \multicolumn{2}{|c|}{ Developed } & \multicolumn{2}{|c|}{$\begin{array}{l}\text { Mechan- } \\
\text { ically } \\
\text { disturbed }\end{array}$} & \multicolumn{2}{|c|}{ Mining } & \multicolumn{2}{|c|}{ Barren } & \multicolumn{2}{|c|}{ Forest } & \multicolumn{2}{|c|}{$\begin{array}{l}\text { Grassland/Shru- } \\
\text { bland }\end{array}$} & \multicolumn{2}{|c|}{ Agriculture } & \multicolumn{2}{|c|}{ Wetland } & \multicolumn{2}{|c|}{$\begin{array}{c}\text { Non- } \\
\text { mechanically } \\
\text { disturbed }\end{array}$} \\
\hline & $\%$ & $+/-$ & $\%$ & $+/-$ & $\%$ & $+/-$ & $\%$ & $+/-$ & $\%$ & $+/-$ & $\%$ & $+/-$ & $\%$ & $+/-$ & $\%$ & $+/-$ & $\%$ & $+/-$ & $\%$ & $+/-$ \\
\hline \multicolumn{21}{|c|}{ Area, in percent stratum } \\
\hline 1973 & 0.1 & 0.0 & 0.4 & 0.2 & 0.0 & 0.0 & 0.0 & 0.0 & 0.3 & 0.1 & 0.8 & 0.4 & 80.3 & 5.3 & 17.9 & 5.3 & 0.2 & 0.1 & 0.0 & 0.0 \\
\hline 1980 & 0.1 & 0.1 & 0.4 & 0.2 & 0.0 & 0.0 & 0.1 & 0.0 & 0.3 & 0.1 & 0.8 & 0.4 & 80.0 & 5.2 & 18.1 & 5.3 & 0.1 & 0.1 & 0.0 & 0.0 \\
\hline 1986 & 0.1 & 0.1 & 0.4 & 0.2 & 0.0 & 0.0 & 0.1 & 0.0 & 0.2 & 0.1 & 0.8 & 0.4 & 80.1 & 5.0 & 18.0 & 5.1 & 0.2 & 0.1 & 0.0 & 0.0 \\
\hline 1992 & 0.1 & 0.0 & 0.4 & 0.2 & 0.0 & 0.0 & 0.1 & 0.0 & 0.2 & 0.1 & 0.8 & 0.4 & 81.7 & 4.6 & 16.5 & 4.7 & 0.2 & 0.1 & 0.0 & 0.0 \\
\hline 2000 & 0.2 & 0.1 & 0.4 & 0.2 & 0.0 & 0.0 & 0.1 & 0.0 & 0.2 & 0.1 & 0.8 & 0.4 & 81.9 & 4.2 & 16.1 & 4.3 & 0.1 & 0.1 & 0.2 & 0.3 \\
\hline $\begin{array}{c}\text { Net } \\
\text { change }\end{array}$ & 0.1 & 0.1 & 0.0 & 0.0 & 0.0 & 0.0 & 0.1 & 0.0 & -0.1 & 0.1 & 0.0 & 0.0 & 1.6 & 2.2 & -1.8 & 2.1 & 0.0 & 0.0 & 0.2 & 0.3 \\
\hline $\begin{array}{l}\text { Gross } \\
\text { change }\end{array}$ & 0.3 & 0.2 & 0.0 & 0.0 & 0.0 & 0.0 & 0.1 & 0.0 & 0.2 & 0.2 & 0.0 & 0.0 & 6.3 & 1.8 & 6.1 & 1.8 & 0.1 & 0.1 & 0.2 & 0.3 \\
\hline \multicolumn{21}{|c|}{ Area, in square kilometers } \\
\hline 1973 & 157 & 60 & 627 & 320 & 0 & 1 & 64 & 28 & 470 & 208 & 1,335 & 692 & 128,432 & 8,427 & 28,610 & 8,556 & 243 & 199 & 0 & 0 \\
\hline 1980 & 182 & 80 & 663 & 355 & 3 & 4 & 85 & 38 & 432 & 194 & 1,334 & 692 & 128,023 & 8,386 & 28,989 & 8,491 & 227 & 196 & 0 & 0 \\
\hline 1986 & 219 & 130 & 669 & 356 & 4 & 4 & 95 & 41 & 340 & 136 & 1,351 & 694 & 128,185 & 8,052 & 28,813 & 8,168 & 264 & 201 & 0 & 0 \\
\hline 1992 & 160 & 65 & 673 & 359 & 3 & 3 & 108 & 44 & 364 & 148 & 1,348 & 694 & 130,666 & 7,401 & 26,344 & 7,492 & 271 & 205 & 0 & 9 \\
\hline 2000 & 263 & 120 & 675 & 360 & 2 & 3 & 153 & 69 & 325 & 134 & 1,348 & 694 & 130,950 & 6,741 & 25,688 & 6,860 & 219 & 164 & 316 & 461 \\
\hline $\begin{array}{c}\text { Net } \\
\text { change }\end{array}$ & 106 & 81 & 48 & 53 & 2 & 2 & 89 & 47 & -146 & 164 & 13 & 19 & 2,518 & 3,503 & $-2,922$ & 3,323 & -24 & 62 & 316 & 461 \\
\hline $\begin{array}{l}\text { Gross } \\
\text { change }\end{array}$ & 444 & 280 & 58 & 54 & 5 & 5 & 93 & 48 & 269 & 264 & 20 & 21 & 10,152 & 2,920 & 9,709 & 2,832 & 155 & 101 & 316 & 461 \\
\hline
\end{tabular}

Table 3. Percentage of Southwestern Tablelands Ecoregion land cover that changed at least one time during study period (19732000) and associated statistical error.

[Most sample pixels remained unchanged (91.2 percent), whereas 8.8 percent changed at least once throughout study period]

\begin{tabular}{ccccccc}
\hline $\begin{array}{c}\text { Number } \\
\text { of } \\
\text { changes }\end{array}$ & $\begin{array}{c}\text { Percent } \\
\text { of } \\
\text { ecoregion }\end{array}$ & $\begin{array}{c}\text { Margin } \\
\text { of error } \\
(+/-\%)\end{array}$ & $\begin{array}{c}\text { Lower } \\
\text { bound } \\
(\%)\end{array}$ & $\begin{array}{c}\text { Upper } \\
\text { bound } \\
(\%)\end{array}$ & $\begin{array}{c}\text { Standard } \\
\text { error } \\
(\%)\end{array}$ & $\begin{array}{c}\text { Relative } \\
\text { error } \\
(\%)\end{array}$ \\
\hline 1 & 7.3 & 1.8 & 5.5 & 9.2 & 1.2 & 17.1 \\
2 & 1.2 & 0.5 & 0.7 & 1.7 & 0.3 & 30.1 \\
3 & 0.2 & 0.2 & 0.1 & 0.4 & 0.1 & 50.5 \\
4 & 0.0 & 0.0 & 0.0 & 0.1 & 0.0 & 82.2 \\
\hline $\begin{array}{c}\text { Overall } \\
\text { spatial } \\
\text { change }\end{array}$ & 8.8 & 2.3 & 6.5 & 11.0 & 1.5 & 17.4 \\
\hline
\end{tabular}


Table 4. Raw estimates of change in Southwestern Tablelands Ecoregion land cover, computed for each of four time periods between 1973 and 2000, and associated error at 85-percent confidence level.

[Estimates of change per period normalized to annual rate of change for each period]

\begin{tabular}{|c|c|c|c|c|c|c|c|}
\hline Period & $\begin{array}{c}\text { Total change } \\
\text { (\% of ecoregion) }\end{array}$ & $\begin{array}{c}\text { Margin of } \\
\text { error } \\
(+/-\%)\end{array}$ & $\begin{array}{c}\text { Lower } \\
\text { bound } \\
(\%)\end{array}$ & $\begin{array}{c}\text { Upper bound } \\
(\%)\end{array}$ & $\begin{array}{c}\text { Standard } \\
\text { error } \\
(\%)\end{array}$ & $\begin{array}{c}\text { Relative } \\
\text { error } \\
(\%)\end{array}$ & $\begin{array}{l}\text { Average rate } \\
\text { (\% per year) }\end{array}$ \\
\hline \multicolumn{8}{|c|}{ Estimate of change, in percent stratum } \\
\hline 1973-1980 & 2.1 & 0.7 & 1.4 & 2.9 & 0.5 & 23.9 & 0.3 \\
\hline 1980-1986 & 1.9 & 0.9 & 1.0 & 2.8 & 0.6 & 30.7 & 0.3 \\
\hline 1986-1992 & 3.4 & 1.2 & 2.3 & 4.6 & 0.8 & 22.8 & 0.6 \\
\hline $1992-2000$ & 3.0 & 1.0 & 2.0 & 4.1 & 0.7 & 23.5 & 0.4 \\
\hline \multicolumn{8}{|c|}{ Estimate of change, in square kilometers } \\
\hline 1973-1980 & 3,377 & 1,192 & 2,185 & 4,568 & 807 & 23.9 & 482 \\
\hline 1980-1986 & 3,051 & 1,383 & 1,668 & 4,434 & 937 & 30.7 & 509 \\
\hline 1986-1992 & 5,500 & 1,854 & 3,647 & 7,354 & 1,256 & 22.8 & 917 \\
\hline 1992-2000 & 4,825 & 1,676 & 3,150 & 6,501 & 1,135 & 23.5 & 603 \\
\hline
\end{tabular}

\section{References Cited}

Kuchler, A.W., 1964, Manual to accompany the map-Potential natural vegetation of the conterminous United States: New York, American Geographical Society Special Publication 36, 116 p.

National Atlas of the United States, 2008, 100-meter resolution elevation of the United States: National Atlas of the United States database, accessed May 21, 2013, at http:// www.nationalatlas.gov.

Omernik, J.M., 1987, Ecoregions of the conterminous United States: Annals of the Association of American Geographers, v. 77, no. 1, p. 118-125.

U.S. Census Bureau, 1970-2000 [various years], Census of population and housing: U.S. Census Bureau database, accessed September 1, 2008, at http://www.census.gov/ $\mathrm{prod} / \mathrm{www} /$ decennial.html.

U.S. Census Bureau, 2003, Technical documentation, 2000 Census of population and housing, 108th Congressional District Summary File (100 Percent): U.S. Census Bureau, 557 p., available at http://www.census.gov/prod/cen2000/ doc/cd108h.pdf.
U.S. Department of Agriculture, 1970-2000 [various years], Census of agriculture: U.S. Department of Agriculture database, accessed September 1, 2008, at http://www.agcensus.usda.gov/.

U.S. Department of Agriculture, 2008, Conservation Reserve Program: U.S. Department of Agriculture Farm Service Agency database, accessed September 1, 2008, at http:// www.nrcs.usda.gov/programs/crp/.

U.S. Environmental Protection Agency, 1997, Descriptions of level III ecological regions for the CEC report on ecological regions of North America: U.S. Environmental Protection Agency database, accessed April 12, 2006, at http://www. epa.gov/wed/pages/ecoregions/na_eco.htm\#Downloads.

U.S. Environmental Protection Agency, 2002, Primary distinguishing characteristics of level III ecoregions of the continental United States, Draft, April 2002: U.S. Environmental Protection Agency database, accessed April 12, 2006, at http://www.epa.gov/wed/pages/ecoregions/level_iii_iv.htm.

Vogelmann, J.E., Howard, S.M., Yang, L., Larson, C.R., Wylie, B.K., and van Driel, N., 2001, Completion of the 1990s National Land Cover Data Set for the conterminous United States from Landsat Thematic Mapper data and ancillary data sources: Photogrammetric Engineering \& Remote Sensing, v. 67, p. 650-662. 



\title{
Chapter 5
}

\section{Western High Plains Ecoregion}

\author{
By Mark A. Drummond
}

\section{Ecoregion Description}

The Western High Plains Ecoregion is a high-elevation, semiarid, shortgrass steppe that covers approximately $288,752 \mathrm{~km}^{2}\left(111,488 \mathrm{mi}^{2}\right)$ across parts of eight states (fig. 1) (Omernik, 1987; U.S. Environmental Protection Agency, 1997). The Southwestern Tablelands Ecoregion splits the Western High Plains Ecoregion into two large areas: the northern part is surrounded by the Northwestern Great Plains, Nebraska Sand Hills, Central Great Plains, Southwestern Tablelands, and Southern Rockies Ecoregions; the southern part is surrounded by the Southwestern Tablelands, Central Great Plains, and Chihuahuan Deserts Ecoregions.

Surficial geology is the result of uplifted late Tertiary sediments that have been eroded from the uplifting Rocky Mountains, overlain by more recent wind-blown sediments. Agriculture is the dominant land use, with cropland, farmsteads, confined feeding operations, and

Figure 1. Map of Western High Plains Ecoregion and surrounding ecoregions, showing land-use/ land-cover classes from 1992 National Land Cover Dataset (Vogelmann and others, 2001); note that not all land-use/land-cover classes shown in explanation may be depicted on map; note also that, for this "Status and Trends of Land Change" study, transitional land-cover class was subdivided into mechanically disturbed and nonmechanically disturbed classes. Squares indicate locations of 10 $x 10 \mathrm{~km}$ sample blocks analyzed in study. Index map shows locations of geographic features mentioned in text. Abbreviations for Great Plains ecoregions are listed in appendix 2. Also shown are parts of six Western United States ecoregions: Arizona/ New Mexico Mountains (ANMM), Arizona/New Mexico Plateau (ANMP), Chihuahuan Deserts, Middle Rockies (MRK), Southern Rockies (SRK), and Wyoming Basin (WB). See appendix 3 for definitions of land-use/land-cover classifications.

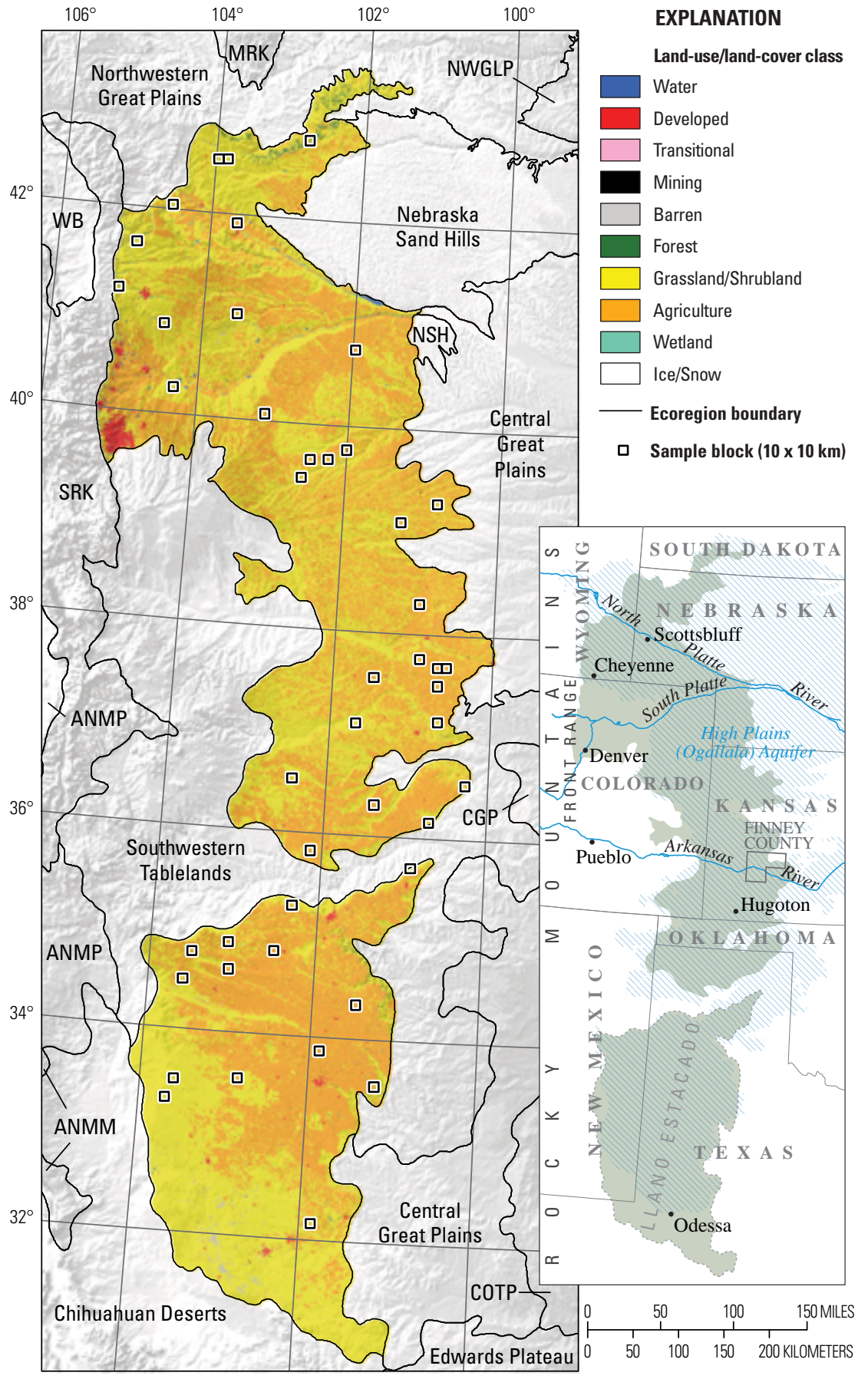


other miscellaneous agricultural uses covering nearly 48 percent of the ecoregion in 2000. Wheat, corn, alfalfa, sorghum, cotton, and specialty crops such as sugar beets have replaced substantial areas of natural land cover within the ecoregion (fig. 2). Livestock grazing is present on much of the remaining grasslands, including large areas of sandy soil that are unsuitable for cultivation (fig. 3). Several National Grasslands lie in the heart of the historic Dust Bowl region in the central part of the ecoregion. Wetland habitat includes a high concentration of small but ecologically important playa lakes, which often are altered by agricultural land use and road construction. Since 1986, the Conservation Reserve Program (CRP), which pays farmers to convert environmentally sensitive land from crops to grassland, has become an important factor in the Western High Plains Ecoregion where many areas are marginal for cultivation. CRP lands covered more than 9 percent of the ecoregion in 2000 (U.S. Department of Agriculture, 1970-2000 [various years]). Oil and natural-gas extraction also is important, and the large Hugoton Field in southwestern Kansas provides fuel for nearby groundwater pumps (fig. 4).

The overall pattern of agricultural land use and the remaining grassland in the Western High Plains Ecoregion is driven largely by climate, soil type, and water availability, as well as by national farm policy, economic opportunity, and other technological and cultural adaptations to the limitations

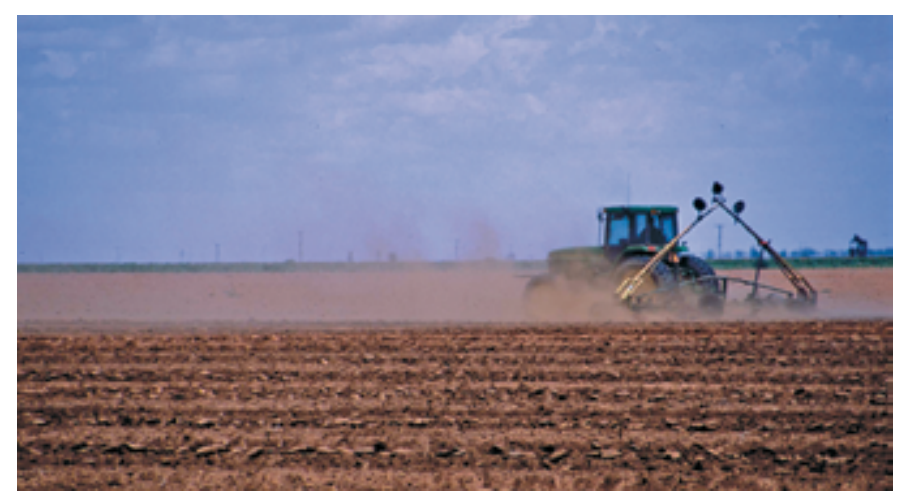

Figure 2. Dryland farming, common in Western High Plains Ecoregion.

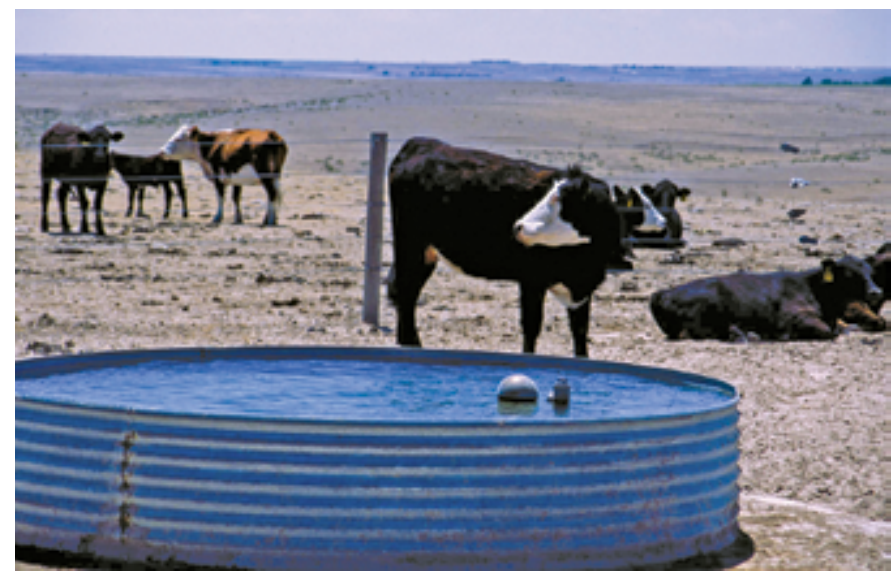

Figure 3. Rangeland cattle, which often rely on stock ponds of water, in semiarid Western High Plains Ecoregion. introduced by physical factors. Important physical forces driving the grassland and agricultural ecosystem include highly variable precipitation levels, which range from about $300 \mathrm{~mm}$ per year (12 in.) in the western part of the ecoregion to $500 \mathrm{~mm}$ per year (under $20 \mathrm{in}$.) in the eastern part, as well as cycles of intense drought. High rates of evapotranspiration can exceed that of precipitation over long time periods and can contribute to a water deficit for growing crops. Average temperatures during the growing season are high and favor warm-season plants. The natural vegetation of the ecoregion primarily is shortgrass prairie dominated by blue grama (Bouteloua gracilis) and buffalo grass (Buchloe dactyloides). Dryland wheat-fallow cropping and no-tillage practices, which improve the retention of soil moisture, are used in areas where water availability is limited but soils are suitable for crops. Streamside irrigation and groundwater pumping are common practices where water is readily available, and these have helped to make the ecoregion important globally for smallgrain production and confined-livestock feeding (fig. 5).

The High Plains (Ogallala) aquifer, the largest groundwater complex in the nation, underlies much of the Western High Plains Ecoregion. About 95 percent of the water pumped from the aquifer is used for crop irrigation (Dennehy and others, 2002). Early irrigation was concentrated in areas of the South Platte and North Platte Rivers and in the cotton region of the Llano Estacado in Texas. Turbine pumps used for groundwater irrigation were introduced in the 1930s, permitting modern farming and cattle-ranching practices (Brooks and others, 2001). Substantial pumping began in the 1940s and intensified as cotton production expanded in the southern part of the ecoregion. Technological advances after World War II allowed for more efficient groundwater pumping that expanded the regional pattern of intensive crop production. The increasing use of center-pivot irrigation, beginning in the mid-1960s, allowed more intensive use of fields with uneven topography and sandy soils, where furrow irrigation is unfeasible (Lichtenberg, 1989).

Aquifer declines of greater than $30 \mathrm{~m}$ had occurred in some areas by 1980 (Dennehy and others, 2002), causing an increase in the cost of extraction and making water more expensive to use as water levels decline (Terrell and others, 2002). Aquifer recharge in many areas is minimal in relation

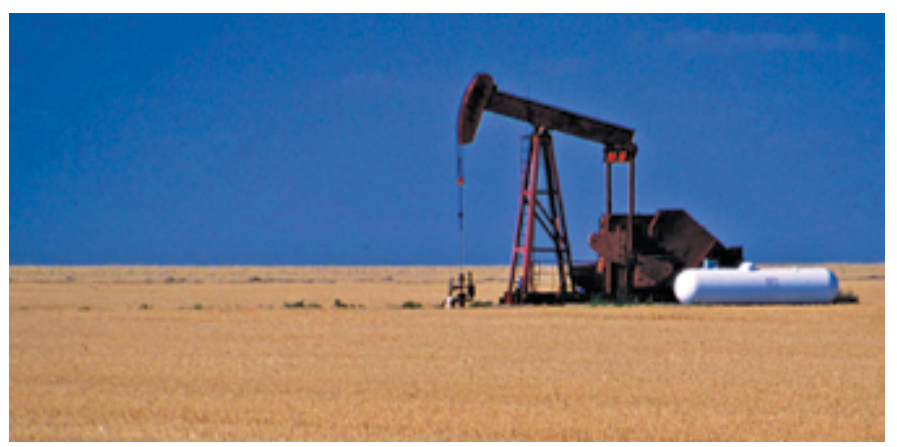

Figure 4. Oil well, many of which dot agricultural landscapes in Western High Plains Ecoregion. 
to pumping rates. As a result, the central and southern parts of the ecoregion have experienced groundwater depletion that makes long-term intensive use of the aquifer unsustainable. Other areas have large underground supplies despite declines in aquifer thickness. Recent conservation measures and improved irrigation technology may be slowing the rate of aquifer decline in some areas (McGuire and others, 2003). Streamside irrigation, practiced in areas of the North Platte, South Platte, and Arkansas Rivers, among others, also is vulnerable to low flows associated with regional drought and groundwater withdrawals that reduce streamflow, as well as to competition with urban and industrial uses.

Although urban areas cover less than 1 percent of the ecoregion, they include large areas of the northern part of the "Front Range urban corridor," which extends from Cheyenne, Wyoming, to Pueblo, Colorado, and includes many population centers from Scottsbluff, Nebraska, to Odessa, Texas (fig. 6). Combined population of the 89 counties of the ecoregion was 2.57 million in 2000, a 28 percent increase since 1970 that occurred primarily in urban centers (U.S. Census Bureau, 19702000 [various years]). The county with the highest percentage gain was Finney County in southwestern Kansas, which grew by 113 percent (about 19,000 people) from 1970 to 2000. Southwestern Kansas in general and Finney County in particular have a high concentration of irrigated feed-grain production,

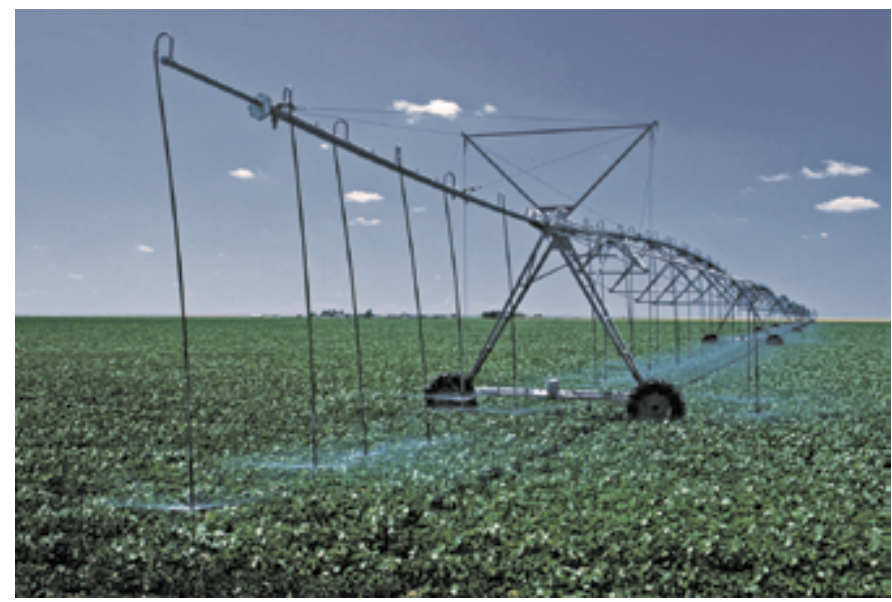

Figure 5. Cropland irrigation in Western High Plains Ecoregion, commonly used along streams and in areas where High Plains (Ogallala) aquifer water is readily available.

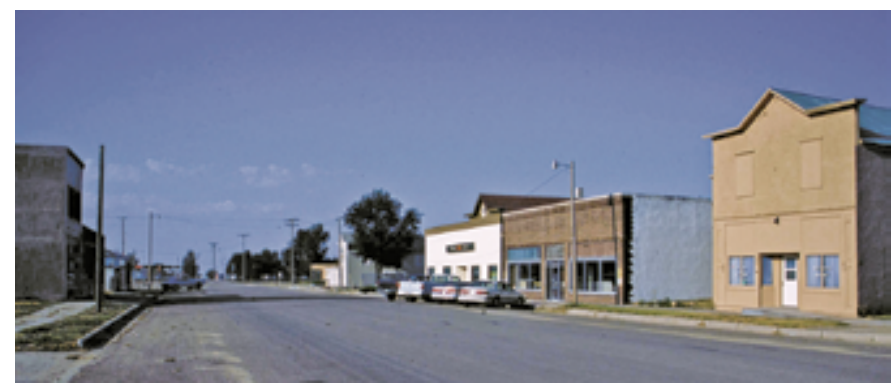

Figure 6. Small town in Western High Plains Ecoregion, many of which are potentially affected by long-term trends in agriculture. cattle feedlots, and beef-processing plants that provide employment (Harrington and Lu, 2002) and may be responsible for the population increase. Large cattle-feeding operations moved into the Western High Plains Ecoregion, and out of the Western Corn Belt Ecoregion, as well as out of the Central Corn Belt and Eastern Corn Belt Ecoregions in the Midwest-South Central United States, in part because the dry climate reduces the economic effects of animal disease (Harrington and $\mathrm{Lu}, 2002$ ).

\section{Contemporary Land-Cover Change (1973 to 2000)}

Several trends emerge from analysis of the land-cover data, which indicate an expansion of agriculture prior to 1986 followed by a larger expansion of grassland/shrubland (fig. 7). Between 1973 and 1980, grassland/shrubland was converted to agriculture because overseas markets for wheat increased and also because national farm policies favored expansion (table 1). Intensification of the agricultural industry, including both the concentration of animal-feeding operations and the expansion of irrigated feed-corn production into the ecoregion, also contributed to the land change. Some expansion continued between 1980 and 1986, although an economic downturn in agriculture caused the trend to nearly level out. Agriculture land cover increased by 1.8 percent between 1973 and 1986 (table 2).

Between 1986 and 1992, the trend reversed as 21,606 km² of agriculture was converted back to grassland/shrubland, primarily in response to the CRP and other economically driven decisions to abandon crop production. The CRP provided economic incentives to limit crop production on marginal lands. Limited net expansion of grassland/shrubland continued between 1992 and 2000. Agriculture decreased by 7.6 percent between 1986 and 2000 (table 2).

Between 1992 and 2000, the net loss of agriculture land cover was small, at 0.3 percent. However, shifts in the spatial location of grassland/shrubland and agriculture caused a large overall change that affected 4.7 percent of the ecoregion. During this time, CRP leases expired and grassland/shrubland was converted back to agriculture, while other cropland was enrolled in the CRP and planted with grass. Between 1973 and 2000, the total area of agriculture land cover decreased by an estimated 5.8 percent, whereas grassland/shrubland increased by 5.7 percent (fig. 7) (table 2). Grassland/shrubland increased from 44.1 percent of the ecoregion in 1973 to 49.8 percent in 2000. Agricultural land cover decreased from 53.6 percent to 47.8 percent (table 2).

The overall spatial change (the percentage of land area that changed at least one time) in the Western High Plains Ecoregion between 1973 and 2000 is estimated at 12.5 percent (table 3). Compared to other Great Plains ecoregions, change in the Western High Plains Ecoregion was relatively high (fig. 8): most of the area that changed (10.1 percent) did so only once during the study period, 2.3 percent changed twice, and 0.1 percent changed three times. These multiple changes typically were fluctuations between grassland/shrubland and agriculture. Overall, the most common conversion between 1973 and 2000 
was from agriculture to grassland/shrubland $\left(29,847 \mathrm{~km}^{2}\right)$, and the second most common conversion was from grassland/ shrubland to agriculture $\left(13,188 \mathrm{~km}^{2}\right)$ (table 1$)$.

Expansion of developed land (net change, 0.1 percent) into areas of grassland/shrubland and agricultural land were the next two most common conversions (194 and $171 \mathrm{~km}^{2}$, respectively) but represent a relatively small proportion of the overall change. Changes among other land-cover classes affected less than 0.1 percent of the ecoregion. The greatest amount of overall change occurred between 1986 and 1992, when 7.7 percent of the ecoregion changed as agricultural land was converted to grassland/ shrubland during the initial phase of the CRP (table 4); during this time period, an estimated 1.3 percent of the ecoregion changed annually (fig. 9; table 4). The period between 1980 and 1986 experienced the least amount of change, at 0.8 percent, when the slow agricultural economy limited the expansion of agriculture.

Land cover changed substantially in the Western High Plains Ecoregion between 1973 and 2000. This change partly resulted from its biological and physical setting (amplified by socioeconomic factors) and an increase in large farming interests, as well as government farm policies and subsidies. More land was used for crop production in good economic times, but marginal farmland was either

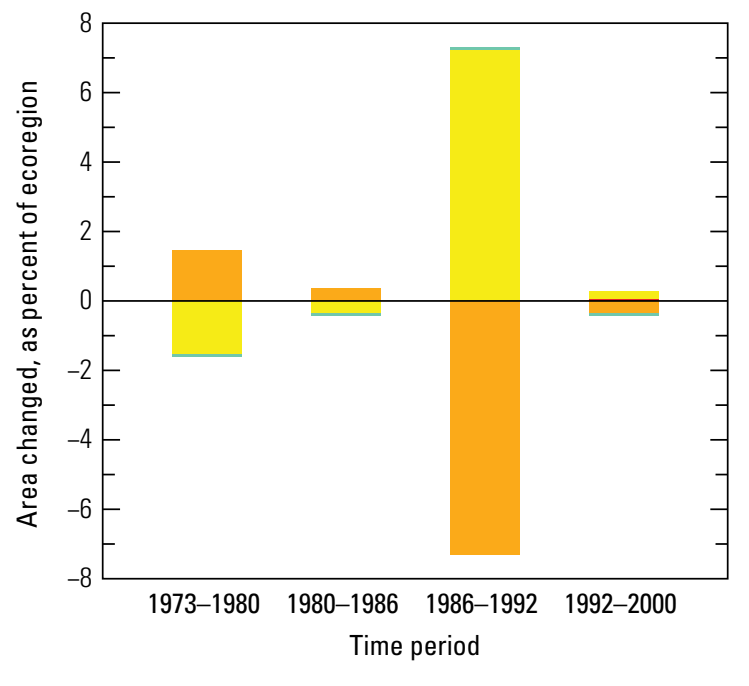

EXPLANATION

LAND-USE/LAND-COVER CLASS

\begin{tabular}{ll}
\hline Water & $\square$ Forest \\
Developed & Grassland/Shrubland \\
\hline Mechanically disturbed & $\square$ Agriculture \\
Mining & Wetland \\
\hline Barren & Nonmechanically disturbed \\
& $\square$ Ice/Snow
\end{tabular}

Figure 7. Normalized average net change in Western High Plains Ecoregion by time period for each land-cover class. Bars above zero axis represent net gain, whereas bars below zero represent net loss. Note that not all land-cover classes shown in explanation may be represented in figure. See appendix 3 for definitions of land-use/land-cover classifications. converted back to grassland/shrubland or abandoned when economic conditions worsened or drought cycles limited crop production. Overall, irrigated agriculture intensified and expanded; however, some areas were affected by declining water availability caused by climate variability, water overuse, or increased costs associated with pumping groundwater. Because of the continuing interaction between environmental and socioeconomic factors, the region is likely to continue to experience land-change fluctuations in the future.

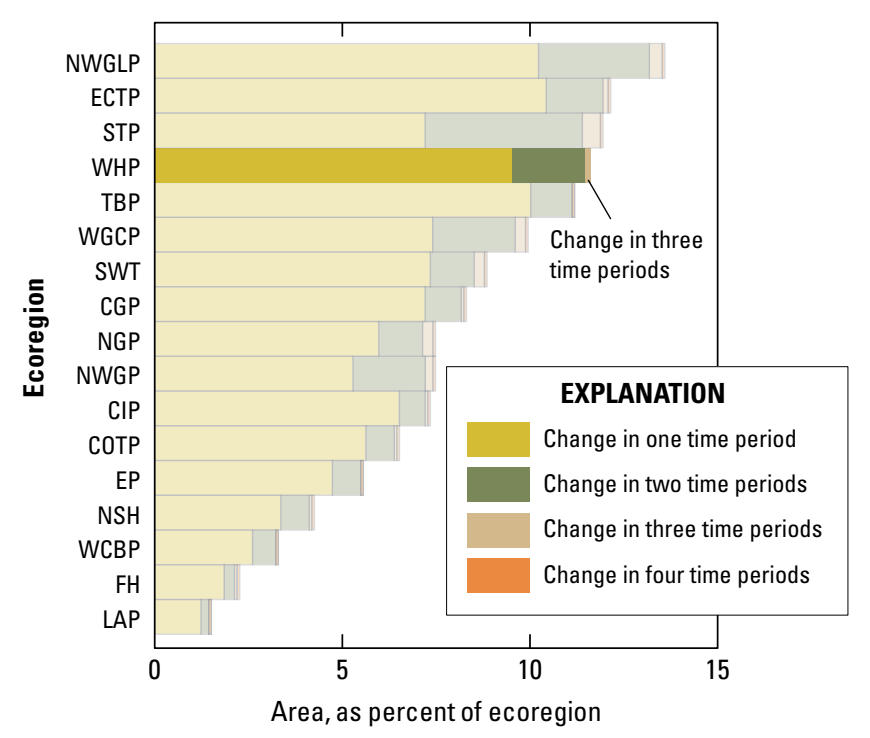

Figure 8. Overall spatial change in Western High Plains Ecoregion (WHP; darker bars) compared with that of all 17 Great Plains ecoregions (lighter bars). Each horizontal set of bars shows proportions of ecoregion that experienced change during one, two, three, or four time periods; highest level of spatial change in Western High Plains Ecoregion (three time periods) labeled for clarity. See table 4 for years covered by each time period. See appendix 2 for key to ecoregion abbreviations.

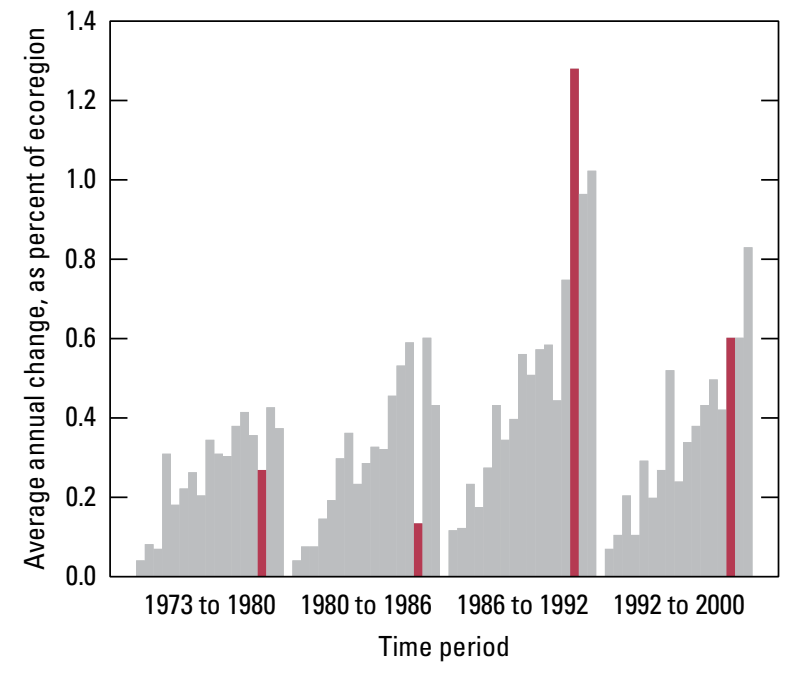

Figure 9. Estimates of land-cover change per time period, normalized to annual rates of change for all 17 Great Plains ecoregions (gray bars). Estimates of change for Western High Plains Ecoregion are represented by red bars in each time period. 
Table 1. Principal land-cover conversions in Western High Plains Ecoregion, showing amount of area changed (and margin of error, calculated at 85-percent confidence level) for each conversion during each of four time periods and also during overall study period. See appendix 3 for definitions of land-cover classifications.

[Values given for “other” classes are combined totals of values for other land-cover classes not listed in that time period. Abbreviations: n/a, not applicable]

\begin{tabular}{|c|c|c|c|c|c|c|c|c|}
\hline Period & From class & To class & & $\begin{array}{c}\begin{array}{c}\text { Area } \\
\text { changed }\end{array} \\
\left(\mathrm{km}^{2}\right)\end{array}$ & $\begin{array}{c}\text { Margin of } \\
\text { error } \\
\left(+/-\mathbf{k m}^{2}\right)\end{array}$ & $\begin{array}{c}\text { Standard } \\
\text { error } \\
\left(\mathrm{km}^{2}\right)\end{array}$ & $\begin{array}{l}\text { Percent of } \\
\text { ecoregion }\end{array}$ & $\begin{array}{l}\text { Percent of all } \\
\text { changes }\end{array}$ \\
\hline \multirow[t]{7}{*}{ 1973-1980 } & Grassland/Shrubland & Agriculture & & 4,718 & 1,667 & 1,138 & 1.6 & 87.9 \\
\hline & Agriculture & Grassland/Shrubland & & 453 & 215 & 147 & 0.2 & 8.4 \\
\hline & Agriculture & Developed & & 103 & 103 & 70 & 0.0 & 1.9 \\
\hline & Grassland/Shrubland & Developed & & 22 & 32 & 22 & 0.0 & 0.4 \\
\hline & Grassland/Shrubland & Mining & & 21 & 20 & 14 & 0.0 & 0.4 \\
\hline & Other & Other & & 49 & $\mathrm{n} / \mathrm{a}$ & $\mathrm{n} / \mathrm{a}$ & 0.0 & 0.9 \\
\hline & & & Totals & 5,366 & & & 1.9 & 100.0 \\
\hline \multirow[t]{7}{*}{ 1980-1986 } & Grassland/Shrubland & Agriculture & & 1,613 & 931 & 635 & 0.6 & 71.9 \\
\hline & Agriculture & Grassland/Shrubland & & 580 & 288 & 196 & 0.2 & 25.9 \\
\hline & Grassland/Shrubland & Developed & & 15 & 22 & 15 & 0.0 & 0.7 \\
\hline & Agriculture & Developed & & 14 & 16 & 11 & 0.0 & 0.6 \\
\hline & Grassland/Shrubland & Mining & & 8 & 11 & 8 & 0.0 & 0.3 \\
\hline & Other & Other & & 12 & $\mathrm{n} / \mathrm{a}$ & $\mathrm{n} / \mathrm{a}$ & 0.0 & 0.5 \\
\hline & & & Totals & 2,243 & & & 0.8 & 100.0 \\
\hline \multirow[t]{7}{*}{ 1986-1992 } & Agriculture & Grassland/Shrubland & & 21,606 & 4,895 & 3,341 & 7.5 & 97.3 \\
\hline & Grassland/Shrubland & Agriculture & & 539 & 257 & 175 & 0.2 & 2.4 \\
\hline & Grassland/Shrubland & Developed & & 16 & 20 & 14 & 0.0 & 0.1 \\
\hline & Agriculture & Developed & & 14 & 14 & 9 & 0.0 & 0.1 \\
\hline & Grassland/Shrubland & Mining & & 9 & 8 & 5 & 0.0 & 0.0 \\
\hline & Other & Other & & 14 & $\mathrm{n} / \mathrm{a}$ & $\mathrm{n} / \mathrm{a}$ & 0.0 & 0.1 \\
\hline & & & Totals & 22,198 & & & 7.7 & 100.0 \\
\hline \multirow[t]{7}{*}{ 1992-2000 } & Agriculture & Grassland/Shrubland & & 7,208 & 2,195 & 1,498 & 2.5 & 52.1 \\
\hline & Grassland/Shrubland & Agriculture & & 6,318 & 2,450 & 1,672 & 2.2 & 45.7 \\
\hline & Grassland/Shrubland & Developed & & 141 & 146 & 99 & 0.0 & 1.0 \\
\hline & Agriculture & Developed & & 41 & 44 & 30 & 0.0 & 0.3 \\
\hline & Wetland & Agriculture & & 28 & 37 & 26 & 0.0 & 0.2 \\
\hline & Other & Other & & 90 & $\mathrm{n} / \mathrm{a}$ & $\mathrm{n} / \mathrm{a}$ & 0.0 & 0.7 \\
\hline & & & Totals & 13,825 & & & 4.8 & 100.0 \\
\hline \multirow{7}{*}{$\begin{array}{c}1973-2000 \\
\text { (overall) }\end{array}$} & Agriculture & Grassland/Shrubland & & 29,847 & 6,602 & 4,506 & 10.3 & 68.4 \\
\hline & Grassland/Shrubland & Agriculture & & 13,188 & 3,530 & 2,410 & 4.6 & 30.2 \\
\hline & Grassland/Shrubland & Developed & & 194 & 216 & 147 & 0.1 & 0.4 \\
\hline & Agriculture & Developed & & 171 & 164 & 112 & 0.1 & 0.4 \\
\hline & Grassland/Shrubland & Mining & & 57 & 43 & 29 & 0.0 & 0.1 \\
\hline & Other & Other & & 175 & $\mathrm{n} / \mathrm{a}$ & $\mathrm{n} / \mathrm{a}$ & 0.1 & 0.4 \\
\hline & & & Totals & 43,631 & & & 15.1 & 100.0 \\
\hline
\end{tabular}


Table 2. Estimated area (and margin of error) of each land-cover class in Western High Plains Ecoregion, calculated five times between 1973 and 2000. See appendix 3 for definitions of land-cover classifications.

\begin{tabular}{|c|c|c|c|c|c|c|c|c|c|c|c|c|c|c|c|c|c|c|c|c|}
\hline & \multicolumn{2}{|c|}{ Water } & \multicolumn{2}{|c|}{ Developed } & \multicolumn{2}{|c|}{$\begin{array}{l}\text { Mechan- } \\
\text { ically } \\
\text { disturbed }\end{array}$} & \multicolumn{2}{|c|}{ Mining } & \multicolumn{2}{|c|}{ Barren } & \multicolumn{2}{|c|}{ Forest } & \multicolumn{2}{|c|}{$\begin{array}{l}\text { Grassland/Shru- } \\
\text { bland }\end{array}$} & \multicolumn{2}{|c|}{ Agriculture } & \multicolumn{2}{|c|}{ Wetland } & \multicolumn{2}{|c|}{$\begin{array}{c}\text { Non- } \\
\text { mechan- } \\
\text { ically } \\
\text { disturbed }\end{array}$} \\
\hline \multicolumn{21}{|c|}{ Area, in percent stratum } \\
\hline 1973 & 0.2 & 0.1 & 0.4 & 0.3 & 0.0 & 0.0 & 0.1 & 0.0 & 0.3 & 0.2 & 0.8 & 1.1 & 44.1 & 7.3 & 53.6 & 7.5 & 0.4 & 0.1 & 0.0 & 0.0 \\
\hline 1992 & 0.2 & 0.1 & 0.5 & 0.3 & 0.0 & 0.0 & 0.1 & 0.0 & 0.3 & 0.2 & 0.8 & 1.1 & 49.6 & 7.0 & 48.1 & 7.2 & 0.4 & 0.1 & 0.0 & 0.0 \\
\hline 2000 & 0.2 & 0.1 & 0.6 & 0.3 & 0.0 & 0.0 & 0.1 & 0.0 & 0.3 & 0.2 & 0.8 & 1.1 & 49.8 & 7.2 & 47.8 & 7.4 & 0.4 & 0.1 & 0.0 & 0.0 \\
\hline $\begin{array}{l}\text { Net } \\
\text { change }\end{array}$ & 0.0 & 0.0 & 0.1 & 0.1 & 0.0 & 0.0 & 0.0 & 0.0 & 0.0 & 0.0 & 0.0 & 0.0 & 5.7 & 2.2 & -5.8 & 2.1 & 0.0 & 0.0 & 0.0 & 0.0 \\
\hline 1973 & 630 & 247 & 1,273 & 745 & 6 & 7 & 224 & 107 & 769 & 444 & 2,436 & 3,246 & 127,408 & 20,965 & 154,880 & 21,568 & 1,126 & 404 & 0 & 0 \\
\hline 1980 & 631 & 246 & 1,398 & 822 & 1 & 1 & 246 & 123 & 755 & 444 & 2,436 & 3,246 & 123,123 & 20,928 & 159,057 & 21,556 & 1,105 & 402 & 0 & 0 \\
\hline 1986 & 631 & 246 & 1,427 & 837 & 2 & 3 & 257 & 130 & 756 & 444 & 2,436 & 3,246 & 122,065 & 20,893 & 160,073 & 21,539 & 1,104 & 403 & 0 & 0 \\
\hline 1992 & 634 & 247 & 1,457 & 854 & 0 & 0 & 266 & 133 & 754 & 445 & 2,436 & 3,246 & 143,111 & 20,247 & 138,987 & 20,782 & 1,106 & 404 & 0 & 0 \\
\hline 2000 & 644 & 253 & 1,639 & 926 & 4 & 6 & 292 & 140 & 754 & 444 & 2,436 & 3,246 & 143,843 & 20,686 & 138,070 & 21,261 & 1,070 & 377 & 0 & 0 \\
\hline $\begin{array}{l}\text { Net } \\
\text { change }\end{array}$ & 14 & 24 & 366 & 273 & -1 & 1 & 69 & 46 & -15 & 15 & 0 & 0 & 16,435 & 6,210 & $-16,811$ & 6,190 & -56 & 55 & 0 & 0 \\
\hline $\begin{array}{l}\text { Gross } \\
\text { change }\end{array}$ & 42 & 23 & 366 & 273 & 12 & 15 & 78 & 46 & 21 & 15 & 0 & 0 & 37,339 & 7,404 & 37,258 & 7,427 & 95 & 58 & 0 & 0 \\
\hline
\end{tabular}


Table 3. Percentage of Western High Plains Ecoregion land cover that changed at least one time during study period (19732000) and associated statistical error.

[Most sample pixels remained unchanged ( 87.5 percent), whereas 12.5 percent changed at least once throughout study period]

\begin{tabular}{ccccccc}
\hline $\begin{array}{c}\text { Number } \\
\text { of } \\
\text { changes }\end{array}$ & $\begin{array}{c}\text { Percent } \\
\text { of } \\
\text { ecoregion }\end{array}$ & $\begin{array}{c}\text { Margin } \\
\text { of error } \\
(+/-\%)\end{array}$ & $\begin{array}{c}\text { Lower } \\
\text { bound } \\
(\%)\end{array}$ & $\begin{array}{c}\text { Upper } \\
\text { bound } \\
(\%)\end{array}$ & $\begin{array}{c}\text { Standard } \\
\text { error } \\
(\%)\end{array}$ & $\begin{array}{c}\text { Relative } \\
\text { error } \\
(\%)\end{array}$ \\
\hline 1 & 10.1 & 2.0 & 8.1 & 12.0 & 1.3 & 13.3 \\
2 & 2.3 & 0.9 & 1.5 & 3.2 & 0.6 & 25.3 \\
3 & 0.1 & 0.1 & 0.0 & 0.2 & 0.1 & 58.7 \\
4 & 0.0 & 0.0 & 0.0 & 0.0 & 0.0 & 0.0 \\
\hline $\begin{array}{c}\text { Overall } \\
\text { spatial } \\
\text { change }\end{array}$ & 12.5 & 2.3 & 10.2 & 14.8 & 1.6 & 12.7 \\
\hline
\end{tabular}

Table 4. Raw estimates of change in Western High Plains Ecoregion land cover, computed for each of four time periods between 1973 and 2000, and associated error at 85-percent confidence level.

[Estimates of change per period normalized to annual rate of change for each period]

\begin{tabular}{|c|c|c|c|c|c|c|c|}
\hline Period & $\begin{array}{c}\text { Total } \\
\text { change } \\
\text { (\% of } \\
\text { ecoregion) }\end{array}$ & $\begin{array}{l}\text { Margin } \\
\text { of error } \\
(+/-\%)\end{array}$ & $\begin{array}{c}\text { Lower } \\
\text { bound } \\
(\%)\end{array}$ & $\begin{array}{c}\text { Upper } \\
\text { bound } \\
(\%)\end{array}$ & $\begin{array}{c}\text { Standard } \\
\text { error } \\
(\%)\end{array}$ & $\begin{array}{c}\text { Relative } \\
\text { error } \\
(\%)\end{array}$ & $\begin{array}{c}\text { Average } \\
\text { rate } \\
\text { (\% per } \\
\text { year) }\end{array}$ \\
\hline \multicolumn{8}{|c|}{ Estimate of change, in percent stratum } \\
\hline 1973-1980 & 1.9 & 0.6 & 1.3 & 2.5 & 0.4 & 22.2 & 0.3 \\
\hline 1980-1986 & 0.8 & 0.3 & 0.4 & 1.1 & 0.2 & 28.8 & 0.1 \\
\hline 1986-1992 & 7.7 & 1.7 & 6.0 & 9.4 & 1.2 & 15.1 & 1.3 \\
\hline 1992-2000 & 4.8 & 1.1 & 3.7 & 5.9 & 0.7 & 15.6 & 0.6 \\
\hline \multicolumn{8}{|c|}{ Estimate of change, in square kilometers } \\
\hline 1973-1980 & 5,366 & 1,745 & 3,621 & 7,110 & 1,191 & 22.2 & 767 \\
\hline 1980-1986 & 2,243 & 947 & 1,296 & 3,190 & 646 & 28.8 & 374 \\
\hline 1986-1992 & 22,198 & 4,911 & 17,287 & 27,109 & 3,352 & 15.1 & 3,700 \\
\hline 1992-2000 & 13,825 & 3,168 & 10,657 & 16,993 & 2,162 & 15.6 & 1,728 \\
\hline
\end{tabular}




\section{References Cited}

Brooks, E., Emel, J., Jokisch, B., and Robbins, P., 2001, The Llano Estacado of the US Southern High Plains-Environmental transformation and the prospect for sustainability: New York, United Nations University Press, 176 p.

Dennehy, K.F., Litke, D.W., and McMahon, P.B., 2002, The High Plains aquifer, USA-Groundwater development and sustainability, in Hiscock, K.M., Rivett, M.O., and Davison, R.M., eds., Sustainable groundwater development: London, Geological Society, Special Publications, v. 193, p. 99-119.

Harrington, L.M.B., and Lu, M., 2002, Beef feedlots in southwestern Kansas - Local change, perceptions, and the global change context: Global Environmental Change, v. 12, p. 273-282.

Lichtenberg, E., 1989, Land quality, irrigation development, and cropping patterns in the northern High Plains: American Journal of Agricultural Economics, v. 71, p. 187-194.

McGuire, V.L., Johnson, M.R., Schieffer, R.L., Stanton, J.S., Sebree, S.K., and Verstraeten, I.M., 2003, Water in storage and approaches to ground-water management, High Plains aquifer, 2000: U.S. Geological Survey Circular 1243, 51 p., available at http://pubs.usgs.gov/circ/2003/circ1243/.

Omernik, J.M., 1987, Ecoregions of the conterminous United States: Annals of the Association of American Geographers, v. 77, no. 1, p. 118-125.
Terrell, B.E., Johnson, P.N., and Segarra, E., 2002, Ogallala aquifer depletion-Economic impact on the Texas high plains: Journal of Water Policy, v. 4, no. 1, p. 33-46.

U.S. Census Bureau, 1970-2000 [various years], Census of population and housing: U.S. Census Bureau database, accessed September 1, 2008, at http://www.census.gov/ prod/www/decennial.html.

U.S. Department of Agriculture, 1970-2000 [various years], Census of agriculture: U.S. Department of Agriculture database, accessed September 1, 2008, at http://www.agcensus. usda.gov/.

U.S. Environmental Protection Agency, 1997, Descriptions of level III ecological regions for the CEC report on ecological regions of North America: U.S. Environmental Protection Agency database, accessed April 12, 2006, at http://www. epa.gov/wed/pages/ecoregions/na_eco.htm\#Downloads.

Vogelmann, J.E., Howard, S.M., Yang, L., Larson, C.R., Wylie, B.K., and van Driel, N., 2001, Completion of the 1990s National Land Cover Data Set for the conterminous United States from Landsat Thematic Mapper data and ancillary data sources: Photogrammetric Engineering \& Remote Sensing, v. 67, p. 650-662. 


\section{Glaciated Plains Ecoregions}

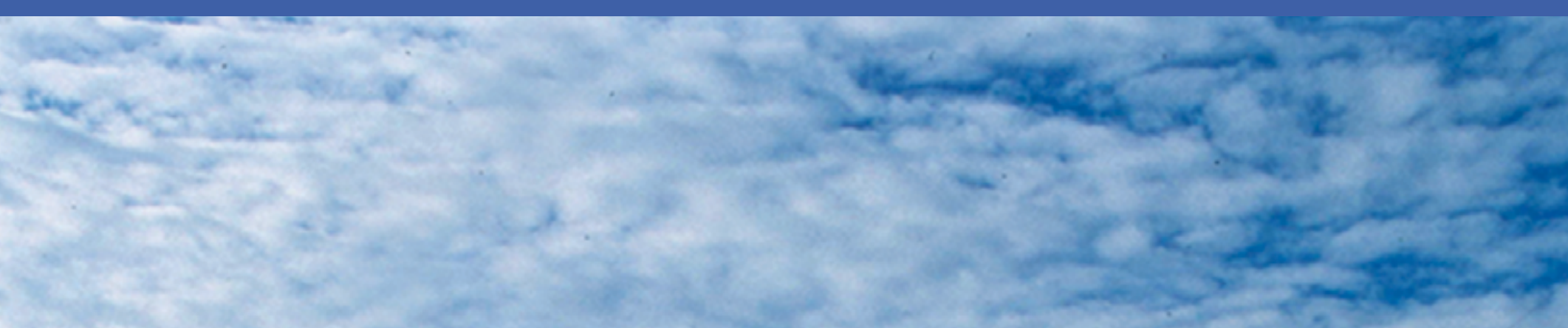




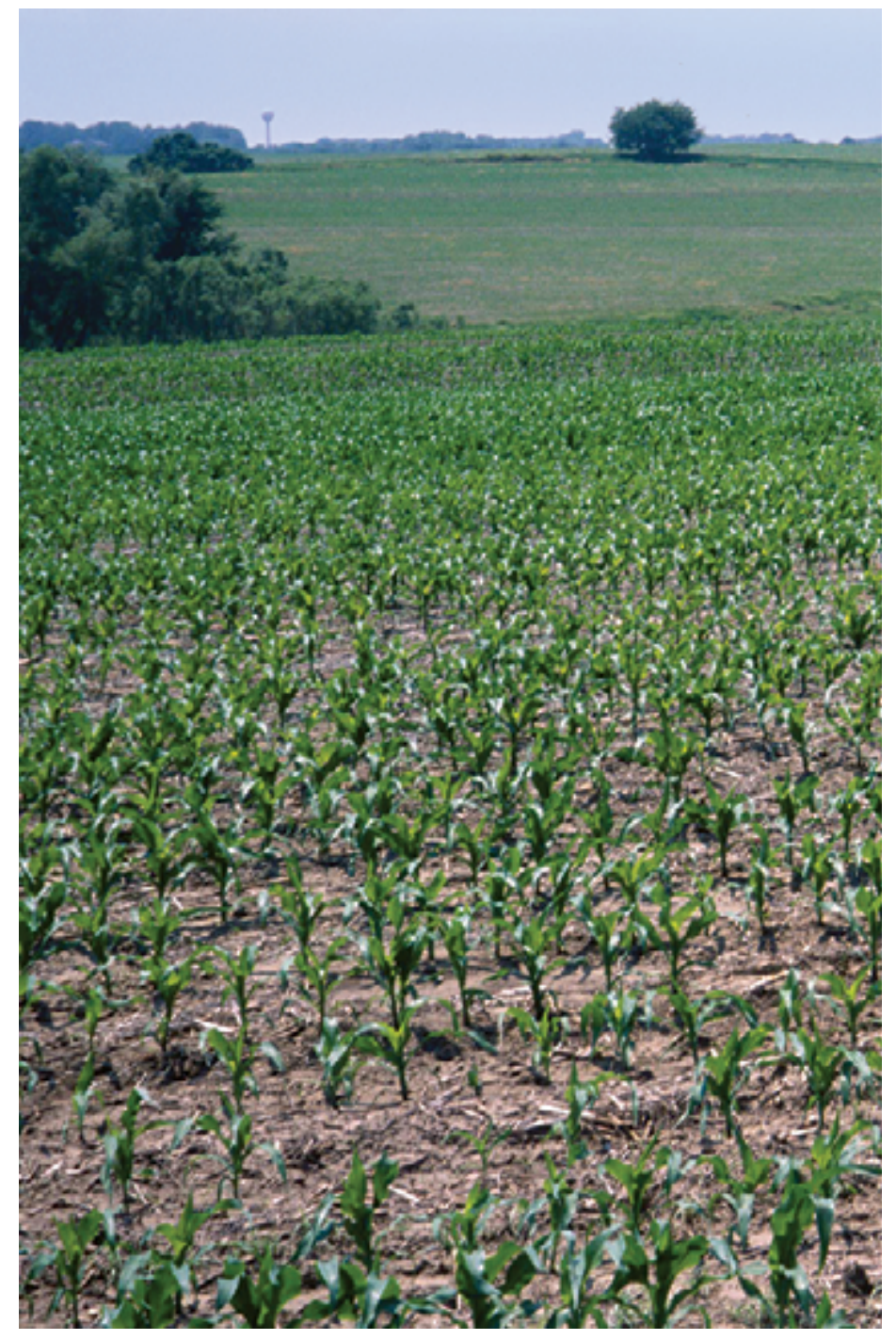




\section{Lake Agassiz Plain Ecoregion}

\author{
By Mark S. Brooks
}

\section{Ecoregion Description}

The Lake Agassiz Plain Ecoregion covers $40,636 \mathrm{~km}^{2}\left(15,690 \mathrm{mi}^{2}\right)$ in eastern North Dakota, northwestern Minnesota, and a small part of northeastern South Dakota (fig 1) (Omernik, 1987; U.S. Environmental Protection Agency, 1997). The ecoregion is bounded, on the west and south, by the Northern Glaciated Plains Ecoregion and, on the east, by the Northern Minnesota Wetlands and North Central Hardwood Forests Ecoregions; the Canadian border forms the northern border of the ecoregion (fig. 1).

The modern-day landscape of the Lake Agassiz Plain Ecoregion formed about 10 thousand years ago when the great continental glaciers of North America started to recede. Blocked by large ice sheets, glacial meltwater formed many large glacial lakes. The last proglacial lake to fill the modern-day Red River valley was Glacial Lake Agassiz. What remains today is an extremely flat plain that has an average gradient of about $9 \mathrm{~cm}$ per $\mathrm{km}$, as well as a lake-washed till plain and gently rolling uplands along the east and west edges of the Red River valley. Because of its poorly defined floodplains, the Red River valley has experienced numerous floods throughout its young geologic history.

The ecoregion has a continental climate: January average low and high temperatures are about $-22^{\circ} \mathrm{C}$ and $11^{\circ} \mathrm{C}$, respectively, and July average low and high temperatures are about $13^{\circ} \mathrm{C}$ and $28^{\circ} \mathrm{C}$, respectively. The average annual number of frost-free days ranges from 95 to 125 days, and the average annual precipitation amount is about $530 \mathrm{~mm}$ (21 in.).

During the 19th century, much of the native tallgrass prairie of the Red River valley was replaced with a mostly agricultural land, and agriculture is the principal landcover class in the ecoregion. The rich, deep, loamy soils, as well as the construction of an extensive drainage system to remove surface

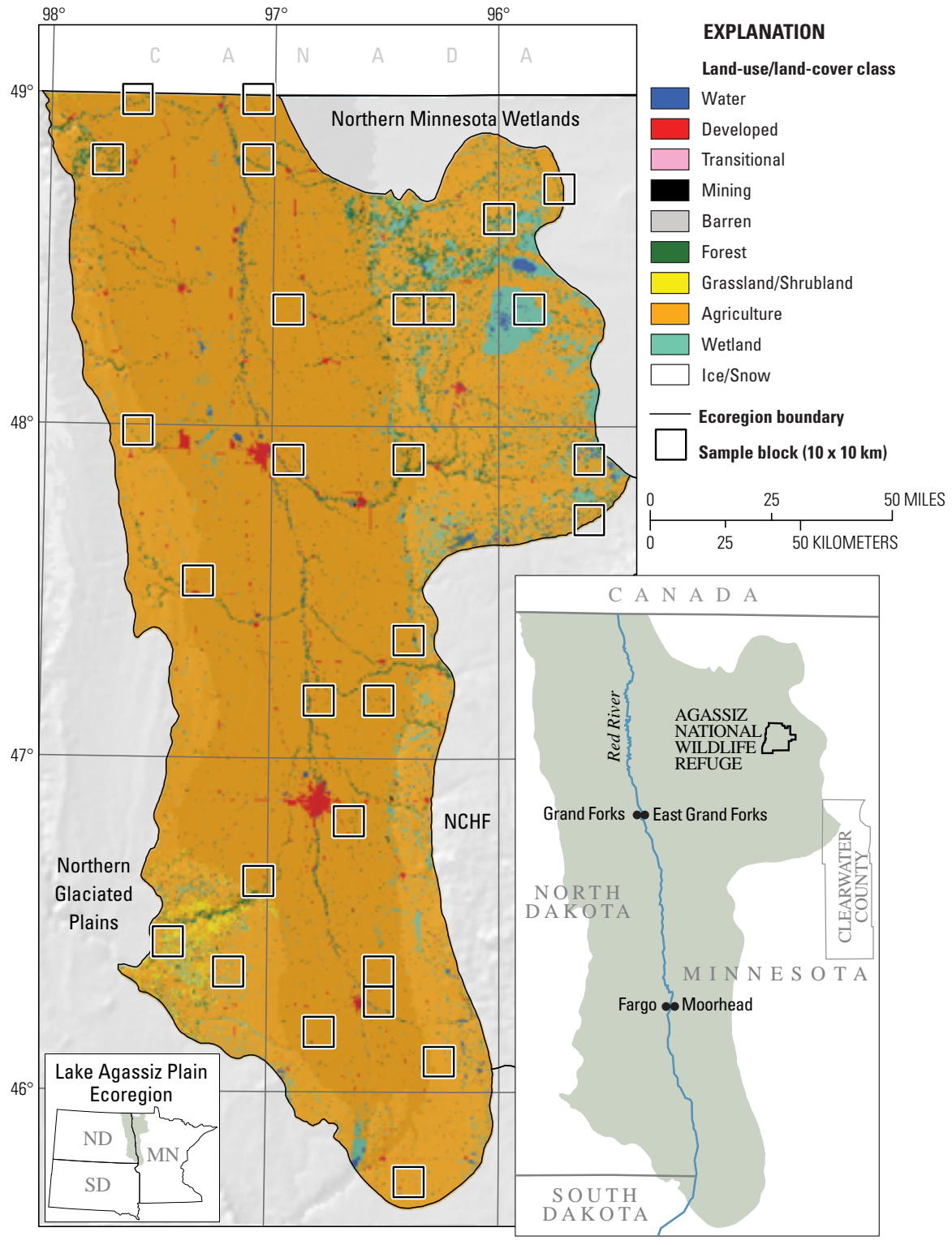

Figure 1. Map of Lake Agassiz Plain Ecoregion and surrounding ecoregions, showing land-use/land-cover classes from 1992 National Land Cover Dataset (Vogelmann and others, 2001); note that not all land-use/land-cover classes shown in explanation may be depicted on map; note also that, for this "Status and Trends of Land Change" study, transitional land-cover class was subdivided into mechanically disturbed and nonmechanically disturbed classes. Squares indicate locations of 10 $x 10 \mathrm{~km}$ sample blocks analyzed in study. Index map shows locations of geographic features mentioned in text. Abbreviations for Great Plains ecoregions are listed in appendix 2. Also shown are parts of two Midwest-South Central United States ecoregions: North Central Hardwood Forests (NCHF) and Northern Minnesota Wetlands. See appendix 3 for definitions of land-use/land-cover classifications. 
water quickly from agricultural lands (fig. 2), have enabled the Red River valley to become one of the most productive agricultural areas in the Great Plains. Major crops produced throughout the Lake Agassiz Plain Ecoregion include potatoes, sugar beets, sunflowers, wheat, barley, corn, and soybeans

(figs. 3,4$)$. Pasture and hay production are common in areas of marginal soils (fig. 5).

Secondary land-cover classes include grassland/ shrubland, forest, and wetland, which tend to be located away from the high-intensity agriculture found along the Red River valley, with the exception of riparian forest cover (fig. 1). Grassland/shrubland primarily is present in the lake-washed till plains, on the beach ridges and sand deltas around the edge of Glacial Lake Agassiz (Bryce and others, 1998). Wetland and forest more commonly are present in the northeastern upland area of the ecoregion where soils are not as rich. One of the largest remaining wetland lies within this upland area, part of the Agassiz National Wildlife Refuge (U.S. Fish and Wildlife Service, 2009).

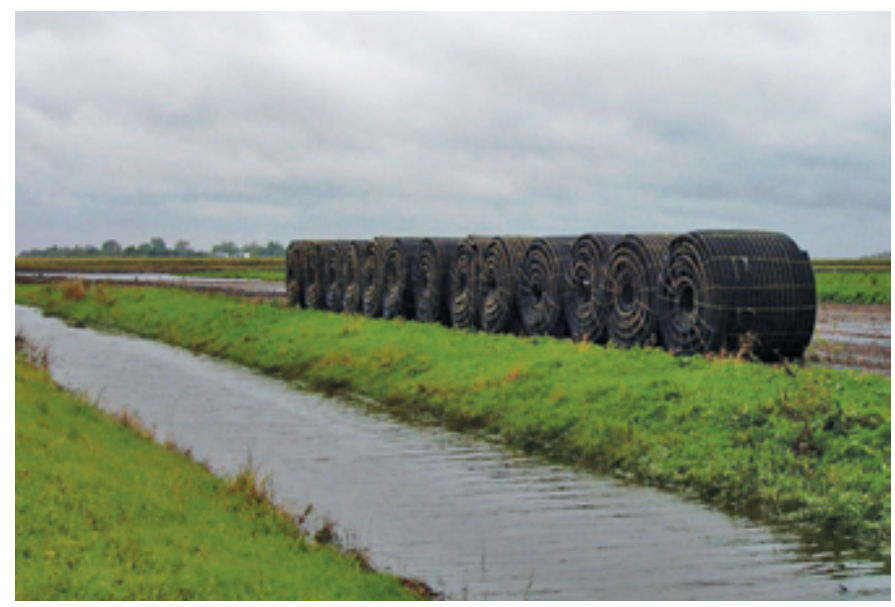

Figure 2. Drainage ditch and rolls of tile piping used for field drainage, in Lake Agassiz Plain Ecoregion.

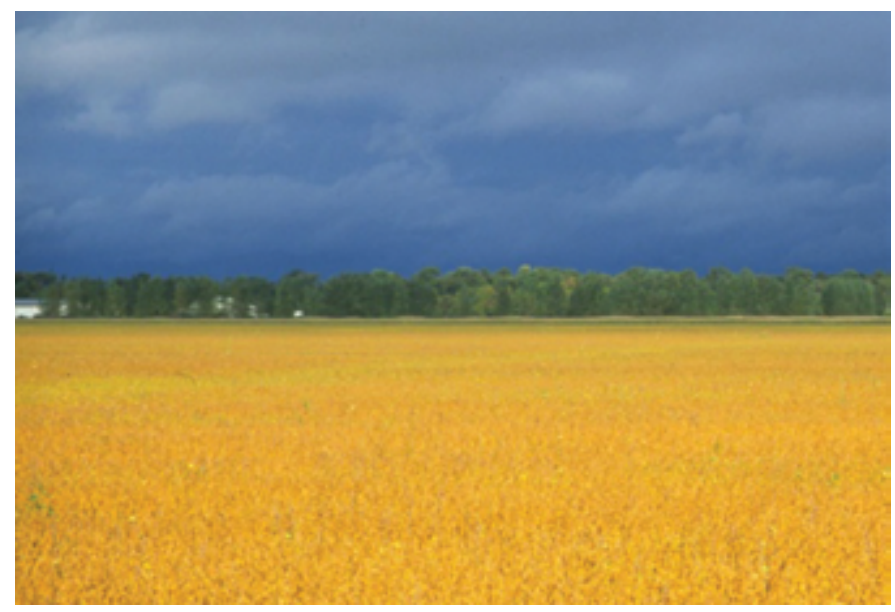

Figure 3. Soybean field ready for harvest, in Lake Agassiz Plain Ecoregion.
Developed land-cover class includes two urban areas situated along the Red River: the Fargo, North DakotaMoorhead, Minnesota metropolitan statistical area (population, 174,367 in 2000) and the Grand Forks, North Dakota-East Grand Forks, Minnesota metropolitan area (population, 97,478 in 2000) (U.S. Census Bureau, 2003). During the study period, the population in both urban areas remained stable, while the population of rural communities declined as younger residents migrated to larger cities in search of better social and economic opportunities.

\section{Contemporary Land-Cover Change (1973 to 2000)}

The overall spatial change (the percentage of land area that changed at least one time) in the Lake Agassiz Plain Ecoregion between 1973 and 2000 is about 1.5 percent (table 1), the lowest amount of change among all 17 Great Plains ecoregions (fig. 6). In addition, the total land-use/landcover change estimated for each time period was extremely

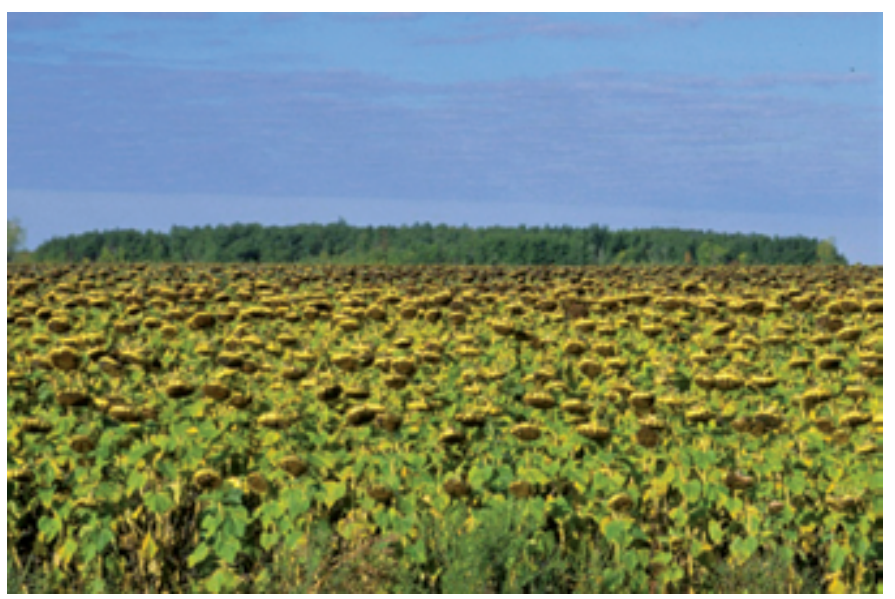

Figure 4. Sunflower field in Lake Agassiz Plain Ecoregion.

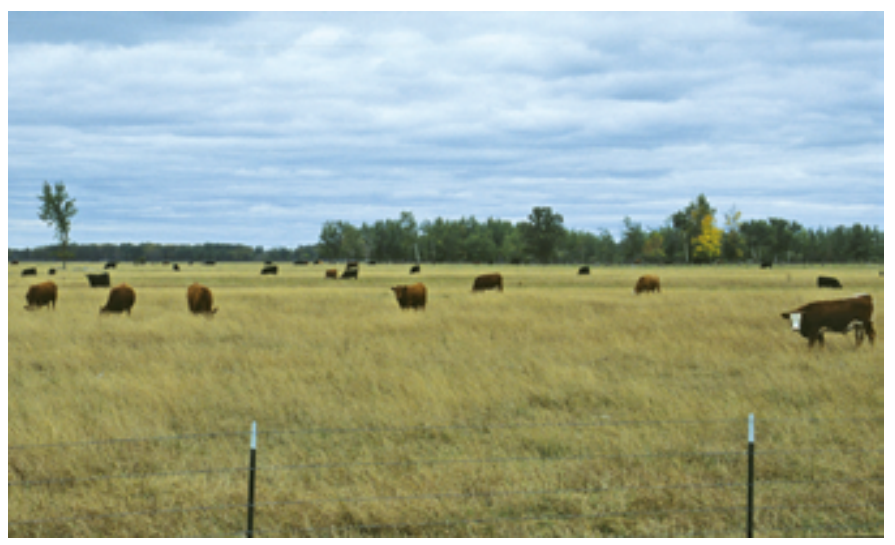

Figure 5. Cattle grazing along County Route 60, in northwestern Clearwater County, Minnesota, Lake Agassiz Plain Ecoregion. 
low: the estimated change was 0.2 percent between 1973 and 1980 and between 1980 and 1986, 0.7 percent between 1986 and 1992, and 0.5 percent between 1992 and 2000 (table 2). When normalized to an annual rate of change to adjust for uneven time periods, all time periods had an estimated annual rate of change of 0.1 percent or less (table 2; fig. 7).

The composition of land-use/land-cover classes in the Lake Agassiz Plain Ecoregion changed very little during the study period. In 2000 , agriculture was the predominant landcover class in the ecoregion (about 80.9 percent), followed by grassland/shrubland (about 7.3 percent), forest (about 5.5 percent), and wetland (about 4.7 percent). The remaining landcover classes combined constituted about 1.6 percent of the ecoregion (table 3).

The largest overall net change during the study period was a 0.6 percent decrease (about $247 \mathrm{~km}^{2}$ ) in agriculture, the greatest amount of change occurring between 1986 and 1992. In contrast, grassland/shrubland increased by 0.5 percent (196 $\mathrm{km}^{2}$ ) over the study period (table 3; fig. 8). The large amount of change between agriculture and grassland/shrubland between 1986 and 1992 was associated with the enrollment of cropland in the Conservation Reserve Program (CRP). The CRP is a Federal program implemented in the mid-1980s to reduce soil erosion and improve water quality and wildlife habitat by paying farmers to remove marginal and erodible cropland from production and to restore it to native grasslands and other natural landscapes.

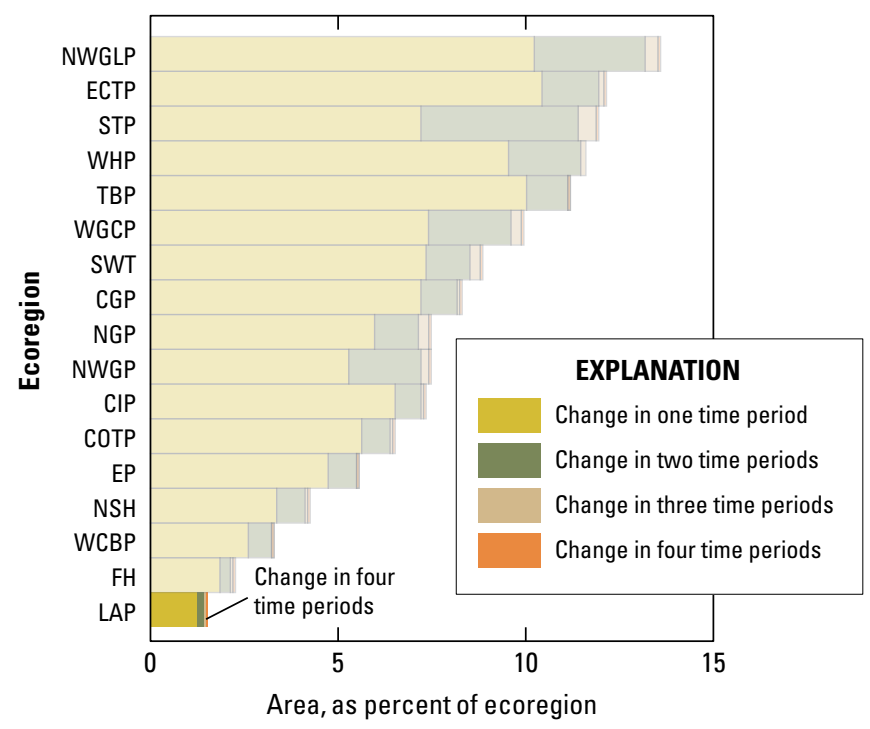

Figure 6. Overall spatial change in Lake Agassiz Plain Ecoregion (LAP; darker bars) compared with that of all 17 Great Plains ecoregions (lighter bars). Each horizontal set of bars shows proportions of ecoregion that changed during one, two, three, or four time periods; highest level of spatial change in Lake Agassiz Plain Ecoregion (four time periods) labeled for clarity. See table 2 for years covered by each time period. See appendix 2 for key to ecoregion abbreviations.

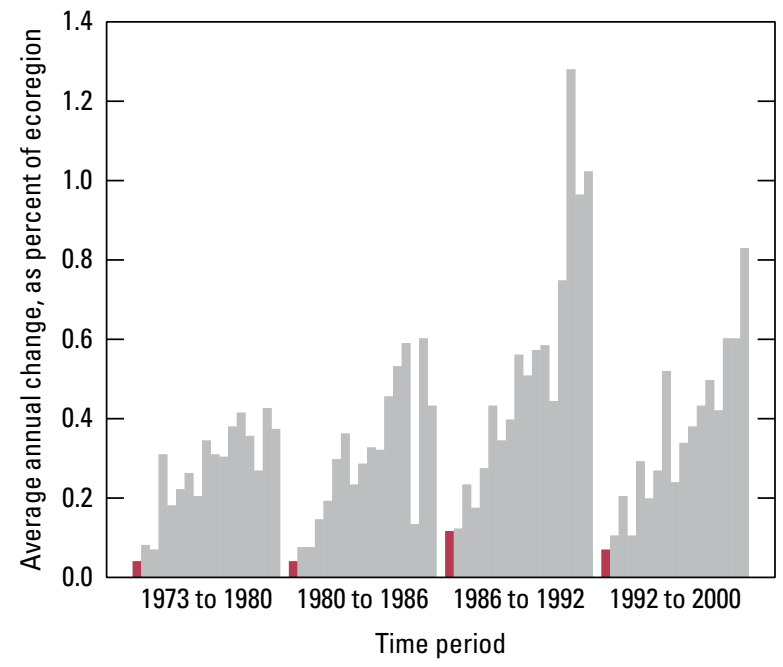

Figure 7. Estimates of land-cover change per time period, normalized to annual rates of change for all 17 Great Plains ecoregions (gray bars). Estimates of change for Lake Agassiz Plain Ecoregion are represented by red bars in each time period.

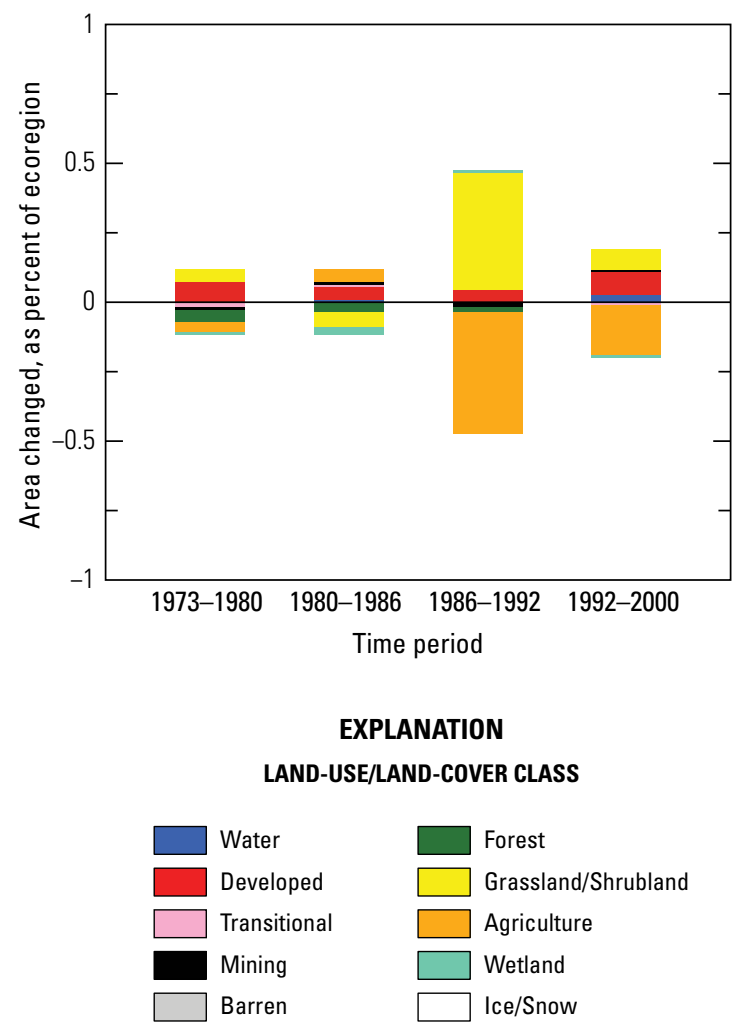

Figure 8. Normalized average net change in Lake Agassiz Plain Ecoregion by time period for each land-cover class. Bars above zero axis represent net gain, whereas bars below zero represent net loss. Note that not all land-cover classes shown in explanation may be represented in figure. See appendix 3 for definitions of land-use/land-cover classifications. 
The most common land-cover conversions during the 27-year study period highlight the strong influence that agriculture had on the ecoregion. Agriculture was part of each of the top five conversions, which included both losses to and gains from other land-cover classes (table 4). The leading changes were the conversions of an estimated $297 \mathrm{~km}^{2}$ of agricultural land to grassland/shrubland and an estimated 104 $\mathrm{km}^{2}$ of grassland/shrubland to agricultural land; these two conversions constituted nearly 60 percent of all change in the ecoregion. Other changes involving agriculture included the conversions of an estimated $80 \mathrm{~km}^{2}$ of agriculture to developed, $44 \mathrm{~km}^{2}$ of forest to agriculture, and $28 \mathrm{~km}^{2}$ of wetland to agriculture (table 4).

The fact that the Lake Agassiz Plain Ecoregion had the lowest amount land-cover change among the 17 Great Plains ecoregions was mainly because of the dominance and stability of agriculture. Although the ecoregion was relatively stable, conversions between agriculture and other land-use/land-cover classes were observed in each time period. The CRP had a moderate influence on land-cover change in the ecoregion; the National Agricultural Statistics Service reported a 6 percent increase in cropland enrollment in the CRP between 1987 and 1997 (Blann and others, 2009), which explains the large amount of agricultural land that converted to grassland/ shrubland between 1986 and 1992. Other government programs have been implemented to mitigate the effects of re-engineered natural waterways and intensive agricultural production that have increased the severity of flooding and soil erosion, reduced water quality, and fragmented wildlife habitat within the Red River valley.

Table 1. Percentage of Lake Agassiz Plain Ecoregion land cover that changed at least one time during study period (1973-2000) and associated statistical error.

[Most sample pixels remained unchanged ( 98.5 percent), whereas 1.5 percent changed at least once throughout study period]

\begin{tabular}{ccccccc}
\hline $\begin{array}{c}\text { Number } \\
\text { of } \\
\text { changes }\end{array}$ & $\begin{array}{c}\text { Percent } \\
\text { of } \\
\text { ecoregion }\end{array}$ & $\begin{array}{c}\text { Margin } \\
\text { of error } \\
(+/-\%)\end{array}$ & $\begin{array}{c}\text { Lower } \\
\text { bound } \\
(\%)\end{array}$ & $\begin{array}{c}\text { Upper } \\
\text { bound } \\
(\%)\end{array}$ & $\begin{array}{c}\text { Standard } \\
\text { error } \\
(\%)\end{array}$ & $\begin{array}{c}\text { Relative } \\
\text { error } \\
(\%)\end{array}$ \\
\hline 1 & 1.3 & 0.4 & 0.9 & 1.7 & 0.2 & 18.8 \\
2 & 0.1 & 0.1 & 0.0 & 0.3 & 0.1 & 44.3 \\
3 & 0.0 & 0.0 & 0.0 & 0.1 & 0.0 & 63.1 \\
4 & 0.0 & 0.0 & 0.0 & 0.0 & 0.0 & 70.9 \\
\hline $\begin{array}{c}\text { Overall } \\
\text { spatial } \\
\text { change }\end{array}$ & 1.5 & 0.4 & 1.1 & 1.9 & 0.3 & 19.1 \\
\hline
\end{tabular}


Table 2. Raw estimates of change in Lake Agassiz Plain Ecoregion land cover, computed for each of four time periods between 1973 and 2000, and associated error at 85-percent confidence level.

[Estimates of change per period normalized to annual rate of change for each period]

\begin{tabular}{cccccccc}
\hline Period & $\begin{array}{c}\text { Total change } \\
(\% \text { of ecore- } \\
\text { gion) }\end{array}$ & $\begin{array}{c}\text { Margin of } \\
\text { error } \\
(+/-\%)\end{array}$ & $\begin{array}{c}\text { Lower } \\
\text { bound } \\
(\%)\end{array}$ & $\begin{array}{c}\text { Upper bound } \\
(\%)\end{array}$ & $\begin{array}{c}\text { Standard } \\
\text { error } \\
(\%)\end{array}$ & $\begin{array}{c}\text { Relative } \\
\text { error } \\
(\%)\end{array}$ & $\begin{array}{c}\text { Average rate } \\
\text { (\% per year) }\end{array}$ \\
\hline \multicolumn{7}{c}{ Estimate of change, in percent stratum } \\
\hline $1973-1980$ & 0.2 & 0.1 & 0.2 & 0.3 & 0.1 & 24.9 & 0.0 \\
$1980-1986$ & 0.2 & 0.1 & 0.1 & 0.3 & 0.1 & 26.6 & 0.0 \\
$1986-1992$ & 0.7 & 0.3 & 0.4 & 1.0 & 0.2 & 29.3 & 0.1 \\
$1992-2000$ & 0.5 & 0.2 & 0.4 & 0.7 & 0.1 & 21.5 & 0.1 \\
\hline & & Estimate of change, in square kilometers & & \\
\hline $1973-1980$ & 101 & 37 & 64 & 138 & 25 & 24.9 & 14 \\
$1980-1986$ & 98 & 39 & 59 & 137 & 26 & 26.6 & 16 \\
$1986-1992$ & 278 & 121 & 157 & 398 & 81 & 29.3 & 46 \\
$1992-2000$ & 212 & 68 & 144 & 279 & 46 & 21.5 & 26 \\
\hline
\end{tabular}

Table 3. Estimated area (and margin of error) of each land-cover class in Lake Agassiz Plain Ecoregion, calculated five times between 1973 and 2000. See appendix 3 for definitions of land-cover classifications.

\begin{tabular}{|c|c|c|c|c|c|c|c|c|c|c|c|c|c|c|c|c|c|c|c|c|}
\hline & \multicolumn{2}{|c|}{ Water } & \multicolumn{2}{|c|}{ Developed } & \multicolumn{2}{|c|}{$\begin{array}{c}\text { Me- } \\
\text { chanically } \\
\text { disturbed }\end{array}$} & \multicolumn{2}{|c|}{ Mining } & \multicolumn{2}{|c|}{ Barren } & \multicolumn{2}{|c|}{ Forest } & \multicolumn{2}{|c|}{$\begin{array}{l}\text { Grassland/ } \\
\text { Shrubland }\end{array}$} & \multicolumn{2}{|c|}{ Agriculture } & \multicolumn{2}{|c|}{ Wetland } & \multicolumn{2}{|c|}{$\begin{array}{c}\text { Non- } \\
\text { mechanically } \\
\text { disturbed }\end{array}$} \\
\hline & $\%$ & $+/-$ & $\%$ & $+/-$ & $\%$ & $+/-$ & $\%$ & $+/-$ & $\%$ & $+/-$ & $\%$ & $+/-$ & $\%$ & $+/-$ & $\%$ & $+/-$ & $\%$ & $+/-$ & $\%$ & $+/-$ \\
\hline \multicolumn{21}{|c|}{ Area, in percent stratum } \\
\hline 1973 & 0.4 & 0.2 & 0.7 & 0.3 & 0.0 & 0.0 & 0.1 & 0.1 & 0.0 & 0.0 & 5.6 & 1.6 & 6.8 & 4.3 & 81.5 & 5.8 & 4.8 & 1.7 & 0.0 & 0.0 \\
\hline 1980 & 0.4 & 0.2 & 0.8 & 0.3 & 0.0 & 0.0 & 0.1 & 0.1 & 0.0 & 0.0 & 5.6 & 1.6 & 6.9 & 4.3 & 81.5 & 5.8 & 4.7 & 1.7 & 0.0 & 0.0 \\
\hline 1986 & 0.4 & 0.2 & 0.8 & 0.3 & 0.0 & 0.0 & 0.1 & 0.1 & 0.0 & 0.0 & 5.5 & 1.6 & 6.8 & 4.3 & 81.5 & 5.8 & 4.7 & 1.7 & 0.0 & 0.0 \\
\hline 1992 & 0.4 & 0.2 & 0.9 & 0.3 & 0.0 & 0.0 & 0.1 & 0.1 & 0.0 & 0.0 & 5.5 & 1.6 & 7.3 & 4.3 & 81.1 & 5.8 & 4.7 & 1.7 & 0.0 & 0.0 \\
\hline 2000 & 0.5 & 0.2 & 1.0 & 0.4 & 0.0 & 0.0 & 0.1 & 0.1 & 0.0 & 0.0 & 5.5 & 1.6 & 7.3 & 4.3 & 80.9 & 5.7 & 4.7 & 1.7 & 0.0 & 0.0 \\
\hline $\begin{array}{l}\text { Net } \\
\text { change }\end{array}$ & 0.0 & 0.0 & 0.3 & 0.1 & 0.0 & 0.0 & 0.0 & 0.0 & 0.0 & 0.0 & -0.1 & 0.1 & 0.5 & 0.2 & -0.6 & 0.3 & 0.0 & 0.0 & 0.0 & 0.0 \\
\hline $\begin{array}{l}\text { Gross } \\
\text { change }\end{array}$ & 0.1 & 0.0 & 0.3 & 0.1 & 0.0 & 0.0 & 0.1 & 0.0 & 0.0 & 0.0 & 0.1 & 0.1 & 0.8 & 0.3 & 1.1 & 0.3 & 0.1 & 0.1 & 0.0 & 0.0 \\
\hline \multicolumn{21}{|c|}{ Area, in square kilometers } \\
\hline 1973 & 169 & 86 & 288 & 115 & 8 & 12 & 45 & 37 & 0 & 0 & 2,288 & 653 & 2,782 & 1,756 & 33,121 & 2,345 & 1,935 & 691 & 0 & 0 \\
\hline 1980 & 170 & 87 & 318 & 122 & 0 & 0 & 44 & 37 & 0 & 0 & 2,268 & 648 & 2,799 & 1,762 & 33,108 & 2,344 & 1,929 & 692 & 0 & 0 \\
\hline 1986 & 174 & 86 & 339 & 135 & 2 & 3 & 47 & 37 & 0 & 0 & 2,253 & 644 & 2,777 & 1,756 & 33,126 & 2,338 & 1,918 & 683 & 0 & 0 \\
\hline 1992 & 174 & 85 & 358 & 138 & 2 & 2 & 40 & 28 & 0 & 0 & 2,246 & 643 & 2,948 & 1,756 & 32,948 & 2,341 & 1,921 & 680 & 0 & 0 \\
\hline 2000 & 186 & 85 & 390 & 158 & 0 & 0 & 43 & 28 & 0 & 0 & 2,245 & 644 & 2,978 & 1,767 & 32,874 & 2,335 & 1,919 & 682 & 0 & 0 \\
\hline $\begin{array}{l}\text { Net } \\
\text { change }\end{array}$ & 17 & 11 & 102 & 52 & -8 & 12 & -2 & 13 & 0 & 0 & -43 & 30 & 196 & 101 & -247 & 109 & -15 & 18 & 0 & 0 \\
\hline $\begin{array}{l}\text { Gross } \\
\text { change }\end{array}$ & 29 & 15 & 102 & 52 & 15 & 13 & 23 & 13 & 0 & 0 & 55 & 29 & 340 & 133 & 455 & 135 & 54 & 29 & 0 & 0 \\
\hline
\end{tabular}


Table 4. Principal land-cover conversions in Lake Agassiz Plain Ecoregion, showing amount of area changed (and margin of error, calculated at 85-percent confidence level) for each conversion during each of four time periods and also during overall study period. See appendix 3 for definitions of land-cover classifications.

[Values given for "other" classes are combined totals of values for other land-cover classes not listed in that time period. Abbreviations: n/a, not applicable]

\begin{tabular}{|c|c|c|c|c|c|c|c|c|}
\hline Period & From class & To class & & $\begin{array}{c}\begin{array}{c}\text { Area } \\
\text { changed }\end{array} \\
\left(\mathbf{k m}^{2}\right)\end{array}$ & $\begin{array}{l}\text { Margin } \\
\text { of error } \\
\left(+/-\mathrm{km}^{2}\right)\end{array}$ & $\begin{array}{c}\text { Standard } \\
\text { error } \\
\left(\mathbf{k m}^{2}\right)\end{array}$ & $\begin{array}{l}\text { Percent of } \\
\text { ecoregion }\end{array}$ & $\begin{array}{c}\text { Percent } \\
\text { of all } \\
\text { changes }\end{array}$ \\
\hline \multirow[t]{7}{*}{ 1973-1980 } & Agriculture & Developed & & 22 & 15 & 10 & 0.1 & 21.5 \\
\hline & Forest & Agriculture & & 20 & 12 & 8 & 0.0 & 19.4 \\
\hline & Agriculture & Grassland/Shrubland & & 19 & 17 & 12 & 0.0 & 19.1 \\
\hline & Grassland/Shrubland & Agriculture & & 11 & 11 & 7 & 0.0 & 11.3 \\
\hline & Mechanically disturbed & Developed & & 8 & 12 & 8 & 0.0 & 8.1 \\
\hline & Other & Other & & 21 & $\mathrm{n} / \mathrm{a}$ & $\mathrm{n} / \mathrm{a}$ & 0.1 & 20.6 \\
\hline & & & Totals & 101 & & & 0.2 & 100.0 \\
\hline \multirow[t]{7}{*}{ 1980-1986 } & Grassland/Shrubland & Agriculture & & 30 & 21 & 14 & 0.1 & 30.2 \\
\hline & Agriculture & Developed & & 17 & 13 & 9 & 0.0 & 17.0 \\
\hline & Forest & Agriculture & & 12 & 11 & 7 & 0.0 & 12.1 \\
\hline & Agriculture & Grassland/Shrubland & & 10 & 8 & 5 & 0.0 & 9.8 \\
\hline & Wetland & Agriculture & & 9 & 10 & 6 & 0.0 & 9.3 \\
\hline & Other & Other & & 21 & $\mathrm{n} / \mathrm{a}$ & $\mathrm{n} / \mathrm{a}$ & 0.1 & 21.5 \\
\hline & & & Totals & 98 & & & 0.2 & 100.0 \\
\hline \multirow[t]{7}{*}{ 1986-1992 } & Agriculture & Grassland/Shrubland & & 188 & 99 & 67 & 0.5 & 67.7 \\
\hline & Grassland/Shrubland & Agriculture & & 18 & 12 & 8 & 0.0 & 6.3 \\
\hline & Agriculture & Wetland & & 13 & 13 & 9 & 0.0 & 4.8 \\
\hline & Wetland & Agriculture & & 11 & 15 & 10 & 0.0 & 4.0 \\
\hline & Agriculture & Developed & & 10 & 7 & 5 & 0.0 & 3.7 \\
\hline & Other & Other & & 37 & $\mathrm{n} / \mathrm{a}$ & $\mathrm{n} / \mathrm{a}$ & 0.1 & 13.5 \\
\hline & & & Totals & 278 & & & 0.7 & 100.0 \\
\hline \multirow[t]{7}{*}{ 1992-2000 } & Agriculture & Grassland/Shrubland & & 80 & 37 & 25 & 0.2 & 37.6 \\
\hline & Grassland/Shrubland & Agriculture & & 46 & 39 & 26 & 0.1 & 21.5 \\
\hline & Agriculture & Developed & & 32 & 24 & 16 & 0.1 & 15.0 \\
\hline & Wetland & Water & & 11 & 9 & 6 & 0.0 & 5.1 \\
\hline & Agriculture & Wetland & & 7 & 7 & 5 & 0.0 & 3.4 \\
\hline & Other & Other & & 37 & $\mathrm{n} / \mathrm{a}$ & $\mathrm{n} / \mathrm{a}$ & 0.1 & 17.4 \\
\hline & & & Totals & 212 & & & 0.5 & 100.0 \\
\hline \multirow{7}{*}{$\begin{array}{c}1973-2000 \\
\text { (overall) }\end{array}$} & Agriculture & Grassland/Shrubland & & 297 & 134 & 90 & 0.7 & 43.1 \\
\hline & Grassland/Shrubland & Agriculture & & 104 & 56 & 38 & 0.3 & 15.1 \\
\hline & Agriculture & Developed & & 80 & 45 & 31 & 0.2 & 11.7 \\
\hline & Forest & Agriculture & & 44 & 28 & 19 & 0.1 & 6.3 \\
\hline & Wetland & Agriculture & & 28 & 33 & 22 & 0.1 & 4.1 \\
\hline & Other & Other & & 136 & $\mathrm{n} / \mathrm{a}$ & $\mathrm{n} / \mathrm{a}$ & 0.3 & 19.7 \\
\hline & & & Totals & 689 & & & 1.7 & 100.0 \\
\hline
\end{tabular}




\section{References Cited}

Blann, Kristen, Webb, Tim, Keeney, Dennis, and Light, Steve, 2009, Alternatives to crisis-An adaptive management model for the Red River Basin of the U.S. and Canada, in Light, Stephen S., ed., 2004, The role of biodiversity conservation in the transition to rural sustainability, Series V: Amsterdam, The Netherlands, IOS Press, Science and Technology Policy, v. 41, p. 173198, accessed April 2009, at http://www.worldcat.org/ title/role-of-biodiversity-conservation-in-the-transitionto-rural-sustainability/oclc/191037976/viewport?bib_ key=ISBN:9781586033958.

Bryce, S.A., Omernik, J.M., Pater, D.E., Ulmer, Michael, Schaar, Jerome, Freeouf, Jerry, Johnson, Rex, Kuck, Pat, and Azevedo, S.H., 1998, Ecoregions of North and South Dakota: U.S. Geological Survey Ecoregion Map Series, scale 1:500,000, accessed June 3, 2013 at http://www. epa.gov/wed/pages/ecoregions/ndsd_eco.htm.

Omernik, J.M., 1987, Ecoregions of the conterminous United States: Annals of the Association of American Geographers, v. 77, no. 1, p. 118-125.
U.S. Census Bureau, 2003, Ranking tables for population of metropolitan statistical areas, micropolitan statistical areas, combined statistical areas, New England city and town areas, and combined New England city and town areas-1990 and 2000: U.S. Census Bureau database, accessed March 16, 2009, at http://www.census.gov/population/www/cen2000/ briefs/phc-t29/tables/tab03a.pdf.

U.S. Environmental Protection Agency, 1997, Descriptions of level III ecological regions for the CEC report on ecological regions of North America: U.S. Environmental Protection Agency database, accessed April 12, 2006, at http://www. epa.gov/wed/pages/ecoregions/na_eco.htm\#Downloads.

U.S. Fish and Wildlife Service, 2009, Agassiz National Wildlife Refuge: U.S. Fish and Wildlife Service Web site, accessed March 15, 2009, at http://www.fws.gov/refuge/agassiz/.

Vogelmann, J.E., Howard, S.M., Yang, L., Larson, C.R., Wylie, B.K., and van Driel, N., 2001, Completion of the 1990s National Land Cover Data Set for the conterminous United States from Landsat Thematic Mapper data and ancillary data sources: Photogrammetric Engineering \& Remote Sensing, v. 67, p. 650-662. 



\title{
Northern Glaciated Plains Ecoregion
}

\author{
By Roger F. Auch
}

\section{Ecoregion Description}

The Northern Glaciated Plains Ecoregion, which covers about $141,340 \mathrm{~km}^{2}\left(54,572 \mathrm{mi}^{2}\right)$, runs north-south across eastern North Dakota and South Dakota, widening to the east into western Minnesota (fig. 1) (Omernik, 1987; U.S. Environmental Protection Agency, 1997). The ecoregion is surrounded by (clockwise, from the east) the Lake Agassiz Plain, North Central Hardwood Forests, Western Corn Belt Plains, and Northwestern Glaciated Plains Ecoregions; the Canadian border forms its northern border (fig. 1).

The climate of the Northern Glaciated Plains Ecoregion is considered to be continental (hot or warm summers and cold winters). Average annual precipitation amounts range from about 510 to $610 \mathrm{~mm}$ ( 20 to $24 \mathrm{in}$.) for most of the ecoregion, but they decrease to the northwest and increase to the southeast (Kottek and others, 2006; PRISM Climate

Figure 1. Map of Northern Glaciated Plains Ecoregion and surrounding ecoregions, showing land-use/land-cover classes from 1992 National Land Cover Dataset (Vogelmann and others, 2001); note that not all land-use/land-cover classes shown in explanation may be depicted on map; note also that, for this "Status and Trends of Land Change" study, transitional land-cover class was subdivided into mechanically disturbed and nonmechanically disturbed classes. Squares indicate locations of $10 \times 10 \mathrm{~km}$ sample blocks analyzed in study. Index map shows locations of geographic features mentioned in text. Abbreviations

for Great Plains ecoregions are listed in appendix 2. Also shown are parts of three Midwest-South Central United States ecoregions: North Central Hardwood Forests (NCHF), Northern Lakes and Forests (NLF), and Northern Minnesota Wetlands (NMW). See appendix 3 for definitions of landuse/land-cover classifications.
Group, 2006). This subhumid climate makes the ecoregion a "transitional grassland," meaning that it contains both tallgrass- and shortgrass-prairie communities. Although the ecoregion historically has been dominated by grasslands, Euro-American settlers converted most of it to farmland. The recent (less than 25,000 years ago) glaciation of most of the Northern Glaciated Plains Ecoregion (Johnson and Higgins, 1997) left many glacial landforms, contributing greatly to the land-use/land-cover classes seen today [2013]. Drift plains, large glacial-lake basins, and shallow river valleys that have level-to-undulating surfaces and deep soils provide the substrate for crop agriculture. Grasslands remain where glaciers left behind large deposits of rock, gravel, and sand, and they generally are used for grazing livestock. This geological history also has resulted in an immature 
drainage system, and the ecoregion is dotted with wetland depressions that vary widely in size and permanence, as well as subregional concentrations of glacially formed permanent lakes. Agricultural land, grasslands, wetlands, and water form the general mosaic of land cover in the ecoregion.

Agriculture is the most common land-cover class in the ecoregion, and grain and cattle production are the dominant land uses. Although most agricultural land cover is cropland, farming is limited by certain soil, topographic, and wetland conditions, and latitudinal and longitudinal differences influence the combinations of crops that can be grown. The main crops grown in the ecoregion are corn and soybeans in the southern part; soybeans and wheat in the central part; and wheat, other small grains, and canola (rapeseed) in the northern part (fig. 2). Hay production, especially from alfalfa, also is a common use of cropland. Small, intensively used pastures also are included in the agriculture land-cover class.

Livestock grazing on large expanses of grasslands typically is considered a localized and low-intensity land use (fig. 3). Rocky soils and steep slopes are the main reasons grasslands persist in these areas, and, to a lesser extent, in the ecoregion in general. Grassland/shrubland land-cover

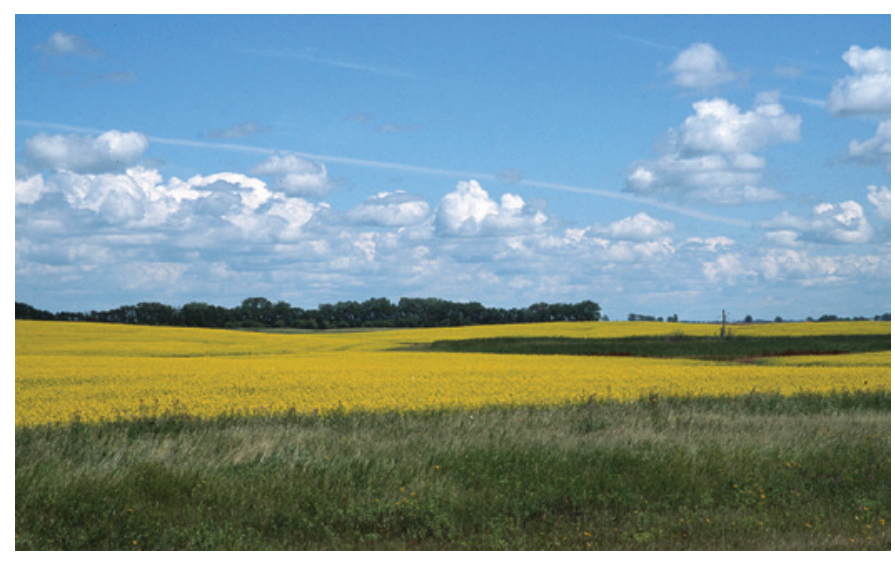

Figure 2. Field of canola (rapeseed) in flower, surrounding wetland in extreme north-central North Dakota, Northern Glaciated Plains Ecoregion.

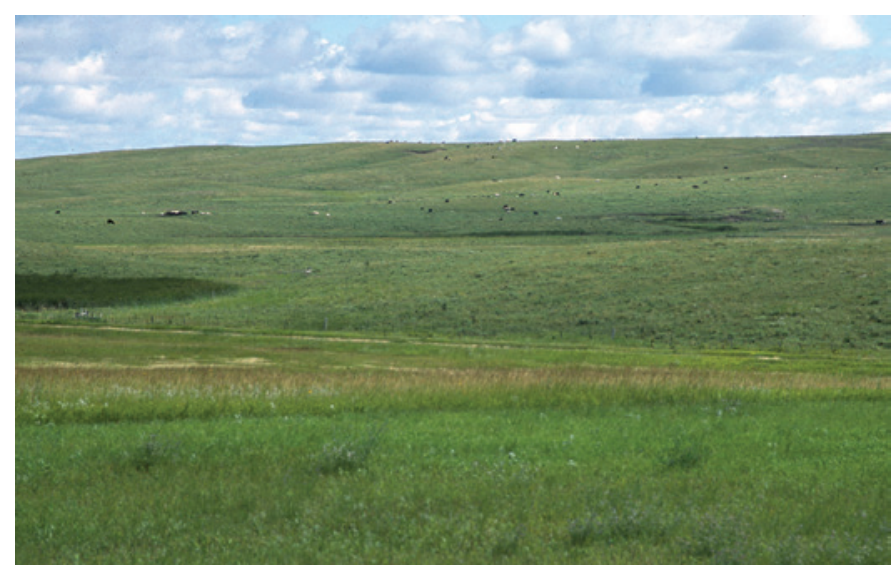

Figure 3. Cattle grazing on distant grassy hillside, in Marshall County, South Dakota, Northern Glaciated Plains Ecoregion. class also is present on wildlife habitat areas such as federally owned and state-owned wildlife refuges and waterfowl production areas, as well as other public lands.

Wetland and water are common land-cover classes in the Northern Glaciated Plains Ecoregion, but their concentration varies (both in number and in size) locally. Water is present mostly in permanent lakes, in semipermanent "wetland" lakes that may be open water in some years and wetland vegetation in others, and in a few reservoirs (fig. 4).

Minor land-cover classes include forest, developed, and mining. Forested land, which is limited and tends to be subregionally concentrated, is present in the Turtle Mountains, in the Coteau des Prairies, and in the northern parts of the ecoregion (Bryce and others, 1998) (fig. 5). Larger riparian areas and farm shelterbelts also may have forest cover but may not have been wide enough (that is, discernable using a 60-m-wide mapping unit) to map continuously, although exceptions are common. Developed land, which was present within cities and towns, constitutes a small part of the ecoregion. Most small towns in the Northern Glaciated Plains Ecoregion grew little in area during the study period, and many of them are declining in population and economic diversity (fig. 6). Aggregate mining also occurs in the ecoregion, owing to its glacial geology, but it tends to be limited in size.

\section{Contemporary Land-Cover Change (1973 to 2000)}

The overall spatial change (the percentage of land area that changed at least one time) in the Northern Glaciated Plains Ecoregion between 1973 and 2000 is 7.4 percent (table 1). Compared to other Great Plains ecoregions, change in the ecoregion was moderate (fig. 7). The Northern Glaciated Plains Ecoregion changed less than the Northwestern Glaciated Plains Ecoregion to the west but more than either the Lake Agassiz Plain Ecoregion to the east-northeast or the Western Corn Belt Plains Ecoregion to the south (fig. 7). Most of the change ( 6.0 percent) occurred only one time during the study period, but some areas (1.4 percent) experienced multiple changes (table 1). The multiple changes typically involved either the back-and-forth conversions between wetlands and open, persistent water owing to changes in climatic cycles or the conversions of grassland to crop production early in the study period and then back to grassland upon enrollment in the Conservation Reserve Program (CRP) after 1985. The last two time periods (1986-1992, 1992-2000) had more change than the first two time periods (1973-1980, 1980-1986) (table 2). When normalized to an annual rate to account for the varying lengths in study periods, the periods between 1973 and 1980 and between 1980 and 1986 had the lowest rate of change ( 0.2 percent) (table 2$)$. The rate of change continued to increase after 1986, and the period 
between 1992 and 2000 had the highest rate of change (0.5 percent) (table 2; fig. 8).

The agriculture and water land-cover classes had the most net change during the study period, followed by wetland and grassland/shrubland (table 3; fig. 9). Agriculture had a net loss of 2.0 percent, changing primarily to grassland/shrubland, wetland, water, developed, and mining. With the exception of
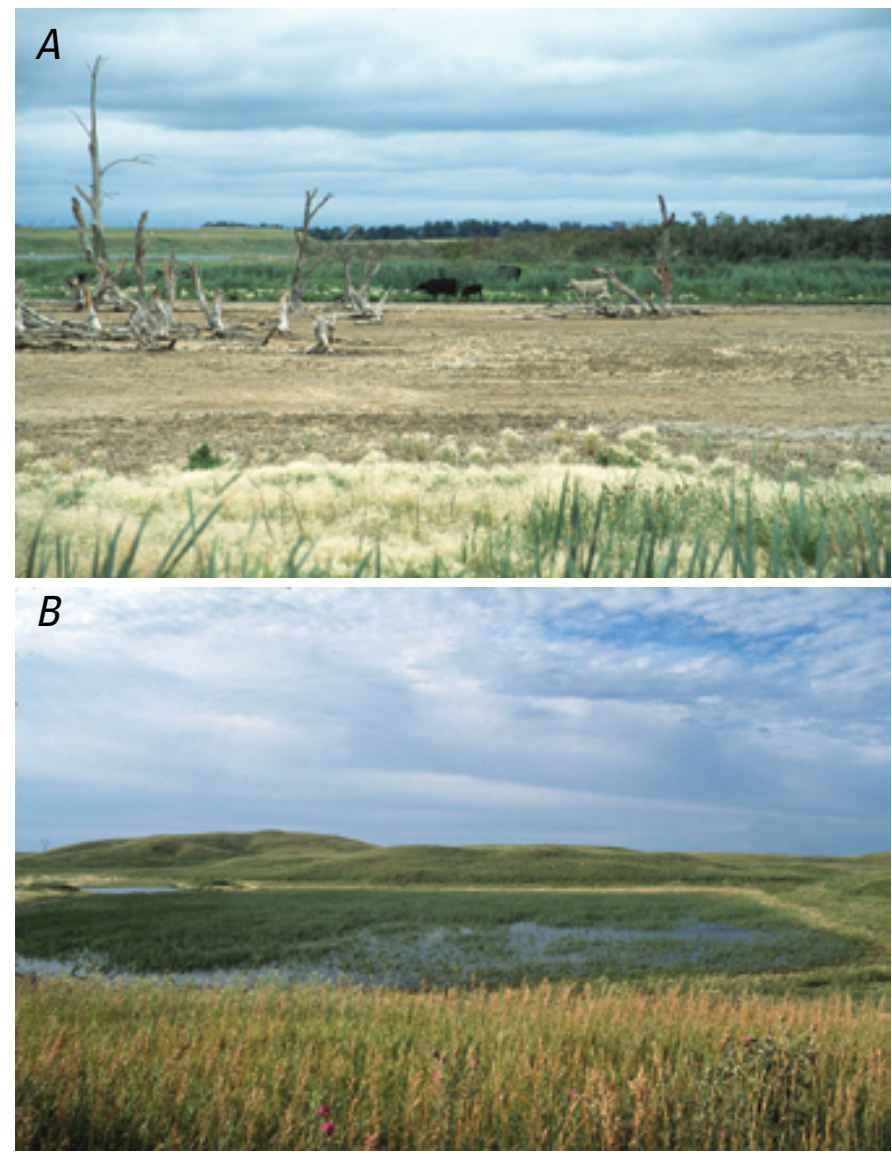

C

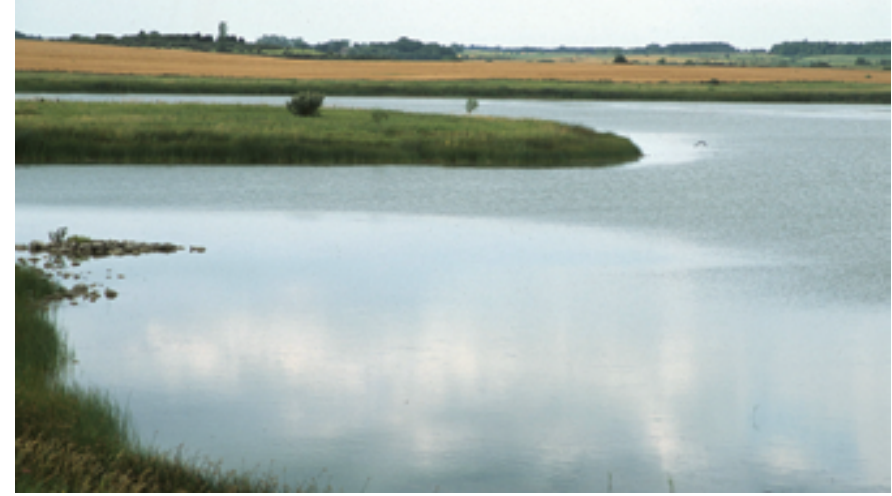

Figure 4. Wetland and water areas in Northern Glaciated Plains Ecoregion. $A$, Cattle grazing in dried-up wetland, in Codington County, South Dakota. $B$, Common scene of grass and wetlands, in Day County, South Dakota. $C$, More permanent natural lake, in Lincoln County, Minnesota. the conversions to developed, all of this agriculture land-use/ land-cover change could be temporary. The most common conversion over the study period was from agriculture to grassland/shrubland. An estimated 3,386 $\mathrm{km}^{2}$ of agriculture changed to grassland/shrubland (table 4), most of it during the last two time periods (1986-1992, 1992-2000) when the CRP was in effect. The CRP paid farmers to retire marginal cropland to native grasslands through contracts, usually 10 years in duration. Although some land in the ecoregion may have been under a second CRP contract by the year 2000, this did not assure a permanent change from agriculture to grassland/shrubland (Leathers and Harrington, 2000). A more ephemeral change was the conversion of agriculture to wetland, as wetter than normal climatic conditions kept many temporary and seasonal wetlands out of crop production (Kirby and others, 2002). A series of wet years in the mid1980s and mid- to late 1990s contributed to most of the agriculture-to-wetland change.

Water land cover increased by a net 2.0 percent during the study period (table 3). Water gained mostly from wetland, agriculture, and grassland/shrubland. The second most common conversion during the study period was wetland to water. An estimated $3,244 \mathrm{~km}^{2}$ of wetland changed to water (table 4), most of it during the last time period (1992-2000). Although gains in water from wetland may be more of an ephemeral event owing to wetter climatic conditions (table 4), gains in water from agriculture and grassland/shrubland could represent a longer term but still cyclic change in which many larger glacial lake basins flooded during the study period. Water bodies such as Lake Thompson and Waubay Lake in South Dakota, Devils Lake in North Dakota, and many more minor lakes expanded in size from the mid-1980s onwards. These water bodies may persist as large surface areas for years (Todhunter and Rundquist, 2004; Shapley and others, 2005; South Dakota Game, Fish and Parks, 2006).

Wetland land cover decreased by a net 0.9 percent between 1973 and 2000 (table 3), much of it a change to

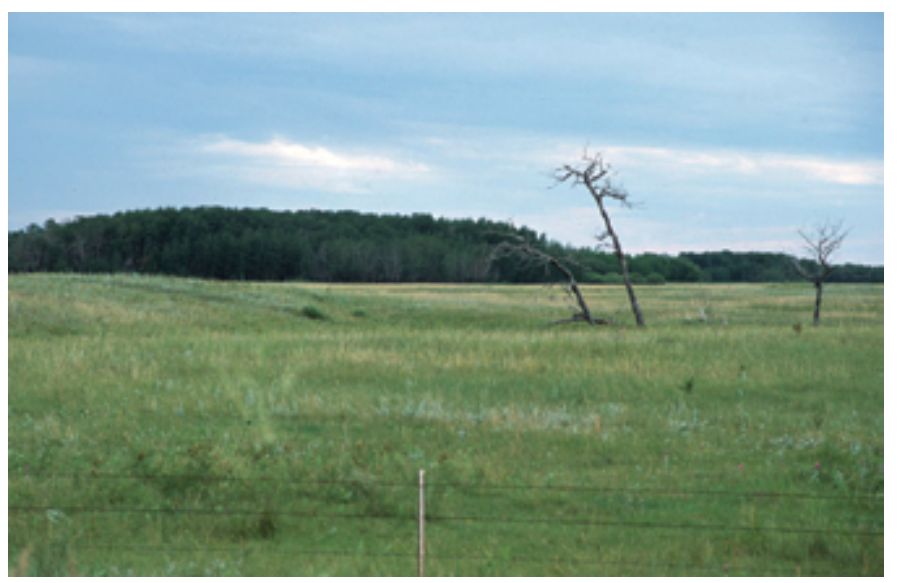

Figure 5. Patch of natural forest surrounded by grasslands, in McHenry County, North Dakota, Northern Glaciated Plains Ecoregion. Cattle ranching is dominant land use in this part of ecoregion. 

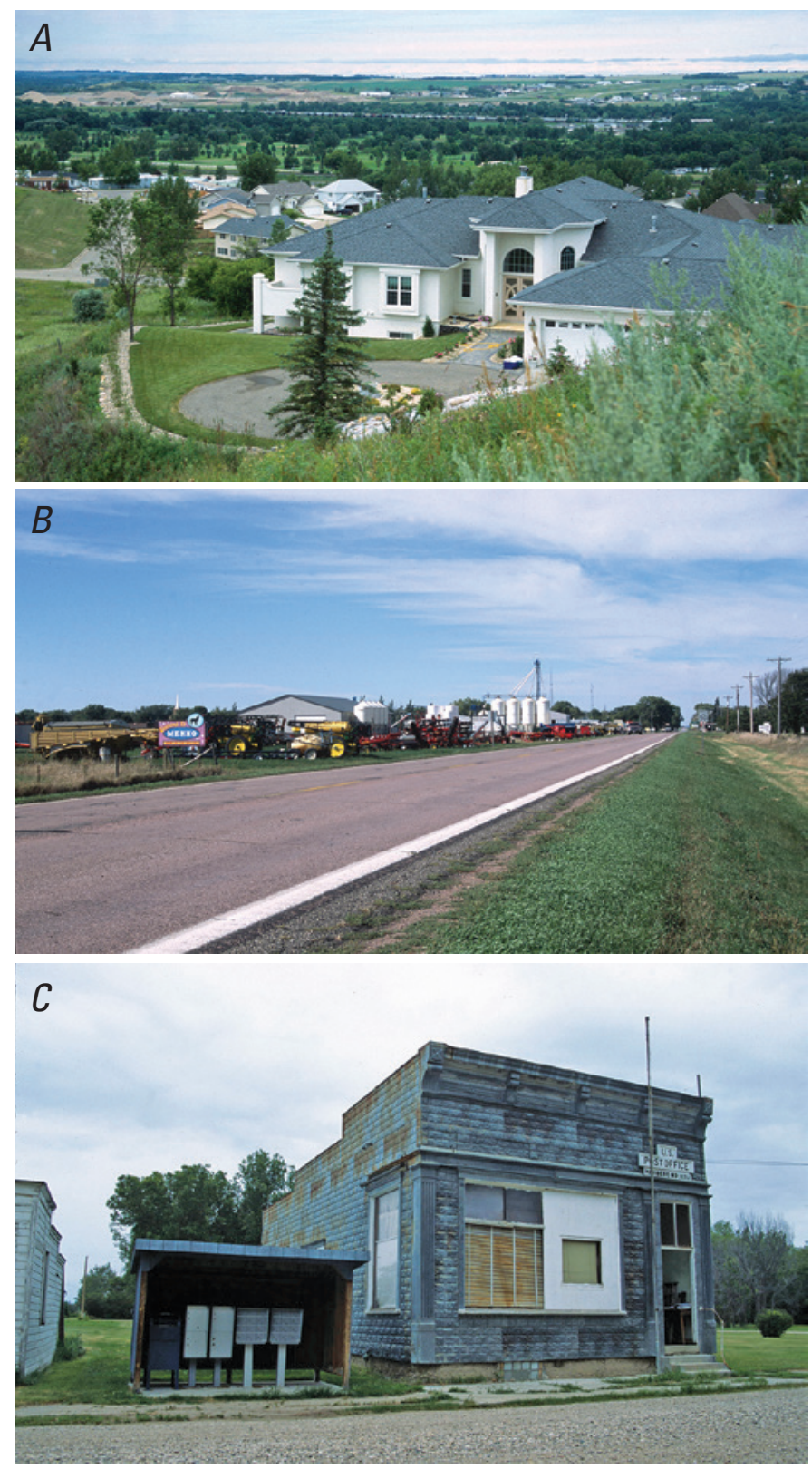

Figure 6. Developed areas in Northern Glaciated Plains Ecoregion. $A$, New developed land on outskirts of Minot, North Dakota. New development was limited almost exclusively to periphery of ecoregion's cities. $B$, Farming community of Menno, South Dakota. Although many small towns in ecoregion experienced little physical growth, they appeared to be economically stable. $C$, Former post office in small central North Dakota town of Hamberg. As communities decline, some developed areas are abandoned.

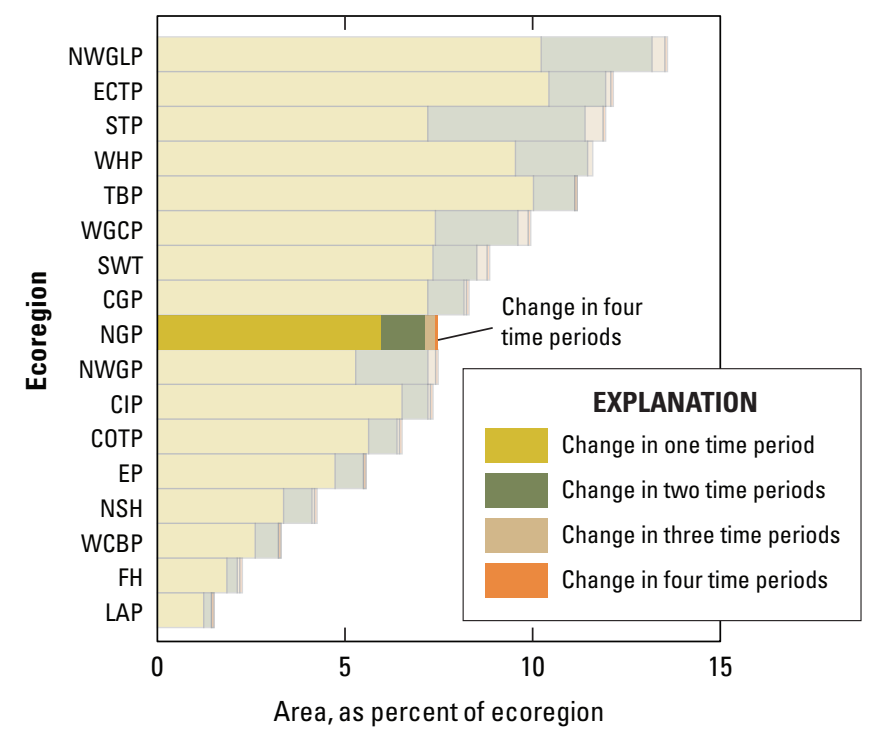

Figure 7. Overall spatial change in Northern Glaciated Plains Ecoregion (NGP; darker bars) compared with that of all 17 Great Plains ecoregions (lighter bars). Each horizontal set of bars shows proportions of ecoregion that changed during one, two, three, or four time periods; highest level of spatial change in Northern Glaciated Plains Ecoregion (four time periods) labeled for clarity. See table 2 for years covered by each time period. See appendix 2 for key to ecoregion abbreviations.

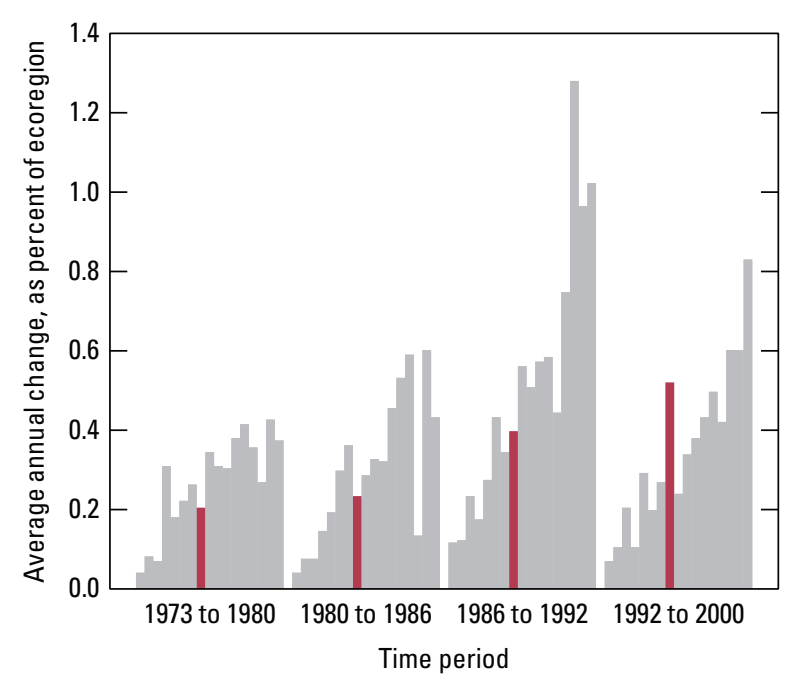

Figure 8. Estimates of land-cover change per time period, normalized to annual rates of change for all 17 Great Plains ecoregions (gray bars). Estimates of change for Northern Glaciated Plains Ecoregion are represented by red bars in each time period. 
open-water conditions. Although this change may reverse itself during drier climatic cycles, the trend from the 1980s onwards was that of wetlands converting to open water, especially during the period between 1992 and 2000.

Although grassland/shrubland land cover increased by a net 0.7 percent during the study period (table 3 ), the change was variable across the ecoregion. It also is possible that multiple conversions affecting grassland/shrubland negated stronger directional trends. Gross change in grassland/ shrubland was much higher, at 2.7 percent (table 3). One of the major factors affecting grassland/shrubland was the dynamic relation between grassland/shrubland and agriculture. When the estimated changes from agriculture to grassland/ shrubland and from grassland/shrubland to agriculture are the

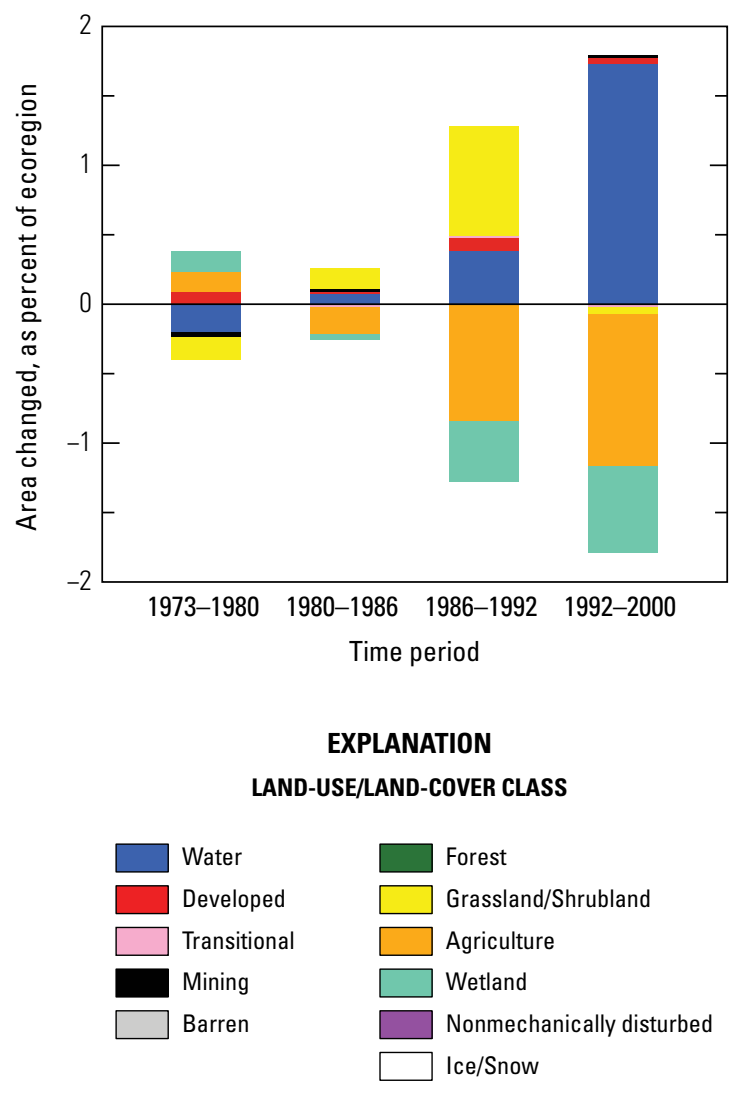

Figure 9. Normalized average net change in Northern Glaciated Plains Ecoregion by time period for each land-cover class. Bars above zero axis represent net gain, whereas bars below zero represent net loss. Note that not all land-cover classes shown in explanation may be represented in figure. See appendix 3 for definitions of land-use/land-cover classifications. only changes considered (table 4), they show that grassland/ shrubland lost to agriculture during the first two time periods (1973-1980, 1980-1986), a time of agricultural economic expansion, but that the trend reversed itself during the last two time periods (1986-1992, 1992-2000), mostly owing to the CRP. The grassland/shrubland net gain decreased between 1992 and 2000, as some of the first CRP contracts expired and were not renewed (Leistritz and others, 2002) and as formerly unbroken grassland/shrubland areas were converted to cropland for the first time (Higgins and others, 2002).

The major factors that affected land-change dynamics in the Northern Glaciated Plains Ecoregion during the study period were (1) shifts in the agricultural economy and in Federal farm policies, causing conversions between grassland/ shrubland and agriculture, and (2) cyclic climatic conditions, resulting in conversions between wetland and water and between agriculture and wetland. All these were temporal pulses of change: more grassland/shrubland was converted to agriculture during the first two time periods (1973-1980, 1980-1986), whereas the reverse occurred in the last two time periods (1986-1992, 1992-2000), after implementation of the CRP. Wetland-to-water and agriculture-to-wetland conversions were much more dominant in the second half of the study period than in the first half, owing to a series of wet years. For the most part, such conversions were temporary in nature. In some cases, however, the conversion of grassland/shrubland and wetland back to agriculture may be permanent because restoration efforts can be cost prohibitive, and, furthermore, they usually do not produce results as ecologically complex as native grassland/shrubland and wetlands.

Table 1. Percentage of Northern Glaciated Plains Ecoregion land cover that changed at least one time during study period (19732000) and associated statistical error.

[Most sample pixels remained unchanged (92.6 percent), whereas 7.4 percent changed at least once throughout study period]

\begin{tabular}{ccccccc}
\hline $\begin{array}{c}\text { Number } \\
\text { of } \\
\text { changes }\end{array}$ & $\begin{array}{c}\text { Percent } \\
\text { of } \\
\text { ecoregion }\end{array}$ & $\begin{array}{c}\text { Margin } \\
\text { of error } \\
(+/-\%)\end{array}$ & $\begin{array}{c}\text { Lower } \\
\text { bound } \\
(\%)\end{array}$ & $\begin{array}{c}\text { Upper } \\
\text { bound } \\
(\%)\end{array}$ & $\begin{array}{c}\text { Standard } \\
\text { error } \\
(\%)\end{array}$ & $\begin{array}{c}\text { Relative } \\
\text { error } \\
(\%)\end{array}$ \\
\hline 1 & 6.0 & 1.1 & 4.9 & 7.1 & 0.8 & 12.7 \\
2 & 1.1 & 0.3 & 0.8 & 1.5 & 0.2 & 19.2 \\
3 & 0.3 & 0.1 & 0.2 & 0.4 & 0.1 & 20.0 \\
4 & 0.0 & 0.0 & 0.0 & 0.1 & 0.0 & 19.8 \\
\hline $\begin{array}{c}\text { Overall } \\
\text { spatial } \\
\text { change }\end{array}$ & 7.4 & 1.4 & 6.1 & 8.8 & 0.9 & 12.5 \\
\hline
\end{tabular}


Table 2. Raw estimates of change in Northern Glaciated Plains Ecoregion land cover, computed for each of four time periods between 1973 and 2000, and associated error at 85-percent confidence level.

[Estimates of change per period normalized to annual rate of change for each period]

\begin{tabular}{cccccccc}
\hline Period & $\begin{array}{c}\text { Total change } \\
(\% \text { of ecoregion) }\end{array}$ & $\begin{array}{c}\text { Margin of } \\
\text { error } \\
(+/-\%)\end{array}$ & $\begin{array}{c}\text { Lower } \\
\text { bound } \\
(\%)\end{array}$ & $\begin{array}{c}\text { Upper bound } \\
(\%)\end{array}$ & $\begin{array}{c}\text { Standard } \\
\text { error } \\
(\%)\end{array}$ & $\begin{array}{c}\text { Relative } \\
\text { error } \\
(\%)\end{array}$ & $\begin{array}{c}\text { Average rate } \\
(\% \text { per year) }\end{array}$ \\
\hline \multicolumn{7}{c}{ Estimate of change, in percent stratum } \\
\hline $1973-1980$ & 1.4 & 0.3 & 1.1 & 1.7 & 0.2 & 13.0 & 0.2 \\
$1980-1986$ & 1.4 & 0.3 & 1.1 & 1.7 & 0.2 & 14.4 & 0.2 \\
$1986-1992$ & 2.4 & 0.5 & 1.8 & 2.9 & 0.4 & 15.2 & 0.4 \\
$1992-2000$ & 4.1 & 1.0 & 3.1 & 5.2 & 0.7 & 16.8 & 0.5 \\
\hline \multicolumn{7}{c}{ Estimate of change, in square kilometers } \\
\hline $1973-1980$ & 2,008 & 386 & 1,622 & 2,393 & 261 & 13.0 & 287 \\
$1980-1986$ & 1,960 & 418 & 1,542 & 2,378 & 282 & 14.4 & 327 \\
$1986-1992$ & 3,333 & 749 & 2,584 & 4,082 & 507 & 15.2 & 556 \\
$1992-2000$ & 5,860 & 1,458 & 4,402 & 7,318 & 986 & 16.8 & 733 \\
\hline
\end{tabular}

Table 3. Estimated area (and margin of error) of each land-cover class in Northern Glaciated Plains Ecoregion, calculated five times between 1973 and 2000. See appendix 3 for definitions of land-cover classifications.

\begin{tabular}{|c|c|c|c|c|c|c|c|c|c|c|c|c|c|c|c|c|c|c|c|c|}
\hline & \multicolumn{2}{|c|}{ Water } & \multicolumn{2}{|c|}{ Developed } & \multicolumn{2}{|c|}{$\begin{array}{l}\text { Mecha- } \\
\text { nically } \\
\text { disturbed }\end{array}$} & \multicolumn{2}{|c|}{ Mining } & \multicolumn{2}{|c|}{ Barren } & \multicolumn{2}{|c|}{ Forest } & \multicolumn{2}{|c|}{$\begin{array}{l}\text { Grassland/ } \\
\text { Shrubland }\end{array}$} & \multicolumn{2}{|c|}{ Agriculture } & \multicolumn{2}{|c|}{ Wetland } & \multicolumn{2}{|c|}{$\begin{array}{c}\text { Non- } \\
\text { mecha- } \\
\text { nically } \\
\text { disturbed }\end{array}$} \\
\hline & $\%$ & $+/-$ & $\%$ & $+/-$ & $\%$ & $+/-$ & $\%$ & $+/-$ & $\%$ & $+/-$ & $\%$ & $+/-$ & $\%$ & $+/-$ & $\%$ & $+/-$ & $\%$ & $+/-$ & $\%$ & $+/-$ \\
\hline \multicolumn{21}{|c|}{ Area, in percent stratum } \\
\hline 1973 & 3.5 & 2.1 & 1.4 & 1.6 & 0.0 & 0.0 & 0.1 & 0.1 & 0.0 & 0.0 & 3.0 & 2.6 & 17.7 & 4.4 & 68.5 & 5.7 & 5.9 & 1.0 & 0.0 & 0.0 \\
\hline 1980 & 3.3 & 2.1 & 1.5 & 1.6 & 0.0 & 0.0 & 0.1 & 0.0 & 0.0 & 0.0 & 3.0 & 2.5 & 17.5 & 4.4 & 68.6 & 5.7 & 6.0 & 1.0 & 0.0 & 0.0 \\
\hline 1986 & 3.4 & 2.1 & 1.5 & 1.6 & 0.0 & 0.0 & 0.1 & 0.1 & 0.0 & 0.0 & 3.0 & 2.5 & 17.7 & 4.5 & 68.4 & 5.7 & 6.0 & 1.0 & 0.0 & 0.0 \\
\hline 1992 & 3.7 & 2.1 & 1.6 & 1.8 & 0.0 & 0.0 & 0.1 & 0.1 & 0.0 & 0.0 & 3.0 & 2.5 & 18.5 & 4.7 & 67.5 & 5.8 & 5.6 & 1.0 & 0.0 & 0.0 \\
\hline 2000 & 5.5 & 2.3 & 1.6 & 1.8 & 0.0 & 0.0 & 0.1 & 0.1 & 0.0 & 0.0 & 3.0 & 2.5 & 18.4 & 4.7 & 66.4 & 5.8 & 4.9 & 1.0 & 0.0 & 0.0 \\
\hline $\begin{array}{l}\text { Net } \\
\text { change }\end{array}$ & 2.0 & 0.7 & 0.2 & 0.2 & 0.0 & 0.0 & 0.0 & 0.0 & 0.0 & 0.0 & 0.0 & 0.0 & 0.7 & 0.7 & -2.0 & 0.9 & -0.9 & 0.6 & 0.0 & 0.0 \\
\hline $\begin{array}{l}\text { Gross } \\
\text { change }\end{array}$ & 2.9 & 0.8 & 0.2 & 0.2 & 0.0 & 0.0 & 0.1 & 0.1 & 0.0 & 0.0 & 0.0 & 0.0 & 0.9 & 0.5 & 0.3 & 0.3 & 2.3 & 0.6 & 0.0 & 0.0 \\
\hline \multicolumn{21}{|c|}{ Area, in square kilometers } \\
\hline 1973 & 4,938 & 2,946 & 1,949 & 2,211 & 12 & 18 & 116 & 110 & 0 & 0 & 4,266 & 3,605 & 25,009 & 6,266 & 96,762 & 8,070 & 8,289 & 1,382 & 0 & 0 \\
\hline 1980 & 4,651 & 2,930 & 2,080 & 2,271 & 8 & 12 & 82 & 66 & 0 & 0 & 4,256 & 3,591 & 24,787 & 6,283 & 96,970 & 8,060 & 8,506 & 1,419 & 0 & 0 \\
\hline 1986 & 4,747 & 2,952 & 2,116 & 2,307 & 0 & 0 & 101 & 86 & 0 & 0 & 4,258 & 3,591 & 24,995 & 6,377 & 96,661 & 8,121 & 8,462 & 1,422 & 0 & 0 \\
\hline 1992 & 5,294 & 3,017 & 2,248 & 2,475 & 15 & 14 & 107 & 87 & 0 & 0 & 4,251 & 3,585 & 26,104 & 6,642 & 95,473 & 8,241 & 7,849 & 1,350 & 0 & 0 \\
\hline 2000 & 7,769 & 3,240 & 2,283 & 2,491 & 5 & 7 & 140 & 103 & 0 & 0 & 4,238 & 3,574 & 26,034 & 6,698 & 93,916 & 8,135 & 6,956 & 1,477 & 0 & 0 \\
\hline $\begin{array}{l}\text { Net } \\
\text { change }\end{array}$ & 2,830 & 932 & 334 & 297 & -7 & 20 & 24 & 30 & 0 & 0 & -27 & 34 & 1,026 & 959 & $-2,846$ & 1,245 & $-1,333$ & 854 & 0 & 0 \\
\hline $\begin{array}{l}\text { Gross } \\
\text { change }\end{array}$ & 4,094 & 1,125 & 334 & 297 & 54 & 43 & 127 & 92 & 0 & 0 & 66 & 33 & 3,790 & 902 & 4,817 & 1,181 & 3,316 & 892 & 0 & 0 \\
\hline
\end{tabular}


Table 4. Principal land-cover conversions in Northern Glaciated Plains Ecoregion, showing amount of area changed (and margin of error, calculated at 85-percent confidence level) for each conversion during each of four time periods and also during overall study period. See appendix 3 for definitions of land-cover classifications.

[Values given for "other” classes are combined totals of values for other land-cover classes not listed in that time period. Abbreviations: n/a, not applicable]

\begin{tabular}{|c|c|c|c|c|c|c|c|c|}
\hline Period & From class & To class & & $\begin{array}{c}\begin{array}{c}\text { Area } \\
\text { changed }\end{array} \\
\left(\mathrm{km}^{2}\right)\end{array}$ & $\begin{array}{c}\text { Margin of } \\
\text { error } \\
\left(+/-\mathrm{km}^{2}\right)\end{array}$ & $\begin{array}{c}\text { Standard } \\
\text { error } \\
\left(\mathbf{k m}^{2}\right)\end{array}$ & $\begin{array}{l}\text { Percent of } \\
\text { ecoregion }\end{array}$ & $\begin{array}{c}\text { Percent of all } \\
\text { changes }\end{array}$ \\
\hline \multirow[t]{7}{*}{ 1973-1980 } & Grassland/Shrubland & Agriculture & & 496 & 204 & 138 & 0.4 & 24.7 \\
\hline & Water & Wetland & & 478 & 220 & 149 & 0.3 & 23.8 \\
\hline & Agriculture & Grassland/Shrubland & & 296 & 186 & 126 & 0.2 & 14.7 \\
\hline & Wetland & Agriculture & & 198 & 78 & 52 & 0.1 & 9.8 \\
\hline & Wetland & Water & & 193 & 64 & 43 & 0.1 & 9.6 \\
\hline & Other & Other & & 347 & $\mathrm{n} / \mathrm{a}$ & $\mathrm{n} / \mathrm{a}$ & 0.2 & 17.3 \\
\hline & & & Totals & 2,008 & & & 1.4 & 100.0 \\
\hline \multirow[t]{7}{*}{ 1980-1986 } & Agriculture & Grassland/Shrubland & & 564 & 278 & 188 & 0.4 & 28.8 \\
\hline & Wetland & Water & & 344 & 122 & 83 & 0.2 & 17.6 \\
\hline & Grassland/Shrubland & Agriculture & & 339 & 204 & 138 & 0.2 & 17.3 \\
\hline & Water & Wetland & & 255 & 72 & 48 & 0.2 & 13.0 \\
\hline & Agriculture & Wetland & & 186 & 72 & 49 & 0.1 & 9.5 \\
\hline & Other & Other & & 272 & $\mathrm{n} / \mathrm{a}$ & $\mathrm{n} / \mathrm{a}$ & 0.2 & 13.9 \\
\hline & & & Totals & 1,960 & & & 1.4 & 100.0 \\
\hline \multirow[t]{7}{*}{ 1986-1992 } & Agriculture & Grassland/Shrubland & & 1414 & 558 & 378 & 1.0 & 42.4 \\
\hline & Wetland & Water & & 791 & 312 & 211 & 0.6 & 23.7 \\
\hline & Water & Wetland & & 247 & 94 & 63 & 0.2 & 7.4 \\
\hline & Grassland/Shrubland & Agriculture & & 226 & 130 & 88 & 0.2 & 6.8 \\
\hline & Wetland & Agriculture & & 211 & 73 & 49 & 0.1 & 6.3 \\
\hline & Other & Other & & 444 & $\mathrm{n} / \mathrm{a}$ & $\mathrm{n} / \mathrm{a}$ & 0.3 & 13.3 \\
\hline & & & Totals & 3,333 & & & 2.4 & 100.0 \\
\hline \multirow[t]{7}{*}{ 1992-2000 } & Wetland & Water & & 1,916 & 496 & 335 & 1.4 & 32.7 \\
\hline & Agriculture & Grassland/Shrubland & & 1,113 & 486 & 328 & 0.8 & 19.0 \\
\hline & Agriculture & Wetland & & 895 & 620 & 419 & 0.6 & 15.3 \\
\hline & Grassland/Shrubland & Agriculture & & 855 & 344 & 232 & 0.6 & 14.6 \\
\hline & Agriculture & Water & & 428 & 296 & 200 & 0.3 & 7.3 \\
\hline & Other & Other & & 654 & $\mathrm{n} / \mathrm{a}$ & $\mathrm{n} / \mathrm{a}$ & 0.5 & 11.2 \\
\hline & & & Totals & 5,860 & & & 4.1 & 100.0 \\
\hline \multirow{7}{*}{$\begin{array}{c}\text { 1973-2000 } \\
\text { (overall) }\end{array}$} & Agriculture & Grassland/Shrubland & & 3,386 & 1,180 & 798 & 2.4 & 25.7 \\
\hline & Wetland & Water & & 3,244 & 814 & 550 & 2.3 & 24.6 \\
\hline & Grassland/Shrubland & Agriculture & & 1,915 & 602 & 407 & 1.4 & 14.6 \\
\hline & Agriculture & Wetland & & 1,356 & 758 & 513 & 1.0 & 10.3 \\
\hline & Water & Wetland & & 1,107 & 325 & 220 & 0.8 & 8.4 \\
\hline & Other & Other & & 2,152 & $\mathrm{n} / \mathrm{a}$ & $\mathrm{n} / \mathrm{a}$ & 1.5 & 16.4 \\
\hline & & & Totals & 13,161 & & & 9.3 & 100.0 \\
\hline
\end{tabular}




\section{References Cited}

Bryce, S.A., Omernik, J.M., Pater, D.E., Ulmer, Michael, Schaar, Jerome, Freeouf, Jerry, Johnson, Rex, Kuck, Pat, and Azevedo, S.H., 1998, Ecoregions of North and South Dakota: U.S. Geological Survey Ecoregion Map Series, scale 1:500,000, available at http://www.epa.gov/wed/ pages/ecoregions/ndsd_eco.htm.

Higgins, K.F., Naugle, D.E., and Forman, K.J., 2002, A case study of changing land use practices in the northern Great Plains, U.S.A.-An uncertain future for waterbird conservation, in Parsons, K.C., Brown, S.C., Erwin, R.M., Czech, H.A., and Coulson, J.C., eds., Managing wetlands for waterbirds - Integrated approaches: Waterbirds - The International Journal of Waterbird Biology, v. 25, Special Publication 2, p. 42-50.

Johnson, R.R., and Higgins, K.F., 1997, Formation of eastern South Dakota basins, Appendix A, in Wetland resources of eastern South Dakota (version July 22, 1999): Brookings, S. Dak., South Dakota State University, and Jamestown, N. Dak., U.S. Geological Survey Northern Prairie Wildlife Research Center database, accessed October 23, 2008, at http://www.fws.gov/wetlands/Documents/WetlandResources-of-Eastern-South-Dakota.pdf.

Kirby, D.R., Krabbenhoft, K.D., Sedivec, K.K., and DeKeyeser, E.S., 2002, Wetlands in northern plains prairies-Benefitting wildlife and livestock: Rangelands, v. 24, no. 2, p. 22-25.

Kottek, M.J., Grieser, J., Beck, C., Rudolf, B., and Rubel, F., 2006, World map of the Köppen-Geiger climate classification updated: Meteorologische Zeitschrift, v. 15, no. 3, p. 259-263, available at http://www.schweizerbart.de/papers/ metz/detail/15/55034/World_Map_of_the_Koppen_.

Leathers, N., and Harrington, L.M.B., 2000, Effectiveness of conservation reserve programs and land "slippage" in southwestern Kansas: Professional Geographer, v. 52, no. 1, p. 83-93.
Leistritz, F.L., Hodur, N.M., and Bangsund, D.A., 2002, Socioeconomic impacts of the conservation reserve program in North Dakota: Rural America, v. 17, no. 3, p. 57-65.

Omernik, J.M., 1987, Ecoregions of the conterminous United States: Annals of the Association of American Geographers, v. 77, no. 1, p. 118-125.

PRISM Climate Group, 2006, Precipitation-Annual climatology (1971-2000): PRISM Climate Group, Oregon State University database, accessed August 29, 2008, at http://www. prism.oregonstate.edu/documents/.

Shapley, M.D., Johnson, W.C., Engstrom, D.R., and Osterkamp, W.R., 2005, Late-Holocene flooding and drought in the northern great plains, USA, reconstructed from tree rings, lake sediments, and ancient shorelines: The Holocene, v. 15, no. 1, p. 29-41.

South Dakota Game, Fish and Parks, 2006, Lake Thompson recreation area: South Dakota Game, Fish and Parks database, accessed August 29, 2008, at http://gfp.sd.gov/stateparks/directory/lake-thompson/.

Todhunter, P.E., and Rundquist, B.C., 2004, Terminal lake flooding and wetland expansion in Nelson County, North Dakota: Physical Geography, v. 25, p. 68-85.

U.S. Environmental Protection Agency, 1997, Descriptions of level III ecological regions for the CEC report on ecological regions of North America: U.S. Environmental Protection Agency database, accessed April 12, 2006, at http://www. epa.gov/wed/pages/ecoregions/na_eco.htm\#Downloads.

Vogelmann, J.E., Howard, S.M., Yang, L., Larson, C.R., Wylie, B.K., and van Driel, N., 2001, Completion of the 1990s National Land Cover Data Set for the conterminous United States from Landsat Thematic Mapper data and ancillary data sources: Photogrammetric Engineering \& Remote Sensing, v. 67, p. 650-662. 


\title{
Northwestern Glaciated Plains Ecoregion
}

\author{
By Janis L. Taylor
}

\section{Ecoregion Description}

The Northwestern Glaciated Plains Ecoregion stretches from the Rocky Mountains across northern Montana, through northwestern and central North Dakota and central South Dakota, into northern Nebraska, covering about 160,684 km² $\left(62,040 \mathrm{mi}^{2}\right)$. The Canadian border forms the northern limit of the ecoregion, and the Missouri River makes up much of its southern and western border (fig. 1), although the large reservoirs along the Missouri River created by dams on the river (for example, Lake Sakakawea in North Dakota and Fort Peck Lake in Montana) are not part of the ecoregion. This ecoregion is located between the more level and moister Northern Glaciated Plains Ecoregion to the east and the more topographically irregular and drier Northwestern Great Plains Ecoregion to the south (Omernik, 1987; U.S. Environmental Protection Agency, 1997; Woods and others, 1999). Other ecoregions that abut the Northwestern Glaciated Plains

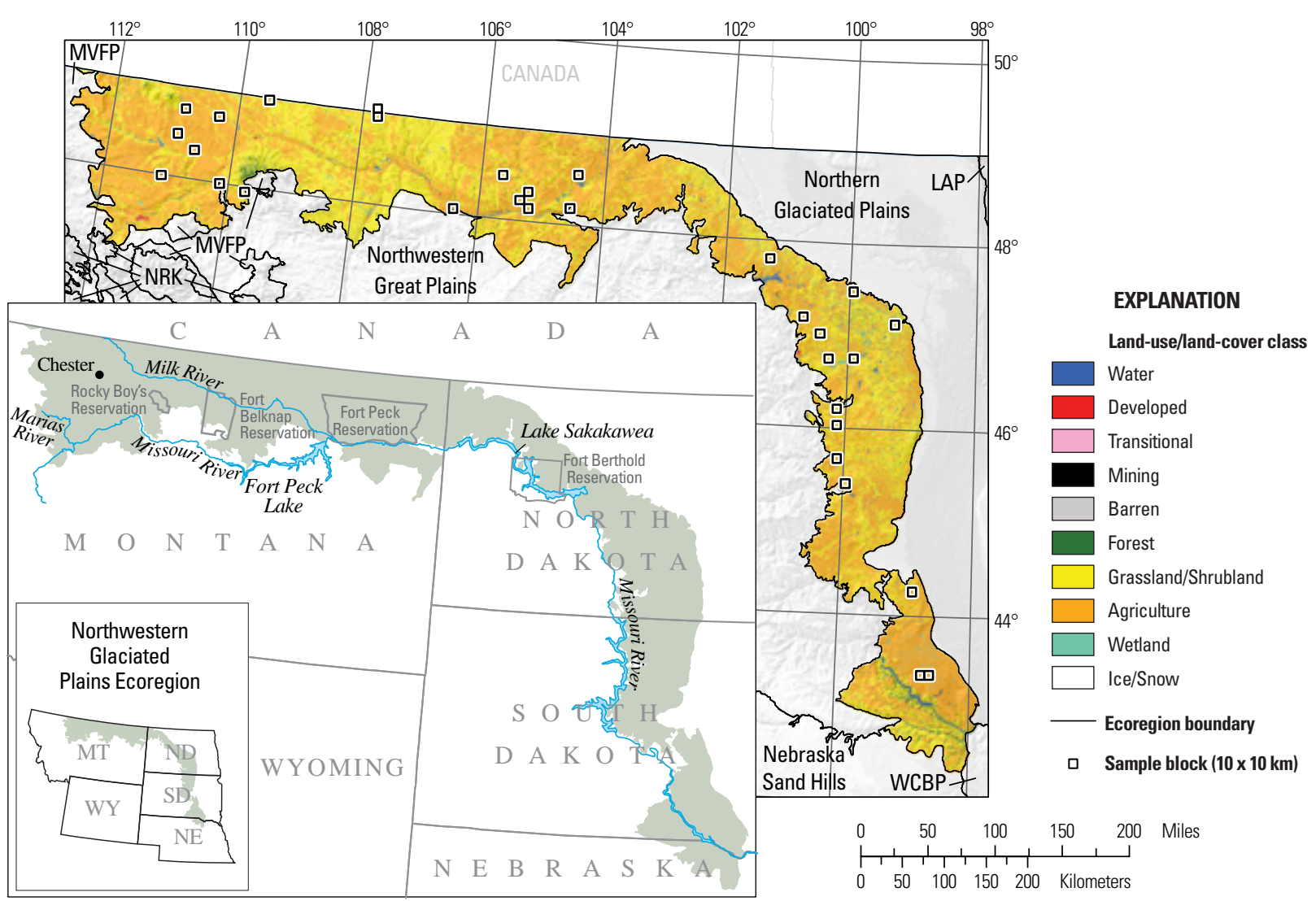

Figure 1. Map of Northwestern Glaciated Plains Ecoregion and surrounding ecoregions, showing land-use/land-cover classes from 1992 National Land Cover Dataset (Vogelmann and others, 2001); note that not all land-use/land-cover classes shown in explanation may be depicted on map; note also that, for this "Status and Trends of Land Change" study, transitional land-cover class was subdivided into mechanically disturbed and nonmechanically disturbed classes. Squares indicate locations of $10 \times 10 \mathrm{~km}$ sample blocks analyzed in study. Index map shows locations of geographic features mentioned in text. Abbreviations for Great Plains ecoregions are listed in appendix 2. Also shown are parts of two Western United States ecoregions: Montana Valley and Foothill Prairies (MVFP) and Northern Rockies (NRK). See appendix 3 for definitions of land-use/land-cover classifications. 
Ecoregion are the Western Corn Belt Plains and the Nebraska Sand Hills Ecoregions to the south and the Montana Valley and Foothill Prairies and the Northern Rockies Ecoregions to the west (fig. 1).

Continental glaciers deposited the gravelly outwash material that marks the western and southwestern border of the ecoregion. Brown clay loam soils and gravelly areas derived from glacial tills are common. Groundwater is shallow and plentiful, and the area is dotted with numerous semipermanent and seasonal wetlands, locally referred to as "prairie potholes" (fig. 2). These wetlands and larger, shallow lakes are rich in wildlife. Rivers that flow through the Northwestern Glaciated Plains Ecoregion include the Marias, Milk, and Missouri Rivers.

The ecoregion, which is in the rain shadow of the Rocky Mountains, has a semiarid climate characterized by cold winters, hot summers, low humidity, light rainfall, and plentiful sunshine. Land uses such as dryland farming and grazing have been shaped by the semiarid climate and strong, drying winds. In the west, rangeland and wheat fields are widespread (fig. 3), with agriculture on the undissected

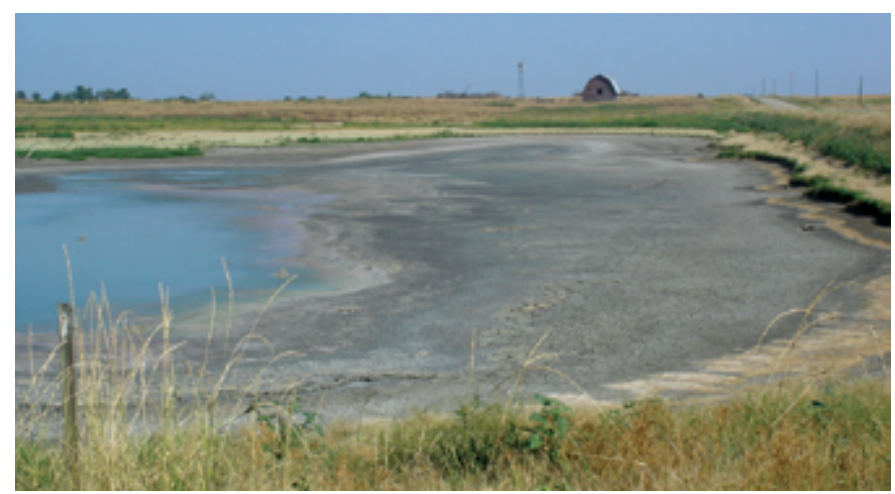

Figure 2. Typical prairie pothole, in Northwestern Glaciated Plains Ecoregion.

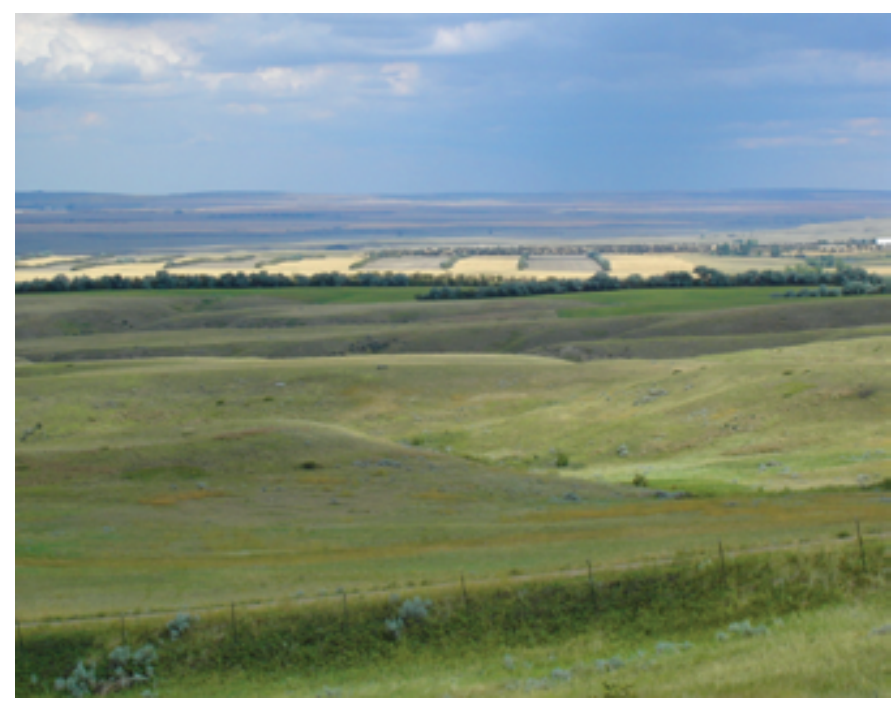

Figure 3. Wheat fields in distance and grassland in foreground, in Northwestern Glaciated Plains Ecoregion. gravel benches and in the alluvial river valleys. Further east, extensive grain farms of wheat, soybeans, sunflowers (fig. $4 A$ ), and corn are common, as are hay and oilseed crops (fig. $4 B$ ). The native vegetation is a mixed-grass prairie consisting primarily of blue grama (Bouteloua gracilis), needlegrass (Stipa spp.), and wheatgrass (Pascopyrum spp.). Oil and gas production also occurs throughout the ecoregion, primarily in the western part.

Most of the land within the Northwestern Glaciated Plains Ecoregion is privately owned. Towns are small and there is little developed land. The four Indian reservations in the ecoregion are the Fort Berthold Reservation in North Dakota and the Rocky Boy's, Fort Belknap, and Fort Peck Reservations in Montana. The rural counties and small towns (fig. 5) that constitute this ecoregion mostly are dependent on agricultural and are isolated from larger metropolitan areas. From 1970 to 2000 , only 5 of the 38 counties that are entirely or partly within the ecoregion increased in population (table 1) (U.S. Census Bureau, 1970-2000 [various years]).
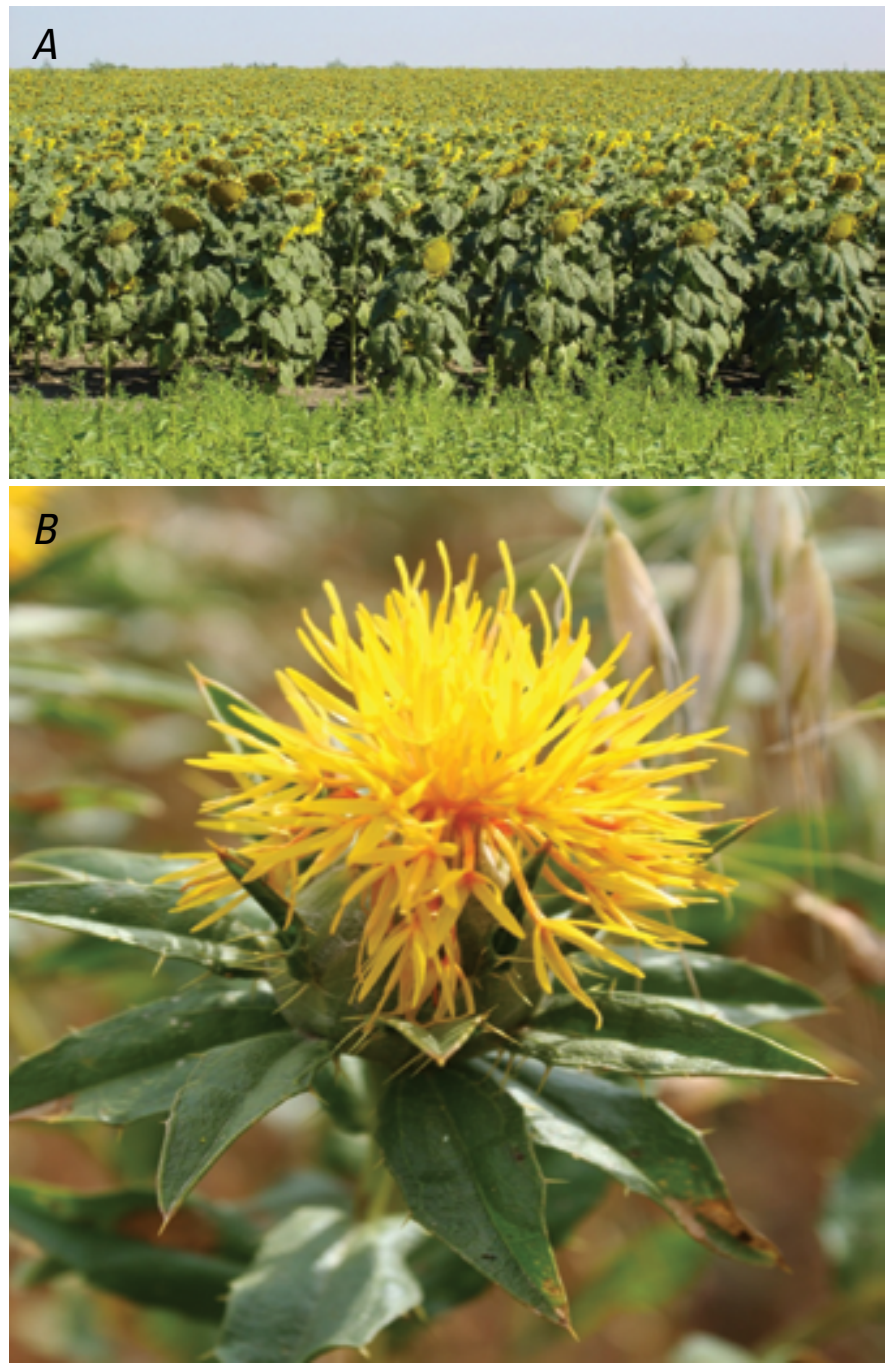

Figure 4. Agricultural land uses in Northwestern Glaciated Plains Ecoregion. $A$, Field of sunflowers. $B$, Safflower in bloom. 


\section{Contemporary Land-Cover Change (1973 to 2000)}

The overall spatial change (the percentage of land area that changed at least one time) in the Northwestern Glaciated Plains Ecoregion between 1973 and 2000 is 14.1 percent (table 2). Of that total, 10.7 percent changed one time, and 3.4 percent changed two or more times (table 2). This ecoregion had the highest overall spatial change among all 17 Great Plains ecoregions (fig. 6).

Total change during the study period ranged from a low of 2.6 percent of the ecoregion between 1973 and 1980 and between 1980 and 1986 to a high of 6.6 percent between

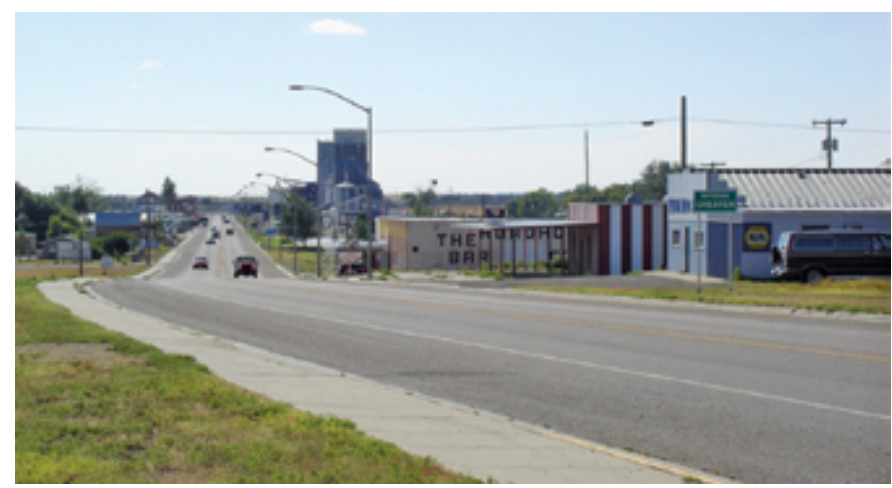

Figure 5. Washington Avenue, a main street in Chester, Montana, in Northwestern Glaciated Plains Ecoregion.

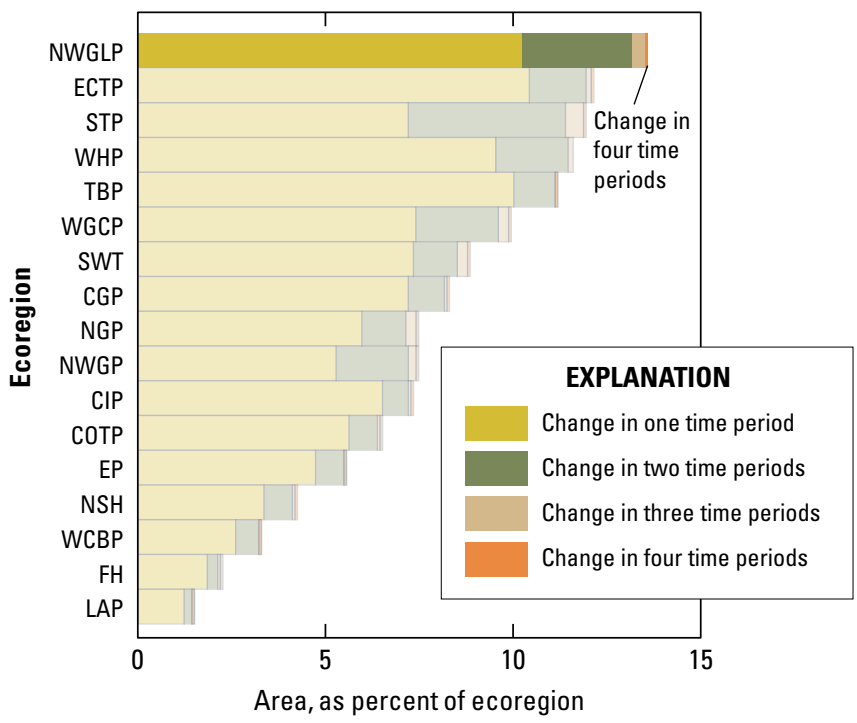

Figure 6. Overall spatial change in Northwestern Glaciated Plains Ecoregion (NWGLP; darker bars) compared with that of all 17 Great Plains ecoregions (lighter bars). Each horizontal set of bars shows proportions of ecoregion that experienced change during one, two, three, or four time periods; highest level of spatial change in Northwestern Glaciated Plains Ecoregion (four time periods) labeled for clarity. See table 3 for years covered by each time period. See appendix 2 for key to ecoregion abbreviations.
1992 and 2000 (table 3). After normalizing to an annual rate of change to adjust for uneven time periods (fig. 7), the rates ranged from a low of 0.4 percent per year between 1973 and 1980 and between 1980 and 1986 to a high of 1.0 percent per year between 1986 and 1992 (table 3; fig. 7). The period between 1992 and 2000 had an annual rate of change of 0.8 percent per year (table 3; fig. 7).

Agriculture, grassland/shrubland, and wetland constituted 97.9 percent $\left(157,130 \mathrm{~km}^{2}\right)$ of the ecoregion in 1973 (table 4). Agriculture decreased from 60.8 percent of the ecoregion in 1973 to 57.1 percent in 2000 (table 4). Grassland/shrubland increased from 33.9 percent in 1973 to 37.3 percent in 2000 (table 4). Grassland/shrubland and agriculture both had a gross change (the total area converting into and out of a class) of about 9.9 percent of ecoregion area during the entire study period, whereas wetland decreased 1.2 percent and water increased 1.3 percent during that same period (table 4; fig. 8).

Between 1973 and 2000, the most common land-cover conversion was from agriculture to grassland/shrubland $\left(14,688 \mathrm{~km}^{2}\right)$, which constituted 50.9 percent of all changes (table 5). The second most common conversion was grassland/ shrubland to agriculture $\left(9,027 \mathrm{~km}^{2}\right)$, 31.3 percent of all changes (table 5). Conversion from grassland/shrubland to agriculture was the leading conversion in the first two time periods (table 5). After 1986, the leading conversion was from agriculture to grassland/shrubland. Between 1986 and 1992, more than three times the area that was converted to agriculture in the two previous time periods was converted to grassland/shrubland (fig. 8). Other notable conversions included wetland to water and water to wetland. Between 1992 and 2000, the area of water more than doubled, most of it coming from the wetland land-cover class.

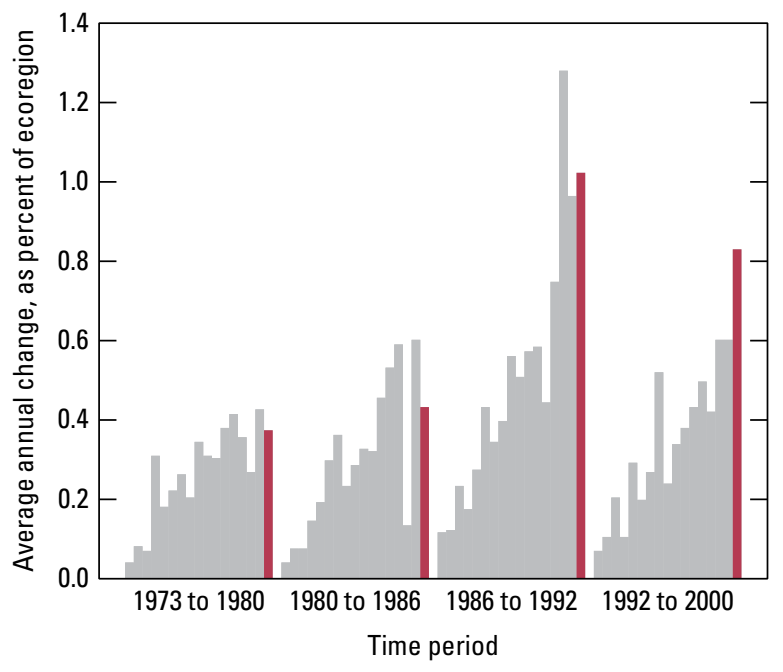

Figure 7. Estimates of land-cover change per time period, normalized to annual rates of change for all 17 Great Plains ecoregions (gray bars). Estimates of change for Northwestern Glaciated Plains Ecoregion are represented by red bars in each time period. 
Most of the change that occurred in the Northwestern Glaciated Plains Ecoregion between 1973 and 2000 can be attributed to anthropogenic drivers, specifically the gains and losses of grassland/shrubland and agriculture. In the 1970s, soaring wheat prices driven by foreign grain purchases, government incentives, and high land values resulted in the conversion of large areas of grazing land or native grassland to agriculture (Watts and others, 1983; Garrett-Davis, 2004). The practice of fallowing in alternating summers allowed for

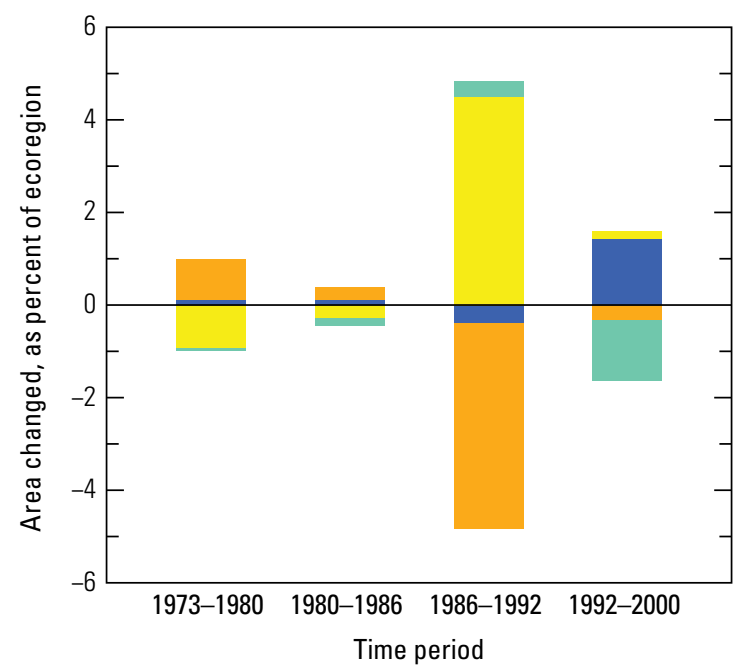

EXPLANATION

LAND-USE/LAND-COVER CLASS
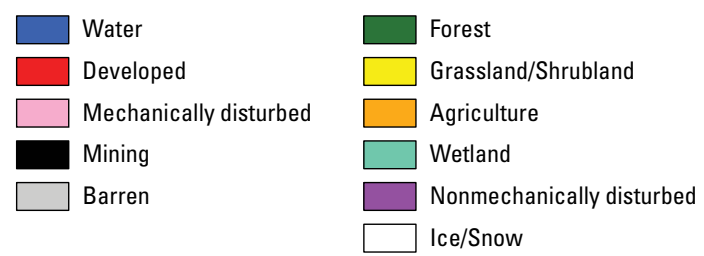

Figure 8. Normalized average net change in Northwestern Glaciated Plains Ecoregion by time period for each land-cover class. Bars above zero axis represent net gain, whereas bars below zero represent net loss. Note that not all land-cover classes shown in explanation may be represented in figure. See appendix 3 for definitions of land-use/land-cover classifications. successful small-grain farming, even in areas having marginal soils (Bryce and others, 1998; Woods and others, 1999). However, in the 1980s, foreign exports of grain declined sharply and farm land prices plummeted. In 1985, the U.S. Department of Agriculture established the Conservation Reserve Program (CRP) to remove highly erodible land from agricultural production (Ribaurdo and others, 1990). By the year 2000, more land in Montana was enrolled in CRP than in either North Dakota or South Dakota (table 6) (U.S. Department of Agriculture, 2008). Conversion from agriculture to grassland/shrubland peaked between 1986 and 1992, and this trend continued throughout the 1990s, although at a slower rate.

Also in the 1990s, soybeans and other genetically modified crops were planted in areas once considered too dry to support them, especially in North Dakota and South Dakota. These new crops, along with crop insurance, decreased the risk of farming in drier areas that had poorer soil quality (Higgins and others, 2002). Agriculture and livestock grazing will remain as the major land uses in the ecoregion as new crops and farming methods will continue to create changes. The trend towards biofuel production also will generate change in the coming years, perhaps increasing incentives for producing certain crops.

Changes to water and wetland primarily were driven by wet-and-dry weather cycles, the 1990s being a much wetter decade than previous decades (Garbrecht and Rossel, 2002). However, some wetland change resulted from the expansion of arable land. In drier years, farmers have access to wetland areas to harvest wild grass hay. In some cases, wetlands are drained and the land is incorporated in adjacent cropland (Leitch and Danielson, 1979).

Protection of grasslands and wetlands for wildlife habitat is being promoted by conservationists, the tourism industry, and outfitters. Some consider grasslands to be the most threatened ecosystem in the United States (Johnson, 2000). The tourism industry sees improvements in wildlife habitat as a means of attracting more visitors to small towns to view wildlife; outfitters see it as a means to attract more hunters and fishermen into the ecoregion. Collectively, increased visitation improves economic vitality of these small towns, as people work hard to make a living in the Northwestern Glaciated Plains Ecoregion. Other changes to the rural communities across the ecoregion will be stimulated as economic opportunities expand. 
Table 1. Population levels and total amounts of population change between 1970 and 2000, as well as future population estimates, of counties that intersect Northwestern Glaciated Plains Ecoregion (U.S. Census Bureau, 1970-2000 [various years]).

[n/a, not available]

\begin{tabular}{|c|c|c|c|c|c|c|c|}
\hline \multirow{2}{*}{ State } & \multirow{2}{*}{ County } & \multicolumn{4}{|c|}{ Population } & \multirow{2}{*}{$\begin{array}{l}\text { Population } \\
\text { change, } \\
\text { 1970-2000 }\end{array}$} & \multirow{2}{*}{$\begin{array}{c}\text { Estimated } \\
\text { population, } 2007\end{array}$} \\
\hline & & 1970 & 1980 & 1990 & 2000 & & \\
\hline \multirow[t]{12}{*}{ Montana } & Blaine & 6,727 & 6,999 & 6,728 & 7,009 & 282 & 6,550 \\
\hline & Chouteau & 6,473 & 6,092 & 5,452 & 5,970 & -503 & 5,254 \\
\hline & Daniels & 3,083 & 2,835 & 2,266 & 2,017 & $-1,066$ & 1,650 \\
\hline & Hill & 17,358 & 17,985 & 17,654 & 16,673 & -685 & 16,568 \\
\hline & Liberty & 2,359 & 2,329 & 2,295 & 2,158 & -201 & 1,796 \\
\hline & Phillips & 5,386 & 5,367 & 5,163 & 4,601 & -785 & 3,948 \\
\hline & Richland & 9,837 & 12,243 & 10,716 & 9,667 & -170 & 9,182 \\
\hline & Roosevelt & 10,365 & 10,467 & 10,999 & 10,620 & 255 & 10,148 \\
\hline & Sheridan & 5,779 & 5,414 & 4,732 & 4,105 & $-1,674$ & 3,373 \\
\hline & Valley & 11,471 & 10,250 & 8,239 & 7,675 & $-3,796$ & 6,899 \\
\hline & Toole & 5,839 & 5,559 & 5,046 & 5,267 & -572 & 5,144 \\
\hline & & & & & & & $\begin{array}{c}\text { Estimated } \\
\text { population, } 2006\end{array}$ \\
\hline \multirow{13}{*}{ North Dakota } & Burleigh & 40,714 & 54,811 & 60,131 & 69,416 & 28,702 & 75,384 \\
\hline & Divide & 4,564 & 3,494 & 2,899 & 2,283 & $-2,281$ & 2,092 \\
\hline & Emmons & 7,200 & 5,877 & 4,830 & 4,331 & $-2,869$ & 3,645 \\
\hline & Kidder & 4,362 & 3,833 & 3,332 & 2,753 & $-1,609$ & 2,453 \\
\hline & Logan & 4,245 & 3,493 & 2,847 & 2,308 & $-1,937$ & 1,999 \\
\hline & McIntosh & 5,545 & 4,800 & 4,021 & 3,390 & $-2,155$ & 2,956 \\
\hline & McLean & 11,251 & 12,383 & 10,457 & 9,311 & $-1,940$ & 8,543 \\
\hline & Mountrail & 8,437 & 7,679 & 7,021 & 6,631 & $-1,806$ & 6,442 \\
\hline & Sheridan & 3,232 & 2,819 & 2,148 & 1,710 & $-1,522$ & 1,408 \\
\hline & Stutsman & 23,550 & 24,154 & 22,241 & 21,908 & $-1,642$ & 20,761 \\
\hline & Wells & 7,847 & 6,979 & 5,864 & 5,102 & $-2,745$ & 4,432 \\
\hline & Williams & 19,301 & 22,237 & 21,129 & 19,761 & 460 & 19,456 \\
\hline & & & & & & & $\begin{array}{c}\text { Estimated } \\
\text { population, } 2006\end{array}$ \\
\hline \multirow[t]{15}{*}{ South Dakota } & Aurora & 4,183 & 3,628 & 3,135 & 3,058 & $-1,125$ & $\mathrm{n} / \mathrm{a}$ \\
\hline & Brule & 5,870 & 5,245 & 5,485 & 5,364 & -506 & 5,167 \\
\hline & Campbell & 2,866 & 2,243 & 1,965 & 1,782 & $-1,084$ & 1,494 \\
\hline & Charles Mix & 9,994 & 9,680 & 9,131 & 9,350 & -644 & 9,224 \\
\hline & Douglas & 4,569 & 4,181 & 3,746 & 3,458 & $-1,111$ & 3,168 \\
\hline & Edmunds & 5,548 & 5,159 & 4,356 & 4,367 & $-1,181$ & 4,062 \\
\hline & Faulk & 3,893 & 3,327 & 2,744 & 2,640 & $-1,253$ & 2,339 \\
\hline & Gregory & 6,710 & 6,015 & 5,359 & 4,792 & $-1,918$ & 4,268 \\
\hline & Hand & 5,883 & 4,948 & 4,272 & 3,741 & $-2,142$ & 3,323 \\
\hline & Hughes & 11,632 & 14,220 & 14,817 & 16,481 & 4,849 & 16,946 \\
\hline & Jerauld & 3,310 & 2,929 & 2,425 & 2,295 & $-1,015$ & 2,071 \\
\hline & McPherson & 5,022 & 4,027 & 3,228 & 2,904 & $-2,118$ & 2,565 \\
\hline & Potter & 4,449 & 3,674 & 3,190 & 2,693 & $-1,756$ & 2,321 \\
\hline & Sully & 2,362 & 1,990 & 1,589 & 1,556 & -806 & 1,435 \\
\hline & Walworth & 7,842 & 7,011 & 6,087 & 5,974 & $-1,868$ & 5,425 \\
\hline
\end{tabular}


Table 2. Percentage of Northwestern Glaciated Plains Ecoregion land cover that changed at least one time during study period (1973-2000) and associated statistical error.

[Most sample pixels remained unchanged (85.9 percent), whereas 14.1 percent changed at least once throughout study period]

\begin{tabular}{ccccccc}
\hline $\begin{array}{c}\text { Number } \\
\text { of } \\
\text { changes ecoregion }\end{array}$ & $\begin{array}{c}\text { Percent } \\
\text { of }\end{array}$ & $\begin{array}{c}\text { Margin } \\
\text { of error } \\
(+/)\end{array}$ & $\begin{array}{c}\text { Lower } \\
\text { bound } \\
(\%)\end{array}$ & $\begin{array}{c}\text { Upper } \\
\text { bound } \\
(\%)\end{array}$ & $\begin{array}{c}\text { Standard Relative } \\
\text { error } \\
\text { (\%) }\end{array}$ & $\begin{array}{c}\text { error } \\
(\%)\end{array}$ \\
\hline 1 & 10.7 & 1.8 & 8.9 & 12.5 & 1.2 & 11.4 \\
2 & 3.0 & 0.8 & 2.2 & 3.8 & 0.5 & 18.2 \\
3 & 0.3 & 0.2 & 0.1 & 0.5 & 0.1 & 40.1 \\
4 & 0.1 & 0.0 & 0.0 & 0.1 & 0.0 & 44.9 \\
\hline $\begin{array}{l}\text { Overall } \\
\text { spatial } \\
\text { change }\end{array}$ & 14.1 & 2.2 & 11.9 & 16.4 & 1.5 & 10.7 \\
\hline
\end{tabular}

Table 3. Raw estimates of change in Northwestern Glaciated Plains Ecoregion land cover, computed for each of four time periods between 1973 and 2000 , and associated error at 85-percent confidence level.

[Estimates of change per period normalized to annual rate of change for each time period]

\begin{tabular}{cccccccc}
\hline Period & $\begin{array}{c}\text { Total change } \\
\text { (\% of } \\
\text { ecoregion) }\end{array}$ & $\begin{array}{c}\text { Margin } \\
\text { of error } \\
(+/-\%)\end{array}$ & $\begin{array}{c}\text { Lower } \\
\text { bound } \\
(\%)\end{array}$ & $\begin{array}{c}\text { Upper } \\
\text { bound } \\
(\%)\end{array}$ & $\begin{array}{c}\text { Standard } \\
\text { error } \\
(\%)\end{array}$ & $\begin{array}{c}\text { Relative } \\
\text { error } \\
(\%)\end{array}$ & $\begin{array}{c}\text { Average } \\
\text { rate } \\
(\% \text { per year) }\end{array}$ \\
\hline \multicolumn{7}{c}{ Estimate of change, in percent stratum } \\
\hline $1973-1980$ & 2.6 & 0.6 & 2.0 & 3.2 & 0.4 & 15.6 & 0.4 \\
$1980-1986$ & 2.6 & 0.7 & 1.9 & 3.3 & 0.5 & 18.5 & 0.4 \\
$1986-1992$ & 6.1 & 1.3 & 4.8 & 7.4 & 0.9 & 14.3 & 1.0 \\
$1992-2000$ & 6.6 & 1.5 & 5.1 & 8.1 & 1.0 & 15.0 & 0.8 \\
\hline \multicolumn{7}{c}{ Estimate of change, in square kilometers } \\
\hline $1973-1980$ & 4,210 & 973 & 3,237 & 5,183 & 658 & 15.6 & 601 \\
$1980-1986$ & 4,158 & 1,136 & 3,022 & 5,294 & 768 & 18.5 & 693 \\
$1986-1992$ & 9,838 & 2,081 & 7,757 & 11,919 & 1,407 & 14.3 & 1,640 \\
$1992-2000$ & 10,628 & 2,356 & 8,271 & 12,984 & 1,593 & 15.0 & 1,328 \\
\hline
\end{tabular}


Table 4. Estimated area (and margin of error) of each land-cover class in Northwestern Glaciated Plains Ecoregion, calculated five times between 1973 and 2000. See appendix 3 for definitions of land-cover classifications.

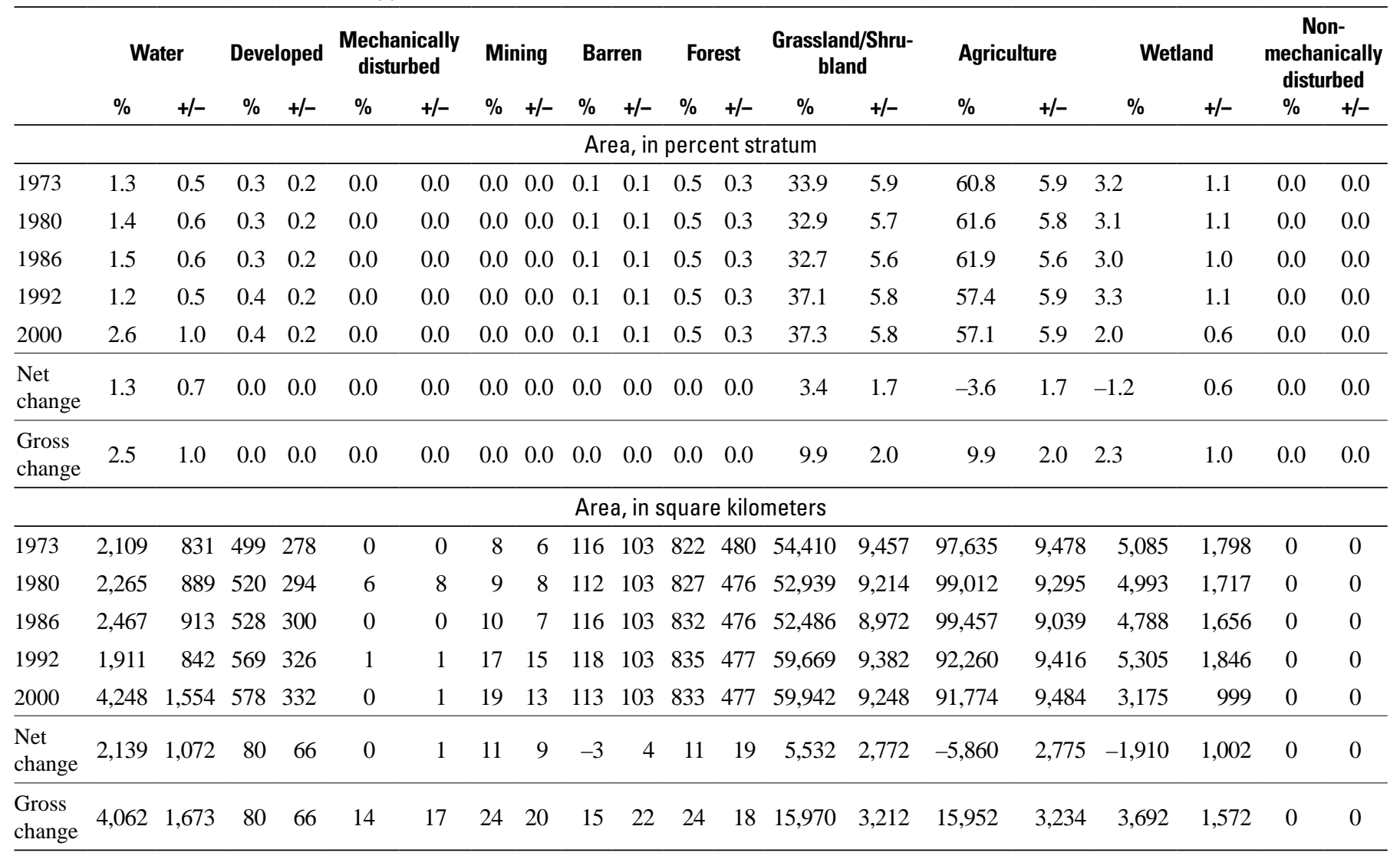


Table 5. Principal land-cover conversions in Northwestern Glaciated Plains Ecoregion, showing amount of area changed (and margin of error, calculated at 85-percent confidence level) for each conversion during each of four time periods and also during overall study period. See appendix 3 for definitions of land-cover classifications.

[Values given for "other" class are combined totals of values for other land-cover classes not listed in that time period. Abbreviations: n/a, not applicable]

\begin{tabular}{|c|c|c|c|c|c|c|c|c|}
\hline Period & From class & To class & & $\begin{array}{c}\text { Area } \\
\text { changed } \\
\left(\mathbf{k m}^{2}\right)\end{array}$ & $\begin{array}{c}\text { Margin of } \\
\text { error } \\
\left(+/-\mathrm{km}^{2}\right)\end{array}$ & $\begin{array}{c}\text { Standard } \\
\text { error } \\
\left(\mathbf{k m}^{2}\right)\end{array}$ & $\begin{array}{l}\text { Percent of } \\
\text { ecoregion }\end{array}$ & $\begin{array}{l}\text { Percent of all } \\
\text { changes }\end{array}$ \\
\hline \multirow[t]{7}{*}{ 1973-1980 } & Grassland/Shrubland & Agriculture & & 2,438 & 840 & 568 & 1.5 & 57.9 \\
\hline & Agriculture & Grassland/Shrubland & & 1,000 & 317 & 214 & 0.6 & 23.8 \\
\hline & Wetland & Water & & 376 & 240 & 162 & 0.2 & 8.9 \\
\hline & Water & Wetland & & 254 & 157 & 106 & 0.2 & 6.0 \\
\hline & Agriculture & Wetland & & 33 & 28 & 19 & 0.0 & 0.8 \\
\hline & Other & Other & & 109 & $\mathrm{n} / \mathrm{a}$ & $\mathrm{n} / \mathrm{a}$ & 0.1 & 2.6 \\
\hline & & & Totals & 4,210 & & & 2.6 & 100.0 \\
\hline \multirow[t]{7}{*}{ 1980-1986 } & Grassland/Shrubland & Agriculture & & 1,976 & 739 & 500 & 1.2 & 47.5 \\
\hline & Agriculture & Grassland/Shrubland & & 1,529 & 669 & 452 & 1.0 & 36.8 \\
\hline & Wetland & Water & & 383 & 227 & 154 & 0.2 & 9.2 \\
\hline & Water & Wetland & & 173 & 100 & 67 & 0.1 & 4.2 \\
\hline & Agriculture & Wetland & & 19 & 13 & 9 & 0.0 & 0.5 \\
\hline & Other & Other & & 78 & $\mathrm{n} / \mathrm{a}$ & $\mathrm{n} / \mathrm{a}$ & 0.0 & 1.9 \\
\hline & & & Totals & 4,158 & & & 2.6 & 100.0 \\
\hline \multirow[t]{7}{*}{ 1986-1992 } & Agriculture & Grassland/Shrubland & & 7,997 & 1,968 & 1,331 & 5.0 & 81.3 \\
\hline & Grassland/Shrubland & Agriculture & & 833 & 337 & 228 & 0.5 & 8.5 \\
\hline & Water & Wetland & & 674 & 370 & 250 & 0.4 & 6.8 \\
\hline & Wetland & Water & & 139 & 89 & 60 & 0.1 & 1.4 \\
\hline & Wetland & Agriculture & & 37 & 19 & 13 & 0.0 & 0.4 \\
\hline & Other & Other & & 159 & $\mathrm{n} / \mathrm{a}$ & $\mathrm{n} / \mathrm{a}$ & 0.1 & 1.6 \\
\hline & & & Totals & 9,838 & & & 6.1 & 100.0 \\
\hline \multirow[t]{7}{*}{ 1992-2000 } & Agriculture & Grassland/Shrubland & & 4,162 & 1,508 & 1,020 & 2.6 & 39.2 \\
\hline & Grassland/Shrubland & Agriculture & & 3,780 & 1,209 & 817 & 2.4 & 35.6 \\
\hline & Wetland & Water & & 2,276 & 1,089 & 736 & 1.4 & 21.4 \\
\hline & Grassland/Shrubland & Water & & 120 & 100 & 68 & 0.1 & 1.1 \\
\hline & Water & Wetland & & 112 & 103 & 70 & 0.1 & 1.1 \\
\hline & Other & Other & & 179 & $\mathrm{n} / \mathrm{a}$ & $\mathrm{n} / \mathrm{a}$ & 0.1 & 1.7 \\
\hline & & & Totals & 10,628 & & & 6.6 & 100.0 \\
\hline \multirow{7}{*}{$\begin{array}{l}\text { 1973-2000 } \\
\text { (overall) }\end{array}$} & Agriculture & Grassland/Shrubland & & 14,688 & 3,103 & 2,098 & 9.1 & 50.9 \\
\hline & Grassland/Shrubland & Agriculture & & 9,027 & 1,947 & 1,316 & 5.6 & 31.3 \\
\hline & Wetland & Water & & 3,172 & 1,388 & 939 & 2.0 & 11.0 \\
\hline & Water & Wetland & & 1,212 & 514 & 347 & 0.8 & 4.2 \\
\hline & Grassland/Shrubland & Water & & 159 & 110 & 74 & 0.1 & 0.6 \\
\hline & Other & Other & & 574 & $\mathrm{n} / \mathrm{a}$ & $\mathrm{n} / \mathrm{a}$ & 0.4 & 2.0 \\
\hline & & & Totals & 28,834 & & & 17.9 & 100.0 \\
\hline
\end{tabular}


Table 6. Areas (in square kilometers) of cumulative enrollment in Conservation Reserve Program by year of counties that intersect Northwestern Glaciated Plains Ecoregion (U.S. Department of Agriculture, 2008).

\begin{tabular}{|c|c|c|c|c|}
\hline \multirow{2}{*}{ State } & \multirow{2}{*}{ County } & \multicolumn{3}{|c|}{ Area $\left(\mathbf{k m}^{2}\right)$} \\
\hline & & 1986 & 1992 & 2000 \\
\hline \multirow[t]{11}{*}{ Montana } & Blaine & 0 & 469 & 651 \\
\hline & Chouteau & 4 & 613 & 950 \\
\hline & Daniels & 13 & 592 & 594 \\
\hline & Hill & 0 & 675 & 1,078 \\
\hline & Liberty & 0 & 331 & 486 \\
\hline & Phillips & 16 & 515 & 682 \\
\hline & Richland & 8 & 296 & 453 \\
\hline & Roosevelt & 13 & 571 & 694 \\
\hline & Sheridan & 14 & 697 & 596 \\
\hline & Valley & 0 & 821 & 824 \\
\hline & Totals & 68 & 5,579 & 6,357 \\
\hline \multirow[t]{13}{*}{ North Dakota } & Burleigh & 3 & 409 & 382 \\
\hline & Divide & 4 & 396 & 269 \\
\hline & Emmons & 2 & 250 & 285 \\
\hline & Kidder & 29 & 438 & 446 \\
\hline & Logan & 0 & 238 & 232 \\
\hline & McIntosh & 2 & 183 & 237 \\
\hline & McLean & 1 & 401 & 292 \\
\hline & Mountrail & 0 & 383 & 204 \\
\hline & Sheridan & 0 & 261 & 240 \\
\hline & Stutsman & 3 & 675 & 711 \\
\hline & Wells & 1 & 268 & 271 \\
\hline & Williams & 0 & 219 & 217 \\
\hline & Totals & 45 & 4,121 & 3,786 \\
\hline \multirow[t]{16}{*}{ South Dakota } & Aurora & 4 & 42 & 55 \\
\hline & Brule & 0 & 27 & 19 \\
\hline & Campbell & 0 & 125 & 161 \\
\hline & Charles Mix & 0 & 33 & 28 \\
\hline & Douglas & 0 & 6 & 16 \\
\hline & Edmunds & 0 & 289 & 99 \\
\hline & Faulk & 0 & 93 & 41 \\
\hline & Gregory & 0 & 20 & 10 \\
\hline & Hand & 0 & 70 & 131 \\
\hline & Hughes & 0 & 48 & 41 \\
\hline & Jerauld & 0 & 87 & 47 \\
\hline & McPherson & 2 & 256 & 185 \\
\hline & Potter & 0 & 160 & 112 \\
\hline & Sully & 0 & 84 & 79 \\
\hline & Walworth & 0 & 124 & 63 \\
\hline & Totals & 6 & 1,464 & 1,087 \\
\hline
\end{tabular}




\section{References Cited}

Bryce, S.A., Omernik, J.A., Pater, D.E., Ulmer, Michael, Schaar, Jerome, Freeouf, Jerry, Johnson, Rex, Kuck, Pat, and Azevedo, S.H., 1998, Ecoregions of North and South Dakota: U.S. Geological Survey Ecoregion Map Series, scale 1:500,000, available at http://www.epa.gov/wed/ pages/ecoregions/ndsd_eco.htm.

Garbrecht, J.D., and Rossel, F.E., 2002, Decade-scale precipitation increase in the Great Plains at end of 20th century: Journal of Hydrologic Engineering, v. 7, no. 1, p. 64-75.

Garrett-Davis, Josh, 2004, The greening of the plains: High Country News, August 2, 2004, accessed August 5, 2005, at http://www.hcn.org/issues/279/14896.

Higgins, K.F., Naugle, D.E., and Forman, K.J., 2002, A case study of changing land use practices in the northern Great Plains, U.S.A.-An uncertain future for waterbird conservation, in Parsons, K.C., Brown, S.C., Erwin, R.M., Czech, H.A., and Coulson, J.C., eds., Managing wetlands for waterbirds - Integrated approaches: Waterbirds-The International Journal of Waterbird Biology, v. 25, Special Publication 2, p. 42-50.

Johnson, D.H., 2000, Grassland bird use of Conservation Reserve Program fields in the Great Plains, in Heard, L.P., Allen, A.W., Best, L.B., Brady, S.J., Burger, W., Esser, A.J., Hackett, E., Johnson, D.H., Pederson, R.L., Reynolds, R.E., Rewa, C., Ryan, M.R., Molleur, R.T., and Buck., P. (Hohman, W.L., and Halloum, D.J., eds.), A comprehensive review of farm bill contributions to wildlife conservation, 1985-2000: U.S. Department of Agriculture, Natural Resources Conservation Service, Wildlife Habitat Management Institute, Technical Report USDA/NRCS/ WHMI-2000, p. 19-33, accessed January 9, 2006, at http://www.nrcs.usda.gov/Internet/FSE_DOCUMENTS/ nrcs143_012881.pdf.

Leitch, J.A., and Danielson, L.E., 1979, Social, economic, and institutional incentives to drain or preserve prairie wetlands: St. Paul, University of Minnesota, Department of Agriculture and Applied Economics, Economic Report ER79-6.
Omernik, J.M., 1987, Ecoregions of the conterminous United States: Annals of the Association of American Geographers, v. 77 , no. 1, p. 118-125.

Ribaurdo, M.O., Colacicco, D., Langner, L.L., Piper, S., and Schaible, G.D., 1990, Natural resources and users benefit from the Conservation Reserve Program: U.S. Department of Agriculture, Resource and Technology Division, Economic Research Service, Agricultural Economic Report No. 627 , p. 6-17.

U.S. Census Bureau, 1970-2000 [various years], Census of population and housing: U.S. Census Bureau database, accessed December 3, 2008, at http://www.census.gov/prod/ www/decennial.html.

U.S. Department of Agriculture, 2008, Conservation Reserve Program-Cumulative enrollment by year (by county, FY 1986-FY 2007): U.S. Department of Agriculture, Farm Services Agency database, accessed December 3, 2008, at http://www.fsa.usda.gov/Internet/FSA_File/public.xls.

U.S. Environmental Protection Agency, 1997, Descriptions of level III ecological regions for the CEC report on ecological regions of North America: U.S. Environmental Protection Agency database, accessed April 12, 2006, at http://www. epa.gov/wed/pages/ecoregions/na_eco.htm\#Downloads.

Vogelmann, J.E., Howard, S.M., Yang, L., Larson, C.R., Wylie, B.K., and van Driel, N., 2001, Completion of the 1990s National Land Cover Data Set for the conterminous United States from Landsat Thematic Mapper data and ancillary data sources: Photogrammetric Engineering \& Remote Sensing, v. 67, p. 650-662.

Watts, M.J., Bender, L.D., and Johnson, J.B., 1983, Economic incentives for converting rangeland to cropland: Bozeman, Montana State University, Cooperative Extension Service Bulletin 1302, p. 8-18.

Woods, A.J., Omernik, J.M., Nesser, J.A., Shelden, J., and Azevedo, S.H., 1999, Ecoregions of Montana: U.S. Geological Survey Ecoregion Map Series, scale 1:1,500,000, available at http://www.epa.gov/wed/pages/ecoregions/mt_eco.htm. 


\title{
Chapter 9
}

\section{Western Corn Belt Plains Ecoregion}

\author{
By Roger F. Auch
}

\section{Ecoregion Description}

The Western Corn Belt Plains Ecoregion is centered in Iowa, with parts extending into southern Minnesota, eastern Nebraska, northeastern Kansas, northwestern Missouri, and small areas of western Wisconsin and southeastern South Dakota (fig. 1), covering about 216,363 $\mathrm{km}^{2}\left(83,538 \mathrm{mi}^{2}\right)$. The ecoregion is surrounded by (clockwise, from its northernmost point) the North Central Hardwood Forests, Driftless Area, Central Corn Belt Plains, Interior River Lowlands, Central Irregular Plains, Flint Hills, Central Great Plains, Nebraska Sand Hills, Northwestern Glaciated Plains, and Northern Glaciated Plains Ecoregions (fig. 1) (Omernik, 1987; U.S. Environmental Protection Agency, 1997).

The climate of the Western Corn Belt Plains Ecoregion is considered to be continental (hot summers and cold winters). Average annual precipitation amounts range from 610 to $915 \mathrm{~mm}$ (24-36 in.),

Figure 1. Map of Western Corn Belt Plains Ecoregion and surrounding ecoregions, showing land-use/landcover classes from 1992 National Land Cover Dataset (Vogelmann and others, 2001); note that not all land-use/landcover classes shown in explanation may be depicted on map; note also that, for this "Status and Trends of Land Change" study, transitional landcover class was subdivided into mechanically disturbed and nonmechanically disturbed classes. Squares indicate locations of $10 \times 10 \mathrm{~km}$ sample blocks analyzed in study. Index map shows locations of geographic features mentioned in text. Abbreviations for Great Plains ecoregions are listed in appendix 2. Also shown are five Midwest-South Central United States ecoregions: Central Corn Belt Plains (CCBP), Driftless Area, Interior River Lowland (IRL), North Central Hardwood Forests, and Northern Lakes and Forests (NLF). See appendix 3 for definitions of land-use/land-cover classifications. slightly less in the northwestern part of the ecoregion (Kottek and others, 2006; PRISM Climate Group, 2006). The topography is level-to-rolling plains underlain by glaciated till, with hilly loess-covered plains in the western part (Omernik, 1987; U.S. Environmental Protection Agency, 2002) (fig. 2).

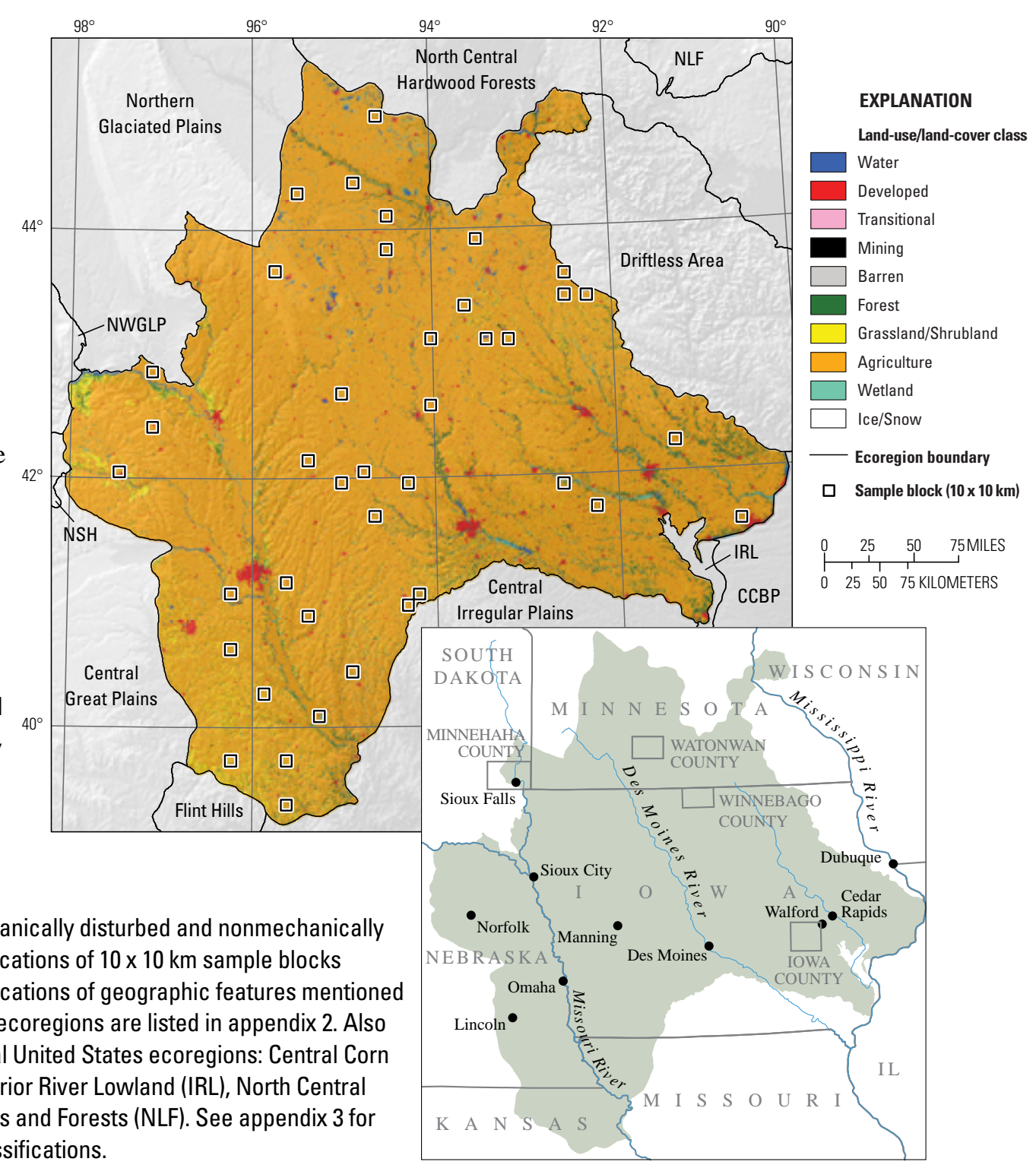


The Western Corn Belt Plains Ecoregion in the first half of the 19th century was predominantly tallgrass prairie, forest (both riparian and oak-prairie savanna), and wetlands (both herbaceous marshes and wooded floodplains) (Dinsmore, 1994; Karnitz and Asbjornsen, 2006). The combination of climate, topography, and soils in the ecoregion enabled EuroAmerican settlers during the second half of the 19th century to convert most of the existing land to farmland (primarily cropland). Draining of herbaceous wetlands to create more farmland peaked in the first decades of the 20th century (Vileisis, 1997; Timmerman, 2001).

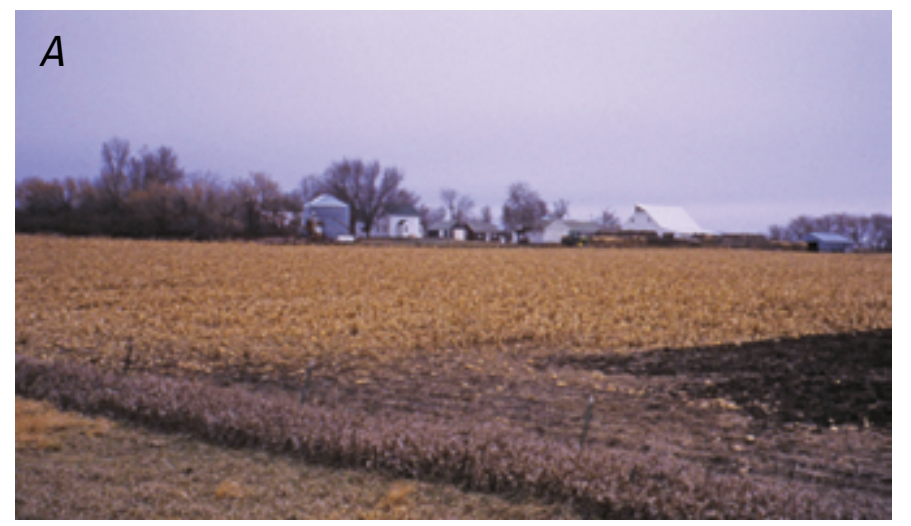

Agriculture continued to dominate the ecoregion during the study period (1973-2000). The Western Corn Belt Plains Ecoregion is a world leader in corn and soybean production (U.S. Environmental Protection Agency, 2002) (figs. 3A,B), although other crops such as alfalfa hay and wheat also are grown there. The agriculture land-use/land-cover class also includes pastureland used for livestock production such as hogs and beef cattle (figs. 3C,D).

Other land-use/land-cover classes present in smaller areas of the ecoregion include forest, grassland/shrubland, developed, wetland, water, and mining. Forests grew

Figure 2. Landforms in Western Corn Belt Plains Ecoregion. $A$, Nearly level plains of glacial till in southwestern Minnesota. $B$, Hilly cropland in northeastern Nebraska.
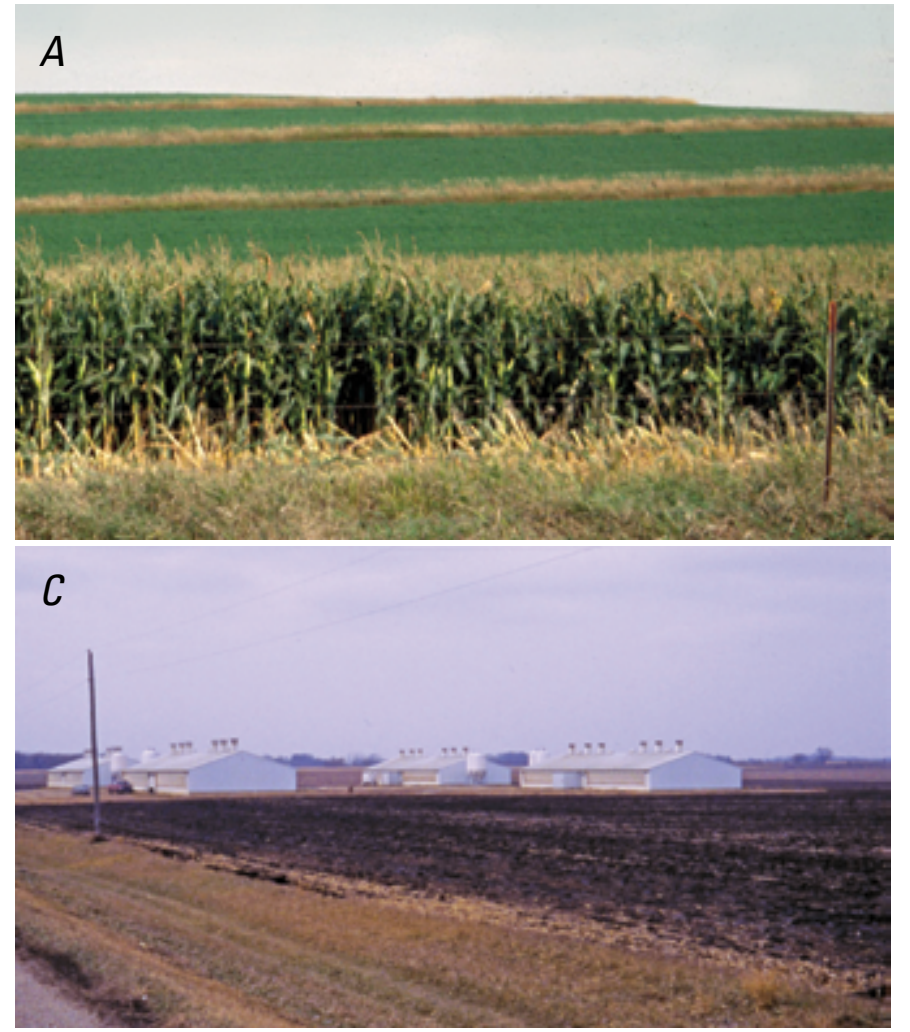

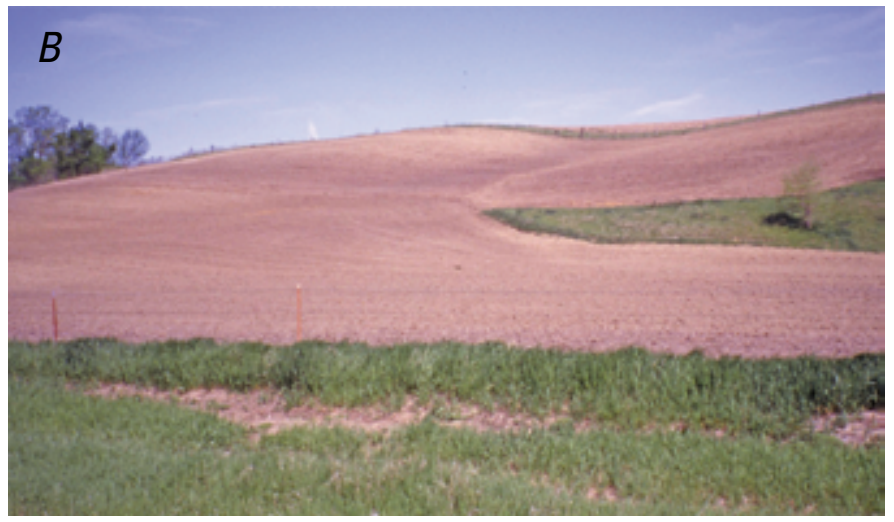

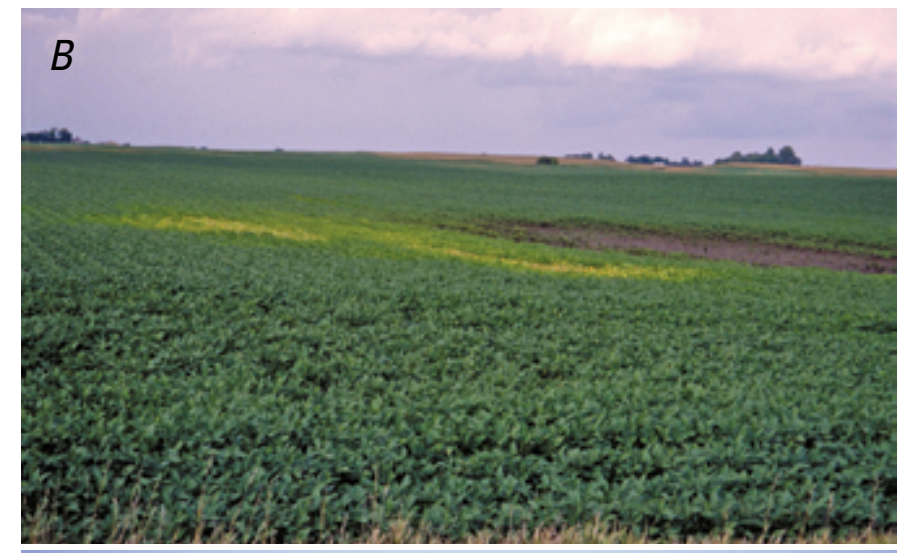

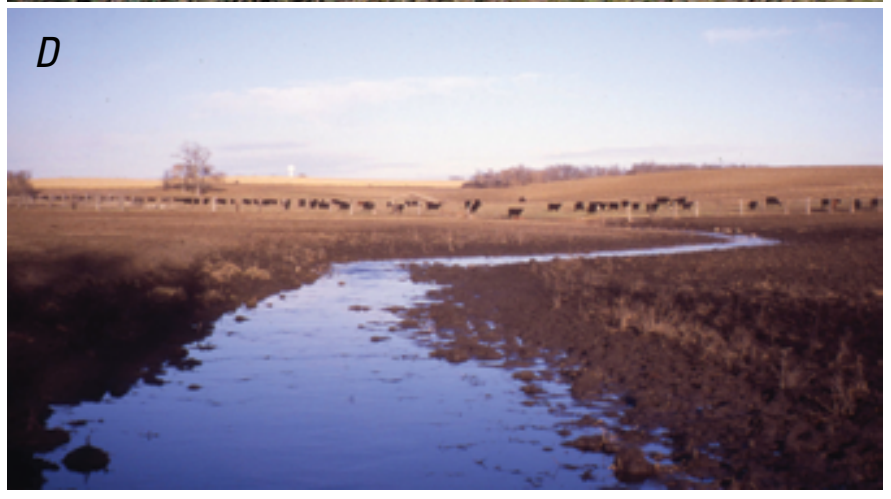

Figure 3. Crops and livestock production in Western Corn Belt Plains Ecoregion. $A$, Field of alfalfa hay and corn near Manning, lowa. $B$, Soybean field in north-central lowa. $C$, Hog confinement buildings in Watonwan County, Minnesota. $D$, Cattle feedlot in Minnehaha County, eastern South Dakota. 
primarily in the larger river valleys and in areas along the eastern and southern margins of the ecoregion (fig. 1). Other forested land may have been present in farm shelterbelts but may not have been wide enough (that is, discernable using a $60 \mathrm{~m} \times 60 \mathrm{~m}$ mapping unit) to map continuously. Grassland/shrubland consisted of less intensively used grazing areas (usually in more topographically varied areas) and
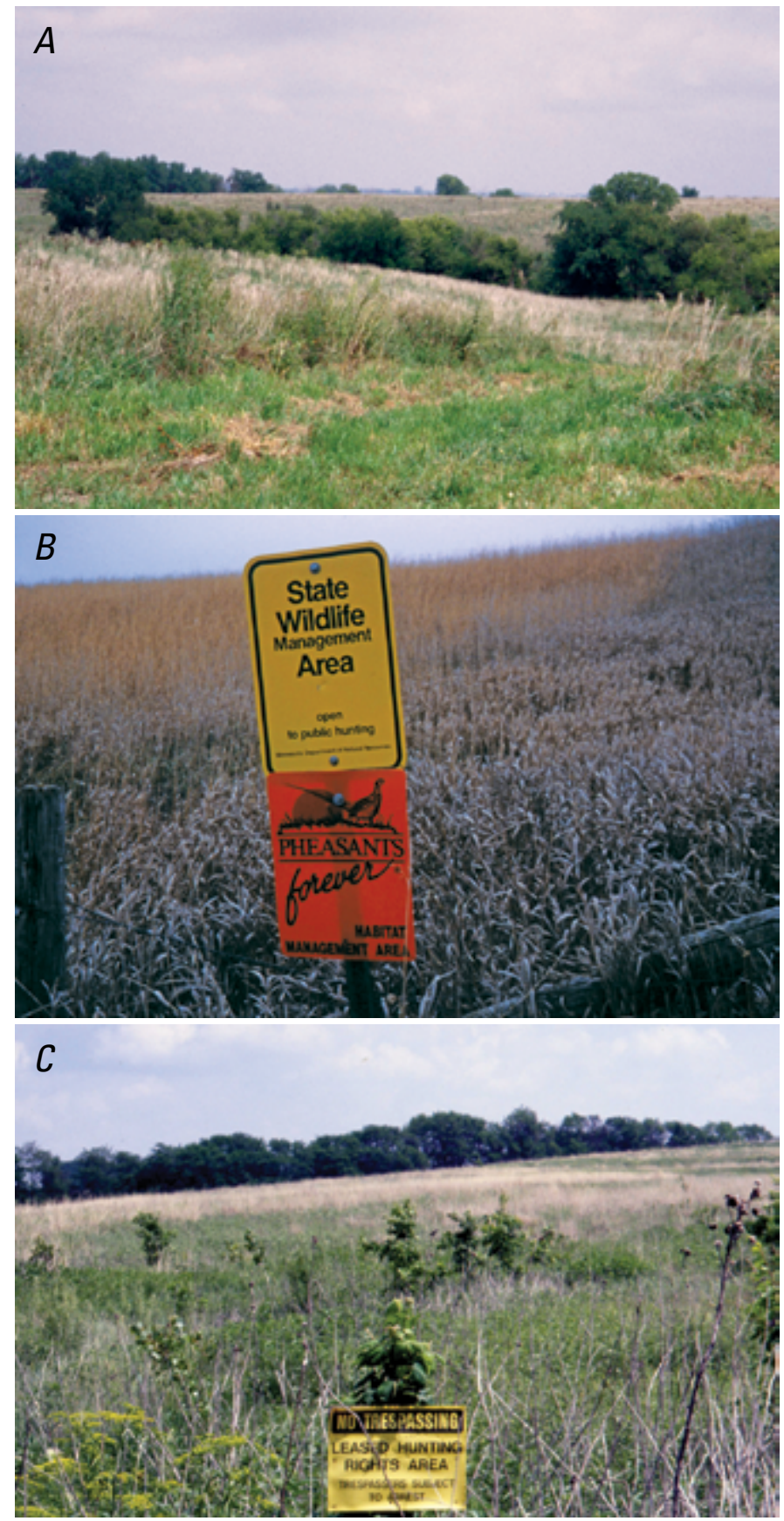

Figure 4. Areas of grassland/shrubland in Western Corn Belt Plains Ecoregion. $A$, Grassy field on sloped land in lowa County, lowa. $B$, Prairie grasses, in wildlife habitat maintained by state and private conservation organizations, in southwestern Minnesota. $C$, Conservation Reserve Program field in northwestern Missouri. wildlife-habitat areas, as well as, in the latter parts of the study period, idled Conservation Reserve Program (CRP) farmland (fig. 4). Developed land was present in major cities such as Omaha, Nebraska, and Des Moines, Iowa, as well as in many small farm towns across the ecoregion (fig. 5). Little exurban development occurred except on the fringes of the cities. Wetland was a minor land-use/land-cover class in the ecoregion, present primarily in bottomland riparian areas and herbaceous marshes.

\section{Contemporary Land-Cover Change (1973 to 2000)}

The overall spatial change (the percentage of land area that changed at least one time) in the Western Corn Belt Plains Ecoregion between 1973 and 2000 is 3.2 percent (table 1). Compared to other Great Plains ecoregions, change in the ecoregion was low (fig. 6). The Western Corn Belt Plains Ecoregion changed less than the Northern Glaciated Plains and Northwestern Glaciated Plains Ecoregions to the
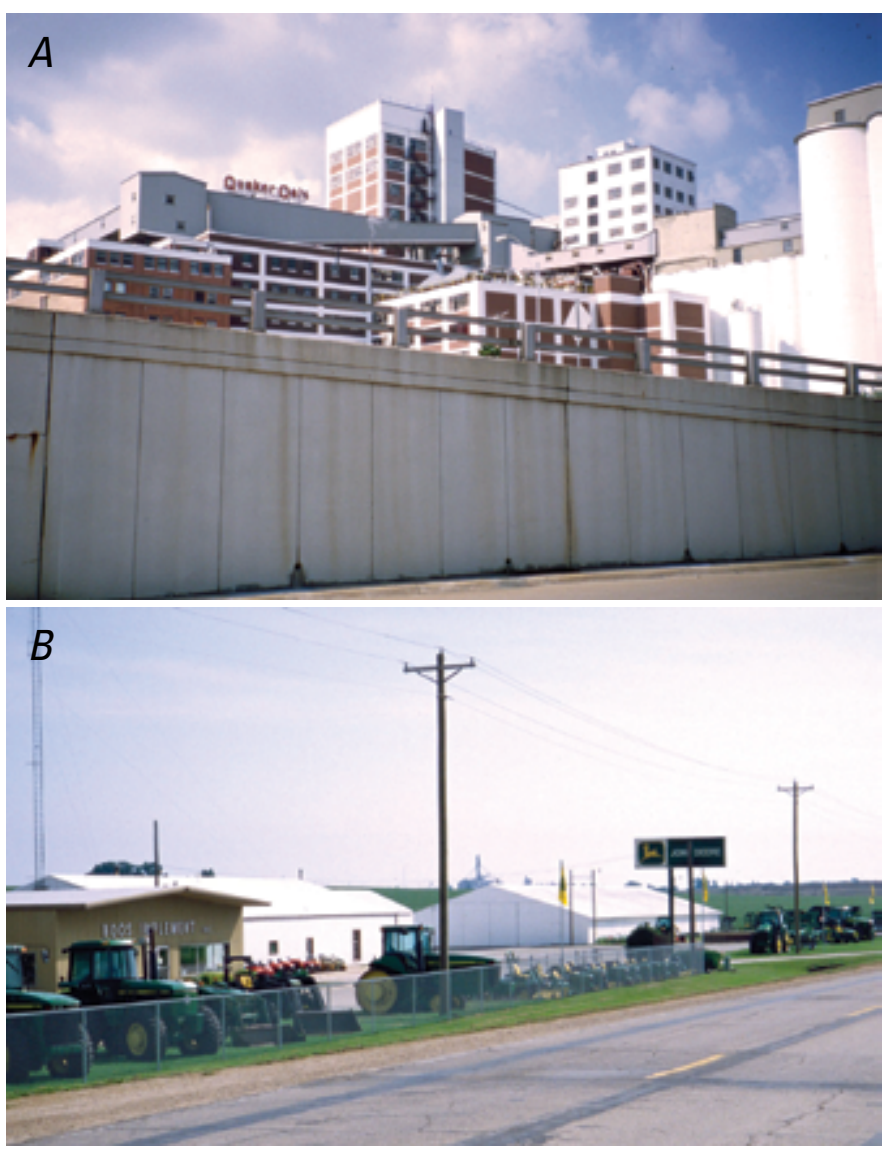

Figure 5. Developed areas in Western Corn Belt Plains Ecoregion. A, Food-processing plant and other buildings in Cedar Rapids, lowa. $B$, Farm equipment business, a common sight in many small towns in ecoregion. 
northwest, the Nebraska Sand Hills and Central Great Plains Ecoregions to the southwest, and the Central Irregular Plains Ecoregion to the south, but it experienced more overall change than the Flint Hills Ecoregion to the south-southwest (fig. 6). Most of the change (2.6 percent) occurred only one time during the study period, but some areas ( 0.6 percent) experienced multiple changes (table 1). Typical examples of land that experienced multiple changes in the ecoregion were agricultural land taken out of production and converted to grassland/shrubland, as well as areas that shifted back and forth between wetland and water, owing to changing climatic cycles. The last two time periods (1986-1992, 1992-2000) had more change than the first two time periods (1973-1980, 1980-1986) (table 2). When the uneven time periods were normalized to an annual rate of change, the periods between 1986 and 1992 and between 1992 and 2000 had the highest rate of change (0.2 percent), and the periods between 1973 and 1980 and between 1980 and 1986 had the lowest rate of change ( 0.1 percent) (fig. 7$)$.

Land cover and land use within the Western Corn Belt Plains Ecoregion was fairly stable during the study period (1973-2000). Agriculture and grassland/shrubland had the most net change during the study period, followed by developed (table 3). Agriculture constituted 90 percent of the ecoregion in 1973, declining to 87.9 percent by 2000

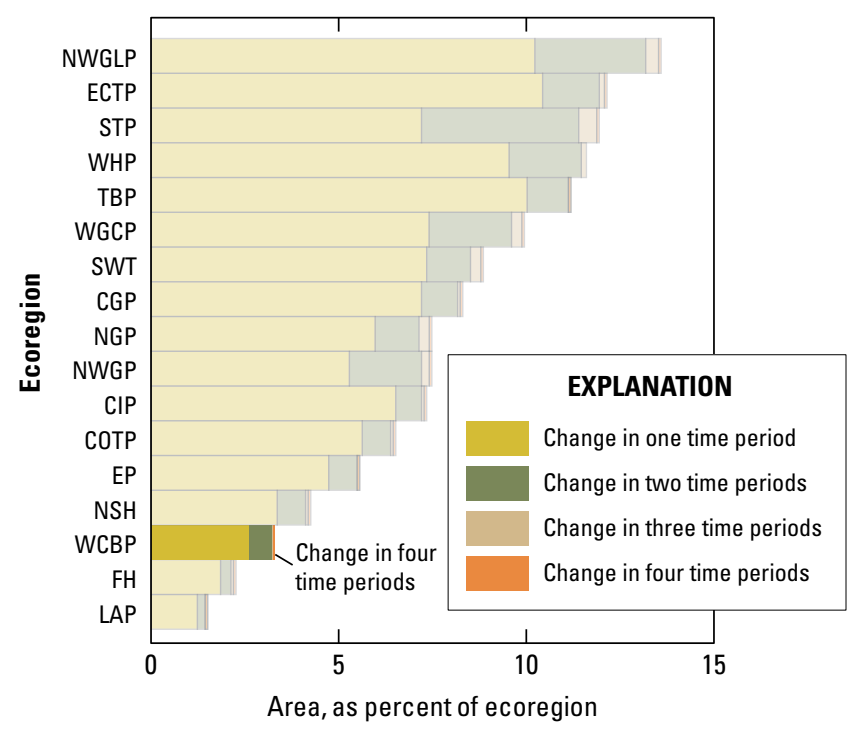

Figure 6. Overall spatial change in Western Corn Belt Plains Ecoregion (WCBP; darker bars) compared with that of all 17 Great Plains ecoregions (lighter bars). Each horizontal set of bars shows proportions of ecoregion that changed during one, two, three, or four time periods; highest level of spatial change in Western Corn Belt Plains Ecoregion (four time periods) labeled for clarity. See table 2 for years covered by each time period. See appendix 2 for key to ecoregion abbreviations. (table 3) primarily through conversion to grassland/shrubland, developed, and, to lesser extent, water and wetland (table 4). Related to this loss was a net gain of 1.4 percent in grassland/ shrubland (table 3). Most of the change from agriculture to grassland/shrubland occurred during the last two time periods (1986-1992, 1992-2000) when the CRP was in effect (table 4). The CRP paid farmers to retire marginal cropland to native grasslands through contracts, usually 10 years in duration. The initial implementation of the CRP had the greatest effect between 1986 and 1992, when conversions from agriculture to grassland/shrubland increased substantially (table 4; fig. 8). Although some land in the ecoregion may have been under a second CRP contract by the year 2000, much grassland/shrubland reverted to agriculture between 1992 and 2000, probably owing to CRP land being placed back into production (table 4; fig. 8) (Leathers and Harrington, 2000). The conversion of agriculture to water, mostly in the form of new reservoirs of various sizes, was a small but noteworthy factor in the loss of agriculture land cover. Agricultural land also was lost through grassland- and wetland-restoration efforts within the ecoregion, especially during the second half of the study period (Fletcher and Koford, 2003; Schilling and Spooner, 2006); however, on a ecoregional scale, such efforts affected only small areas of farmland. Grassland- and wetlandrestoration efforts can result in more permanent conversions of agricultural land, whereas conversions of agricultural land enrolled in the CRP can be temporary (fig. 9).

An increase in developed land was the third largest net change ( 0.5 percent) in the ecoregion between 1973 and 2000 (table 3). The conversion of agriculture to developed was the most permanent change in the ecoregion. The Western

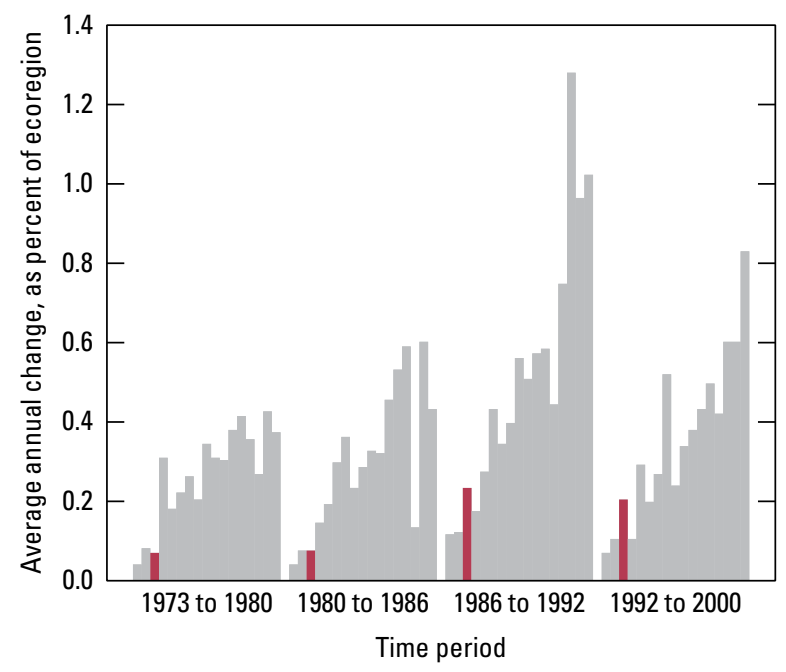

Figure 7. Estimates of land-cover change per time period, normalized to annual rates of change for all 17 Great Plains ecoregions (gray bars). Estimates of change for Western Corn Belt Plains Ecoregion are represented by red bars in each time period. 
Corn Belt Plains Ecoregion gained an estimated 1,102 km² of developed land (table 3), 1,033 km² of which was from agricultural land (table 4). The number of people needed to farm and support agricultural land continued to decrease during the study period, and many rural counties continued to decline in population (Waisanen, 2003). However, small- and medium-sized urban areas in the ecoregion attracted people, especially as service-based employment became a larger part of urban economies. Manufacturing remained as an important part of the economy of the ecoregion, and smaller cities benefited by physically growing by adding new, small-scale manufacturing plants (Waisanen, 2003) (fig. 10).

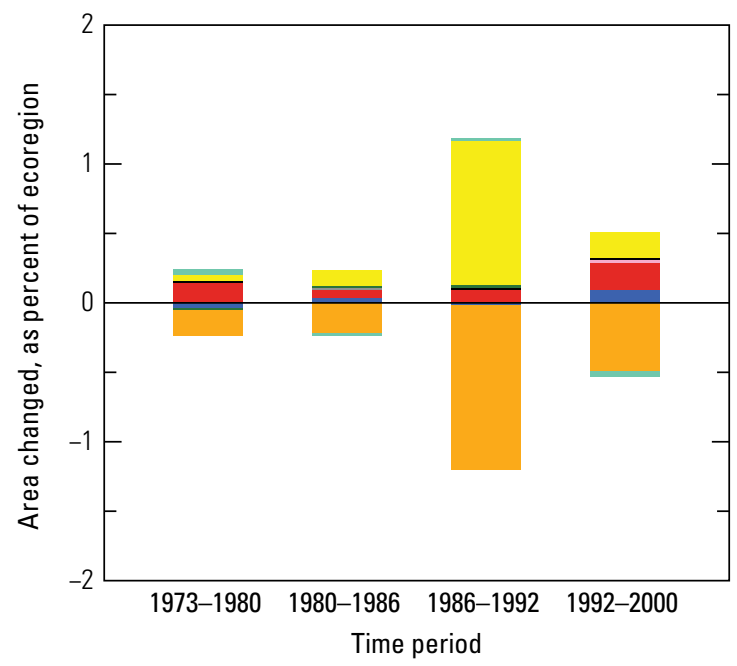

EXPLANATION

LAND-USE/LAND-COVER CLASS

\begin{tabular}{ll}
\hline Water & $\square$ Forest \\
Developed & $\square$ Grassland/Shrubland \\
Transitional & $\square$ Agriculture \\
Mining & $\square$ Wetland \\
\hline Barren & $\square$ Nonmechanically disturbed \\
& $\square$ Ice/Snow
\end{tabular}

Figure 8. Normalized average net change in Western Corn Belt Plains Ecoregion by time period for each land-cover class. Bars above zero axis represent net gain, whereas bars below zero represent net loss. Note that not all land-cover classes shown in explanation may be represented in figure. See appendix 3 for definitions of land-use/land-cover classifications.
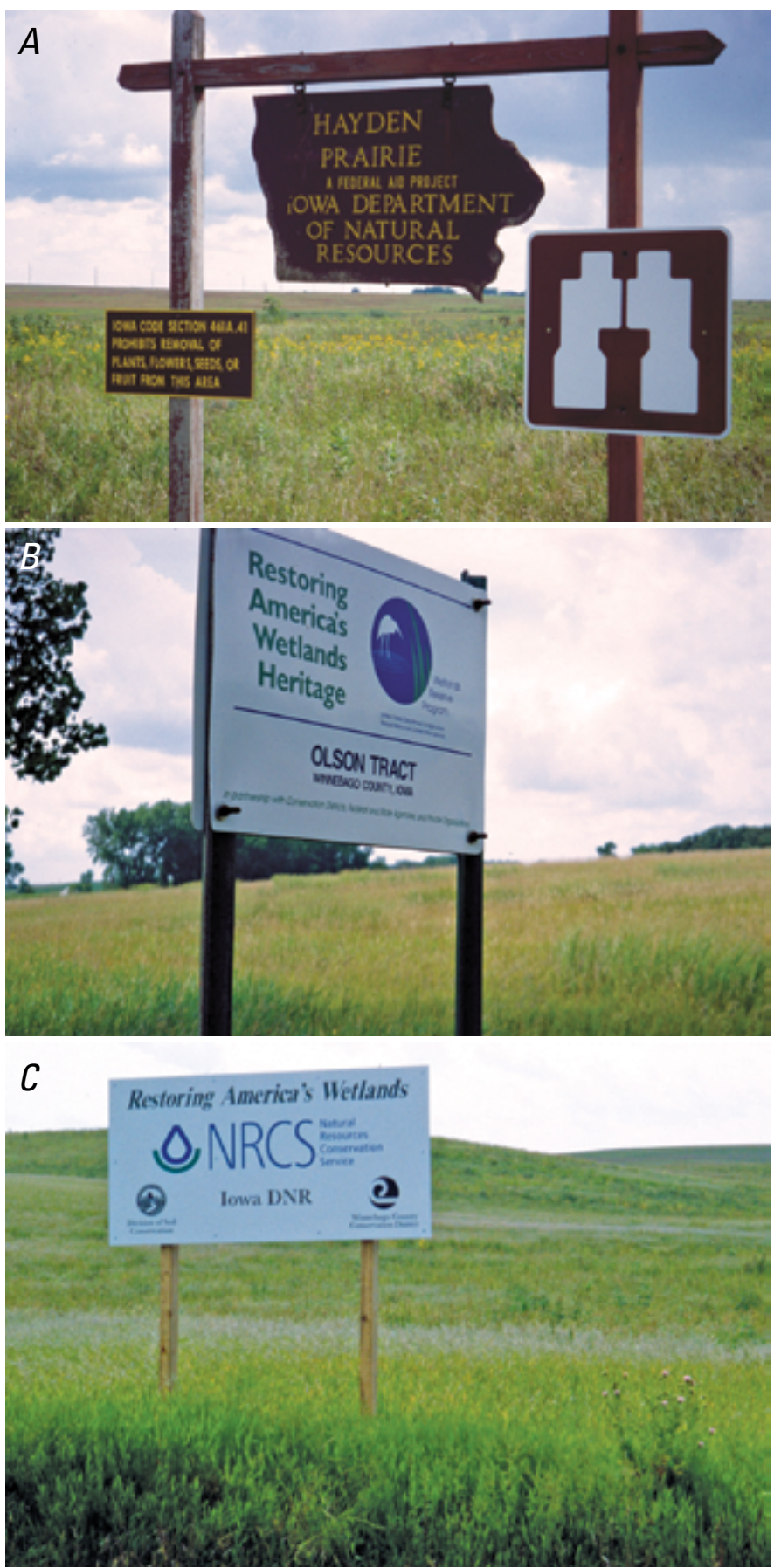

Figure 9. Restoration efforts in Western Corn Belt Plains Ecoregion. $A$, Tallgrass prairie conservation and restoration in northern lowa. $B$, Wetlands restoration, in Winnebago County, lowa, a cooperative effort by multiple parties. $C$, Federal- and statefunded wetlands restoration project in Winnebago County, lowa. 

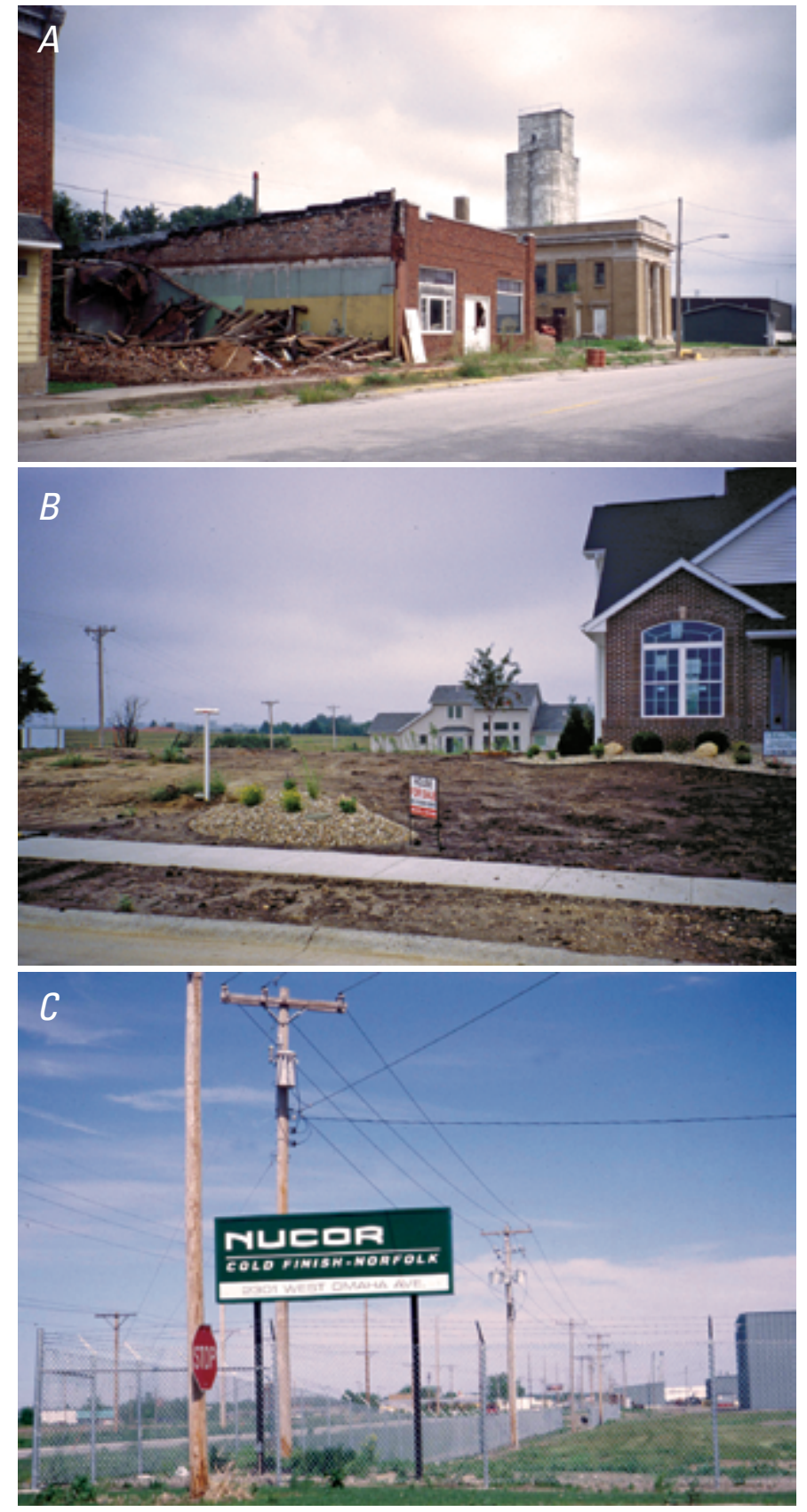

Figure 10. Developed areas in Western Corn Belt Plains Ecoregion. $A$, Abandoned businesses in small east-central lowa town, one of many farm towns in decline in ecoregion. $B$, New housing in Walford, lowa, just southwest of Cedar Rapids. Most newly developed land was on edge of cities or in nearby small towns. $C$, New manufacturing plant that makes new steel products from scrap metal, in Norfolk, Nebraska, one of several small cities attracting new industries. 
Table 1. Percentage of Western Corn Belt Plains Ecoregion land cover that changed at least one time during study period (19732000) and associated statistical error.

[Most sample pixels remained unchanged (96.8 percent), whereas 3.2 percent changed at least once throughout study period]

\begin{tabular}{crrrrrr}
\hline $\begin{array}{c}\text { Number } \\
\text { of } \\
\text { changes }\end{array}$ & $\begin{array}{c}\text { Percent } \\
\text { of } \\
\text { ecoregion }\end{array}$ & $\begin{array}{c}\text { Margin } \\
\text { of error } \\
(+/-\%)\end{array}$ & $\begin{array}{c}\text { Lower } \\
\text { bound } \\
(\%)\end{array}$ & $\begin{array}{c}\text { Upper } \\
\text { bound } \\
(\%)\end{array}$ & $\begin{array}{c}\text { Standard } \\
\text { error } \\
(\%)\end{array}$ & $\begin{array}{c}\text { Relative } \\
\text { error } \\
(\%)\end{array}$ \\
\hline 1 & 2.6 & 0.7 & 1.9 & 3.3 & 0.5 & 17.5 \\
2 & 0.6 & 0.2 & 0.4 & 0.7 & 0.1 & 20.0 \\
3 & 0.0 & 0.0 & 0.0 & 0.1 & 0.0 & 35.1 \\
4 & 0.0 & 0.0 & 0.0 & 0.0 & 0.0 & 44.6 \\
\hline $\begin{array}{l}\text { Overall } \\
\text { spatial } \\
\text { change }\end{array}$ & 3.2 & 0.8 & 2.5 & 4.0 & 0.5 & 16.1 \\
\hline
\end{tabular}

Table 2. Raw estimates of change in Western Corn Belt Plains Ecoregion land cover, computed for each of four time periods between 1973 and 2000, and associated error at 85 -percent confidence level.

[Estimates of change per period normalized to annual rate of change for each time period]

\begin{tabular}{cccccccc}
\hline Period & $\begin{array}{c}\text { Total change } \\
\text { (\%) of } \\
\text { ecoregion) }\end{array}$ & $\begin{array}{c}\text { Margin of } \\
\text { error } \\
(+/-\%)\end{array}$ & $\begin{array}{c}\text { Lower } \\
\text { bound } \\
(\%)\end{array}$ & $\begin{array}{c}\text { Upper bound } \\
\text { (\%) }\end{array}$ & $\begin{array}{c}\text { Standard } \\
\text { error } \\
(\%)\end{array}$ & $\begin{array}{c}\text { Relative } \\
\text { error } \\
(\%)\end{array}$ & $\begin{array}{c}\text { Average } \\
\text { rate } \\
\text { (\% per year) }\end{array}$ \\
\hline \multicolumn{7}{c}{ Estimate of change, in percent stratum } \\
\hline $1973-1980$ & 0.5 & 0.2 & 0.3 & 0.7 & 0.1 & 28.6 & 0.1 \\
$1980-1986$ & 0.5 & 0.2 & 0.3 & 0.6 & 0.1 & 23.0 & 0.1 \\
$1986-1992$ & 1.4 & 0.4 & 1.0 & 1.7 & 0.2 & 17.7 & 0.2 \\
$1992-2000$ & 1.6 & 0.4 & 1.2 & 2.0 & 0.3 & 17.3 & 0.2 \\
\hline $1973-1980$ & 1,002 & 421 & 581 & 1,422 & 286 & 28.6 & 143 \\
$1980-1986$ & 991 & 334 & 657 & 1,326 & 228 & 23.0 & 165 \\
$1986-1992$ & 2,972 & 771 & 2,201 & 3,744 & 525 & 17.7 & 495 \\
$1992-2000$ & 3,496 & 886 & 2,609 & 4,382 & 604 & 17.3 & 437 \\
\hline
\end{tabular}


Table 3. Estimated area (and margin of error) of each land-cover class in Western Corn Belt Plains Ecoregion, calculated five times between 1973 and 2000. See appendix 3 for definitions of land-cover classifications.

\begin{tabular}{|c|c|c|c|c|c|c|c|c|c|c|c|c|c|c|c|c|c|c|c|c|}
\hline & \multicolumn{2}{|c|}{ Water } & \multicolumn{2}{|c|}{ Developed } & \multicolumn{2}{|c|}{$\begin{array}{l}\text { Mecha- } \\
\text { nically } \\
\text { disturbed }\end{array}$} & \multicolumn{2}{|c|}{ Mining } & \multicolumn{2}{|c|}{ Barren } & \multicolumn{2}{|c|}{ Forest } & \multicolumn{2}{|c|}{$\begin{array}{l}\text { Grassland/ } \\
\text { Shrubland }\end{array}$} & \multicolumn{2}{|c|}{ Agriculture } & \multicolumn{2}{|c|}{ Wetland } & \multicolumn{2}{|c|}{$\begin{array}{c}\text { Non- } \\
\text { mechanically } \\
\text { disturbed }\end{array}$} \\
\hline & $\%$ & $+/-$ & $\%$ & $+/-$ & $\%$ & $+/-$ & $\%$ & $+1-$ & $\%$ & $+/-$ & $\%$ & $+/-$ & $\%$ & $+/-$ & $\%$ & $+/-$ & $\%$ & $+/-$ & $\%$ & $+1-$ \\
\hline \multicolumn{21}{|c|}{ Area, in percent stratum } \\
\hline 1973 & 0.8 & 0.5 & 1.7 & 0.7 & 0.0 & 0.0 & 0.1 & 0.0 & 0.0 & 0.0 & 3.3 & 0.9 & 2.5 & 0.7 & 90.0 & 2.0 & 1.6 & 0.9 & 0.0 & 0.0 \\
\hline 1980 & 0.8 & 0.5 & 1.8 & 0.8 & 0.0 & 0.0 & 0.1 & 0.0 & 0.0 & 0.0 & 3.2 & 0.9 & 2.5 & 0.7 & 89.8 & 2.1 & 1.7 & 1.0 & 0.0 & 0.0 \\
\hline 1986 & 0.8 & 0.5 & 1.9 & 0.8 & 0.0 & 0.0 & 0.1 & 0.0 & 0.0 & 0.0 & 3.3 & 0.9 & 2.6 & 0.7 & 89.6 & 2.1 & 1.7 & 1.0 & 0.0 & 0.0 \\
\hline 1992 & 0.8 & 0.5 & 2.0 & 0.9 & 0.0 & 0.0 & 0.1 & 0.0 & 0.0 & 0.0 & 3.3 & 0.9 & 3.7 & 0.9 & 88.4 & 2.3 & 1.7 & 1.0 & 0.0 & 0.0 \\
\hline 2000 & 0.9 & 0.5 & 2.2 & 1.0 & 0.0 & 0.0 & 0.1 & 0.1 & 0.0 & 0.0 & 3.3 & 0.9 & 3.9 & 1.0 & 87.9 & 2.4 & 1.7 & 1.0 & 0.0 & 0.0 \\
\hline $\begin{array}{l}\text { Net } \\
\text { change }\end{array}$ & 0.1 & 0.2 & 0.5 & 0.3 & 0.0 & 0.0 & 0.1 & 0.0 & 0.0 & 0.0 & 0.0 & 0.0 & 1.4 & 0.4 & -2.1 & 0.6 & 0.0 & 0.1 & 0.0 & 0.0 \\
\hline $\begin{array}{l}\text { Gross } \\
\text { change }\end{array}$ & 0.4 & 0.2 & 0.5 & 0.3 & 0.0 & 0.0 & 0.1 & 0.1 & 0.0 & 0.0 & 0.2 & 0.1 & 2.0 & 0.5 & 2.7 & 0.7 & 0.3 & 0.1 & 0.0 & 0.0 \\
\hline \multicolumn{21}{|c|}{ Area, in square kilometers } \\
\hline 1973 & 1,745 & 1,121 & 3,670 & 1,479 & 9 & 13 & 131 & 59 & 9 & 13 & 7,061 & 1,924 & 5,452 & 1,460 & 194,763 & 4,378 & 3,523 & 2,040 & 0 & 0 \\
\hline 1980 & 1,683 & 1,098 & 3,984 & 1,691 & 15 & 15 & 172 & 79 & 3 & 4 & 7,003 & 1,913 & 5,517 & 1,472 & 194,370 & 4,520 & 3,615 & 2,179 & 0 & 0 \\
\hline 1986 & 1,776 & 1,123 & 4,109 & 1,775 & 9 & 10 & 178 & 81 & 9 & 12 & 7,073 & 1,934 & 5,731 & 1,504 & 193,890 & 4,613 & 3,588 & 2,166 & 0 & 0 \\
\hline 1992 & 1,741 & 1,114 & 4,321 & 1,944 & 2 & 2 & 217 & 104 & 8 & 9 & 7,093 & 1,956 & 7,987 & 2,010 & 191,340 & 4,998 & 3,655 & 2,205 & 0 & 0 \\
\hline 2000 & 1,952 & 1,159 & 4,772 & 2,143 & 17 & 16 & 245 & 122 & 11 & 14 & 7,088 & 1,943 & 8,406 & 2,066 & 190,276 & 5,267 & 3,597 & 2,216 & 0 & 0 \\
\hline $\begin{array}{l}\text { Net } \\
\text { change }\end{array}$ & 207 & 356 & 1,102 & 717 & 8 & 5 & 114 & 81 & 2 & 2 & 26 & 91 & 2,955 & 882 & $-4,487$ & 1,331 & 74 & 210 & 0 & 0 \\
\hline $\begin{array}{l}\text { Gross } \\
\text { change }\end{array}$ & 774 & 391 & 1,102 & 717 & 50 & 37 & 218 & 114 & 20 & 27 & 341 & 111 & 4,414 & 1,151 & 5,794 & 1,443 & 560 & 258 & 0 & 0 \\
\hline
\end{tabular}


Table 4. Principal land-cover conversions in Western Corn Belt Plains Ecoregion, showing amount of area changed (and margin of error, calculated at 85-percent confidence level) for each conversion during each of four time periods and also during overall study period. See appendix 3 for definitions of land-cover classifications.

[Values given for “other” classes are combined totals of values for other land-cover classes not listed in that time period. Abbreviations: n/a, not applicable]

\begin{tabular}{|c|c|c|c|c|c|c|c|c|}
\hline Period & From class & To class & & $\begin{array}{c}\begin{array}{c}\text { Area } \\
\text { changed }\end{array} \\
\left(\mathbf{k m}^{2}\right)\end{array}$ & $\begin{array}{c}\text { Margin of } \\
\text { error } \\
\left(+/-\mathrm{km}^{2}\right)\end{array}$ & $\begin{array}{c}\text { Standard } \\
\text { error } \\
\left(\mathrm{km}^{2}\right)\end{array}$ & $\begin{array}{l}\text { Percent of } \\
\text { ecoregion }\end{array}$ & $\begin{array}{l}\text { Percent of } \\
\text { all changes }\end{array}$ \\
\hline \multirow[t]{7}{*}{ 1973-1980 } & Agriculture & Developed & & 301 & 236 & 161 & 0.1 & 30.1 \\
\hline & Water & Wetland & & 159 & 153 & 104 & 0.1 & 15.9 \\
\hline & Agriculture & Grassland/Shrubland & & 155 & 80 & 54 & 0.1 & 15.4 \\
\hline & Grassland/Shrubland & Agriculture & & 89 & 74 & 51 & 0.0 & 8.9 \\
\hline & Wetland & Water & & 65 & 55 & 37 & 0.0 & 6.4 \\
\hline & Other & Other & & 233 & $\mathrm{n} / \mathrm{a}$ & $\mathrm{n} / \mathrm{a}$ & 0.1 & 23.3 \\
\hline & & & Totals & 1,002 & & & 0.5 & 100.0 \\
\hline \multirow[t]{7}{*}{ 1980-1986 } & Agriculture & Grassland/Shrubland & & 303 & 120 & 81 & 0.1 & 30.6 \\
\hline & Agriculture & Developed & & 114 & 95 & 65 & 0.1 & 11.5 \\
\hline & Wetland & Water & & 106 & 83 & 56 & 0.0 & 10.7 \\
\hline & Water & Wetland & & 69 & 52 & 35 & 0.0 & 7.0 \\
\hline & Grassland/Shrubland & Forest & & 55 & 38 & 26 & 0.0 & 5.5 \\
\hline & Other & Other & & 344 & $\mathrm{n} / \mathrm{a}$ & $\mathrm{n} / \mathrm{a}$ & 0.2 & 34.7 \\
\hline & & & Totals & 991 & & & 0.5 & 100.0 \\
\hline \multirow[t]{7}{*}{ 1986-1992 } & Agriculture & Grassland/Shrubland & & 2,311 & 702 & 478 & 1.1 & 77.8 \\
\hline & Agriculture & Developed & & 198 & 192 & 131 & 0.1 & 6.7 \\
\hline & Water & Wetland & & 89 & 83 & 57 & 0.0 & 3.0 \\
\hline & Agriculture & Wetland & & 46 & 46 & 31 & 0.0 & 1.6 \\
\hline & Grassland/Shrubland & Forest & & 42 & 27 & 19 & 0.0 & 1.4 \\
\hline & Other & Other & & 285 & $\mathrm{n} / \mathrm{a}$ & $\mathrm{n} / \mathrm{a}$ & 0.1 & 9.6 \\
\hline & & & Totals & 2,972 & & & 1.4 & 100.0 \\
\hline \multirow[t]{7}{*}{ 1992-2000 } & Agriculture & Grassland/Shrubland & & 1,514 & 606 & 413 & 0.7 & 43.3 \\
\hline & Grassland/Shrubland & Agriculture & & 1,014 & 403 & 274 & 0.5 & 29.0 \\
\hline & Agriculture & Developed & & 419 & 226 & 154 & 0.2 & 12.0 \\
\hline & Agriculture & Water & & 98 & 103 & 70 & 0.0 & 2.8 \\
\hline & Wetland & Water & & 59 & 50 & 34 & 0.0 & 1.7 \\
\hline & Other & Other & & 391 & $\mathrm{n} / \mathrm{a}$ & $\mathrm{n} / \mathrm{a}$ & 0.2 & 11.2 \\
\hline & & & Totals & 3,496 & & & 1.6 & 100.0 \\
\hline \multirow{7}{*}{$\begin{array}{c}\text { 1973-2000 } \\
\text { (overall) }\end{array}$} & Agriculture & Grassland/Shrubland & & 4,283 & 1,137 & 774 & 2.0 & 50.6 \\
\hline & Grassland/Shrubland & Agriculture & & 1,175 & 461 & 314 & 0.5 & 13.9 \\
\hline & Agriculture & Developed & & 1,033 & 691 & 471 & 0.5 & 12.2 \\
\hline & Water & Wetland & & 334 & 203 & 138 & 0.2 & 4.0 \\
\hline & Wetland & Water & & 264 & 127 & 87 & 0.1 & 3.1 \\
\hline & Other & Other & & 1,372 & $\mathrm{n} / \mathrm{a}$ & $\mathrm{n} / \mathrm{a}$ & 0.6 & 16.2 \\
\hline & & & Totals & 8,461 & & & 3.9 & 100.0 \\
\hline
\end{tabular}




\section{References Cited}

Dinsmore, J.J., 1994, A country so full of game-The story of wildlife in Iowa: Iowa City, University of Iowa Press, 249 p.

Fletcher, R.J., Jr., and Koford, R.R., 2003, Changes in breeding bird populations with habitat restoration in northern Iowa: American Midland Naturalist, v. 150, p. 83-94.

Karnitz, Holly, and Asbjornsen, Heidi, 2006, Composition and age structure of a degraded tallgrass oak savanna in central Iowa: Natural Areas, v. 26, p. 179-186.

Kottek, M.J., Grieser, J., Beck, C., Rudolf, B., and Rubel, F., 2006, World map of the Köppen-Geiger climate classification updated: Meteorologische Zeitschrift, v. 15, no. 3, p. 259-263, available at http://www.schweizerbart.de/papers/ metz/detail/15/55034/World_Map_of_the_Koppen_Geiger_climate_classificat.

Leathers, N., and Harrington, L.M.B., 2000, Effectiveness of conservation reserve programs and land "slippage" in southwestern Kansas: Professional Geographer, v. 52, no. 1, p. 83-93.

Omernik, J.M., 1987, Ecoregions of the conterminous United States: Annals of the Association of American Geographers, v. 77 , no. 1, p. 118-125.

PRISM Climate Group, 2006, Precipitation-Annual climatology (1971-2000): PRISM Climate Group, Oregon State University database, accessed August 29, 2008, at http://prism.nacse.org/documents/.

Schilling, K.E., and Spooner, Jean, 2006, Effects of watershedscale land-use change on stream nitrate concentrations: Journal of Environmental Quality, v. 35, p. 2,132-2,145.
Timmerman, Janet, 2001, Draining the great oasis, in Amato, A.J., Timmerman, J., and Amato, J.A., eds., Draining the great oasis-An environmental history of Murray County, Minnesota: Marshall, Minn., Crossings Press, p. 125-141.

U.S. Environmental Protection Agency, 1997, Descriptions of level III ecological regions for the CEC report on ecological regions of North America: U.S. Environmental Protection Agency database, accessed April 12, 2006, at http://www. epa.gov/wed/pages/ecoregions/na_eco.htm\#Downloads.

U.S. Environmental Protection Agency, 2002, Primary distinguishing characteristics of level III ecoregions of the continental United States: U.S. Environmental Protection Agency database, accessed September 22, 2008, at http:// www.epa.gov/wed/pages/ecoregions/level_iii.htm.

Vileisis, Ann, 1997, Discovering the unknown landscape-A history of America's wetlands: Washington, D.C., Island Press, $433 \mathrm{p}$.

Vogelmann, J.E., Howard, S.M., Yang, L., Larson, C.R., Wylie, B.K., and van Driel, N., 2001, Completion of the 1990s National Land Cover Data Set for the conterminous United States from Landsat Thematic Mapper data and ancillary data sources: Photogrammetric Engineering \& Remote Sensing, v. 67, p. 650-662.

Waisanen, P.J., 2003, Land-use and land-cover change in the Western Corn Belt Plains Ecoregion, 1970-2000: Brookings, South Dakota State University, M.S. thesis, 124 p. 


\section{East-Central Plains Ecoregions}

*

s.

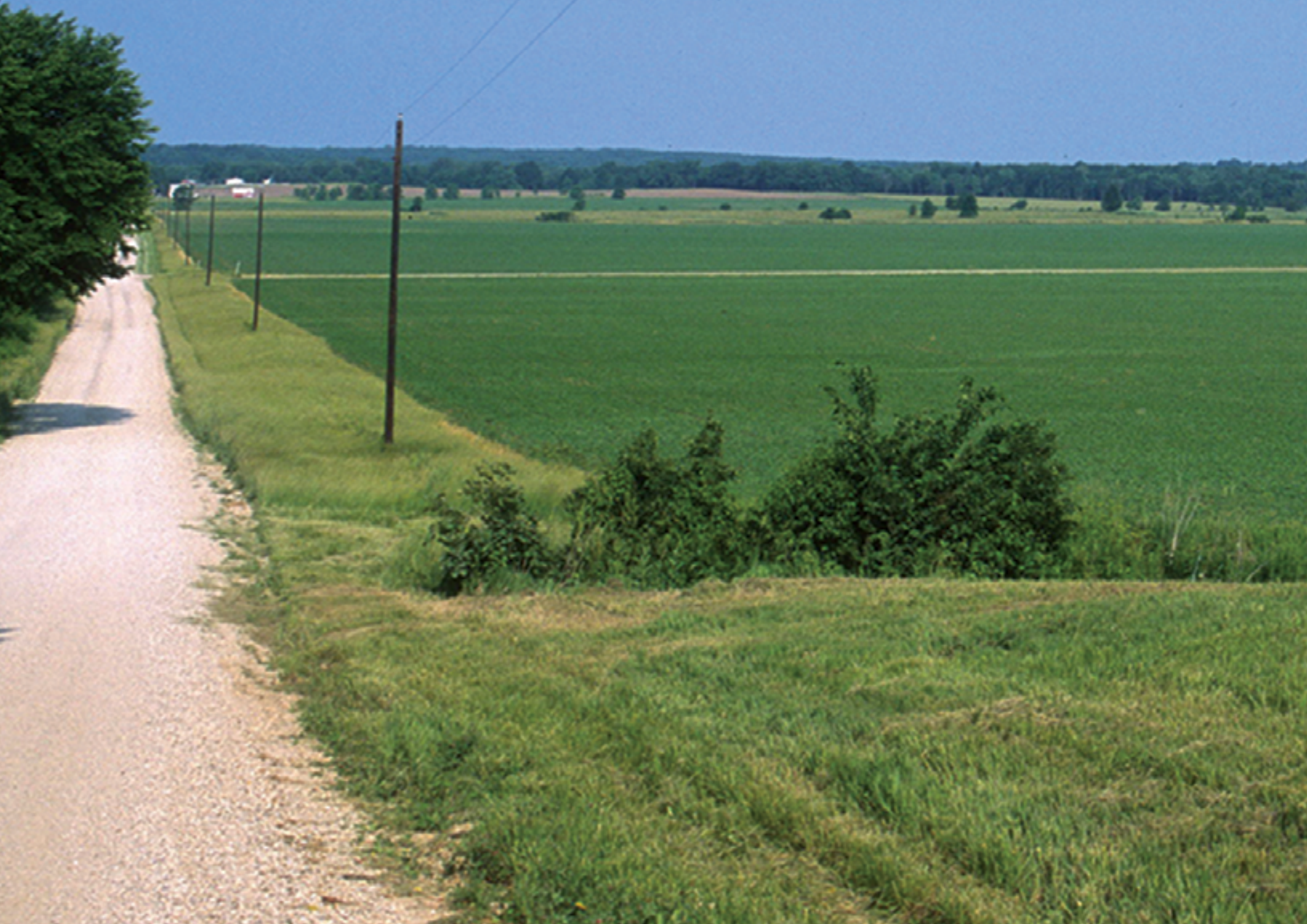




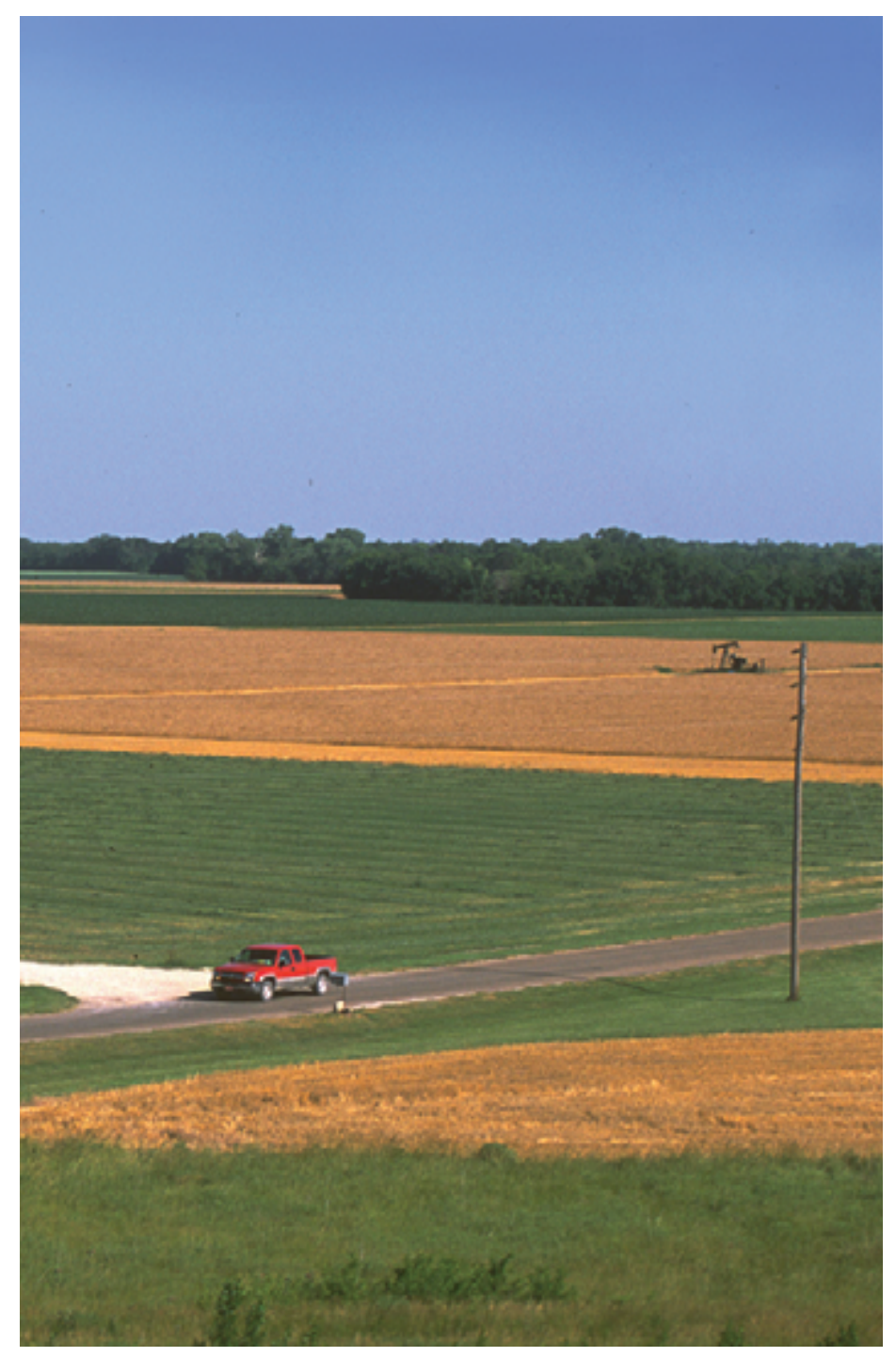




\title{
Central Irregular Plains Ecoregion
}

\author{
By Krista A. Karstensen
}

\section{Ecoregion Description}

The Central Irregular Plains Ecoregion encompasses $122,589 \mathrm{~km}^{2}\left(47,332 \mathrm{mi}^{2}\right)$ of southern Iowa, northern and central Missouri, eastern Kansas, and northeastern Oklahoma (fig. 1) (Omernik, 1987; U.S. Environmental Protection Agency, 1997). The ecoregion is surrounded by (clockwise, from the north) the Western Corn Belt Plains, Interior River Lowland, Ozark Highlands, Boston Mountains, Arkansas Valley, Central Oklahoma/Texas Plains, and Flint Hills Ecoregions (fig. 1). The most populous cities in the ecoregion are Kansas City, Missouri, and Tulsa, Oklahoma, with populations of 441,545 and 393,049, respectively, in the year 2000 (U.S. Census Bureau, 2010).

The topography of the Central Irregular Plains Ecoregion is more variable than that of the Western Corn Belt Plains Ecoregion to the north but less irregular and less forested than that of the ecoregions to the south and east (Chapman and

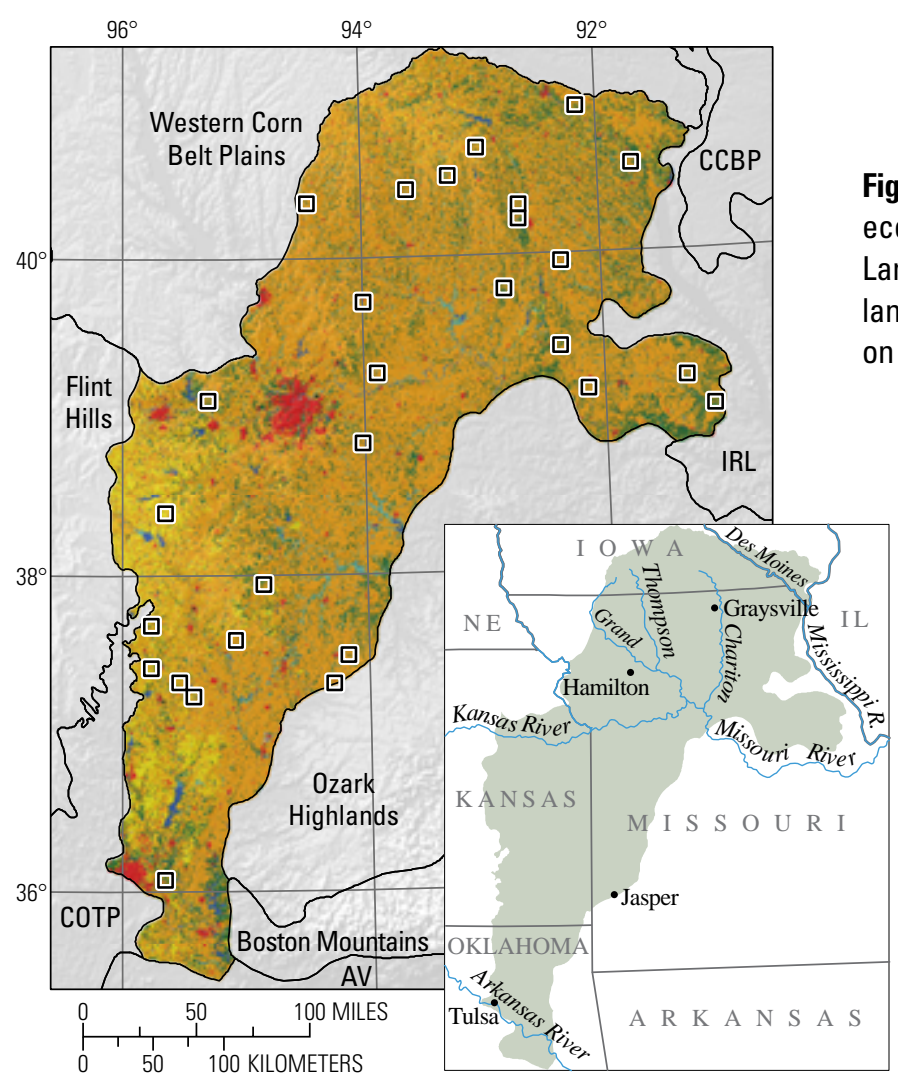

Figure 1. Map of Central Irregular Plains Ecoregion and surrounding ecoregions, showing land-use/land-cover classes from 1992 National Land Cover Dataset (Vogelmann and others, 2001); note that not all land-use/land-cover classes shown in explanation may be depicted on map; note also that, for this "Status and Trends of Land Change" study, transitional land-cover class was subdivided into mechanically

\section{EXPLANATION}

Land-use/land-cover class

Water

Developed

Transitional

Mining

Barren

Forest

Grassland/Shrubland

Agriculture

Wetland

Ice/Snow

Ecoregion boundary

․ Sample block (10 x 10 km) disturbed and nonmechanically disturbed classes. Squares indicate locations of $10 \times 10 \mathrm{~km}$ sample blocks analyzed in study. Index map shows locations of geographic features mentioned in text. Abbreviations for Great Plains ecoregions are listed in appendix 2. Also shown are parts of five Midwest-South Central United States ecoregions: Arkansas Valley (AV), Boston Mountains, Central Corn Belt Plains (CCBP), Interior River Lowland (IRL), and Ozark Highlands. See appendix 3 for definitions of landuse/land-cover classifications. 
(32-40 in.) (Chapman and others, 2002). In 1993, the

Mississippi River system flood (known informally as the "Great Flood of 1993;" Johnson and others, 2004) inundated a large part of the ecoregion's agricultural areas in northern Missouri and southern Iowa. Although patterns of flooding in this ecoregion depend on basin size and topography, the high incidence of large floods in the central Midwest and upper Mississippi River valley (for example, the 1993 flood) also is due to the mesoscale convective complexes-large, multiple-celled, persistent thunderstorm systems largely fed by moisture from the Gulf of Mexico - that frequently strike the ecoregion ( $\mathrm{O}^{\prime}$ Connor and Costa, 2003).

Glacial tills form the parent material for most of the soil in Iowa and the northern part of Missouri, whereas the

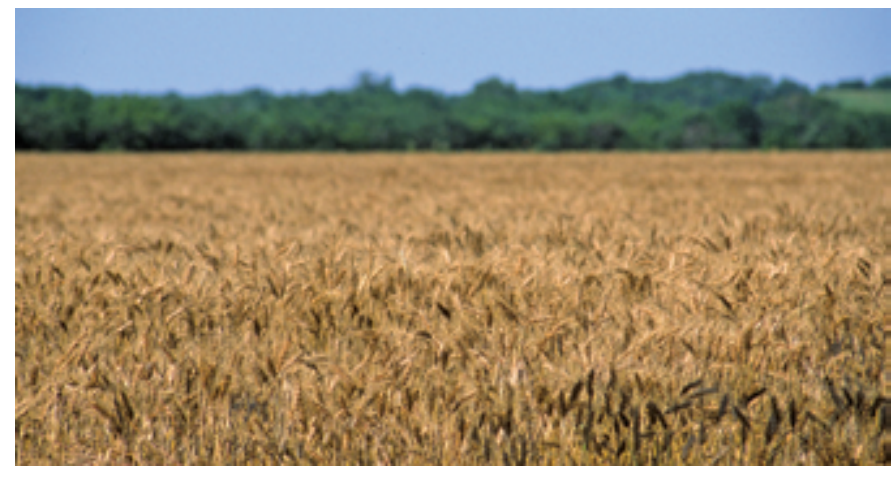

Figure 2. Wheat field near Jasper, Missouri, in Central Irregular Plains Ecoregion.

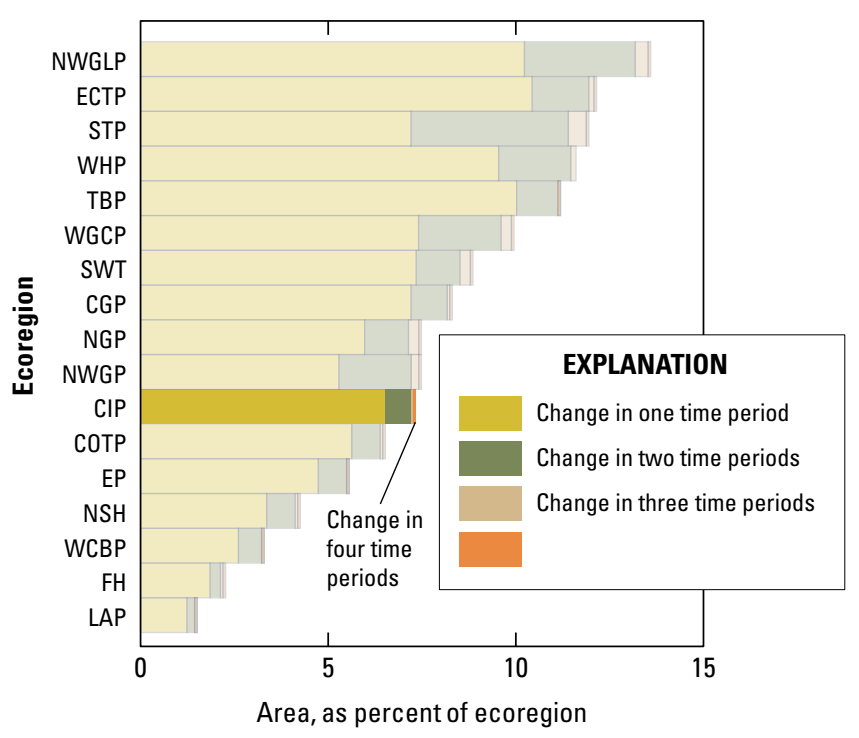

Figure 3. Overall spatial change in Central Irregular Plains Ecoregion (CIP; darker bars) compared with that of all 17 Great Plains ecoregions (lighter bars). Each horizontal set of bars shows proportions of ecoregion that experienced change during one, two, three, or four time periods; highest level of spatial change in Central Irregular Plains Ecoregion (four time periods) labeled for clarity. See table 2 for years covered by each time period. See appendix 2 for key to ecoregion abbreviations. southern part of the ecoregion was not glaciated (Chapman and others, 2002). Loess deposits generally increase near the Missouri River (Chapman and others, 2002). The southwestern part of the ecoregion (west-central Missouri, western Kansas, and northern Oklahoma) has claypan soils and a smoother topography (Chapman, and others, 2002).

Although the Central Irregular Plains Ecoregion has a variety of land uses, agriculture dominates much of the landscape. The gently rolling topography and generally fertile soils are conducive to various agricultural practices such as contour farming, which is common in Iowa and northern Missouri (Chapman and others, 2002). Crops common to the ecoregion include corn, soybeans, wheat (fig. 2), and sorghum (U.S. Department of Agriculture, 2009b,c,d,e). Cattle production also is an important land use (U.S. Department of Agriculture, 2009b,c,d,e). Most Iowa counties in this ecoregion have 50 percent or more of their land in agricultural production (U.S. Department of Agriculture, 2009b). The Conservation Reserve Program (CRP) is a Federal program created in 1985 to provide financial assistance to eligible farmers to help manage natural resource concerns on their land, particularly through the conversion of marginal agricultural land to grassland/shrubland.

\section{Contemporary Land-Cover Change (1973 to 2000)}

The overall spatial change (the percentage of land area that changed at least one time) in the Central Irregular Plains Ecoregion between 1973 and 2000 is 7.3 percent (table 1). Compared to other Great Plains ecoregions, change in the ecoregion was moderate, but it was greater than in two neighboring ecoregions: the Flint Hills Ecoregion, mostly rangeland, and the intensively cropped Western Corn Belt Plains Ecoregion (fig. 3). An estimated 6.5 percent of the ecoregion changed one time during the 27-year study period, while 0.7 percent changed two times and 0.1 percent changed three times.

Change percentages varied only slightly from 1973 to 2000 , with the total change (percent of the ecoregion affected) ranging from a low of 1.8 percent to a high of 2.2 percent (table 2). The average annual rate of change was highest between 1980 and 1986, at 0.4 percent $\left(444 \mathrm{~km}^{2}\right)$ per year (table 2; fig. 4).

In 2000, agriculture was the largest land-cover class in the ecoregion, estimated at 59.9 percent $\left(73,466 \mathrm{~km}^{2}\right)$, with a net decrease of 3.0 percent over the study period (table 3 ; fig. 5). Large areas of agricultural land were converted to grassland/shrubland and developed land. Forest was the second largest land-cover class, encompassing 20.4 percent $\left(24,956 \mathrm{~km}^{2}\right)$ of the ecoregion in 1973 and 20.0 percent $\left(24,539 \mathrm{~km}^{2}\right)$ in 2000 (table 3). Grassland/shrubland, the third most extensive land-cover class, increased from 13.5 percent $\left(16,572 \mathrm{~km}^{2}\right)$ of the ecoregion in 1973 to 15.9 percent $\left(19,462 \mathrm{~km}^{2}\right)$ in 2000 (table 3). 
Overall, the most common land-cover conversion in every study period was the conversion from agriculture to grassland/shrubland. Between 1973 and 2000, 5,366 km² were converted from agriculture to grassland/shrubland (table 4). However, this conversion did not result in a large net increase in grassland/shrubland because, during the same time period, the second most common conversion was from grassland/shrubland to agricultural land (2,128 $\mathrm{km}^{2}$ ). The inception of the Conservation Reserve Program (CRP) and the economic crisis of the 1980s may explain much of this conversion. Forested land also declined in the ecoregion, which can be attributed primarily to clearing for agricultural expansion.

Economics play an important role in the land-use story of the Central Irregular Plains Ecoregion. Major factors influencing conversion of agricultural land to grassland/ shrubland during the study period include the economic crisis of the 1980s, the socioeconomic repercussions of the "Great Flood of 1993" (Johnson and others, 2004), and the CRP.

The economic climate of the 1970s encouraged farmers to expand production to benefit from improved export opportunities, strong commodity prices, increased farm income, and higher farmland values. Abundant credit financed the expansion as high rates of inflation and low real interest rates encouraged investment in farmland, and many farmers took on heavy debt loads, becoming vulnerable to sudden shifts in economic forces (Stam and Dixon, 2004; Cofer and others, 2009).

The economic crisis of the early 1980s greatly changed these conditions as export markets contracted and input

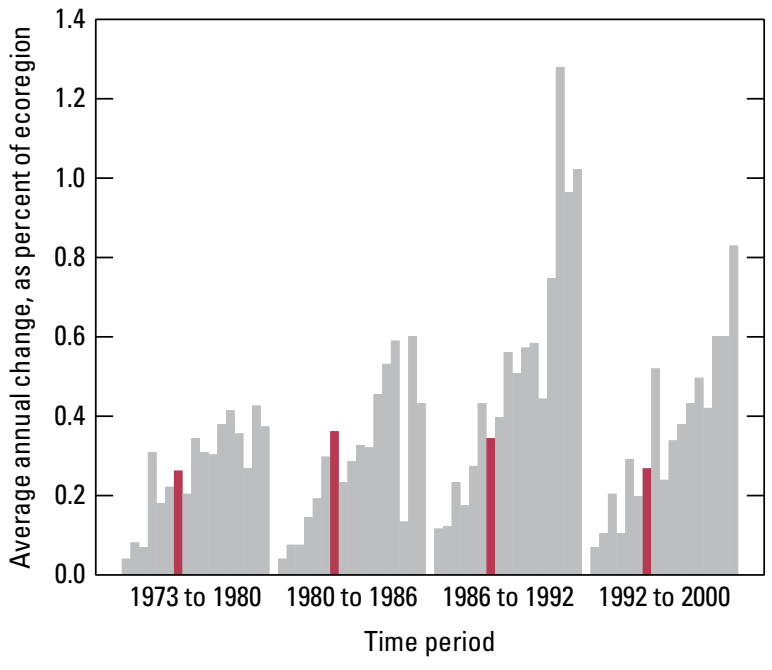

Figure 4. Normalized average net change in Central Irregular Plains Ecoregion by time period for each land-cover class. Bars above zero axis represent net gain, whereas bars below zero represent net loss. Note that not all land-cover classes shown in explanation may be represented in figure. See appendix 3 for definitions of land-use/land-cover classifications. prices and interest rates rose. The financial stress became more severe when declines in farm commodity prices, income, and land values (the asset used to secure debt) made it difficult for some farmers to service their debts (Stam and Dixon, 2004; Cofer and others, 2009). The crisis may have had an influence in the amount of agricultural land that was converted to grassland/shrubland in the 1980s. The associated banking crisis of the early 1980s imposed particular economic hardship on small, family-operated farms as many farm banks failed, and many farms faced foreclosure. Many of these farms may have been converted from agricultural land to grassland/shrubland.

The "Great Flood of 1993" devastated cropland, also influencing land-use changes in the Central Irregular Plains Ecoregion. From April 1 to August 31, 1993, precipitation amounts approached 1,219 $\mathrm{mm}$ (48 in.) in east-central Iowa, surpassing the normal annual precipitation average of 762 to $914 \mathrm{~mm}$ (30-36 in.) in that area (Johnson and others, 2004). The extent of the damage caused by the flood to agricultural resources shows how climatic influences may affect landcover change by decreasing agricultural production.

The inception of the CRP in 1985 contributed significantly to the conversion from agriculture to grassland/

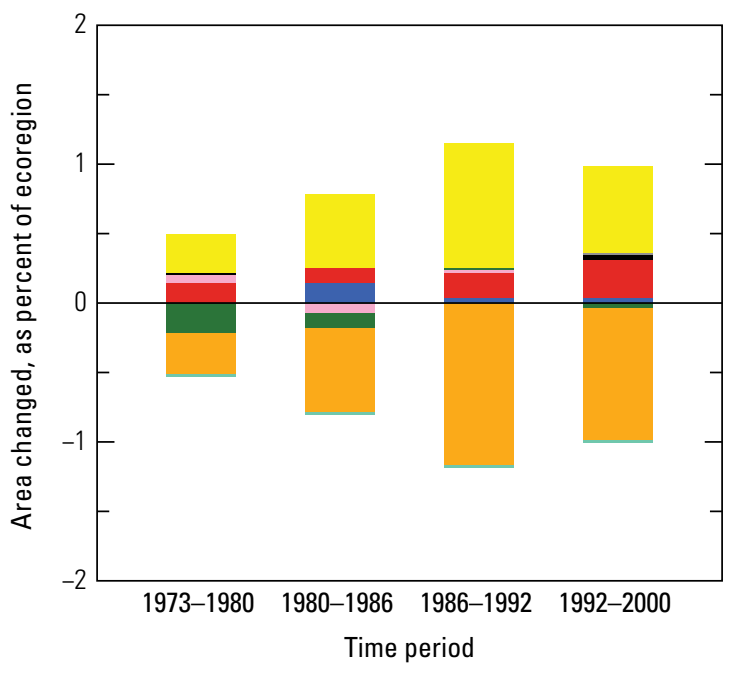

EXPLANATION LAND-USE/LAND-COVER CLASS

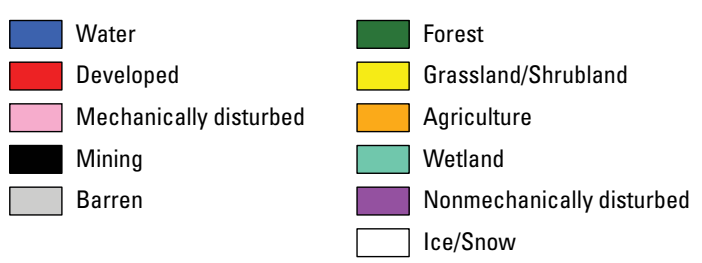

Figure 5. Estimates of land-cover change per time period, normalized to annual rates of change for all 17 Great Plains ecoregions (gray bars). Estimates of change for Central Irregular Plains Ecoregion are represented by red bars in each time period. 
shrubland (fig. 6). The CRP annual cumulative enrollment statistics show that the acreage enrolled in CRP greatly increased between 1986 and 1992, from $321 \mathrm{~km}^{2}$ (79,400 acres) to 5,058 $\mathrm{km}^{2}$ (1,250,000 acres), respectively, before declining in 2000 by about $647 \mathrm{~km}^{2}$ (160,000 acres) (U.S. Department of Agriculture, 2009a).

No-till conservation tillage was encouraged in many parts of the ecoregion in the 1980s, and it continues to be widely practiced. Conservation tillage provides a more economical way to manage cropland, and it likely contributed to grassland/shrubland being converted back to agriculture (fig. 7) (U.S. Department of Agriculture, 1997). Between 1990 and 2010, the population and settlements of the Amish-a distinctly rural people who live on and cultivate small but diversified farms - increased throughout the ecoregion (Elizabethtown College, 2010), possibly adding to the increase in agriculture.

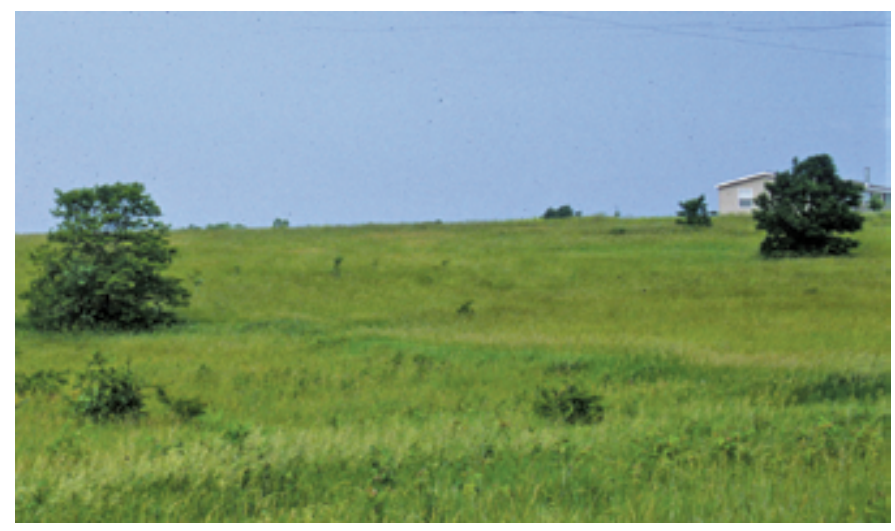

Figure 6. Land enrolled in Conservation Reserve Program, near Graysville, Missouri, in Central Irregular Plains Ecoregion.

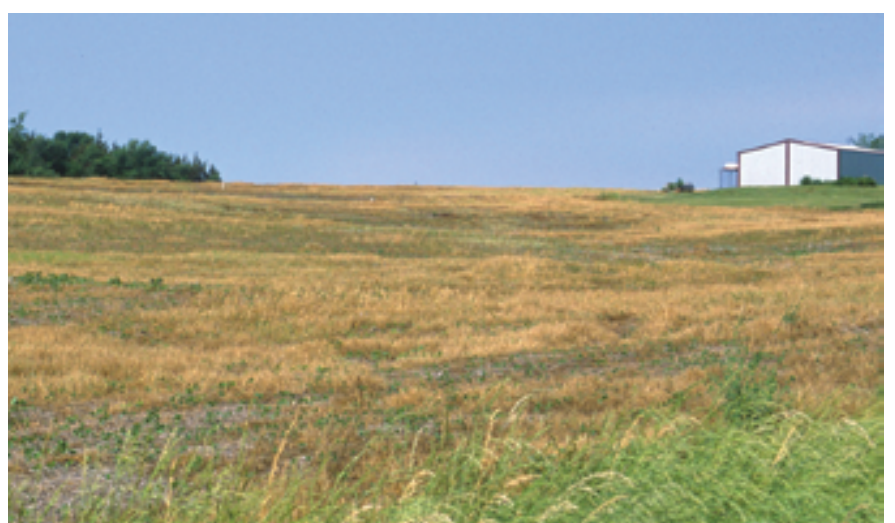

Figure 7. Conservation tillage on farm near Hamilton, Missouri, in Central Irregular Plains Ecoregion.

Table 1. Percentage of Central Irregular Plains Ecoregion land cover that changed at least one time during study period (19732000) and associated statistical error.

[Most sample pixels remained unchanged ( 92.7 percent), whereas 7.3 percent changed at least once throughout study period]

\begin{tabular}{cllcccc}
\hline $\begin{array}{c}\text { Number } \\
\text { of } \\
\text { changes }\end{array}$ & $\begin{array}{c}\text { Percent } \\
\text { of } \\
\text { ecoregion }\end{array}$ & $\begin{array}{c}\text { Margin } \\
\text { of error } \\
(+/-\%)\end{array}$ & $\begin{array}{c}\text { Lower } \\
\text { bound } \\
(\%)\end{array}$ & $\begin{array}{c}\text { Upper } \\
\text { bound } \\
(\%)\end{array}$ & $\begin{array}{c}\text { Standard } \\
\text { error } \\
(\%)\end{array}$ & $\begin{array}{c}\text { Relative } \\
\text { error } \\
(\%)\end{array}$ \\
\hline 1 & 6.5 & 1.7 & 4.8 & 8.2 & 1.1 & 17.5 \\
2 & 0.7 & 0.4 & 0.4 & 1.0 & 0.2 & 32.1 \\
3 & 0.1 & 0.1 & 0.0 & 0.1 & 0.0 & 64.1 \\
4 & 0.0 & 0.0 & 0.0 & 0.0 & 0.0 & 98.8 \\
\hline Overall & & & & & & \\
spatial \\
change
\end{tabular}


Table 2. Raw estimates of change in Central Irregular Plains Ecoregion land cover, computed for each of four time periods between 1973 and 2000, and associated error at 85-percent confidence level.

[Estimates of change per period normalized to annual rate of change for each period]

\begin{tabular}{|c|c|c|c|c|c|c|c|}
\hline Period & $\begin{array}{c}\text { Total change } \\
\text { (\% of ecoregion) }\end{array}$ & $\begin{array}{c}\text { Margin of } \\
\text { error } \\
(+/-\%)\end{array}$ & $\begin{array}{c}\text { Lower } \\
\text { bound } \\
(\%)\end{array}$ & $\begin{array}{c}\text { Upper bound } \\
(\%)\end{array}$ & $\begin{array}{c}\text { Standard } \\
\text { error } \\
(\%)\end{array}$ & $\begin{array}{c}\text { Relative } \\
\text { error } \\
(\%)\end{array}$ & $\begin{array}{r}\text { Average rate } \\
\text { (\% per year) }\end{array}$ \\
\hline \multicolumn{8}{|c|}{ Estimate of change, in percent stratum } \\
\hline 1973-1980 & 1.8 & 0.6 & 1.2 & 2.4 & 0.4 & 22.3 & 0.3 \\
\hline 1980-1986 & 2.2 & 0.8 & 1.3 & 3.0 & 0.6 & 25.6 & 0.4 \\
\hline 1986-1992 & 2.0 & 0.6 & 1.4 & 2.7 & 0.4 & 20.8 & 0.3 \\
\hline $1992-2000$ & 2.2 & 0.8 & 1.3 & 3.0 & 0.6 & 25.9 & 0.3 \\
\hline \multicolumn{8}{|c|}{ Estimate of change, in square kilometers } \\
\hline 1973-1980 & 2,218 & 734 & 1,484 & 2,951 & 495 & 22.3 & 317 \\
\hline 1980-1986 & 2,663 & 1,012 & 1,652 & 3,675 & 683 & 25.6 & 444 \\
\hline 1986-1992 & 2,511 & 774 & 1,737 & 3,285 & 522 & 20.8 & 418 \\
\hline 1992-2000 & 2,644 & 1,017 & 1,628 & 3,661 & 686 & 25.9 & 331 \\
\hline
\end{tabular}


Table 3. Estimated area (and margin of error) of each land-cover class in Central Irregular Plains Ecoregion, calculated five times between 1973 and 2000. See appendix 3 for definitions of land-cover classifications.

\begin{tabular}{|c|c|c|c|c|c|c|c|c|c|c|c|c|c|c|c|c|c|c|c|c|}
\hline & \multicolumn{2}{|c|}{ Water } & \multicolumn{2}{|c|}{ Developed } & \multicolumn{2}{|c|}{$\begin{array}{l}\text { Mecha- } \\
\text { nically } \\
\text { disturbed }\end{array}$} & \multicolumn{2}{|c|}{ Mining } & \multicolumn{2}{|c|}{ Barren } & \multicolumn{2}{|c|}{ Forest } & \multicolumn{2}{|c|}{$\begin{array}{c}\text { Grassland/Shru- } \\
\text { bland }\end{array}$} & \multicolumn{2}{|c|}{ Agriculture } & \multicolumn{2}{|c|}{ Wetland } & \multicolumn{2}{|c|}{$\begin{array}{c}\text { Non- } \\
\text { mechanically } \\
\text { disturbed }\end{array}$} \\
\hline & $\%$ & $+/-$ & $\%$ & $+/-$ & $\%$ & $+/-$ & $\%$ & $+1-$ & $\%$ & $+1-$ & $\%$ & $+/-$ & $\%$ & $+/-$ & $\%$ & $+/-$ & $\%$ & $+/-$ & $\%$ & $+/-$ \\
\hline 1973 & 0.7 & 0.2 & 1.4 & 0.4 & 0.0 & 0.0 & 0.0 & 0.0 & 0.0 & 0.0 & 20.4 & 3.1 & 13.5 & 3.3 & 62.9 & 4.4 & 1.0 & 0.4 & 0.0 & 0.0 \\
\hline 1980 & 0.7 & 0.2 & 1.5 & 0.5 & 0.1 & 0.1 & 0.0 & 0.0 & 0.0 & 0.0 & 20.1 & 3.1 & 13.8 & 3.4 & 62.7 & 4.4 & 1.0 & 0.4 & 0.0 & 0.0 \\
\hline 1992 & 0.9 & 0.2 & 1.8 & 0.7 & 0.0 & 0.0 & 0.1 & 0.0 & 0.0 & 0.0 & 20.0 & 3.1 & 15.2 & 3.7 & 60.9 & 4.6 & 1.0 & 0.4 & 0.0 & 0.0 \\
\hline 2000 & 0.9 & 0.2 & 2.1 & 0.8 & 0.0 & 0.0 & 0.1 & 0.0 & 0.0 & 0.0 & 20.0 & 3.1 & 15.9 & 3.8 & 59.9 & 4.8 & 1.0 & 0.4 & 0.0 & 0.0 \\
\hline $\begin{array}{l}\text { Net } \\
\text { change }\end{array}$ & 0.2 & 0.1 & 0.7 & 0.4 & 0.0 & 0.0 & 0.1 & 0.0 & 0.0 & 0.0 & -0.3 & 0.2 & 2.4 & 1.5 & -3.0 & 1.6 & 0.0 & 0.0 & 0.0 & 0.0 \\
\hline $\begin{array}{l}\text { Gross } \\
\text { change }\end{array}$ & 0.3 & 0.1 & 0.7 & 0.4 & 0.2 & 0.1 & 0.1 & 0.0 & 0.0 & 0.0 & 0.7 & 0.2 & 4.2 & 1.3 & 4.8 & 1.4 & 0.0 & 0.0 & 0.0 & 0.0 \\
\hline \multicolumn{21}{|c|}{ Area, in square kilometers } \\
\hline 1980 & 831 & 213 & 1,894 & 596 & 88 & 88 & 54 & 30 & 35 & 38 & 24,697 & 3,751 & 16,912 & 4,202 & 76,813 & 5,399 & 1,265 & 517 & 0 & 0 \\
\hline 1986 & 1,011 & 246 & 2,022 & 660 & 0 & 0 & 58 & 31 & 30 & 37 & 24,564 & 3,755 & 17,575 & 4,321 & 76,072 & 5,518 & 1,257 & 512 & 0 & 0 \\
\hline 1992 & 1,059 & 247 & 2,259 & 798 & 5 & 8 & 73 & 36 & 29 & 37 & 24,570 & 3,766 & 18,694 & 4,533 & 74,648 & 5,694 & 1,253 & 510 & 0 & 0 \\
\hline 2000 & 1,100 & 247 & 2,611 & 975 & 8 & 7 & 110 & 57 & 42 & 39 & 24,539 & 3,741 & 19,462 & 4,692 & 73,466 & 5,920 & 1,251 & 509 & 0 & 0 \\
\hline $\begin{array}{l}\text { Net } \\
\text { change }\end{array}$ & 279 & 127 & 889 & 537 & -21 & 36 & 82 & 52 & 14 & 13 & -418 & 290 & 2,890 & 1,888 & $-3,700$ & 2,009 & -16 & 20 & 0 & 0 \\
\hline $\begin{array}{l}\text { Gross } \\
\text { change }\end{array}$ & 389 & 147 & 892 & 536 & 219 & 177 & 84 & 52 & 29 & 33 & 873 & 254 & 5,116 & 1,643 & 5,907 & 1,734 & 40 & 24 & 0 & 0 \\
\hline
\end{tabular}


Table 4. Principal land-cover conversions in Central Irregular Plains Ecoregion, showing amount of area changed (and margin of error, calculated at 85-percent confidence level) for each conversion during each of four time periods and also during overall study period. See appendix 3 for definitions of land-cover classifications.

[Values given for “other” classes are combined totals of values for other land-cover classes not listed in that time period. Abbreviations: n/a, not applicable]

\begin{tabular}{|c|c|c|c|c|c|c|c|c|}
\hline Period & From class & To class & & $\begin{array}{c}\begin{array}{c}\text { Area } \\
\text { changed }\end{array} \\
\left(\mathbf{k m}^{2}\right)\end{array}$ & $\begin{array}{c}\text { Margin of } \\
\text { error } \\
\left(+/-\mathrm{km}^{2}\right)\end{array}$ & $\begin{array}{c}\text { Standard } \\
\text { error } \\
\left(\mathbf{k m}^{2}\right)\end{array}$ & $\begin{array}{l}\text { Percent of } \\
\text { ecoregion }\end{array}$ & $\begin{array}{c}\text { Percent of all } \\
\text { changes }\end{array}$ \\
\hline \multirow[t]{7}{*}{ 1973-1980 } & Agriculture & Grassland/Shrubland & & 905 & 381 & 257 & 0.7 & 40.8 \\
\hline & Grassland/Shrubland & Agriculture & & 585 & 480 & 324 & 0.5 & 26.4 \\
\hline & Forest & Grassland/Shrubland & & 146 & 108 & 73 & 0.1 & 6.6 \\
\hline & Forest & Agriculture & & 144 & 65 & 44 & 0.1 & 6.5 \\
\hline & Agriculture & Developed & & 106 & 116 & 78 & 0.1 & 4.8 \\
\hline & Other & Other & & 331 & $\mathrm{n} / \mathrm{a}$ & $\mathrm{n} / \mathrm{a}$ & 0.3 & 14.9 \\
\hline & & & Totals & 2,218 & & & 1.8 & 100.0 \\
\hline \multirow[t]{7}{*}{ 1980-1986 } & Agriculture & Grassland/Shrubland & & 1,342 & 606 & 409 & 1.1 & 50.4 \\
\hline & Grassland/Shrubland & Agriculture & & 648 & 450 & 304 & 0.5 & 24.3 \\
\hline & Forest & Grassland/Shrubland & & 106 & 96 & 65 & 0.1 & 4.0 \\
\hline & Grassland/Shrubland & Forest & & 95 & 65 & 44 & 0.1 & 3.6 \\
\hline & Forest & Agriculture & & 85 & 44 & 30 & 0.1 & 3.2 \\
\hline & Other & Other & & 388 & $\mathrm{n} / \mathrm{a}$ & $\mathrm{n} / \mathrm{a}$ & 0.3 & 14.6 \\
\hline & & & Totals & 2,663 & & & 2.2 & 100.0 \\
\hline \multirow[t]{7}{*}{ 1986-1992 } & Agriculture & Grassland/Shrubland & & 1,663 & 594 & 401 & 1.4 & 66.2 \\
\hline & Grassland/Shrubland & Agriculture & & 391 & 289 & 195 & 0.3 & 15.6 \\
\hline & Agriculture & Developed & & 136 & 85 & 57 & 0.1 & 5.4 \\
\hline & Grassland/Shrubland & Forest & & 73 & 39 & 26 & 0.1 & 2.9 \\
\hline & Grassland/Shrubland & Developed & & 70 & 83 & 56 & 0.1 & 2.8 \\
\hline & Other & Other & & 178 & $\mathrm{n} / \mathrm{a}$ & $\mathrm{n} / \mathrm{a}$ & 0.1 & 7.1 \\
\hline & & & Totals & 2,511 & & & 2.0 & 100.0 \\
\hline \multirow[t]{7}{*}{ 1992-2000 } & Agriculture & Grassland/Shrubland & & 1,456 & 878 & 592 & 1.2 & 55.0 \\
\hline & Grassland/Shrubland & Agriculture & & 505 & 312 & 211 & 0.4 & 19.1 \\
\hline & Agriculture & Developed & & 206 & 139 & 94 & 0.2 & 7.8 \\
\hline & Grassland/Shrubland & Developed & & 105 & 107 & 72 & 0.1 & 4.0 \\
\hline & Grassland/Shrubland & Forest & & 89 & 54 & 36 & 0.1 & 3.4 \\
\hline & Other & Other & & 284 & $\mathrm{n} / \mathrm{a}$ & $\mathrm{n} / \mathrm{a}$ & 0.2 & 10.7 \\
\hline & & & Totals & 2,644 & & & 2.2 & 100.0 \\
\hline \multirow{7}{*}{$\begin{array}{c}\text { 1973-2000 } \\
\text { (overall) }\end{array}$} & Agriculture & Grassland/Shrubland & & 5,366 & 2,005 & 1,353 & 4.4 & 53.5 \\
\hline & Grassland/Shrubland & Agriculture & & 2,128 & 1,243 & 839 & 1.7 & 21.2 \\
\hline & Agriculture & Developed & & 503 & 253 & 171 & 0.4 & 5.0 \\
\hline & Forest & Agriculture & & 323 & 125 & 84 & 0.3 & 3.2 \\
\hline & Grassland/Shrubland & Forest & & 304 & 124 & 84 & 0.2 & 3.0 \\
\hline & Other & Other & & 1,412 & $\mathrm{n} / \mathrm{a}$ & $\mathrm{n} / \mathrm{a}$ & 1.2 & 14.1 \\
\hline & & & Totals & 10,036 & & & 8.2 & 100.0 \\
\hline
\end{tabular}




\section{References Cited}

Chapman, S.S., Omernik, J.M., Griffith, G.E., Schroeder, W.A., Nigh, T.A., and Wilton, T.F., 2002, Ecoregions of Iowa and Missouri: U.S. Geological Survey Ecoregion Map Series, scale 1:1,800,000, available at http://www.epa.gov/ wed/pages/ecoregions/moia_eco.htm.

Cofer, R.D., Walser, J.W., and Osborne, T.D., 2009, Do record farmland prices portend another steep downturn for agriculture and farm banks?: Federal Deposit Insurance Corporation database, accessed March 18, 2009, at http://www.fdic. gov/bank/analytical/quarterly/2008_vol2_4/farmland.html.

Elizabethtown College, 2010, Amish studies: Elizabethtown College, The Young Center for Anabaptist and Pietist Studies Web site, accessed November 4, 2010, at http:// www2.etown.edu/amishstudies/Index.asp.

Johnson, G.P., Holmes, R.R., and Waite, L.A., 2004, The Great Flood of 1993 on the upper Mississippi River-10 years later: U.S. Geological Survey Fact Sheet 2004-3024, 6 p., available at http://il.water.usgs.gov/pubs/fs2004-3024.pdf.

O'Connor, J.E., and Costa, J.E., 2003, Large floods in the United States-Where they happen and why: U.S. Geological Survey Circular 1245, p. 9, available at http:// pubs.usgs.gov/circ/2003/circ1245/.

Omernik, J.M., 1987, Ecoregions of the conterminous United States: Annals of the Association of American Geographers, v. 77, no. 1, p. 118-125.

Stam, J.M., and Dixon, B.L., 2004, Farmer bankruptcies and farm exits in the United States, 1899-2002: U.S. Department of Agriculture, Economic Research Service, Agriculture Information Bulletin No. 788, 36 p., accessed March 18, 2009, at http://www.ers.usda.gov/media/479214/aib788_1_.pdf.

U.S. Census Bureau, 2010, Census 2000-Demographic profiles: U.S. Census Bureau database, accessed November 4, 2010, at http://www.census.gov/prod/www/decennial.html.

U.S. Department of Agriculture, 1997, Agricultural resources and environmental indicators: U.S. Department of Agriculture, Economic Research Service, Agricultural Handbook No. 712, 347 p.

U.S. Department of Agriculture, 2002a, Plant fact sheetLittle bluestem: U.S. Department of Agriculture, Natural Resources Conservation Service Plant Fact Sheet, 2 p., accessed November 1, 2010, at http://plants.usda.gov/ factsheet/pdf/fs_scsc.pdf.
U.S. Department of Agriculture, 2002b, Plant fact sheetSideoats grama: U.S. Department of Agriculture, Natural Resources Conservation Service Plant Fact Sheet, 2 p., accessed November 1, 2010, at http://plants.usda.gov/ factsheet/pdf/fs_bocu.pdf.

U.S. Department of Agriculture, 2009a, Conservation programs - CRP contract and summary statistics: U.S. Department of Agriculture, Farm Service Agency database, accessed March 11, 2009, at http://www.fsa.usda. gov/FSA/webapp? area $=$ home\&subject $=$ copr\&topic $=c r$ p-st.

U.S. Department of Agriculture, 2009b, Iowa statistics: U.S. Department of Agriculture, National Agricultural Statistics Service database, accessed March 11, 2009, at http://www. nass.usda.gov/Statistics_by_State/Iowa/index.asp.

U.S. Department of Agriculture, 2009c, Kansas statistics: U.S. Department of Agriculture, National Agricultural Statistics Service database, accessed March 11, 2009, at http:// www.nass.usda.gov/Statistics_by_State/Kansas/index.asp.

U.S. Department of Agriculture, 2009d, Missouri statistics: U.S. Department of Agriculture, National Agricultural Statistics Service database, accessed March 11, 2009, at http://www.nass.usda.gov/Statistics_by_State/Missouri/ index.asp.

U.S. Department of Agriculture, 2009e, Oklahoma statistics: U.S. Department of Agriculture, National Agricultural Statistics Service database, accessed March 11, 2009, at http://www.nass.usda.gov/Statistics_by_State/Oklahoma/ index.asp.

U.S. Environmental Protection Agency, 1997, Descriptions of level III ecological regions for the CEC report on ecological regions of North America: U.S. Environmental Protection Agency database, accessed November 4, 2010, at http://www.epa.gov/wed/pages/ecoregions/na_eco. htm\#Downloads.

Vogelmann, J.E., Howard, S.M., Yang, L., Larson, C.R., Wylie, B.K., and van Driel, N., 2001, Completion of the 1990s National Land Cover Data Set for the conterminous United States from Landsat Thematic Mapper data and ancillary data sources: Photogrammetric Engineering \& Remote Sensing, v. 67, p. 650-662. 


\section{Chapter 11}

\section{Flint Hills Ecoregion}

\author{
By Steven Kambly
}

\section{Ecoregion Description}

The Flint Hills Ecoregion, which extends about $350 \mathrm{~km}$ north-south from Marshall County, Kansas, to Osage County, Oklahoma, includes the Flint Hills in eastern Kansas and the Osage Hills in northcentral Oklahoma. The ecoregion covers an area of about $27,911 \mathrm{~km}^{2}\left(10,777 \mathrm{mi}^{2}\right)$ and is about $100 \mathrm{~km}$ wide at its widest point, between Lyon and Marion Counties, Kansas (fig. 1) (Omernik, 1987; U.S. Environmental Protection Agency, 1997). The ecoregion is bounded on the west by the Central Great Plains Ecoregion, on the north by the Western Corn Belt Plains Ecoregion, and on the east by the Central Irregular Plains and Central Oklahoma/ Texas Plains Ecoregions.

A subhumid continental climate accounts for large daily and seasonal temperature fluctuations in the Flint Hills Ecoregion. Summer high temperatures may reach $38^{\circ} \mathrm{C}$, whereas winter temperatures may fall as low as $-12^{\circ} \mathrm{C}$. The ecoregion receives about 760 to $960 \mathrm{~mm}$ (30-38 in.) of annual precipitation, the high end of the range occurring in the southern part of the ecoregion. Most precipitation falls during the growing season, from April to September.

Expansive areas of grazed uplands and cultivated lowlands characterize the Flint Hills Ecoregion. Upland topography includes rolling hills that have moderately steep to steep slopes and areas of relatively flat terrain. Soils are derived from underlying limestones, shales, and sandstones (Malin, 1942). Many upland areas have thin soils underlain by limestone that contains bands of erosion-resistant chert, or flint, thus giving the ecoregion its name. Chert stones and rock outcroppings are scattered throughout the upland areas, making it difficult to plow for crop production. Some upland soils support farming, but cost efficiency and other

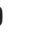


factors (including historical and sociological circumstances) contribute to the lack of upland crop production (Kollmorgen and Simonett, 1965). The lowland and lower slope soils, which include deep and permeable silt loams and silty clay loams (Bragg and Hulbert, 1976), support various crops such as wheat, corn, sorghum, soybeans, alfalfa, and oats (figs. 2,3 ). Lowland fields tend to be medium to small in size, whereas upland rangelands typically are much larger.

The ecoregion's leading land-cover class is grassland/ shrubland, dominated by warm-season grasses, particularly big bluestem (Andropogon gerardii), little bluestem (Schizachyrium scoparium), and Indiangrass (Sorghastrum nutans) (Briggs and others, 2002). Since the 1880s, the grasses have served as forage for cattle transported from Texas and other parts of the southwestern plains. The grazing season usually begins in early spring and continues during the summer, after which the cattle are shipped to slaughterhouses or feedlots. The grasses are maintained through spring burning of the lands to eliminate shrubs and small trees. With their growing tip near the surface, grasses

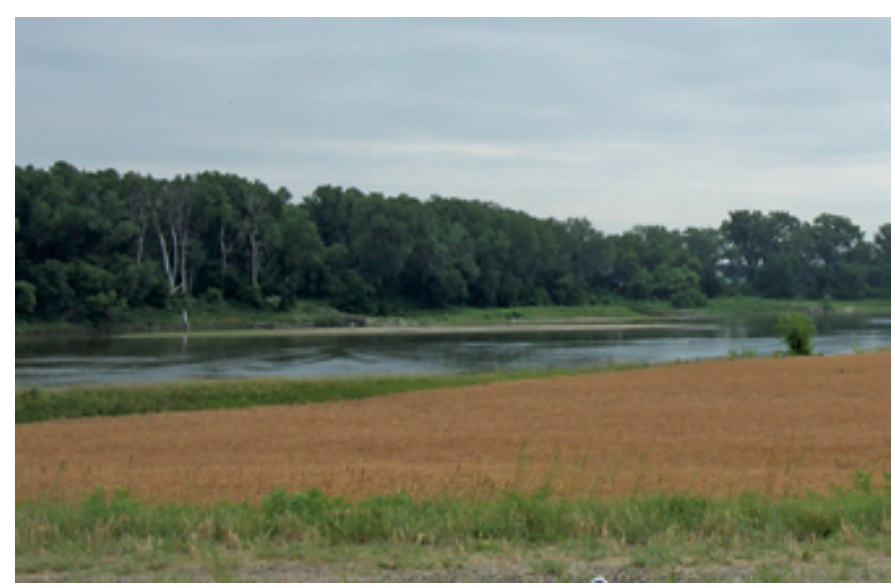

Figure 2. Wheat field adjacent to Kansas River, which traverses northern part of Flint Hills Ecoregion.

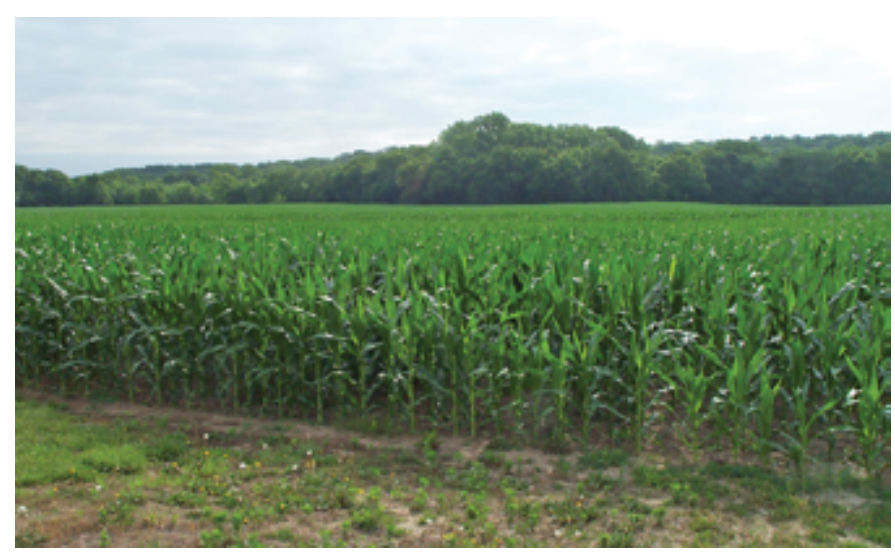

Figure 3. Corn field in Kansas River valley, in Flint Hills Ecoregion. withstand the burns and reemerge each year (Klinkenborg, 2007). Before Euro-American settlement, Native Americans maintained grazing areas for bison using a similar management regime.

The Flint Hills Ecoregion is dotted with small towns (figs. 4,5), most of which have lost much population in the last several decades, a pattern typical of rural communities in the Great Plains (Licht, 1997). Some larger Kansas towns

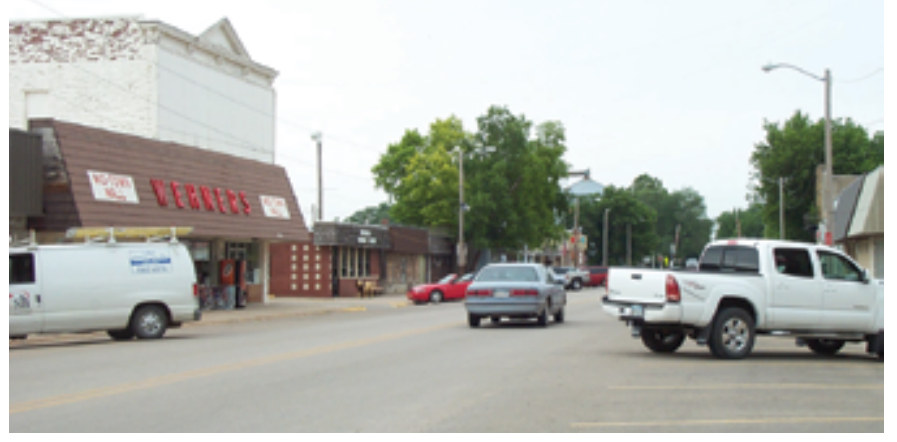

Figure 4. Small town of Rossville, Kansas (population 1,014 in 2000), in Flint Hills Ecoregion.

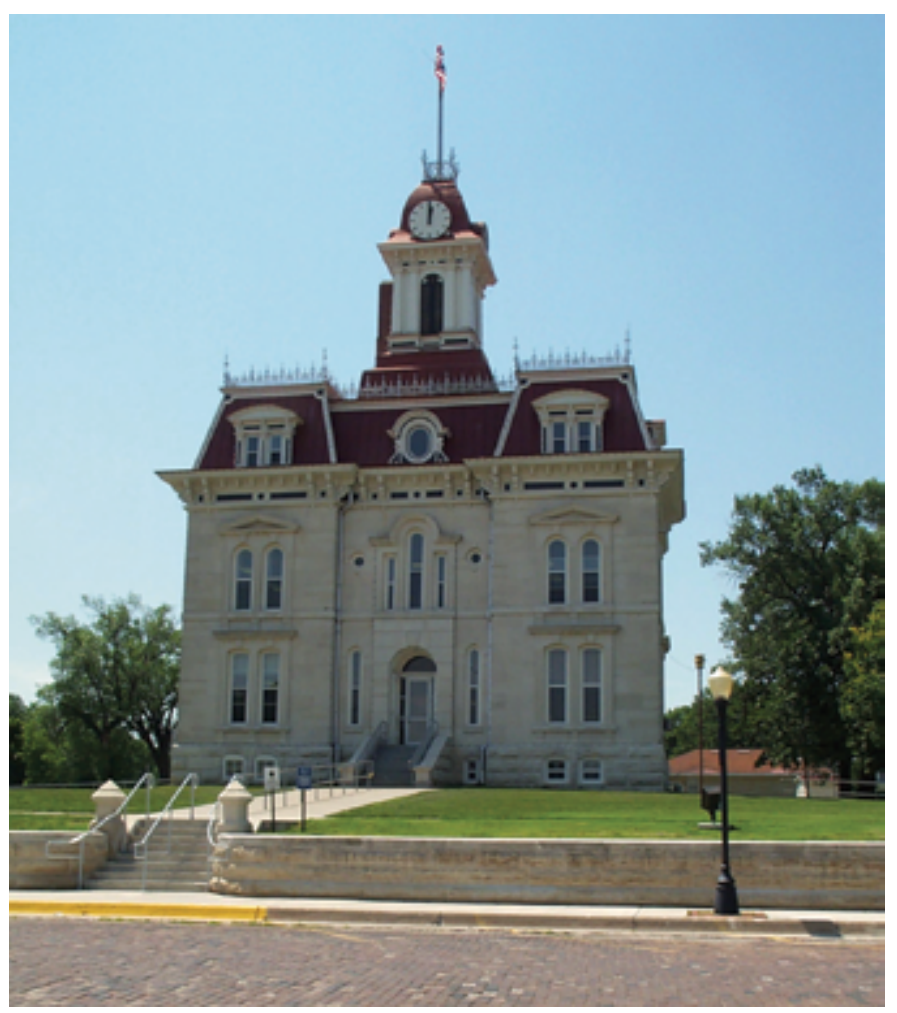

Figure 5. Chase County Courthouse, Cottonwood Falls, Kansas (population 966 in 2000), in Flint Hills Ecoregion. Completed in 1873 , courthouse was built using limestone that is available in abundance in Flint Hills and that has been used as building material since beginning of Euro-American settlement. 
such as Emporia and El Dorado, which are not exclusively linked to the rural economy, grew by less than 5 percent between 1970 and 2000. Manhattan, Kansas, a college town, increased by 62 percent during this same time. Despite these population increases, the amount of developed lands in the ecoregion remained less than 1 percent during the entire 27-year study period.

Although widespread agricultural production in the Great Plains has resulted in the near-total loss of onceextensive native prairie lands, the Flint Hills Ecoregion includes the largest remnant of tallgrass prairie in North America (Knapp and Seastedt, 1998). In 1996, Congress passed legislation to create the Tallgrass Prairie National Preserve, near the geographic center of the ecoregion, to protect $44 \mathrm{~km}^{2}$ of tallgrass-prairie ecosystem. Additional preserves have been established in the Flint Hills Ecoregion, including the $35 \mathrm{~km}^{2}$ Konza Prairie Biological Station near Manhattan, Kansas, and the $166 \mathrm{~km}^{2}$ Tallgrass Prairie Preserve near Pawhuska, Oklahoma. Both preserves, which are owned partly by The Nature Conservancy, are research oriented and work jointly with local universities.

Potential changes to the Flint Hills Ecoregion include those resulting from certain grazing management practices that may affect the diversity and composition of tallgrassprairie plant communities (Hickman and others, 2004). In addition, grazing and burning practices have disturbed bird nesting habitats, particularly the habitat of the endangered Greater Prairie Chicken (Tympanuchus cupido) (Robbins and others, 2002). Moreover, invasion of eastern redcedar (Juniperus virginiana) populations (fig. 6) in the northern part of the Flint Hills Ecoregion has resulted in conversions of grasslands to forest; drivers include an increase in human settlement and overgrazing, which have led to fire suppression practices and low fire intensity, respectively (Briggs and others, 2002). Grasslands also are threatened by the spread of Sericea lespedeza, an Asian legume that diminishes the diversity of native grasses (Middendorf and others, 2008).

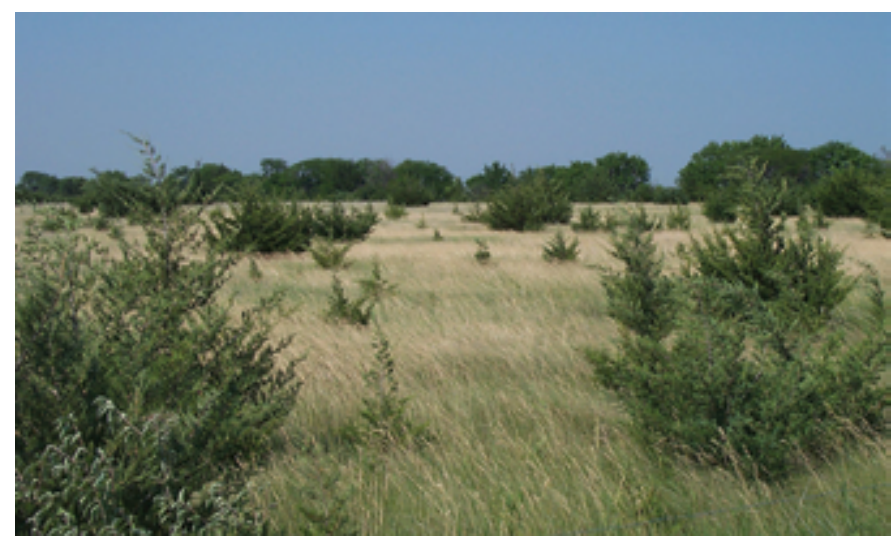

Figure 6. Eastern redcedar (Juniperus virginiana) trees invading prairie lands in eastern part of Flint Hills Ecoregion.

\section{Contemporary Land-Cover Change (1973 to 2000)}

The overall spatial change (the percentage of land area that changed at least one time) in the Flint Hills Ecoregion between 1973 and 2000 is estimated at 2.2 percent (table 1). Compared to other Great Plains ecoregions, change in the Flint Hills Ecoregion was small (fig. 7). An estimated 1.9 percent of the ecoregion was converted from one land-cover class to another, and 0.3 percent underwent two changes (table 1). The small extent of change shows the overall stability of the ecoregion. Change occurred more frequently in lowland areas owing to conversions between grassland/shrubland and agriculture. Estimated change per time period ranged from a low of 0.4 percent between 1980 and 1986 to a high of 0.8 percent between 1992 and 2000 (table 2). The other two time periods (1973-1980, 1986-1992) had changes of 0.6 percent and 0.7 percent, respectively. When change per time period is normalized by year, all four had a low change rate of 0.1 percent per year (table 2; fig. 8). The low change rates primarily reflect the stability of the ecoregion, although these rates can mask fluctuations in the extent of grassland/shrubland and agricultural lands.

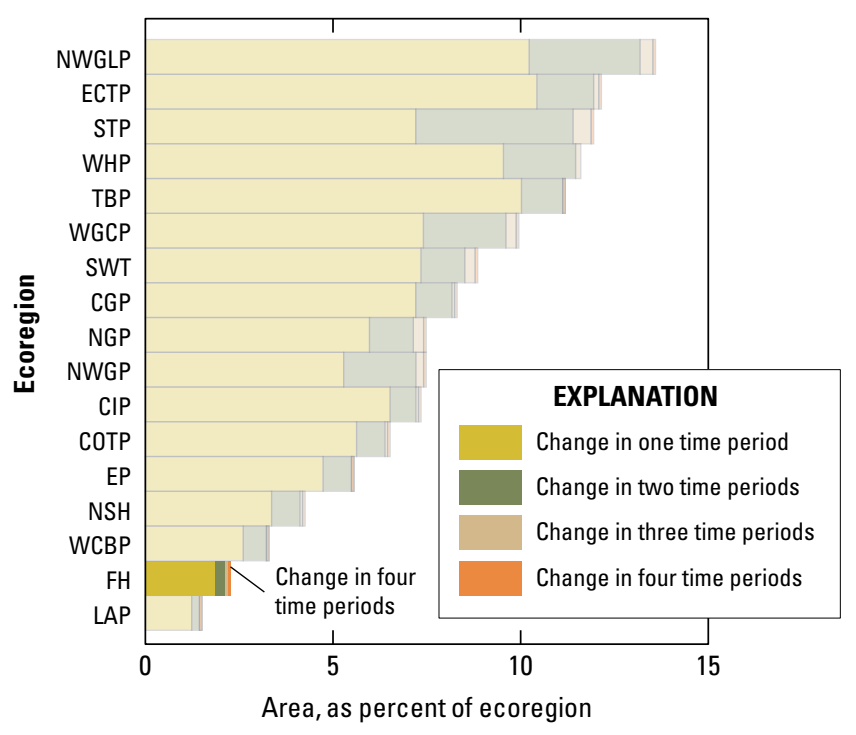

Figure 7. Overall spatial change in Flint Hills Ecoregion (FH; darker bars) compared with that of all 17 Great Plains ecoregions (lighter bars). Each horizontal set of bars shows proportions of ecoregion that experienced change during one, two, three, or four time periods; highest level of spatial change in Flint Hills Ecoregion (four time periods) labeled for clarity. See table 2 for years covered by each time period. See appendix 2 for key to ecoregion abbreviations. 
Grassland/shrubland and agriculture, which are the predominant land-cover classes, extending over an estimated 90 percent of the ecoregion, showed the greatest change per time period. Changes in these two were often complementary: as grassland/shrubland increased in area, agricultural land decreased in area (fig. 9). During the study period (1973-2000), grassland/shrubland increased overall, as well as in three of the four time periods (table 3), and agriculture decreased by amounts that are similar to the increases in grassland/shrubland: grassland/ shrubland increased by 0.6 percent, while agricultural lands decreased by 0.7 percent (table 3 ; fig 9 ). The remaining land-cover classes showed small amounts of change as forested lands decreased consistently in each time period while developed lands increased. However, these changes, when added to changes within other landcover classes, constituted less than 0.1 percent of the ecoregion's land area.

The most common land-cover conversion between 1973 and 2000 (and the most common in each time period) was the conversion of an estimated $344 \mathrm{~km}^{2}$ of agricultural land to grassland/shrubland (table 4). The second most common was the conversion of about $148 \mathrm{~km}^{2}$ of grassland/shrubland to agriculture. These two leading conversions account for nearly 70 percent of the landcover conversions during the study period, possibly reflecting the activities of small farm operations as they convert grassland/shrubland to and from pasture or cropland (agriculture land-cover class).

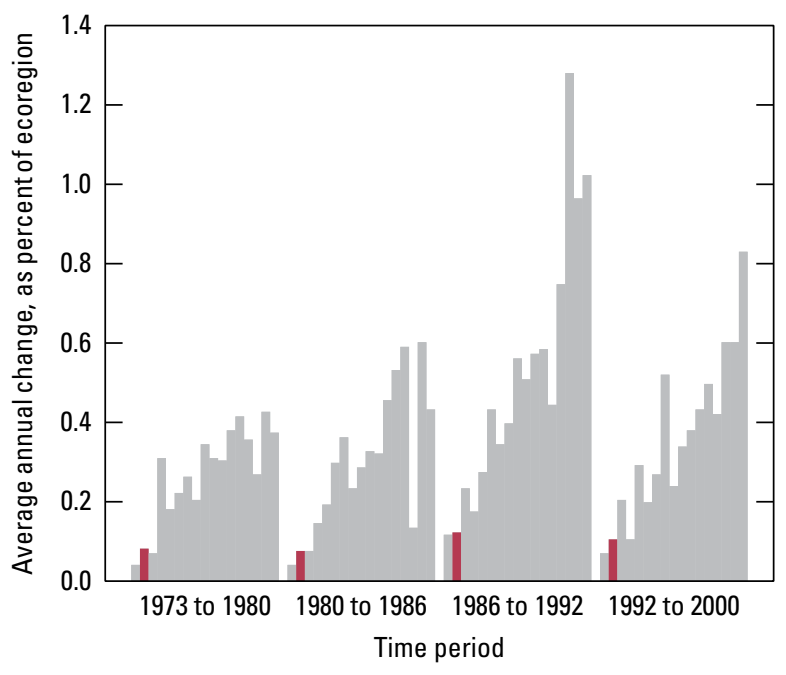

Figure 8. Estimates of land-cover change per time period, normalized to annual rates of change for all 17 Great Plains ecoregions (gray bars). Estimates of change for Flint Hills Ecoregion are represented by red bars in each time period.
Other than the conversions between these two major land-cover types (agriculture and grassland/shrubland), land cover changed only infrequently in the ecoregion during the study period. The lack of change is partly due to steep slopes and thin, rocky soils on the uplands, which make it poorly suited to farming. In addition, the ongoing practices of burning and grazing have been essential to the maintenance of the tallgrass ecosystem (Middendorf and others, 2008). In areas where fire is suppressed, prairie grasses may be overtaken by forest (Briggs and others, 2002).

The small change that occurred was mostly in the lowlands where grassland/shrubland and agriculture are frequently situated next to each other. Many conversions from agriculture to grassland/shrubland after 1985 are likely due to participation in the Conservation Reserve Program (CRP), which was created by the U.S. Congress in 1985 and became a key factor in agriculture-tograssland/shrubland conversions. In Kansas, the CRP
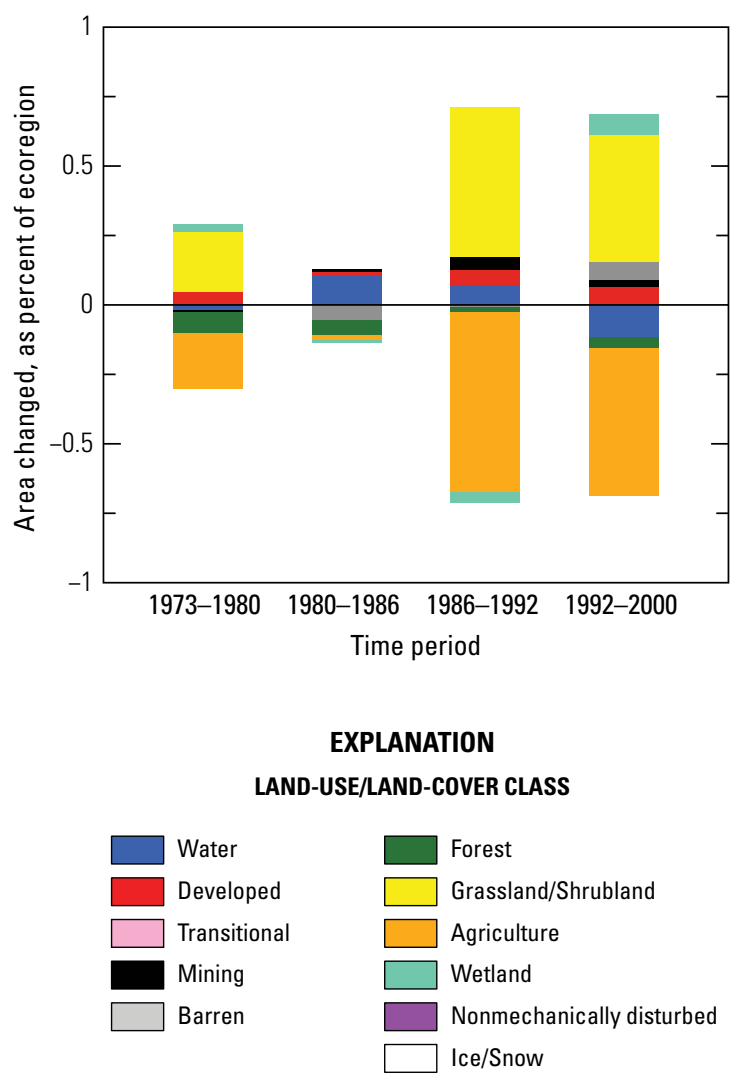

Figure 9. Normalized average net change in Flint Hills Ecoregion by time period for each land-cover class. Bars above zero axis represent net gain, whereas bars below zero represent net loss. Note that not all land-cover classes shown in explanation may be represented in figure. See appendix 3 for definitions of land-use/land-cover classifications. 
has been responsible for about $11,700 \mathrm{~km}^{2}$ of conversions from agriculture to grassland/shrubland (Egbert and others, 2001). Although large areas of agriculture were being converted to grassland/shrubland, a smaller amount of land was being converted from grassland/shrubland to agriculture. The reasons for the loss of grassland/shrubland to agriculture are unclear, although some may be due to a process called "slippage," in which farmers place additional agricultural lands into production to compensate for lands enrolled in the CRP (Peterson and others, 2004).

Future land-cover conversions would likely include an increase of residential home construction (developed land-cover class) on grassland/shrubland or agricultural lands. The Flint Hills and their environs have become increasingly known for their scenic value, and development pressures have begun to influence land-management decisions on the part of conservation organizations, landowners, and government.
Table 1. Percentage of Flint Hills Ecoregion land cover that changed at least one time during study period (1973-2000) and associated statistical error.

[Most sample pixels remained unchanged (97.8 percent), whereas 2.2 percent changed at least once throughout study period]

\begin{tabular}{ccccccc}
\hline $\begin{array}{c}\text { Number } \\
\text { of } \\
\text { changes }\end{array}$ & $\begin{array}{c}\text { Percent } \\
\text { of } \\
\text { ecoregion }\end{array}$ & $\begin{array}{c}\text { Margin } \\
\text { of error } \\
(+/-\%)\end{array}$ & $\begin{array}{c}\text { Lower } \\
\text { bound } \\
(\%)\end{array}$ & $\begin{array}{c}\text { Upper } \\
\text { bound } \\
(\%)\end{array}$ & $\begin{array}{c}\text { Standard } \\
\text { error } \\
(\%)\end{array}$ & $\begin{array}{c}\text { Relative } \\
\text { error } \\
(\%)\end{array}$ \\
\hline 1 & 1.9 & 0.4 & 1.5 & 2.3 & 0.3 & 15.4 \\
2 & 0.3 & 0.1 & 0.2 & 0.4 & 0.1 & 28.4 \\
3 & 0.0 & 0.0 & 0.0 & 0.1 & 0.0 & 51.7 \\
4 & 0.0 & 0.0 & 0.0 & 0.0 & 0.0 & 65.8 \\
\hline $\begin{array}{c}\text { Overall } \\
\text { spatial } \\
\text { change }\end{array}$ & 2.2 & 0.5 & 1.7 & 2.7 & 0.3 & 15.4 \\
\hline
\end{tabular}

Table 2. Raw estimates of change in Flint Hills Ecoregion land cover, computed for each of four time periods between 1973 and 2000, and associated error at 85-percent confidence level.

[Estimates of change per period normalized to annual rate of change for each period]

\begin{tabular}{cccccccc}
\hline Period & $\begin{array}{c}\text { Total } \\
\text { change } \\
\text { (\% of } \\
\text { ecoregion) }\end{array}$ & $\begin{array}{c}\text { Margin of } \\
\text { error } \\
(+/-\%)\end{array}$ & $\begin{array}{c}\text { Lower } \\
\text { bound } \\
(\%)\end{array}$ & $\begin{array}{c}\text { Upper } \\
\text { bound } \\
(\%)\end{array}$ & $\begin{array}{c}\text { Standard } \\
\text { error } \\
(\%)\end{array}$ & $\begin{array}{c}\text { Relative } \\
\text { error } \\
(\%)\end{array}$ & $\begin{array}{c}\text { Average } \\
\text { rate } \\
(\% \text { per year) }\end{array}$ \\
\hline \multicolumn{7}{c}{ Estimate of change, in percent stratum } \\
\hline $1973-1980$ & 0.6 & 0.2 & 0.4 & 0.8 & 0.1 & 21.7 & 0.1 \\
$1980-1986$ & 0.4 & 0.1 & 0.3 & 0.6 & 0.1 & 19.8 & 0.1 \\
$1986-1992$ & 0.7 & 0.2 & 0.6 & 0.9 & 0.1 & 15.0 & 0.1 \\
$1992-2000$ & 0.8 & 0.3 & 0.5 & 1.1 & 0.2 & 22.3 & 0.1 \\
\hline \multicolumn{7}{c}{ Estimate of change, in square kilometers } \\
\hline $1973-1980$ & 160 & 51 & 109 & 211 & 35 & 21.7 & 23 \\
$1980-1986$ & 124 & 36 & 88 & 161 & 25 & 19.8 & 21 \\
$1986-1992$ & 198 & 44 & 154 & 241 & 30 & 15.0 & 33 \\
$1992-2000$ & 228 & 75 & 152 & 303 & 51 & 22.3 & 28 \\
\hline
\end{tabular}


Table 3. Estimated area (and margin of error) of each land-cover class in Flint Hills Ecoregion, calculated five times between 1973 and 2000. See appendix 3 for definitions of land-cover classifications.

\begin{tabular}{|c|c|c|c|c|c|c|c|c|c|c|c|c|c|c|c|c|c|c|c|c|}
\hline & \multicolumn{2}{|c|}{ Water } & \multicolumn{2}{|c|}{ Developed } & \multicolumn{2}{|c|}{$\begin{array}{l}\text { Mechani- } \\
\text { cally dis- } \\
\text { turbed }\end{array}$} & \multicolumn{2}{|c|}{ Mining } & \multicolumn{2}{|c|}{ Barren } & \multicolumn{2}{|c|}{ Forest } & \multicolumn{2}{|c|}{$\begin{array}{l}\text { Grassland/Shru- } \\
\text { bland }\end{array}$} & \multicolumn{2}{|c|}{ Agriculture } & \multicolumn{2}{|c|}{ Wetland } & \multicolumn{2}{|c|}{$\begin{array}{c}\text { Non- } \\
\text { mechanically } \\
\text { disturbed }\end{array}$} \\
\hline & $\%$ & $+1-$ & $\%$ & $+1-$ & $\%$ & $+/-$ & $\%$ & $+/-$ & $\%$ & $+/-$ & $\%$ & $+/-$ & $\%$ & $+/-$ & $\%$ & $+1-$ & $\%$ & $+1-$ & $\%$ & $+1-$ \\
\hline 1973 & 1.2 & 0.4 & 0.9 & 0.3 & 0.0 & 0.0 & 0.0 & 0.0 & 0.1 & 0.1 & 6.2 & 1.1 & 50.9 & 6.5 & 40.4 & 6.7 & 0.4 & 0.2 & 0.0 & 0.0 \\
\hline 1980 & 1.2 & 0.4 & 0.9 & 0.3 & 0.0 & 0.0 & 0.0 & 0.0 & 0.1 & 0.1 & 6.1 & 1.1 & 51.0 & 6.5 & 40.3 & 6.7 & 0.5 & 0.2 & 0.0 & 0.0 \\
\hline 2000 & 1.2 & 0.4 & 0.9 & 0.4 & 0.0 & 0.0 & 0.1 & 0.1 & 0.1 & 0.1 & 6.1 & 1.2 & 51.5 & 6.5 & 39.7 & 6.7 & 0.5 & 0.2 & 0.0 & 0.0 \\
\hline $\begin{array}{l}\text { Net } \\
\text { change }\end{array}$ & 0.0 & 0.1 & 0.1 & 0.0 & 0.0 & 0.0 & 0.0 & 0.0 & 0.0 & 0.0 & -0.1 & 0.1 & 0.6 & 0.3 & -0.7 & 0.4 & 0.0 & 0.0 & 0.0 & 0.0 \\
\hline $\begin{array}{l}\text { Gross } \\
\text { change }\end{array}$ & 0.2 & 0.1 & 0.1 & 0.0 & 0.0 & 0.0 & 0.1 & 0.1 & 0.1 & 0.1 & 0.2 & 0.1 & 1.3 & 0.4 & 1.4 & 0.3 & 0.1 & 0.1 & 0.0 & 0.0 \\
\hline 1980 & 323 & 104 & 245 & 94 & 0 & 0 & 8 & 6 & 18 & 18 & 1,715 & 317 & 14,231 & 1,818 & 11,243 & 1,871 & 128 & 63 & 0 & 0 \\
\hline 1986 & 339 & 106 & 247 & 95 & 0 & 0 & 9 & 8 & 10 & 13 & 1,709 & 318 & 14,230 & 1,817 & 11,241 & 1,873 & 126 & 64 & 0 & 0 \\
\hline 1992 & 350 & 109 & 254 & 97 & 0 & 0 & 16 & 13 & 9 & 10 & 1,706 & 324 & 14,305 & 1,820 & 11,150 & 1,877 & 121 & 63 & 0 & 9 \\
\hline 2000 & 334 & 103 & 263 & 99 & 0 & 0 & 20 & 14 & 19 & 19 & 1,701 & 323 & 14,369 & 1,818 & 11,075 & 1,870 & 130 & 62 & 0 & 0 \\
\hline $\begin{array}{l}\text { Net } \\
\text { change }\end{array}$ & 8 & 14 & 24 & 12 & 0 & 0 & 11 & 12 & 0 & 7 & -24 & 28 & 169 & 91 & -195 & 100 & 7 & 7 & 0 & 0 \\
\hline $\begin{array}{l}\text { Gross } \\
\text { change }\end{array}$ & 58 & 27 & 24 & 12 & 0 & 0 & 19 & 14 & 27 & 27 & 49 & 27 & 368 & 99 & 390 & 98 & 28 & 17 & 0 & 0 \\
\hline
\end{tabular}


Table 4. Principal land-cover conversions in Flint Hills Ecoregion, showing amount of area changed (and margin of error, calculated at 85-percent confidence level) for each conversion during each of four time periods and also during overall study period. See appendix 3 for definitions of land-cover classifications.

[Values given for "other" classes are combined totals of values for other land-cover classes not listed in that time period. Abbreviations: n/a, not applicable]

\begin{tabular}{|c|c|c|c|c|c|c|c|c|}
\hline \multirow[t]{2}{*}{ Period } & \multirow[t]{2}{*}{ From class } & \multirow{2}{*}{\multicolumn{2}{|c|}{ To class }} & $\begin{array}{c}\text { Area } \\
\text { changed }\end{array}$ & $\begin{array}{c}\text { Margin of } \\
\text { error }\end{array}$ & $\begin{array}{c}\text { Standard } \\
\text { error }\end{array}$ & \multirow{2}{*}{$\begin{array}{l}\text { Percent of } \\
\text { ecoregion }\end{array}$} & \multirow{2}{*}{$\begin{array}{l}\text { Percent of } \\
\text { all changes }\end{array}$} \\
\hline & & & & $\left(\mathrm{km}^{2}\right)$ & $\left(+/-\mathrm{km}^{2}\right)$ & $\left(\mathrm{km}^{2}\right)$ & & \\
\hline \multirow[t]{6}{*}{ 1973-1980 } & Agriculture & Grassland/Shrubland & & 71 & 33 & 22 & 0.3 & 44.2 \\
\hline & Grassland/Shrubland & Agriculture & & 42 & 27 & 18 & 0.1 & 26.1 \\
\hline & Water & Barren & & 8 & 8 & 6 & 0.0 & 5.2 \\
\hline & Barren & Water & & 8 & 7 & 5 & 0.0 & 4.7 \\
\hline & Other & Other & & 25 & $\mathrm{n} / \mathrm{a}$ & $\mathrm{n} / \mathrm{a}$ & 0.1 & 15.5 \\
\hline & & & Totals & 160 & & & 0.6 & 100.0 \\
\hline \multirow[t]{4}{*}{ 1980-1986 } & Agriculture & Grassland/Shrubland & & 42 & 22 & 15 & 0.2 & 33.8 \\
\hline & Grassland/Shrubland & Agriculture & & 34 & 20 & 13 & 0.1 & 27.2 \\
\hline & Other & Other & & 24 & $\mathrm{n} / \mathrm{a}$ & $\mathrm{n} / \mathrm{a}$ & 0.1 & 19.6 \\
\hline & & & Totals & 124 & & & 0.4 & 100.0 \\
\hline \multirow[t]{7}{*}{ 1986-1992 } & Agriculture & Grassland/Shrubland & & 111 & 39 & 27 & 0.4 & 56.2 \\
\hline & Grassland/Shrubland & Agriculture & & 24 & 11 & 8 & 0.1 & 12.3 \\
\hline & Grassland/Shrubland & Forest & & 8 & 8 & 6 & 0.0 & 3.9 \\
\hline & Forest & Agriculture & & 7 & 6 & 4 & 0.0 & 3.7 \\
\hline & Barren & Water & & 6 & 8 & 5 & 0.0 & 2.9 \\
\hline & Other & Other & & 42 & $\mathrm{n} / \mathrm{a}$ & $\mathrm{n} / \mathrm{a}$ & 0.1 & 21.0 \\
\hline & & & Totals & 198 & & & 0.7 & 100.0 \\
\hline 1992-2000 & & & Totals & 228 & & & 0.8 & 100.0 \\
\hline \multirow{7}{*}{$\begin{array}{c}\text { 1973-2000 } \\
\text { (overall) }\end{array}$} & Agriculture & Grassland/Shrubland & & 344 & 120 & 81 & 1.2 & 48.4 \\
\hline & Grassland/Shrubland & Agriculture & & 148 & 55 & 37 & 0.5 & 20.8 \\
\hline & Water & Barren & & 28 & 27 & 18 & 0.1 & 3.9 \\
\hline & Forest & Agriculture & & 26 & 19 & 13 & 0.1 & 3.6 \\
\hline & Barren & Water & & 26 & 25 & 17 & 0.1 & 3.6 \\
\hline & Other & Other & & 139 & $\mathrm{n} / \mathrm{a}$ & $\mathrm{n} / \mathrm{a}$ & 0.5 & 19.6 \\
\hline & & & Totals & 709 & & & 2.5 & 100.0 \\
\hline
\end{tabular}




\section{References Cited}

Bragg, T.B., and Hulbert, L.C., 1976, Woody plant invasion of unburned Kansas bluestem prairie: Journal of Range Management, v. 29, no. 1, p. 19-24.

Briggs, J.M., Hoch, G.A., and Johnson, L.C., 2002, Assessing the rate, mechanisms, and consequences of the conversion of tallgrass prairie to Juniperus virginiana forest:

Ecosystems, v. 5., no. 6, p. 578-586.

Egbert, S.L., Peterson, D.L., Stewart, A.M., Lauver, C.L., Blodgett, C.F., Price, K.P., and Martinko, E.A., 2001, The Kansas GAP land cover map final report: Kansas Biological Survey Report 99.

Hickman, K.R., Hartnett, D.C., Cochran, R.C., and Owensby, C.E., 2004, Grazing management effects on plant species diversity in tallgrass prairie: Journal of Range Management, v. 57, no. 1 , p. 58-65.

Klinkenborg, Verlyn, 2007, Splendor of the grass: National Geographic Magazine Online, April 2007, accessed May 23, 2013, at http://ngm.nationalgeographic.com/2007/04/ tallgrass-prairie/klinkenborg-text.

Knapp, A.K., and Seastedt, T.R., 1998, IntroductionGrasslands, Konza Prairie, and long-term ecological research, in Knapp, A.K., Briggs, J.M., Hartnett, D.C., and Collins, S.L, eds., Grassland Dynamics-Long-Term Ecological Research in Tallgrass Prairie: New York, Oxford University Press, p. 3-15.

Kollmorgen, W.M, and Simonett, D.S., 1965, Grazing operations in the Flint Hills-bluestem pastures of Chase County, Kansas: Annals of the Association of American Geographers, v. 55, no. 2, p. 260-290.

Licht, D.S., 1997, Ecology and economics of the Great Plains: Lincoln, University of Nebraska Press, 225 p.
Malin, J.C., 1942, An introduction to the history of the bluestem pasture region of Kansas: Kansas Historical Quarterly, v. 11, no. 2, p. 3-28.

Middendorf, Gerad, Cline, Derrick, and Bloomquist, Leonard, 2008, Agrarian landscape transition in the Flint Hills of Kansas-Legacies and resilience, in Redman, C.L., and Foster, D.R., eds., 2008, Agrarian landscapes in transitionComparisons of long-term ecological and cultural change: New York, Oxford University Press, p. 206-237.

Omernik, J.M., 1987, Ecoregions of the conterminous United States: Annals of the Association of American Geographers, v. 77 , no. 1 , p. $118-125$.

Peterson, D.L., Egbert, S.L., Price, K.P., and Marinko, E.A., 2004, Identifying historical and recent land-cover changes in Kansas using post-classification change detection techniques: Transactions of the Kansas Academy of Science, v. 107, no. 3-4, p. 105-118.

Robbins, M.B., Peterson, A.T., and Ortega-Huerta, M.A., 2002, Major negative impacts of early intensive cattle stocking on tallgrass prairies-The case of the greater prairie-chicken (Tympanuchus cupido): North American Birds, v. 56, no. 2, p. 239-244.

U.S. Environmental Protection Agency, 1997, Descriptions of level III ecological regions for the CEC report on ecological regions of North America: U.S. Environmental Protection Agency database, accessed April 12, 2006, at http://www. epa.gov/wed/pages/ecoregions/na_eco.htm\#Downloads.

Vogelmann, J.E., Howard, S.M., Yang, L., Larson, C.R., Wylie, B.K., and van Driel, N., 2001, Completion of the 1990s National Land Cover Data Set for the conterminous United States from Landsat Thematic Mapper data and ancillary data sources: Photogrammetric Engineering \& Remote Sensing, v. 67, p. 650-662. 


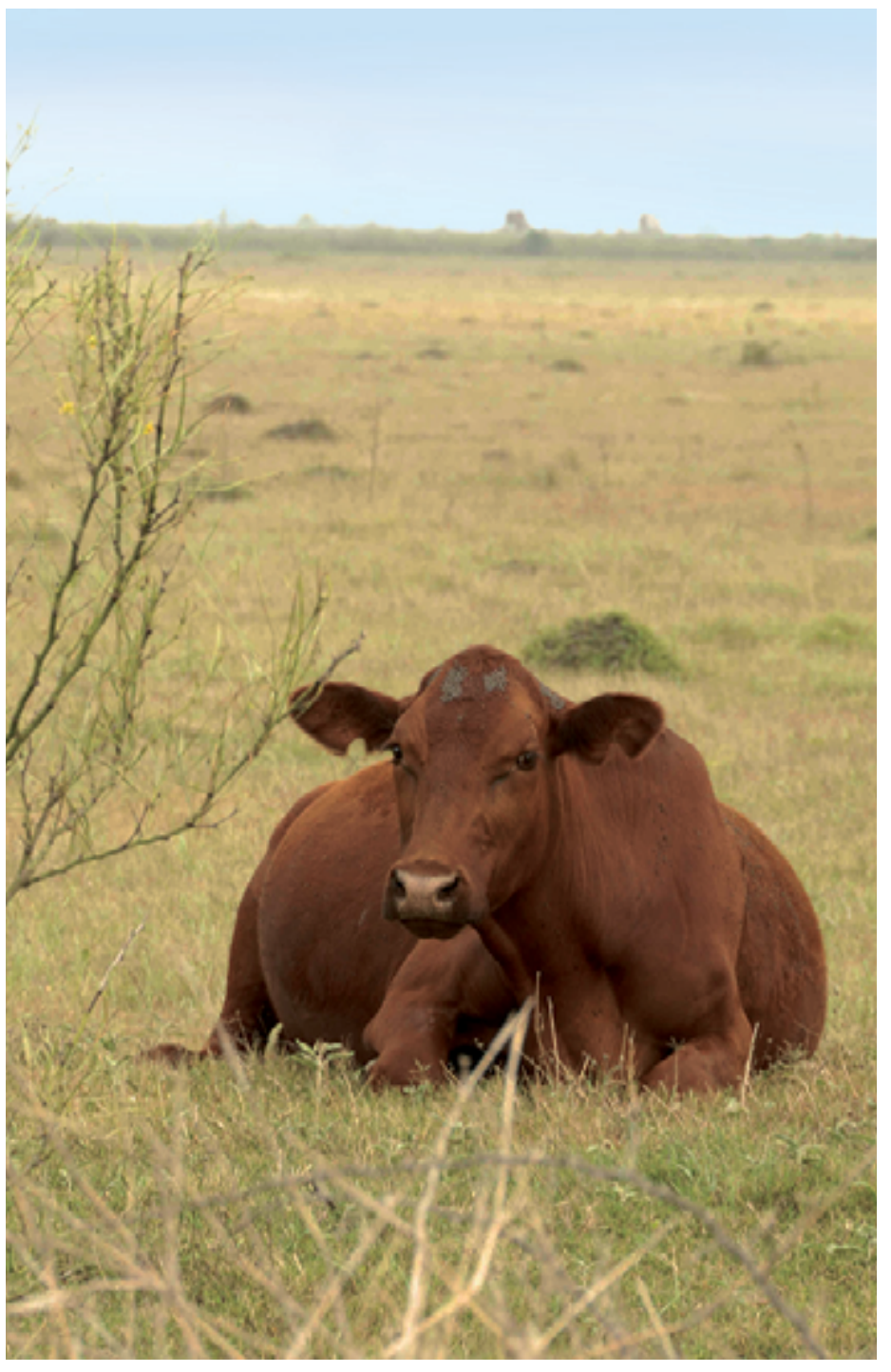




\title{
Central Oklahoma/Texas Plains Ecoregion
}

\author{
By Michael P. Stier
}

\section{Ecoregion Description}

The Central Oklahoma/Texas Plains Ecoregion covers more than $103,412 \mathrm{~km}^{2}$ $\left(39,928 \mathrm{mi}^{2}\right)$ of southeastern Kansas, central Oklahoma, and north-central Texas (fig. 1). The ecoregion is bounded on the west by the Central Great Plains Ecoregion; on the north by the Flint Hills Ecoregion; on the east by the Central Irregular Plains, Arkansas Valley, Ouachita Mountains, South Central Plains, and Texas Blackland Prairies Ecoregions; and on the south by the Edwards Plateau Ecoregion (Omernik, 1987; U.S. Environmental Protection Agency, 1997).

The Central Oklahoma/ Texas Plains Ecoregion, also referred to as "Cross Timbers," is characterized by a complex mosaic of upland deciduous forest, savanna, and prairie communities (fig. 2) that make up the broad ecotone between the forested low mountains of eastern Oklahoma and the grasslands to the west. Two large forest zones, which run northeast to southwest from central Oklahoma to northcentral Texas, are dominated by blackjack oak (Quercus marilandica), post oak (Quercus stellata), and eastern redcedar (Juniperus virginiana). Fourhundred-year-old post oaks live in the "Cross Timbers" region. These forests, which are among the least disturbed forests east of the Rocky Mountains, have survived because they were not ideal for lumber production, and their steep terrain is unsuitable for farming (fig. 3) (University of Arkansas Tree-Ring Laboratory, 2007; see also, Stahle and others,

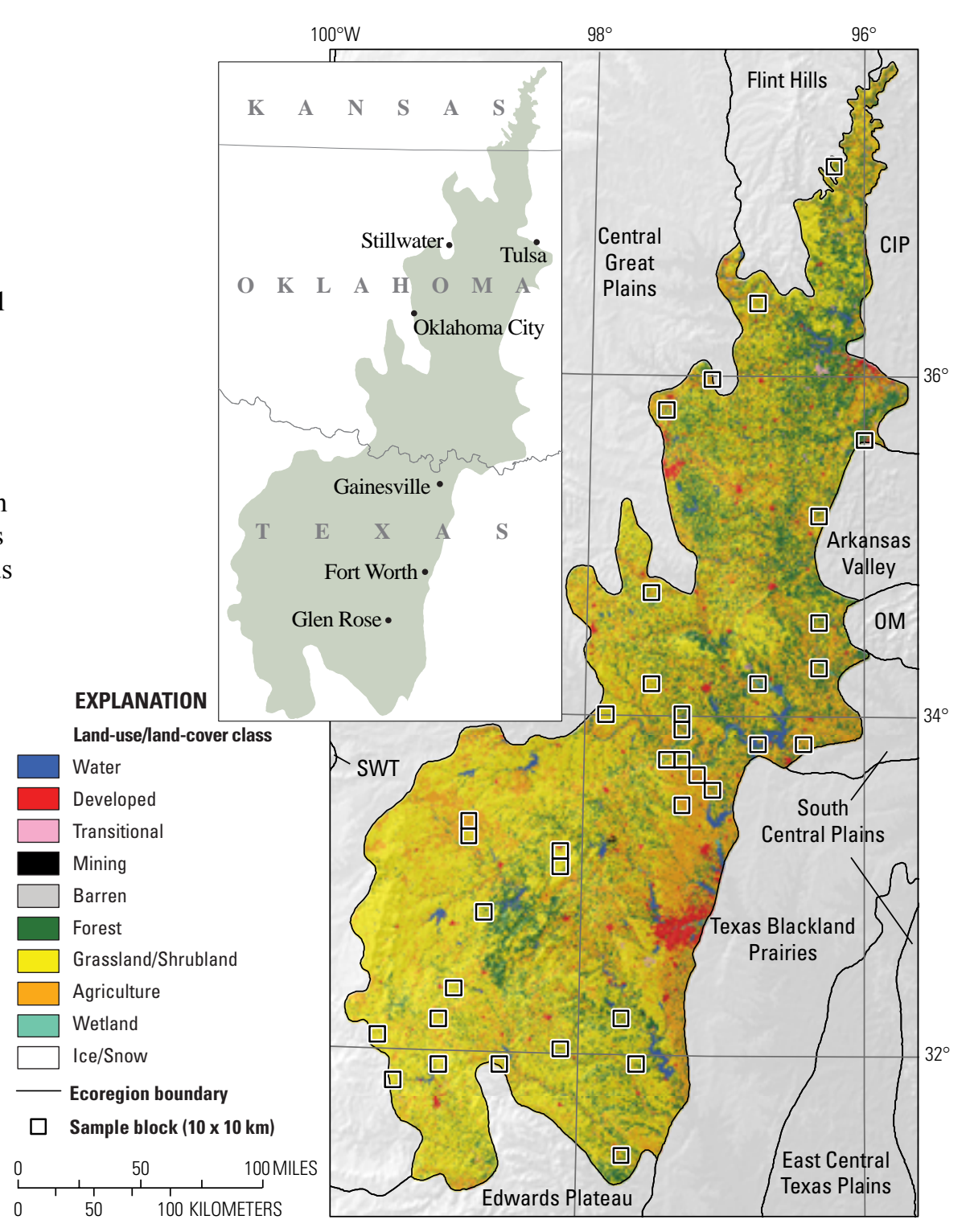

Figure 1. Map of Central Oklahoma /Texas Plains Ecoregion and surrounding ecoregions, showing land-use/land-cover classes from 1992 National Land Cover Dataset (Vogelmann and others, 2001); note that not all land-use/land-cover classes shown in explanation may be depicted on map; note also that, for this "Status and Trends of Land Change" study, transitional land-cover class was subdivided into mechanically disturbed and nonmechanically disturbed classes. Squares indicate locations of $10 \times 10 \mathrm{~km}$ sample blocks analyzed in study. Index map shows locations of geographic features mentioned in text. Abbreviations for Great Plains ecoregions are listed in appendix 2. Also shown are parts of three Midwest-South Central United States ecoregions: Arkansas Valley, Ouachita Mountains (OM), and South Central Plains. See appendix 3 for definitions of land-use/land-cover classifications. 
2003). The large, gently sloping prairie that separates these forests consists of thin soils over hard layers of resistant limestone. Other areas of the ecoregion include patches of mixed-grass prairie habitat embedded within the oak woodlands.

The topography of the Central Oklahoma/Texas Plains Ecoregion is rolling to hilly uplands separated by narrow stream valleys that have steep gradients. Elevations range from 100 to $400 \mathrm{~m}$ (McNab and Avers, 1996). The climate is considered subhumid, with average annual precipitation levels that vary from $525 \mathrm{~mm}$ (20 in.) in the southwestern part of the ecoregion to $900 \mathrm{~mm}$ (35 in.) in the northeastern part. Most precipitation falls in spring, and winter is the driest season.

The most common land use is livestock ranching of cattle, sheep, and goats. Crops grown in the deeper and more fertile soils include small grains, sorghum, cotton, and alfalfa. Peanuts, tree fruits, and vegetables are grown

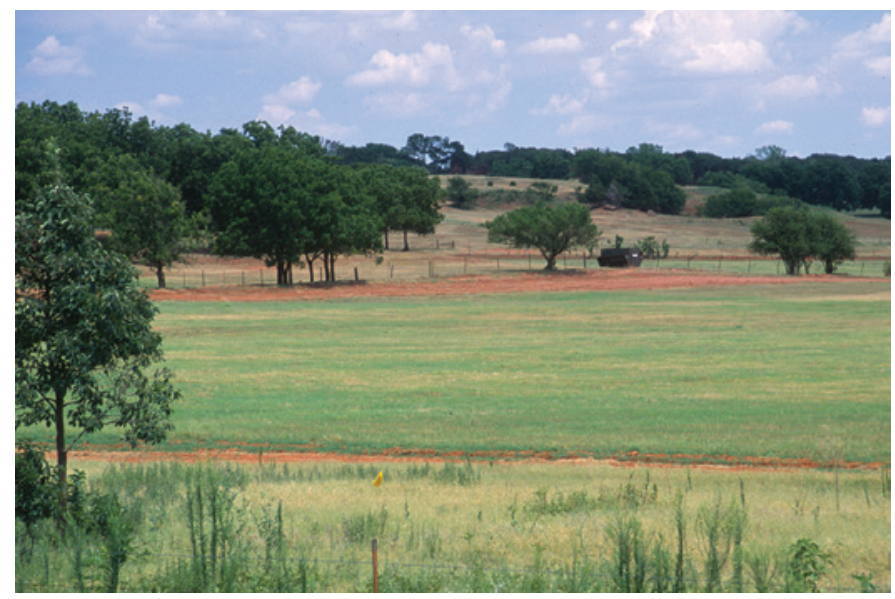

Figure 2. Savanna landscape with grasses and scattered trees surrounding pasture in Central Oklahoma/Texas Plains Ecoregion.

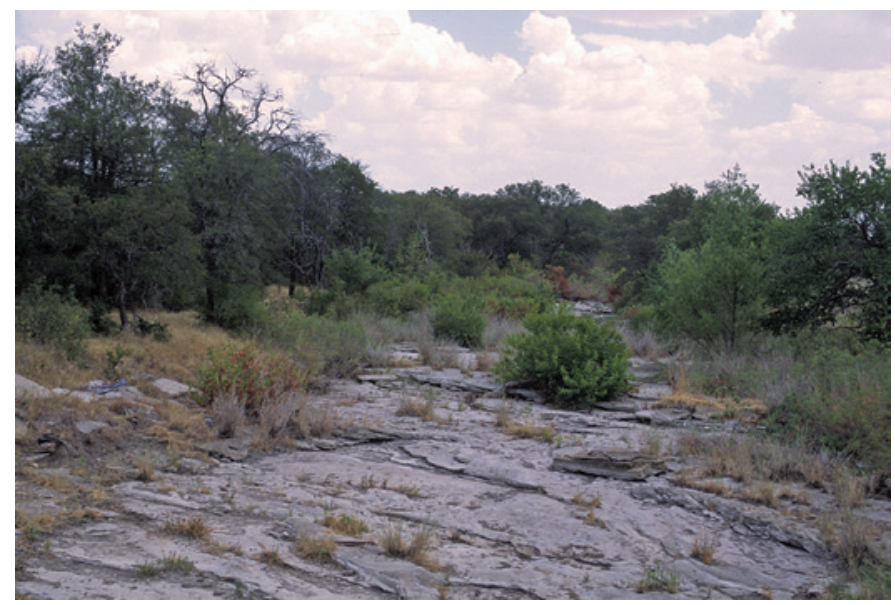

Figure 3. Post oak forest in Central Oklahoma/Texas Plains Ecoregion. in the south (U.S. Department of Agriculture, 1981). Overall, nearly 75 percent of the natural vegetation has been cleared for ranching and cultivation (McNab and Avers, 1996). Grassland/shrubland is the most extensive land-cover class, followed by agricultural land.

Lease hunting is common on large ranches, providing an additional source of income to private landowners. Big-game species commonly hunted, especially in the Texas part of the ecoregion, include white-tailed deer (Odocoileus virginianus), pronghorn (Antilocapra americana), mule deer (Odocoileus hemionus), wild turkey (Meleagris gallopavo), and javelina (Pecari tajacu).

Other land uses include urban and exurban development and oil and gas extraction (fig. 4). Much of the increase in the ecoregion's population is supported by the growing oil industry, which attracts numerous jobs to the area. Nearly all the counties in the ecoregion increased in population from 1980 to 2005 (U.S. Census Bureau, 2005). As the population grew, urban centers benefitting from the oil and gas industry expanded, causing new development along the ecoregion's periphery near Tulsa, Oklahoma, and Fort Worth, Texas.

A growing concern in this ecoregion is the loss and fragmentation of wildlife habitat owing to land-use/ land-cover change. The clearing of brush and forests for pasture, cropland, or development affects wildlife resources. Threatened or endangered species observed in this area include the black-capped vireo (Vireo atricapilla), the golden-cheeked warbler (Dendroica chrysoparia), the Texas kangaroo rat (Dipodomys elator), and the Texas horned lizard (Phrynosoma cornutum). Long-term declines in big-game species such as the pronghorn or white-tailed deer are attributed primarily to habitat loss, competition with livestock for food and forage, and losses to predators (Texas Parks and Wildlife, 2007).

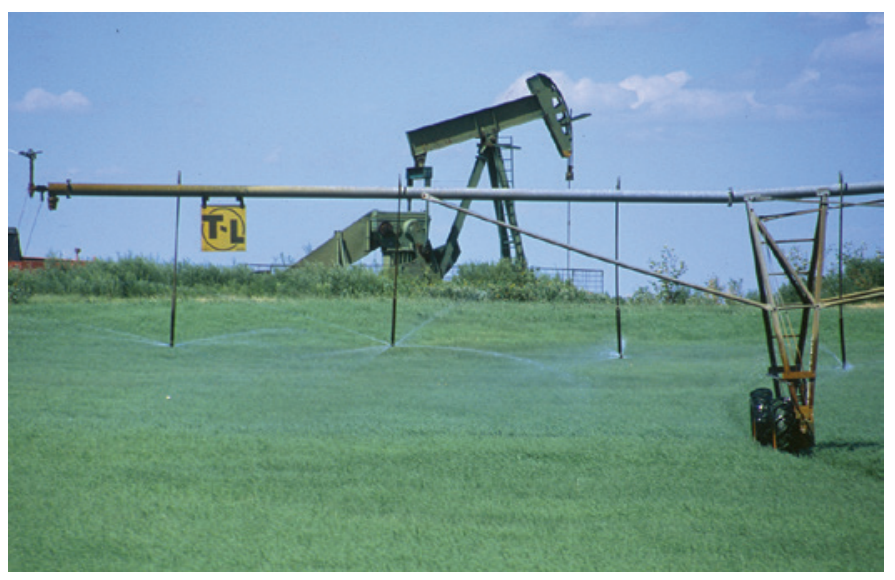

Figure 4. Oil pump next to irrigated pasture in Central Oklahoma/ Texas Plains Ecoregion. 


\section{Contemporary Land-Cover Change (1973 to 2000)}

The overall spatial change (the percentage of land area that changed at least one time) in the Central Oklahoma/ Texas Plains Ecoregion between 1973 and 2000 is estimated at 6.5 percent (table 1). Compared to other Great Plains ecoregions, change in the Central Oklahoma/Texas Plains Ecoregion was moderate (fig. 5). Of the land that changed, 5.6 percent changed one time, 0.8 percent changed two times, and 0.1 percent changed three times (table 1). For those few land areas that changed two or more times, the change generally was back and forth between two land-cover classes: for example, between agriculture and grassland/ shrubland. Although the total change per time period was less than 2 percent in three of the four time periods (table 2), the period between 1986 and 1992 had a slightly higher percentage of land-cover change, at 2.6 percent. Much of this increase was a result of conversion of agricultural land to grassland/shrubland (table 3). When normalized to account for varying time-period lengths, the estimated annual rates of change increased gradually in the first three time periods (1973-1980, 1980-1986, 1986-1992), from 0.2 to 0.4 percent of the ecoregion per year, before dropping to 0.2 percent between 1992 and 2000 (table 2; fig. 6).

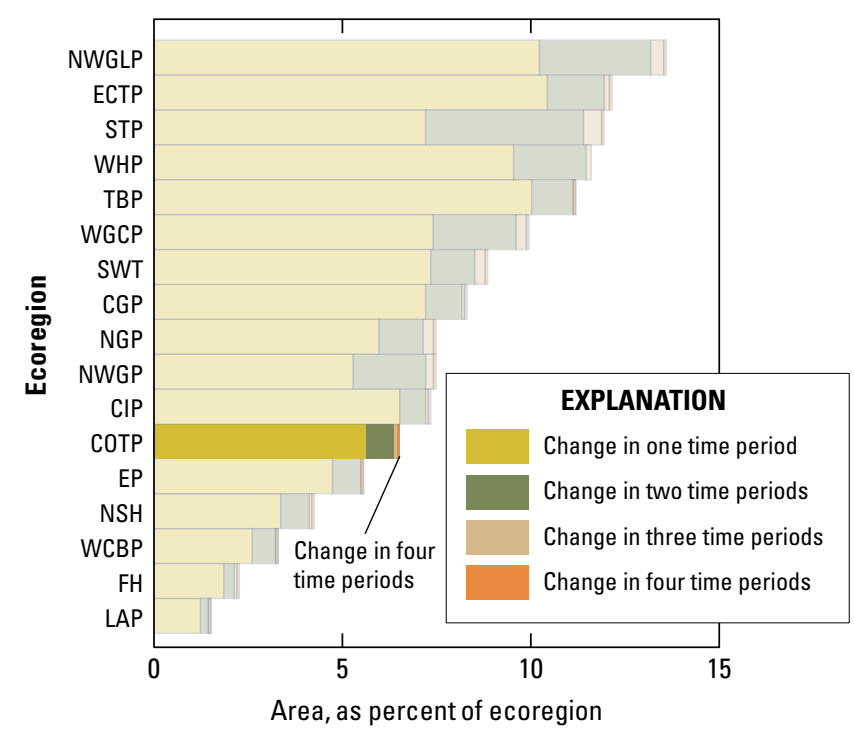

Figure 5. Overall spatial change in Central Oklahoma/Texas Plains Ecoregion (COTP; darker bars) compared with that of all 17 Great Plains ecoregions (lighter bars). Each horizontal set of bars shows proportions of ecoregion that experienced change during one, two, three, or four time periods; highest level of spatial change in Central Oklahoma/Texas Plains Ecoregion (four time periods) labeled for clarity. See table 2 for years covered by each time period. See appendix 2 for key to ecoregion abbreviations.
Grassland/shrubland, agriculture, and forest areas constitute an estimated 93 percent of the land cover in this ecoregion. Grassland/shrubland, the dominant landcover class, remained relatively stable between 1973 and 2000, ranging from 46.5 to 46.9 percent of the ecoregion (table 4). Between 1973 and 2000, forest decreased by 0.4 percent, from 19.6 to 19.2 percent of the ecoregion (table 4). In the early part of the study period, forest was cleared for agriculture and grassland/shrubland. Much of the cleared forest land was used to support the growing livestock industry. As part of the forest-clearing process, aerial applications of broadleaf herbicides were used to kill oaks and to release understory grasses for grazing. The resulting dead trees were gathered in piles and burned. In some cases, large areas of ancient post oaks, red cedar, and blackjack oaks were removed and replaced by rangeland (Francaviglia, 2003).

The largest net changes over the entire study period (1973-2000) were a 0.7 percent increase in developed land and a 0.7 decrease in agricultural land. Developed land steadily increased throughout the study period, with an estimated net increase of $677 \mathrm{~km}^{2}$ (table 4). About 50 percent of the new developed land was formerly grassland/ shrubland (table 3). A steady increase in population likely contributed to the increase in developed land throughout the ecoregion. Overall, the decline in agriculture resulted from new development and also participation in the Conservation Reserve Program (CRP). The CRP provided economic incentives to farmers to convert highly erodible cropland or other environmentally sensitive acreage to vegetative cover,

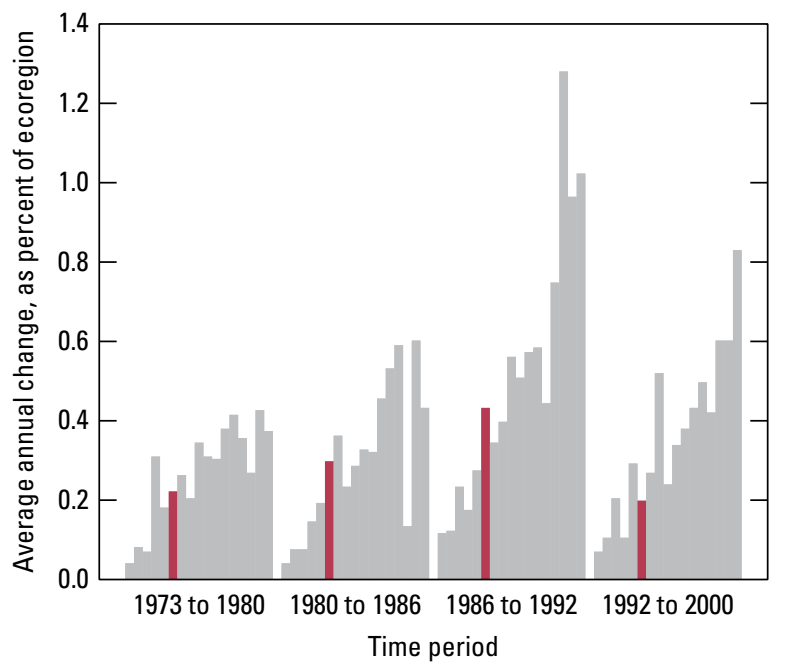

Figure 6. Estimates of land-cover change per time period, normalized to annual rates of change for all 17 Great Plains ecoregions (gray bars). Estimates of change for Central Oklahoma/Texas Plains Ecoregion are represented by red bars in each time period. 
such as grasses and forbes, specific wildlife plantings, trees, filter strips (vegetated surfaces designed to treat surface runoff), or riparian buffers (U.S. Department of Agriculture, 2008).

Between 1973 and 2000, the most significant landcover conversions in the Central Oklahoma/Texas Plains Ecoregion were fluctuations between grassland/shrubland and agriculture that were influenced by government

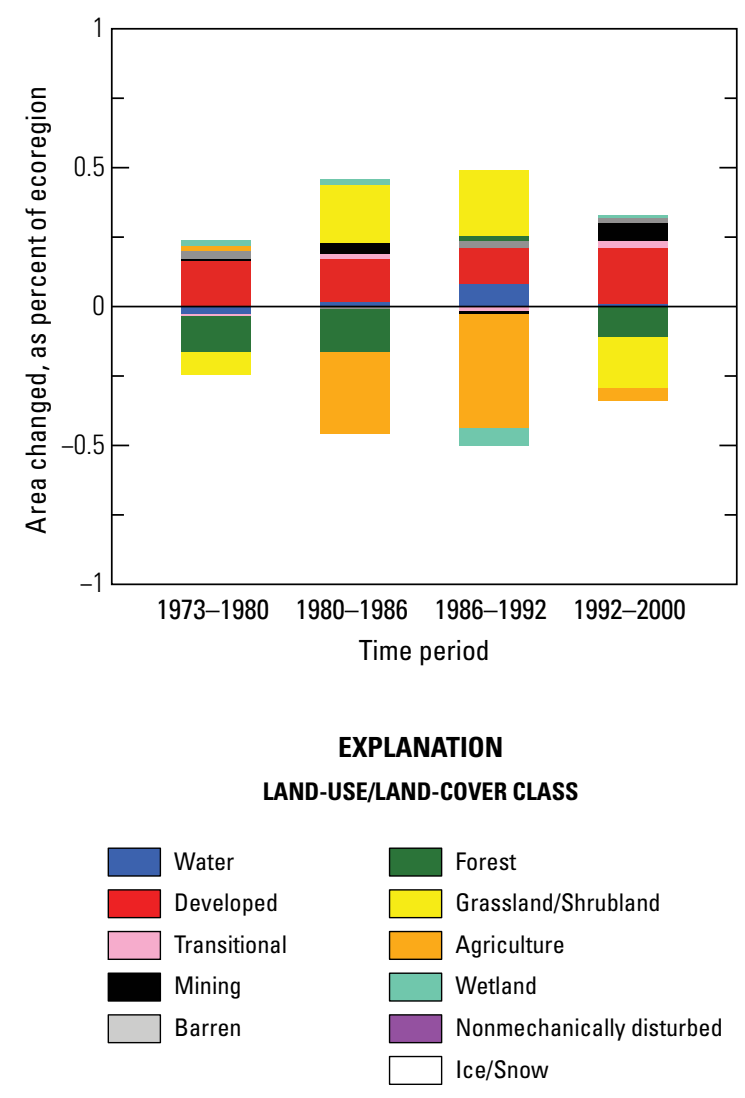

Figure 7. Normalized average net change in Central Oklahoma/ Texas Plains Ecoregion by time period for each land-cover class. Bars above zero axis represent net gain, whereas bars below zero represent net loss. Note that not all land-cover classes shown in explanation may be represented in figure. See appendix 3 for definitions of land-use/land-cover classifications. policies and the global economic climate. Conversions to and from grassland/shrubland and agriculture were nearly equal between 1973 and 1980 and between 1992 and 2000 (table 3). In the other two time periods, however, this was not the case. Between 1980 and 1986, agriculture decreased, likely owing to the global recession in the early 1980s that caused a reduced grain demand and a decrease in farm land values. Between 1986 and 1992, the rapid increase in the conversion of agriculture back to grassland/ shrubland likely was related to the initiation of the CRP (U.S. Department of Agriculture, 2009). Between 1992 and 2000, the conversion of grassland/shrubland to agriculture was significantly less, probably owing to CRP land going back into crop production.

Another notable change in the ecoregion was the steady increase in development, especially exurban development (fig. 7). Population growth in Oklahoma City, Tulsa, and Stillwater, Oklahoma, as well as in Gainesville, Glen Rose, and Fort Worth, Texas, contributed to the expansion of developed land. In addition, new developed land near or along reservoirs and lakes increased as people built homes near outdoor recreational sites.

Rangeland expanded at times during the study period as forest areas were converted to grassland/shrubland for livestock grazing (fig. 8). Tall brush, which includes mesquite (Prosopis spp.) and live oak (Quercus virginiana) was cleared for raising cattle and, to a lesser degree, along with some forest areas, for growing hay and expanding pastures.

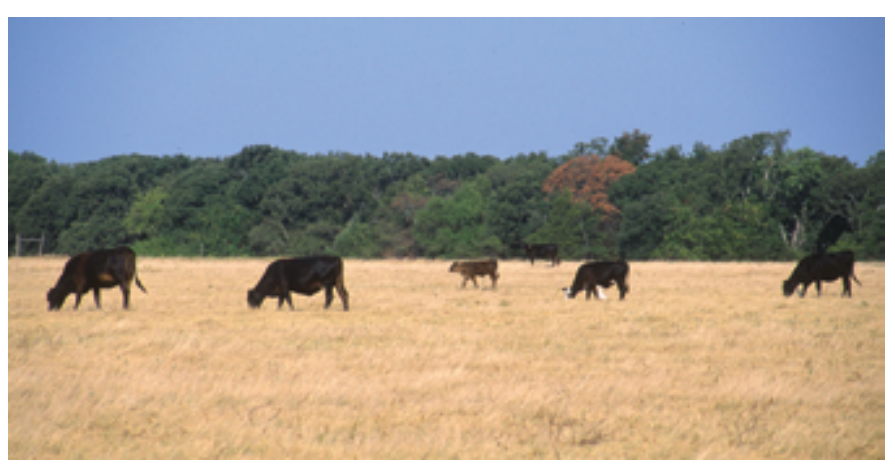

Figure 8. Cattle grazing in open pasture in Central Oklahoma/ Texas Plains Ecoregion. 
Table 1. Percentage of Central Oklahoma/Texas Plains Ecoregion land cover that changed at least one time during study period (1973-2000) and associated statistical error.

\begin{tabular}{|c|c|c|c|c|c|c|}
\hline $\begin{array}{c}\text { Number } \\
\text { of } \\
\text { changes }\end{array}$ & $\begin{array}{c}\text { Percent } \\
\text { of } \\
\text { ecoregion }\end{array}$ & $\begin{array}{l}\text { Margin } \\
\text { of error } \\
(+/-\%)\end{array}$ & $\begin{array}{c}\text { Lower } \\
\text { bound } \\
(\%)\end{array}$ & $\begin{array}{c}\text { Upper } \\
\text { bound } \\
(\%)\end{array}$ & $\begin{array}{c}\text { Standard } \\
\text { error } \\
(\%)\end{array}$ & $\begin{array}{c}\text { Relative } \\
\text { error } \\
(\%)\end{array}$ \\
\hline 1 & 5.6 & 1.0 & 4.6 & 6.6 & 0.7 & 12.6 \\
\hline 2 & 0.8 & 0.3 & 0.5 & 1.1 & 0.2 & 28.2 \\
\hline 3 & 0.1 & 0.0 & 0.0 & 0.1 & 0.0 & 34.1 \\
\hline 4 & 0.0 & 0.0 & 0.0 & 0.0 & 0.0 & 67.0 \\
\hline $\begin{array}{l}\text { Overall } \\
\text { spatial } \\
\text { change }\end{array}$ & 6.5 & 1.2 & 5.2 & 7.7 & 0.8 & 13.0 \\
\hline
\end{tabular}

Table 2. Raw estimates of change in Central Oklahoma/Texas Plains Ecoregion land-cover, computed for each of four time periods between 1973 and 2000, and associated error at 85-percent confidence level.

[Estimates of change per period normalized to annual rate of change for each period]

\begin{tabular}{|c|c|c|c|c|c|c|c|}
\hline Period & $\begin{array}{c}\text { Total change } \\
\text { (\% of ecoregion) }\end{array}$ & $\begin{array}{c}\text { Margin of } \\
\text { error } \\
(+/-\%)\end{array}$ & $\begin{array}{c}\text { Lower } \\
\text { bound } \\
(\%)\end{array}$ & $\begin{array}{c}\text { Upper bound } \\
(\%)\end{array}$ & $\begin{array}{c}\text { Standard } \\
\text { error } \\
(\%)\end{array}$ & $\begin{array}{c}\text { Relative } \\
\text { error } \\
(\%)\end{array}$ & $\begin{array}{l}\text { Average rate } \\
\text { (\% per year) }\end{array}$ \\
\hline \multicolumn{8}{|c|}{ Estimate of change, in percent stratum } \\
\hline 1973-1980 & 1.5 & 0.4 & 1.1 & 2.0 & 0.3 & 19.2 & 0.2 \\
\hline 1980-1986 & 1.8 & 0.5 & 1.3 & 2.2 & 0.3 & 17.9 & 0.3 \\
\hline 1986-1992 & 2.6 & 0.8 & 1.8 & 3.4 & 0.6 & 21.7 & 0.4 \\
\hline 1992-2000 & 1.6 & 0.3 & 1.3 & 1.9 & 0.2 & 13.4 & 0.2 \\
\hline \multicolumn{8}{|c|}{ Estimate of change, in square kilometers } \\
\hline 1973-1980 & 1,595 & 452 & 1,144 & 2,047 & 307 & 19.2 & 228 \\
\hline 1980-1986 & 1,842 & 485 & 1,357 & 2,326 & 329 & 17.9 & 307 \\
\hline 1986-1992 & 2,664 & 852 & 1,812 & 3,516 & 579 & 21.7 & 444 \\
\hline 1992-2000 & 1,616 & 319 & 1,296 & 1,935 & 217 & 13.4 & 202 \\
\hline
\end{tabular}


Table 3. Principal land-cover conversions in Central Oklahoma/Texas Plains Ecoregion, showing amount of area changed (and margin of error, calculated at 85-percent confidence level) for each conversion during each of four time periods and also during overall study period. See appendix 3 for definitions of land-cover classifications.

[Values given for "other" class are combined totals of values for other land-cover classes not listed in that time period. Abbreviations: n/a, not applicable]

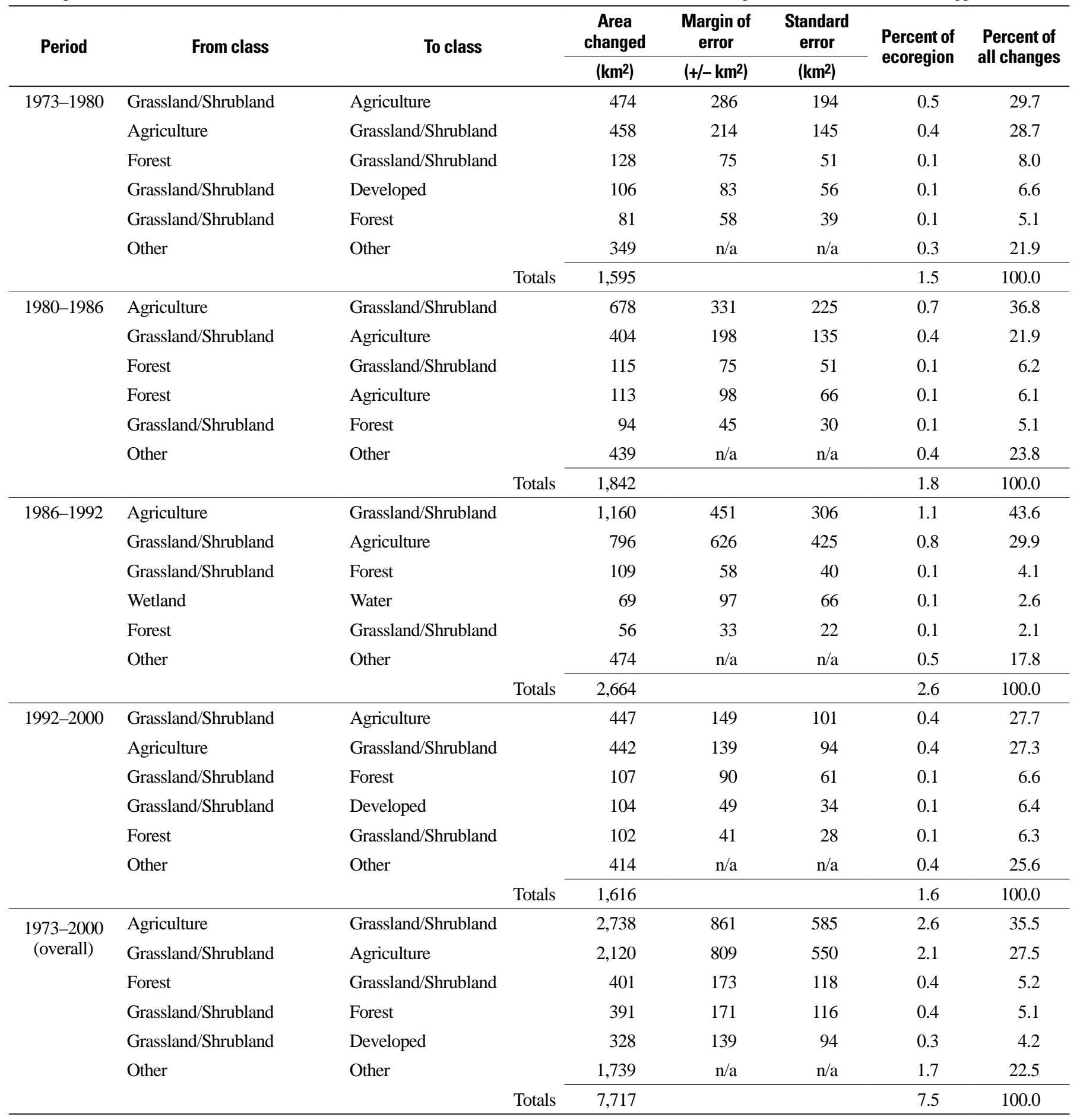


Table 4. Estimated area (and margin of error) of each land-cover class in Central Oklahoma/Texas Plains Ecoregion, calculated five times between 1973 and 2000. See appendix 3 for definitions of land-cover classifications.

\begin{tabular}{|c|c|c|c|c|c|c|c|c|c|c|c|c|c|c|c|c|c|c|c|c|}
\hline & \multicolumn{2}{|c|}{ Water } & \multicolumn{2}{|c|}{ Developed } & \multicolumn{2}{|c|}{$\begin{array}{l}\text { Mechan- } \\
\text { ically } \\
\text { disturbed }\end{array}$} & \multicolumn{2}{|c|}{ Mining } & \multicolumn{2}{|c|}{ Barren } & \multicolumn{2}{|c|}{ Forest } & \multicolumn{2}{|c|}{$\begin{array}{l}\text { Grassland/Shru- } \\
\text { bland }\end{array}$} & \multicolumn{2}{|c|}{ Agriculture } & \multicolumn{2}{|c|}{ Wetland } & \multicolumn{2}{|c|}{$\begin{array}{c}\text { Non- } \\
\text { mechanically } \\
\text { disturbed }\end{array}$} \\
\hline & $\%$ & $+/-$ & $\%$ & $+/-$ & $\%$ & $+/-$ & $\%$ & $+/-$ & $\%$ & $+/-$ & $\%$ & $+/-$ & $\%$ & $+/-$ & $\%$ & $+/-$ & $\%$ & $+/-$ & $\%$ & $+/-$ \\
\hline \multicolumn{21}{|c|}{ Area, in percent stratum } \\
\hline 1973 & 2.3 & 1.8 & 2.9 & 1.2 & 0.0 & 0.0 & 0.1 & 0.0 & 0.0 & 0.0 & 0.0 & 19.6 & 3.0 & 46.5 & 6.0 & 4.4 & 1.0 & 0.7 & 0.0 & 0.0 \\
\hline 1980 & 2.3 & 1.8 & 3.0 & 1.2 & 0.0 & 0.0 & 0.1 & 0.0 & 0.0 & 0.1 & 0.1 & 19.5 & 3.0 & 46.5 & 5.9 & 4.4 & 1.0 & 0.7 & 0.0 & 0.0 \\
\hline 1992 & 2.4 & 1.8 & 3.3 & 1.3 & 0.0 & 0.0 & 0.1 & 0.1 & 0.1 & 0.1 & 0.1 & 19.3 & 3.0 & 46.9 & 5.9 & 4.3 & 0.9 & 0.7 & 0.0 & 0.0 \\
\hline 2000 & 2.4 & 1.8 & 3.5 & 1.4 & 0.0 & 0.0 & 0.2 & 0.1 & 0.1 & 0.1 & 0.1 & 19.2 & 3.0 & 46.7 & 5.9 & 4.3 & 1.0 & 0.7 & 0.0 & 0.0 \\
\hline $\begin{array}{l}\text { Net } \\
\text { change }\end{array}$ & 0.1 & 0.0 & 0.7 & 0.2 & 0.0 & 0.0 & 0.1 & 0.1 & 0.1 & 0.1 & 0.1 & -0.4 & 0.2 & 0.2 & 0.9 & 1.0 & 0.0 & 0.0 & 0.0 & 0.0 \\
\hline $\begin{array}{l}\text { Gross } \\
\text { change }\end{array}$ & 0.2 & 0.1 & 0.7 & 0.2 & 0.1 & 0.1 & 0.2 & 0.1 & 0.1 & 0.1 & 0.1 & 0.9 & 0.2 & 3.3 & 0.8 & 0.9 & 0.1 & 0.1 & 0.0 & 0.0 \\
\hline 1980 & 2,378 & 1,847 & 3,135 & 1,249 & 7 & 7 & 118 & 47 & 71 & 70 & 20,122 & 3,102 & 48,058 & 6,141 & 28,489 & 4,502 & 1,034 & 745 & 0 & 0 \\
\hline 1986 & 2,401 & 1,852 & 3,291 & 1,293 & 29 & 23 & 157 & 64 & 65 & 59 & 19,963 & 3,059 & 48,279 & 5,982 & 28,184 & 4,398 & 1,044 & 776 & 0 & 0 \\
\hline 1992 & 2,484 & 1,856 & 3,424 & 1,334 & 13 & 9 & 148 & 56 & 94 & 100 & 19,988 & 3,062 & 48,526 & 6,127 & 27,756 & 4,479 & 981 & 712 & 6 & 9 \\
\hline 2000 & 2,489 & 1,854 & 3,640 & 1,406 & 40 & 26 & 211 & 88 & 112 & 121 & 19,876 & 3,056 & 48,333 & 6,124 & 27,714 & 4,444 & 994 & 725 & 0 & 0 \\
\hline $\begin{array}{l}\text { Net } \\
\text { change }\end{array}$ & 80 & 49 & 677 & 258 & 28 & 25 & 101 & 90 & 76 & 101 & -381 & 234 & 197 & 914 & -759 & 1,008 & -22 & 35 & 0 & 0 \\
\hline $\begin{array}{l}\text { Gross } \\
\text { change }\end{array}$ & 211 & 151 & 677 & 258 & 93 & 58 & 240 & 113 & 91 & 124 & 962 & 255 & 3,413 & 876 & 3,449 & 949 & 133 & 142 & 0 & 0 \\
\hline
\end{tabular}




\section{References Cited}

Francaviglia, Richard, 2003, The cast iron forest-A natural and cultural history of the North American cross timbers: Austin, University of Texas Press, 296 p.

McNab, W.H., and Avers, Peter, 1996, Prairie parkland (subtropical)—Cross timbers and prairie, in Ecological subregions of the United States: U.S. Department of Agriculture, Forest Service, WO-WSA-5, Section 255A, p. 1-6, available at http://www.fs.fed.us/land/pubs/ecoregions/ ch29.html.

Omernik, J.M., 1987, Ecoregions of the conterminous United States: Annals of the Association of American Geographers, v. 77, no. 1, p.118-125.

Stahle, D.W., Therrell, M.D., and Clements, K.L., 2003, The Ancient Cross Timbers Consortium for Research, Education, and Conservation-A proposal from the Tree-Ring Laboratory, University of Arkansas, August 2003: Fayetteville, University of Arkansas, Tree-Ring Laboratory, 15 p., available at http:// www.uark.edu/misc/xtimber/consortium.pdf.

Texas Parks and Wildlife, 2007, Big game: Texas Parks and Wildlife database, accessed October 30, 2007, at http:// www.tpwd.state.tx.us/landwater/land/habitats/cross_ timbers/big_game/.

U.S. Census Bureau, 2005, Census of population and housing: U.S. Census Bureau database, accessed February 26, 2008, at http://www.census.gov/prod/www/decennial.html.
U.S. Department of Agriculture Natural Resources Conservation Service, 2006, Land resource regions and major land resource areas of the United States, the Caribbean, and the Pacific Basin: U.S. Department of Agriculture Handbook 296, 669 p., available at http:// www.nrcs.usda.gov/Internet/FSE_DOCUMENTS/ nrcs142p2_050898.pdf.

U.S. Department of Agriculture, 2008, Conservation Reserve Program: U.S. Department of Agriculture Farm Service Agency database, accessed February 26, 2008, at http:// www.nrcs.usda.gov/programs/crp/.

U.S. Environmental Protection Agency, 1997, Descriptions of level III ecological regions for the CEC report on ecological regions of North America: U.S. Environmental Protection Agency database, accessed February 26, 2008, at http://www.epa.gov/wed/pages/ecoregions/na_eco. htm\#Downloads.

University of Arkansas Tree-Ring Laboratory, 2007, Ancient Cross Timbers Consortium: University of Arkansas TreeRing Laboratory database, accessed February 26, 2008, at http://www.uark.edu/misc/xtimber/index.html.

Vogelmann, J.E., Howard, S.M., Yang, L., Larson, C.R., Wylie, B.K., and van Driel, N., 2001, Completion of the 1990s National Land Cover Data Set for the coterminous United States from Landsat Thematic Mapper data and ancillary data sources: Photogrammetric Engineering \& Remote Sensing, v. 67, p. 650-662. 


\title{
East Central Texas Plains Ecoregion
}

\author{
By Krista A. Karstensen
}

\section{Ecoregion Description}

The East Central Texas Plains Ecoregion, which encompasses 44,076 km² (17,018 $\left.\mathrm{mi}^{2}\right)$ in east Texas (Omernik, 1987; U.S. Environmental Protection Agency, 1997) (fig. 1), extends north from just south of the San Antonio River to an area near the Oklahoma border. The ecoregion is bounded by (clockwise, from its east end) the South Central Plains,

Figure 1. Map of East Central Texas Plains Ecoregion and surrounding ecoregions, showing land-use/landcover classes from 1992 National Land-Cover Dataset (Vogelmann and others, 2001); note that not all land-use/ land-cover classes shown in explanation may be depicted on map; note also that, for this "Status and Trends of Land Change" study, transitional land-cover class was subdivided into mechanically disturbed and nonmechanically disturbed classes. Squares indicate locations of $10 \times 10 \mathrm{~km}$ sample blocks analyzed in study. Index map shows locations of geographic features mentioned in text. Abbreviations for Great Plains ecoregions are listed in appendix 2. Also shown is part of one Midwest-South Central United States ecoregion, South Central Plains. See appendix 3 for definitions of land-use/landcover classifications.

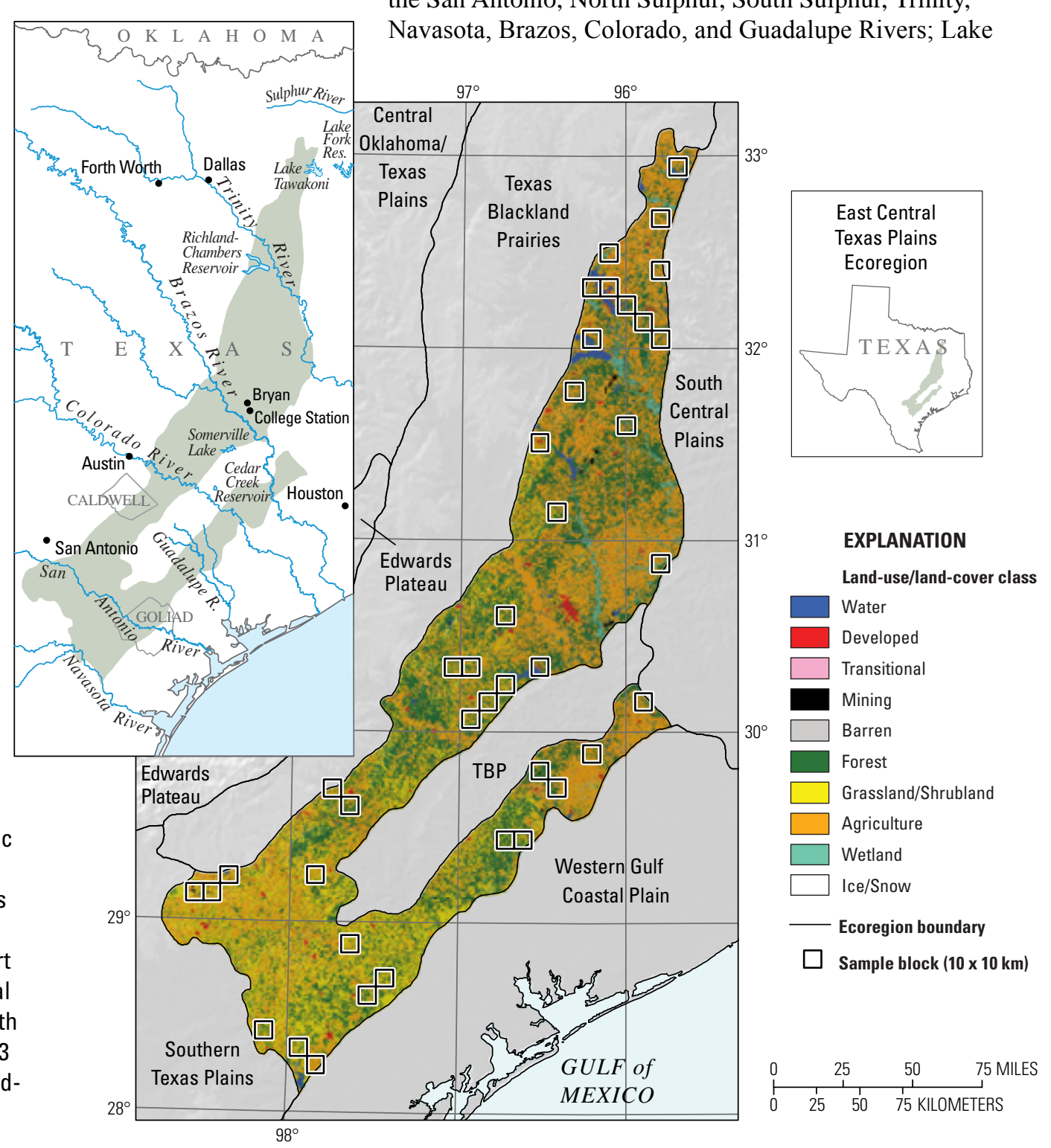
Navasota, Brazos, Colorado, and Guadalupe Rivers; Lake

Western Gulf Coastal Plain, and Southern Texas Plains Ecoregions, as well as the northern section of the Texas Blackland Prairies Ecoregion; in addition, it almost completely surrounds the separate, smaller, southern section of the Texas Blackland Prairies Ecoregion (fig. 1).

The East Central Texas Plains Ecoregion includes the San Antonio, North Sulphur, South Sulphur, Trinity, 
Tawakoni and Somerville Lake; and Lake Fork, RichlandChambers, and Cedar Creek Reservoirs. Two neighboring cities in the ecoregion, Bryan and College Station, Texas, had a combined population of 152,415 in April 2000, an increase of 9.7 percent since 1990 (U.S. Census Bureau, 2001).

Elevations in the ecoregion increase gradually from southeast to northwest. The topography is characterized by irregular plains that have acidic soils along the parallel ridges and valleys, sandy and sandy loam soils on the uplands, and clay and clay loams in the low-lying areas (Griffith and others, 2004). Additionally, much of the ecoregion is underlain by claypan, which affects the movement and availability of water for plant growth (Griffith and others, 2004). Annual precipitation amounts range from 1,000 to $1,200 \mathrm{~mm}$ (40-48 in.) north of Cedar Creek Reservoir and from 700 to $1,000 \mathrm{~mm}(28-40 \mathrm{in}$.) south of the Trinity River.

Historically, fire has played an essential role in maintaining grassy clearings. In the absence of fire, woody invasions have taken place (Griffith and others, 2004). The clearing of woody vegetation has permitted the regrowth of mixed native or introduced grasses and forbs on grassland sites or mixed herbaceous communities (Texas Parks and Wildlife, 2008). The deciduous forest in the East Central Texas Plains Ecoregion mostly is composed of post oak (Quercus stellata) and blackjack oak (Quercus marilandica). Post oak forests are prevalent on sandy soils in the ecoregion, particularly in the area north of College Station (Yantis, 1984; Amy Hays, Texas A\&M University, oral commun., 2009). The south-central part of the ecoregion, along the Colorado River, has the westernmost tract of longleaf pine (Pinus palustris) in the United States (Griffith and others, 2004; Amy Hays, Texas A\&M University, oral commun., 2009).

\section{Contemporary Land-Cover Change (1973 to 2000)}

The overall spatial change (the percentage of land area that changed at least one time) in the East Central Texas Plains Ecoregion between 1973 and 2000 is estimated at 12.1 percent (table 1). Compared to the other Great Plains ecoregions, change in the East Central Texas Plains Ecoregion was the second highest (fig. 2). An estimated 10.5 percent of the ecoregion changed only one time, whereas 1.5 percent and 0.1 percent changed two and three times, respectively, during the entire 27-year study period (table 1). When normalized to account for varying lengths of study periods, annual rates of change ranged from a low of 0.4 percent per year, between 1973 and 1980 and between 1992 and 2000, to a high of 0.7 percent per year, between 1986 and 1992 (table 2; fig. 3).

Agriculture covered 46.3 percent of the ecoregion in 2000, despite an overall net decrease of 2.7 percent by the end of the study period (table 3 ). Forest was the second leading land-cover class, at 30.5 percent of the ecoregion in 2000, despite an overall net decrease of 1.8 percent since 1973 (table 3). Grassland/ shrubland constituted 14.4 percent of the ecoregion in 2000.

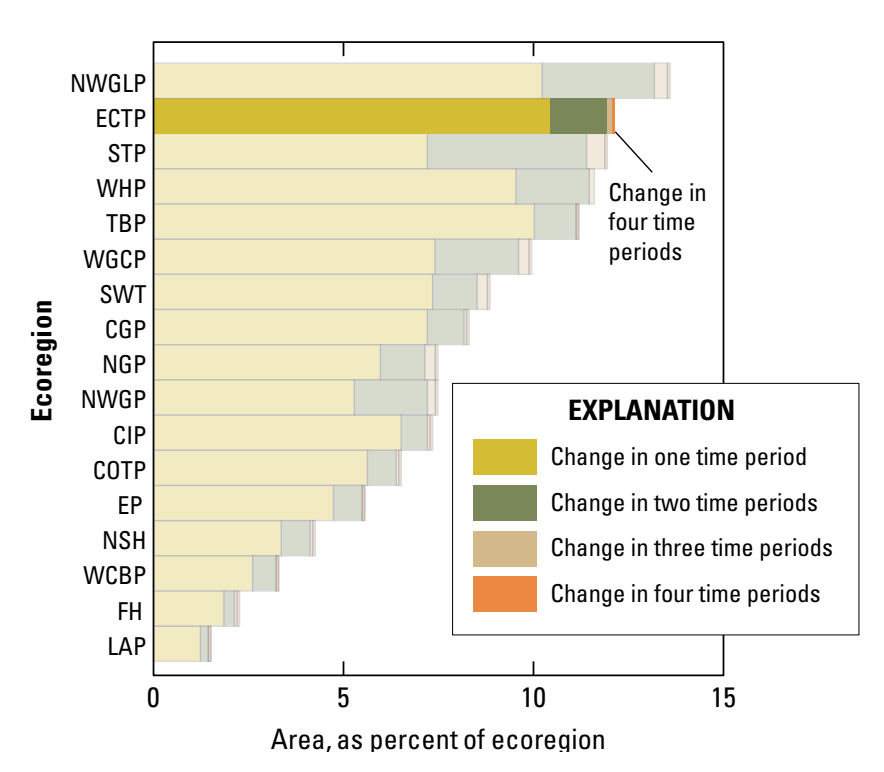

Figure 2. Overall spatial change in East Central Texas Plains Ecoregion (ECTP; darker bars) compared with that of all 17 Great Plains ecoregions (lighter bars). Each horizontal set of bars shows proportions of ecoregion that changed during one, two, three, or four time periods; highest level of spatial change in East Central Texas Plains Ecoregion (four time periods) labeled for clarity. See table 2 for years covered by each time period. See appendix 2 for key to ecoregion abbreviations.

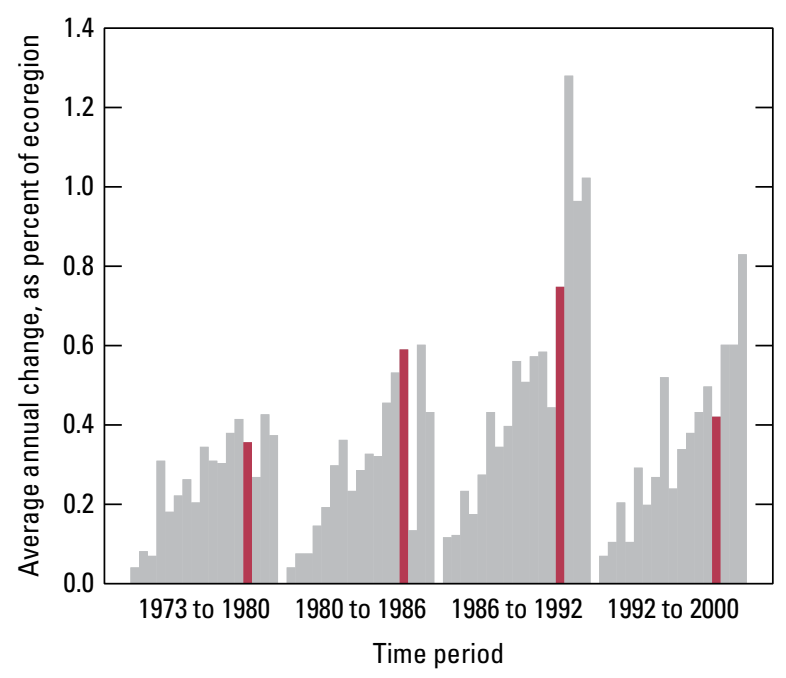

Figure 3. Estimates of land-cover change per time period, normalized to annual rates of change for all 17 Great Plains ecoregions (gray bars). Estimates of change for East Central Texas Plains Ecoregion are represented by red bars in each time period. 
Of all the land-cover classes in the East Central Texas Plains Ecoregion, grassland/shrubland, developed, and water had the largest overall net increases, at 1.3 percent (table 3; fig. 4).

Between 1973 and 2000, the five most common land-cover conversions were (1) agriculture to grassland/shrubland, (2) forest to agriculture, (3) grassland/shrubland to forest, (4) grassland/ shrubland to agriculture, and (5) agriculture to forest (table 4). Although conversions to developed were not among the top five leading land-cover conversions during the study period, the net increase of 1.3 percent $\left(581 \mathrm{~km}^{2}\right)$ in developed land was significant.

The East Central Texas Plains Ecoregion is a mosaic of improved pastureland, rangeland, and cropland (Griffith and others, 2004). Although agricultural lands declined overall during the study period, it still constitutes the largest land-cover class in the ecoregion. Between 1970 and 2000, about 1,000 new farms and ranches were established in Texas each year, even though the total area in farms and ranches has declined by almost 3 million acres during the same time period, a statewide trend that is apparent in the East Central Texas Plains Ecoregion (U.S. Department of Agriculture, 2009).

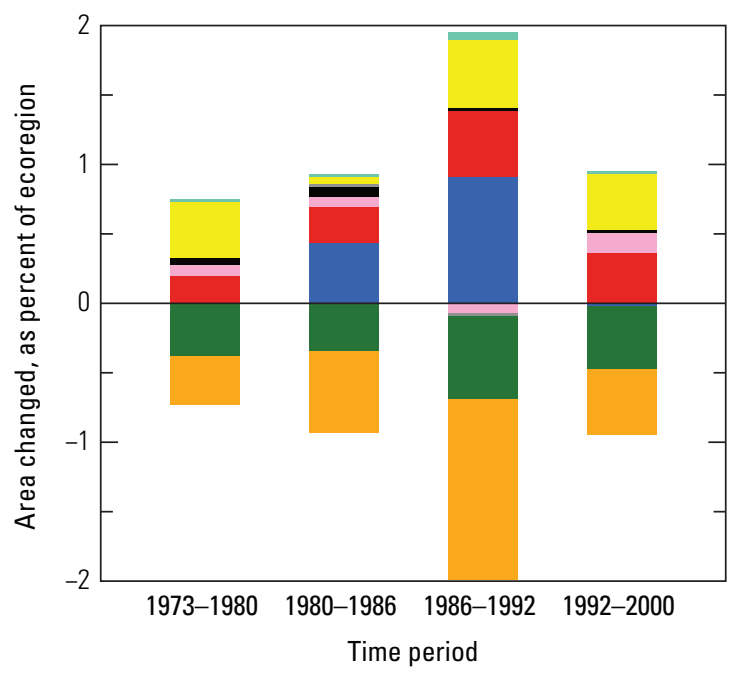

EXPLANATION

LAND-USE/LAND-COVER CLASS

Water
$\square$ Developed
$\square$ Mechanically disturbed
Mining
$\square$ Barren

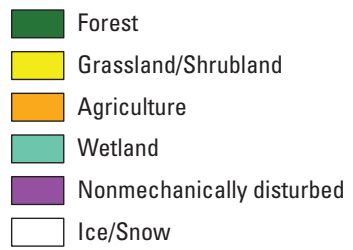

Figure 4. Normalized average net change in East Central Texas Plains Ecoregion by time period for each land-cover class. Bars above zero axis represent net gain, whereas bars below zero represent net loss. Note that not all land-cover classes shown in explanation may be represented in figure. See appendix 3 for definitions of land-use/land-cover classifications.
The East Central Texas Plains Ecoregion historically has been a mix of post oak and blackjack oak forest and savanna on sandy soils, interspersed with midgrass and tallgrass prairie on areas of heavier soil (Chuck Kowaleski, Texas Parks and Wildlife, written commun., 2009). Although much of this land originally was farmed, the sandier sites quickly lost their fertility (Chuck Kowaleski, Texas Parks and Wildlife, written commun., 2009). The average land-ownership size increased as old farms were consolidated into ranches (Yantis, 1984). In 1974, the central part of the ecoregion had about 18 people, 104 cattle, and 11 hogs per square mile (Yantis, 1984). Starting in the 1980s, Texas A\&M AgriLife Extension Service promoted the idea of converting native grasses to coastal Bermudagrass (Cynodon dactylon) tame pastures, which, when limed and fertilized, allowed much higher stocking rates (1 cow per acre) than can be achieved on native ranges (Chuck Kowaleski, Texas Parks and Wildlife, written commun., 2009) (fig. 5). Although the land use in the 1980s was similar to that of the 1970 s, the continued increase in human population was bringing more "weekend ranchers" to the area, and the average size of landholdings was decreasing (Yantis, 1984).

The impact of population on land use in the later part of the study period is correlated with changes in ownership and size of tracts (Wilkins and others, 2003). Between 1992 and 2001, the most notable land-use trend was the conversion of native rangelands and croplands to nonnative "improved pastures" (Wilkins and others, 2003). Unlike the consolidation that occurred in the early 1970s, fragmentation of rural acreage became dominant in the 1990s as large properties were divided into smaller parcels (Wilkins and others, 2003). This may help to describe the principal land-cover change in this ecoregion, namely agriculture to grassland/shrubland. As the land becomes fragmented, the tracts become too small for traditional farming and ranching (Wilkins and others, 2003) (fig. 6).

Land in the ecoregion also has become increasingly valuable with the expanding population of the nearby metropolitan areas. In about 1994, a trend began in which land use shifted from high intensity (crop production) to low intensity (rangeland). Such lands are not considered abandoned agriculture; rather,

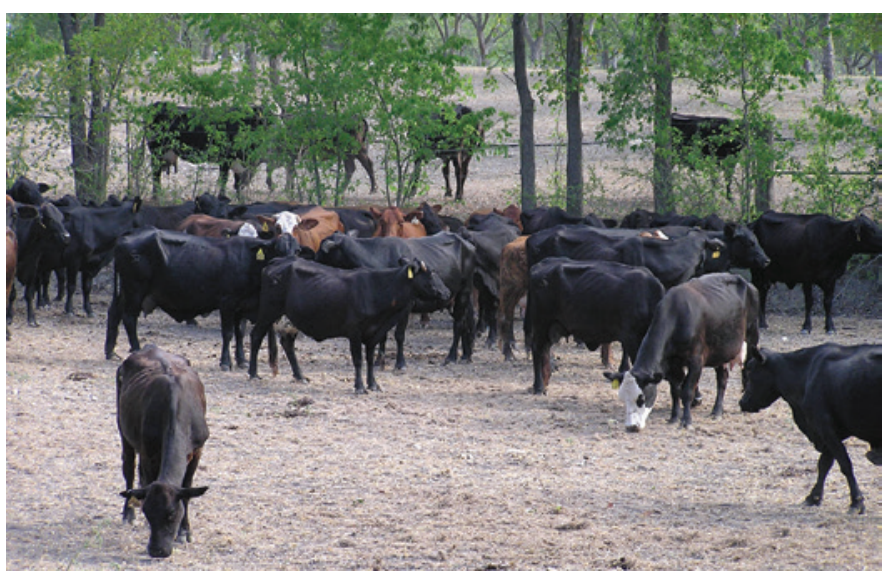

Figure 5. Cattle in pasture in Caldwell County, Texas, in East Central Texas Plains Ecoregion. 
the owners simply find more economic value in holding these lands than in growing crops on them (Amy Hays, Texas A\&M University, oral commun., 2009). Additionally, the shift from high intensity to low intensity, or tame pasture, has allowed many of the former savanna areas to become heavily overgrown with a yaupon (Ilex vomitoria) understory (Chuck Kowaleski, Texas Parks and Wildlife, written commun., 2009).

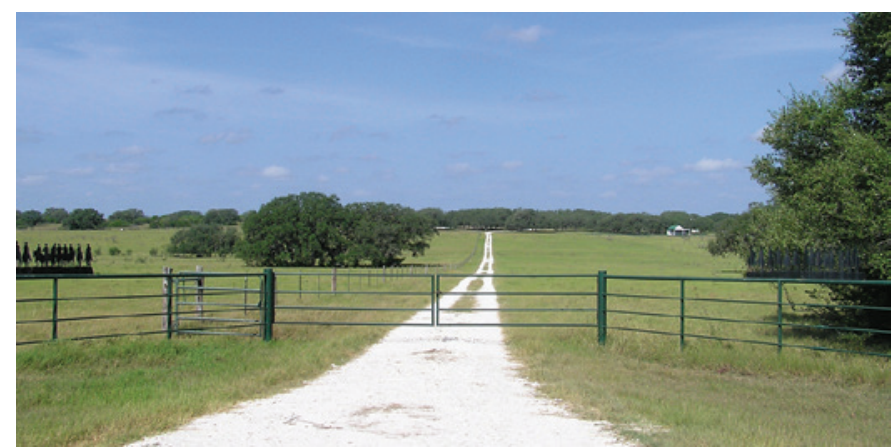

Table 1. Percentage of East Central Texas Plains Ecoregion land cover that changed at least one time during study period (19732000) and associated statistical error.

[Most sample pixels remained unchanged (87.9 percent), whereas 12.1 percent changed at least once throughout study period]

\begin{tabular}{ccccccc}
\hline $\begin{array}{c}\text { Number } \\
\text { of } \\
\text { changes }\end{array}$ & $\begin{array}{c}\text { Percent } \\
\text { of } \\
\text { ecoregion }\end{array}$ & $\begin{array}{c}\text { Margin } \\
\text { of error } \\
(+/-\%)\end{array}$ & $\begin{array}{c}\text { Lower } \\
\text { bound } \\
(\%)\end{array}$ & $\begin{array}{c}\text { Upper } \\
\text { bound } \\
(\%)\end{array}$ & $\begin{array}{c}\text { Standard } \\
\text { error } \\
(\%)\end{array}$ & $\begin{array}{c}\text { Relative } \\
\text { error } \\
(\%)\end{array}$ \\
\hline 1 & 10.5 & 1.5 & 8.9 & 12.0 & 1.0 & 10.1 \\
2 & 1.5 & 0.3 & 1.2 & 1.8 & 0.2 & 15.2 \\
3 & 0.1 & 0.0 & 0.1 & 0.2 & 0.0 & 24.0 \\
4 & 0.0 & 0.0 & 0.0 & 0.0 & 0.0 & 39.5 \\
\hline $\begin{array}{l}\text { Overall } \\
\text { spatial } \\
\text { change }\end{array}$ & 12.1 & 1.8 & 10.3 & 13.9 & 1.2 & 10.2 \\
\hline
\end{tabular}

Figure 6. Ranchland in Goliad County, Texas, in East Central Texas Plains Ecoregion. 
Table 2. Raw estimates of change in East Central Texas Plains Ecoregion land cover, computed for each of four time periods between 1973 and 2000, and associated error at 85-percent confidence level.

[Estimates of change per period normalized to annual rate of change for each period]

\begin{tabular}{cccccccc}
\hline Period & $\begin{array}{c}\text { Total change } \\
(\% \text { of ecoregion) }\end{array}$ & $\begin{array}{c}\text { Margin of } \\
\text { error } \\
(+/-\%)\end{array}$ & $\begin{array}{c}\text { Lower } \\
\text { bound } \\
(\%)\end{array}$ & $\begin{array}{c}\text { Upper bound } \\
(\%)\end{array}$ & $\begin{array}{c}\text { Standard } \\
\text { error } \\
(\%)\end{array}$ & $\begin{array}{c}\text { Relative } \\
\text { error } \\
(\%)\end{array}$ & $\begin{array}{c}\text { Average rate } \\
(\% \text { per year) }\end{array}$ \\
\hline \multicolumn{7}{|c|}{ Estimate of change, in percent stratum } \\
\hline $1973-1980$ & 2.5 & 0.5 & 2.0 & 2.9 & 0.3 & 12.4 & 0.4 \\
$1980-1986$ & 3.5 & 0.8 & 2.8 & 4.3 & 0.5 & 14.8 & 0.6 \\
$1986-1992$ & 4.5 & 1.4 & 3.1 & 5.9 & 1.0 & 21.2 & 0.7 \\
$1992-2000$ & 3.4 & 0.5 & 2.9 & 3.9 & 0.3 & 10.1 & 0.4 \\
\hline $1973-1980$ & 1,100 & 200 & 900 & 1,300 & 136 & 12.4 & 157 \\
$1980-1986$ & 1,558 & 338 & 1,219 & 1,896 & 231 & 14.8 & 260 \\
$1986-1992$ & 1,977 & 615 & 1,362 & 2,592 & 419 & 21.2 & 329 \\
$1992-2000$ & 1,487 & 219 & 1,267 & 1,706 & 149 & 10.1 & 186 \\
\hline
\end{tabular}


Table 3. Estimated area (and margin of error) of each land-cover class in East Central Texas Plains Ecoregion, calculated five times between 1973 and 2000. See appendix 3 for definitions of land-cover classifications.

\begin{tabular}{|c|c|c|c|c|c|c|c|c|c|c|c|c|c|c|c|c|c|c|c|c|}
\hline & \multicolumn{2}{|c|}{ Water } & \multicolumn{2}{|c|}{ Developed } & \multicolumn{2}{|c|}{$\begin{array}{l}\text { Mechanically } \\
\text { disturbed }\end{array}$} & \multicolumn{2}{|c|}{ Mining } & \multicolumn{2}{|c|}{ Barren } & \multicolumn{2}{|c|}{ Forest } & \multicolumn{2}{|c|}{$\begin{array}{l}\text { Grassland/ } \\
\text { Shrubland }\end{array}$} & \multicolumn{2}{|c|}{ Agriculture } & \multicolumn{2}{|c|}{ Wetland } & \multicolumn{2}{|c|}{$\begin{array}{c}\text { Non- } \\
\text { mechanically } \\
\text { disturbed }\end{array}$} \\
\hline & $\%$ & $+1-$ & $\%$ & $+1-$ & $\%$ & $+/-$ & $\%$ & $+/-$ & $\%$ & $+/-$ & $\%$ & $+/-$ & $\%$ & $+1-$ & $\%$ & $+/-$ & $\%$ & $+/-$ & $\%$ & $+/-$ \\
\hline 1973 & 2.6 & 1.3 & 1.8 & 0.5 & 0.0 & 0.0 & 0.2 & 0.1 & 0.1 & 0.1 & 32.3 & 4.0 & 13.0 & 3.0 & 49.0 & 4.5 & 1.0 & 0.3 & 0.0 & 0.0 \\
\hline 1980 & 2.6 & 1.3 & 2.0 & 0.6 & 0.1 & 0.0 & 0.3 & 0.2 & 0.1 & 0.1 & 31.9 & 3.9 & 13.4 & 3.0 & 48.6 & 4.4 & 1.0 & 0.3 & 0.0 & 0.0 \\
\hline 1992 & 4.0 & 1.7 & 2.8 & 0.8 & 0.1 & 0.0 & 0.4 & 0.2 & 0.1 & 0.1 & 30.9 & 3.8 & 14.0 & 2.9 & 46.8 & 4.3 & 1.1 & 0.3 & 0.0 & 0.0 \\
\hline 2000 & 4.0 & 1.7 & 3.2 & 0.9 & 0.2 & 0.2 & 0.4 & 0.2 & 0.1 & 0.1 & 30.5 & 3.7 & 14.4 & 3.0 & 46.3 & 4.3 & 1.1 & 0.3 & 0.0 & 0.0 \\
\hline $\begin{array}{l}\text { Net } \\
\text { change }\end{array}$ & 1.3 & 1.3 & 1.3 & 0.5 & 0.2 & 0.2 & 0.2 & 0.1 & 0.0 & 0.0 & -1.8 & 1.0 & 1.3 & 0.8 & -2.7 & 1.4 & 0.1 & 0.1 & 0.0 & 0.0 \\
\hline $\begin{array}{l}\text { Gross } \\
\text { change }\end{array}$ & 1.6 & 1.3 & 1.3 & 0.5 & 0.6 & 0.3 & 0.3 & 0.2 & 0.0 & 0.0 & 3.6 & 0.8 & 3.7 & 0.6 & 5.5 & 1.0 & 0.2 & 0.1 & 0.0 & 0.0 \\
\hline 1980 & 1,156 & 559 & 903 & 270 & 33 & 21 & 118 & 79 & 30 & 30 & 14,059 & 1,700 & 5,907 & 1,324 & 21,434 & 1,929 & 436 & 147 & 0 & 0 \\
\hline 1986 & 1,350 & 600 & 1,020 & 303 & 62 & 47 & 155 & 106 & 32 & 30 & 13,910 & 1,662 & 5,934 & 1,294 & 21,174 & 1,909 & 437 & 144 & 0 & 0 \\
\hline 1992 & 1,756 & 758 & 1,232 & 370 & 28 & 19 & 159 & 108 & 31 & 30 & 13,640 & 1,671 & 6,150 & 1,291 & 20,613 & 1,907 & 465 & 145 & 0 & 0 \\
\hline 2000 & 1,747 & 751 & 1,393 & 418 & 98 & 72 & 161 & 101 & 31 & 30 & 13,444 & 1,632 & 6,330 & 1,310 & 20,403 & 1,898 & 470 & 146 & 0 & 0 \\
\hline $\begin{array}{l}\text { Net } \\
\text { change }\end{array}$ & 593 & 564 & 581 & 230 & 94 & 72 & 69 & 48 & 1 & 2 & -782 & 432 & 595 & 357 & $-1,187$ & 604 & 36 & 30 & 0 & 0 \\
\hline $\begin{array}{l}\text { Gross } \\
\text { change }\end{array}$ & 685 & 563 & 581 & 230 & 268 & 119 & 119 & 73 & 6 & 5 & 1,603 & 341 & 1,642 & 279 & 2,406 & 461 & 69 & 42 & 0 & 0 \\
\hline
\end{tabular}


Table 4. Principal land-cover conversions in East Central Texas Plains Ecoregion, showing amount of area changed (and margin of error, calculated at 85-percent confidence level) for each conversion during each of four time periods and also during overall study period. See appendix 3 for definitions of land-cover classifications.

[Values given for "other" classes are combined totals of values for other land-cover classes not listed in that time period. Abbreviations: n/a, not applicable]

\begin{tabular}{|c|c|c|c|c|c|c|c|c|}
\hline Period & From class & To class & & $\begin{array}{c}\begin{array}{c}\text { Area } \\
\text { changed }\end{array} \\
\left(\mathbf{k m}^{2}\right)\end{array}$ & $\begin{array}{c}\text { Margin of } \\
\text { error } \\
\left(+/-\mathrm{km}^{2}\right)\end{array}$ & $\begin{array}{c}\text { Standard } \\
\text { error } \\
\left(\mathbf{k m}^{2}\right)\end{array}$ & $\begin{array}{l}\text { Percent of } \\
\text { ecoregion }\end{array}$ & $\begin{array}{c}\text { Percent of all } \\
\text { changes }\end{array}$ \\
\hline \multirow[t]{7}{*}{ 1973-1980 } & Agriculture & Grassland/Shrubland & & 334 & 98 & 67 & 0.8 & 30.3 \\
\hline & Forest & Agriculture & & 208 & 85 & 58 & 0.5 & 18.9 \\
\hline & Grassland/Shrubland & Forest & & 102 & 48 & 32 & 0.2 & 9.3 \\
\hline & Grassland/Shrubland & Agriculture & & 91 & 37 & 25 & 0.2 & 8.3 \\
\hline & Agriculture & Forest & & 74 & 37 & 25 & 0.2 & 6.7 \\
\hline & Other & Other & & 291 & $\mathrm{n} / \mathrm{a}$ & $\mathrm{n} / \mathrm{a}$ & 0.7 & 26.5 \\
\hline & & & Totals & 1,100 & & & 2.5 & 100.0 \\
\hline \multirow[t]{7}{*}{ 1980-1986 } & Agriculture & Grassland/Shrubland & & 369 & 116 & 79 & 0.8 & 23.7 \\
\hline & Forest & Agriculture & & 197 & 48 & 33 & 0.4 & 12.7 \\
\hline & Grassland/Shrubland & Forest & & 189 & 69 & 47 & 0.4 & 12.1 \\
\hline & Grassland/Shrubland & Agriculture & & 139 & 55 & 38 & 0.3 & 9.0 \\
\hline & Agriculture & Forest & & 114 & 54 & 36 & 0.3 & 7.3 \\
\hline & Other & Other & & 549 & $\mathrm{n} / \mathrm{a}$ & $\mathrm{n} / \mathrm{a}$ & 1.2 & 35.3 \\
\hline & & & Totals & 1,558 & & & 3.5 & 100.0 \\
\hline \multirow[t]{7}{*}{ 1986-1992 } & Agriculture & Grassland/Shrubland & & 563 & 154 & 105 & 1.3 & 28.5 \\
\hline & Forest & Water & & 200 & 202 & 138 & 0.5 & 10.1 \\
\hline & Grassland/Shrubland & Agriculture & & 175 & 81 & 55 & 0.4 & 8.9 \\
\hline & Agriculture & Water & & 149 & 199 & 135 & 0.3 & 7.5 \\
\hline & Grassland/Shrubland & Forest & & 149 & 51 & 35 & 0.3 & 7.5 \\
\hline & Other & Other & & 741 & $\mathrm{n} / \mathrm{a}$ & $\mathrm{n} / \mathrm{a}$ & 1.7 & 37.5 \\
\hline & & & Totals & 1,977 & & & 4.5 & 100.0 \\
\hline \multirow[t]{7}{*}{ 1992-2000 } & Agriculture & Grassland/Shrubland & & 430 & 153 & 104 & 1.0 & 28.9 \\
\hline & Forest & Agriculture & & 197 & 73 & 50 & 0.4 & 13.3 \\
\hline & Grassland/Shrubland & Forest & & 147 & 38 & 26 & 0.3 & 9.9 \\
\hline & Grassland/Shrubland & Agriculture & & 139 & 52 & 35 & 0.3 & 9.4 \\
\hline & Forest & Grassland/Shrubland & & 78 & 37 & 25 & 0.2 & 5.3 \\
\hline & Other & Other & & 496 & $\mathrm{n} / \mathrm{a}$ & $\mathrm{n} / \mathrm{a}$ & 1.1 & 33.3 \\
\hline & & & Totals & 1,487 & & & 3.4 & 100.0 \\
\hline \multirow{7}{*}{$\begin{array}{l}\text { 1973-2000 } \\
\text { (overall) }\end{array}$} & Agriculture & Grassland/Shrubland & & 1,695 & 338 & 230 & 3.8 & 27.7 \\
\hline & Forest & Agriculture & & 746 & 179 & 122 & 1.7 & 12.2 \\
\hline & Grassland/Shrubland & Forest & & 587 & 163 & 111 & 1.3 & 9.6 \\
\hline & Grassland/Shrubland & Agriculture & & 545 & 177 & 121 & 1.2 & 8.9 \\
\hline & Agriculture & Forest & & 326 & 123 & 84 & 0.7 & 5.3 \\
\hline & Other & Other & & 2,222 & $\mathrm{n} / \mathrm{a}$ & $\mathrm{n} / \mathrm{a}$ & 5.0 & 36.3 \\
\hline & & & Totals & 6,121 & & & 13.9 & 100.0 \\
\hline
\end{tabular}




\section{References Cited}

Griffith, G.E., Bryce, S.A., Omernik, J.M., Comstock, J.A., Rogers, A.C., Harrison, B., Hatch, S.L., and Bezanson, D., 2004, Ecoregions of Texas: U.S. Geological Survey Ecoregion Map Series, scale 1:2,500,000, accessed September 9, 2008, at ftp://ftp.epa.gov/wed/ecoregions/tx/tx_front.pdf.

Omernik, J.M., 1987, Ecoregions of the conterminous United States: Annals of the Association of American Geographers, v. 77, no. 1, p. 118-125.

Texas Parks and Wildlife, 2008, The vegetation types of Texas: Texas Parks and Wildlife database, accessed September 25, 2008, at http://www.tpwd.state.tx.us/publications/pwdpubs/ pwd_bn_w7000_0120/grassland/.

U.S. Census Bureau, 2001, Ranking tables for metropolitan areas-1990 and 2000: U.S. Census Bureau database, accessed April 1, 2009, at http://www.census.gov/ population/www/cen2000/briefs/phc-t3/tables/tab03.txt.

U.S. Department of Agriculture, 2009, Texas statistics: U.S. Department of Agriculture, National Agricultural Statistics Service database, accessed April 1, 2009, at http://www. nass.usda.gov/Statistics_by_State/Texas/.
U.S. Environmental Protection Agency, 1997, Descriptions of level III ecological regions for the CEC report on ecological regions of North America: U.S. Environmental Protection Agency database, accessed April 12, 2006, at http://www. epa.gov/wed/pages/ecoregions/na_eco.htm\#Downloads.

Vogelmann, J.E., Howard, S.M., Yang, L., Larson, C.R., Wylie, B.K., and van Driel, N., 2001, Completion of the 1990s National Land Cover Data Set for the conterminous United States from Landsat Thematic Mapper data and ancillary data sources: Photogrammetric Engineering \& Remote Sensing, v. 67, p. 650-662.

Wilkins, N., Hays, A., Kubenka, D., Steinbach, D., Grant, W., Gonzalez, E., Kjelland, M., and Shackelford, J., 2003, Texas rural lands - Trends and conservation implications for the 21st century: Texas Wildlife Association, 26 p., available at http://www.texas-wildlife.org/program-areas/texas-rurallands-trends-and-conservation-implications-for-the-21stcentury.

Yantis, J.H., 1984, The Lexington-Marquez wildlife unit: Texas Parks and Wildlife, Federal Aid Series No. 23, 27 p. 


\title{
Chapter 14
}

\section{Edwards Plateau Ecoregion}

\author{
By Michael P. Stier and Beverly A. Friesen
}

\section{Ecoregion Description}

The Edwards Plateau Ecoregion covers about 58,634 km² $\left(22,639 \mathrm{mi}^{2}\right)$ in south-central Texas (fig. 1). It is mainly an eroded and uplifted limestone plateau commonly referred to as the "hill country" (fig. 2). In the south and east, the ecoregion is characterized by hilly topography, and it is separated from neighboring ecoregions further south and east by a geologic

feature known as the "Balcones Escarpment," a fault zone containing numerous cliffs and springs. The ecoregion is surrounded by (clockwise, from its southwest end) the Chihuahuan Deserts, Central Great Plains, Central Oklahoma/ Texas Plains, Texas Blackland Prairies, and Southern Texas Plains Ecoregions (Omernik, 1987; U.S. Environmental Protection Agency, 1997).

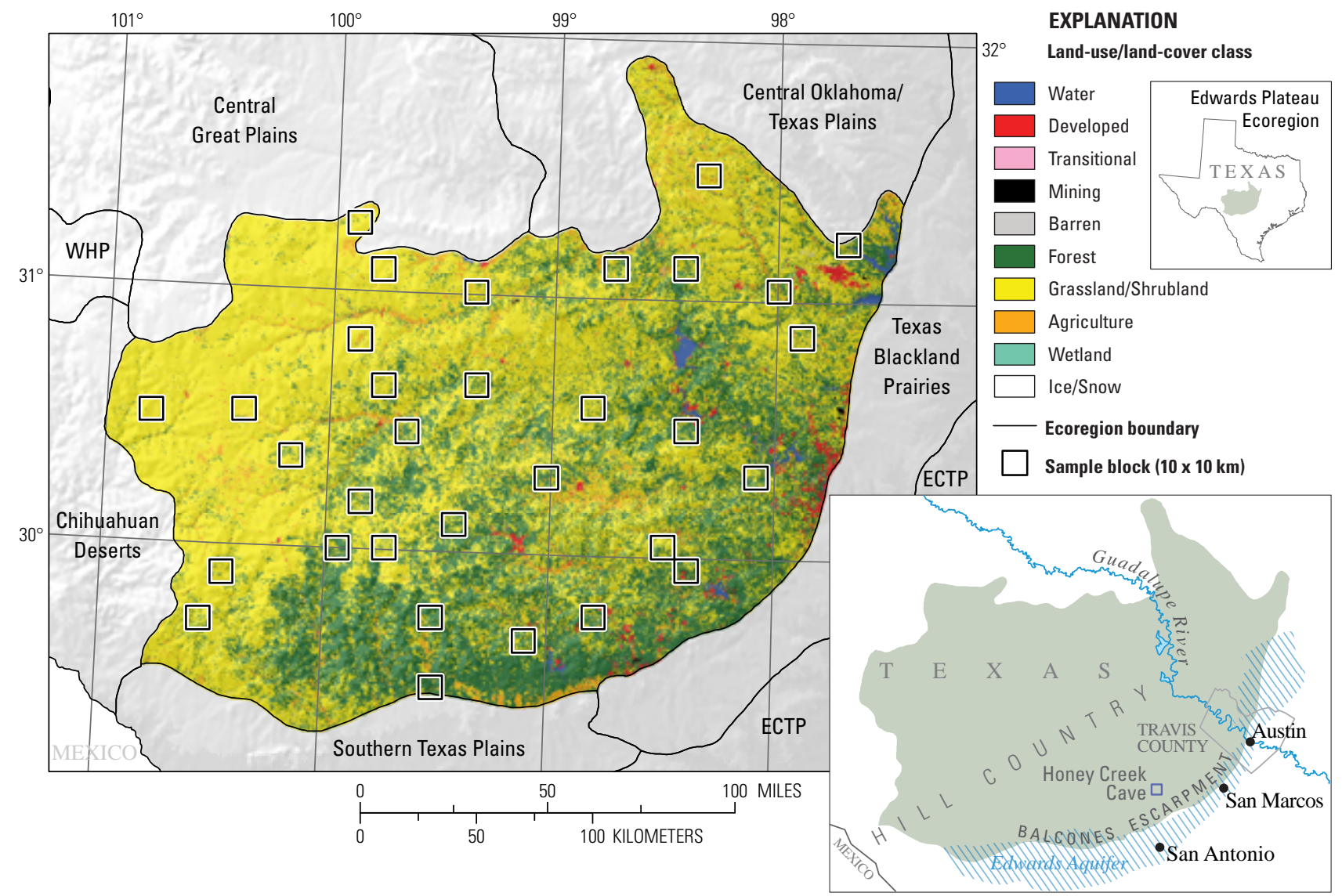

Figure 1. Map of Edwards Plateau Ecoregion and surrounding ecoregions, showing land-use/land-cover classes from 1992 National Land Cover Dataset (Vogelmann and others, 2001); note that not all land-use/land-cover classes shown in explanation may be depicted on map; note also that, for this "Status and Trends of Land Change" study, transitional land-cover class was subdivided into mechanically disturbed and nonmechanically disturbed classes. Squares indicate locations of $10 \times 10 \mathrm{~km}$ sample blocks analyzed in study. Index map shows locations of geographic features mentioned in text. Abbreviations for Great Plains ecoregions are listed in appendix 2. Also shown is part of one Western United States ecoregion, Chihuahuan Deserts. See appendix 3 for definitions of land-use/land-cover classifications. 
Elevations in the Edwards Plateau Ecoregion range from about $100 \mathrm{~m}$ to more than $1,000 \mathrm{~m}$. Average annual rainfall amounts are 380 to $840 \mathrm{~mm}(15-33 \mathrm{in}$.), increasing from west to east and peaking in May, June, and September. The Edwards Plateau Ecoregion is one of the largest areas of continuous karst topography in the United States. Karst terrain, formed by the erosion of limestone bedrock, is characterized by sinkholes and caves that allow water to flow in underground drainage systems. Cave and karst aquifers, such as the large Edwards aquifer, are important economic and scientific resources (fig. 3). Honey Creek Cave, a tributary of the Guadalupe River, is the longest cave in Texas (32 km long) and is still being explored (Texas State Historical Association, 2007).

Vegetation primarily consists of small trees, shrubs, and grasses in juniper (Juniperus spp.) and oak (Quercus spp.) associations, mesquite (Prosopis spp.) and oak savannas, and scrub oak (Quercus turbinella) forests (fig. 4). The major land use is livestock grazing of beef cattle, sheep, and goats (fig. 5). In addition to livestock production, many ranches offer commercial hunting of exotic and native species to provide an additional source of income. In more populated areas throughout the ecoregion, the diverse economy is

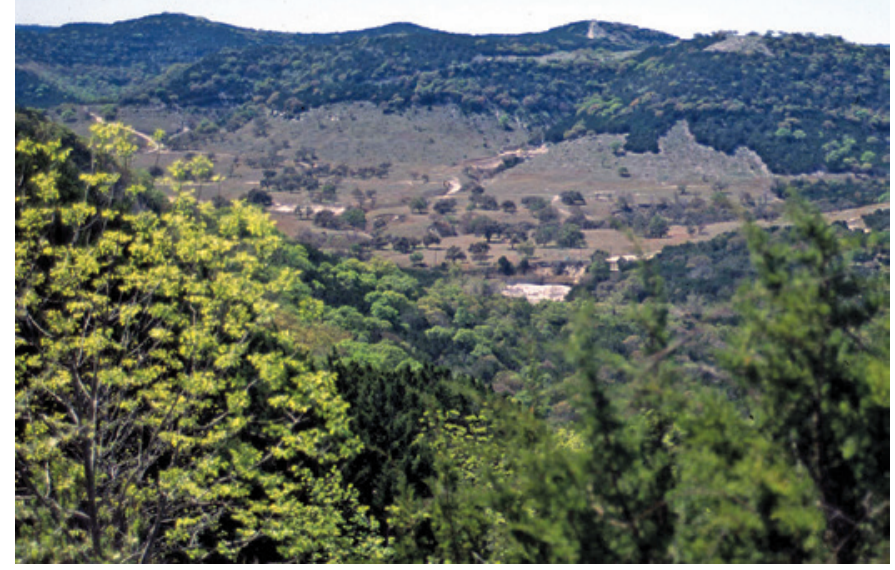

Figure 2. "Hill country" in Edwards Plateau Ecoregion.

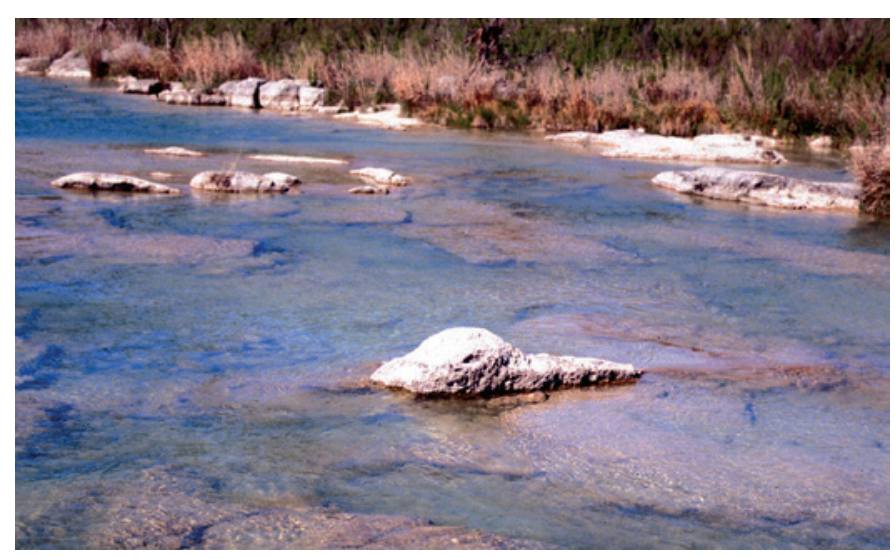

Figure 3. Source water for Edwards aquifer flowing through limestone, in Edwards Plateau Ecoregion. driven by tourism, pharmaceutical and high-tech companies, military installations, and numerous universities and colleges (for example, University of Texas at Austin, as well as Texas State University, in San Marcos).

The two largest urban centers in the Edwards Plateau Ecoregion are San Antonio and Austin, which lie near its southeastern edge. Nearly all municipal, industrial, and irrigation water used in the San Antonio area comes from the Edwards aquifer (Blome and others, 2006). Although the ecoregion historically has been a semiarid, sparsely populated rangeland, development in this rugged area has expanded. As urban areas and economic activities continue to flourish, the population of the ecoregion is expected to grow considerably. Travis County (which includes Austin) is the most populous county in the ecoregion, and its population is expected to nearly double between 2000 and 2050 (El-Hage and Moulton, 1999). Expected population growth and the increasing demand for water raise concerns for the sustainability of the Edwards aquifer and the future availability of water resources in the ecoregion.

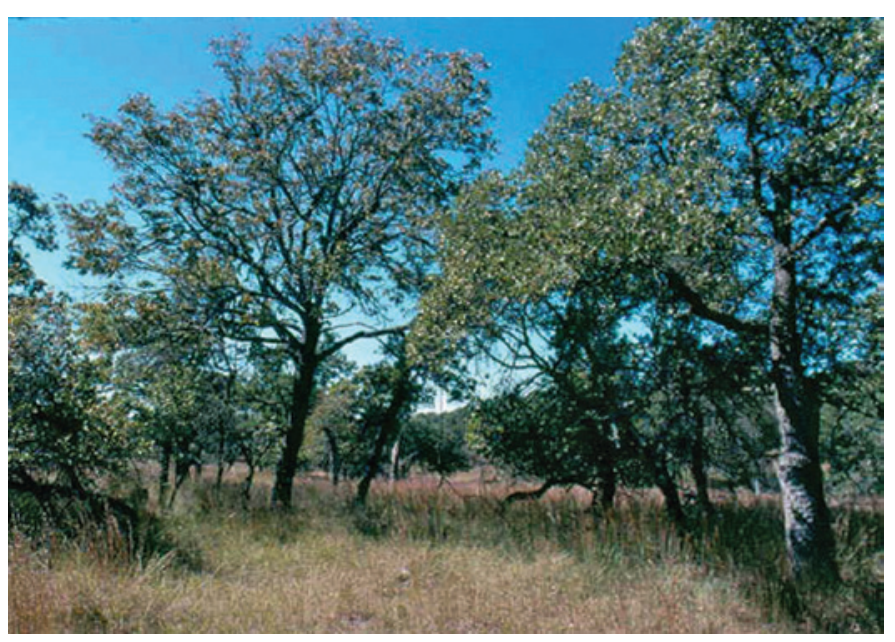

Figure 4. Prairie oak savanna with post oak (Quercus stellata) and live oak (Quercus virginiana) mixed with Indiangrass (Sorghastrum nutans) and little bluestem (Schizachyrium scoparium) grasses, in Edwards Plateau Ecoregion.

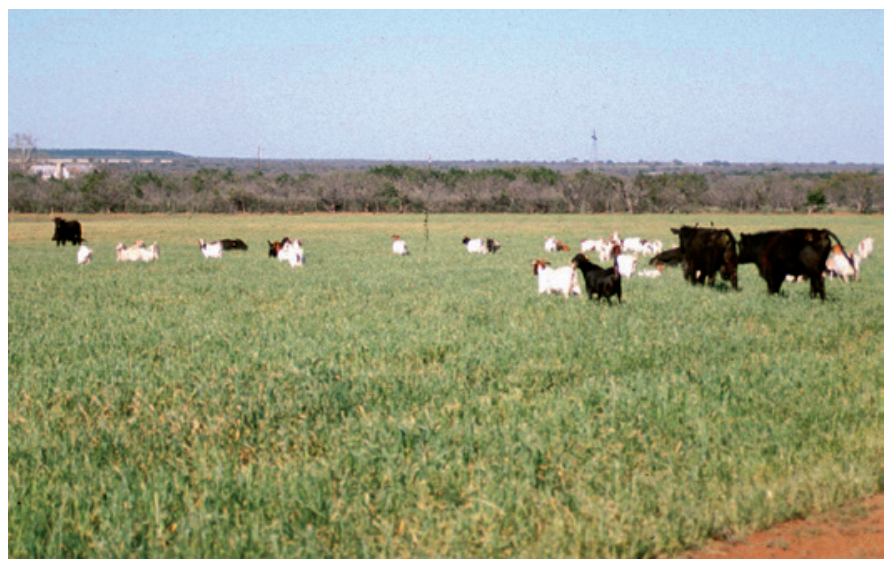

Figure 5. Cattle and goats grazing in open pasture in Edwards Plateau Ecoregion. 


\section{Contemporary Land-Cover Change (1973 to 2000)}

The overall spatial change (the percentage of land area that changed at least one time) in the Edwards Plateau Ecoregion between 1973 and 2000 is estimated at 5.5 percent (table 1). Compared to other Great Plains ecoregions, change in the Edwards Plateau Ecoregion was moderate (fig. 6). Of the land that changed, 4.7 percent changed one time, and 0.7 percent changed two times (table 1 ). Two or more changes occurred when forest and grassland/shrubland areas were cleared for pasture (agriculture land-cover class) or to enhance rangeland for grazing (mechanically disturbed landcover class). Over time, however, some of these cleared areas reverted back to their original forested state if they were not continually managed.

Land-use/land-cover change per time period was relatively small for the first three time periods (1973-1980, 1980-1986, 1986-1992), ranging from about 1.2 to 1.6 percent (table 2). Between 1992 and 2000, change across the ecoregion increased by a modest 2.3 percent. Comparing normalized annual rates of land-cover change (table 2; fig. 7), the period between 1986 and 1992 experienced nearly the same normalized annual rate of change as the period between 1992 and 2000, but they experienced different types of landcover conversions (table 3 ).

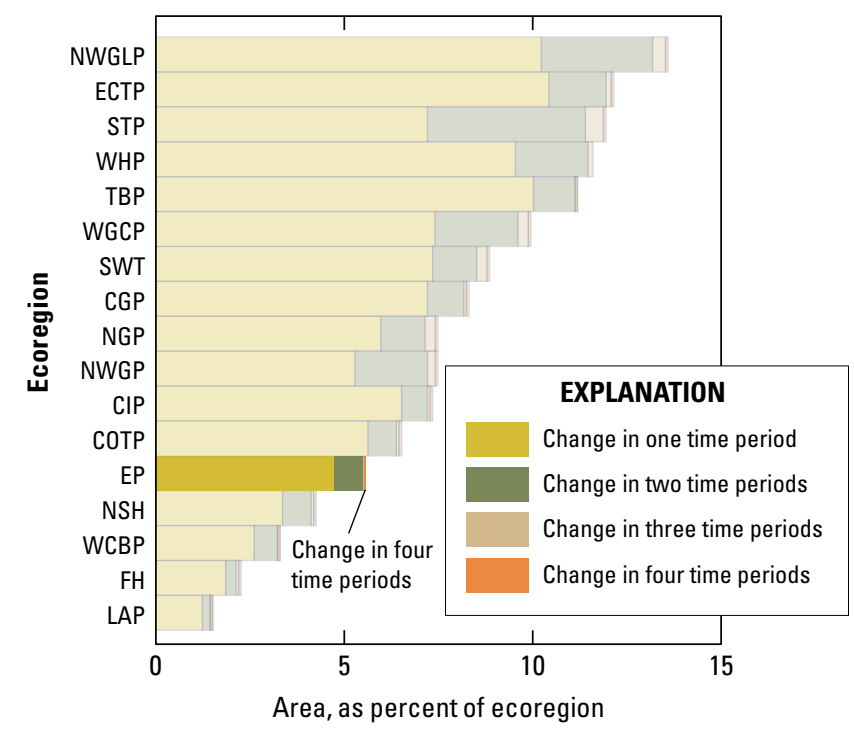

Figure 6. Overall spatial change in Edwards Plateau Ecoregion (EP; darker bars) compared with that of all 17 Great Plains ecoregions (lighter bars). Each horizontal set of bars shows proportions of ecoregion that experienced change during one, two, three, or four time periods; highest level of spatial change in Edwards Plateau Ecoregion (four time periods) labeled for clarity. See table 2 for years covered by each time period. See appendix 2 for key to ecoregion abbreviations.
Grassland/shrubland and forest constitute nearly 83 percent of the ecoregion's area (table 4). The dominant land cover is grassland/shrubland; throughout the study period (1973-2000), the amount of grassland/shrubland remained stable at about 56 percent of the ecoregion. Forest and agriculture were not as stable as grassland/shrubland during the study period: forest declined from 28.5 to 27.0 percent of the ecoregion, while agriculture increased from 13.7 to 14.3 percent of the ecoregion (table 4; figure 8).

The dominant land-cover conversions between 1986 and 1992 were in the grassland/shrubland class. During this time period, however, grassland/shrubland increased rather than decreased in coverage at the expense of forest and agricultural land (table 3). Contributing to these land-cover conversions were extensive brush management to improve livestock pasture, as well as the enactment of the Conservation Reserve Program (CRP) in 1985, which provided incentives to convert highly erodible cropland to permanent vegetative cover.

Over the entire study period (1973-2000), the dominant factor influencing land-use/land-cover change in the Edwards Plateau Ecoregion was the clearing of forest to expand rangeland for livestock grazing and to create open range for lease hunting on ranchlands (table 3). Trees and shrubs were removed to increase the diversity needed to support a range of wildlife. Lease hunting offered by ranchers was an important recreational and economic activity in the ecoregion.

Additionally, ranchers clear mesquite and other brush to improve conditions for white-tailed deer (Odocoileus virginianus), quail (Colinus virginianus and Callipepla squamata), wild turkey (Meleagris gallopavo), javelina (Pecari tajacu), and blackbuck (Antilope cervicapra), as well as endangered wildlife species such as the black-capped vireo

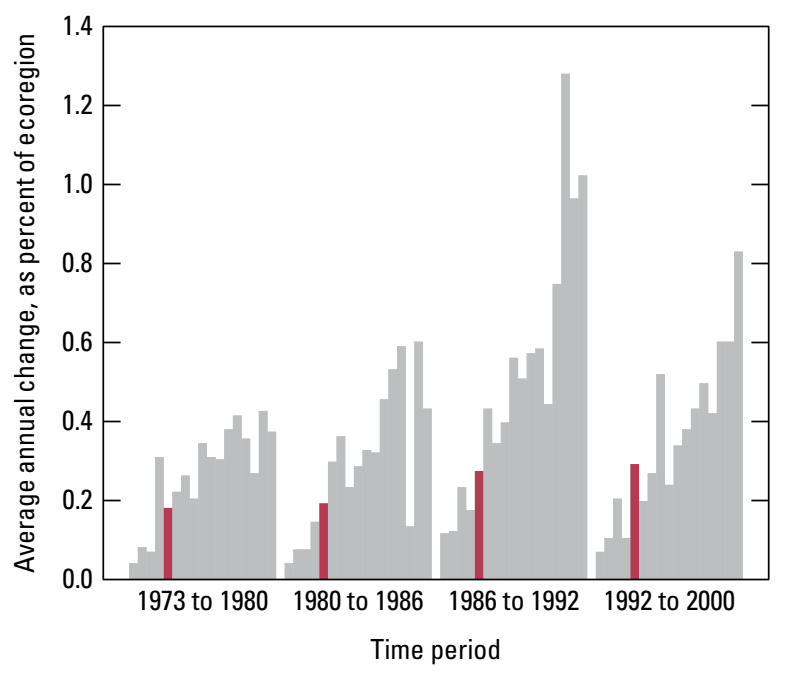

Figure 7. Estimates of land-cover change per time period, normalized to annual rates of change for all 17 Great Plains ecoregions (gray bars). Estimates of change for Edwards Plateau Ecoregion are represented by red bars in each time period. 
(Vireo atricapilla) (Texas Parks and Wildlife, 2007). Ranchers use mechanical methods such as root plowing to thin out or remove unwanted brush, and they also use herbicides and biological methods to keep brush from returning (Bovey, 2001).

Agricultural land increased slightly between 1973 and 2000 as grassland/shrubland was converted to pasture for enhanced livestock grazing (table 3). Developed lands also increased throughout the study period, resulting in a net gain of more than 0.5 percent $\left(314 \mathrm{~km}^{2}\right)$ between 1973 and 2000 (table 4; fig. 8). Population gains in the urbanizing areas surrounding the Austin and San Antonio metropolitan regions contributed most of this increase (U.S. Census Bureau, 1970-2000 [various years]). After 1986, most development occurred on forest or grassland/shrubland (fig. 8).

The Edwards Plateau Ecoregion is changing from a characteristically rural region to an urban one. Since 1940, the population growth rate of the Edwards Plateau Ecoregion has surpassed that of the United States as a whole, with most of the population increases occurring in the ecoregion's urban areas. As population grows and land development expands, one of the main challenges within the ecoregion will be to maintain an adequate supply of clean water from the Edwards aquifer. Declining groundwater levels of the Edwards aquifer are making the water susceptible to contamination. As groundwater levels decline, salt-water intrusion from the Texas Gulf Coast into the aquifer is possible (McCormick and others, unpub. data, 2004). Additionally, expanding land development is causing groundwater to become more susceptible to urban-pollutant runoff. To address these issues, communities within the Edwards Plateau Ecoregion are working with scientists and urban and regional planners to ensure that the water resources of the Edwards aquifer will be adequate for future generations.

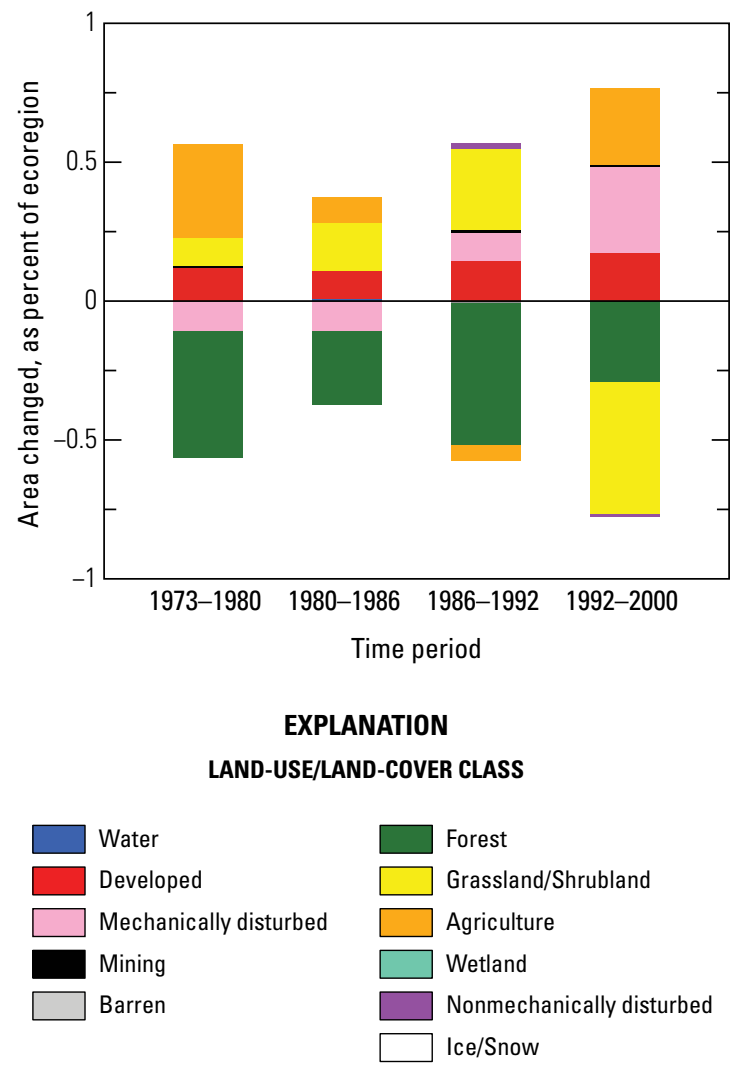

Figure 8. Normalized average net change in Edwards Plateau Ecoregion by time period for each land-cover class. Bars above zero axis represent net gain, whereas bars below zero represent net loss. Note that not all land-cover classes shown in explanation may be represented in figure. See appendix 3 for definitions of land-use/land-cover classifications. 
Table 1. Percentage of Edwards Plateau Ecoregion land cover that changed at least one time during study period (1973-2000) and associated statistical error.

[Most sample pixels remained unchanged (94.5 percent), whereas 5.5 percent changed at least once throughout study period]

\begin{tabular}{ccccccc}
\hline $\begin{array}{c}\text { Number } \\
\text { of } \\
\text { changes }\end{array}$ & $\begin{array}{c}\text { Percent } \\
\text { of } \\
\text { ecoregion }\end{array}$ & $\begin{array}{c}\text { Margin } \\
\text { of error } \\
(+/-\%)\end{array}$ & $\begin{array}{c}\text { Lower } \\
\text { bound } \\
(\%)\end{array}$ & $\begin{array}{c}\text { Upper } \\
\text { bound } \\
(\%)\end{array}$ & $\begin{array}{c}\text { Standard } \\
\text { error } \\
(\%)\end{array}$ & $\begin{array}{c}\text { Relative } \\
\text { error } \\
(\%)\end{array}$ \\
\hline 1 & 4.7 & 1.0 & 3.7 & 5.7 & 0.8 & 14.5 \\
2 & 0.8 & 0.4 & 0.4 & 1.1 & 0.2 & 34.6 \\
3 & 0.0 & 0.0 & 0.0 & 0.0 & 0.0 & 49.8 \\
4 & 0.0 & 0.0 & 0.0 & 0.0 & 0.0 & 97.2 \\
\hline $\begin{array}{l}\text { Overall } \\
\text { spatial } \\
\text { change }\end{array}$ & 5.5 & 1.2 & 4.3 & 6.7 & 0.8 & 14.5 \\
\hline
\end{tabular}

Table 2. Raw estimates of change in Edwards Plateau Ecoregion land cover, computed for each of four time periods between 1973 and 2000, and associated error at 85-percent confidence level.

[Estimates of change per period normalized to annual rate of change for each period]

\begin{tabular}{|c|c|c|c|c|c|c|c|}
\hline Period & $\begin{array}{c}\text { Total } \\
\text { change } \\
\text { (\% of eco- } \\
\text { region) }\end{array}$ & $\begin{array}{l}\text { Margin } \\
\text { of error } \\
(+/-\%)\end{array}$ & $\begin{array}{l}\text { Lower } \\
\text { bound } \\
(\%)\end{array}$ & $\begin{array}{c}\text { Upper } \\
\text { bound } \\
(\%)\end{array}$ & $\begin{array}{c}\text { Standard } \\
\text { error } \\
(\%)\end{array}$ & $\begin{array}{c}\text { Relative } \\
\text { error } \\
(\%)\end{array}$ & $\begin{array}{c}\text { Average } \\
\text { rate } \\
\text { (\% per } \\
\text { year) }\end{array}$ \\
\hline \multicolumn{8}{|c|}{ Estimate of change, in percent stratum } \\
\hline 1973-1980 & 1.2 & 0.6 & 0.7 & 1.8 & 0.4 & 30.1 & 0.2 \\
\hline 1980-1986 & 1.2 & 0.4 & 0.7 & 1.6 & 0.3 & 24.6 & 0.2 \\
\hline 1986-1992 & 1.6 & 0.4 & 1.2 & 2.0 & 0.3 & 17.2 & 0.3 \\
\hline 1992-2000 & 2.3 & 0.5 & 1.8 & 2.8 & 0.4 & 15.6 & 0.3 \\
\hline \multicolumn{8}{|c|}{ Estimate of change, in square kilometers } \\
\hline 1973-1980 & 729 & 324 & 405 & 1,053 & 220 & 30.1 & 104 \\
\hline 1980-1986 & 676 & 245 & 431 & 921 & 166 & 24.6 & 113 \\
\hline 1986-1992 & 950 & 242 & 709 & 1,192 & 164 & 17.2 & 158 \\
\hline 1992-2000 & 1,352 & 311 & 1,041 & 1,663 & 211 & 15.6 & 169 \\
\hline
\end{tabular}


Table 3. Principal land-cover conversions in Edwards Plateau Ecoregion, showing amount of area changed (and margin of error, calculated at 85-percent confidence level) for each conversion during each of four time periods and also during overall study period. See appendix 3 for definitions of land-cover classifications.

\begin{tabular}{|c|c|c|c|c|c|c|c|}
\hline Period & From class & To class & $\begin{array}{c}\begin{array}{c}\text { Area } \\
\text { changed }\end{array} \\
\left(\mathbf{k m}^{2}\right)\end{array}$ & $\begin{array}{c}\text { Margin of } \\
\text { error } \\
\left(+/-\mathrm{km}^{2}\right)\end{array}$ & $\begin{array}{c}\text { Standard } \\
\text { error } \\
\left(\mathbf{k m}^{2}\right)\end{array}$ & $\begin{array}{l}\text { Percent of } \\
\text { ecoregion }\end{array}$ & $\begin{array}{c}\text { Percent of all } \\
\text { changes }\end{array}$ \\
\hline \multirow[t]{7}{*}{ 1973-1980 } & Forest & Grassland/Shrubland & 145 & 91 & 61 & 0.2 & 19.8 \\
\hline & Mechanically disturbed & Grassland/Shrubland & 143 & 203 & 138 & 0.2 & 19.6 \\
\hline & Forest & Agriculture & 114 & 136 & 92 & 0.2 & 15.7 \\
\hline & Grassland/Shrubland & Mechanically disturbed & 108 & 136 & 92 & 0.2 & 14.8 \\
\hline & Grassland/Shrubland & Agriculture & 96 & 72 & 49 & 0.2 & 13.1 \\
\hline & Other & Other & 124 & $\mathrm{n} / \mathrm{a}$ & $\mathrm{n} / \mathrm{a}$ & 0.2 & 17.0 \\
\hline & & Totals & 729 & & & 1.2 & 100.0 \\
\hline \multirow[t]{7}{*}{ 1980-1986 } & Forest & Grassland/Shrubland & 180 & 129 & 87 & 0.3 & 26.7 \\
\hline & Mechanically disturbed & Grassland/Shrubland & 100 & 136 & 92 & 0.2 & 14.8 \\
\hline & Grassland/Shrubland & Agriculture & 97 & 46 & 31 & 0.2 & 14.4 \\
\hline & Grassland/Shrubland & Forest & 91 & 104 & 71 & 0.2 & 13.4 \\
\hline & Agriculture & Grassland/Shrubland & 67 & 67 & 46 & 0.1 & 10.0 \\
\hline & Other & Other & 140 & $\mathrm{n} / \mathrm{a}$ & $\mathrm{n} / \mathrm{a}$ & 0.2 & 20.7 \\
\hline & & Totals & 676 & & & 1.2 & 100.0 \\
\hline \multirow[t]{7}{*}{ 1986-1992 } & Forest & Grassland/Shrubland & 315 & 180 & 122 & 0.5 & 33.1 \\
\hline & Agriculture & Grassland/Shrubland & 148 & 67 & 46 & 0.3 & 15.6 \\
\hline & Grassland/Shrubland & Agriculture & 100 & 53 & 36 & 0.2 & 10.5 \\
\hline & Grassland/Shrubland & Forest & 92 & 57 & 39 & 0.2 & 9.6 \\
\hline & Grassland/Shrubland & Mechanically disturbed & 91 & 65 & 44 & 0.2 & 9.6 \\
\hline & Other & Other & 204 & $\mathrm{n} / \mathrm{a}$ & $\mathrm{n} / \mathrm{a}$ & 0.3 & 21.5 \\
\hline & & Totals & 950 & & & 1.6 & 100.0 \\
\hline \multirow[t]{7}{*}{ 1992-2000 } & Grassland/Shrubland & Agriculture & 291 & 146 & 99 & 0.5 & 21.5 \\
\hline & Grassland/Shrubland & Mechanically disturbed & 232 & 163 & 110 & 0.4 & 17.2 \\
\hline & Agriculture & Grassland/Shrubland & 200 & 137 & 93 & 0.3 & 14.8 \\
\hline & Forest & Grassland/Shrubland & 168 & 77 & 52 & 0.3 & 12.4 \\
\hline & Grassland/Shrubland & Forest & 134 & 74 & 50 & 0.2 & 9.9 \\
\hline & Other & Other & 328 & $\mathrm{n} / \mathrm{a}$ & $\mathrm{n} / \mathrm{a}$ & 0.6 & 24.3 \\
\hline & & Totals & 1,352 & & & 2.3 & 100.0 \\
\hline \multirow{7}{*}{$\begin{array}{c}1973-2000 \\
\text { (overall) }\end{array}$} & Forest & Grassland/Shrubland & 807 & 369 & 250 & 1.4 & 21.8 \\
\hline & Grassland/Shrubland & Agriculture & 584 & 210 & 142 & 1.0 & 15.7 \\
\hline & Grassland/Shrubland & Mechanically disturbed & 472 & 277 & 187 & 0.8 & 12.7 \\
\hline & Agriculture & Grassland/Shrubland & 436 & 209 & 141 & 0.7 & 11.8 \\
\hline & Grassland/Shrubland & Forest & 322 & 153 & 104 & 0.5 & 8.7 \\
\hline & Other & Other & 1,087 & $\mathrm{n} / \mathrm{a}$ & $\mathrm{n} / \mathrm{a}$ & 1.9 & 29.3 \\
\hline & & Totals & 3,708 & & & 6.3 & 100.0 \\
\hline
\end{tabular}


Table 4. Estimated area (and margin of error) of each land-cover class in Edwards Plateau Ecoregion, calculated five times between 1973 and 2000. See appendix 3 for definitions of land-cover classifications.

\begin{tabular}{|c|c|c|c|c|c|c|c|c|c|c|c|c|c|c|c|c|c|c|c|c|}
\hline & \multicolumn{2}{|c|}{ Water } & \multicolumn{2}{|c|}{ Developed } & \multicolumn{2}{|c|}{$\begin{array}{l}\text { Mechanically } \\
\text { disturbed }\end{array}$} & \multicolumn{2}{|c|}{ Mining } & \multicolumn{2}{|c|}{ Barren } & \multicolumn{2}{|c|}{ Forest } & \multicolumn{2}{|c|}{$\begin{array}{l}\text { Grassland/Shru- } \\
\text { bland }\end{array}$} & \multicolumn{2}{|c|}{ Agriculture } & \multicolumn{2}{|c|}{ Wetland } & \multicolumn{2}{|c|}{$\begin{array}{c}\text { Non- } \\
\text { mechanically } \\
\text { disturbed }\end{array}$} \\
\hline & $\%$ & $+1-$ & $\%$ & $+1-$ & $\%$ & $+/-$ & $\%$ & $+1-$ & $\%$ & $+1-$ & $\%$ & $+/-$ & $\%$ & $+/-$ & $\%$ & $+/-$ & $\%$ & $+/-$ & $\%$ & $+/-$ \\
\hline 1973 & 0.3 & 0.1 & 1.2 & 0.6 & 0.3 & 0.4 & 0.1 & 0.0 & 0.2 & 0.1 & 28.5 & 6.0 & 55.7 & 6.5 & 13.7 & 4.3 & 0.0 & 0.0 & 0.0 & 0.0 \\
\hline 1980 & 0.3 & 0.1 & 1.4 & 0.7 & 0.2 & 0.2 & 0.1 & 0.0 & 0.2 & 0.1 & 28.0 & 5.9 & 55.8 & 6.5 & 14.0 & 4.3 & 0.0 & 0.0 & 0.0 & 0.0 \\
\hline 1992 & 0.3 & 0.1 & 1.6 & 0.8 & 0.2 & 0.1 & 0.1 & 0.0 & 0.2 & 0.1 & 27.3 & 5.6 & 56.2 & 6.4 & 14.1 & 4.3 & 0.0 & 0.0 & 0.0 & 0.0 \\
\hline 2000 & 0.3 & 0.1 & 1.8 & 0.9 & 0.5 & 0.3 & 0.1 & 0.0 & 0.2 & 0.1 & 27.0 & 5.5 & 55.8 & 6.2 & 14.3 & 4.2 & 0.0 & 0.0 & 0.0 & 0.0 \\
\hline $\begin{array}{l}\text { Net } \\
\text { change }\end{array}$ & 0.0 & 0.0 & 0.6 & 0.3 & 0.2 & 0.2 & 0.0 & 0.0 & 0.0 & 0.0 & -1.5 & 0.8 & 0.1 & 0.9 & 0.6 & 0.5 & 0.0 & 0.0 & 0.0 & 0.0 \\
\hline $\begin{array}{l}\text { Gross } \\
\text { change }\end{array}$ & 0.0 & 0.0 & 0.5 & 0.3 & 1.3 & 0.8 & 0.0 & 0.0 & 0.0 & 0.0 & 2.0 & 0.7 & 3.8 & 0.9 & 1.6 & 0.5 & 0.0 & 0.0 & 0.1 & 0.1 \\
\hline 1980 & 174 & 51 & 797 & 398 & 115 & 136 & 36 & 14 & 137 & 72 & 16,439 & 3,466 & 32,701 & 3,838 & 8,227 & 2,514 & 8 & 7 & 0 & 0 \\
\hline 1986 & 181 & 52 & 853 & 433 & 53 & 47 & 38 & 15 & 135 & 72 & 16,283 & 3,385 & 32,805 & 3,786 & 8,278 & 2,510 & 8 & 7 & 0 & 0 \\
\hline 1992 & 180 & 52 & 938 & 489 & 114 & 66 & 45 & 18 & 134 & 72 & 15,983 & 3,297 & 32,974 & 3,737 & 8,244 & 2,508 & 8 & 7 & 13 & 19 \\
\hline 2000 & 181 & 52 & 1,040 & 543 & 297 & 167 & 49 & 20 & 134 & 72 & 15,811 & 3,233 & 32,697 & 3,650 & 8,410 & 2,469 & 8 & 6 & 7 & 11 \\
\hline $\begin{array}{l}\text { Net } \\
\text { change }\end{array}$ & 7 & 11 & 314 & 183 & 117 & 141 & 18 & 14 & -2 & 6 & -894 & 444 & 55 & 518 & 377 & 317 & 0 & 0 & 7 & 11 \\
\hline $\begin{array}{l}\text { Gross } \\
\text { change }\end{array}$ & 21 & 9 & 314 & 183 & 755 & 452 & 23 & 13 & 9 & 7 & 1,196 & 429 & 2,218 & 547 & 963 & 289 & 0 & 0 & 34 & 39 \\
\hline
\end{tabular}




\section{References Cited}

Blome, C.D., Faith, J.R., and Ozuna, G.B., 2006, Geohydrologic framework of the Edwards and Trinity aquifers, southcentral Texas: U.S. Geological Survey Fact Sheet 20063145, 4 p., available at http://pubs.usgs.gov/fs/2006/3145/.

Bovey, W. Rodney, 2001, Woody plants and woody plant management-Ecology, safety, and environmental impact: Boca Raton, Fla., CRC Press, p. 379-381.

El-Hage, Albert, and Moulton, D.W., 1999, Area studyWilliamson and parts of adjacent counties, evaluation of selected natural resources within Williamson and parts of adjacent counties, Texas: Texas Parks and Wildlife, 23 p., available at www.tpwd.state.tx.us/publications/pwdpubs/ media/pwd_rp_t3200_1050e.pdf.

Omernik, J.M., 1987, Ecoregions of the conterminous United States: Annals of the Association of American Geographers, v. 77, no. 1, p. 118-125.

Texas Parks and Wildlife, 2007, South Texas wildlife management-Historical perspective: Texas Parks and Wildlife database, accessed April 27, 2007, at http://www.tpwd.state. tx.us/huntwild/wild/species/.
Texas State Historical Association, 2007, The handbook of Texas online: Texas State Historical Association database, accessed April 27, 2007, at http://www.tshaonline.org/ handbook/online.

U.S. Census Bureau, 1970-2000 [various years], Census of population and housing: U.S. Census Bureau database, accessed April 27, 2007, at http://www.census.gov/prod/ www/decennial.html.

U.S. Environmental Protection Agency, 1997, Descriptions of level III ecological regions for the CEC report on ecological regions of North America: U.S. Environmental Protection Agency database, accessed April 12, 2006, at http://www. epa.gov/wed/pages/ecoregions/na_eco.htm\#Downloads.

Vogelmann, J.E, Howard, S.M., Yang, L., Larson, C.R., Wylie, B.K., and van Driel, N., 2001, Completion of the 1990s National Land Cover Data Set for the conterminous United States from Landsat Thematic Mapper data and ancillary data sources: Photogrammetric Engineering \& Remote Sensing, v. 67, p. 650-662. 


\title{
Chapter 15
}

\section{Southern Texas Plains Ecoregion}

\author{
By Michael P. Stier
}

\section{Ecoregion Description}

The Southern Texas Plains Ecoregion covers an area of about $54,744 \mathrm{~km}^{2}\left(21,137 \mathrm{mi}^{2}\right)$ that stretches from just southwest of San Antonio, Texas, south to the Mexican border (fig.1) (Omernik, 1987; U.S. Environmental Protection Agency, 1997). The Balcones Escarpment, which extends eastward from the Rio Grande, near the city of Del Rio, Texas, to San Antonio, is the northern boundary of the ecoregion. The ecoregion is surrounded by, from northwest to southeast, the Chihuahuan Deserts, Edwards Plateau, Texas Blackland Prairies, East Central Texas Plains, and Western Gulf Coastal Plain Ecoregions.
The terrain in the Southern Texas Plains Ecoregion is relatively flat, with areas of rolling hills that range in elevation from 30 to $300 \mathrm{~m}$ (fig. 2). The ecoregion consists of three major subdivisions: (1) the Interior Lowland Belt, which is characterized by black soils; (2) the Coastal Belt, which is blanketed by a thick cover of sand; and (3) the Central Dissected Belt, which consists of mostly calcareous clays and some areas of deep sand (Texas State Historical Association, 2007). Average annual rainfall amounts range from 510 to $760 \mathrm{~mm}$ (20-30 in.), increasing from west to east across the ecoregion (Conservation History Association of Texas, 2008).

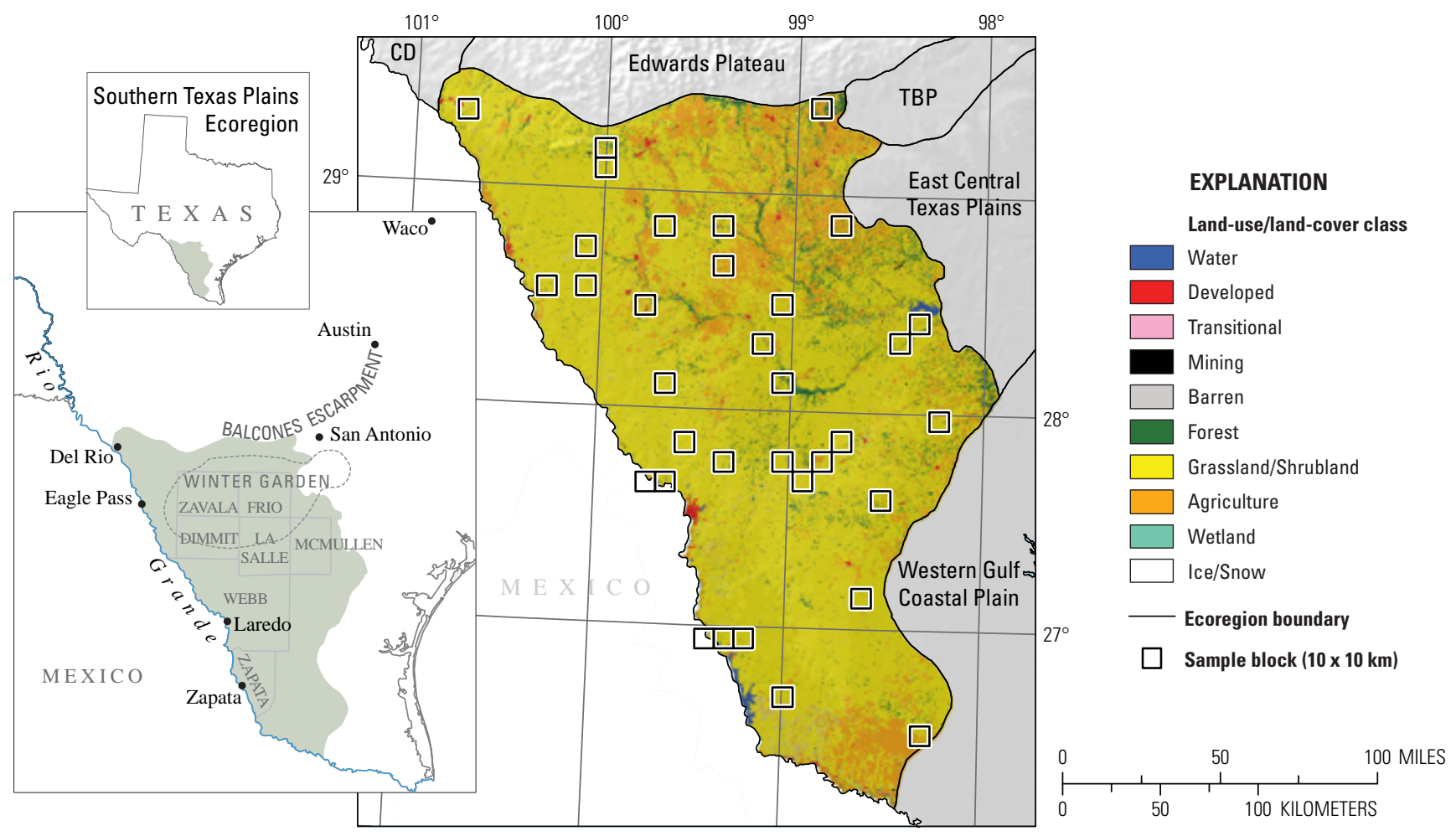

Figure 1. Map of Southern Texas Plains Ecoregion and surrounding ecoregions, showing land-use/land-cover classes from 1992 National Land Cover Dataset (Vogelmann and others, 2001); note that not all land-use/land-cover classes shown in explanation may be depicted on map; note also that, for this "Status and Trends of Land Change" study, transitional land-cover class was subdivided into mechanically disturbed and nonmechanically disturbed classes. Squares indicate locations of $10 \times 10 \mathrm{~km}$ sample blocks analyzed in study. Index map shows locations of geographic features mentioned in text. Abbreviations for Great Plains ecoregions are listed in appendix 2. Also shown is part of one Western United States ecoregion, Chihuahuan Deserts (CD). See appendix 3 for definitions of land-use/land-cover classifications. 
This ecoregion is characterized by savannas, plains, and shrublands that are dominated by drought-tolerant, and often thorn-laden, small trees and shrubs (Omernik, 1987). Mesquite (Prosopis spp.), which often is the dominant woody species, is found as scattered individuals or in grouped stands in grasslands. Historically, grasses were a major component of the ecoregion prior to settlement. As grasses were grazed by livestock, the fragile soil structure eroded away, leaving mostly rocky, dry soils that mainly support woody species (Texas A\&M Forest Service, 2008). Today (2014), as a result of overgrazing and the suppression of natural wildfires, mesquite, pricklypear (Opuntia spp.) cactus, eastern redcedar (Juniperus virginiana), Ashe's juniper (Juniperus ashei), and abundant blackbrush (Coleogyne ramosissima) are encroaching into the grasslands (Harker, 1999). Because of woody encroachment into grassland areas, brush management is often necessary to improve range for livestock grazing.

Although the predominant land cover is grassland/ shrubland, agriculture is present in subregional concentrations. Major crops grown include hay, wheat, oats, cotton, sorghum, and sunflowers. Bermuda onions, cabbage, spinach, beets, and other vegetables are grown in the "Winter Garden" region

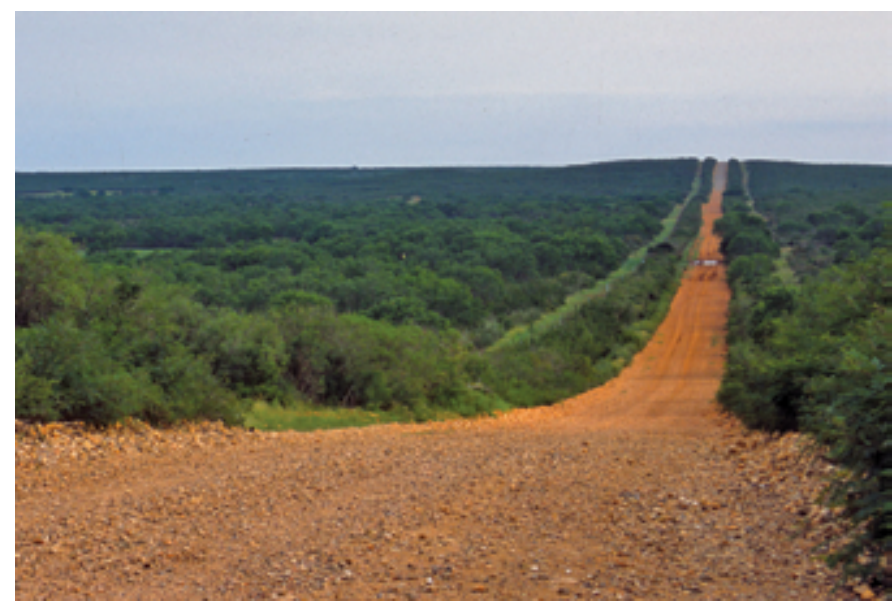

Figure 2. Shrub-dominated grassland/shrubland in Southern Texas Plains Ecoregion.

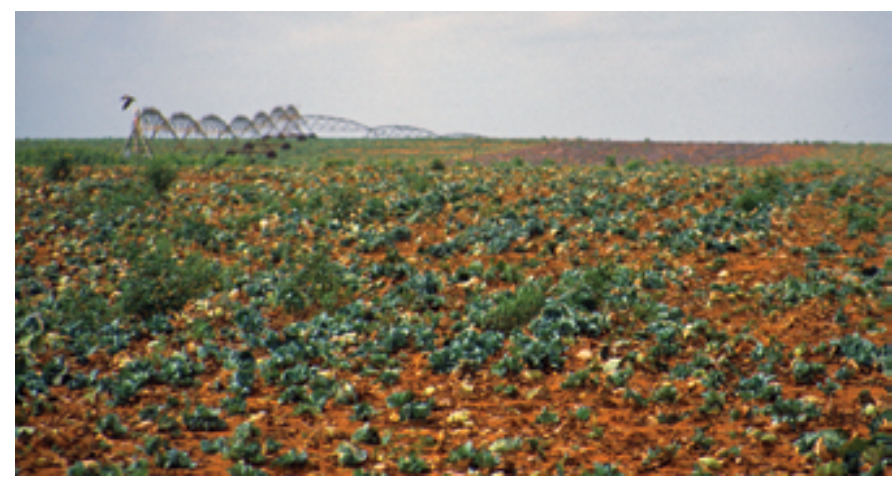

Figure 3. Field of irrigated cabbage in "Winter Garden" agricultural area, located in south Texas, north of Laredo and southwest of San Antonio, in Southern Texas Plains Ecoregion. (fig. 3), located in the northeast corner of the Southern Texas Plains Ecoregion, north of Laredo, Texas, and centered around Dimmit, Zavala, Frio, and La Salle Counties. This irrigated area also produces melons and nuts. Most land outside the irrigated areas is rangeland devoted to livestock production. Other major rural industries include petroleum and natural-gas extraction and lease hunting.

Border cities such as Laredo and Eagle Pass, Texas, play an increasingly important role in the economy of the ecoregion through cross-border trade with Mexico, including trucking and health services (Patrick, 2000; Gilmer and others, 2001). The population within the ecoregion grew considerably during the study period (1973-2000). Webb County, which includes Laredo, the largest city in the ecoregion, grew from 99,258 in 1980 to 193,117 in 2000 (U.S. Census Bureau, 1970-2000 [various years]). Only the already sparsely populated McMullen County decreased in population, from 879 in 1980 to 851 in 2000 (U.S. Census Bureau, 1970-2000 [various years]).

\section{Contemporary Land-Cover Change (1973 to 2000)}

The overall spatial change (the percentage of land area that changed at least one time) in the Southern Texas Plains Ecoregion between 1973 and 2000 is estimated at 12 percent (table 1). Compared to other Great Plains ecoregions, change in the Southern Texas Plains Ecoregion was moderately high (fig. 4). Of the land that changed, 7.2 percent changed one time, 4.2 percent change two times, and 0.5 percent changed three times (table 1). In many instances, grassland/shrubland was converted to agriculture or mechanically disturbed in one time period, only to revert to grassland/shrubland in a subsequent time period.

Change per time period was moderate between 1973 and 1980 (3.0 percent) and between 1980 and 1986 (3.6 percent) (table 2). During the last two time periods (1986-1992, 1992-2000), land-use/land-cover change was significantly higher (5.8 percent and 4.8 percent, respectively). Much of this change can be attributed to brush-management activities to improve livestock grazing and wildlife habitat. Principal land-cover conversions during these last two time periods involved grassland/shrubland and mechanically disturbed land (table 3). When normalized to account for varying lengths in study periods, annual rates of change increased gradually between 1973 and 1992, from 0.4 percent to 1.0 percent, and then decreased to 0.6 percent between 1992 and 2000 (table 2; fig. 5).

Grassland/shrubland and agriculture make up almost 92 percent of the ecoregion. The largest net change that occurred between 1973 and 2000 was a 1.0 percent $\left(544 \mathrm{~km}^{2}\right)$ increase in agricultural land and a 0.9 percent $\left(517 \mathrm{~km}^{2}\right)$ decrease in grassland/shrubland (table 4).

Between 1973 and 2000, mechanically disturbed land had little net increase but experienced a gross change equivalent 


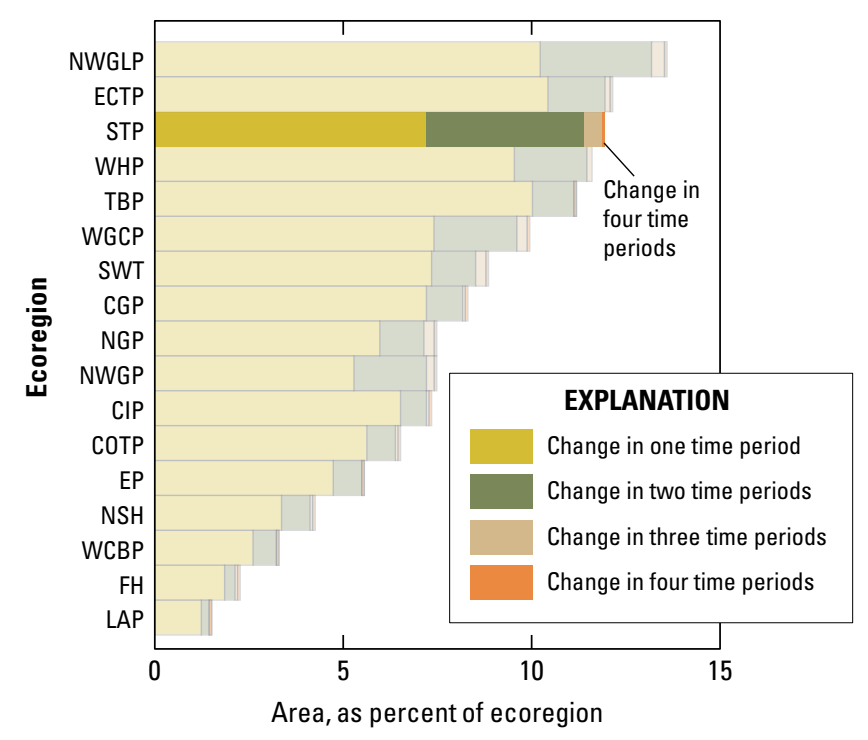

Figure 4. Overall spatial change in Southern Texas Plains Ecoregion (STP; darker bars) compared with that of all 17 Great Plains ecoregions (lighter bars). Each horizontal set of bars shows proportions of ecoregion that experienced change during one, two, three, or four time periods; highest level of spatial change in Southern Texas Plains Ecoregion (four time periods) labeled for clarity. See table 2 for years covered by each time period. See appendix 2 for key to ecoregion abbreviations.

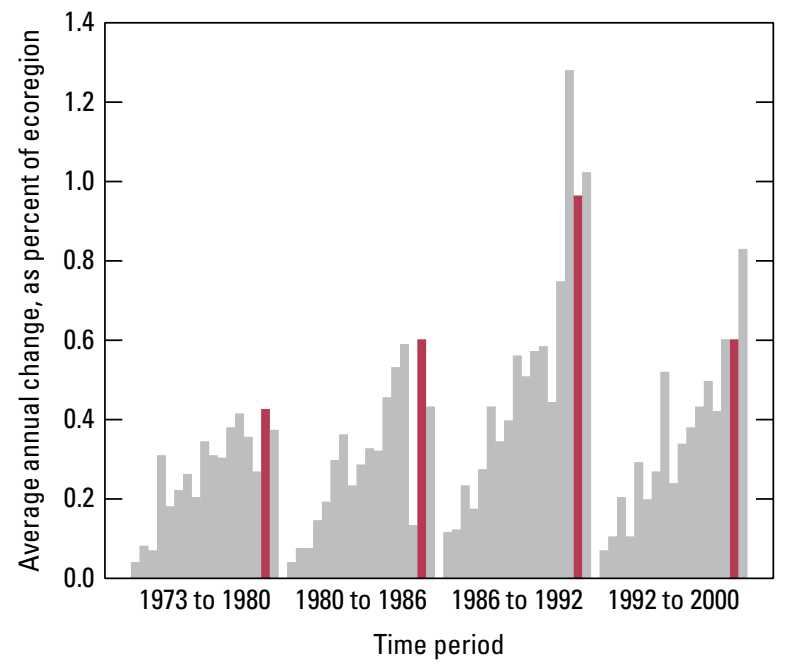

Figure 5. Estimates of land-cover change per time period, normalized to annual rates of change for all 17 Great Plains ecoregions (gray bars). Estimates of change for Southern Texas Plains Ecoregion are represented by red bars in each time period. to 4.2 percent of the ecoregion $\left(2,279 \mathrm{~km}^{2}\right)$. A large amount of grassland/shrubland was converted to mechanically disturbed land between 1986 and 1992 (table 3). By 2000, most of the mechanically disturbed land was converted back to grassland/ shrubland, and, as a result, the amount of mechanically disturbed land showed very little net change between 1973 and 2000. This also was true for grassland/shrubland, which had large amounts of gross change (8.4 percent) and much less net change ( -0.9 percent) (table 4$)$.

Other net changes generally were minor in terms of total area affected. Surface-water area decreased by $283 \mathrm{~km}^{2}$ (table 4). Wetland expanded by $129 \mathrm{~km}^{2}$ as surface water retreated from small lakes, reservoirs, and ponds likely because of annual or seasonal variation in precipitation levels (table 4). A slight increase in mining land of $115 \mathrm{~km}^{2}$ was caused by the expansion of gas- and oil-drilling activities (table 4).

Developed land steadily increased throughout the study period: in 1973, it covered 0.5 percent of the ecoregion (296 $\mathrm{km}^{2}$ ), and by 2000, it covered 0.8 percent of the ecoregion $\left(454 \mathrm{~km}^{2}\right)$ (table 4; fig. 6). Population gains in the urbanizing areas of Laredo, Del Rio, and Zapata, Texas, contributed to the expansion of developed land (U.S. Census Bureau, 1970-2000 [various years]). Most development expanded

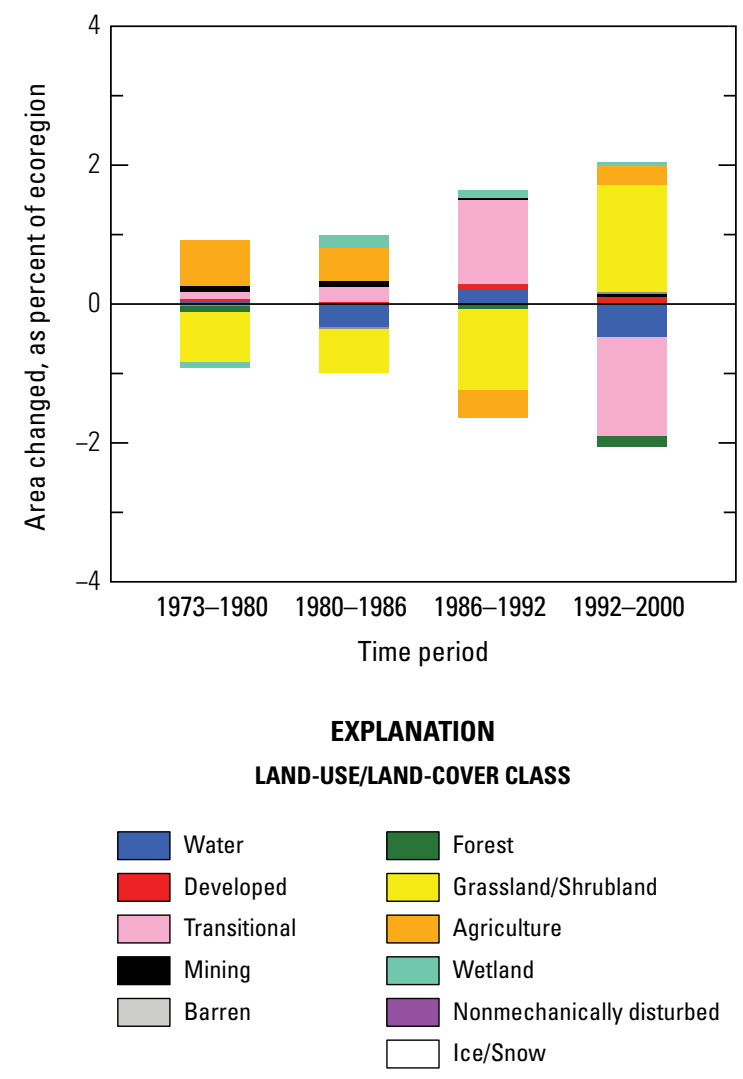

Figure 6. Normalized average net change in Southern Texas Plains Ecoregion by time period for each land-cover class. Bars above zero axis represent net gain, whereas bars below zero represent net loss. Note that not all land-cover classes shown in explanation may be represented in figure. See appendix 3 for definitions of land-use/land-cover classifications. 
onto grassland/shrubland and agricultural land, especially during the last two time periods (1986-1992, 1992-2000).

The four most common land-cover conversions were grassland/shrubland to agriculture, agriculture to grassland/ shrubland, grassland/shrubland to mechanically disturbed, and mechanically disturbed to grassland/shrubland (table 3). Agricultural land increased over the entire study period, at the expense of grassland/shrubland. Demand for livestock and agricultural products such as wheat, vegetables, and cotton led to the expansion of agriculture, specifically in the irrigated "Winter Garden" region. Not all of the grassland/shrublandto-agriculture conversions were successful, however, especially when crops were grown on poor soils with limited water supplies. The failure of farmers and ranchers to raise crops in these areas caused some of the agricultural land to revert to grassland/shrubland.

Another major factor that influenced land-use/land-cover change in the Southern Texas Plains Ecoregion was brush clearing to improve wildlife habitat and grazing conditions for livestock, which caused a temporary increase in the amount of mechanically disturbed land between 1986 and 1992 (most of the cleared land had reverted to grassland/ shrubland by 2000). Ranchers used mechanical means such as root plowing and front-end stacking, as well as fire, herbicides, and biological means, to thin out mesquite and other woody brush (Bovey, 2001). In many areas of the ecoregion, "checkerboard," or "patchwork style" brushclearing patterns were created by the ranchers (Archer and others, 2011) to provide the diversity of cover needed to support a range of wildlife species, including white-tailed deer (Odocoileus virginianus), quail (Cyrtonyx montezumae, Callipepla squamata, and Colinus virginianus), the endangered black-capped vireo (Vireo atricapilla), mourning dove (Zenaida macroura), white-winged dove (Zenaida asiatica), javelina (Pecari tajacu), and blackbuck (Antilope cervicapra) (Texas Parks and Wildlife, 2007) (fig. 7). The rows of brush that were left unplowed provided cover for many birds, whereas the brush-cleared rows that were reseeded with grass improved grazing for both livestock and wildlife, including game wildlife, and so the lease hunting offered by ranchers flourished in the ecoregion. As these brush-management techniques increased, so, too, did the amount of land-cover change during the study period.

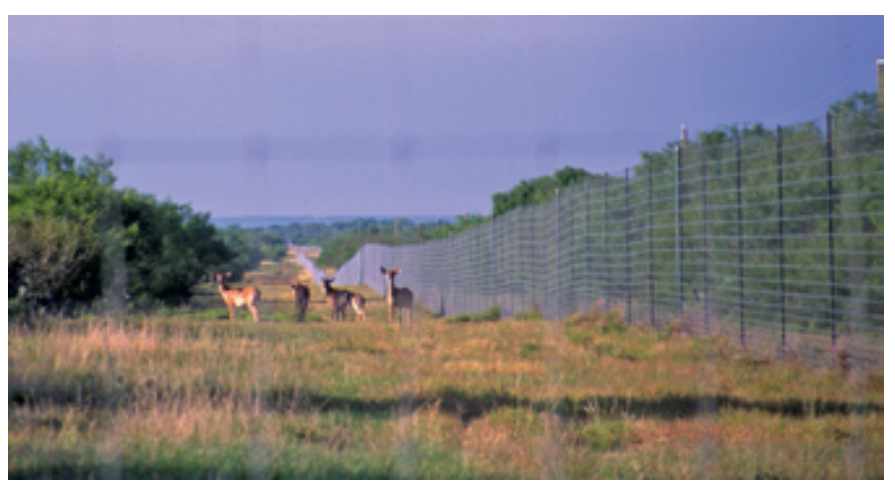

Figure 7. White-tailed deer in brush-cleared lane on ranch in Southern Texas Plains Ecoregion. 
Table 1. Percentage of Southern Texas Plains Ecoregion land cover that changed at least one time during study period (19732000) and associated statistical error.

[Most sample pixels remained unchanged ( 88.0 percent), whereas 12.0 percent changed at least once throughout study period]

\begin{tabular}{ccccccc}
\hline $\begin{array}{c}\text { Number } \\
\text { of } \\
\text { changes }\end{array}$ & $\begin{array}{c}\text { Percent } \\
\text { of } \\
\text { ecoregion }\end{array}$ & $\begin{array}{c}\text { Margin } \\
\text { of error } \\
(+/-\%)\end{array}$ & $\begin{array}{c}\text { Lower } \\
\text { bound } \\
(\%)\end{array}$ & $\begin{array}{c}\text { Upper } \\
\text { bound } \\
(\%)\end{array}$ & $\begin{array}{c}\text { Standard } \\
\text { error } \\
(\%)\end{array}$ & $\begin{array}{c}\text { Relative } \\
\text { error } \\
(\%)\end{array}$ \\
\hline 1 & 7.2 & 1.2 & 6.0 & 8.4 & 0.8 & 11.4 \\
2 & 4.2 & 2.1 & 2.1 & 6.3 & 1.4 & 33.7 \\
3 & 0.5 & 0.5 & 0.0 & 0.9 & 0.3 & 62.2 \\
4 & 0.0 & 0.0 & 0.0 & 0.0 & 0.0 & 66.1 \\
\hline $\begin{array}{l}\text { Overall } \\
\text { spatial } \\
\text { change }\end{array}$ & 12.0 & 2.5 & 9.4 & 14.5 & 1.7 & 14.4 \\
\hline
\end{tabular}

Table 2. Raw estimates of change in Southern Texas Plains Ecoregion land cover, computed for each of four time periods between 1973 and 2000, and associated error at 85-percent confidence level.

[Estimates of change per period normalized to annual rate of change for each period]

\begin{tabular}{|c|c|c|c|c|c|c|c|}
\hline Period & $\begin{array}{c}\text { Total change } \\
\text { (\% of ecoregion) }\end{array}$ & $\begin{array}{c}\text { Margin of } \\
\text { error } \\
(+/-\%)\end{array}$ & $\begin{array}{c}\text { Lower } \\
\text { bound } \\
(\%)\end{array}$ & $\begin{array}{c}\text { Upper bound } \\
(\%)\end{array}$ & $\begin{array}{c}\text { Standard } \\
\text { error } \\
(\%)\end{array}$ & $\begin{array}{c}\text { Relative } \\
\text { error } \\
(\%)\end{array}$ & $\begin{array}{l}\text { Average rate } \\
\text { ( } \% \text { per year) }\end{array}$ \\
\hline \multicolumn{8}{|c|}{ Estimate of change, in percent stratum } \\
\hline 1973-1980 & 3.0 & 0.7 & 2.2 & 3.7 & 0.5 & 16.8 & 0.4 \\
\hline 1980-1986 & 3.6 & 1.0 & 2.7 & 4.6 & 0.6 & 17.9 & 0.6 \\
\hline 1986-1992 & 5.8 & 2.3 & 3.5 & 8.1 & 1.6 & 26.8 & 1.0 \\
\hline $1992-2000$ & 4.8 & 1.9 & 3.0 & 6.7 & 1.3 & 26.2 & 0.6 \\
\hline \multicolumn{8}{|c|}{ Estimate of change, in square kilometers } \\
\hline 1973-1980 & 1,625 & 402 & 1,223 & 2,027 & 272 & 16.8 & 232 \\
\hline 1980-1986 & 1,979 & 522 & 1,456 & 2,501 & 354 & 17.9 & 330 \\
\hline 1986-1992 & 3,172 & 1,255 & 1,917 & 4,426 & 850 & 26.8 & 529 \\
\hline 1992-2000 & 2,639 & 1,021 & 1,619 & 3,660 & 692 & 26.2 & 330 \\
\hline
\end{tabular}


Table 3. Principal land-cover conversions in Southern Texas Plains Ecoregion, showing amount of area changed (and margin of error, calculated at 85-percent confidence level) for each conversion during each of four time periods and also during overall study period. See appendix 3 for definitions of land-cover classifications.

[Values given for "other" classes are combined totals of values for other land-cover classes not listed in that time period. Abbreviations: n/a, not applicable]

\begin{tabular}{|c|c|c|c|c|c|c|c|}
\hline Period & From class & To class & $\begin{array}{c}\begin{array}{c}\text { Area } \\
\text { changed }\end{array} \\
\left(\mathrm{km}^{2}\right)\end{array}$ & $\begin{array}{c}\text { Margin of } \\
\text { error } \\
\left(+/-\mathbf{k m}^{2}\right)\end{array}$ & $\begin{array}{c}\text { Standard } \\
\text { error } \\
\left(\mathrm{km}^{2}\right) \\
\end{array}$ & $\begin{array}{l}\text { Percent of } \\
\text { ecoregion }\end{array}$ & $\begin{array}{c}\text { Percent of all } \\
\text { changes }\end{array}$ \\
\hline \multirow[t]{7}{*}{ 1973-1980 } & Grassland/Shrubland & Agriculture & 689 & 267 & 181 & 1.3 & 42.4 \\
\hline & Agriculture & Grassland/Shrubland & 338 & 161 & 109 & 0.6 & 20.8 \\
\hline & Grassland/Shrubland & Mechanically disturbed & 168 & 107 & 72 & 0.3 & 10.3 \\
\hline & Mechanically disturbed & Grassland/Shrubland & 136 & 99 & 67 & 0.2 & 8.4 \\
\hline & Grassland/Shrubland & Mining & 61 & 82 & 55 & 0.1 & 3.7 \\
\hline & Other & Other & 233 & $\mathrm{n} / \mathrm{a}$ & $\mathrm{n} / \mathrm{a}$ & 0.4 & 14.4 \\
\hline & & Totals & 1,625 & & & 3.0 & 100.0 \\
\hline \multirow[t]{7}{*}{ 1980-1986 } & Grassland/Shrubland & Agriculture & 640 & 269 & 182 & 1.2 & 32.4 \\
\hline & Agriculture & Grassland/Shrubland & 413 & 156 & 105 & 0.8 & 20.8 \\
\hline & Grassland/Shrubland & Mechanically disturbed & 296 & 328 & 222 & 0.5 & 14.9 \\
\hline & Mechanically disturbed & Grassland/Shrubland & 125 & 85 & 58 & 0.2 & 6.3 \\
\hline & Water & Grassland/Shrubland & 124 & 165 & 112 & 0.2 & 6.3 \\
\hline & Other & Other & 381 & $\mathrm{n} / \mathrm{a}$ & $\mathrm{n} / \mathrm{a}$ & 0.7 & 19.3 \\
\hline & & Totals & 1,979 & & & 3.6 & 100.0 \\
\hline \multirow[t]{7}{*}{ 1986-1992 } & Grassland/Shrubland & Mechanically disturbed & 976 & 982 & 666 & 1.8 & 30.8 \\
\hline & Agriculture & Grassland/Shrubland & 755 & 259 & 176 & 1.4 & 23.8 \\
\hline & Grassland/Shrubland & Agriculture & 395 & 153 & 104 & 0.7 & 12.5 \\
\hline & Mechanically disturbed & Grassland/Shrubland & 230 & 222 & 151 & 0.4 & 7.3 \\
\hline & Grassland/Shrubland & Water & 116 & 115 & 78 & 0.2 & 3.7 \\
\hline & Other & Other & 699 & $\mathrm{n} / \mathrm{a}$ & $\mathrm{n} / \mathrm{a}$ & 1.3 & 22.0 \\
\hline & & Totals & 3,172 & & & 5.8 & 100.0 \\
\hline \multirow[t]{7}{*}{ 1992-2000 } & Mechanically disturbed & Grassland/Shrubland & 834 & 961 & 651 & 1.5 & 31.6 \\
\hline & Grassland/Shrubland & Agriculture & 377 & 165 & 111 & 0.7 & 14.3 \\
\hline & Agriculture & Grassland/Shrubland & 360 & 133 & 90 & 0.7 & 13.6 \\
\hline & Grassland/Shrubland & Mechanically disturbed & 178 & 129 & 88 & 0.3 & 6.7 \\
\hline & Water & Wetland & 147 & 135 & 91 & 0.3 & 5.6 \\
\hline & Other & Other & 744 & $\mathrm{n} / \mathrm{a}$ & $\mathrm{n} / \mathrm{a}$ & 1.4 & 28.2 \\
\hline & & Totals & 2,639 & & & 4.8 & 100.0 \\
\hline \multirow{7}{*}{$\begin{array}{l}\text { 1973-2000 } \\
\text { (overall) }\end{array}$} & Grassland/Shrubland & Agriculture & 2,101 & 591 & 400 & 3.8 & 22.3 \\
\hline & Agriculture & Grassland/Shrubland & 1,865 & 546 & 370 & 3.4 & 19.8 \\
\hline & Grassland/Shrubland & Mechanically disturbed & 1,618 & 1,155 & 783 & 3.0 & 17.2 \\
\hline & Mechanically disturbed & Grassland/Shrubland & 1,326 & 1,046 & 709 & 2.4 & 14.1 \\
\hline & Water & Wetland & 311 & 223 & 151 & 0.6 & 3.3 \\
\hline & Other & Other & 2,194 & $\mathrm{n} / \mathrm{a}$ & $\mathrm{n} / \mathrm{a}$ & 4.0 & 23.3 \\
\hline & & Totals & 9,414 & & & 17.2 & 100.0 \\
\hline
\end{tabular}


Table 4. Estimated area (and margin of error) of each land-cover class in Southern Texas Plains Ecoregion, calculated five times between 1973 and 2000. See appendix 3 for definitions of land-cover classifications.

\begin{tabular}{|c|c|c|c|c|c|c|c|c|c|c|c|c|c|c|c|c|c|c|c|c|}
\hline & \multicolumn{2}{|c|}{ Water } & \multicolumn{2}{|c|}{ Developed } & \multicolumn{2}{|c|}{$\begin{array}{l}\text { Mechanically } \\
\text { disturbed }\end{array}$} & \multicolumn{2}{|c|}{ Mining } & \multicolumn{2}{|c|}{ Barren } & \multicolumn{2}{|c|}{ Forest } & \multicolumn{2}{|c|}{$\begin{array}{l}\text { Grassland/Shru- } \\
\text { bland }\end{array}$} & \multicolumn{2}{|c|}{ Agriculture } & \multicolumn{2}{|c|}{ Wetland } & \multicolumn{2}{|c|}{$\begin{array}{c}\text { Non- } \\
\text { mechanically } \\
\text { disturbed }\end{array}$} \\
\hline & $\%$ & $+/-$ & $\%$ & $+/-$ & $\%$ & $+/-$ & $\%$ & $+/-$ & $\%$ & $+/-$ & $\%$ & $+1-$ & $\%$ & $+/-$ & $\%$ & $+1-$ & $\%$ & $+/-$ & $\%$ & $+/-$ \\
\hline \multicolumn{21}{|c|}{ Area, in percent stratum } \\
\hline 1973 & 0.8 & 0.7 & 0.5 & 0.4 & 0.6 & 0.4 & 0.2 & 0.1 & 0.1 & 0.1 & 5.5 & 2.3 & 79.1 & 4.7 & 12.5 & 3.4 & 0.8 & 0.3 & 0.0 & 0.0 \\
\hline 1980 & 0.9 & 0.6 & 0.6 & 0.4 & 0.6 & 0.4 & 0.2 & 0.2 & 0.1 & 0.1 & 5.4 & 2.3 & 78.4 & 4.8 & 13.1 & 3.6 & 0.7 & 0.3 & 0.0 & 0.0 \\
\hline 1986 & 0.5 & 0.2 & 0.6 & 0.4 & 0.9 & 0.8 & 0.3 & 0.2 & 0.1 & 0.1 & 5.4 & 2.3 & 77.7 & 4.9 & 13.6 & 3.7 & 0.9 & 0.3 & 0.0 & 0.0 \\
\hline 1992 & 0.8 & 0.5 & 0.7 & 0.4 & 2.1 & 1.9 & 0.3 & 0.2 & 0.1 & 0.1 & 5.3 & 2.3 & 76.6 & 5.0 & 13.2 & 3.7 & 1.0 & 0.4 & 0.0 & 0.0 \\
\hline 2000 & 0.3 & 0.1 & 0.8 & 0.5 & 0.6 & 0.4 & 0.4 & 0.2 & 0.1 & 0.1 & 5.1 & 2.2 & 78.1 & 5.0 & 13.5 & 3.8 & 1.0 & 0.4 & 0.0 & 0.0 \\
\hline $\begin{array}{l}\text { Net } \\
\text { change }\end{array}$ & -0.5 & 0.6 & 0.3 & 0.2 & 0.1 & 0.3 & 0.2 & 0.1 & 0.0 & 0.0 & -0.3 & 0.2 & -0.9 & 1.2 & 1.0 & 1.1 & 0.2 & 0.2 & 0.0 & 0.0 \\
\hline $\begin{array}{l}\text { Gross } \\
\text { change }\end{array}$ & 1.5 & 1.2 & 0.3 & 0.2 & 4.2 & 3.6 & 0.4 & 0.2 & 0.1 & 0.1 & 0.5 & 0.2 & 8.4 & 3.3 & 4.7 & 1.0 & 0.6 & 0.4 & 0.0 & 0.0 \\
\hline \multicolumn{21}{|c|}{ Area, in square kilometers } \\
\hline 1973 & 448 & 357 & 296 & 200 & 306 & 220 & 83 & 62 & 61 & 72 & 2,998 & 1,243 & 43,294 & 2,573 & 6,831 & 1,887 & 426 & 165 & 0 & 0 \\
\hline 1980 & 477 & 354 & 320 & 205 & 353 & 229 & 124 & 115 & 55 & 63 & 2,941 & 1,239 & 42,896 & 2,640 & 7,195 & 1,973 & 383 & 159 & 0 & 0 \\
\hline 1986 & 291 & 129 & 354 & 212 & 468 & 417 & 155 & 124 & 43 & 46 & 2,933 & 1,249 & 42,562 & 2,689 & 7,459 & 2,007 & 479 & 187 & 0 & 0 \\
\hline 1992 & 423 & 288 & 393 & 221 & 1,129 & 1,015 & 167 & 113 & 39 & 41 & 2,904 & 1,246 & 41,924 & 2,738 & 7,226 & 2,004 & 538 & 212 & 0 & 0 \\
\hline 2000 & 165 & 74 & 454 & 246 & 350 & 217 & 198 & 95 & 50 & 55 & 2,819 & 1,227 & 42,777 & 2,756 & 7,376 & 2,061 & 555 & 206 & 0 & 0 \\
\hline $\begin{array}{l}\text { Net } \\
\text { change }\end{array}$ & -283 & 346 & 158 & 96 & 44 & 187 & 115 & 66 & -12 & 17 & -179 & 87 & -517 & 630 & 544 & 628 & 129 & 108 & 0 & 0 \\
\hline $\begin{array}{l}\text { Gross } \\
\text { change }\end{array}$ & 839 & 641 & 159 & 96 & 2,279 & 1,990 & 206 & 134 & 33 & 47 & 256 & 111 & 4,606 & 1,830 & 2,588 & 537 & 351 & 196 & 0 & 0 \\
\hline
\end{tabular}




\section{References Cited}

Archer, S.R., Davies, K.W., Fulbright, T.E., McDaniel, K.C., Wilcox, B.P., and Predick, K.I., 2011, Brush management as a rangeland conservation strategy-A critical evaluation, in Briske, D.D., ed., Conservation benefits of rangeland practices-Assessment, recommendations, and knowledge gaps: U.S. Department of Agriculture, Natural Resources Conservation Service, p. 105-170, accessed September 9, 2013, at http://www.nrcs.usda.gov/Internet/ FSE_DOCUMENTS/stelprdb1045798.pdf.

Bovey, W. Rodney, 2001, Woody plants and woody plant management-Ecology, safety, and environmental impact: Boca Raton, Fla., CRC Press, p. 379-381.

Conservation History Association of Texas, 2008, Rio Grande valley, in The Texas Legacy Project: Conservation History Association of Texas database, accessed October 6, 2008, at http://texaslegacy.org/m/regions/riograndevalley.html.

Gilmer, R.W., Gurch, M., and Wang, T., 2001, Texas border citiesAn income growth perspective: Federal Reserve Bank of Dallas, accessed March 17, 2009, at http://www.dallasfed.org/assets/ documents/research/border/tbe_gilmer.pdf.

Harker, F. Donald, 1999, Landscape restoration handbook: Boca Raton, Fla., CRC Press, p. 231-238.

Omernik, J.M., 1987, Ecoregions of the conterminous United States: Annals of the Association of American Geographers, v. 77, no. 1, p. 118-125.

Patrick, Michael, 2000, The Texas border region enjoys a decade of strong growth: Texas A\&M International University, Texas Center for Border Economic and Enterprise Development, accessed March 17, 2009, at http://texascenter.tamiu.edu/pdf_ vision/vision0300present.pdf.
Texas A\&M Forest Service, 2008, Trees of Texas: Texas A\&M Forest Service database, accessed November 3, 2008, at http://texastreeid.tamu.edu/.

Texas Parks and Wildlife, 2007, Wildlife Fact Sheets: Texas Parks and Wildlife database, accessed April 27, 2007, at http://www.tpwd.state.tx.us/huntwild/wild/species/.

Texas State Historical Association, 2007, The handbook of Texas online: Texas State Historical Association database, accessed November 3, 2008, at http://www.tshaonline.org/ handbook/online.

U.S. Census Bureau, 1970-2000 [various years], Census of population and housing: U.S. Census Bureau database, accessed October 6, 2008, at http://www.census.gov/prod/ www/decennial.html.

U.S. Environmental Protection Agency, 1997, Descriptions of level III ecological regions for the CEC report on ecological regions of North America: U.S. Environmental Protection Agency database, accessed April 12, 2006, at http://www.epa.gov/wed/pages/ecoregions/na_eco. htm\#Downloads.

Vogelmann, J.E., Howard, S.M., Yang, L., Larson, C.R., Wylie, B.K., and van Driel, N., 2001, Completion of the 1990s National Land Cover Data Set for the conterminous United States from Landsat Thematic Mapper data and ancillary data sources: Photogrammetric Engineering \& Remote Sensing, v. 67, p. 650-662. 


\title{
Chapter 16
}

\section{Texas Blackland Prairies Ecoregion}

\author{
By Roger F. Auch
}

\section{Ecoregion Description}

The Texas Blackland Prairies Ecoregion, located in central Texas, consists of two disjunct sections (fig. 1) (Omernik, 1987; U.S. Environmental Protection Agency, 1997). The larger, northern section runs roughly north-south, from San Antonio, Texas, to the Oklahoma border north-northeast of Dallas, Texas; it is bounded by (clockwise, from its southwest end) the Southern Texas Plains, Edwards Plateau, Central Oklahoma/Texas Plains, South Central Plains, and East Central Texas Plains Ecoregions. The smaller, southern section, which is located about $88 \mathrm{~km}$ southeast of San Antonio and is oriented northeast-southwest, is commonly called the "Fayette Prairie" (Griffith and others, 2004).
The southern section is almost entirely surrounded by the East Central Texas Plains Ecoregion; a small part of the South Central Plains Ecoregion abuts its east end. The entire Texas Blackland Prairies Ecoregion covers about 50,501 km² (19,498 mi²).

The climate is classified as warm temperate (hot summers and cool winters), with precipitation levels that range from 710 to $1,015 \mathrm{~mm}$ (28-40 in.) in an average year. Precipitation is less in the western part of the ecoregion and more in the eastern part (Kottek and others, 2006; PRISM Climate Group, 2006). The landforms are level-to-rolling plains, and soils typically are fine textured, clayey, and high in shrink-and-swell potential (Omernik, 1987; U.S. Environmental Protection Agency, 2002; U.S. Department of Agriculture, 2008b) (fig. 2).

Figure 1. Map of Texas Blackland Prairies Ecoregion and surrounding ecoregions, showing land-use/landcover classes from 1992 National Land Cover Dataset (Vogelmann and others, 2001); note that not all land-use/ land-cover classes shown in explanation may be depicted on map; note also that, for this "Status and Trends of Land Change" study, transitional land-cover class was subdivided into mechanically disturbed and nonmechanically disturbed classes. Squares indicate locations of $10 \times 10 \mathrm{~km}$ sample blocks analyzed in study. Index map shows locations of geographic features mentioned in text. Abbreviations for Great Plains ecoregions are listed in appendix 2. Also shown are parts of two Midwest-South Central United States ecoregions: Ouachita Mountains (OM) and South Central Plains. See appendix 3 for definitions of land-use/land-cover classifications.

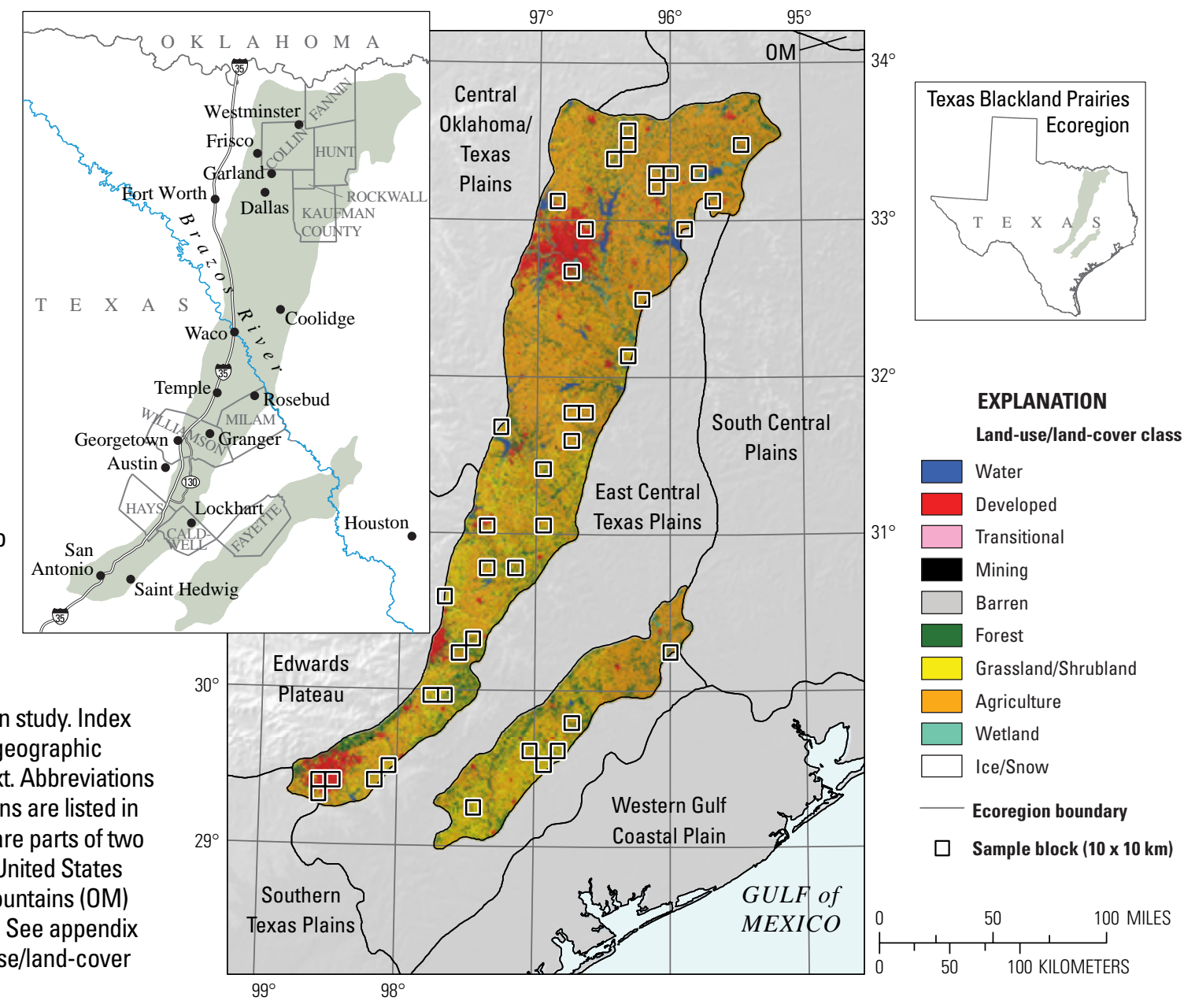


The Texas Blackland Prairies Ecoregion at the beginning of the 19th century was predominantly tallgrass prairie, with forest along stream courses and in upland areas (White, 2006). By the end of the 1800s, most of the ecoregion had been converted to farmland (primarily cropland), although much of this cropland had been converted to well-maintained tame grass pastureland by 1973, the start of the study period (White, 2006) (fig. 3). This pastureland is classified with cropland as agriculture land-cover class.

Agriculture remained the predominant land-cover class in the ecoregion during the entire 27-year study period. The major crops grown in the Texas Blackland Prairies Ecoregion in 2002 were hay, corn, wheat, sorghum, cotton, pecans, and soybeans. Types of livestock production were primarily beef cattle and some goats and horses, as well as poultry in localized areas (U.S. Department of Agriculture, 2008c) (fig. 4).

Other principal land-cover classes of the ecoregion during the study period included forest, grassland/shrubland, and developed. Minor land-cover classes included wetland, water, and mining. Forest was found primarily in stream drainages throughout the ecoregion and, in particular, where mesquite (Prosopis spp.) and juniper (Juniperus spp.) shrubland was allowed to grow into tree-height woodlands (fig. 5). Forested wetlands in riparian bottomlands were another minor natural land-cover class (Texas Parks and Wildlife, 1997). Grassland/ shrubland was found in less intensely used grazing land, which typically had more varied topography, and on land where woody vegetation, such as shrub-sized mesquite and juniper, was allowed to grow on pastureland. Later in the study period, other areas of grassland/shrubland may have been farmland that was idled as part of the Conservation Reserve Program (CRP), although this program was much less important in the Texas Blackland Prairies Ecoregion than in ecoregions of the northern and central Great Plains (U.S. Department of Agriculture, 2008a) (fig. 6).

Development occurred in a variety of places, from small farming communities to booming metropolitan areas such as the

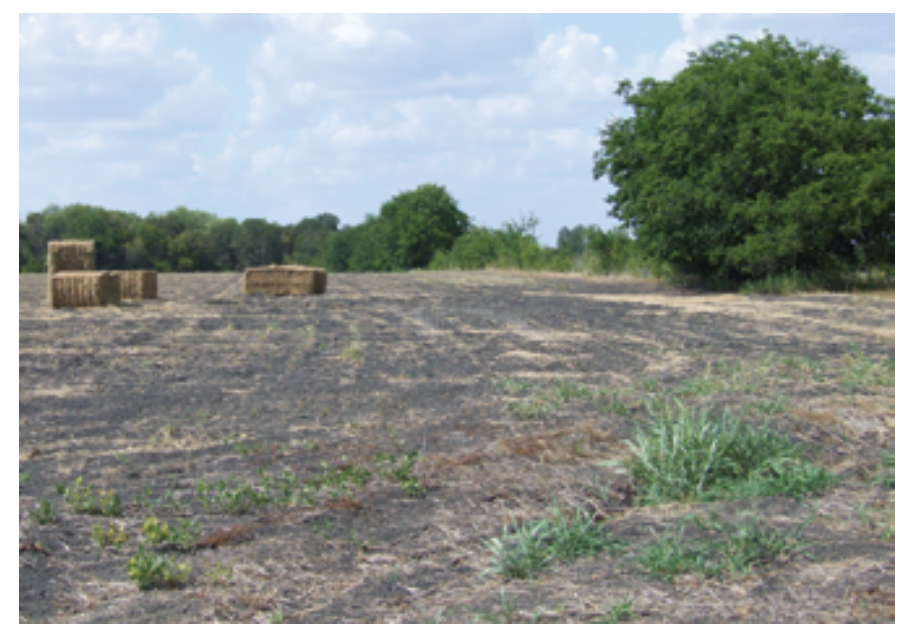

Figure 2. Harvested field in Hunt County, Texas, in northern part of Texas Blackland Prairies Ecoregion, showing soils that helped give ecoregion its name. greater Dallas, Austin, and San Antonio, Texas, areas. Exurban residential development, although widespread throughout the ecoregion, was more prevalent in areas within commuting distances of the major urban centers (fig. 7). Water land-cover class was present primarily as reservoirs and stock ponds, some of which were constructed during the study period. Aggregate production was the dominant mining land use.

\section{Contemporary Land-Cover Change (1973 to 2000)}

The overall spatial change (the percentage of land area that changed at least one time) in the Texas Blackland Prairies Ecoregion between 1973 and 2000 is estimated at 11.1 percent (table 1). Compared to other Great Plains ecoregions, change in the Texas Blackland Prairies Ecoregion was relatively high (fig. 8). The amount of change was similar to that of the East Central Texas Plains and Southern Texas Plains Ecoregions but greater than that of the Central Oklahoma/Texas Plains and Edwards Plateau Ecoregions (fig. 8). Most of the land (10.0 percent) changed only once during the study period, but some areas (1.1 percent) changed multiple times (table 1$)$. The multiple changes typically involved change between agriculture

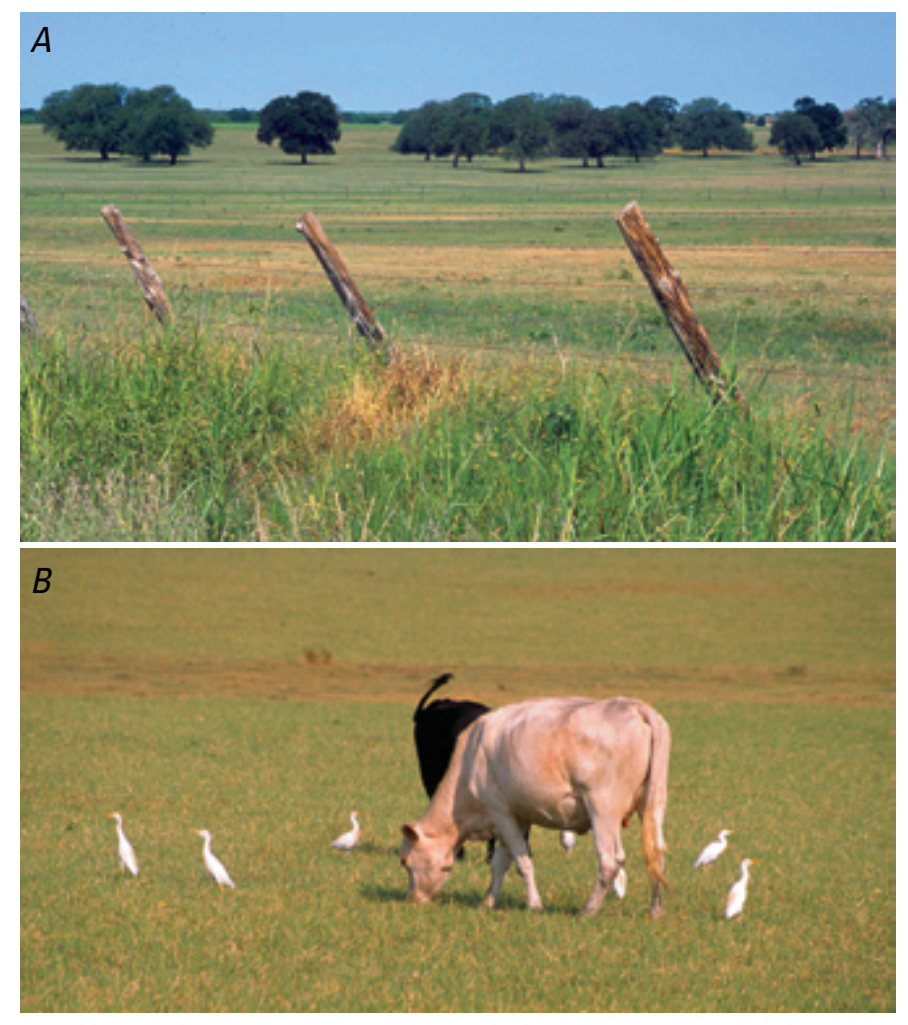

Figure 3. Well-maintained pastures in Texas Blackland Prairies Ecoregion. A, Level pasture with scattered oak trees in “Fayette Prairie" (southern section of Texas Blackland Prairies Ecoregion), east of Saint Hedwig, Texas. B, Cattle and cattle egrets (Bubulcus ibis), in pasture north of Lockhart, Texas. 


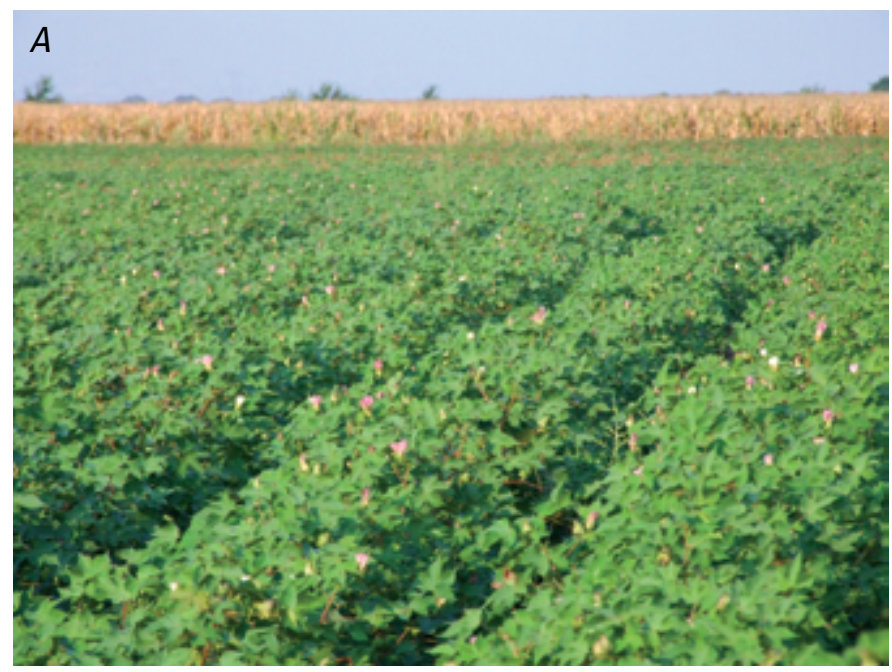

$B$
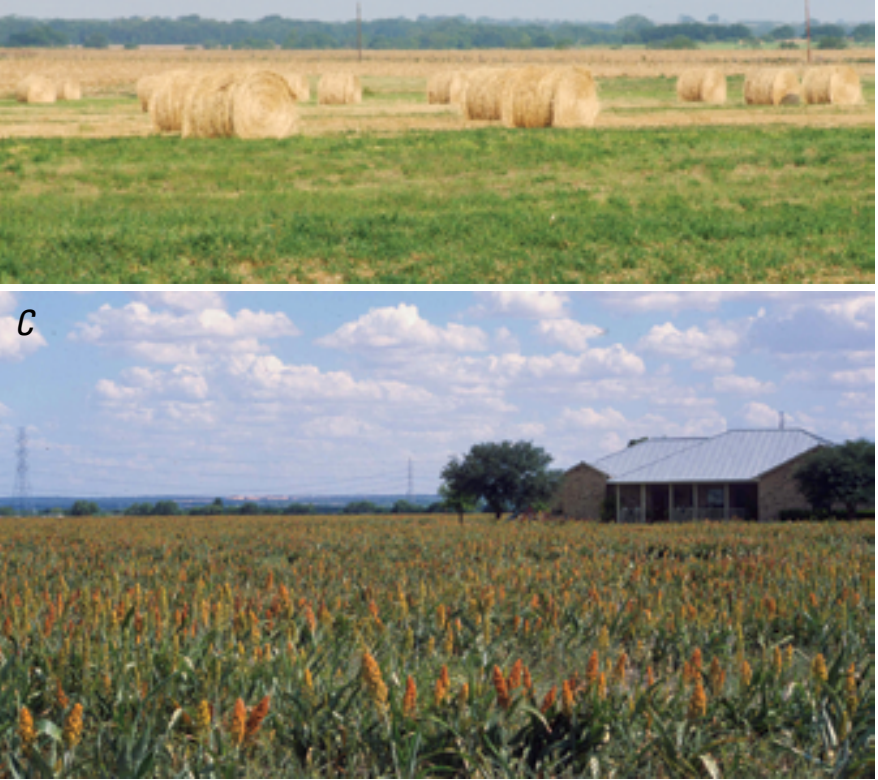

$D$

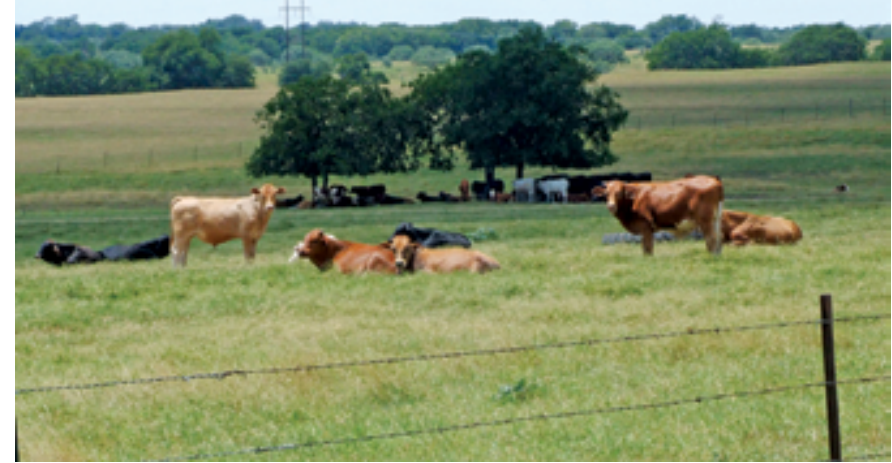

Figure 4. Crops and livestock found in Texas Blackland Prairies Ecoregion. $A$, Cotton and corn fields in northern Caldwell County, Texas. $B$, Hay bales in field east of Rosebud, Texas. C, Sorghum field south of San Antonio, Texas, near southwest border of ecoregion. $D$, Cattle grazing and getting shade on pasture east of Georgetown, Texas. (marginal farmland) and grassland/shrubland, as well as some conversion of agriculture to grassland/shrubland or forest. When change per time period is normalized to account for varying lengths in study periods, the annual rate of change was highest between 1986 and 1992, at 0.6 percent $\left(296 \mathrm{~km}^{2}\right)$ (table 2; fig. 9).

The agriculture land-cover class had the most net change during the study period (table 3). Agriculture had a net loss of 5.6 percent $\left(2,814 \mathrm{~km}^{2}\right)$ (table 3$)$, primarily through conversion to grassland/shrubland and developed land (table 4) and, to a lesser extent, to forest and mining. The conversion of agriculture to grassland/shrubland occurred mostly because of less intense management of pastureland and abandonment of
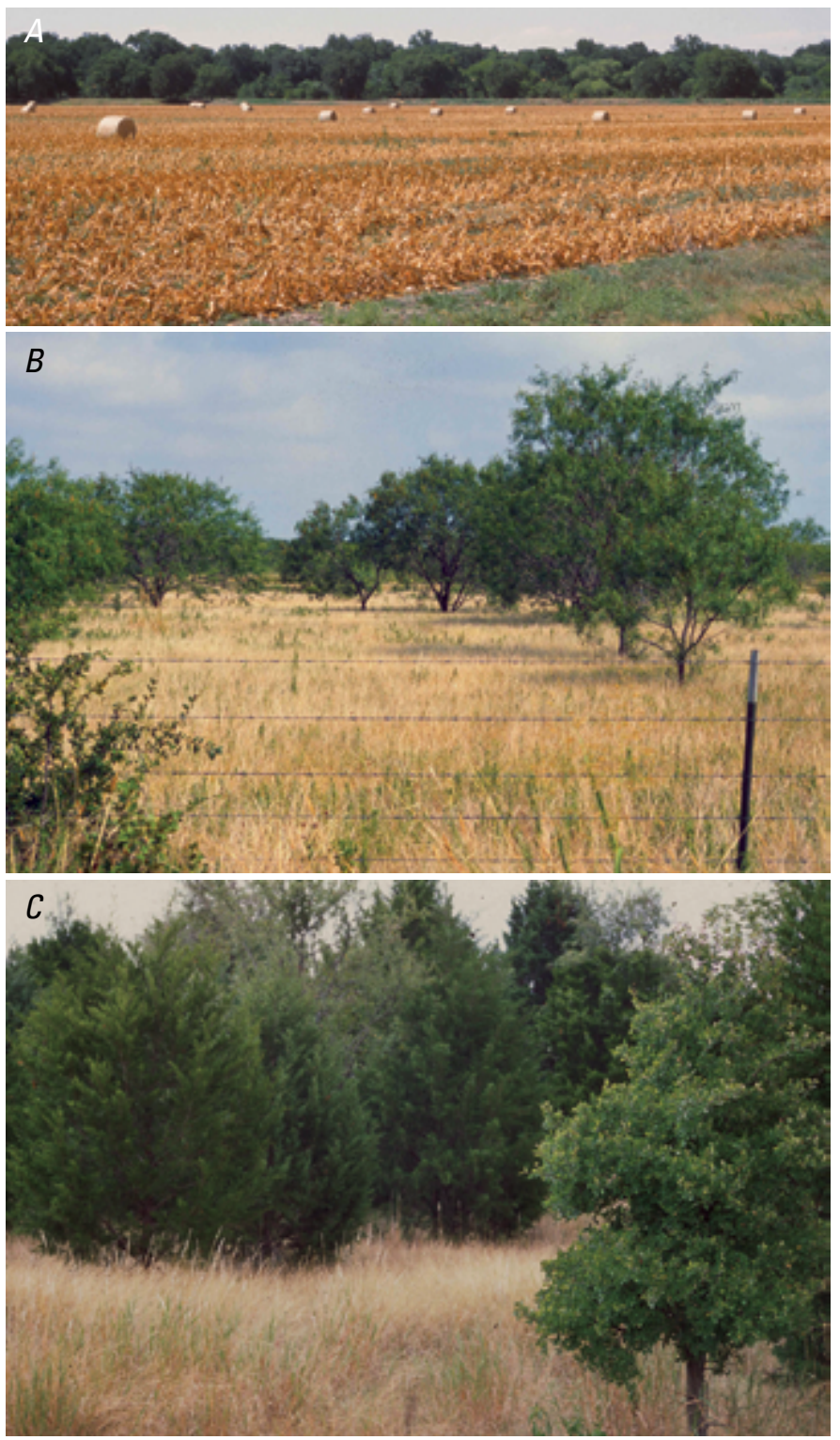

Figure 5. Forested land in Texas Blackland Prairies Ecoregion. Patch of forest $(A)$ that follows stream drainage behind cropland, in western Milam County, Texas; mesquite $(B)$ and juniper $(C)$ woodlands, which are becoming more common in ecoregion, from area east of Brazos River southeast of Waco, Texas (heights of trees are $5-7 \mathrm{~m}$ ). 
agricultural land. The permanent conversion of agriculture to developed was caused mainly by the increasing population and the subsequent economic growth. Changes from agriculture to grassland/shrubland or to forest can be temporary because this land is easily returned to agricultural use.

\section{$A$}

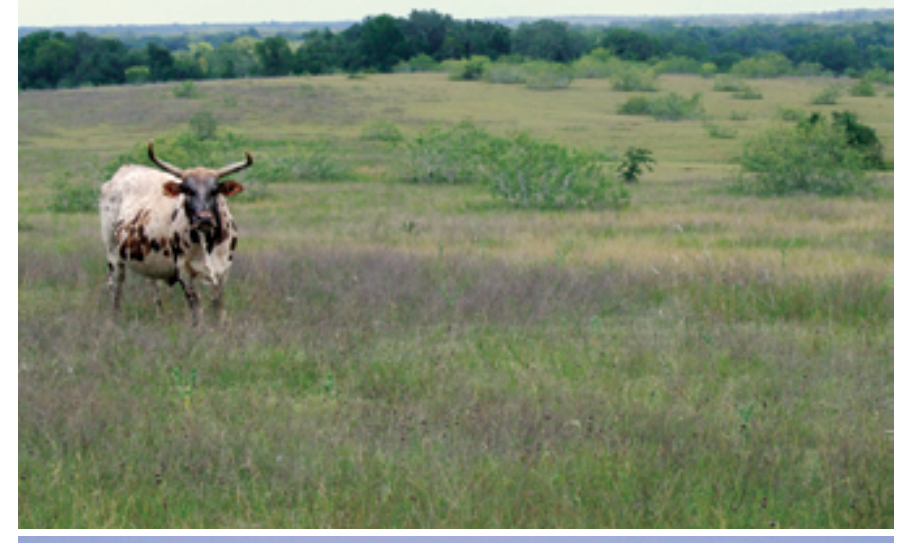

B

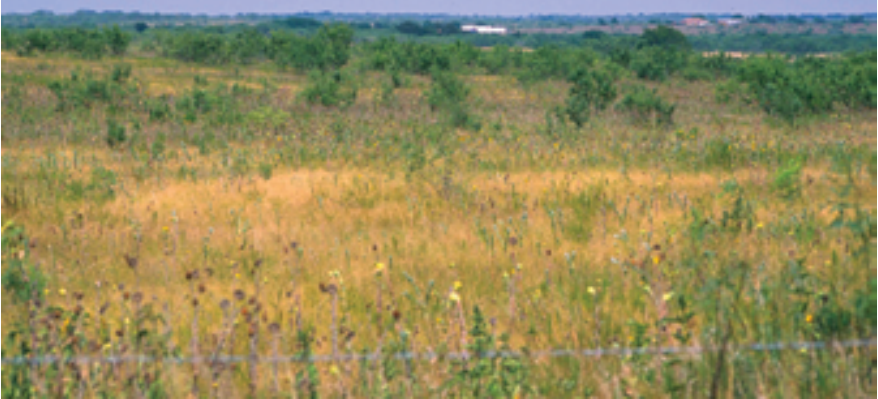

C

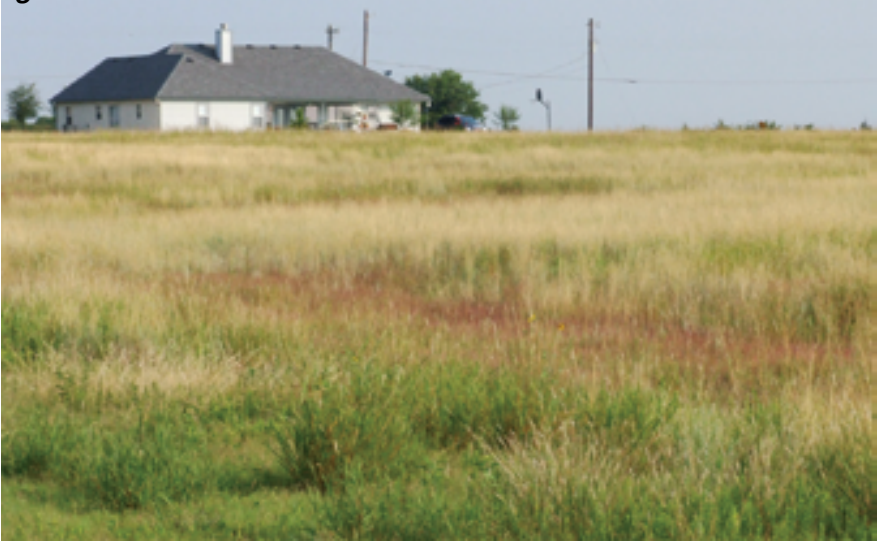

Figure 6. Grassland/shrubland in Texas Blackland Prairies Ecoregion. $(A)$ Less intensely used grazing land in eastern Fayette County, Texas. (B) Overgrown pasture with mesquite encroachment of shrub-sized woody vegetation, in pasture north of Coolidge, Texas. $(C)$ Idled farmland, possibly from participation in Conservation Reserve Program, in northern Caldwell County, Texas.
Between 1973 and 2000, the developed land-cover class had the second largest net change, an increase of 3.8 percent (table 3). The Texas Blackland Prairies Ecoregion gained an estimated 1,933 $\mathrm{km}^{2}$ of developed land (table 3), from multiple sources: the increase in developed land came predominantly from agriculture $(1,172$ $\mathrm{km}^{2}$ ) and grassland/shrubland (590 $\mathrm{km}^{2}$ ) (table 4), as well as from forest $\left(158 \mathrm{~km}^{2}\right.$ ) (fig. 10). Most new development was along the Interstate 35 corridor that follows the west side of the ecoregion from San Antonio to Dallas. Economic growth in metropolitan

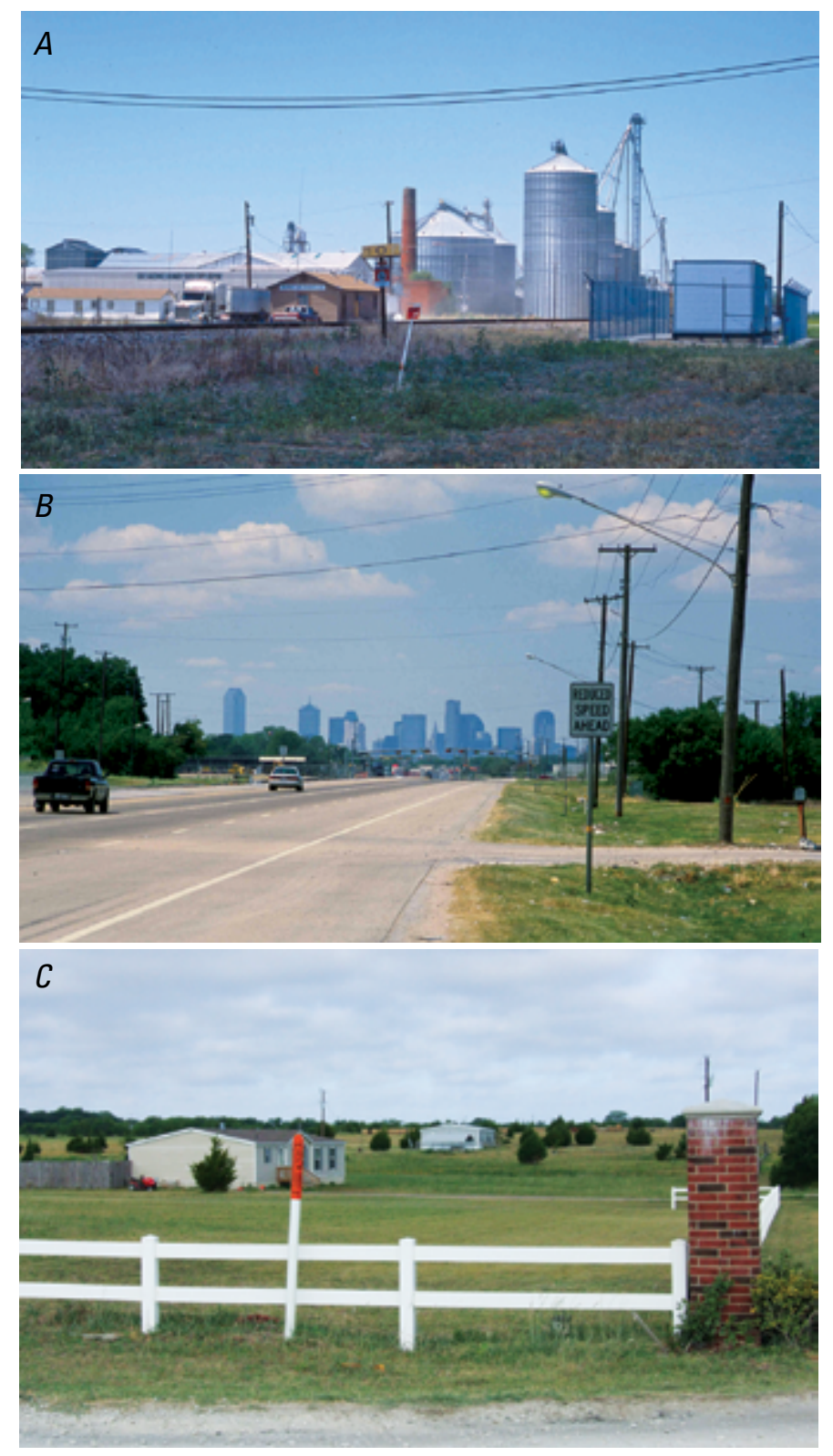

Figure 7. Developed land in Texas Blackland Prairies Ecoregion. $A$, Agricultural infrastructure businesses in farming community of Granger, Texas. $B$, View of downtown Dallas skyline taken from south side of city. $C$, Exurban housing (common in ecoregion, usually on larger lots), in Fannin County, Texas, northeast of Dallas metropolitan area. 


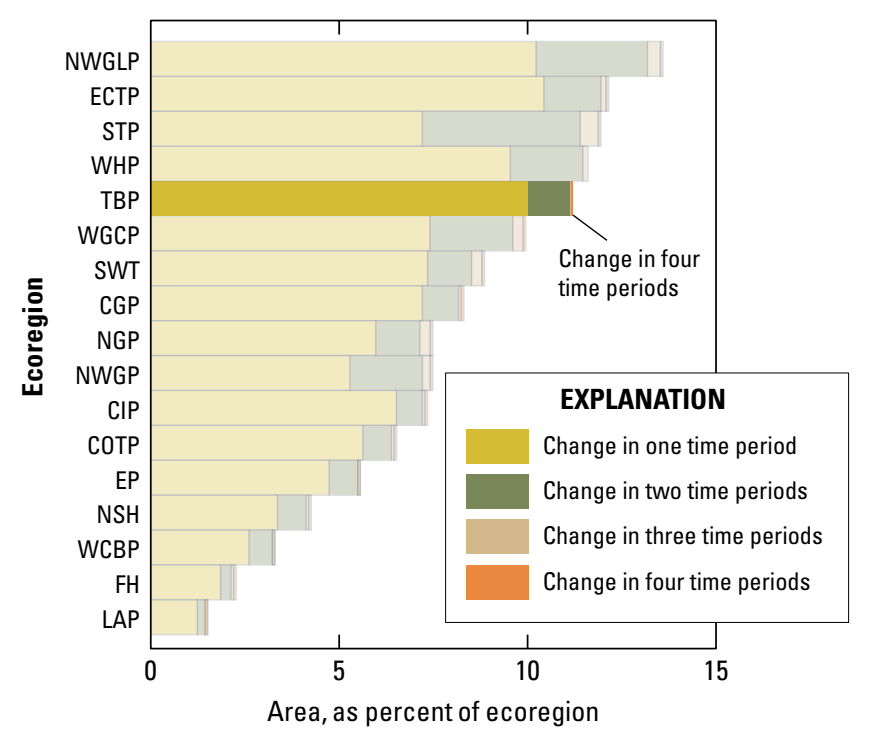

Figure 8. Overall spatial change in Texas Blackland Prairies Ecoregion (TBP; darker bars) compared with that of all 17 Great Plains ecoregions (lighter bars). Each horizontal set of bars shows proportions of ecoregion that experienced change during one, two, three, or four time periods; highest level of spatial change in Texas Blackland Prairies Ecoregion (four time periods) labeled for clarity. See table 2 for years covered by each time period. See appendix 2 for key to ecoregion abbreviations.

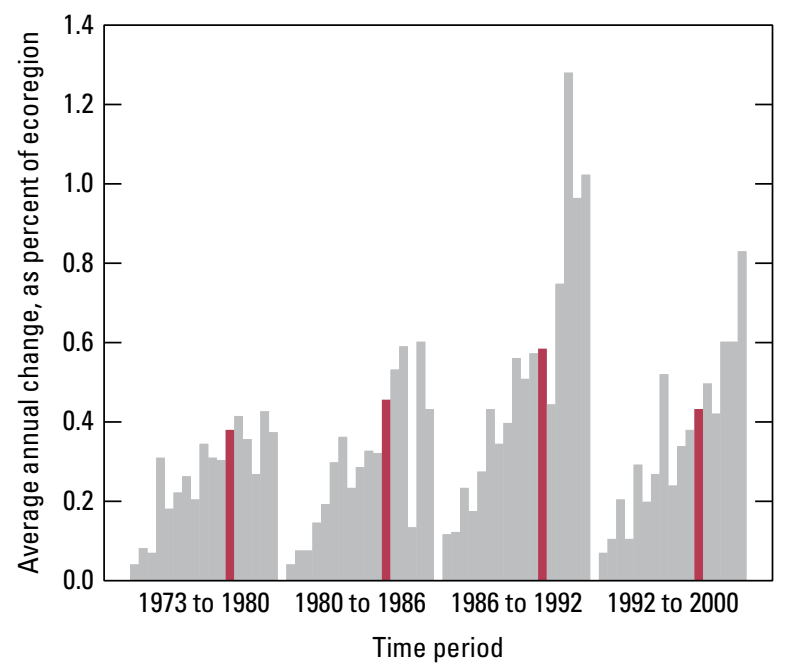

Figure 9. Estimates of land-cover change per time period, normalized to annual rates of change for all 17 Great Plains ecoregions (gray bars). Estimates of change for Texas Blackland Prairies Ecoregion are represented by red bars in each time period.
San Antonio, Austin, and Dallas, as well as in smaller cities such as Temple and Waco, Texas, fueled much of the increased development in the ecoregion (Scarbrough, 2005; Erlichman, 2006).

Grassland/shrubland had the third largest net change during the study period, increasing by 0.9 percent $\left(436 \mathrm{~km}^{2}\right)$ (table 3), almost exclusively from agriculture. At the same time, grassland/shrubland was lost to developed, agriculture, and forest (fig. 11). This high rate of conversion into and out of grassland/shrubland gave that class a large gross change of

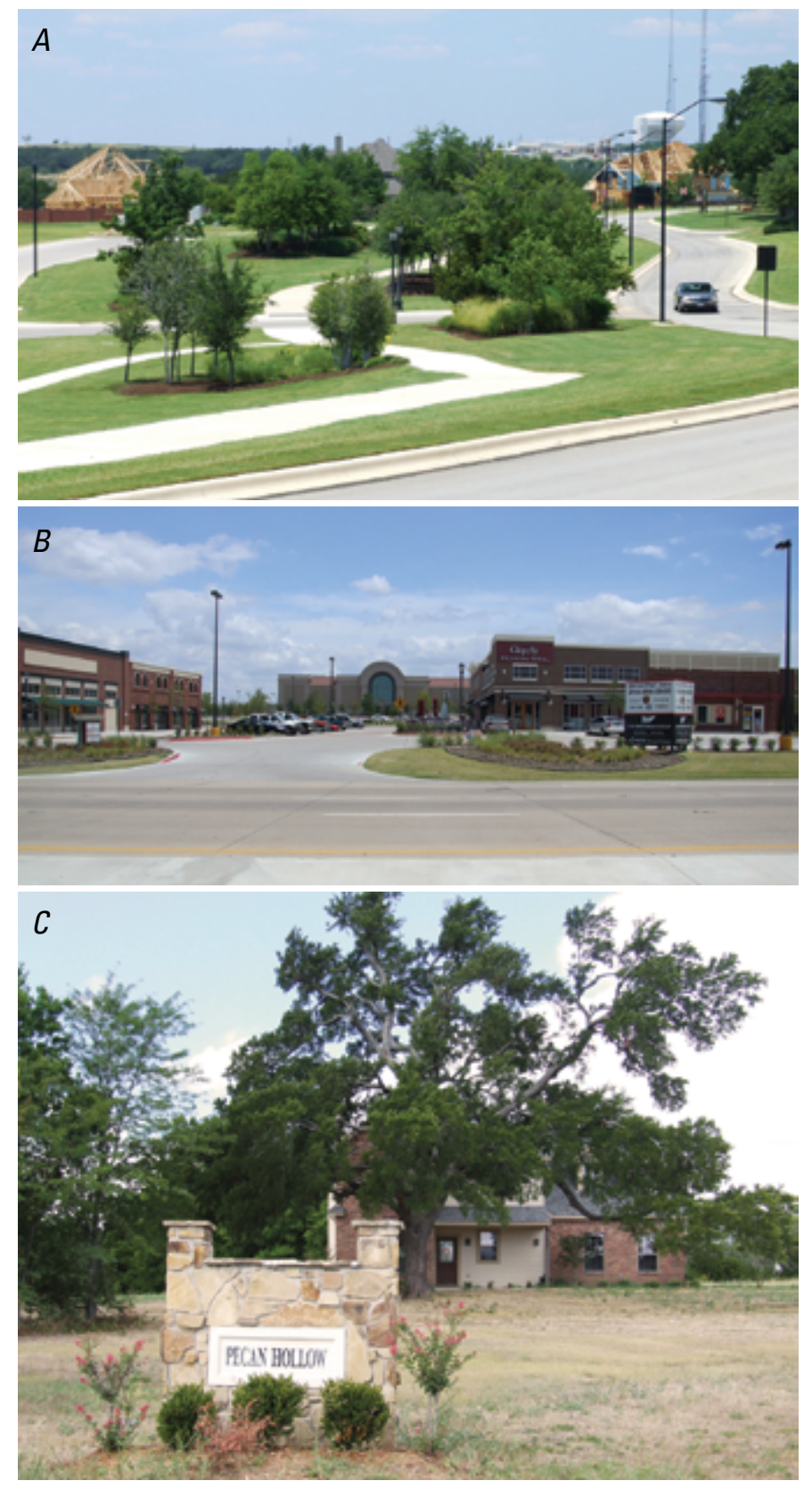

Figure 10. New developed land in Texas Blackland Prairies Ecoregion. $A$, New construction in subdivision of larger lots associated with golf course, in Georgetown, Texas, north of Austin. $B$, Retail shopping center, in Garland, Texas. $C$, Newer housing on edge of Westminster, Texas, in northeast Collin County. 
3.9 percent $\left(1,952 \mathrm{~km}^{2}\right)$ that was much larger than the overall net change of 0.9 percent (table 3 ). Land held in speculation for future development on the periphery of metropolitan areas may have increased the amount of grassland/shrubland in the ecoregion. Other changes include the conversion from grassland/shrubland "brush" to forest-height woodlands as woody vegetation was allowed to mature.

The main stories of change in the Texas Blackland Prairies Ecoregion between 1973 and 2000 were the deintensification of agriculture to both grassland/shrubland and forest, as well as the continued growth of the major metropolitan areas within the ecoregion. The deintensification of agriculture (usually converting to grassland/shrubland) occurred primarily because of less intense management of pastureland, outright agricultural abandonment, and extensive

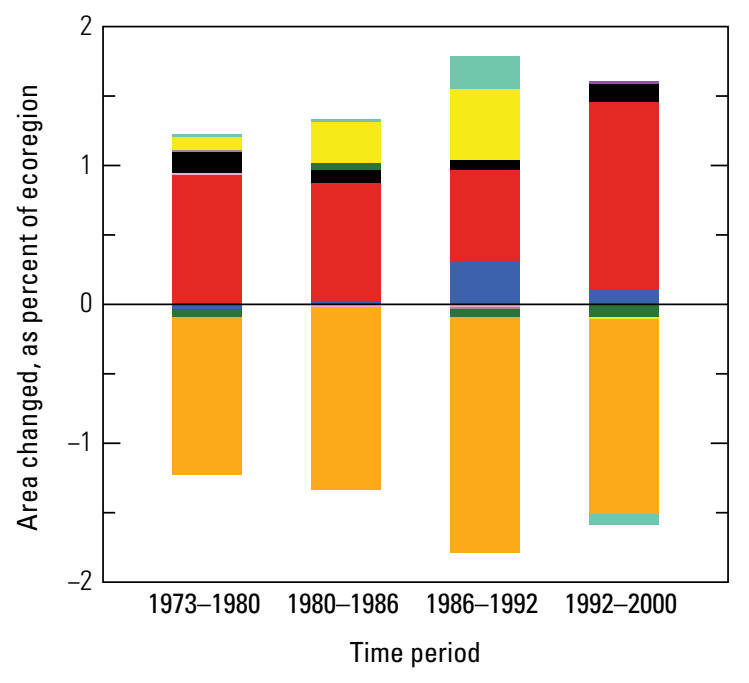

EXPLANATION LAND-USE/LAND-COVER CLASS

\begin{tabular}{ll}
\hline Water & Forest \\
\hline Developed & Grassland/Shrubland \\
\hline Transitional & Agriculture \\
Mining & Wetland \\
$\square$ Barren & Nonmechanically disturbed \\
& Ice/Snow
\end{tabular}

Figure 11. Normalized average net change in Texas Blackland Prairies Ecoregion by time period for each land-cover class. Bars above zero axis represent net gain, whereas bars below zero represent net loss. Note that not all land-cover classes shown in explanation may be represented in figure. See appendix 3 for definitions of land-use/land-cover classifications. land speculation at the periphery of metropolitan areas. The conversion of agriculture to grassland/shrubland and even forest may have been the result of changing patterns of landownership, in which the emphasis by new owners was not on production of livestock but, instead, on wildlife habitat, aesthetic values, and other environmentally conscious land uses (Hamilton and Ueckert, 2004).

The conversions of agriculture, grassland/shrubland, and forest to developed accounted for about 31.0 percent of the estimated total area that changed during the study period. Conversions of agriculture and grassland/shrubland to developed were among the top land-use/land-cover changes during all four time periods (table 4). Altogether, developed land gained an estimated 1,933 $\mathrm{km}^{2}$ between 1973 and 2000 (table 3), and more increases in developed land are expected, as three counties on the outskirts of Dallas (Collin, Rockwall, and Kaufman Counties), as well as two counties that flank Austin to the north and southwest (Williamson and Hays Counties), ranked in the top 100 fastest growing counties in the United States between 2000 and 2006 (Advertising Age, 2008) (fig. 12).

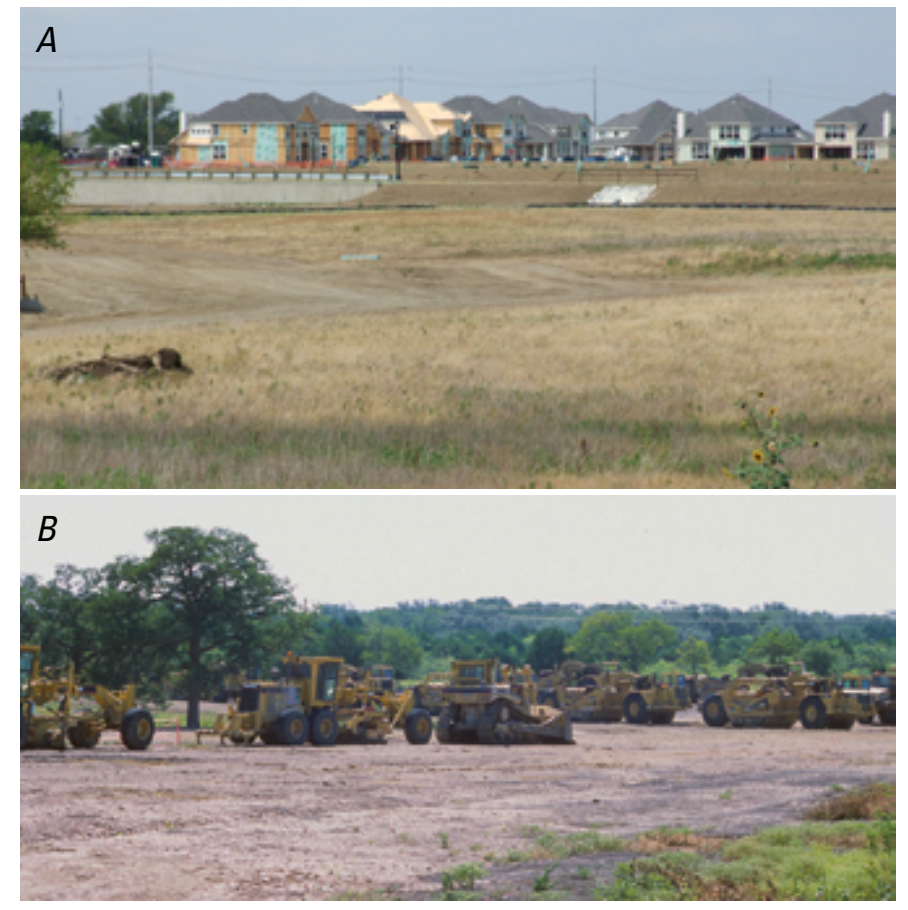

Figure 12. More developed land in Texas Blackland Prairies Ecoregion post-2000. $A$, Rooftops of new residential housing advancing in Frisco, Texas, on north side of Dallas urbanized area. $B$, Earth-moving equipment poised to work on Texas State Highway 130 toll road east of Austin, a divided highway that arcs around Austin urbanized area to relieve congestion on Interstate 35 . 
Table 1. Percentage of Texas Blackland Prairies Ecoregion land cover that changed at least one time during study period (19732000) and associated statistical error.

[Most sample pixels remained unchanged (88.9 percent), whereas 11.1 percent changed at least once throughout study period]

\begin{tabular}{ccccccc}
\hline $\begin{array}{c}\text { Number } \\
\text { of } \\
\text { changes }\end{array}$ & $\begin{array}{c}\text { Percent } \\
\text { of } \\
\text { ecoregion }\end{array}$ & $\begin{array}{c}\text { Margin } \\
\text { of error } \\
(+/-\%)\end{array}$ & $\begin{array}{c}\text { Lower } \\
\text { bound } \\
(\%)\end{array}$ & $\begin{array}{c}\text { Upper } \\
\text { bound } \\
(\%)\end{array}$ & $\begin{array}{c}\text { Standard } \\
\text { error } \\
(\%)\end{array}$ & $\begin{array}{c}\text { Relative } \\
\text { error } \\
(\%)\end{array}$ \\
\hline 1 & 10.0 & 2.3 & 7.7 & 12.3 & 1.5 & 15.5 \\
2 & 1.1 & 0.4 & 0.7 & 1.5 & 0.3 & 23.2 \\
3 & 0.0 & 0.0 & 0.0 & 0.0 & 0.0 & 25.6 \\
4 & 0.0 & 0.0 & 0.0 & 0.0 & 0.0 & 76.1 \\
\hline $\begin{array}{l}\text { Overall } \\
\text { spatial } \\
\text { change }\end{array}$ & 11.1 & 2.6 & 8.5 & 13.7 & 1.8 & 16.0 \\
\hline
\end{tabular}

Table 2. Raw estimates of change in Texas Blackland Prairies Ecoregion land cover, computed for each of four time periods between 1973 and 2000, and associated error at 85-percent confidence level.

[Estimates of change per period normalized to annual rate of change for each period]

\begin{tabular}{cccccccc}
\hline Period & $\begin{array}{c}\text { Total change } \\
(\% \text { of ecoregion) }\end{array}$ & $\begin{array}{c}\text { Margin of } \\
\text { error } \\
(+/-\%)\end{array}$ & $\begin{array}{c}\text { Lower } \\
\text { bound } \\
(\%)\end{array}$ & $\begin{array}{c}\text { Upper bound } \\
(\%)\end{array}$ & $\begin{array}{c}\text { Standard } \\
\text { error } \\
(\%)\end{array}$ & $\begin{array}{c}\text { Relative } \\
\text { error } \\
(\%)\end{array}$ & $\begin{array}{c}\text { Average rate } \\
(\% \text { per year) }\end{array}$ \\
\hline \multicolumn{7}{c}{ Estimate of change, in percent stratum } \\
\hline $1973-1980$ & 2.6 & 0.9 & 1.8 & 3.5 & 0.6 & 22.3 & 0.4 \\
$1980-1986$ & 2.7 & 0.6 & 2.1 & 3.3 & 0.4 & 14.2 & 0.5 \\
$1986-1992$ & 3.5 & 1.3 & 2.2 & 4.8 & 0.9 & 25.6 & 0.6 \\
$1992-2000$ & 3.5 & 1.0 & 2.4 & 4.5 & 0.7 & 19.9 & 0.4 \\
\hline $1973-1980$ & 1,332 & 436 & 896 & 1,769 & 297 & 22.3 & 190 \\
$1980-1986$ & 1,369 & 285 & 1,084 & 1,655 & 194 & 14.2 & 228 \\
$1986-1992$ & 1,774 & 668 & 1,106 & 2,442 & 455 & 25.6 & 296 \\
$1992-2000$ & 1,742 & 508 & 1,234 & 2,251 & 346 & 19.9 & 218 \\
\hline
\end{tabular}


Table 3. Estimated area (and margin of error) of each land-cover class in Texas Blackland Prairies Ecoregion, calculated five times between 1973 and 2000. See appendix 3 for definitions of land-cover classifications.

\begin{tabular}{|c|c|c|c|c|c|c|c|c|c|c|c|c|c|c|c|c|c|c|c|c|}
\hline & \multicolumn{2}{|c|}{ Water } & \multicolumn{2}{|c|}{ Developed } & \multicolumn{2}{|c|}{$\begin{array}{l}\text { Mechan- } \\
\text { ically } \\
\text { disturbed }\end{array}$} & \multicolumn{2}{|c|}{ Mining } & \multicolumn{2}{|c|}{ Barren } & \multicolumn{2}{|c|}{ Forest } & \multicolumn{2}{|c|}{$\begin{array}{l}\text { Grassland/ } \\
\text { Shrubland }\end{array}$} & \multicolumn{2}{|c|}{ Agriculture } & \multicolumn{2}{|c|}{ Wetland } & \multicolumn{2}{|c|}{$\begin{array}{c}\text { Non- } \\
\text { me- } \\
\text { chanically } \\
\text { disturbed }\end{array}$} \\
\hline & $\%$ & $+1-$ & $\%$ & $+1-$ & $\%$ & $+/-$ & $\%$ & $+/-$ & $\%$ & $+/-$ & $\%$ & $+/-$ & $\%$ & $+/-$ & $\%$ & $+/-$ & $\%$ & $+/-$ & $\%$ & $+/-$ \\
\hline \multicolumn{21}{|c|}{ Area, in percent stratum } \\
\hline 1973 & 0.8 & 0.2 & 8.9 & 4.7 & 0.0 & 0.0 & 0.2 & 0.1 & 0.0 & 0.0 & 14.0 & 1.7 & 11.8 & 2.9 & 63.4 & 4.9 & 0.9 & 0.3 & 0.0 & 0.0 \\
\hline 1980 & 0.8 & 0.2 & 9.8 & 4.8 & 0.0 & 0.0 & 0.3 & 0.2 & 0.0 & 0.0 & 13.9 & 1.7 & 11.9 & 2.9 & 62.3 & 5.0 & 0.9 & 0.3 & 0.0 & 0.0 \\
\hline 1986 & 0.8 & 0.2 & 10.7 & 5.0 & 0.0 & 0.0 & 0.4 & 0.3 & 0.0 & 0.0 & 14.0 & 1.7 & 12.2 & 2.8 & 60.9 & 5.1 & 0.9 & 0.3 & 0.0 & 0.0 \\
\hline 1992 & 1.1 & 0.4 & 11.3 & 5.1 & 0.0 & 0.0 & 0.5 & 0.4 & 0.0 & 0.0 & 13.9 & 1.7 & 12.7 & 2.9 & 59.2 & 5.3 & 1.2 & 0.6 & 0.0 & 0.0 \\
\hline 2000 & 1.2 & 0.5 & 12.7 & 5.4 & 0.0 & 0.0 & 0.6 & 0.4 & 0.0 & 0.0 & 13.9 & 1.7 & 12.7 & 2.8 & 57.8 & 5.5 & 1.1 & 0.5 & 0.0 & 0.0 \\
\hline $\begin{array}{l}\text { Net } \\
\text { change }\end{array}$ & 0.4 & 0.5 & 3.8 & 1.9 & 0.0 & 0.0 & 0.4 & 0.3 & 0.0 & 0.0 & -0.2 & 0.4 & 0.9 & 1.1 & -5.6 & 2.1 & 0.2 & 0.3 & 0.0 & 0.0 \\
\hline $\begin{array}{l}\text { Gross } \\
\text { change }\end{array}$ & 0.6 & 0.5 & 3.8 & 1.9 & 0.1 & 0.1 & 0.5 & 0.3 & 0.0 & 0.0 & 1.5 & 0.4 & 3.9 & 0.9 & 6.6 & 2.0 & 0.5 & 0.5 & 0.0 & 0.0 \\
\hline \multicolumn{21}{|c|}{ Area, in square kilometers } \\
\hline 1973 & 407 & 102 & 4,490 & 2,362 & 5 & 5 & 81 & 55 & 17 & 14 & 7,074 & 875 & 5,965 & 1,471 & 32,011 & 2,468 & 452 & 138 & 0 & 0 \\
\hline 1980 & 395 & 91 & 4,961 & 2,447 & 20 & 18 & 155 & 105 & 25 & 19 & 7,042 & 865 & 6,008 & 1,443 & 31,440 & 2,512 & 455 & 136 & 0 & 0 \\
\hline 1986 & 406 & 91 & 5,396 & 2,531 & 16 & 16 & 206 & 154 & 18 & 15 & 7,062 & 868 & 6,159 & 1,434 & 30,776 & 2,582 & 463 & 137 & 0 & 0 \\
\hline 1992 & 564 & 184 & 5,731 & 2,594 & 5 & 7 & 247 & 184 & 16 & 12 & 7,034 & 864 & 6,410 & 1,452 & 29,913 & 2,658 & 582 & 286 & 0 & 0 \\
\hline 2000 & 617 & 243 & 6,423 & 2,713 & 6 & 4 & 304 & 213 & 14 & 10 & 6,995 & 850 & 6,401 & 1,416 & 29,196 & 2,755 & 544 & 238 & 1 & 1 \\
\hline $\begin{array}{l}\text { Net } \\
\text { change }\end{array}$ & 210 & 235 & 1,933 & 949 & 1 & 5 & 223 & 172 & -3 & 8 & -79 & 210 & 436 & 567 & $-2,814$ & 1,069 & 92 & 133 & 1 & 1 \\
\hline $\begin{array}{l}\text { Gross } \\
\text { change }\end{array}$ & 315 & 234 & 1,933 & 949 & 67 & 44 & 263 & 173 & 21 & 16 & 760 & 196 & 1,952 & 461 & 3,345 & 1,018 & 245 & 239 & 1 & 1 \\
\hline
\end{tabular}


Table 4. Principal land-cover conversions in Texas Blackland Prairies Ecoregion, showing amount of area changed (and margin of error, calculated at 85-percent confidence level) for each conversion during each of four time periods and also during overall study period. See appendix 3 for definitions of land-cover classifications.

[Values given for "other” classes are combined totals of values for other land-cover classes not listed in that time period. Abbreviations: n/a, not applicable]

\begin{tabular}{|c|c|c|c|c|c|c|c|c|}
\hline Period & From class & To class & & $\begin{array}{c}\text { Area } \\
\text { changed } \\
\left(\mathbf{k m}^{2}\right)\end{array}$ & $\begin{array}{c}\text { Margin of } \\
\text { error } \\
\left(+/-\mathrm{km}^{2}\right)\end{array}$ & $\begin{array}{c}\text { Standard } \\
\text { error } \\
\left(\mathbf{k m}^{2}\right)\end{array}$ & $\begin{array}{l}\text { Percent of } \\
\text { ecoregion }\end{array}$ & $\begin{array}{c}\text { Percent of all } \\
\text { changes }\end{array}$ \\
\hline \multirow[t]{7}{*}{ 1973-1980 } & Agriculture & Grassland/Shrubland & & 351 & 161 & 109 & 0.7 & 26.3 \\
\hline & Agriculture & Developed & & 331 & 300 & 204 & 0.7 & 24.8 \\
\hline & Grassland/Shrubland & Agriculture & & 150 & 99 & 67 & 0.3 & 11.2 \\
\hline & Grassland/Shrubland & Developed & & 109 & 89 & 60 & 0.2 & 8.2 \\
\hline & Forest & Agriculture & & 71 & 37 & 25 & 0.1 & 5.3 \\
\hline & Other & Other & & 321 & $\mathrm{n} / \mathrm{a}$ & $\mathrm{n} / \mathrm{a}$ & 0.6 & 24.1 \\
\hline & & & Totals & 1,332 & & & 2.6 & 100.0 \\
\hline \multirow[t]{7}{*}{ 1980-1986 } & Agriculture & Grassland/Shrubland & & 444 & 137 & 94 & 0.9 & 32.4 \\
\hline & Agriculture & Developed & & 263 & 142 & 97 & 0.5 & 19.2 \\
\hline & Grassland/Shrubland & Forest & & 109 & 64 & 44 & 0.2 & 8.0 \\
\hline & Grassland/Shrubland & Developed & & 109 & 56 & 38 & 0.2 & 8.0 \\
\hline & Grassland/Shrubland & Agriculture & & 76 & 34 & 23 & 0.2 & 5.6 \\
\hline & Other & Other & & 369 & $\mathrm{n} / \mathrm{a}$ & $\mathrm{n} / \mathrm{a}$ & 0.7 & 26.9 \\
\hline & & & Totals & 1,369 & & & 2.7 & 100.0 \\
\hline \multirow[t]{7}{*}{ 1986-1992 } & Agriculture & Grassland/Shrubland & & 592 & 230 & 157 & 1.2 & 33.4 \\
\hline & Agriculture & Developed & & 204 & 98 & 67 & 0.4 & 11.5 \\
\hline & Grassland/Shrubland & Forest & & 115 & 53 & 36 & 0.2 & 6.5 \\
\hline & Grassland/Shrubland & Agriculture & & 108 & 40 & 27 & 0.2 & 6.1 \\
\hline & Grassland/Shrubland & Developed & & 105 & 57 & 39 & 0.2 & 5.9 \\
\hline & Other & Other & & 651 & $\mathrm{n} / \mathrm{a}$ & $\mathrm{n} / \mathrm{a}$ & 1.3 & 36.7 \\
\hline & & & Totals & 1,774 & & & 3.5 & 100.0 \\
\hline \multirow[t]{7}{*}{ 1992-2000 } & Agriculture & Grassland/Shrubland & & 453 & 146 & 99 & 0.9 & 26.0 \\
\hline & Agriculture & Developed & & 375 & 239 & 163 & 0.7 & 21.5 \\
\hline & Grassland/Shrubland & Developed & & 267 & 139 & 95 & 0.5 & 15.3 \\
\hline & Grassland/Shrubland & Agriculture & & 123 & 51 & 35 & 0.2 & 7.1 \\
\hline & Grassland/Shrubland & Forest & & 97 & 38 & 26 & 0.2 & 5.5 \\
\hline & Other & Other & & 429 & $\mathrm{n} / \mathrm{a}$ & $\mathrm{n} / \mathrm{a}$ & 0.8 & 24.6 \\
\hline & & & Totals & 1,742 & & & 3.5 & 100.0 \\
\hline \multirow{7}{*}{$\begin{array}{c}\text { 1973-2000 } \\
\text { (overall) }\end{array}$} & Agriculture & Grassland/Shrubland & & 1,839 & 537 & 366 & 3.6 & 29.6 \\
\hline & Agriculture & Developed & & 1,172 & 698 & 476 & 2.3 & 18.8 \\
\hline & Grassland/Shrubland & Developed & & 590 & 298 & 203 & 1.2 & 9.5 \\
\hline & Grassland/Shrubland & Agriculture & & 456 & 144 & 98 & 0.9 & 7.3 \\
\hline & Grassland/Shrubland & Forest & & 376 & 148 & 101 & 0.7 & 6.1 \\
\hline & Other & Other & & 1,785 & $\mathrm{n} / \mathrm{a}$ & $\mathrm{n} / \mathrm{a}$ & 3.5 & 28.7 \\
\hline & & & Totals & 6,218 & & & 12.3 & 100.0 \\
\hline
\end{tabular}




\section{References Cited}

Advertising Age, 2008, Nation's fastest-growing counties from 2000 to 2006: Advertising Age's American Demographics, 100 Fastest growing counties-Summary, Excel spreadsheet, accessed October 3, 2008, at http://adage. com/images/bin/excel/100counties0606.xls.

Erlichman, H.J., 2006, Camino del Norte-How a series of watering holes, fords, and dirt trails evolved into Interstate 35 in Texas: College Station, Texas A\&M University Press, 284 p.

Griffith, G.E., Bryce, S.A., Omernik, J.M., Comstock, J.A., Rogers, A.C., Harrison, B., Hatch, S.L., and Benzanson, D., 2004, Ecoregions of Texas: U.S. Geological Survey Ecoregion Map Series, scale 1:2,500,000, available at ftp://ftp.epa.gov/wed/ecoregions/tx/tx_front.pdf.

Hamilton, W.T., and Ueckert, D.N., 2004, Introduction Rangeland woody plant and weed management-Past, present, and future, in Hamilton, W.T., McGinty, A., Ueckert, D.N., Hanselka, C.W., and Lee, M.R., eds., Brush management-Past, present, future: College Station, Texas A\&M University Press, p. 3-13.

Kottek, M.J., Grieser, J., Beck, C., Rudolf, B., and Rubel, F., 2006, World map of the Köppen-Geiger climate classification updated: Meteorologische Zeitschrift, v. 15, no. 3, p. 259-263, available at http://www.schweizerbart. de/papers/metz/detail/15/55034/World_Map_of_the_ Koppen_Geiger_climate_classificat.

Omernik, J.M., 1987, Ecoregions of the conterminous United States: Annals of the Association of American Geographers, v. 77, no. 1, p. 118-125.

PRISM Climate Group, 2006, Precipitation-Annual climatology (1971-2000): PRISM Climate Group, Oregon State University database, accessed August 29, 2008, at http://prism.nacse.org/documents/.

Scarbrough, Linda, 2005, Road, river, and ol' boy politicsA Texas county's path from farm to supersuburb: Austin, Texas State Historical Association, 402 p.
Texas Parks and Wildlife, 1997, Texas wetlands conservation plan: Texas Parks and Wildlife database, Texas Wetlands Conservation Program, Resource Protection Division, 64 p., available at https://tpwd.texas.gov/publications/pwdpubs/ media/pwd_pl_r2000_0005_textonly.pdf.

U.S. Department of Agriculture, 2008a, Conservation programsStatistics: U.S. Department of Agriculture, Farm Service Agency database, accessed September 30, 2008, at http://www.fsa.usda. gov/FSA/webapp?area=home\&subject $=$ copr\&topic $=$ crp-st.

U.S. Department of Agriculture, 2008b, The soil orders of Texas: U.S. Department of Agriculture, Natural Resources Conservation Service database, accessed September 30, 2008, at http://www.nrcs.usda.gov/wps/portal/nrcs/detail/tx/ soils/?cid=nrcs144p2_003094.

U.S. Department of Agriculture, 2008c, 2002 Census publications - State and county profiles - Texas: U.S Department of Agriculture, Census of Agriculture database, accessed October 3, 2008, at http://www.agcensus.usda.gov/ Publications/2002/County_Profiles/Texas/index.asp.

U.S. Environmental Protection Agency, 1997, Descriptions of level III ecological regions for the CEC report on ecological regions of North America: U.S. Environmental Protection Agency database, accessed September 30, 2008, at http://www.epa.gov/wed/ pages/ecoregions/na_eco.htm\#Downloads.

U.S. Environmental Protection Agency, 2002, Primary distinguishing characteristics of level III ecoregions of the continental United States: U.S. Environmental Protection Agency database, accessed September 30, 2008, at http:// www.epa.gov/wed/pages/ecoregions/level_iii.htm.

Vogelmann, J.E., Howard, S.M., Yang, L., Larson, C.R., Wylie, B.K., and van Driel, N., 2001, Completion of the 1990s National Land Cover Data Set for the conterminous United States from Landsat Thematic Mapper data and ancillary data sources: Photogrammetric Engineering \& Remote Sensing, v. 67, p. 650-662.

White, Matt, 2006, Prairie time-A Blackland portrait: College Station, Texas A\&M University Press, 251 p. 


\title{
Western Gulf Coastal Plain Ecoregion
}

\author{
By Mark A. Drummond
}

\section{Ecoregion Description}

The Western Gulf Coastal Plain Ecoregion is an elongated, low-elevation area that covers $80,965 \mathrm{~km}^{2}$ $\left(31,261 \mathrm{mi}^{2}\right)$. The ecoregion extends from west of the Mississippi River delta in southwestern Louisiana into Texas, running along the entire Gulf Coast of Texas to the Mexican border (fig. 1) (Omernik, 1987; U.S. Environmental Protection Agency, 1997). It is surrounded by, from southwest to northeast, the Southern Texas Plains, East Central Texas Plains, South Central Plains, and Mississippi Alluvial Plain Ecoregions (fig. 1).

The Western Gulf Coastal Plain Ecoregion is a level plain composed mostly of sedimentary strata deposited by repeated cycles of sea-level fluctuations, overlain by finetextured clays and sand. Several major waterways (including

Figure 1. Map of Western Gulf Coastal Plain Ecoregion and surrounding ecoregions, showing land-use/land-cover classes from 1992 National Land-cover Dataset (Vogelmann and others, 2001); note that not all landuse/land-cover classes shown in explanation may be depicted on map; note also that, for this "Status and Trends of Land Change" study, transitional land-cover class was subdivided into mechanically disturbed and nonmechanically disturbed classes. Squares indicate locations of $10 \times 10$ km sample blocks analyzed in study. Index map shows locations of geographic features mentioned in text. Abbreviations for Great

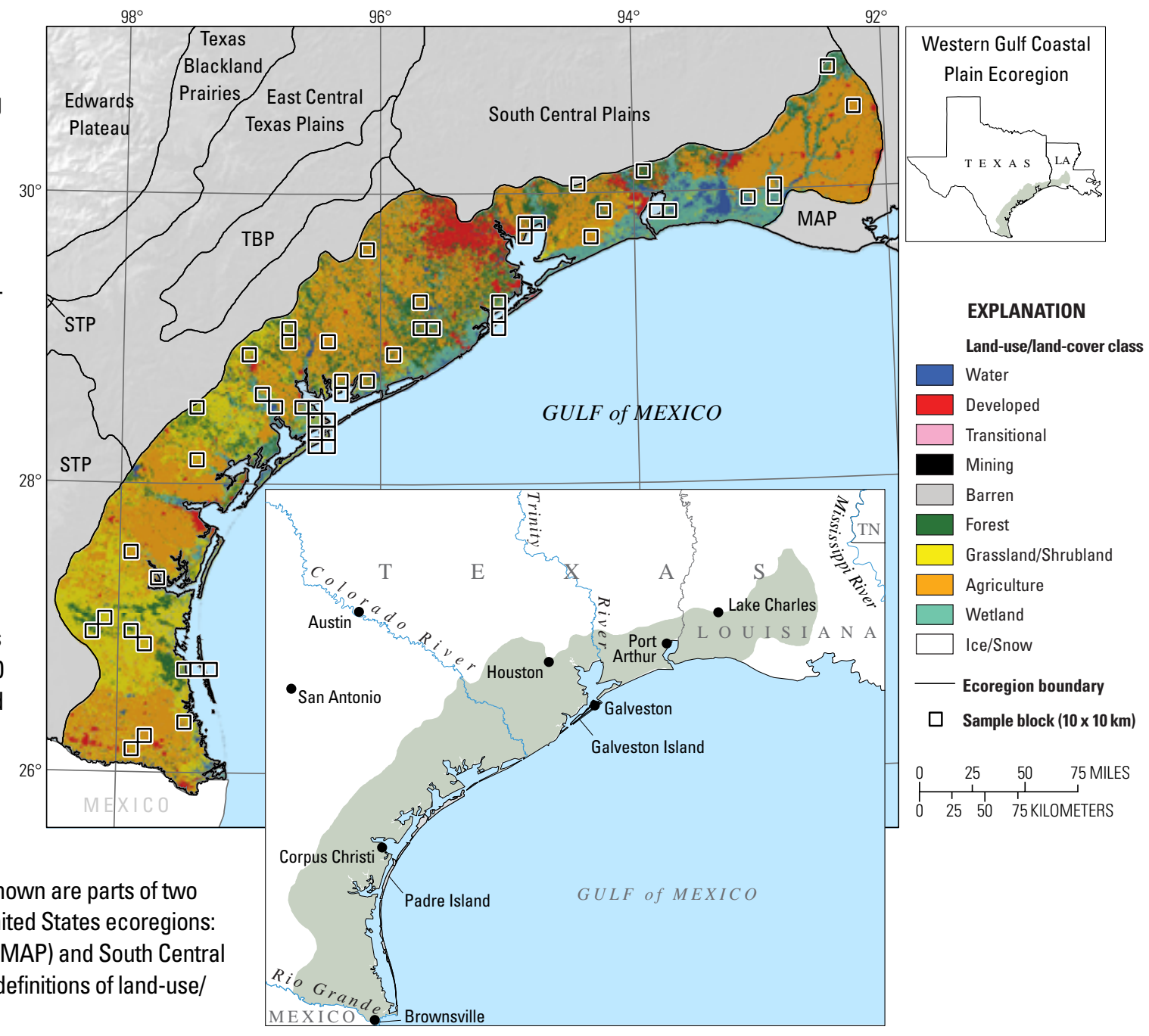
Plains ecoregions are listed in appendix 2. Also shown are parts of two Midwest-South Central United States ecoregions: Mississippi Alluvial Plains (MAP) and South Central Plains. See appendix 3 for definitions of land-use/ land-cover classifications. 
the Trinity River, the Colorado River, and the Rio Grande) dissect the coastal plain, emptying into the Gulf of Mexico. The Coastal Lowlands aquifer, which underlies much of the ecoregion, is the main source of groundwater. However, aquifer pumping rates are a concern, especially in the greater Houston-Galveston, Texas, area where groundwater levels have declined by as much as $100 \mathrm{~m}$, causing saltwater intrusion and land subsidence (Davidson and Mace, 2006).

The Western Gulf Coastal Plain Ecoregion primarily is a flat grassland prairie, dominated by little bluestem (Schizachyrium scoparium) and other grasses. Woody vegetation has encroached on areas of intensive livestock grazing and also of fire suppression (Archer, 1990) (fig. 2). Loblolly pine (Pinus taeda), grown for both lumber and paper production, and hardwoods grow along the higher elevation margins of the ecoregion. In the southern part of the ecoregion, clusters of live oak (Quercus virginiana) grow on sandy ridges, known as oak mottes. Hardwoods also grow along numerous wooded bottomland floodplains

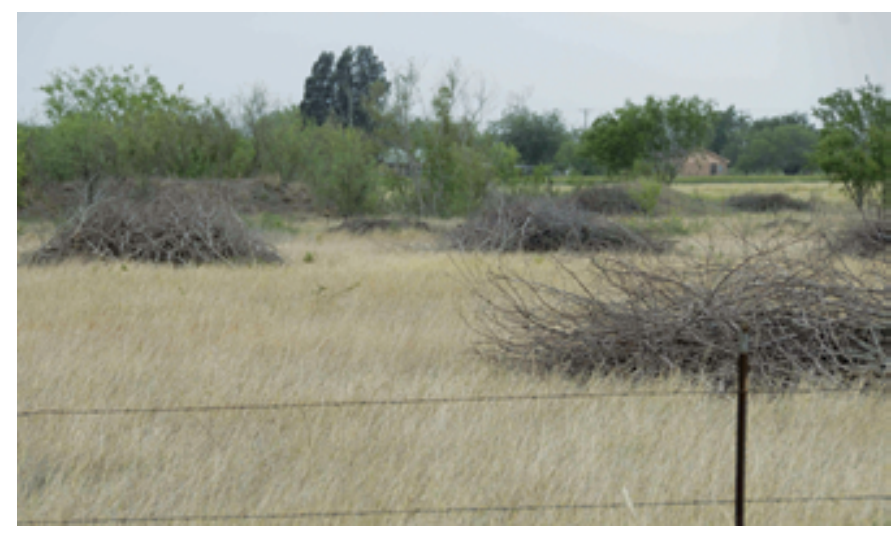

Figure 2. Brush clearance of livestock pasture, in Western Gulf Coastal Plain Ecoregion.

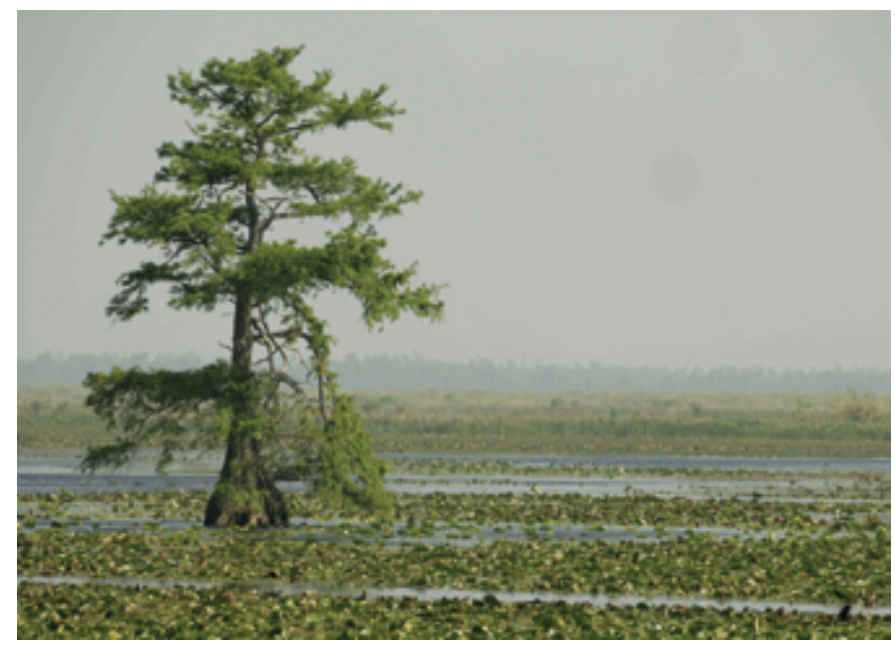

Figure 3. Freshwater marsh in southwestern Louisiana, Western Gulf Coastal Plain Ecoregion. throughout the ecoregion, although many of these forests have been cleared for cropland, pastureland, and urbanization. Coastal marshes and estuaries are extensive along the Gulf of Mexico, from the southern Louisiana parishes into eastern Texas (fig. 3). About 85 percent of wetlands are freshwater environments, and 15 percent are saltwater environments (Moulton and others, 1997). Long barrier islands and adjoining lagoons are more prevalent along the southern Texas coast, including the area from Galveston Island in the north to Padre Island in the south. Several large bays line the Texas coastline, including six deep-water harbors; the port of Houston is the largest of these harbors.

Sand plains and dunes, which are found in a limited area north of the lower Rio Grande valley, support little cropland compared to the rest of the ecoregion, much of which is intensively cropped and irrigated. Honey mesquite (Prosopis glandulosa) and granjeno (Celtis pallida) shrubs have invaded much of the valley. Natural habitat in the southern tip of Texas and elsewhere in the ecoregion supports various subtropical and marine bird communities, as well as Central Flyway species, making it an area of high species diversity.

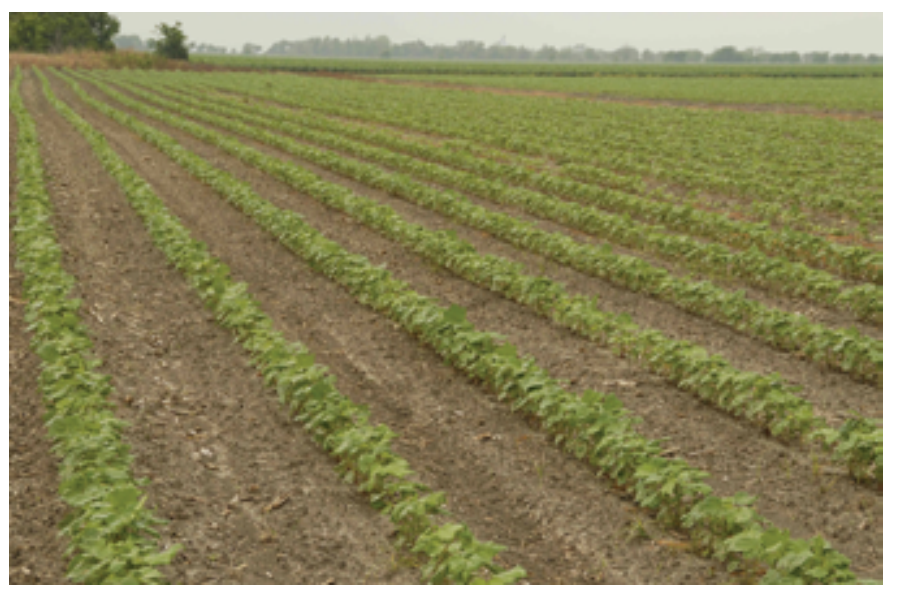

Figure 4. Cotton field in Western Gulf Coastal Plain Ecoregion.

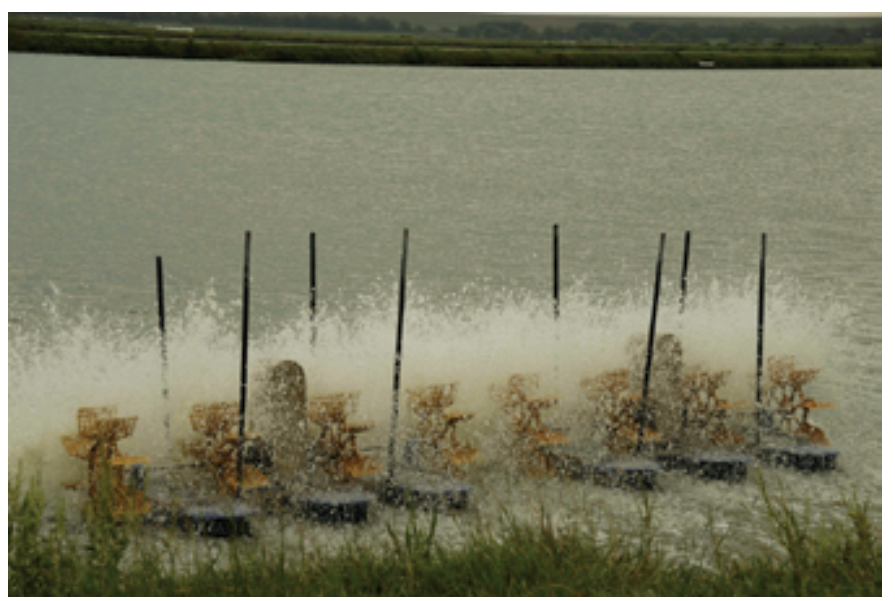

Figure 5. Catfish farm in Western Gulf Coastal Plain Ecoregion. 
Large areas in the Western Gulf Coastal Plain Ecoregion are used to grow crops and to graze livestock (fig. 4), and smaller areas are used for inland fish production (fig. 5). Agriculture is aided by a subtropical climate of mild winters and hot summers influenced by the Gulf of Mexico. Precipitation amounts in the ecoregion range from about $650 \mathrm{~mm}$ (25 in.) in the southwest to $1,500 \mathrm{~mm}$ (60 in.) in the northeast. The southernmost part of the ecoregion has a long growing season, having frost-free periods of more than 320 days, which allows cotton, corn, sorghum, sugarcane, citrus, melons, and vegetables to be grown along the Rio Grande floodplain (Griffith and others, 2004). About one-half of freshwater wetlands also are used for growing rice (often referred to as agricultural wetlands), particularly in the middle part of the ecoregion (Moulton and others, 1997).

Ecological goods and services from coastal wetlands and water bodies are important to the economy of the ecoregion; activities include commercial and recreational fishing, oyster harvesting and shrimp nurseries, waterfowl hunting, and birdwatching (Moulton and others, 1997). Overall, about 70 percent of Texas industry and commerce happens within $160 \mathrm{~km}$ of the coast, and more than one-half of petroleum production in the United States is located in the region (fig. 6) (Texas General Land Office, 1995; Moulton and others, 1997). Various human land uses (including canal dredging and channelization, aquifer drawdown, urbanization, and agriculture) contribute to wetland loss in southwestern Louisiana and Texas.

The largest population center in the ecoregion is Houston, Texas, where population nearly doubled during the study period. Between 1970 and 2000, the population of the ecoregion increased by 85 percent, and more than one-half of the increase was concentrated in the Houston area (U.S. Bureau of Census, 1970-2000 [various years]); only four counties lost population. The southern coastal cities of Texas have populations that are increasingly seasonal, as tourism increases and retirees and others temporarily move south for the mild climate during the winter months.

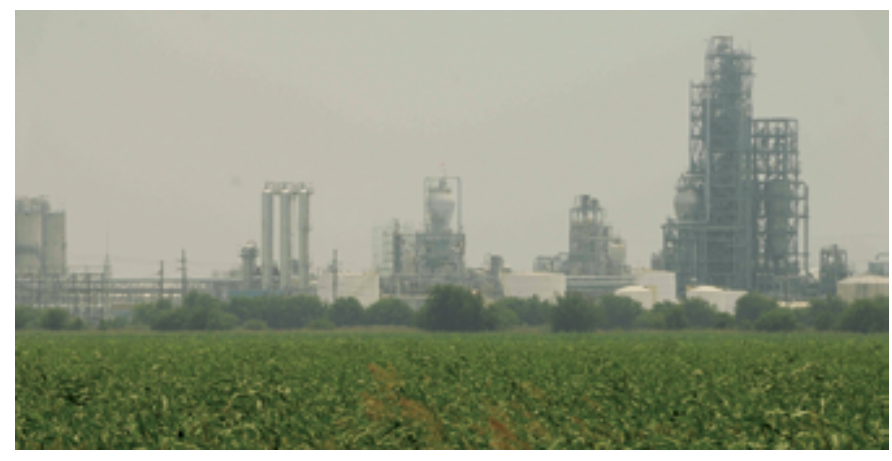

Figure 6. Petroleum processing plant in Western Gulf Coastal Plain Ecoregion. Petroleum-related industries are important to ecoregion's economic base.

\section{Contemporary Land-Cover Change (1973 to 2000)}

Land cover is diverse in the Western Gulf Coastal Plain Ecoregion, with agriculture, grassland/shrubland, wetland, forest, and water each constituting more than 10 percent of the total area during all time periods (table 1 ). The overall spatial change (the percentage of land area that changed at least one time) in the ecoregion between 1973 and 2000 is 9.9 percent (table 2; fig. 7). Compared to other Great Plains ecoregions, change in the ecoregion was higher than average (fig. 7). About 2.5 percent of the overall change was caused by multiple conversions (table 2), representing large land areas shifting between grassland/ shrubland and agriculture. The large gross changes between grassland/shrubland and agriculture were the two most common conversions between 1973 and 2000 (table 3).

Although agriculture covered the most total area in the ecoregion, it declined from 31.6 percent in 1973 to 30.6 percent in 2000 (table 1). The estimated 1.0 percent decline was the largest loss of land cover during the study period (fig. 8). Although substantial gross fluctuations between agriculture and grassland/shrubland occurred during the study period, most of the net loss of agriculture occurred because of conversion to wetland and developed land,

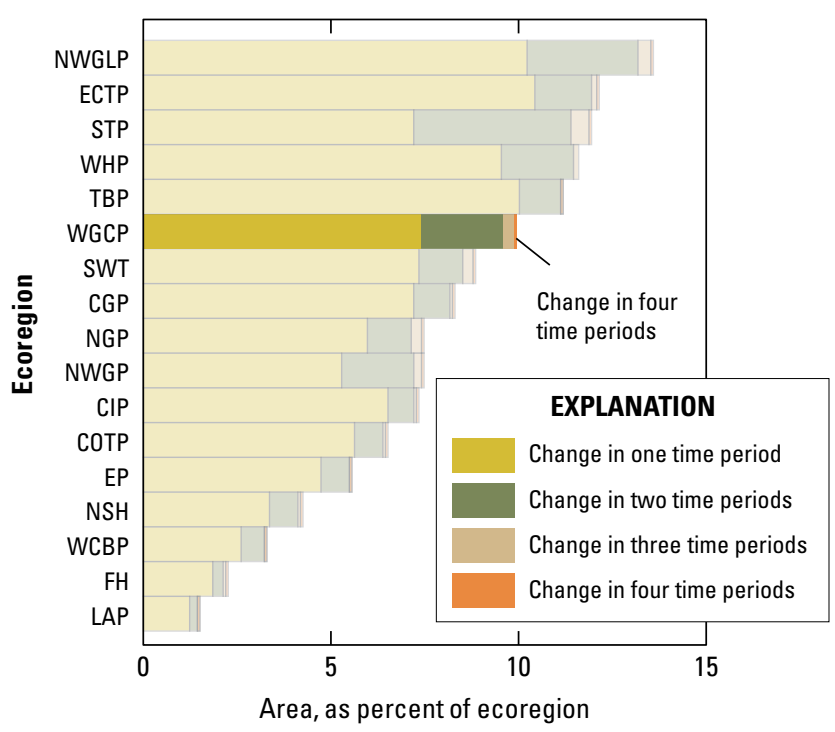

Figure 7. Overall spatial change in Western Gulf Coastal Plain Ecoregion (WGCP; darker bars) compared with that of all 17 Great Plains ecoregions (lighter bars). Each horizontal set of bars shows proportions of ecoregion that experienced change during one, two, three, or four time periods; highest level of spatial change in Western Gulf Coastal Plain Ecoregion (four time periods) labeled for clarity. See table 4 for years covered by each time period. See appendix 2 for key to ecoregion abbreviations. 
as well as to grassland/shrubland and forest. The loss of agricultural land to wetlands may have been caused by land subsidence where coastal aquifer groundwater levels have declined or by wetland engineering.

The largest single net gain among all land-cover classes in the ecoregion was an estimated 1.2 percent increase in developed land, increasing from 2.4 percent in 1973 to 3.6 percent in 2000 (table 1). Most developed land was converted from agricultural land, particularly around large metropolitan areas such as Houston, Texas, but also in many smaller population centers across the ecoregion. Expansion of developed land was relatively steady across all time periods.

Between 1973 and 1980, the largest net changes in land cover across the ecoregion were a decrease in grassland/ shrubland ( 0.5 percent) and an increase in developed (0.3 percent) (fig. 9). Agriculture expanded at the expense of grassland/shrubland in response to favorable farm policies, as well as to economic opportunities such as increased grain exports, and developed land mainly expanded onto agricultural land. Between 1980 and 1986, agriculture decreased by $320 \mathrm{~km}^{2}$, and grassland/shrubland increased by $194 \mathrm{~km}^{2}$ (table 1); both trends likely are related to unfavorable economic conditions such as inflation and the steep decline in farmland value (Lindert, 1988). The decrease also was a result of continued increase in development, mainly on former agricultural land.

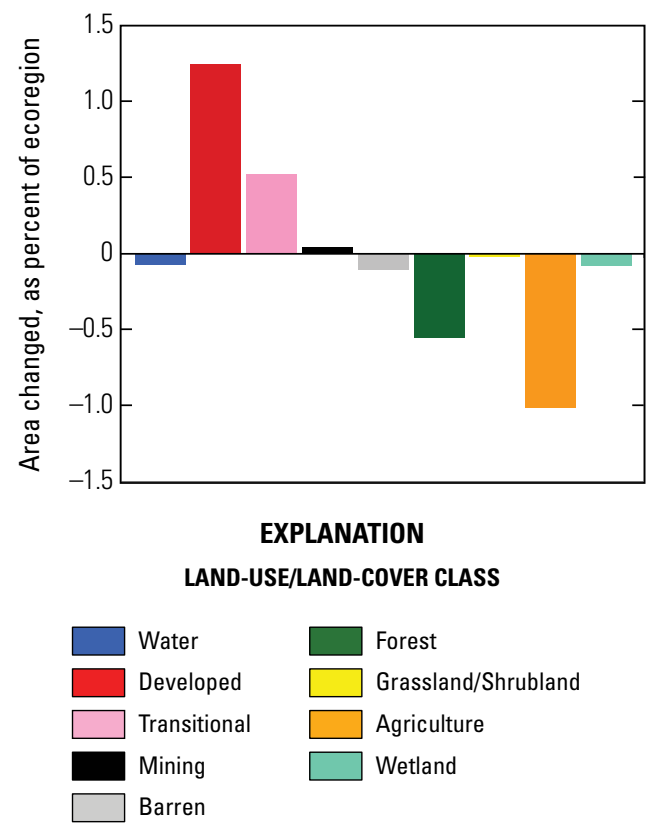

Figure 8. Estimates of net land-cover change in Western Gulf Coastal Plain Ecoregion for each land-cover class between 1973 and 2000. Bars above zero axis represent net gain, whereas bars below zero represent net loss. See appendix 3 for definitions of land-use/land-cover classifications.
Between 1986 and 1992, agriculture continued to decline by $301 \mathrm{~km}^{2}$ as it was converted to wetland, forest, developed, and grassland/shrubland (table 1). However, small gains in grassland/shrubland caused by agricultural abandonment were offset by conversions to forest elsewhere in the ecoregion. Conversion of forest to mechanically disturbed (primarily by forest clearcutting, but also by timber harvesting on loblolly pine plantations) also was a common type of land-cover conversion.

Between 1992 and 2000, developed land had the most net change, increasing by $342 \mathrm{~km}^{2}$ (table 1 ), with conversions dispersed among grassland/shrubland, agriculture, and forest. The leading land-cover conversions during this time period also were related to timber harvest and regrowth. While some forest was converted to mechanically disturbed, other clearcut areas revegetated to grassland/shrubland, often an intermediate stage between mechanically disturbed and forest.

Other important land-cover changes during the study period included conversions from grassland/shrubland to

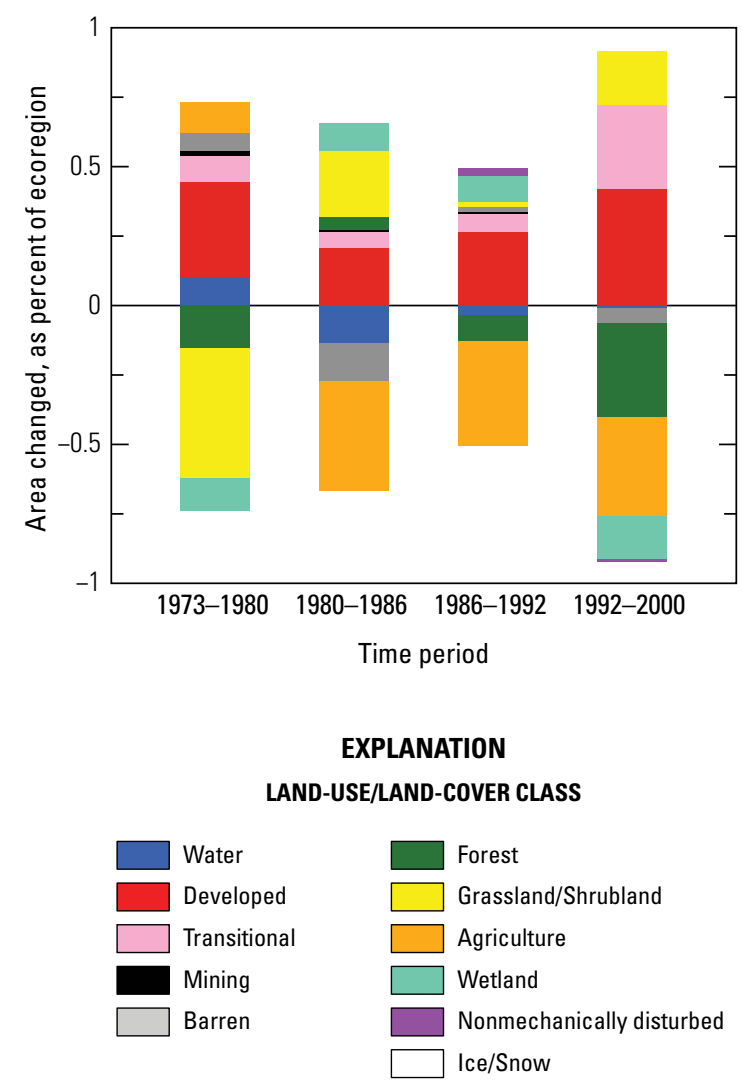

Figure 9. Normalized average net change in Western Gulf Coastal Plain Ecoregion by time period for each land-cover class. Bars above zero axis represent net gain, whereas bars below zero represent net loss. Note that not all land-cover classes shown in explanation may be represented in figure. See appendix 3 for definitions of land-use/land-cover classifications. 
mechanically disturbed and then back to grassland/shrubland. These changes are related to the removal of invading woody vegetation through mechanical means, prescribed burns, and herbicide treatments (Archer, 1990).

Overall, the estimated annual rates of change during each of the four time periods were relatively consistent, ranging from about 0.4 percent to 0.5 percent (table 4 ; fig. 10). The greatest rates of change were between 1980 and 1986, when agriculture had a large decline that likely was caused by the economic downturn, and between 1992 and 2000, when conversions involving developed land and forest were prominent.

During the entire study period, much of the change occurred between agriculture and grassland/shrubland (table 3), driven by agricultural expansion during economic booms followed by agricultural decline caused by cropland abandonment during economic downturns and also by conversions to developed land. However, much land-cover change also was caused by forest harvesting and regrowth. The largest net change between 1973 and 2000 was an expansion of developed land (table 1), caused by urban growth and population increase.

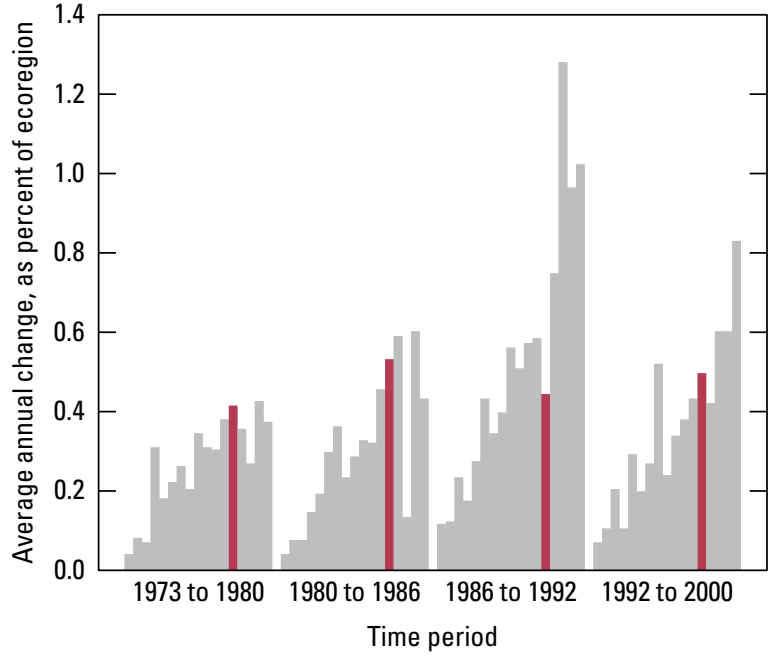

Figure 10. Estimates of land-cover change per time period, normalized to annual rates of change for all 17 Great Plains ecoregions (gray bars). Estimates of change for Western Gulf Coastal Plain Ecoregion are represented by red bars in each time period. 
Table 1. Estimated area (and margin of error) of each land-cover class in Western Gulf Coastal Plain Ecoregion, calculated five times between 1973 and 2000. See appendix 3 for definitions of land-cover classifications.

\begin{tabular}{|c|c|c|c|c|c|c|c|c|c|c|c|c|c|c|c|c|c|c|c|c|}
\hline & \multicolumn{2}{|c|}{ Water } & \multicolumn{2}{|c|}{ Developed } & \multicolumn{2}{|c|}{$\begin{array}{l}\text { Mechanically } \\
\text { disturbed }\end{array}$} & \multicolumn{2}{|c|}{ Mining } & \multicolumn{2}{|c|}{ Barren } & \multicolumn{2}{|c|}{ Forest } & \multicolumn{2}{|c|}{$\begin{array}{l}\text { Grassland/ } \\
\text { Shrubland }\end{array}$} & \multicolumn{2}{|c|}{ Agriculture } & \multicolumn{2}{|c|}{ Wetland } & \multicolumn{2}{|c|}{$\begin{array}{c}\text { Non- } \\
\text { mecha- } \\
\text { nically } \\
\text { disturbed }\end{array}$} \\
\hline \multicolumn{21}{|c|}{ Area, in percent stratum } \\
\hline 1973 & 17.5 & 7.8 & 2.4 & 0.7 & 0.1 & 0.1 & 0.0 & 0.0 & 2.1 & 2.4 & 12.1 & 3.5 & 20.4 & 5.9 & 31.6 & 6.0 & 13.8 & 4.4 & 0.0 & 0.0 \\
\hline 1992 & 17.5 & 7.7 & 3.2 & 0.9 & 0.3 & 0.2 & 0.1 & 0.1 & 2.1 & 2.3 & 11.8 & 3.4 & 20.2 & 5.7 & 30.9 & 5.8 & 13.8 & 4.5 & 0.0 & 0.0 \\
\hline 2000 & 17.5 & 7.7 & 3.6 & 1.1 & 0.6 & 0.4 & 0.1 & 0.1 & 2.0 & 2.2 & 11.5 & 3.3 & 20.4 & 5.7 & 30.6 & 5.7 & 13.7 & 4.4 & 0.0 & 0.0 \\
\hline $\begin{array}{l}\text { Net } \\
\text { change }\end{array}$ & -0.1 & 0.2 & 1.2 & 0.5 & 0.5 & 0.4 & 0.0 & 0.0 & -0.1 & 0.2 & -0.6 & 0.4 & 0.0 & 0.9 & -1.0 & 0.9 & -0.1 & 0.2 & 0.0 & 0.0 \\
\hline \multicolumn{21}{|c|}{ Area, in square kilometers } \\
\hline 1973 & 14,192 & 6,280 & 1,918 & 571 & 75 & 44 & 34 & 32 & 1,739 & 1,936 & 9,758 & 2,862 & 16,526 & 4,749 & 25,581 & 4,853 & 11,141 & 3,598 & 0 & 0 \\
\hline 1980 & 14,274 & 6,238 & 2,202 & 628 & 150 & 81 & 48 & 35 & 1,792 & 1,945 & 9,636 & 2,831 & 16,148 & 4,625 & 25,669 & 4,775 & 11,046 & 3,647 & 0 & 0 \\
\hline 1986 & 14,166 & 6,277 & 2,373 & 688 & 200 & 118 & 55 & 37 & 1,680 & 1,816 & 9,672 & 2,840 & 16,342 & 4,640 & 25,349 & 4,740 & 11,128 & 3,584 & 0 & 0 \\
\hline 1992 & 14,142 & 6,268 & 2,587 & 765 & 255 & 183 & 63 & 43 & 1,696 & 1,861 & 9,592 & 2,769 & 16,357 & 4,624 & 25,048 & 4,678 & 11,203 & 3,640 & 23 & 32 \\
\hline 2000 & 14,133 & 6,251 & 2,929 & 928 & 499 & 307 & 67 & 43 & 1,656 & 1,802 & 9,311 & 2,639 & 16,509 & 4,588 & 24,764 & 4,595 & 11,079 & 3,600 & 17 & 21 \\
\hline $\begin{array}{l}\text { Net } \\
\text { change }\end{array}$ & -59 & 150 & 1,011 & 435 & 424 & 293 & 33 & 26 & -83 & 138 & -447 & 317 & -17 & 733 & -818 & 757 & -62 & 140 & 17 & 21 \\
\hline $\begin{array}{l}\text { Gross } \\
\text { change }\end{array}$ & 979 & 315 & 1,012 & 435 & 1,038 & 449 & 38 & 26 & 292 & 256 & 1,312 & 472 & 3,167 & 1,011 & 3,266 & 1,014 & 1,226 & 459 & 58 & 65 \\
\hline
\end{tabular}

Table 2. Percentage of Western Gulf Coastal Plain Ecoregion land cover that changed at least one time during study period (1973-2000) and associated statistical error.

[Most sample pixels remained unchanged (90.1 percent), whereas 9.9 percent changed at least once throughout study period]

\begin{tabular}{ccccccc}
\hline $\begin{array}{c}\text { Number } \\
\text { of } \\
\text { changes }\end{array}$ & $\begin{array}{c}\text { Percent } \\
\text { of } \\
\text { ecoregion }\end{array}$ & $\begin{array}{c}\text { Margin } \\
\text { of error } \\
(+/-\%)\end{array}$ & $\begin{array}{c}\text { Lower } \\
\text { bound } \\
(\%)\end{array}$ & $\begin{array}{c}\text { Upper } \\
\text { bound } \\
(\%)\end{array}$ & $\begin{array}{c}\text { Standard } \\
\text { error } \\
(\%)\end{array}$ & $\begin{array}{c}\text { Relative } \\
\text { error } \\
(\%)\end{array}$ \\
\hline 1 & 7.4 & 1.7 & 5.7 & 9.1 & 1.1 & 15.4 \\
2 & 2.2 & 0.5 & 1.7 & 2.8 & 0.4 & 16.6 \\
3 & 0.3 & 0.1 & 0.1 & 0.4 & 0.1 & 28.5 \\
4 & 0.0 & 0.0 & 0.0 & 0.0 & 0.0 & 38.7 \\
\hline $\begin{array}{c}\text { Overall } \\
\text { spatial } \\
\text { change }\end{array}$ & 9.9 & 2.2 & 7.7 & 12.1 & 1.5 & 15.0 \\
\hline
\end{tabular}


Table 3. Principal land-cover conversions in Western Gulf Coastal Plain Ecoregion, showing amount of area changed (and margin of error, calculated at 85-percent confidence level) for each conversion during each of four time periods and also during overall study period. See appendix 3 for definitions of land-cover classifications.

[Values given for "other" classes are combined totals of values for other land-cover classes not listed in that time period. Abbreviations: n/a, not applicable]

\begin{tabular}{|c|c|c|c|c|c|c|c|}
\hline Period & From class & To class & $\begin{array}{c}\text { Area } \\
\text { changed } \\
\left(\mathbf{k m}^{2}\right)\end{array}$ & $\begin{array}{c}\text { Margin of } \\
\text { error } \\
\left(+/-\mathrm{km}^{2}\right)\end{array}$ & $\begin{array}{c}\text { Standard } \\
\text { error } \\
\left(\mathbf{k m}^{2}\right)\end{array}$ & $\begin{array}{l}\text { Percent of } \\
\text { ecoregion }\end{array}$ & $\begin{array}{c}\text { Percent of all } \\
\text { changes }\end{array}$ \\
\hline \multirow[t]{7}{*}{ 1973-1980 } & Grassland/Shrubland & Agriculture & 635 & 373 & 254 & 0.8 & 27.0 \\
\hline & Agriculture & Grassland/Shrubland & 349 & 169 & 115 & 0.4 & 14.8 \\
\hline & Wetland & Water & 165 & 104 & 71 & 0.2 & 7.0 \\
\hline & Agriculture & Wetland & 163 & 169 & 115 & 0.2 & 6.9 \\
\hline & Agriculture & Developed & 146 & 132 & 90 & 0.2 & 6.2 \\
\hline & Other & Other & 893 & $\mathrm{n} / \mathrm{a}$ & $\mathrm{n} / \mathrm{a}$ & 1.1 & 38.0 \\
\hline & & Totals & 2,351 & & & 2.9 & 100.0 \\
\hline \multirow[t]{7}{*}{ 1980-1986 } & Agriculture & Grassland/Shrubland & 478 & 268 & 183 & 0.6 & 18.5 \\
\hline & Water & Wetland & 265 & 137 & 93 & 0.3 & 10.3 \\
\hline & Wetland & Agriculture & 193 & 252 & 171 & 0.2 & 7.5 \\
\hline & Wetland & Water & 167 & 137 & 93 & 0.2 & 6.5 \\
\hline & Grassland/Shrubland & Forest & 160 & 114 & 78 & 0.2 & 6.2 \\
\hline & Other & Other & 1,314 & $\mathrm{n} / \mathrm{a}$ & $\mathrm{n} / \mathrm{a}$ & 1.6 & 51.0 \\
\hline & & Totals & 2,577 & & & 3.2 & 100.0 \\
\hline \multirow[t]{7}{*}{ 1986-1992 } & Agriculture & Grassland/Shrubland & 331 & 144 & 98 & 0.4 & 15.4 \\
\hline & Grassland/Shrubland & Agriculture & 243 & 125 & 85 & 0.3 & 11.3 \\
\hline & Forest & Mechanically disturbed & 232 & 181 & 123 & 0.3 & 10.8 \\
\hline & Agriculture & Wetland & 119 & 168 & 114 & 0.1 & 5.5 \\
\hline & Grassland/Shrubland & Forest & 115 & 64 & 43 & 0.1 & 5.3 \\
\hline & Other & Other & 1,105 & $\mathrm{n} / \mathrm{a}$ & $\mathrm{n} / \mathrm{a}$ & 1.4 & 51.5 \\
\hline & & Totals & 2,145 & & & 2.6 & 100.0 \\
\hline \multirow[t]{7}{*}{ 1992-2000 } & Agriculture & Grassland/Shrubland & 594 & 489 & 333 & 0.7 & 18.6 \\
\hline & Grassland/Shrubland & Agriculture & 427 & 289 & 197 & 0.5 & 13.4 \\
\hline & Forest & Mechanically disturbed & 381 & 264 & 180 & 0.5 & 11.9 \\
\hline & Grassland/Shrubland & Forest & 167 & 76 & 52 & 0.2 & 5.2 \\
\hline & Mechanically disturbed & Grassland/Shrubland & 151 & 121 & 82 & 0.2 & 4.7 \\
\hline & Other & Other & 1,476 & $\mathrm{n} / \mathrm{a}$ & $\mathrm{n} / \mathrm{a}$ & 1.8 & 46.2 \\
\hline & & Totals & 3,196 & & & 3.9 & 100.0 \\
\hline \multirow{7}{*}{$\begin{array}{c}1973-2000 \\
\text { (overall) }\end{array}$} & Agriculture & Grassland/Shrubland & 1,751 & 817 & 557 & 2.2 & 17.1 \\
\hline & Grassland/Shrubland & Agriculture & 1,458 & 737 & 502 & 1.8 & 14.2 \\
\hline & Forest & Mechanically disturbed & 779 & 510 & 348 & 1.0 & 7.6 \\
\hline & Water & Wetland & 549 & 208 & 141 & 0.7 & 5.3 \\
\hline & Grassland/Shrubland & Forest & 528 & 243 & 166 & 0.7 & 5.1 \\
\hline & Other & Other & 5,204 & $\mathrm{n} / \mathrm{a}$ & $\mathrm{n} / \mathrm{a}$ & 6.4 & 50.7 \\
\hline & & Totals & 10,269 & & & 12.7 & 100.0 \\
\hline
\end{tabular}


Table 4. Raw estimates of change in Western Gulf Coastal Plain Ecoregion land cover, computed for each of four time periods between 1973 and 2000, and associated error at an 85-percent confidence level.

[Estimates of change per period normalized to annual rate of change for each period]

\begin{tabular}{cccccccc}
\hline Period & $\begin{array}{c}\text { Total change } \\
(\% \text { of ecoregion) }\end{array}$ & $\begin{array}{c}\text { Margin of } \\
\text { error } \\
(+-\%)\end{array}$ & $\begin{array}{c}\text { Lower } \\
\text { bound } \\
(\%)\end{array}$ & $\begin{array}{c}\text { Upper bound } \\
(\%)\end{array}$ & $\begin{array}{c}\text { Standard } \\
\text { error } \\
(\%)\end{array}$ & $\begin{array}{c}\text { Relative } \\
\text { error } \\
(\%)\end{array}$ & $\begin{array}{c}\text { Average rate } \\
(\% \text { per year) }\end{array}$ \\
\hline \multicolumn{7}{c}{ Estimate of change, in percent stratum } \\
\hline $1973-1980$ & 2.9 & 0.7 & 2.2 & 3.6 & 0.5 & 16.0 & 0.4 \\
$1980-1986$ & 3.2 & 0.8 & 2.4 & 4.0 & 0.6 & 17.5 & 0.5 \\
$1986-1992$ & 2.6 & 0.6 & 2.0 & 3.3 & 0.4 & 15.7 & 0.4 \\
$1992-2000$ & 3.9 & 1.2 & 2.7 & 5.1 & 0.8 & 20.7 & 0.5 \\
\hline \multicolumn{7}{c}{ Estimate of change, in square kilometers } \\
\hline $1973-1980$ & 2,351 & 553 & 1,798 & 2,904 & 377 & 16.0 & 336 \\
$1980-1986$ & 2,577 & 663 & 1,914 & 3,241 & 452 & 17.5 & 430 \\
$1986-1992$ & 2,145 & 495 & 1,650 & 2,640 & 337 & 15.7 & 357 \\
$1992-2000$ & 3,196 & 973 & 2,223 & 4,169 & 663 & 20.7 & 399 \\
\hline
\end{tabular}

\section{References Cited}

Archer, Steve, 1990, Development and stability of grass/ woody mosaics in a subtropical savanna parkland, Texas, U.S.A.: Journal of Biogeography, v. 17, no. 4-5, p. 453-462.

Davidson, S.C., and Mace, R.E., 2006, Aquifers of the Gulf Coast of Texas-An overview, in Mace, R.E., Davidson, S.C., Angle, E.S., and Mullican, W.F., III, Aquifers of the Gulf Coast of Texas: Texas Water Development Board Report 365, p. 1-21, available at http://www.twdb.texas. gov/publications/reports/numbered_reports/doc/R365/ ch01_intro.pdf.

Griffith, G.E., Bryce, S.A., Omernik, J.M., Comstock, J.A., Rogers, A.C., Harrison, B., Hatch, S.L., and Bezanson, D., 2004, Ecoregions of Texas: U.S. Geological Survey Ecoregion Map Series, scale 1:2,500,000, available at http://www. epa.gov/wed/pages/ecoregions/tx_eco.htm.

Lindert, P.H., 1988, Long-run trends in American farmland values: Agricultural History, v. 62, p. 45-85.

Moulton, D.W., Dahl, T.E., and Dall, D.M., 1997, Texas coastal wetlands-Status and trends, mid-1950s to early 1990s: U.S. Fish and Wildlife Service, 32 p.
Omernik, J.M., 1987, Ecoregions of the conterminous United States: Annals of the Association of American Geographers, v. 77, no. 1, p. 118-125.

Texas General Land Office, 1995, Coastal management program: Texas General Land Office database, available at http://www.glo.texas.gov/what-we-do/caring-for-the-coast/ grants-funding/cmp/.

U.S. Census Bureau, 1970-2000 [various years], Census of population and housing: U.S. Census Bureau database, accessed September 1, 2008, at http://www.census.gov/ $\mathrm{prod} / \mathrm{www} / \mathrm{decennial.html.}$

U.S. Environmental Protection Agency, 1997, Descriptions of level III ecological regions for the CEC report on ecological regions of North America: U.S. Environmental Protection Agency database, accessed April 12, 2006, at http://www. epa.gov/wed/pages/ecoregions/na_eco.htm\#Downloads.

Vogelmann, J.E., Howard, S.M., Yang, L., Larson, C.R., Wylie, B.K., and van Driel, N., 2001, Completion of the 1990s National Land Cover Data Set for the conterminous United States from Landsat Thematic Mapper data and ancillary data sources: Photogrammetric Engineering \& Remote Sensing, v. 67, p. 650-662. 
Appendixes 1-4 



\title{
Appendix 1. Map of Ecoregions in Conterminous United States
}

This volume-U.S. Geological Survey Professional Paper 1794-B, which covers 17 ecoregions in the Great Plains of the United States - provides an assessment of the rates and causes of land-use and land-cover change in the Great Plains of the United States region between 1973 and 2000. The other three volumes of this Professional Paper (1794-A, 1794-C, and 1794-D) provide similar analyses for the Western United States, the Midwest-South Central United States, and the Eastern United States regions, respectively.

The map contained in this appendix (fig. 1.1) shows all 84 ecoregions in the conterminous United States, as originally defined by Omernik and others (1987) and later modified by the U.S. Environmental Protection Agency (1999), in addition to the ecoregions that are contained in the Western United States, Great Plains of the United States, Midwest-South Central United States, and Eastern United States regions. Also shown are the land-use/land-cover classes from the 2001 National Land-Cover Database (Homer and others, 2004).

\section{References Cited}

Homer, C., Huang, C., Yang, L., Wylie, B., and Coan, M., 2004, Development of a 2001 National Land-Cover Database for the United States: Photogrammetric Engineering and Remote Sensing, v. 70, no. 7, p. 829-840.

Omernik, J.M., 1987, Ecoregions of the conterminous United States: Annals of the Association of American Geographers, v. 77, no. 1, p. 118-125.

U.S. Environmental Protection Agency, 1997, Descriptions of level III ecological regions for the CEC report on ecological regions of North America: U.S. Environmental Protection Agency database, accessed April 12, 2006, at http://www.epa.gov/ wed/pages/ecoregions/na_eco.htm\#Downloads.

\author{
Ecoregion Abbreviations Used on Map \\ [Map is on following pages] \\ ACPB Atlantic Coastal Pine Barrens Ecoregion \\ ANMM Arizona/New Mexico Mountains Ecoregion \\ CR Coast Range Ecoregion \\ CRK Canadian Rockies Ecoregion \\ EGLHL Eastern Great Lakes and Hudson Lowlands Ecoregion \\ HELP Huron/Erie Lake Plains Ecoregion \\ LPH Laurentian Plains and Hills Ecoregion \\ MACP Middle Atlantic Coastal Plain Ecoregion \\ MRK Middle Rockies Ecoregion \\ MVFP Montana Valley and Foothill Prairies Ecoregion \\ MVLP Mississippi Valley Loess Plains Ecoregion \\ NAPU Northern Appalachian Plateau and Uplands Ecoregion \\ NCA North Central Appalachians Ecoregion \\ NCHF North Central Hardwood Forests Ecoregion \\ NECZ Northeastern Coastal Zone Ecoregion \\ NEH Northeastern Highlands Ecoregion \\ NLF Northern Lakes and Forests Ecoregion \\ NMW Northern Minnesota Wetlands Ecoregion \\ $\mathrm{PL} \quad$ Puget Lowland Ecoregion \\ SCCCOW Southern and Central California Chaparral and Oak Woodlands Ecoregion \\ SCM Southern California Mountains Ecoregion \\ SEWTP Southeastern Wisconsin Till Plains Ecoregion \\ SFCP Southern Florida Coastal Plain Ecoregion \\ TBP Texas Blackland Prairies Ecoregion \\ WUM Wasatch and Uinta Mountains Ecoregion \\ WV Willamette Valley Ecoregion
}




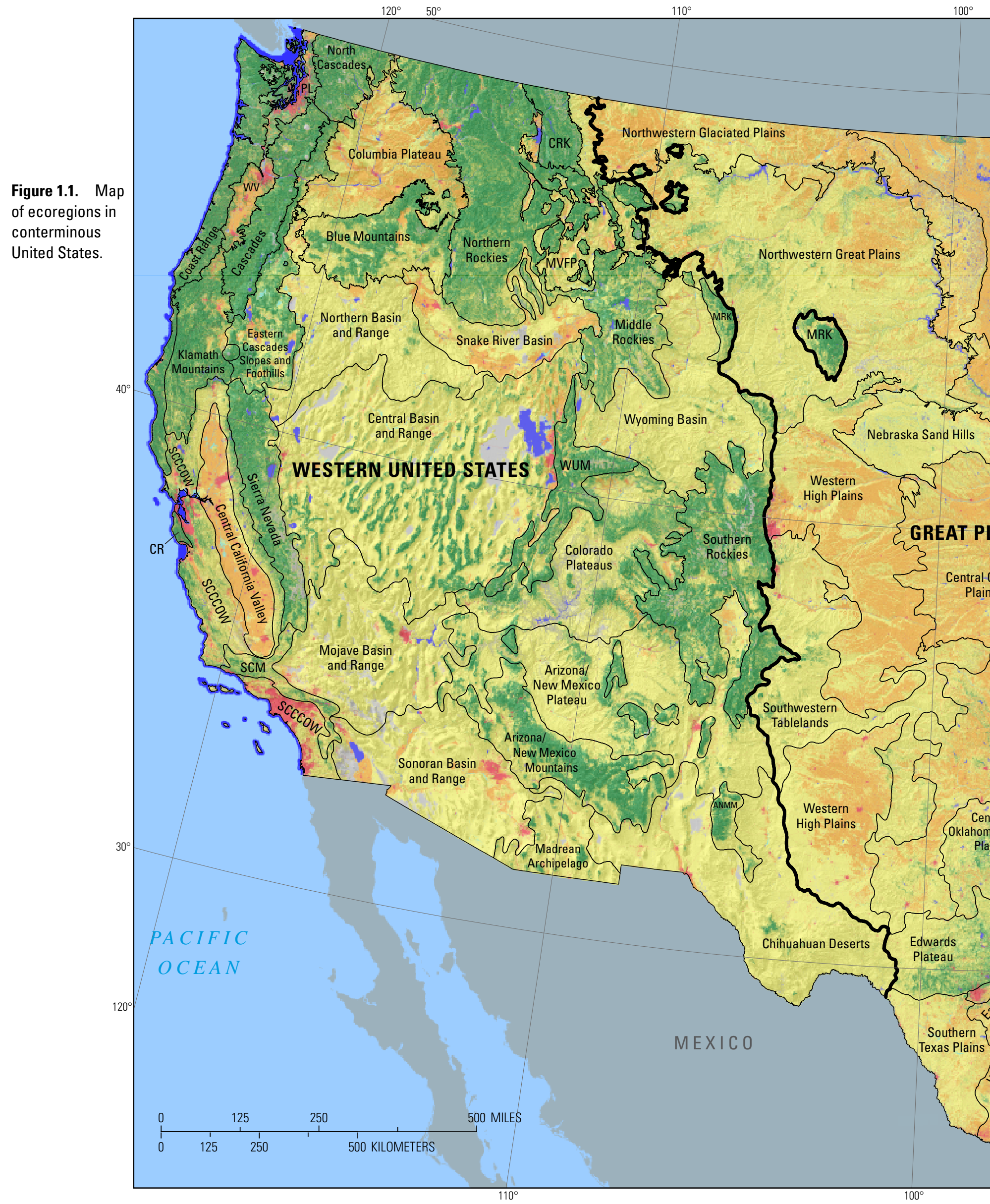




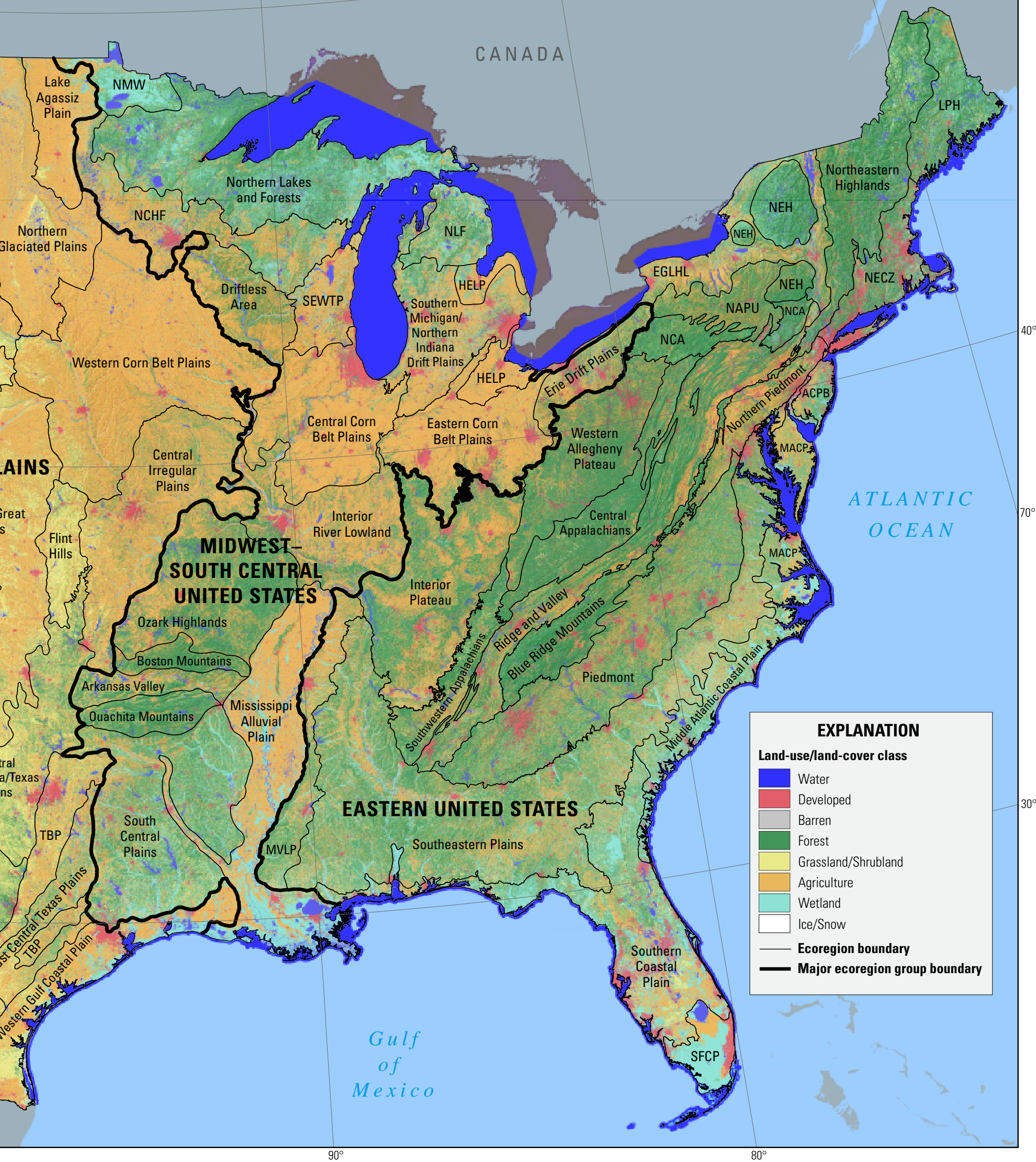




\section{Appendix 2. Abbreviations for Ecoregions in the Great Plains of the United States}

$\begin{array}{ll}\text { CGP } & \text { Central Great Plains Ecoregion } \\ \text { CIP } & \text { Central Irregular Plains Ecoregion } \\ \text { COTP } & \text { Central Oklahoma/Texas Plains Ecoregion } \\ \text { ECTP } & \text { East Central Texas Plains Ecoregion } \\ \text { EP } & \text { Edwards Plateau Ecoregion } \\ \text { FH } & \text { Flint Hills Ecoregion } \\ \text { LAP } & \text { Lake Agassiz Plain Ecoregion } \\ \text { NGP } & \text { Northern Glaciated Plains Ecoregion } \\ \text { NSH } & \text { Nebraska Sand Hills Ecoregion } \\ \text { NWGLP } & \text { Northwestern Glaciated Plains Ecoregion } \\ \text { NWGP } & \text { Northwestern Great Plains Ecoregion } \\ \text { STP } & \text { Southern Texas Plains Ecoregion } \\ \text { SWT } & \text { Southwestern Tablelands Ecoregion } \\ \text { TBP } & \text { Texas Blackland Prairies Ecoregion } \\ \text { WCBP } & \text { Western Corn Belt Plains Ecoregion } \\ \text { WGCP } & \text { Western Gulf Coastal Plain Ecoregion } \\ \text { WHP } & \text { Western High Plains Ecoregion }\end{array}$




\section{Appendix 3. Land-Cover Classification System Used in "Status and Trends of Land Change" Study}

This analysis of land-use/land-cover change during the 1973-2000 study period is based on land-cover classifications mapped for five study dates - 1973, 1980, 1986, 1992, and 2000. The use of moderate-resolution imagery-Landsat Multispectral Scanner, Thematic Mapper, and Enhanced Thematic Mapper Plus-necessitated a land-cover classification system that was fairly general in order to achieve high levels of accuracy and consistency in the interpretations. The classification system also needed to contain classes that could be used as an appropriate surrogate for land use. This classification, which is based on the Anderson Level I classes (Anderson and others, 1976), was used because the classes have been designed as use surrogates, but this system has been further modified by adding two transitional disturbance categories, mechanically disturbed (human induced) and nonmechanically disturbed (natural).

The classification system used consists of the following 11 general land-cover classes: water, developed, mechanically disturbed, mining, barren, forest, grassland/shrubland, agriculture, wetland, nonmechanically disturbed, and ice/ snow. Classes are defined as follows:

Water-Areas that are persistently covered with water, such as perennial streams, canals, rivers, lakes, reservoirs, bays, and oceans.

Developed-Areas of intensive use, in which much of the land is covered with structures or other anthropogenically induced, impermeable surfaces (for example, high-density residential, commercial, and industrial areas, as well as roads, highways, and other transportation corridors), or less intensive use, in which the land-cover matrix includes both vegetation and structures (for example, low-density residential areas, recreational facilities, cemeteries, parking lots, and utility corridors). Land that is functionally related to urban or built-up environments (for example, parks and golf courses) is also included.

M echanically disturbed - Land in an altered and often unvegetated state owing to disturbance by mechanical (that is, human) means. Mechanically disturbed land is in transition from one land-cover class to another. Processes leading to mechanical disturbance include forest clearcutting, earthmoving, scraping, chaining, reservoir drawdown, and other types of anthropogenically induced changes.
Mining - Areas of extractive mining activities that have significant surface expression, including mining buildings and apparatus, quarry pits, evaporation and leach ponds, tailings and overburden piles, and other components related to mining, to the extent that these features can be detected.

Barren - Areas of bare soil, sand, or rock, in which less than 10 percent of the area is vegetated. Barren lands generally are naturally occurring.

F orest-Tree-covered land where the tree-cover density is greater than 10 percent. Cleared forest land is mapped (according to land cover at the time of the imagery) as either mechanically disturbed or grassland/shrubland.

G rassland/Shrubland - Land that is predominately covered with grasses, forbs, or shrubs. Vegetated cover must make up at least 10 percent of the area.

Agriculture -Land, in either a vegetated or an unvegetated state, used for the production of food or fiber. This includes cultivated and uncultivated croplands, hay lands, pasture, orchards, vineyards, and confined-livestock operations. However, forest plantations always are classified as forest, regardless of how the wood products are used.

Wetland-Land where water saturation is the determining factor in soil characteristics, vegetation types, and animal communities. Wetlands usually contain both water and vegetated cover.

Nonmechanically disturbed - Land in an altered and often unvegetated state owing to disturbance by nonmechanical (that is, natural) means. Nonmechanically disturbed land is in transition from one land-cover class to another. Causes of nonmechanical disturbance include fire, wind, floods, animals, and other similar phenomena.

Ice/Snow - Land where the accumulation of snow and ice does not completely melt during the summer period (for example, alpine glaciers and perennial snowfields).

\section{Reference Cited}

Anderson, J.R., Hardy, E.E., Roach, J.T., and Witmer, R.E., 1976, A Land Use and Land Cover Classification System for Use with Remote Sensor Data: U.S. Geological Survey Professional Paper 964, 28 p., available at http://pubs.usgs. gov/pp/0964/report.pdf. 


\section{Appendix 4. Methodology Used in "Status and Trends of Land Change" Study}

This appendix describes the methodology used to document the temporal and spatial rates, trends, and types of change documented in this "Status and Trends of Land Change" study. The methodology is based on a statistical sampling approach, manual classification of land use and land cover, and postclassification comparisons of land cover over five different study dates (Loveland and others, 2002). U.S. Environmental Protection Agency's (1999) Level III ecoregions provided the geographic framework for regional land-cover change estimates, and land-use/land-cover change was estimated on an ecoregion-by-ecoregion basis using a probability sample of randomly selected blocks within each of 84 ecoregions across the conterminous United States. For each sample block, five dates of Landsat imagery were interpreted in order to map land use and land cover, using a classification system that consists of 11 general land-cover classes (see appendix 3, entitled "Land-Cover Classification System Used in 'Status and Trends of Land Change' Study"). The resulting land-cover data for each sample block were used to determine change for four time periods, and sample-block data were used to calculate change estimates for each ecoregion.

\section{Sampling Strategy}

In this study, a sampling strategy was used as a costefficient method for characterizing land-cover change in an area as large as the conterminous United States. The study used a stratified random sample of 2,688 square blocks (fig. 1); a random sample of these blocks was independently selected for each ecoregion analyzed. Because the study used a probability sample, the estimates of land-use/land-cover change that are derived can be considered as categorically representative of the population (Kish, 1987).

The size of each sample block in this study, as well as the sampling density (that is, the number of sample blocks analyzed per ecoregion), was based on a compromise between two conflicting objectives: (1) estimating change in landcover area, and (2) estimating change in landscape pattern. Larger numbers of smaller sample blocks would result in more precise estimates of change in land-cover area, whereas smaller numbers of larger sample blocks would be more desirable for characterizing landscape pattern.

\section{Size of Samples}

In the initial study design, a $20 \times 20 \mathrm{~km}\left(400 \mathrm{~km}^{2}\right)$ sample-block size was used, and nine ecoregions were analyzed, each analysis consisting of 9 to 11 sample blocks. On the basis of results from these initial ecoregion analyses, a decision was made to use a higher density of smaller (10 $\times 10 \mathrm{~km} ; 100 \mathrm{~km}^{2}$ ) sample blocks for the remainder of the ecoregion analyses in order to maximize the precision of the land-cover change estimates.
Sampling Density

The sampling density was determined by both the project requirements for precision in the change estimates and the expected characteristics of change within the ecoregion being studied. As precision requirements increase, so must the sampling density. Similarly, a greater sampling density is required when areas of change are expected to be less evenly distributed throughout an ecoregion.

In this study, the target precision level was to map gross overall change to within a $\pm 1 \%$ margin of error at an $85 \%$ confidence level for each ecoregion. On the basis of this target precision level and the expected characteristics of change within all 84 ecoregions in the conterminous United States, it was determined that between 25 and 48 of the $10 \times 10$ $\mathrm{km}$ sample blocks per ecoregion would likely be needed to adequately characterize overall change in each ecoregion.

\section{Implementation of the Sampling Strategy}

The sampling strategy outlined above was fairly straightforward to implement. A regular grid of $10 \times 10 \mathrm{~km}$ (or, in a few cases, $20 \times 20 \mathrm{~km}$ ) sample blocks was overlain on an ecoregion map of the conterminous United States. Blocks whose centers fell within the boundaries of an ecoregion were highlighted as potentially valid sample blocks for that ecoregion and then were assigned a unique numerical value from 1 to $\mathrm{N}$. A random number generator was then used to select sample blocks, one at a time, until the desired number was reached. Thus, each sample block within an ecoregion had an equal probability of being included in the final sample analysis.

Although the number of sample blocks selected and analyzed was based on both the target precision level and the expected characteristics of change within the ecoregion, unexpected heterogeneity in the distribution of change could still result in the estimates of change having levels of precision that are lower than desired. Should this occur, the sampling strategy allowed for the selection and interpretation of additional sample blocks. The inclusion of these reserve blocks allowed the analysis to achieve change estimates that have acceptable levels of precision. In actuality, for various reasons, no reserve blocks were implemented.

\section{Geographic Framework}

A central premise of the study design was the use of a geographic framework to provide regional land-cover change estimates. Geographers have long used regional frameworks because they capture the essence and potential of the landscape without masking the roles of environmental, social, and economic forces (Turner and Meyer, 1991). This "Status and Trends of Land Change" study chose to use ecoregions, as originally defined by Omernik (1987) and later modified 
by the U.S. Environmental Protection Agency (1999), as the framework from which to tell the regional story of change.

Ecoregions were chosen as the unit of analysis because (1) they provide a means to localize estimates of the rates and driving forces of change, (2) they were developed by synthesizing information on a wide variety of factors (for example, climate, geology, physiography, soils, vegetation, hydrology, and human influences) and, therefore, should reflect both current land-use and land-cover types and future change trajectories, and (3) they provide a framework that can be extended globally.

\section{Landsat Data}

Landsat satellite imagery was the primary source of data used for detecting land-cover change in this study. Data from the Landsat Multispectral Scanner (MSS), Thematic Mapper (TM), and Enhanced Thematic Mapper Plus (ETM+) instruments were acquired from the Landsat data archive: Landsat MSS datasets are available from late-1972 through late-1992; Landsat TM data are available from 1982 to the present; and Landsat ETM+ data are available from 1999 to the present. Each of these products provided a consistent, synoptic, multispectral view of the land surface from which land cover could be interpreted for the period between 1972 and 2000. To analyze trends in land-use/land-cover change throughout this period, five target study dates spaced at semiregular intervals (1973, 1980, 1986, 1992, and 2000) were selected. Landsat imagery corresponding to each $10 \times 10 \mathrm{~km}$ (or $20 \times 20 \mathrm{~km}$ ) sample block was extracted from full Landsat scenes, resulting in five dates of satellite imagery for each sample block. To reduce expenses, the initial data-acquisition strategy was to use existing geoprocessed Landsat datasets as the primary input data source. Four of the five dates of Landsat MSS, $\mathrm{TM}$, and $\mathrm{ETM}+$ data were available in a geocoded format as a result of processing done for two previous projects: (1) the North American Landscape Characterization (NALC) project produced 1973, 1986, and 1992 geocoded Landsat MSS datasets for the conterminous United States and Mexico (Lunetta and others, 1998), and (2) the $1992 \mathrm{TM}$ and $2000 \mathrm{ETM}+$ data came from the Multiresolution Landscape Characterization initiative (Loveland and Shaw, 1996). New 1980 Landsat MSS acquisitions were obtained in order to maintain the six- to eightyear interval between the five target dates.

The Landsat MSS, TM, and ETM+ scenes obtained were previously georeferenced to root-mean-square error of 1 pixel or less but to differing map projections. For this study, all scenes were translated to a common Albers equal-area projection. Most of the NALC MSS data had also been terraincorrected, but approximately one-third of the NALC data (path and rows) had been processed before the implementation of terrain-correction techniques. However, this was not considered a problem because the early NALC scenes were located primarily in areas with negligible terrain variability.

\section{Ancillary Data}

Additional ancillary data were acquired to aid interpreters in delineating land use and land cover from the Landsat data. For example, aerial photography was acquired for each sample block to provide a high-resolution data source to help with difficult interpretations. The National Aerial Photography Program (NAPP) generally provided one or two dates of color-infrared (CIR) and (or) black-and-white aerial photographs from 1987 to the present. The National High Altitude Photograph (NHAP) Program generally provided one date of CIR and (or) black-and-white aerial photographs between 1980 and 1986. Although the Landsat imagery was always used as the source material for delineating land use and land cover, these higher resolution aerial photographs were invaluable for assisting in the interpretation of the imagery. Topographic maps, census data, other electronic sources of aerial photographs (for example, Google Earth), and digital raster graphics were among the other sources of information that interpreters found useful when processing the data.

\section{Land-Cover Classification Scheme}

The analysis of land use and land cover change during the 1973 to 2000 study period was based on classifications of land cover for the five target dates mentioned previously. The classification system used consists of the following 11 general land-cover classes: water, developed, mechanically disturbed, mining, barren, forest, grassland/shrubland, agriculture, wetland, nonmechanically disturbed, and ice/ snow. See appendix 3, entitled "Land-Cover Classification System Used in 'Status and Trends of Land Change' Study," for definitions of these 11 classifications.

Two primary factors affected the design of the classification system. The first factor was recognizing that the use of moderate-resolution Landsat imagery would necessitate a land-cover classification system that was fairly general in order to achieve high interpretation accuracy and consistency. The ability to identify and map land cover would be limited both by the technical specifications of the Landsat MSS, TM, and ETM sensors and by the local and regional landscape characteristics that affect the form and contrast visible in satellite imagery. This would be especially true when interpreting Landsat MSS data.

The second factor involved choosing land-cover classes that captured the land-cover changes of interest. Because the project's interest was in land-use change, with land cover serving as a surrogate for land use, the decision was to use the Anderson Level I classes (Anderson and others, 1976) because they were designed as use surrogates. However, the Anderson system was selectively modified by adding two disturbance categories, mechanically disturbed (human induced) and nonmechanically disturbed (natural). 


\section{Manual Land-Cover Delineation}

Land-cover delineation for each sample block began with the creation of a baseline reference land-cover dataset. The 1992 date usually was the starting point owing to the availability of the 30-m-resolution 1992 National Land Cover Data (NLCD) dataset (Vogelmann and others, 2001). The NLCD dataset provided a starting template after the more detailed NLCD classes were aggregated to match the general land-cover classification described above.

The NLCD data first were manually edited on the computer screen, using on-screen interpretation methods, while using the 1992 Landsat TM data and the NAPP aerial photographs as interpretation aids. This cleanup procedure to improve the NLCD classification accuracy was carried out because the NLCD data were created using automated imageprocessing procedures, and they were not meant for use in local- or ecoregional-scale assessments. A minimum mapping unit of $60 \times 60$ meters was used for this study. Thus, features having ground footprints less than $60 \mathrm{~m}$ wide generally were not mapped, resulting in the exclusion of high-contrast features such as roads, which have a distinct spectral signature but have ground dimensions of less than $60 \mathrm{~m}$.

To carry out the NLCD editing for a particular sample block, the analyst displayed the NLCD data alongside the 1992 Landsat TM data on the computer screen. These data sources, along with hard-copy prints of NAPP aerial photography roughly corresponding to the 1992 date, were visually inspected by the analyst to determine if any corrections were needed in the sample block. The analyst manually delineated polygons that consisted of contiguous blocks of specific land-cover classes. Each of these polygons was then given a code value that corresponded to the land-cover classes outlined in the classification scheme in appendix 3 . The process continued until the entire sample block was manually inspected, mapped, and coded by the analyst.

To analyze change, land-cover classes for the 1973, 1980, 1986, and 2000 study dates were backward- or forwardclassified using the 1992 land-cover dataset as the template.
For example, creation of the 2000 land-cover product began by making an exact copy of the 1992 land-cover product. This copy served as a baseline for the 2000 land-cover product, in which identified changes between 1992 and 2000 were manually edited into the copied image. This baseline 2000 land-cover product was displayed on screen, along with the 1992 Landsat imagery and the 2000 Landsat imagery, allowing the analyst to pan through the entire area of the sample block while examining the 1992 and 2000 Landsat imagery and any relevant aerial photography for valid land-cover changes between the two study dates. Any identified land-cover changes were manually digitized on screen, and the land cover was recoded on the 2000 land-cover product.

Upon completion of the 2000 land-cover product, the same procedures were used to create the 1986, 1980, and 1973 land-cover products. This manual process eliminated errors that may occur between independently created land-cover products that are compared in a subsequent change analysis. Because only manually identified, delineated, and coded landcover changes were analyzed during this phase, classification errors were greatly reduced.

\section{Statistical Analysis}

The resulting land-cover data for each sample block was used in postclassification comparisons to determine change between study years (fig. 2). Sample blocks within each ecoregion were used to generate change statistics for all 84 ecoregions. These statistics were used to determine the predominant types of land-cover conversions occurring within each ecoregion, the estimated rates of change for these conversions, and whether these types and rates of change are constant or variable across time. The analysis of change also involved looking for spatial correlations between conversion types and selected socioeconomic and environmental factors, such as timber production, agricultural yields, precipitation amounts, population levels, proximity to urban development, and overall economic conditions, in order to improve the understanding of potential drivers of change. 


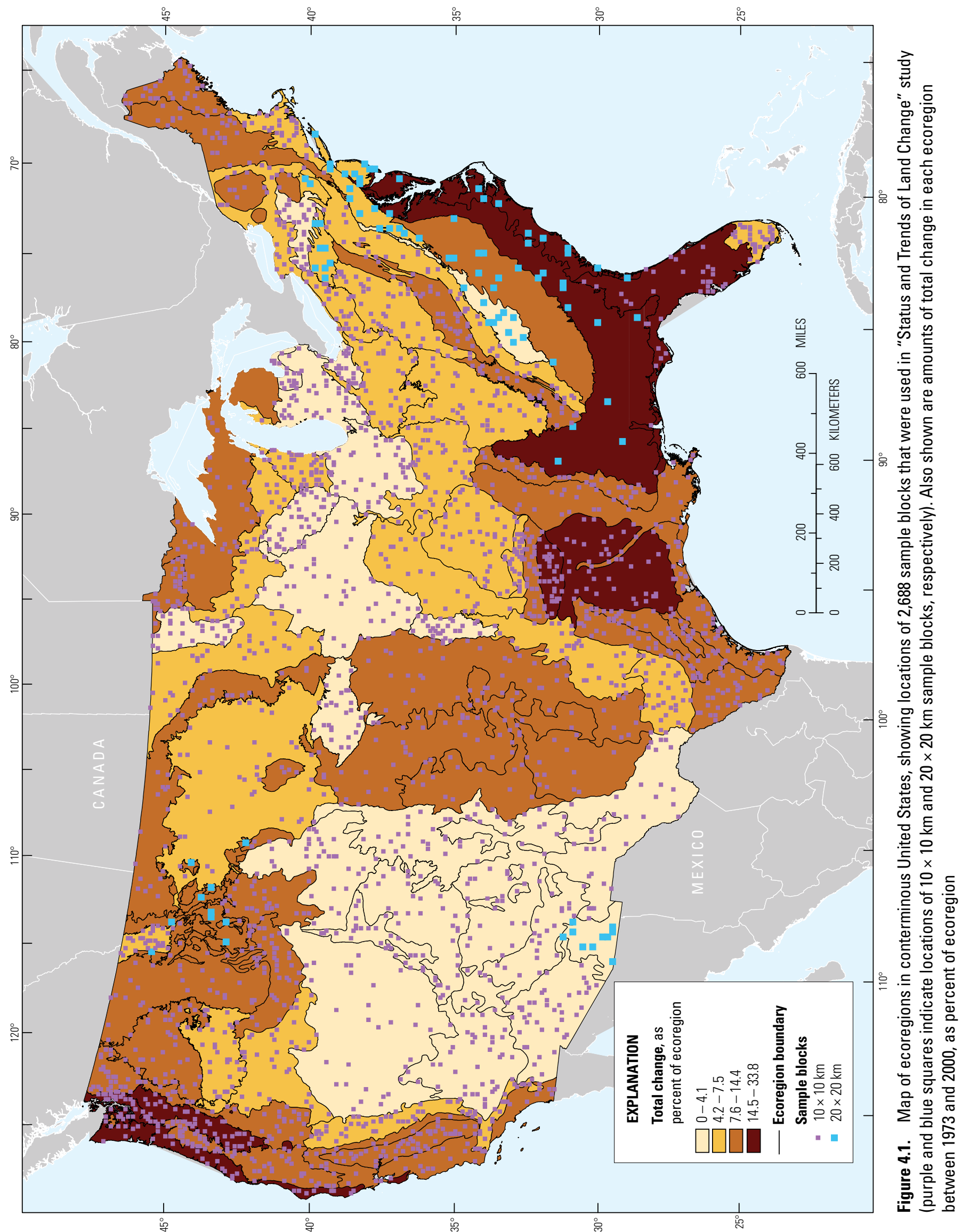



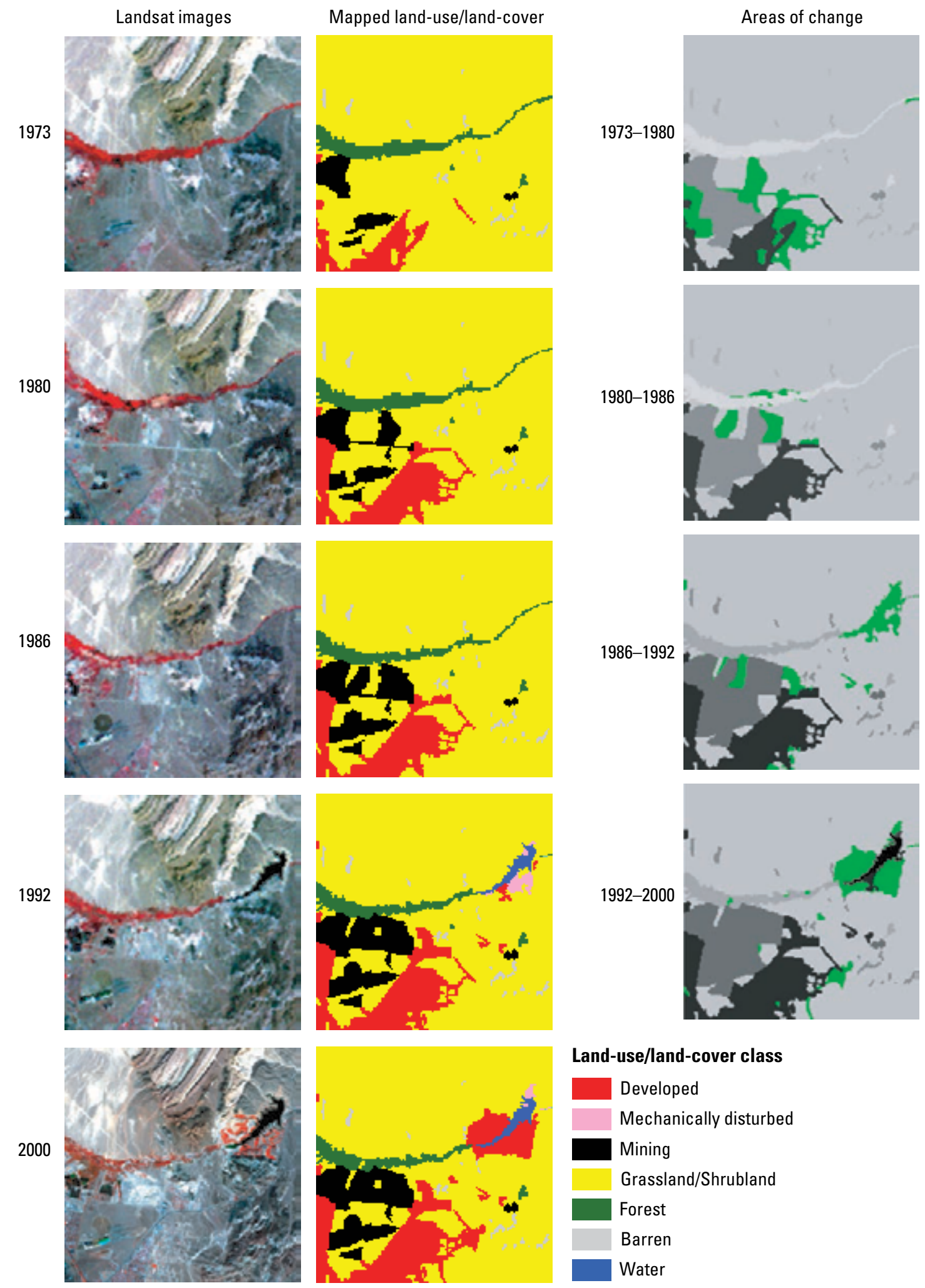

Figure 4.2. Example of data compiled for each sample block, showing sample block 14-0555 (located near Henderson, Nevada, in Mojave Basin and Range Ecoregion, one of Western United States ecoregions). Left column is satellite imagery collected for each of five years analyzed in study (imagery sources for study years: 1973, 1980, and 1986 are Landsat Multispectral Scanner (MSS) images; 1992 is Landsat Thematic Mapper (TM) image; 2000 is Landsat Enhanced Thematic Mapper (ETM) image). Center column is mapped land-use/ land-cover data for each study year. Right column shows areas that changed (green areas) in each of four time periods between study years; light- and dark-gray-shaded areas show areas of previous change and represent overall land-change footprint throughout study period. 


\section{References Cited}

Anderson, J.R., Hardy, E.E., Roach, J.T., and Witmer, R.E., 1976, A Land Use and Land Cover Classification System for Use with Remote Sensor Data: U.S. Geological Survey Professional Paper 964, 28 p., available at http://pubs.usgs. gov/pp/0964/report.pdf.

Kish, L., 1987, Statistical Design for Research: New York, John Wiley \& Sons, Inc., 296 p.

Loveland, T.R., and Shaw, D.M., 1996, Multiresolution land characterization-Building collaborative partnerships, in Scott, J.M., Tear, T.H., and Davis, F.W., eds., Gap Analysis-A landscape approach to biodiversity planning: Bethesda, Maryland, American Society for Photogrammetry and Remote Sensing, p. 17-25.

Loveland, T.R., Sohl, T.L., Stehman, S.V., Gallant, A.L., Sayler, K.L., and Napton, D.E., 2002, A strategy for estimating the rates of recent United States land cover changes: Photogrammetric Engineering and Remote Sensing, v. 68, no. 10, p. 1,091-1,099.

Lunetta, R.S., Lyon, J.G., Guindon, B., and Elvidge, C.D., 1998, North American landscape characterization dataset development and data fusion issues: Photogrammetric Engineering and Remote Sensing, v. 64, no. 8, p. 821-829.

Omernik, J.M., 1987, Ecoregions of the conterminous United States: Annals of the Association of American Geographers, v. 77 , no. 1 , p. $118-125$.

Turner, B.L., II, and Meyer, W.B., 1991, Land use and land cover in global environmental change-Considerations for study: International Social Science Journal, v. 130, p. 669-677.

U.S. Environmental Protection Agency, 1999, Level III Ecoregions of the continental United States: U.S. Environmental Protection Agency National Health and Environmental Effects Research Laboratory, scale 1:7,500,000, available at ftp://ftp.epa.gov/wed/ecoregions/ us/Eco_Level_III_US.pdf.

Vogelmann, J.E., Howard, S.M., Yang, L., Larson, C.R., Wylie, B.K., and van Driel, N., 2001, Completion of the 1990s National Land Cover Data Set for the conterminous United States from Landsat Thematic Mapper data and ancillary data sources: Photogrammetric Engineering \& Remote Sensing, v. 67, p. 650-662. 
Produced in the Menlo Park Publishing Service Center, Menlo Park, California Manuscript approved for publication June 18, 2015

Edited by Taryn A. Lindquist and John S. Osias

Design and layout by Jeanne S. DiLeo and David R. Jones 


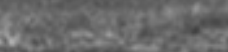

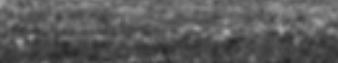

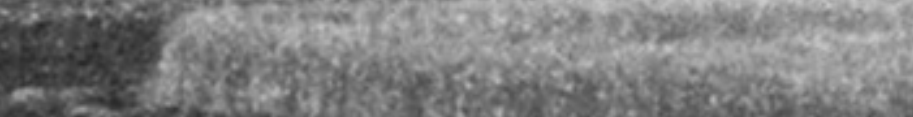
(3)

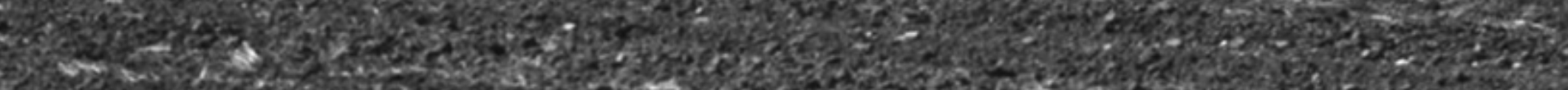

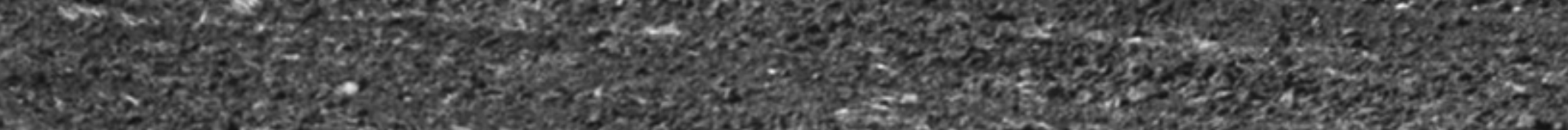
H.

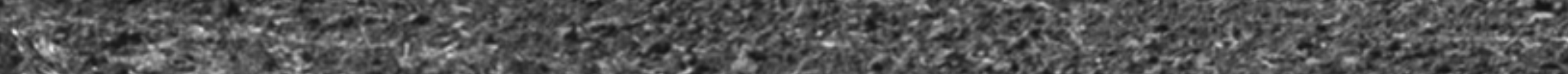

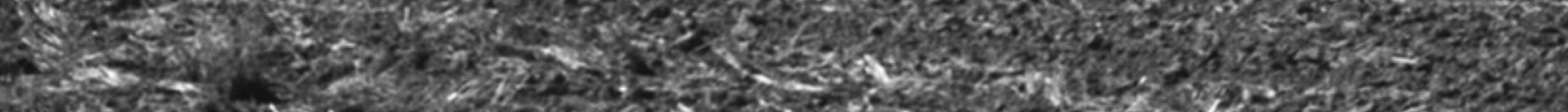
I. (5) (6)

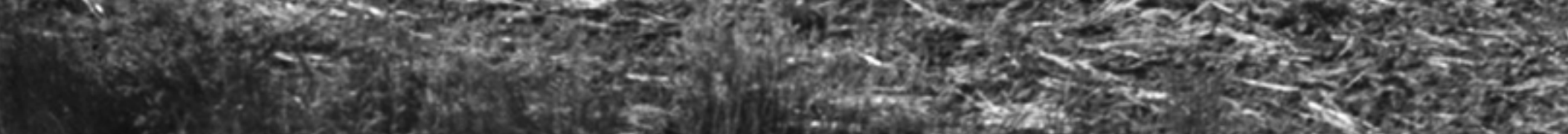

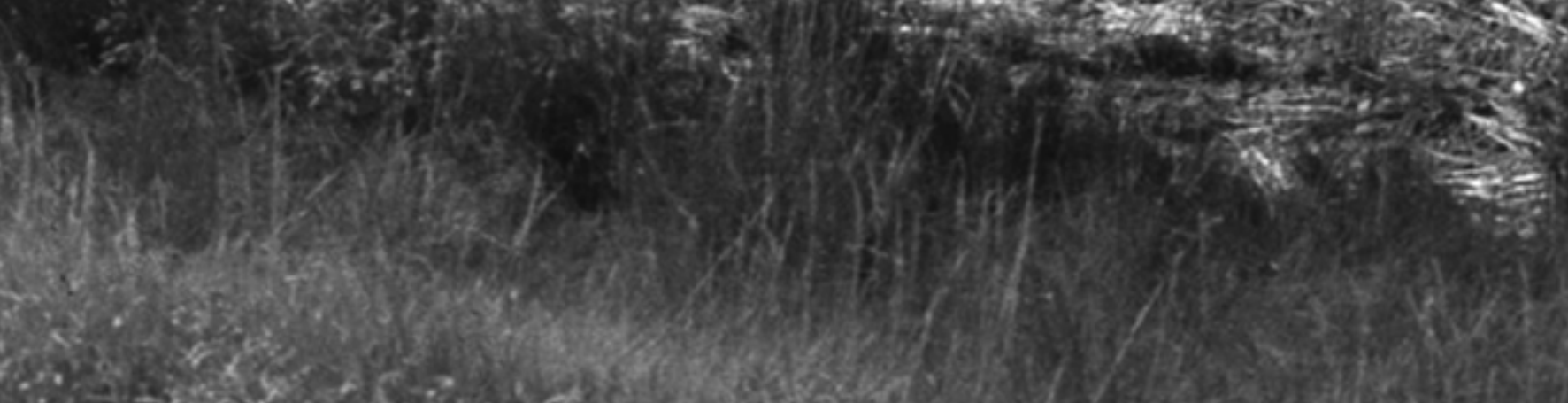
Fif 


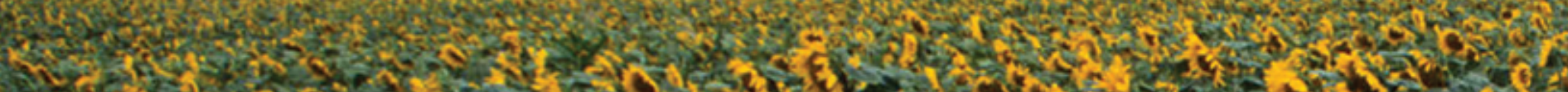
6.5 2.

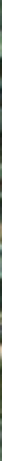

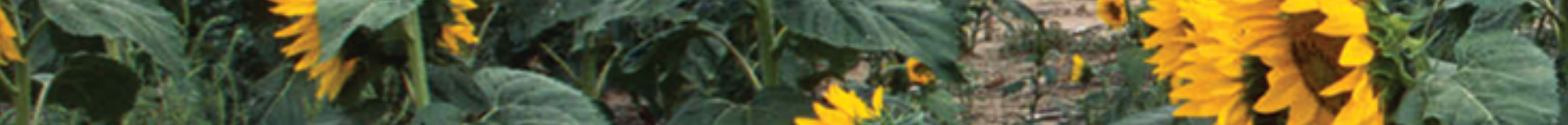

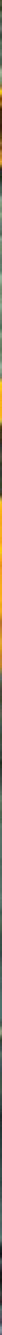

